\title{
Groundwater Flow Model for the General Separations Area, Savannah River Site (U)
}

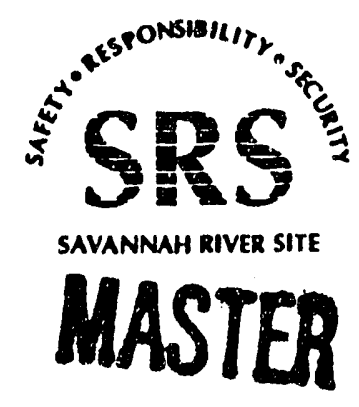


WSRC-TR-92-300

Publication Date: 5/15/92

\section{Groundwater Flow Model for the General Separations Area, Savannah River Site (U)}

Authorized Derivative Classifier:

$m a \cdot \varepsilon b+a-1 / 28 / 93$

Prepared for:

Westinghouse Savannah River Company

Environmental Restoration Department

Corporate Parkway, CCC4

Aiken, SC 29803

Prepared by:

GeoTrans, Inc.

46050 Manekin Plaza

Suite 100

Sterling, Virginia 22170

Prepared for the U.S. Department of Energy under contract No. DE-AC09-89SR18035

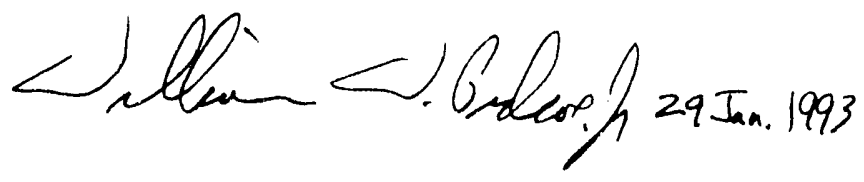




\section{Disclaimer}

This report was prepared as an account of work sponsored by an agency of the United States Government. Neither the United States Government nor any agency thereof, nor any of their employees, makes any warranty, express or implied, or assumes any legal liability or responsibility for the accuracy, completeness, or usefulness of any information, apparatus, product, or process disclosud, or represents that its use would not infringe privately owned rights. Reference herein to any specific commercial product, process, or service by trade name, trademark, manufacturer, or otherwise does not necessarily constitute or imply its endorsement, recommendation, or favoring by the United States Government or any agency thereof. The views and opinions of authors expressed herein do not necessarily state or reflect those of the United States Government or any agency thereof. 
1 INTRODUCTION ..................... 1

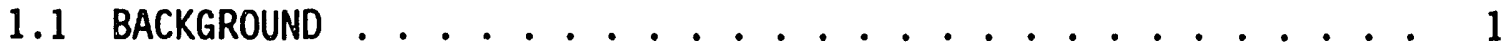

1.2 PREVIOUS INVESTIGATIONS ............... 4

1.3 PURPOSE OF THE STUDY .............. 5

1.4 METHOD OF INVESTIGATION .............. 6

2 HYDROGEOLOGIC FRAMEWORK ............... . . 8

2.1 GEOLOGIC SETTING OF THE STUDY AREA ........... 8

2.2 HYDROSTRATIGRAPHIC FRAMEWORK AND UNITS ........ 8

2.2.1 Confining System I-II (Ellenton Clays) . . . . . 12

2.2.2 Aquifer Unit IIA (Congaree Aquifer) . . . . . . 12

2.2.3 Confining Unit IIA - IIB (Green Clay) ........ 13

2.2.4 Aquifer Unit IIB Zone 1 (Barnwe11/McBean) . . . . . . 14

2.2.5 Confining Zone IIB1-IIB2 (Tan Clay) ....... 15

2.2.6 Aquifer Unit IIB Zone 2 (Water Table) ........ 16

2.2.7 Conceptualization of the Hydrostratigraphic Framework - 17

2.3 HYDRAULIC PROPERTIES OF HYDROSTRATIGRAPHIC UNITS ..... 17

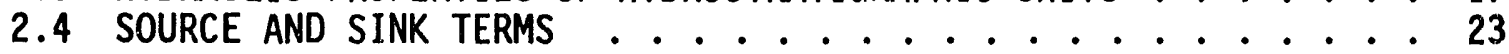

2.4.1 Groundwater Recharge .............. 23

2.4.2 Boundary Stream Discharge . . . . . . . . . . 27

2.5 POTENTIOMETRIC SURFACES . . . . . . . . . . . 31

2.5.1 Aquifer Unit IIA (Congaree) . . . . . . . . 34

2.5.2 Aquifer Unit IIB Zone 1 (Barnwell/McBean) ...... 34

2.5.3 Aquifer Unit IIB Zone 2 (Water Table) ....... 39

2.5.4 Vertical Interactions of Aquifers .........442

2.5.5 Water Elevation Fluctuations .......... 43

3 GROUNDWATER FLOW MODEL OF THE GENERAL SEPARATIONS AREA . . . . . 44

3.1 CODE SELECTION ................... . . 44

3.1 .1 Version Utilized ............. 46

3.2 GEOGRAPHIC INFORMATION SYSTEM . . . . . . . . . 47

3.2.1 Data Compilation . . . . . . . . . . 47

3.2.2 Integration of Data Compilation With Model Input Data

Sets................. 49

3.2.3 Advantages of GIS Approach ........... 49

3.3 MODEL CONFIGURATION .............. 49

3.3.1 Horizontal Discretization ........... 50

3.3.2 Vertical Discretization ............ 50

3.3.2.1 Data Sources and Techniques ......... 50

3.3.2.2 Stratigraphic Surfaces Implemented in the Mode 153

3.3.2.3 Stratigraphic Cross Sections ........ 56

3.3.3 Boundary Conditions ............... 63

3.3.3.1 Types of Boundaries .......... 69

3.3.3.2 Boundary Assignment in the Model with the GIS . 69

3.3.4 Other Model Parameters ............. 81

3.4 MODEL CALIBRATION ................ 81

3.4 .1 Approach .............. 83 
3.4.2 Calibration Criteria ............ . . 84

3.4.3 Issues Pertaining To Water Level Targets . . . . . . . 87

3.4.4 Summary of Model Calibration Procedure and Results . . 102

3.4.4.1 Initial Efforts............... 102

3.4.4.2 Addition of Zones .............. 103

3.4.4.3 Calibration Results . . . . . . . . . 104

3.5 SENSITIVITY ANALYSIS . . . . . . . . . . . . . . . 123

3.5.1 Sensitivity to Horizontal Hydraulic Conductivity . . . 124

3.5.2 Sensitivity to Vertical Hydraulic Conductivity . . . . 126

3.5.3 Sensitivity to Recharge . . . . . . . . . . . . . 133

3.5.4 Sensitivity Analysis Conclusions . . . . . . . . . . 140

3.6 CODE MODIFICATIONS .................. . . . 140

4 DESCRIPTION OF FLOW NEAR THE MIXED WASTE MANAGEMENT FACILITY . - . 142

4.1 SIMULATED FLOW DIRECTIONS . . . . . . . . . . . . . . 142

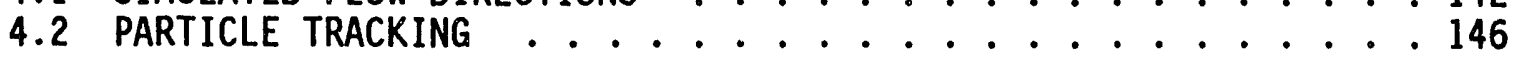

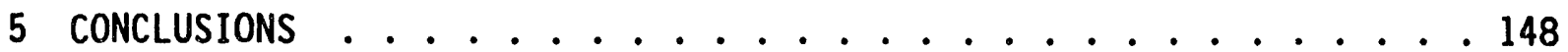

5.1 MODEL ASSESSMENT . . . . . . . . . . . . . . . . 148

5.2 DATA NEEDS .......................... . . . 149

5.3 TRANSPORT MODEL CONSIDERATIONS . . . . . . . . . . . . 152

REFERENCES . . . . . . . . . . . . . . 154 
1.1. Location map for General Separations Area. . . . . . . . . 2

1.2. Detailed location map for vicinity of the MWMF. . . . . . . . 3

2.1. Generalized hydrostratigraphic section for the GSA. . . . . . 10

2.2. Hydrostratigraphic units exposed at land surface. . . . . . . 11

2.3. Distribution and thickness of carbonates in Confining Unit IIA-

2.4. Distribution and thickness of carbonates in Aquifer Unit IIB

Zone 1 (Barnwel1/McBean). . . . . . . . . . . . . 22

2.5. Average monthly precipitation (inches), Bush Field Weather

2.6. Locations of stream gaging stations in the general vicinity of

2.7. Upper Three Runs Creek discharge gain between gaging station $c$ and the New Ellenton gaging station for the period 1975 1989.

2.8. Upper Three Runs creek discharge gain between gaging stations $\dot{c}$ and $A$ for the period 1975 - 1989. . . . . . . . . . . . 30

2.9. Four Mile Branch discharge gain between gaging stations 3 and 4 for the period 1973 - 1989. . . . . . . . . . . . . . . 32

2.10. Four Mile Branch discharge gain between gaging stations 4 and 6 for the period 1973 - 1989. . . . . . . . . . . . . 33

2.11. Potentiometric map of entire GSA, June 1982 , for illustrating general flow patterns in Aquifer Unit IIA (Congaree) (from Root, 1987).

2.12. Potentiometric map in the vicinity of the MWMF, Fourth Quarter 1989, for Aquifer Unit IIA (Congaree) (from SRS, 1990). . . .

2.13. Potentiometric map of entire GSA, June 1982, for illustrating general flow patterns in Aquifer Unit IIB Zone I (Barnwel1/McBean) (from Root, 1987).

2.14. Potentiometric map in the vicinity of the MWMF, Fourth Quarter 1989, for Aquifer Unit IIB Zone I, (Barnwe11/McBean) (from SRS, 1990).

2.15. Potentiometric map of entire GSA, June 1982 , for illustrating general flow patterns in Aquifer Unit IIB Zone II (Water Tabie) (from Root, 1987).

2.16. Potentiometric map in the vicinity of the MWMF, Fourth Quarter 1989, for Aquifer Unit IIB Zone II (Water Table) (based on SRS, 1990).

3.1. Summary of data stored in the GIS. . . . . . . . . . . . . . . . . 48

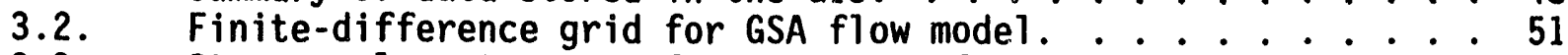

3.3. Structural contour map for top of Confining Unit IIBI-IIB2 (Tan Clay, model layer 2) used to generate model input. . . . . . 54

3.4. Thickness map for Confining Unit IIB1-IIB2 (Tan Clay, mode)

3.5. Calculated structural contour map for top of Aquifer Unit IIB

Zone 1 (Barnwel1/McBean, model layer 3)......... 57

3.6. Calculated thickness map for Aquifer Unit IIB Zone 1
(Barnwell/McBean, Model layer 3). . . . . . . . . . . 58 
3.7. Structural contour map for top of Confining Unit IIA-IIB (Green Clay, model layer 4) used to generate model input. ..... 59

3.8. Thickness map for Confining Unit IIA-IIB (Green Clay, model layer 4) used to generate model input. . . . . . . . 60

3.9. Calculated structural contour map for top of Aquifer Unit IIA (model layer 5)................. 61

3.10. Locations of stratigraphic sections presented in Figures 3.11

3.11. Stratigraphic section 1 , based on three-dimensional $\cdots \cdots 62$

3.12 stratigraphic surfaces used to define model input. . . . . 64

3.12. Stratigraphic section 2, based on three-dimensional
stratigraphic surfaces used to define model input. ..... 65

3.13. Stratigraphic section 3 , based on three-dimensional

3.14. Stratigraphic surfaces used to define mode? input. . . . . 66

3tratigraphic surfaces used to define model input. . . . . 67

3.15. Stratigraphic section 5 , based on three-dimensional $\ldots 6$
stratigraphic surfaces used to define model input. . . . . 68

3.16. Boundary conditions assigned in model layer 1 , which represents Aquifer Unit IIB Zone 2 (Water Table Aquifer). ..... 71

3.17. Boundary conditions assigned in model layer 3 , which represents Aquifer Unit IIB Zone 1 (Barnwell/McBean Aquifer). . . . 72

3.18. Boundary conditions assigned in model layer 5 , which represents Aquifer Unit IIA (Congaree Aquifer).

3.19. Hydrostratigraphic units exposed at 1 and surface, modified from Root (1987.). . . . . . . . 75

3.20. Grid-based representation of capped areas in the flow model. Some capped areas are not represented by any grid cells due to size of the cap relative to grid spacing. ..... 82

3.21. Gaging stations with available stream flow data. ..... 86

3.22. Values for vertical hydraulic conductivity for Confining Unit IIB1-IIB2 (Tan Clay, model layer 2) in the calibrated flow model.

3.23. Values for horizontal hydraulic conductivity for Aquifer Unit IIB Zone 1 (Barnwell/McBean, model layer 3 ) in the calibrated flow model.

3.24. Values for vertical hydraulic conductivity for confining Unit IIA-IIB (Congaree, model layer 4 ) for the calibrated flow mode1. . . . . . 108

3.25. Values for net recharge for the calibrated flow model. $\therefore 109$

3.26. Calibrated equipotential surface ( $\mathrm{ft} \mathrm{ms} 1$ ) for Aquifer Unit IIB Zone 2 (Water Table, model layer 1). . . . . . . . 110

3.27. Residuals (simulated minus measured water level, in $\mathrm{ft}$ ) for Aquifer Unit IIB Zone 2 (Water Table, model layer 1). . . . 111

3.28. Calibrated equipotential surface ( $\mathrm{ft} \mathrm{ms} 1$ ) for Aquifer Unit IIB

3.29. Residuals (simulated minus measured water level, in $\mathrm{ft}$ ) for $\cdots 112$

3. Aquifer Unit IIB Zone 1 (Barnwel1/McBean, model layer 3). . 114

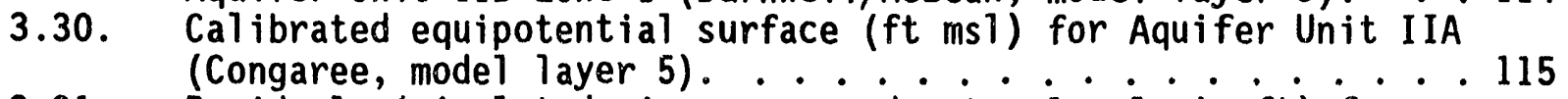

3.31. Residuals (simulated minus measured water level, in ft) for
Aquifer Unit IIA (Congaree, model layer 5). . . . . 116 
3.32. Line graph of measured versus simulated water-levels in Aquifer Unit IIB Zone 2 (Water Table, model layer 1). . . . . . . . . 117

3.33. Line graph of measured versus simulated water-levels in Aquifer Unit IIB Zone I (Barnwell/McBean, model layer 3). . . . . . 118

3.34. Line graph of measured versus simulated water-levels in Aquifer Unit IIA (Congaree, model layer 5). ............ 119

3.35. Histogram of residuals in all model layers. ......... . 121

3.36. Summary of mass balance for calibrated flow model. . . . . . . 122

3.37. Head change in Aquifer Unit IIB Zone 2 (Water Table, model layer 1) resulting from a 10 percent increase of Aquifer Unit IIB Zone 2 (Water Table, model layer 1) bulk model area horizontal hydraulic conductivity. . . . . . . . . . . 125

3.38. Head change in Aquifer Unit IIB Zone 2 (Water Table, model layer 1) resulting from a 10 percent increase of Aquifer Unit IIB Zone 1 (Barnwell/McBean, model layer 3) bulk model area horizontal hydraulic conductivity. . . . . . . . . . . 127

3.39. Head change in Aquifer Unit IIB Zone 1 (Barnwell/McBean, model layer 3) resulting from a 10 percent increase of bulk model area horizontal hydraulic conductivity for this unit. . . . . 128

3.40. Head change in Aquifer Unit IIB Zone 2 (Water Table, model layer 1) resulting from a 10 percent decrease of Confining Zone IIB1-IIB2 (Tan Clay, model layer 2) bulk model area vertical hydraulic conductivity. . . . . . . . . . . . . . . 129

3.41. Head change in Aquifer Unit IIB Zone 1 (Barnwe11/McBean, model layer 3) resulting from a 10 percent decrease of Confining Zone IIB1-IIB2 ( Tan Clay, model layer 2) bulk model area vertical hydraulic conductivity. ................ 130

3.42. Head change in Aquifer Unit IIB Zone 2 (Water Table, model layer 1) resulting from a 10 percent decrease of Confining Zone IIB1-IIB2 (Tan Clay, model layer 2) vertical hydraulic conductivity in the eastern portion of the model area. . . . . 131

3.43. Head change in Aquifer Unit IIB Zone 1 (Barnwell/McBean, model layer 3) resulting from a 10 percent decrease of Confining Zone IIB1-IIB2 (Tan Clay, model layer 2) vertical hydraulic conductivity in the eastern portion of the model area. . . . 132

3.44. Head change in Aquifer Unit IIB Zone 2 (Water Table, model layer 1) resulting from a 10 percent decrease of Confining Unit IIA-IIB (Green Clay, model layer 4) vertical hydraulic conductivity in the western model area. . . . . . . . . . . 134

3.45. Head change in Aquifer Unit IIB Zone 1 (Barnwell/McBean, model layer 3) resulting from a 10 percent decrease of Confining Unit IIA-IIB (Green Clay, model layer 4) vertical hydraulic conductivity in the western model area.

3.46. Head change in Aquifer Unit IIB Zone 2 (Water Table, model layer 1) resulting from a 10 percent decrease of Confining Unit IIA-IIB (Green Clay, model layer 4) vertical hydraulic conductivity in the north-central model area. . . . . . . . 136

3.47. Head change in Aquifer Unit IIB Zone 1 (Barnwel1/McBean, model layer 3) resulting from a 10 percent decrease of Confining Unit IIA-IIB (Green Clay, model layer 4) vertical hydraulic conductivity in the north-central model area. 
3.48. Head change in Aquifer Unit IIB Zone 2 (Water Table, model layer 1) resulting from a 10 percent decrease of Confining Unit IIA-IIB (Green Clay, model layer 4) vertical hydraulic conductivity in the south-central model area.

3.49. Head change in Aquifer Unit IIB Zone 1 (Barnwe11/McBean, model layer 3) resulting from a 10 percent decrease of Confining Unit IIA-IIB (Green Clay, model layer 4) vertical hydraulic conductivity in the south-central model area.

4.1. Simulated equipotentials in the vicinity of the MWMF in Aquifer Unit IIB Zone 2 (Water Table, model layer 1). . . . . . . . 143

4.2. Simulated equipotentials in the vicinity of the MWMF in Aquifer Unit IIB Zone 1 (Barnwe11/McBean, model layer 3). . . . . . . 144

4.3. Simulated equipotentials in the vicinity of the MWMF in Aquifer

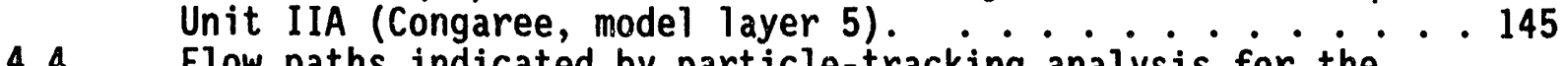

4.8. Flow paths indicated by particle-tracking analysis for the MWMF. 
viii

\section{LIST OF TABLES}

Page

3.1. Assumed creek widths assigned in the model (from J. Haselow, personal communication, 1992). . . . . . . . . . . 77

3.2. Depth of water in creeks assigned to the model....... .78

3.3. Observed water elevations for second quarter 1991 used for model calibration. . . . . . . . . . . . . . . . . 88

3.4. Wells with measured water-levels in second quarter 1991 removed from the calibration process. . . . . . . . . . . 98

3.5. Wells sampled multiple times in second quarter 1991. . . . . 100 3.6. Hydraulic parameters in the General Separations Area Model and their calibrated estimates. . . . . . . . . . . 105 
$\mathrm{ix}$

\section{LIST OF PLATES}

1. Locations with stratigraphic data, Confining Unit IIB1-IIB2 (Tan Clay).

2. Top elevations ( $\mathrm{ft}, \mathrm{ms}$ ) for Confining Unit IIB1-IIB2 (Tan Clay).

3. Thickness in $\mathrm{ft}$ for Confining Unit IIB1-IIB2 (Tan Clay).

4. Locations with stratigraphic data, Confining Unit IIA-IIB (Green Clay).

5. Top elevations ( $\mathrm{ft}, \mathrm{msl}$ ) for Confining Unit IIA-IIB (Green Clay).

6. Thickness in ft for Confining Unit IIA-IIB (Green Clay).

7. Water levels (second quarter 1991) Aquifer Unit IIB Zone II, used for model calibration.

8. Water levels (second quarter 1991) Aquifer Unit IIB Zone I, (Barnwe11/McBean) used for model calibration.

9. Water levels (second quarter 1991) Aquifer Unit IIA, (Congaree) used for model calibration. 


\section{INTRODUCTION}

\subsection{BACKGROUND}

The Savannah River Site (SRS) is a Department of Energy (DOE) facility located near Aiken, South Carolina. It is managed and operated by the Westinghouse Savannah River Company (WSRC). The General Separations Area (GSA) is a portion of SRS that is bounded to the north by Upper Three Runs Creek and to the south by Four Mile Branch (Figure 1.1). The GSA contains several sites which are undergoing environmental assessments and/or closure under State and Federal environmental regulations. These sites include the 01d Burial Ground (OBG), the Mixed Waste Management Facility (MWMF), the Low Level Radiation Waste Disposal Facility (LLRWDF), the proposed Hazardous Waste/Mixed Waste Facility (HW/MW), the proposed Burial Ground Expansion (BGE), F-Area acid/caustic basins, and the F- and H-Area seepage basins.

Assessment of groundwater flow rates and directions, potential contaminant transport times, and concentration of potential contaminants is required to determine current and future environmental effects resulting from releases by these facilities. Proposed closure actions and/or remedial alternatives also need to be evaluated. Numerical groundwater flow and solute transport models are a means of assessing the environmental effects on the groundwater system. They provide a logical method of integrating all available data into a consistent framework for quantitative analysis. The results of groundwater models can be used directly for input to management decisions and design/construct issues or can provide input into risk assessment models for site evaluations.

GeoTrans, Inc. was contracted by the Environmental Restoration Department of WSRC to develop a groundwater model of the entire GSA. Of particular interest is the area surrounding the MWMF as shown in Figure 1.2. The model developed in this phase of the study will be used to assess groundwater flow issues for the entire GSA. The second phase of the study will address contaminant transport issues specific to the area surrounding the MWMF. 


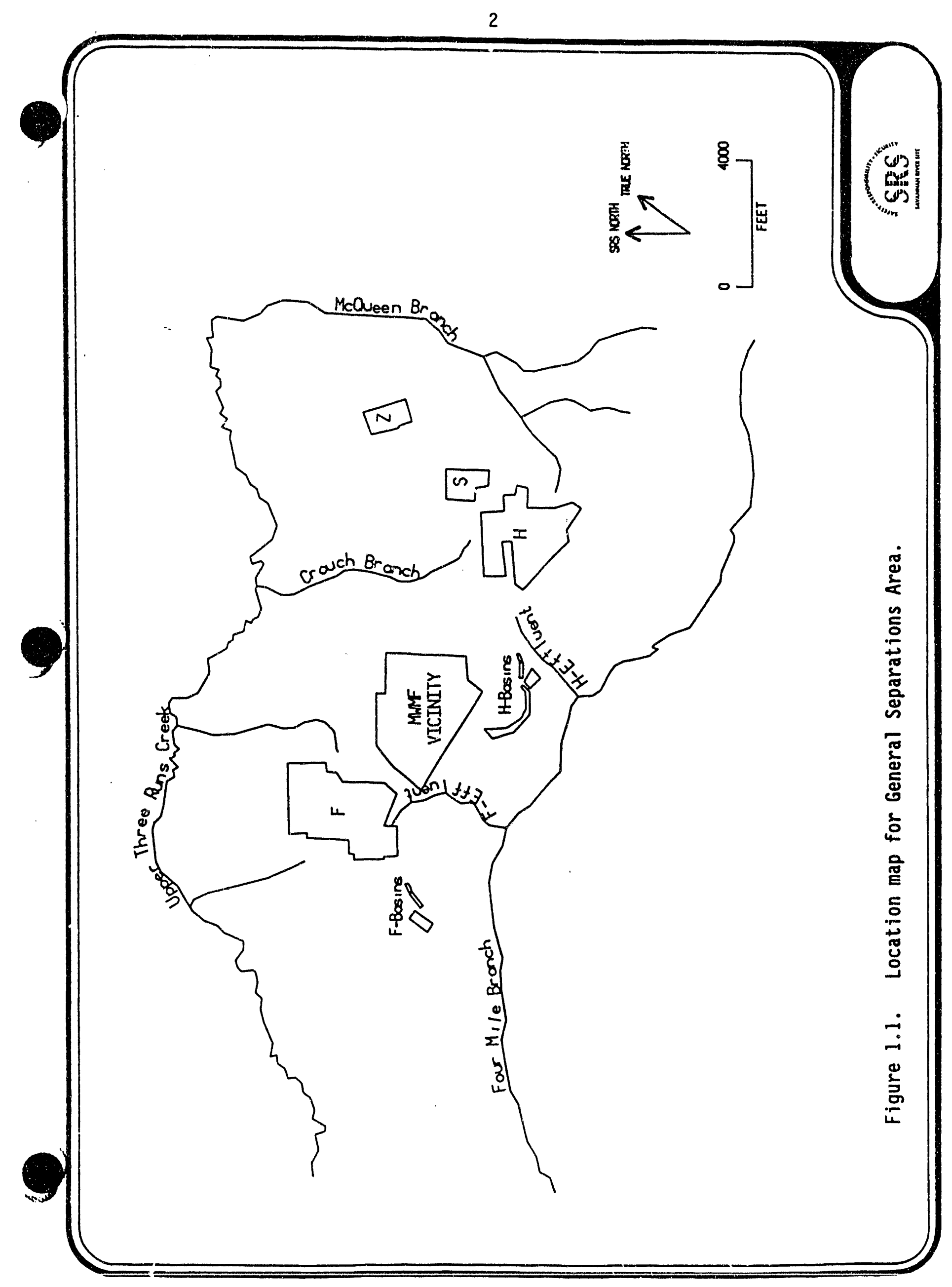




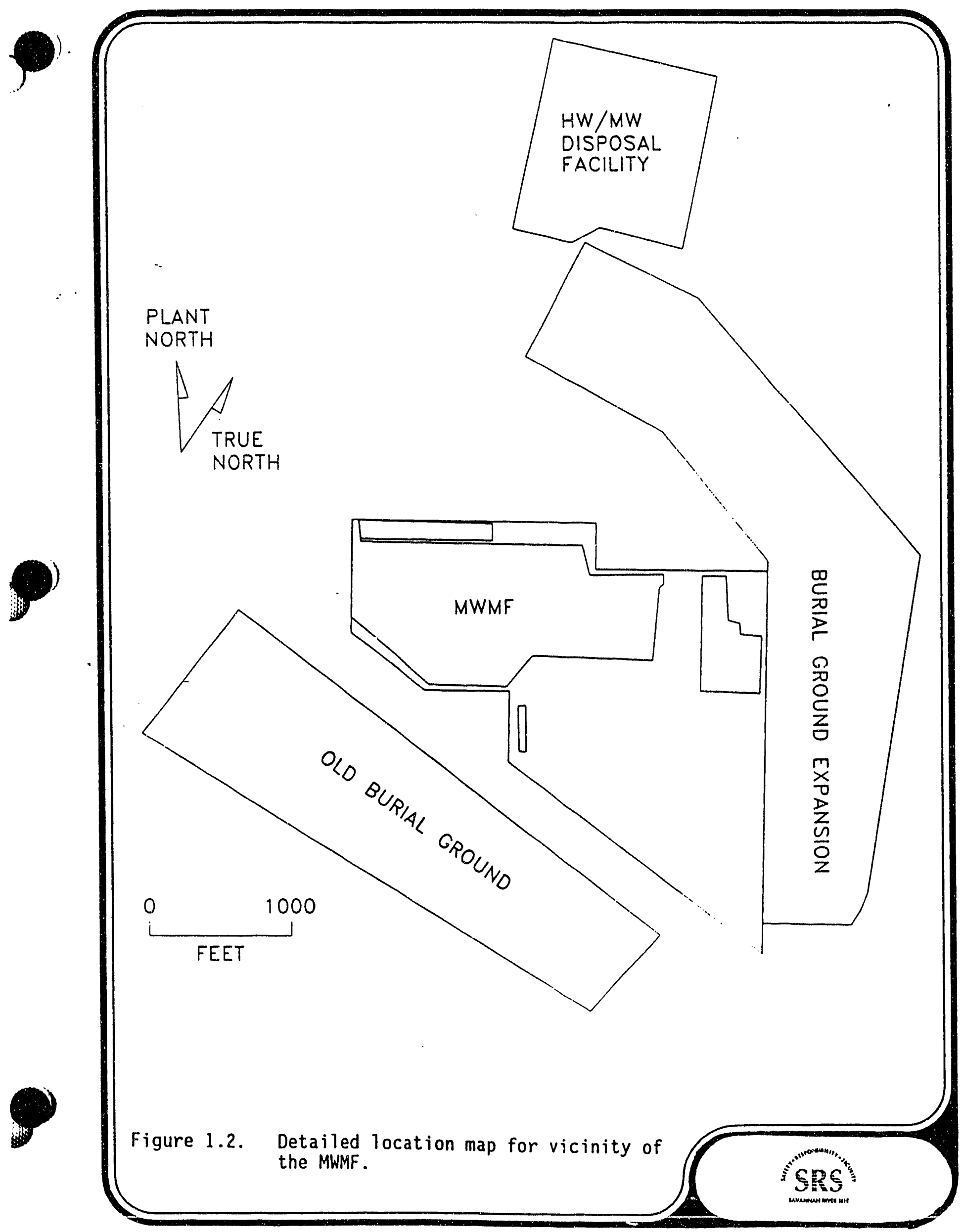


For simplicity, the remaining figures in this report will use the representation of the MWMF vicinity in Figure 1.1. Note that this tiundary incorporates both the MWMF and OBG.

\subsection{PREVIOUS INVESTIGATIONS}

Three-dimensional groundwater flow and solute transport models have been utilized since the mid $1980^{\prime}$ 's to investigate subsurface conditions in the General Separations Area. Modeling has been performed in support of environmental management programs for Environmental Impact Statements (EIS), RCRA, and CERCLA concerns.

Modeling of the groundwater flow system of the entire GSA has been performed by Parizek and Root (1986), Buss, et al. (1986), Duffield, et al. (1986), and Geraghty and Miller, Inc. (1990). These models are very similar in flow system conceptualization, data utilized, and model configuration. The Duffield, et al. (1986) study is essentially an update using an expanded data base of the Buss, et al. (1986) study. Both studies were conducted by GeoTrans which worked closely with Robert Root during his development of the Parizek and Root (1986) model. Similarity of these models is apparent in the boundary conditions, grid spacing; and aquifer parameters utilized. The Geraghty and Miller, Inc. (1990) model builds upon these studies by incorporating additional parameter zonation, adding explicit layers for one of the confining beds, and by including updated calibration targets. The grid resolution and conceptual model of the Geraghty and Miller, Inc. (1990) study are essentially the same as was used in the previous studies.

Groundwater flow modeling of specific sites within the GSA have also been conducted. This includes the F-Area seepage basins (GeoTrans 1988a; and GeoTrans 1990). The H-Area seepage basins (GeoTrans 1988b; and GeoTrans 1990) and the MWMF (Duffield et al., 1987). Except for the application to the MMMF, which used the Duffield et a1. (1986) model framework, subregional models of the specific sites were constructed. These models used boundary conditions derived from the Duffield et al. (1986) model to focus on the localized areas of interests. Extension to solute transport modeling has been made for investigations of the F-Area 
seepage basins (GeoTrans 1988c; and GeoTrans 1991), the H-Area seepage basins (GeoTrans 1988d; and GeoTrans 1991) and the MWMF (GeoTrans 1988e).

\subsection{PURPOSE OF THE STUDY}

The site-specific models described previousiy are capabie of addressing more localized hydrogeological and management issues, such as preferential seepage, effects of low permeability caps, seepline locations, etc., than the regional model. This is primarily due to the grid resolution which is used. Because boundary conditions are derived from results of the regional model, these site-specific models have a dependence on the regional model which is often difficult to resolve. This dependence becomes apparent when localized changes to the hydrogeologic system represented in the site-specific model propagate to the boundaries of the model. Because the boundary is usually an assigned head (as opposed to a natural regional boundary such as a river), the analyst is faced with the dilemma of assigning a head which is not known a-priori. Even when stresses do not propagate to the boundaries, the site-specific model boundary assignments should change with time due to climatic variation and stresses external to the system. Again, the analyst is faced with the dilemma of having to assign a head which is not known a-priori. In order to be technically correct and accurate, the regional model should be run to develop new boundaries for the subregional or site-specific models.

In addition to the hydrologic changes to the groundwater system that have occurred in the past six years, the geologic interpretation and data base have changed dramatically. An aggressive drilling program and data collection system have provided considerably more detail in the description of aquifer geometry and hydraulic characteristics. The water-level data base, for example, now contains 394 locations with water levels useful for model calibration within the GSA, compared to only 50 locations in 1986.

During the past six years changes have also occurred in groundwater modeling technology. Computers are much faster; larger and more complex problems can be handled. Graphical techniques of developing model input and checking for data consistency have been developed. Data management programs may be used to transfer data directly to the models without time consuming manual manipulations. 
Because of the following three factors: (1) the realization that the site-specific models cannot be accurately updated without updating the regional mode1; (2) the changes to the geologic interpretation and data base; and (3) changes in modeling and data management technologies, it was decided to update the regional General Separations Area model to provide a state-of-the-art groundwater management and assessment tool. Results of the model will be used to perform a site-specific evaluation of flow near the MWMF and eventually, to evaluate solute transport from the $O B G$, MWMF, LLRWDF, the proposed HW/MW, and the proposed BGE.

\subsection{METHOD OF INVESTIGATION}

The development of groundwater flow and soluce transport modeling was conducted in two phases. Phase I consisted of updating the regional model of the GSA. Phase II will involve developing and updating a solute transport model of the sites designated above. This report covers Phase I, which is limited to groundwater flow simulation.

The groundwater modeling study consisted of: (1) incorporation of available data into the model; (2) assessing, reviewing, and modifying the current conceptual model of the GSA; (3) recalibrating the groundwater flow model; (4) evaluating data for incorporation into the model as they became available; (5) preparing and presenting a draft report on the modeling; and (6) producing a final copy of the report, based on WSRC comments.

In addition to data already utilized in the existing data base, new data on stratigraphic layering, water levels, hydraulic properties, special geologic and hydrologic features, and stream data were assembled and incorporated into a series of data bases. This effort is documented in GeoTrans (1992). In all cases data were input in such a way that it could be assessed by a Geographic Information System (GIS), which allows manipulation and assessment of data in a graphical environment. The previous conceptual model of the GSA was assessed and modified using the newly created data base and GIS techniques. The update included incorporating stratigraphic elevation and thickness variations, confining bed properties, hydraulic property variation, areal extent of aquifers, and seeplines. Special features, such as carbonate zones and faults/slumps 
were implicitly accounted for in the model by their representation in the confining beds as thickness or hydraulic conductivity variations.

The model was recalibrated to match observed hydraulic heads and gradients within the GSA. A semi-automatic history matching technique was utilized to assist in the calibration. Qualitative considerations were also used in the calibration effort to reduce bias towards matching areas of abundant data at the expense of less data-rich areas.

Data were added and revised throughout the calibration effort. Additional data for areas away from the MWMF were requested and received from SRS. Updates to geologic interpretations were also made throughout the study. To ensure project focus and that time schedules were being met, project coordination meetings were held at project inception (September 5, 1991) at WSRC offices in Augusta, Georgia and on November 14, 1991 and February 20, 1992 in GeoTrans offices in Sterling, Virginia.

This report constitutes the final report submittal, which incorporates comments by WSRC following their review of a draft report and a presentation of the groundwater flow model in North Augusta, South Carolina on Apri1 13, 1992. 


\section{HYDROGEOLOGIC FRAMEWORK}

Available geologic and hydrologic data on the GSA are summarized in this section. Data were obtained from a variety of sources including U.S. Geological Survey reports, SRS documents and data bases, and consultant reports prepared for SRS. This information is the basis for construction and calibration of the three-dimensional groundwater flow model of the GSA. The discussion is subdivided into five parts: (1) geologic setting (2) hydrostratigraphic framework and units, (3) hydraulic properties, (4) source and sink terms, and (4) potentiometric levels.

\subsection{GEOLOGIC SETTING OF THE STUDY AREA}

SRS is situated in the Upper Atlantic Coastal Plain Province on what is locally known as the Aiken Plateau. In general, the elevation of this plateau varies from 270 to $400 \mathrm{ft}$ above mean sea level (ms 1). Numerous streams have dissected this plateau into broad interstream uplands with narrow, steep-sided valleys. This is of primary importance to local groundwater flow systems because it creates hydrologically isolated areas within the groundwater flow system. In the GSA, these isolated areas are bounded by second and third order streams including Upper Three Runs Creek and Four Mile Branch. The geologic units consist primarily of unconsolidated interbedded gravels, sands, silts, and clays (including some carbonates) that are deposited upon a sloping crystalline basement and/or Triassic bedrock. This wedge of sediments exhibits a gentle dip and a general increase in thickness to the southeast. The geologic units range from Cretaceous to Recent in age. Some units display variable thickness and limited areal extent. As a whole, the sequence of units acts as a multi-aquifer groundwater system with significant vertical leakage between the aquifers and complex stream-aquifer interactions.

\subsection{HYDROSTRATIGRAPHIC FRAMEWORK AND UNITS}

The hydrogeology of SRS and the GSA has been described in numerous sources (Siple, 1967; Colquhoun, 1983; Price et al., 1988; Parizek and Root, 1986; Bledsoe, 1988; and Aadlarid, 1990). The definition of stratigraphic and hydrostratigraphic units varies from source to source. 
The most recent classification system proposed by SRS (Aadland, 1990) recognizes two major aquifer systems in the GSA (SRS, 1990) and is presented in Figure 2.1. The lowermost aquifer system, referred to as Aquifer System I, is regional in nature and includes the Middendorf Formation, the $\mathrm{Black}$ Creek Formation, and the Pee Dee Formation. These formations are of Cretaceous age and consist of beds of sands, silts, and clays. Aquifer System I is further subdivided into aquifer zones and confining zones depending upon hydraulic properties. This system serves as a major source of water for SRS and the region.

Confining System I-II separates Aquifer System I from Aquifer System II (Figure 2.1). Greater than $100 \mathrm{ft}$ thick, it is comprised of the Ellenton Clays. Hydraulically, it restricts flow between Aquifer System I and Aquifer System II.

Because of relative hydrologic isolation, only the uppermost system of the two major aquifer systems is of interest for contamination studies. This aquifer system, referred to as Aquifer System II, is broken into individual units and further subdivided into zones. These units and zones primarily relate to hydrogeological characteristics. The units and zones which comprise the aquifer system are as follows:

\begin{tabular}{|c|c|}
\hline Nomencl ature of Aadl and (1990) & Common Nomenclature \\
\hline \multicolumn{2}{|l|}{ Aquifer System II } \\
\hline Aquifer Unit IIB Zone 2 & Water Table Aquifer \\
\hline Confining Unit IIB1-IIB2 & Tan Clay \\
\hline Aquifer Unit IIB Zone 1 & Barnwel1/McBean Aquifer \\
\hline Confining Unit IIA-IIB & Green Clay \\
\hline Aquifer Unit IIA & Congaree Aquifer \\
\hline Confining System I-II & Ellenton Clays \\
\hline
\end{tabular}

The areal distribution of the hydrostratigraphic units in the GSA is presented in Figure 2.2. This map is based upon structure contour elevations of Confining Zone IIBI-IIB2 (Tan Clay) and Confining Unit IIAIIB (Green Clay). The outcrop location between sediments comprising Aquifer Unit IIB Zone 1 (Barnwe11/McBean) and Aquifer Unit IIB Zone 2 (Water Table) is inferred from drilling information. As illustrated, most 


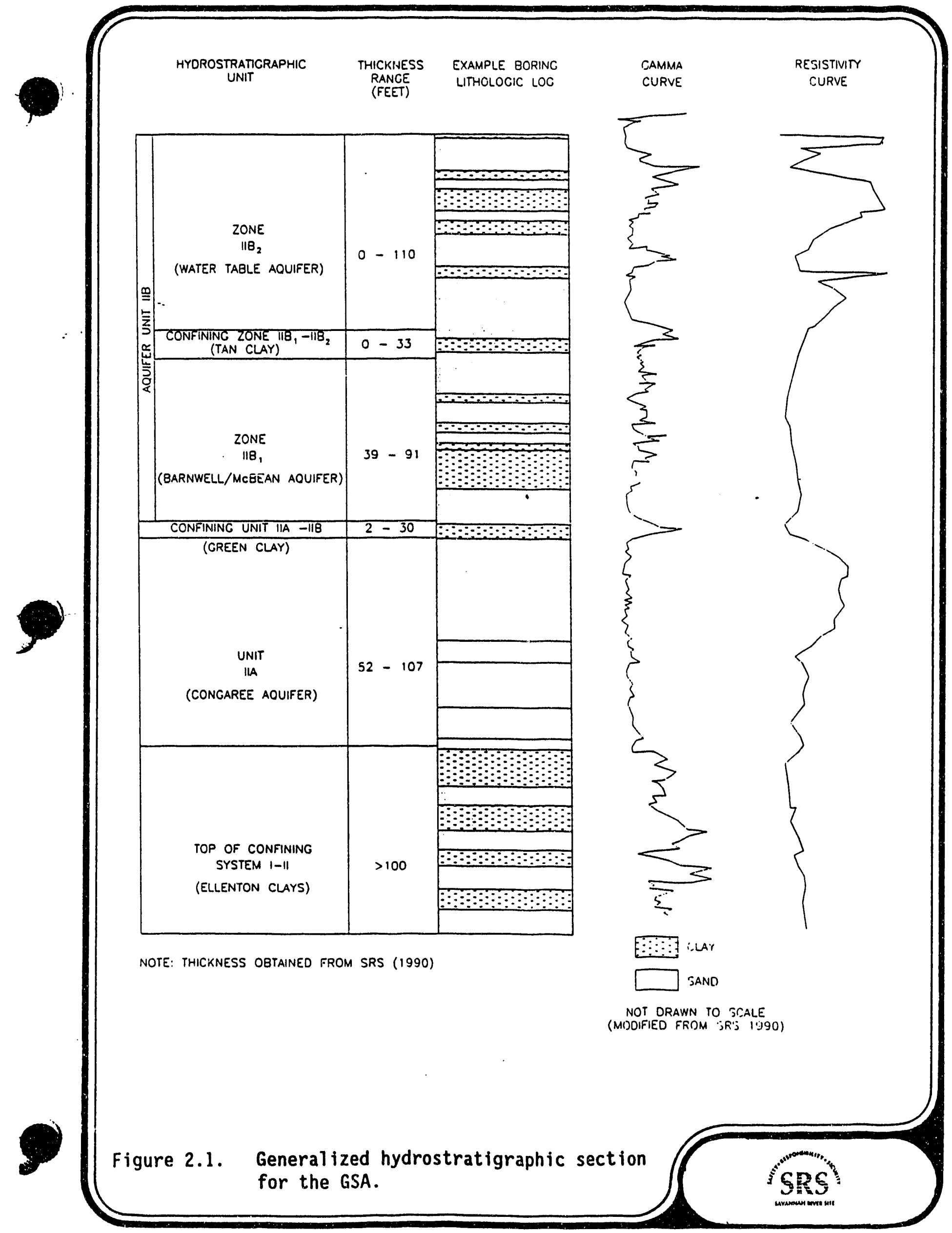




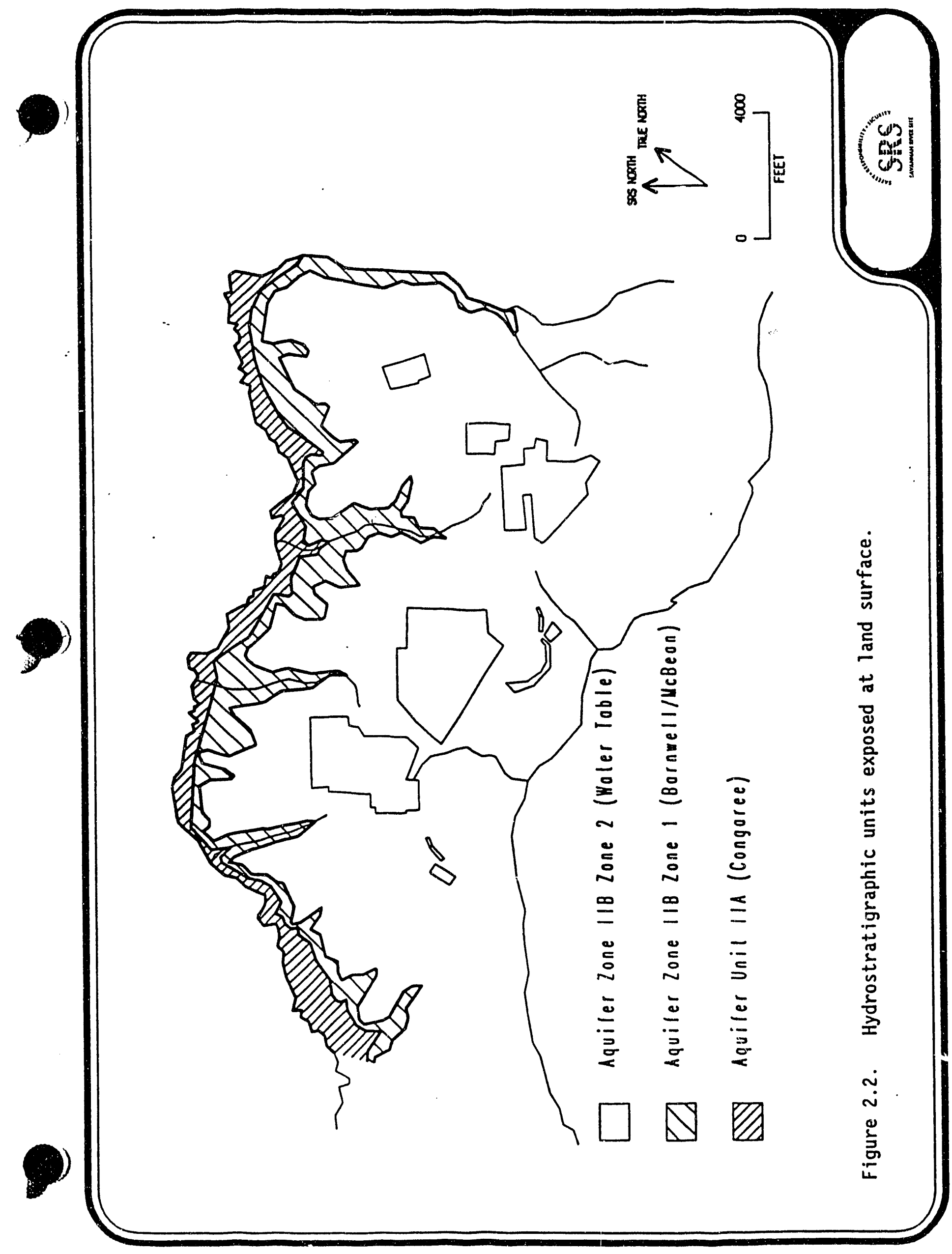


of the area is immediately underlain by Aquifer Unit IIB Zone 2 (Water Table). Aquifer Unit IIB Zone 1 (Barnwell/McBean) and Aquifer Unit IIA (Congaree) crop out in the deeply-incised Upper Three Runs Creek valley. Confining System I-II (Ellenton Clays) is continuous in the subsurface beneath the GSA. The following discussion of the lithologic characteristics of the hydrostratigraphic units in the GSA is largely taken from the RCRA Part B Closure Care Document for F- and H-Areas prepared by SRS (1990).

\subsubsection{Confining System I-II (Ellenton Clays)}

Confining System I-II is a silty to sandy lignitic, micaceous clay interbedded with fine to coarse quartz sand. Individual layers of clays, silts, and sandy clays range in thickness from 2 to $22 \mathrm{ft}$. Individual layers of clayey sands and sands range in thickness from 1 to $15 \mathrm{ft}$. Clay and silt lenses of Confining System I-II (Ellenton Clays) consist of buff and light gray to black $\mathrm{clay}$ and sandy $\mathrm{clay}$. The interbeds of clayey sands and sands are generally fine to coarse grained and range from moderate to very poorly sorted. Grains are sub-angular to angular.

Confining System I-II (Ellenton Clays) attains a thickness of over $100 \mathrm{ft}$ in the GSA. The unit appears to occur no further northwest than the northwest boundary of SRS where it is about $40 \mathrm{ft}$ in thickness.

Regionally, the unit thickens toward the southeast.

The high mica and kaolinite content of the Confining System I-II (Ellenton Clays) sediments result in uniformly distinct, natural gamma ray curve spikes typical of clays (Figure 2.1). These spikes are very conspicuous in the borings that penetrate Confining System I-II (Ellenton Clays) in the GSA.

\subsubsection{Aquifer Unit IIA (Congaree Aquifer)}

Aquifer Unit IIA unconformably overlies Confining System I-II (Ellenton Clays) and ranges from 52 to $107 \mathrm{ft}$ thick within the GSA. The unit dips at 8-9 ft per mile to the south and southeast. Additionally, the unit thickens in the western portion of the GSA and to a minor extent, thickens to the southeast. Present data indicates a minor thinning of this aquifer under the MWMF. 
Clayey layers are encountered to some degree at all depths throughout the formation. However, by far the majority of such layers occur below an elevation of about $80 \mathrm{ft} \mathrm{msl}$ which corresponds to the lower and middle portions of the formation. The unit consists predominantly of sands and clayey sands with small interbeds of sandy clays, clays, and calcareous sands. The sands and clayey sands range in thickness from 2 to $84 \mathrm{ft}$ while the sandy clays and clays range in thickness from 1 to $9 \mathrm{ft}$. Calcareous sands range in thickness from 2 to $3 \mathrm{ft}$. Sands and clayey sands of Aquifer Unit IIA (Congaree) are largely yellow to orange in color and consist of fine to coarse grained, subangular to subrounded quartz. The sands vary from well to poorly sorted.

Aquifer Unit IIA (Congaree) typically exhibits a natural gamma ray curve normally associated with clean sands (Figure 2.1). The contact between Aquifer Unit IIA (Congaree) and Confining System I-II (Ellenton Clays) is readily apparent on the $\log$ as transition occurs from clean sands to clayey/silty sediments.

\subsubsection{Confining Unit IIA - IIB (Green Clay)}

Confining Unit IIA-IIB separates Aquifer Unit IIA and Aquifer Unit IIB. This confining unit is locally known as the Green Clay. Recent investigations have indicated that this unit is comprised of several lenses of green clay that thicken, thin, and pinch out abruptly. Thickness can be variable, from $2 \mathrm{ft}$ to $30 \mathrm{ft}$. Although Confining Unit IIA-IIB (Green Clay) does not always appear during drilling to be a significant geologic feature, wells screened above and below the layer routinely have very different hydraulic heads. Thus, Confining Unit IIA-IIB (Green Clay) retards downward vertical leakage from Aquifer Unit IIB Zone 1 (Barnwe11/McBean) into Aquifer Unit IIA (Congaree). The unit is thin to the west and southeast, becoming thicker to the north. Structural lows in the unit tend to correspond to areas of carbonate accumulation in the overlying sediments. In addition, the clays of the unit thin or truncate in these areas.

Confining Unit IIA-IIB (Green Clay) consists predominantly of clays, sandy clays, and clayey sands. Locally, beds of calcareous mud contribute significant thickness to the unit. Minor interbeds of sands are also 
present. The clay and sandy clay lenses in the unit range in thickness from 2 to $12 \mathrm{ft}$. The clayey sand beds range in thickness from 1 to $14 \mathrm{ft}$. Calcareous muds range in thickness from 3 to $11 \mathrm{ft}$ and the sand beds range in thickness from 1 to $6 \mathrm{ft}$.

The clayey sands are generally moderately to poorly sorted with grain sizes ranging from medium to very coarse. They are described as light tan to orange in color, fine to very fine grained, well sorted and occasionally indurated. Grains are usually subangular and in some layers cemented with silica.

The dark green clay facies of Confining Unit IIA-IIB (Green Clay) exhibits a distinct natural gamma ray signature (Figure 2.1). A large spike on the gamma curve makes this unit easily distinguishable from the overlying and underlying sediments.

\subsubsection{Aquifer Unit IIB Zone 1 (Barnwell/McBean)}

Aquifer Unit IIB Zone 1 (Barnwell/McBean) overlies Confining Unit IIA-IIB (Green Clay) and underlies Confining Zone IIBI-IIB2 (Tan Clay). This zone ranges in thickness from 39 to $91 \mathrm{ft}$. It thins toward the western portion of the GSA, in the vicinity of the F-Area Seepige Basins. Thickening of the zone occurs to the southeast, in the vicinity of the $\mathrm{H}$ Area Seepage Basins. Aquifer Unit IIB Zone 1 (Barnwe11/McBean) dips of approximately 8 to $9 \mathrm{ft}$ per mile to the southeast.

This aquifer zone consists predominantly of sand and clayey sand sequences with localized zones of abundant calcareous sands, sandy and muddy limestones, and limestones. Minor interbeds of clay and sandy clay are also present. Sands and clayey sands within the zone range in thickness from 2 to $60 \mathrm{ft}$. Calcareous sands range in thickness from 2 to $33 \mathrm{ft}$. Sandy and muddy limestones, and 1 imestones range in thickness from 3 to $30 \mathrm{ft}$.

The sand and clayey sand beds are generally yellow to tan, occasionally greenish brown to light brown. The sand is fine to coarse grained, moderately to well sorted, and generally subangular. The calcareous sands are white to buff in color and contain up to 50 percent calcareous materials. The sandy and muddy limestones and limestones are white to buff in color and contain greater than 80 percent calcareous 
material. The interbeds of the clays and sandy $\mathrm{clays}$ in this unit are light tan to orange in color. Sand is quartz, fine to medium grained, subangular, and well to moderately sorted.

Sirrine, Inc. (1991a) indicates that in the MWMF vicinity of the GSA, Aquifer Unit IIB Zone 1 (Barnwe11/McBean) can be subdivided into an upper and a lower zone. The lower zone ranges from a partially indurated limestone to a pale olive to white fossiliferous silt or clay. The upper portion is characterized as a yellowish orange to light brown, fine to coarse, silty/clayey sand.

The calcareous sands and limestones contained within Aquifer Unit IIB Zone 1 (Barnwe11/McBean) are generally not recognizable on natural gamma curves in the GSA.

\subsubsection{Confining Zone IIB1-IIB2 (Tan Clay)}

Consisting of multiple, discontinuous clay layers, this confining zone separates underlying Aquifer Unit IIB Zone 1 (Barnwell/McBean) from overlying Aquifer Unit IIB Zone 2 (Water Table). The two aquifer zones are in direct contact where this confining zone is absent. Thickness varies from 0 to $33 \mathrm{ft}$. Confining Zone IIBI-IIB2 (Tan Clay) is not always clearly observed during drilling. Where the zone is present in the GSA, however, head differences between wells screened above and below the zone range from 3 to $5 \mathrm{ft}$.

At several locations within the GSA, the zone is absent as evidenced by the lithologic and hydraulic data from these areas. The zone was not observed in a group of wells east of the MWMF and in an area west of the FArea Seepage Basins. Minor gaps in the confining zone were identified from the lithologic data from the vicinity of the H-Area Seepage Basins. El sewhere within the GSA the zone thickens and thins abruptly.

Confining Zone IIB1-IIB2 ( $\operatorname{Tan} \mathrm{Clay}$ ) consists predominantly of clays and sandy clays with minor to equal interbeds of clayey sands and sands. Calcareous sand occurs within the zone at some locations at the MWMF. Clays and sandy clays range in thickness from 1 to $11 \mathrm{ft}$. Clayey sands and sands range in thickness from 1 to $8 \mathrm{ft}$. Where present, the calcareous sand is approximately $2 \mathrm{ft}$ thick. 
The clays, clayey sands, and sands within Confining Zon: IIBI-IIB2 (Tan Clay) are light tan to light orange in color. The sands are predominantly medium to coarse grained with a moderate degree of sorting. Grain size tends to coarsen upward. The calcareous sand is composed of shell fragments and fine grained subrounded quartz sand in a clay matrix.

The thicker clays within the confining zone exhibit a natural gamma spike typical of clays. However, natural gamma spikes may also be related to concentrations of heavy minerals.

\subsubsection{Aquifer Unit IIB Zone \& (Water Table)}

Aquifer Unit IIB Zone : (Water Table) is the uppermost aquifer. Although sometimes referred to as the "Water Table Aquifer", it is defined stratigraphically, not by degree of saturation. In portions of the GSA this aquifer is completely cesaturated. It overlies Confining Zone IIBIIIB2 (Tan Clay) where the confining zone is present and Aquifer Unit IIB Zone 1 (Barnwe11/McBean) where the confining zone is absent. This aquifer zone attains a maximum thickness of $110 \mathrm{ft}$ within the GSA. The aquifer zone ranges from 0 to $66 \mathrm{ft}$ in thickness along Four Mile Branch which partially ir.cises it within the GiA. Additionally, the aquifer zone dips at a rate of 8 to $9 \mathrm{ft}$ por mile to the southeast.

Aquifer Urit IIB Zone 2 (Water Tabie) consists predominantly of sands and $c l$ ayey sands with lesser or equal mounts of clay and sandy clay. Gravel and pebble layers occur localiy. The sands and clayey sands within the zone range in thickness from 2 to $107 \mathrm{ft}$ while the clays and sandy clays range in thickness from 1 to $18 \mathrm{ft}$. Gravel and pebble layers range in thickness from 1 to $5 \mathrm{ft}$.

Sands and clayey sands are tan to red to purple and are often highly variegated in color. Sands are fine to very cojarse, subangular to angular and moderately to poorly sorted.

The unit is difficult to correlate on geophysical data alone. As in Confining Zore IIBI-IIB2 (Tan (lay) the natural gamma spikes resembling clays may be attributed to concentrations of heavy minerals. 


\subsubsection{Conceptualization of the Hydrostratigraphic Framework}

The package of sediments considered in this investigation has been broadly subdivided into a series of aquifers and confining layers. As was noted in the lithologic descriptions of the hydrostratigraphic units, however, the aquifers frequently contain clay interbeds while the confining layers are indicated to include interbeds of quartz sand. Additionally, SRS (1990) report that slump-fault features are common in the GSA.

Development of the regional flow model of the GSA necessitates the generalization of this complex hydrostratigraphic framework into a relatively few model layers. The process by which this is achieved is described later in this report.

\subsection{HYDRAULIC PROPERTIES OF HYDROSTRATIGRAPHIC UNITS}

Four basic methods are generally utilized to determine the hydraulic properties of aquifer materials. These are: (1) laboratory tests; (2) slug tests; (3) single and multiple well aquifer tests; and (4) numerical modeling. Each method measures properties of a volume of aquifer that is limited to the area influenced by the test. For example, laboratory tests on soil core samples are performed using either constant head or falling head permeameters. Permeabilities measured using this method are strictly valid only for the specific soil volume tested. Slug tests provide a means for measuring permeability from a single well without the extraction of groundwater from the formation. This measurement, however, has an effective radius limited to a cylinder of only several feet in diameter around the submerged portion of the well screen. These tests can be influenced by well construction factors.

Long-term aquifer tests measure a larger effective volume of the aquifer. The hydraulic properties derived for an aquifer test are typical for an area which is limited by the duration of the test, pumping rate, and hydraulic properties that determine the cone of influence. Normally, this effective volume is measured in tens to hundreds of feet. The properties determined from the test represent the bulk behavior of the aquifer within the cone of influence. The fourth method, numerical modeling, is sometimes utilized to estimate regional aquifer properties. For this method, aquifer parameters are adjusted within reasonable bounds in a model of the flow 
system until a satisfactory match is obtained between modeled and actual hydraulic heads. The ability of the model to match heads is assumed to. result from an accurate quantification of aquifer parameters. The model estimates represent the bulk average properties of the aquifer for the given size of the parameter zones or the extent of the mode1. The properties derived from various test methods will be typical of a distance of several inches to several miles. Thus, these four methods of parameter estimation are extremely scale dependent and can yield markedly different permeability results for the same formation material. Aquifer permeability data from the study area are predominantly in the form of slug test results.

Aquifer parameters, particularly the hydraulic conductivity distribution, control hydraulic heads and groundwater velocities. Hydraulic parameter data for each of the hydrostratigraphic units present in the GSA are discussed below. This discussion is a summary of the information presented in SRS (1990), Evans and Parizek (1991), Sirrine (1991a), Sirrine (1991b), Westinghouse (1990) and other documents which were reviewed in GeoTrans (1992). For each hydrostratigraphic unit, hydraulic conductivity data are summarized for the following areas within the GSA: the F-area seepage basins, the $\mathrm{H}$-area seepage basins, the MWMF, the Burial Grounds Expansion, the HW/MW Disposal Facility, and the Waste Solidification and Disposal Facility near $Y$-area.

Slug tests on Aquifer Unit IIA (Congaree) wells in F-area exhibit a range in hydraulic conductivity from 0.33 to $0.85 \mathrm{ft} / \mathrm{d}$ and average 0.59 $\mathrm{ft} / \mathrm{d}$. Hydraulic conductivity in $\mathrm{H}$-area ranges from 0.16 to $12 \mathrm{ft} / \mathrm{d}$ and average $6.98 \mathrm{ft} / \mathrm{d}$. In the MWMF, hydraulic conductivity ranges form 0.5 to $12 \mathrm{ft} / \mathrm{d}$ and average $4.42 \mathrm{ft} / \mathrm{d}$ (SRS, 1990). Sirrine (1991a) estimated hydraulic conductivity near the Burial Grounds Expansion to be $1.83 \mathrm{ft} / \mathrm{d}$ from a slug test. These values may be contrasted to an aquifer test north of $\mathrm{H}$-area which yielded a transmissivity range of 2000 to $2290 \mathrm{ft}^{2} / \mathrm{d}$. This corresponds to a hydraulic conductivity range of 30.8 to $35.2 \mathrm{ft} / \mathrm{d}$, assuming a thickness of $65 \mathrm{ft}$ (CH2M Hill, 1989). Westinghouse (1990) obtained a transmissivity range of 2700 to $2800 \mathrm{ft}^{2} / \mathrm{d}$ near $Y$-area. Hydraulic conductivity data obtained from this test ranged from 22 to 62 $\mathrm{ft} / \mathrm{d}$. 
Laboratory permeability tests on Confining Unit IIA-B (Green Clay) in the entire GSA give a range in vertical hydraulic conductivity of $3.8 \times 10^{-6}$ to $2.7 \times 10^{-3} \mathrm{ft} / \mathrm{d}$ (SRS, 1990). Sirrine (1991a) report a range in vertical hydraulic conductivity from $1.8 \times 10^{-5}$ to $1.3 \times 10^{-4} \mathrm{ft} / \mathrm{d}$ from laboratory test on undisturbed samples located near the Burial Grounds Expansion. Three core samples were obtained from the HW/MW disposal facility and subjected to laboratory determinations of hydraulic conductivity. Vertical hydraulic conductivities derived from the tests were $1.33 \times 10^{-6}, 1.13 \times 10^{-6}$, and $1.90 \times 10^{-3} \mathrm{ft} / \mathrm{d}$. Near Y-area Westinghouse (1990) obtained vertical hydraulic conductivity values that range from $2.6 \times 10^{-6}$ to $1.4 \times 10^{-3} \mathrm{ft} / \mathrm{d}$.

As discussed in the previous section, Confining Unit IIA-IIB (Green Clay) is characterized as including substantial thicknesses of carbonate sediment. Figure 2.3 indicates the distribution and thickness of the carbonate sediments classified by SRS $(1990,1992)$ as belonging to this unit. Lithologically these sediments are described as calcareous muds, clayey limestone, and muddy limestone. Hydraulic conductivity data that is characteristic specifically of the Green Clay carbonate materials is unavailable.

Hydraulic conductivity estimates for Aquifer Unit IIB, Zone 1 (Barnwe11/McBean) for four wells near the HW/MW disposal facility were determined from constant head inflow tests, falling head inflow tests, and for two wells from rising head slug tests (Sirrine, 1991b). The constant head tests gave a range of 7.48 to $50.7 \mathrm{ft} / \mathrm{d}$, the falling head tests gave a range of 0.03 to $0.91 \mathrm{ft} / \mathrm{d}$, while the slug tests gave a range of 0.26 to $4.14 \mathrm{ft} / \mathrm{d}$ for the Bouwer and Rice method of analysis. Sirrine (1991b) comment that the results of the siug tests should be considered most reliable due to the proven status of the testing and analytical methods. Hydraulic conductivity data derived from slug tests in F-Area exhibit a range of values varying from 0.14 to $24.0 \mathrm{ft} / \mathrm{d}$, and averaging $3.77 \mathrm{ft} / \mathrm{d}$. Similarly, in H-Area, the range is from 0.25 to $136 \mathrm{ft} / \mathrm{d}$ with an average of $12.9 \mathrm{ft} / \mathrm{d}$. Based on slug test results from seven wells installed in the MWMF, Sirrine, Inc., (1991a) indicate that hydraulic conductivity values range from 0.34 to $20.38 \mathrm{ft} / \mathrm{d}$ and average $3.69 \mathrm{ft} / \mathrm{d}$ for the upper portion of Aquifer Unit IIB Zone 1 (Barnwell/McBean). 


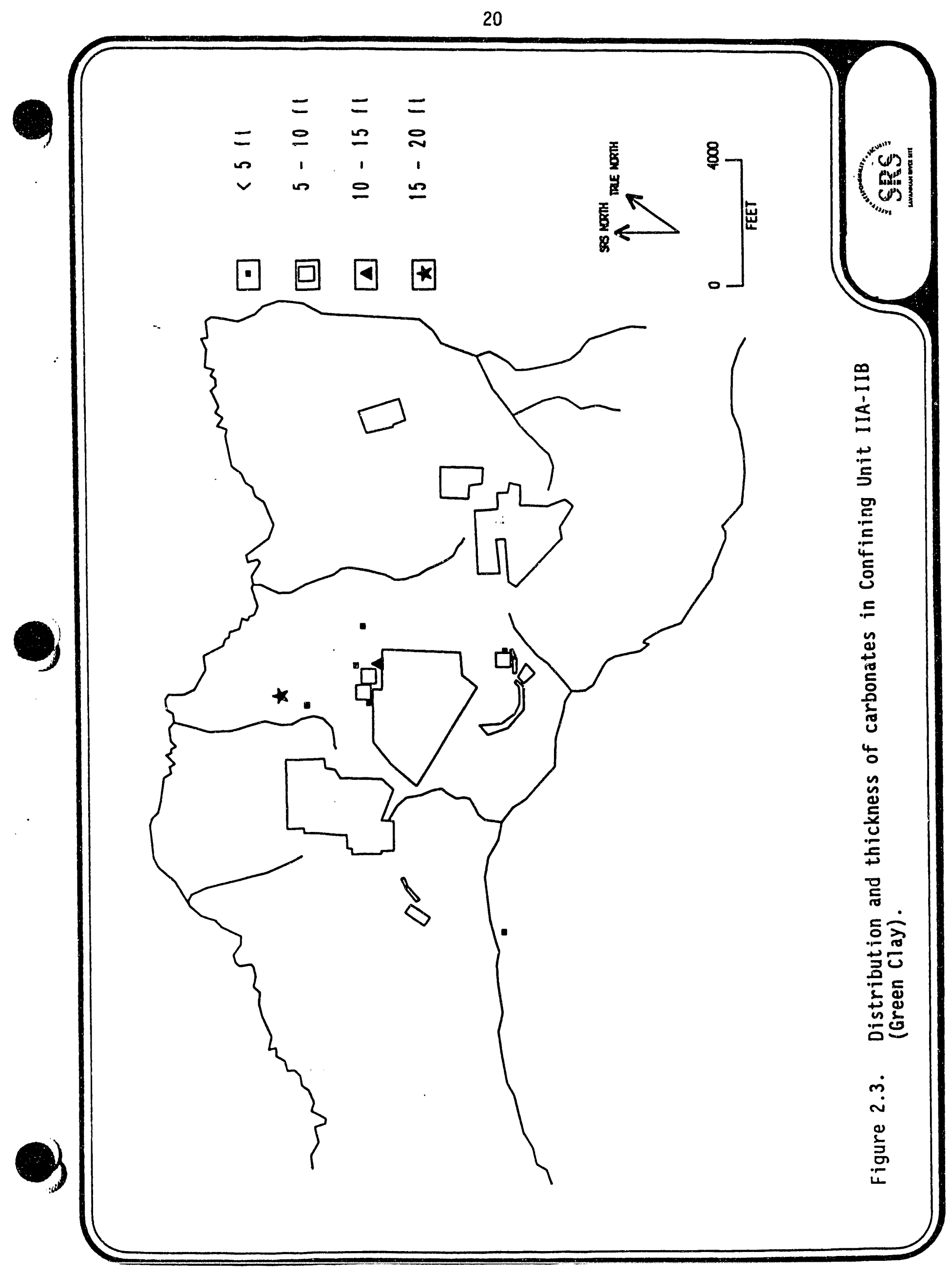


Westinghouse (1990) report hydraulic conductivities in the range of 1.3 to $2.5 \mathrm{ft} / \mathrm{d}$ near $\mathrm{Y}$-area, derived from slug tests. Parizek and Root (1986). conducted 51 single well pump tests in the GSA for this aquifer zone. They derived a range of 0.17 to $2.6 \mathrm{ft} / \mathrm{d}$ for hydraulic conductivity. A median value of $0.9 \mathrm{ft} / \mathrm{d}$ was obtained. SRS (1990) conducted an aquifer test in Farea which yielded a hydraulic conductivity of 10 to $12 \mathrm{ft} / \mathrm{d}$. Evans and Parizek (1991) conducted seven single well constant discharge aquifer tests in this aquifer. They obtained hydraulic conductivities ranging from 0.27 to $130.0 \mathrm{ft} / \mathrm{d}$, with a median value of $1.67 \mathrm{ft} / \mathrm{d}$.

The distribution and thickness of the carbonate sediments in Aquifer Unit IIB Zone 1 (Barnwe11/McBean) are summarized on Figure 2.4. Siug test results obtained by Sirrine, Inc., (1991a) indicate that the carbonate materials of Aquifer Unit IIB Zone 1 (Barnwe11/McBean) in the vicinity of the MWMF have a hydraulic conductivity of $0.21 \mathrm{ft} / \mathrm{d}$.

The hydraulic properties of Confining Unit IIB1-IIB2 (Tan Clay) are derived primarily from laboratory tests. Four core samples taken in F-Area yielded vertical hydraulic conductivities ranging from $1.87 \mathrm{x}$ $10^{-5}$ to $1.15 \times 10^{-4} \mathrm{ft} / \mathrm{d}$ and averaged $6.89 \times 10^{-5} \mathrm{ft} / \mathrm{d}$. Hydraulic conductivities from core samples in $\mathrm{H}$-Area ranged from $1.9 \times 10^{-5} \mathrm{ft} / \mathrm{d}$ to $0.12 \mathrm{ft} / \mathrm{d}$. Sirrine (1991a) report a range in vertical hydraul ic conductivity from $3.4 \times 10^{-6}$ to $1.1 \times 10^{-3} \mathrm{ft} / \mathrm{d}$ from laboratory tests on undisturbed samples collected near the Burial Grounds Expansion. A vertical hydraulic conductivity of $9.07 \times 10^{-3} \mathrm{ft} / \mathrm{d}$ was determined from a laboratory test on a Shelby tube sample collected near the HW/MW disposal facility (Sirrine, 1991b). Westinghouse (1990) obtained a range in vertical hydraulic conductivity of $1.2 \times 10^{-5}$ to $1.7 \times 10^{-3} \mathrm{ft} / \mathrm{d}$ near $\mathrm{Y}$ area.

Hydraulic conductivities derived from slug tests in Aquifer Unit IIB2 (Water Table) range from 0.05 to $23.1 \mathrm{ft} / \mathrm{d}$ in F-Area and 0.08 to $45.4 \mathrm{ft} / \mathrm{d}$ in H-Area (SRS, 1990). The values reported for the MWMF range from 0.10 to $15.2 \mathrm{ft} / \mathrm{d}$. Average values for hydraulic conductivity are $2.52 \mathrm{ft} / \mathrm{d}$ from 17 wells in F-Area, $10.6 \mathrm{ft} / \mathrm{d}$ from 28 wells in $\mathrm{H}$-Area, and $2.35 \mathrm{ft} / \mathrm{d}$ for 17 wells in the MWMF. Parizek and Root (1986) conducted 38 single well pump 


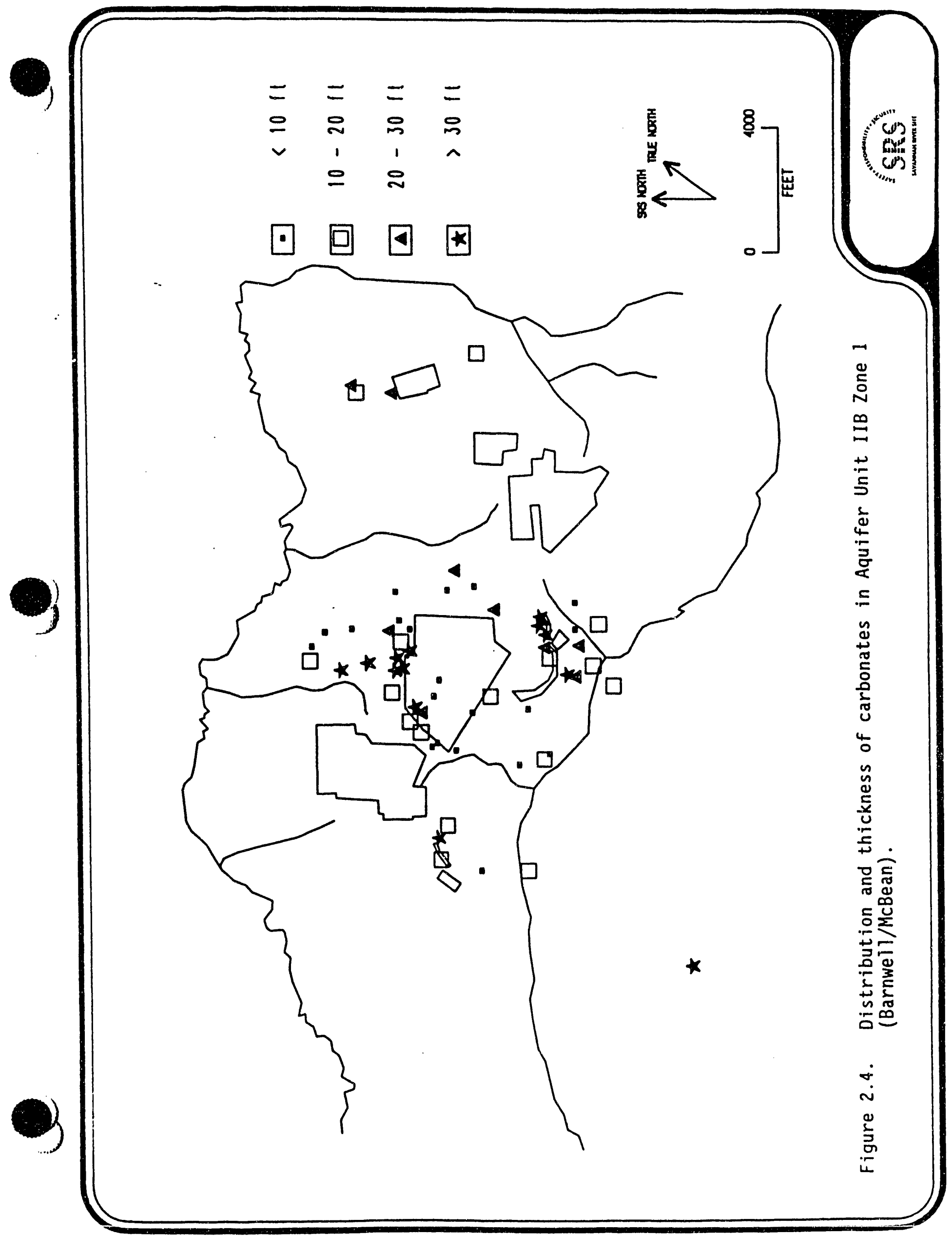


tests in the General Separations Area and for this zone calculated a range of 0.30 to $3.6 \mathrm{ft} / \mathrm{d}$ for hydraulic conductivities. A median value of 0.61 $\mathrm{ft} / \mathrm{d}$ was obtained from the tests. Evans and Parizek (1991) obtained hydraulic conductivity values form 14 single well constant discharge aquifer tests. These values range from 0.18 to $40.42 \mathrm{ft} / \mathrm{d}$ with a median hydraulic conductivity of $1.22 \mathrm{ft} / \mathrm{d}$.

\subsection{SOURCE AND SINK TERMS}

For this model flow application, only two source and sink terms are of interest for the study area. These terms include: (1) groundwater recharge to the surficial units, and (2) groundwater discharge to the wetlands bounding streams of Upper Three Runs Creek and Four Mile Branch.

\subsubsection{Groundwater Recharge}

Recharge to the groundwater system is controlled by many factors that vary in time and space. These factors include:

- Duration;

- Intensity, and amount of precipitation;

- Antecedent soil conditions;

- Land use and vegetation characteristics;

- Evapotranspiration;

- Depth to the water table;

- Topography; and

- Soir character.

Regional precipitation data are collected at the Bush Field Weather Station in Aligusta, Georgia, located approximately 20 miles from SRS. The average annual precipitation at Augusta, from 1951 to 1986 was approximately 42.9 inches. Figure 2.5 indicates the average monthly precipitation during the period from 1980 to mid-1991. From visual inspection of this figure these data indicate that relatively wetter conditions have prevailed through the 


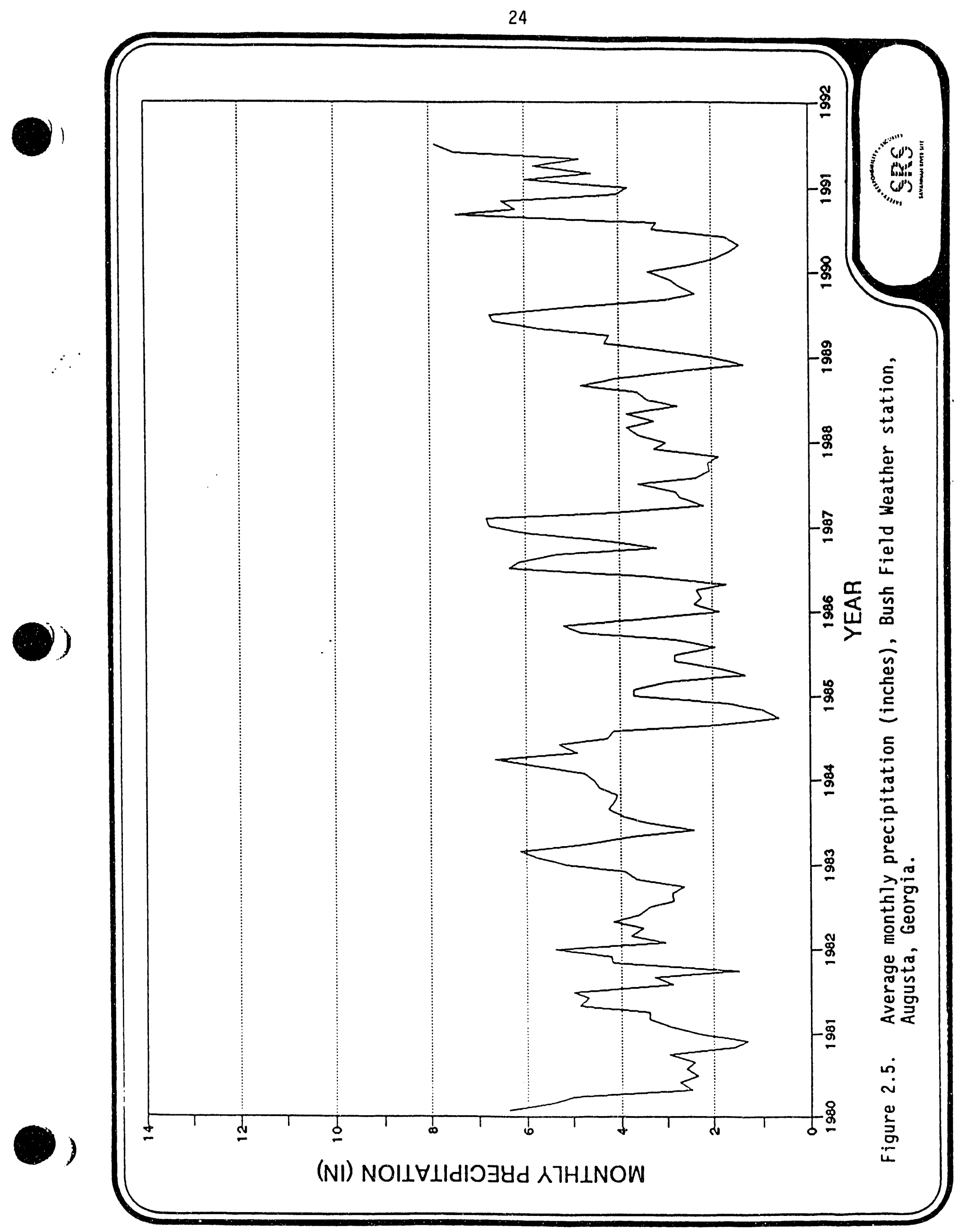


last year of record as compared to the majority of the record through the 1980s.

In a steady-state modeling approach, the recharge value of intercst represents average long-term conditions. Quantification of this source term is usually performed through the development of a water budget for a particular hydrologic drainage basin.

Three water budget studies have been conducted in the area of the SRS. Two of the water budgets were calculated within the present study area (Parizek and Root, 1986; Hubbard, 1986). The third water budget was conducted to the east of SRS near the Barnwell low-level radioactive waste disposal facility (Cahill, 1982). Through a baseflow analys is of Mary's Branch Creek, Lower Three Runs Creek, and Duncannon Creek, Cahill estimated average annual recharge in the vicinity of the Barnwell facility to range from 14 to 17 inches or about 40 percent of precipitation. Hubbard computed a water budget for the MWMF. The following are estimates of the annual average for each budget component expressed in inches over a given area:

$\begin{array}{lr}\text { Precipitation } & 47 \\ \text { Evapotranspiration } & 30 \\ \text { Run-off } & 2 \\ \text { Groundwater Recharge } & 15\end{array}$

In this analysis, Hubbard estimated evapotranspiration through the use of three methods: water balance analyses of three watersheds in the SRS vicinity, a climatic water balance developed from mean monthly temperature and precipitation, and analysis of lysimeter data. These methods yielded evapotranspiration estimates ranging from 30 to 36 inches. Additionally, Hubbard indicates that his runoff estimate was made subjectively from streamflow records. Hubbard concludes that about one-third of the annual precipitation amount can be expected to reach the water table. Interestingly, Hubbard also concluded based upon limited streamflow measurements in the F-Area effluent stream at the point of Confining Zone IIBI-IIB2 (Tan Clay) outcrop that the Aquifer Unit IIB Zone 2 (Water Table) discharges on average 5 inches annually. This suggests that 10 inches per 
annum leaks vertically to underlying Aquifer Unit IIB Zone 1 (Barnwe11/McBean).

Parizek and Root (1986) conducted a water budget study for the McQueen Branch surface water basin. This water budget, a rather complete quantification of each component, estimated the following rates for a period from March 1, 1983 through March 31, 1984.

$\begin{array}{lr}\text { Stream Baseflow } & 11.87 \text { inches } \\ \text { Actual Evapotranspiration } & 33.53 \text { inches } \\ \text { Groundwater Storage } & 3.48 \text { inches } \\ \text { Average Runoff } & 3.60 \text { inches }\end{array}$

Assuming a two-month travel time to the water table, the total precipitation for the period was 52.48 inches. This recharge value represents 29.5 percent of the total precipitation for the period. For the average annual precipitation of 42.9 inches, groundwater recharge would average 12.7 inches. This budget assumes negligible underflow and no leakage through the Green clay within the McQueen Branch Drainage Basin.

Various numerical models of the GSA and $F$ - and $H$-Area seepage basins have also derived recharge rates as a part of the model calibration phase. The original GSA model (Buss, et al. 1986) used the $15 \mathrm{in} / \mathrm{yr}$ as a given and varied other hydraulic parameters to achieve a calibration. Subsequent and more site specific studies (GeoTrans, 1990; and 1991) required that recharge rates be reduced in the vicinity of the seepage basins in order to maintain reasonable values for hydraulic conductivities. A value of 10.5 in/yr was used in GeoTrans (1990). Recharge determinations using the Hydrologic Evaluation of Landfill Performance (HELP) (U.S. EPA, 1984) model have been made for the capped and uncapped portions of the F- and H-Area seepage basins. SRS (1990) derived values of $11.25 \mathrm{in} / \mathrm{yr}$ for uncapped portions of F-Area and $11.81 \mathrm{in} / \mathrm{yr}$ for uncapped portions of H-Area. These determinations were used in GeoTrans (1991). Beaudoin, et al. (1991) used a value of $15 \mathrm{in} / \mathrm{yr}$ in the level areas near $A$ and $M$ areas of SRS, but assigned a value of $10 \mathrm{in} / \mathrm{yr}$ in the relatively steep areas near Upper Three Runs Creek. 
In summary, recharge values at SRS have been derived by a number of methods. Although not necessarily independently derived, they support the use of a long-term average recharge of 10 to $17 \mathrm{in} / \mathrm{yr}$.

\subsubsection{Boundary Stream Discharge}

The study area encompasses $10.6 \mathrm{mi}^{2}$ and is bounded on three sides by Upper Three Runs Creek, Four Mile Branch, and McQueen Branch. All of these streams flow continuously due primarily to groundwater baseflow. Upper Three Runs Creek, the largest of the three bounding streams, has its headwaters to the north of SRS in Aiken county. The stream flows southwest to the Savannah River and receives some non-thermal effluents from the GSA. Several of the intermittent streams in the northern portion of the study area and McQueen Branch are tributaries to this creek. Discharge has been measured at two locations on Upper Three Runs Creek for over 15 years by the U.S. Geological Survey. One of these locations is at the crossing of Road $C$ in the extreme west of the study area (Figure 2.6). Discharge at Road $C$ is on the order of 165 to $185 \mathrm{ft}^{3} / \mathrm{s}$. A few measurements were also made by Parizek and Root (1986) in 1982 at the crossing of Road F. These discharge values ranged from 135 to $150 \mathrm{ft}^{3} / \mathrm{s}$. The reach of Upper Three Runs Creek between Road $F$ and Road $C$, therefore, gains on the order of 20 to $40 \mathrm{ft}^{3} / \mathrm{s}$, contributed by both groundwater baseflow and tributary discharge from both sides of the creek. Parizek and Root (1986) estimate the total tributary discharge at 7 to $10 \mathrm{ft}^{3} / \mathrm{s}$. Thus, groundwater baseflow is estimated at 10 to $30 \mathrm{ft}^{3} / \mathrm{s}$ for Upper Three Runs Creek between Road $\mathrm{F}$ and Road C.

Gains in discharge for Upper Three Runs Creek between gaging Stations $C$ and $A$ and between gaging Station $C$ and the New Ellenton gaging station are presented for the period 1975 to 1989 in Figures 2.7 and 2.8, respectively. The distance between the New Ellenton Station and Station C is approximately 9 miles (Figure 2.6). The gain in Upper Three Runs Creek discharge between these two stations is about $90 \mathrm{ft}^{3} / \mathrm{s}$ during this period. Gaging Station $A$ is approximately 5 miles downstream from Station $C$. The gain in discharge of this stream between these two stations is shown to have declined from approximately $80 \mathrm{ft}^{3} / \mathrm{s}$ in 1976 to $20 \mathrm{ft}^{3} / \mathrm{s}$ in 1989 . 


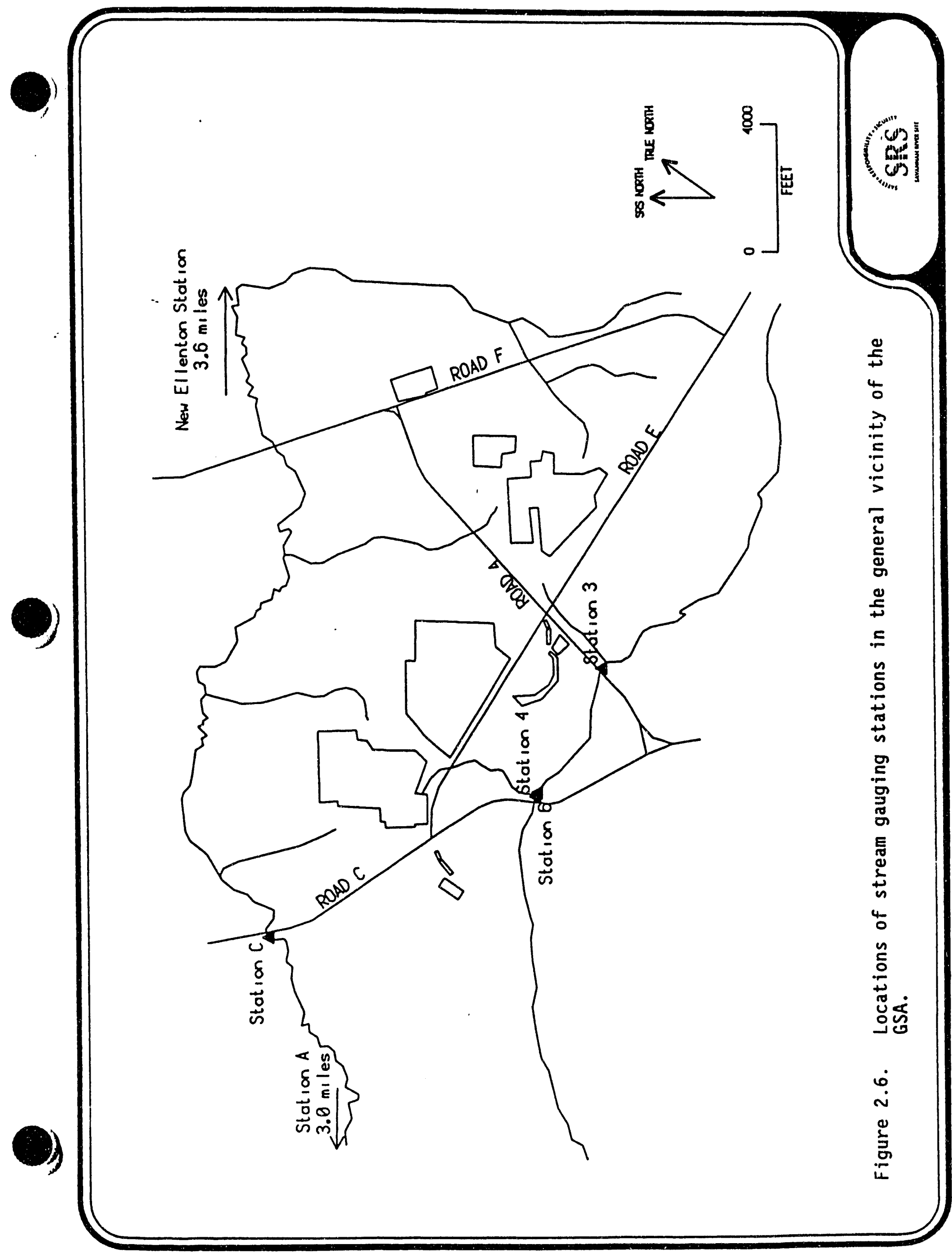




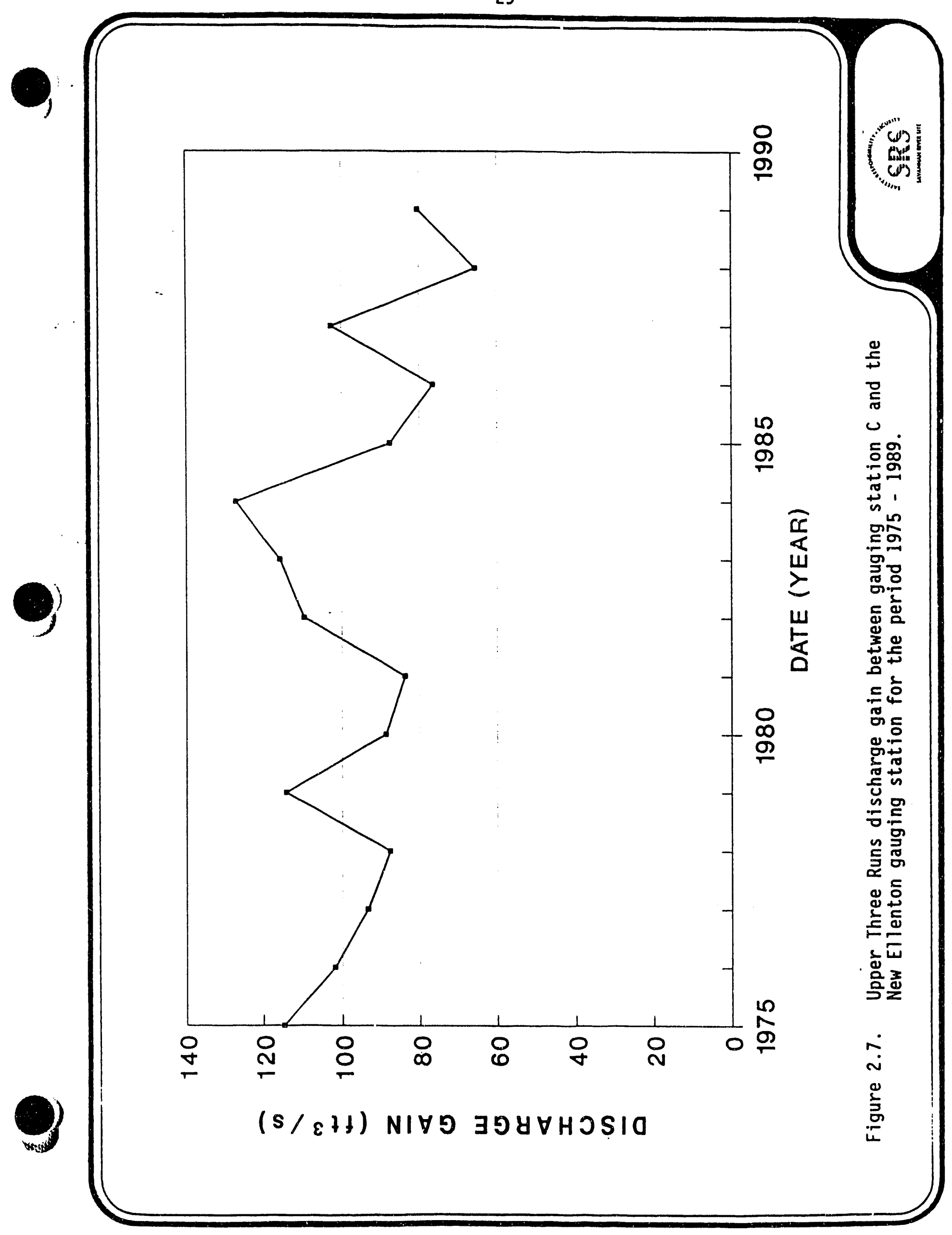




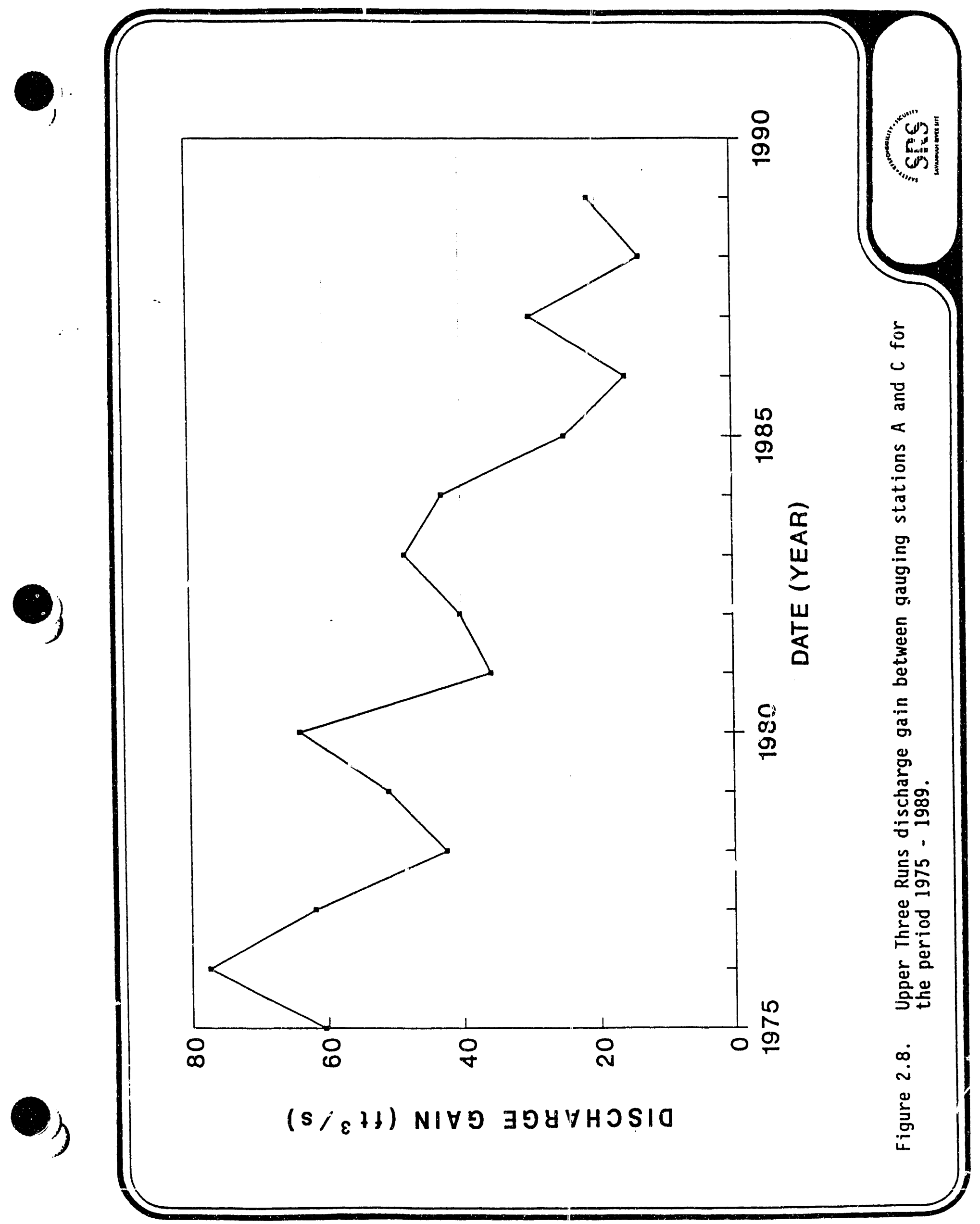


Four Mile Branch has its headwaters in swampy areas near the center of SRS. Flow is generally westward, then southwestward toward the Savannah River. The U.S.G.S. measures dis harge in Four Mile Branch and along tributaries within the study area. Two major effluent streams to the creek originate in F-Area and H-Area.

Gaging Stations 6, 4, and 3 are located on Four Mile Branch immediately south of MWMF (Figure 2.6). The distance from Station 3 downstream to Station 4 is approximately $4500 \mathrm{ft}$. The gain in discharge between these two stations during the period 1973 to 1989 averaged about $1.0 \mathrm{ft}^{3} / \mathrm{s}$ (Figure 2.9). Station 6 is located about $200 \mathrm{ft}$ from Station 4 , downstream of the confluence between the F-Area effluent stream and Four Mile Branch. In contrast to the average gain observed between Stations 3 and 4 , of $1 \mathrm{ft}^{3} / \mathrm{s}$, the gain between Stations 4 and 6 has averaged approximately $5 \mathrm{ft}^{3} / \mathrm{s}$ for the period 1973 to 1989 (Figure 2.10). This gain reflects the contribution of the F-Area effluent stream to Four Mile Branch discharge along this segment of the stream.

McQueen Branch originates in the upland area between Upper Three Runs Creek and Four Mile Branch and flows northwestward towards Upper Three Runs creek. The creek drains an area of about 4.4 square miles. Several intermittent streams are tributary to it. Parizek and Root (1986) conducted a water budget for this basin and estimated baseflow in the stream to be 3 to $5 \mathrm{ft}^{3} / \mathrm{s}$.

\subsection{POTENTIOMETRIC SURFACES}

The hydraulic head distribution of each aquifer and the observed flow directions for these units are integrated into a single multi-aquifer groundwater system. This system is characterized by complex horizontal and vertical flow directions. These flow paths result from the interplay of four principal controlling factors: (1) structural attitude of units; (2) the topographic relief and outcrop pattern; (3) the lithologic character of tive unit; and (4) locations of recharge and discharge. Generalized data regarding the potentiometric surfaces of the aquifers are presented in this section. For each of the three aquifers included in the model, two figures are presented. One of the two presents relatively old (1982) water levels 


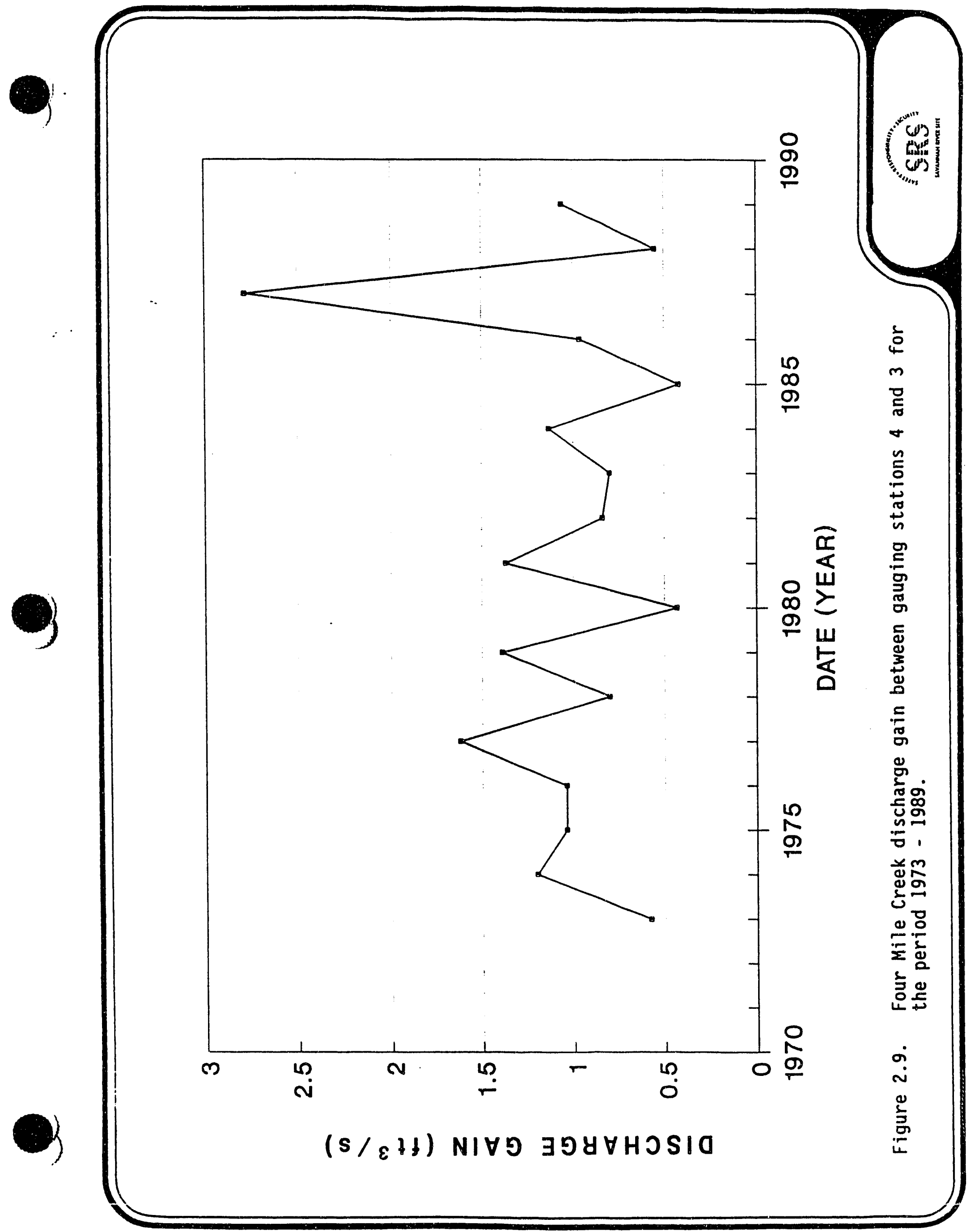




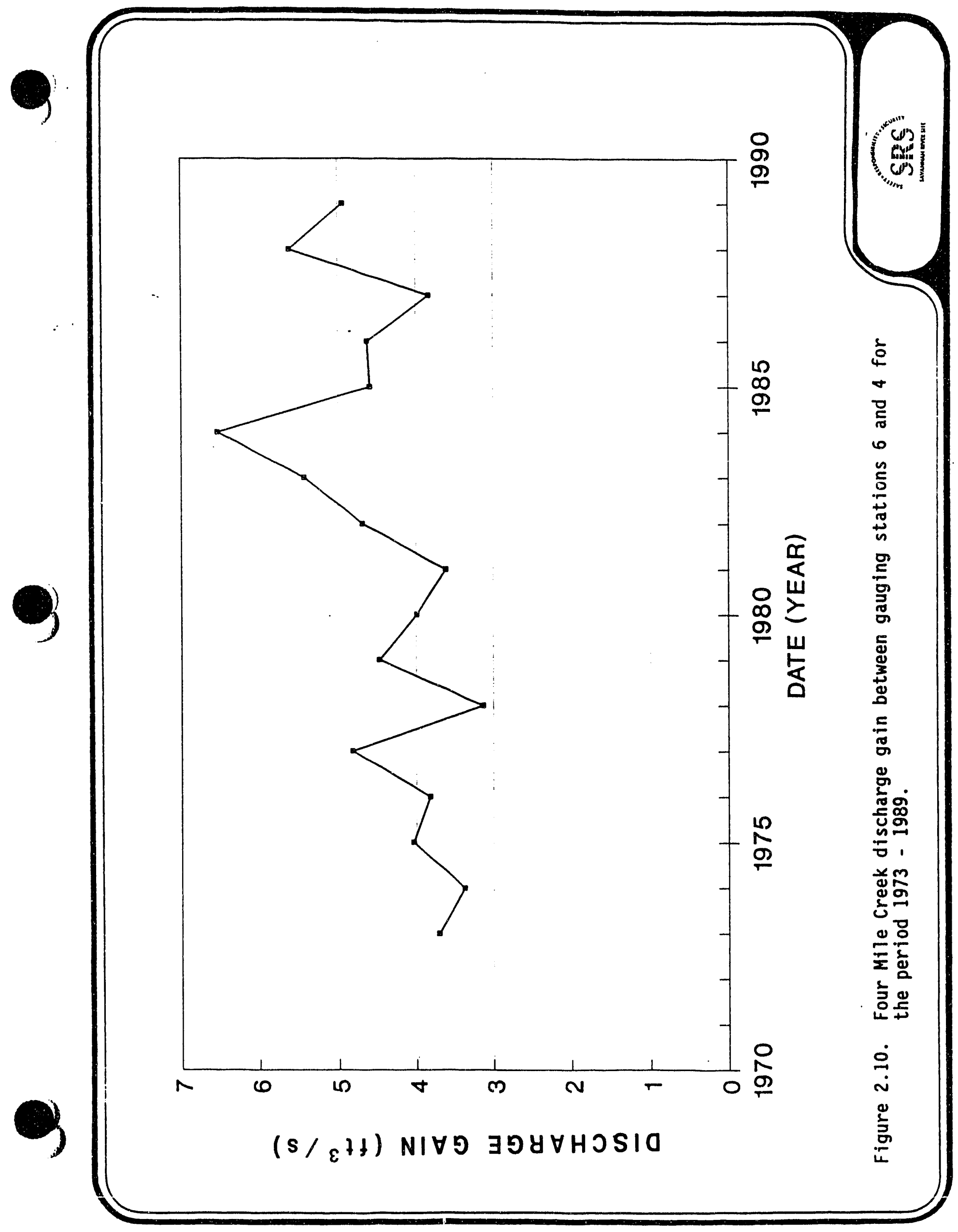


across the entire GSA, to provide an illustration of general flow directions across the entire model domain. The other figure provides more recent water-level information, though for a more focused region in the vicinity of the MWMF. Calibration of the flow model was performed by matching model results to measured groundwater levels at specific target monitor wells for a specific time period, and comparing to the generalized flow directions described herein.

\subsubsection{Aquifer Unit IIA (Congaree)}

The hydraulic head distribution for Aquifer Unit IIA (Congaree) declines, in general, from the southeast to the northwest following the trend of the Upper Three Runs Creek drainage system (Figures 2.11 and 2.12). In the study area, the aquifer unit is under confined conditions except along the fringe of Upper Three Runs Creek. In this limited area, the aquifer converts to water-table conditions because of the outcrop of Confining Unit IIA-IIB (Green Clay). The potentiometric level of the aquifer ranges from approximately $180 \mathrm{ft} \mathrm{msl}$ to below $130 \mathrm{ft} \mathrm{msl}$. Aquifer Unit IIA (Congaree) exhibits flow directions under the study area both across and up the structural dip. Upper Three Runs Creek is a local groundwater discharge boundary for this aquifer in the proximity of the GSA.

\subsubsection{Aquifer Unit IIB Zone I (Barnwell/McBean)}

The hydraulic head distribution in Aquifer Unit IIB Zone 1 (Barnwell/McBean) is controlled by location and depth of incisement of streams and creeks that dissect the Aiken Plateau. In the study area, the aquifer zone exhibits varying degrees of saturation in the interstream area south of Upper Three Runs Creek. Upper Three Runs Creek has eroded through Confining Zone IIBI-IIB2 (Tan Clay), and Aquifer Unit IIB Zone 1 (Barnwel1/McBean). Potentiometric surface maps of the Aquifer Unit IIB Zone 1 (Barnwe11/McBean) are presented in Figure 2.13. and 2.14. Heads decline toward the bounding streams of Upper Three Runs Creek, McQueen Branch, and Four Mile Branch. Thus, a groundwater divide develops separating flow in the aquifer to the north and south. The divide follows the trend of the topographic upland between Upper Three Runs Creek and Four 


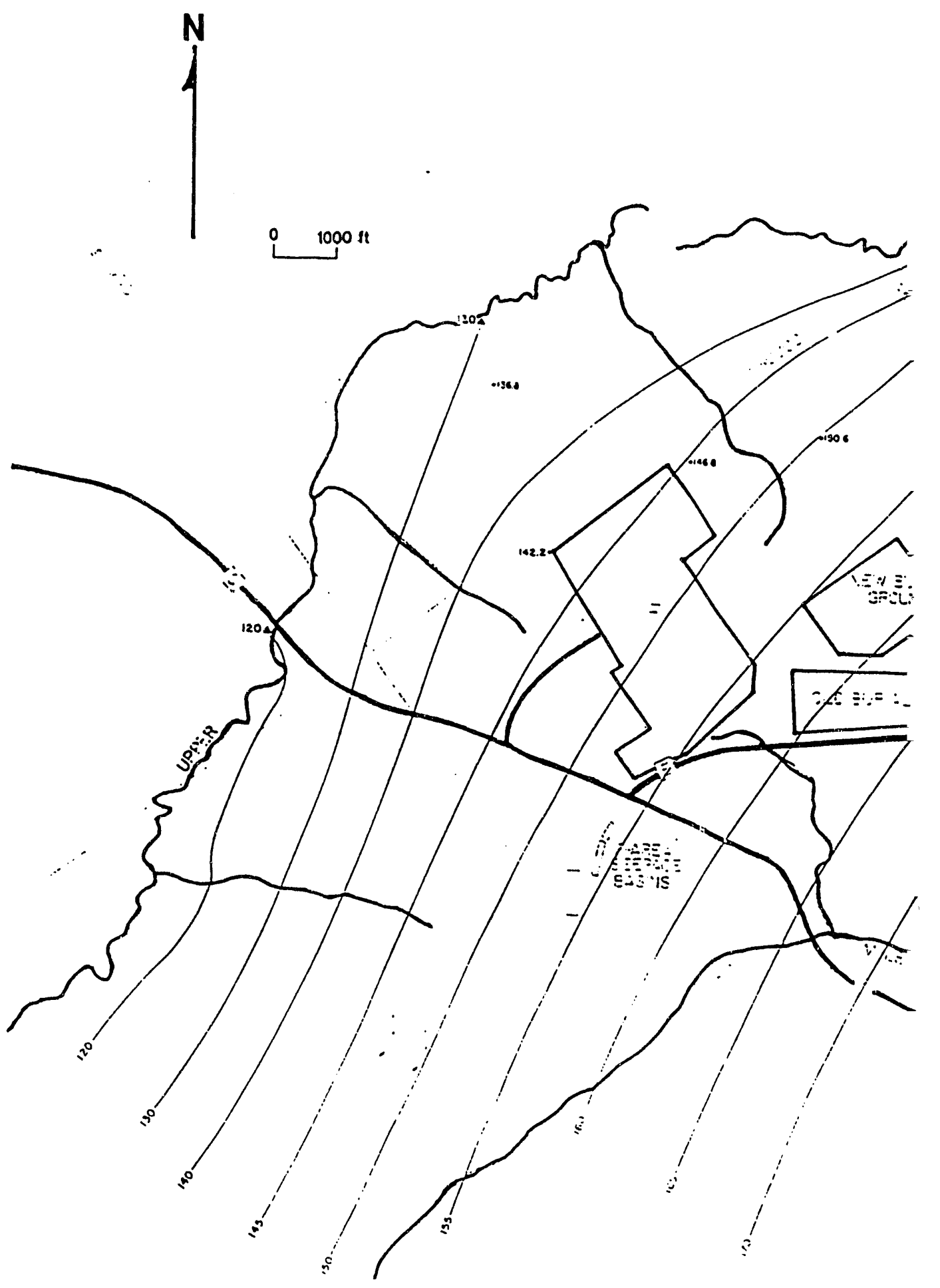

Figure 2.11. Potentiometric map of Aquii Root (1987). 


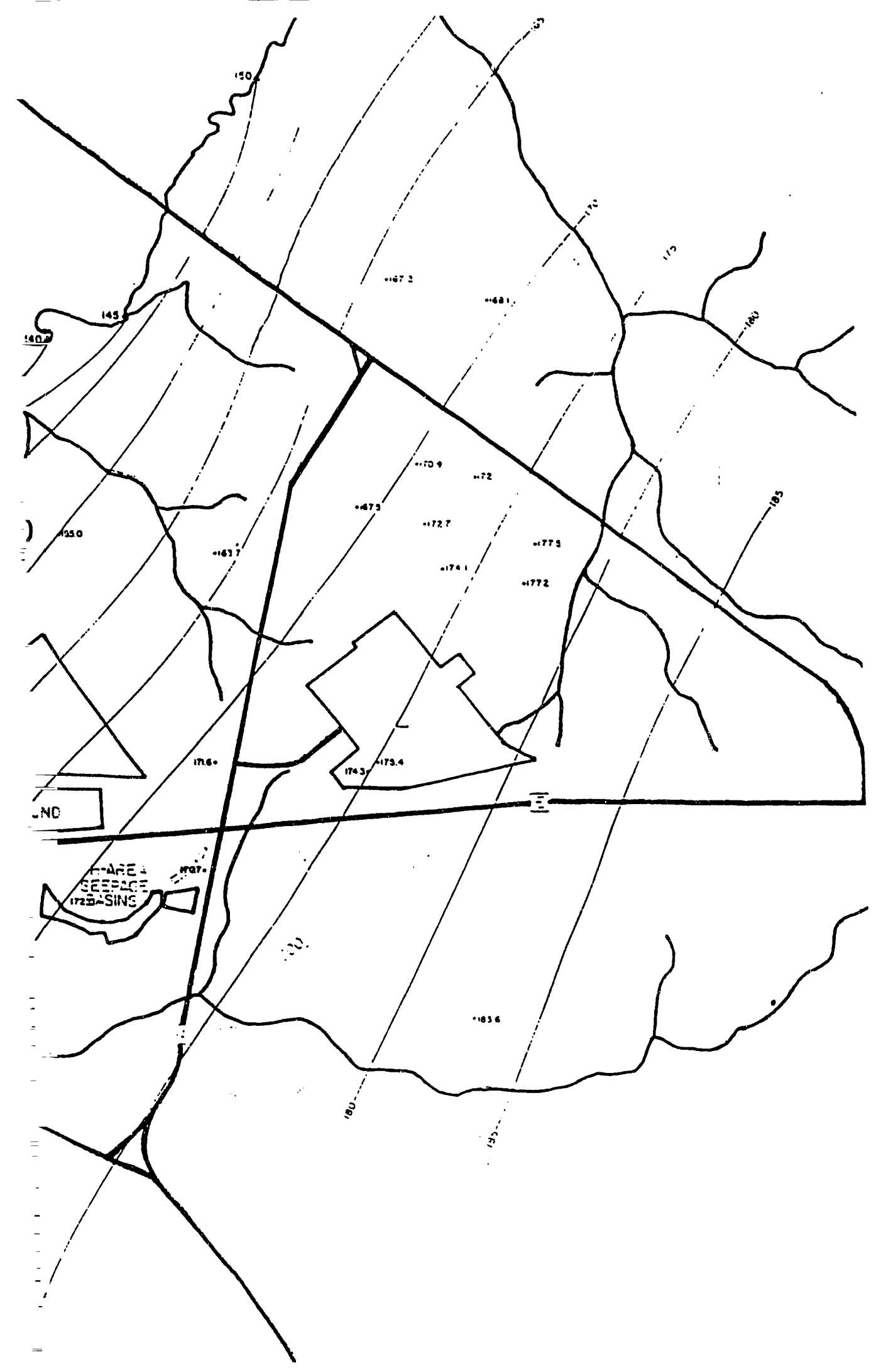

Unit IIA (Congaree) in the GSA, from 


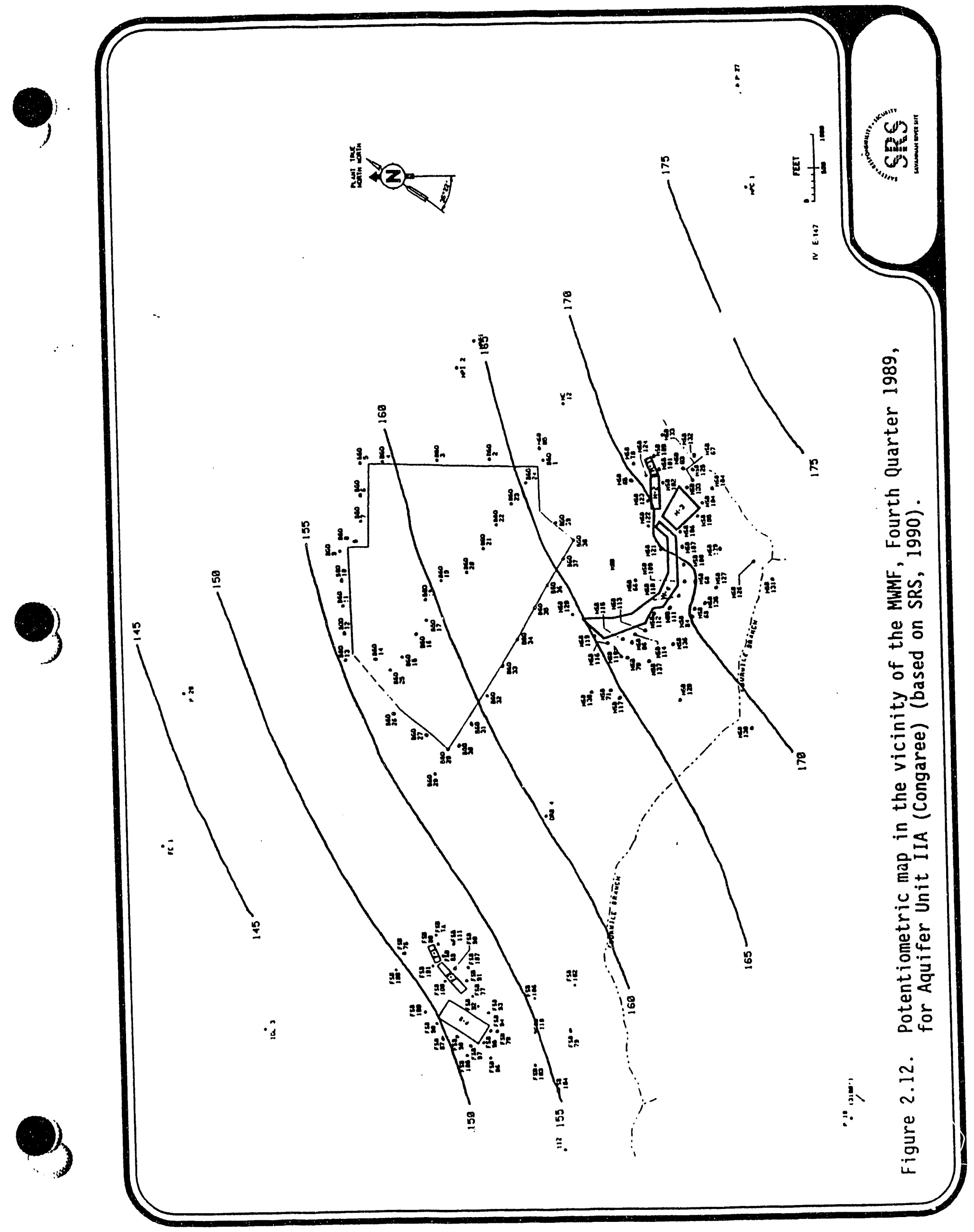




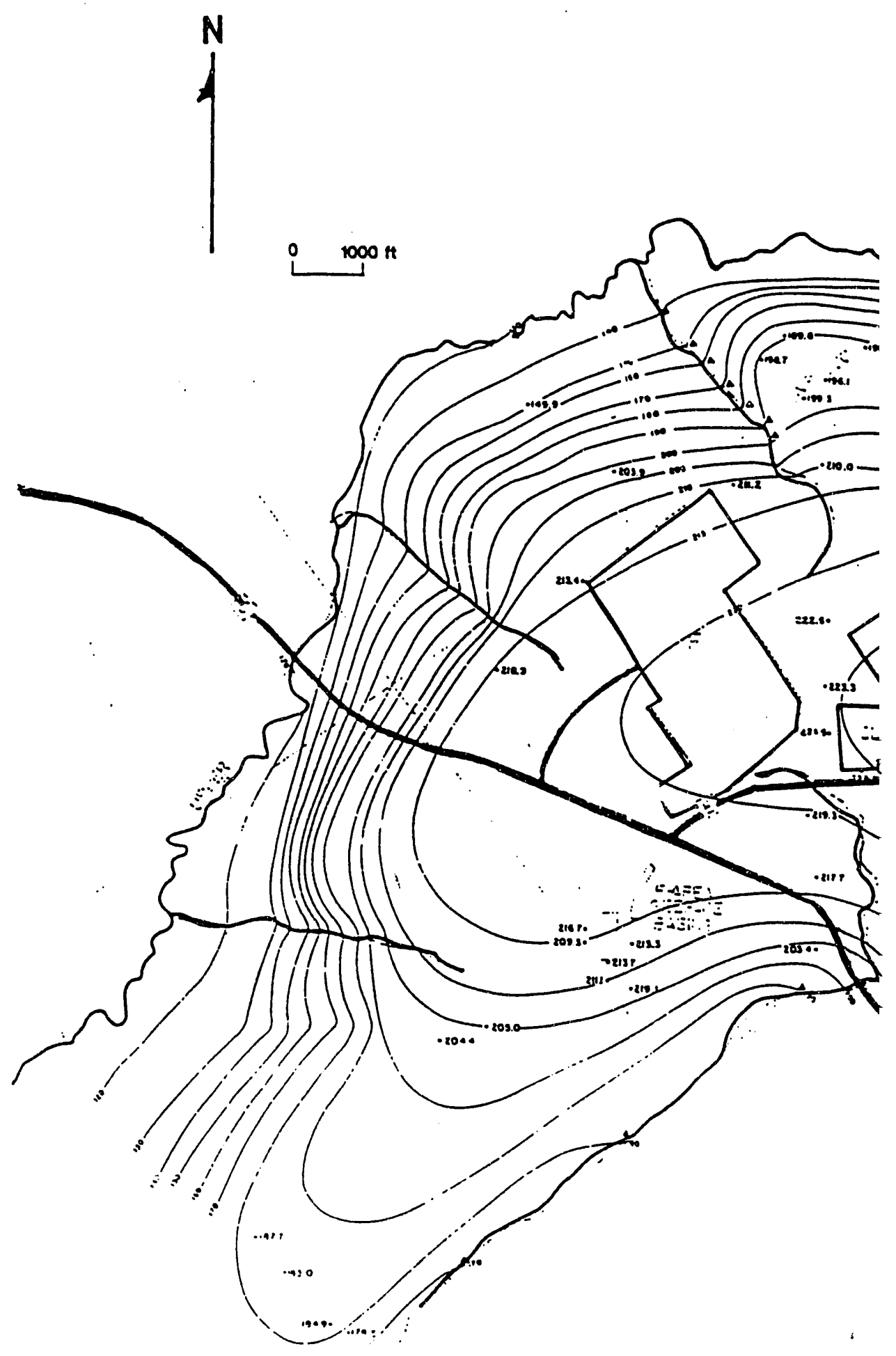

Figure 2.13. Potentiometric map of general flow pattern: (from Root, 1987). 


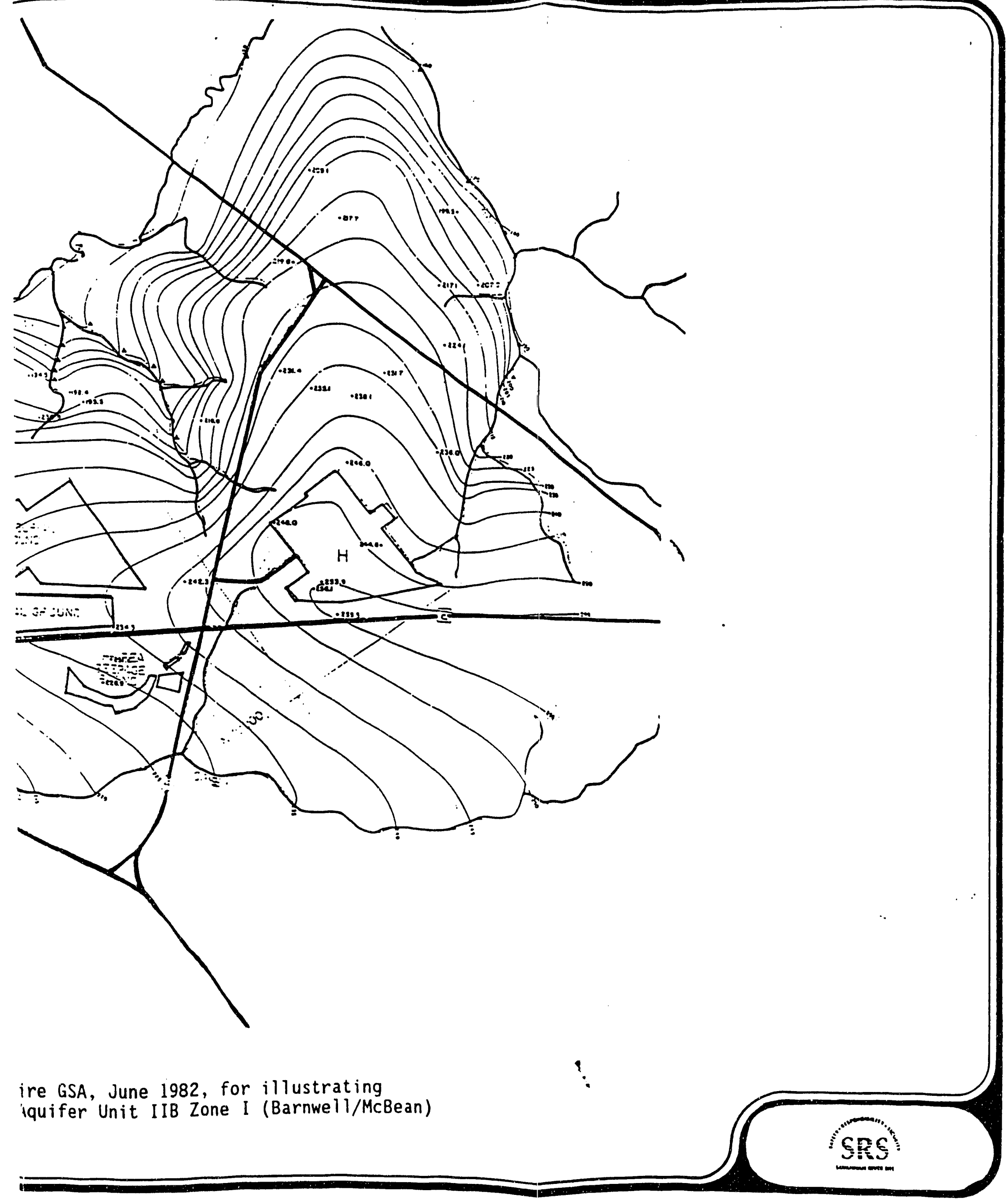




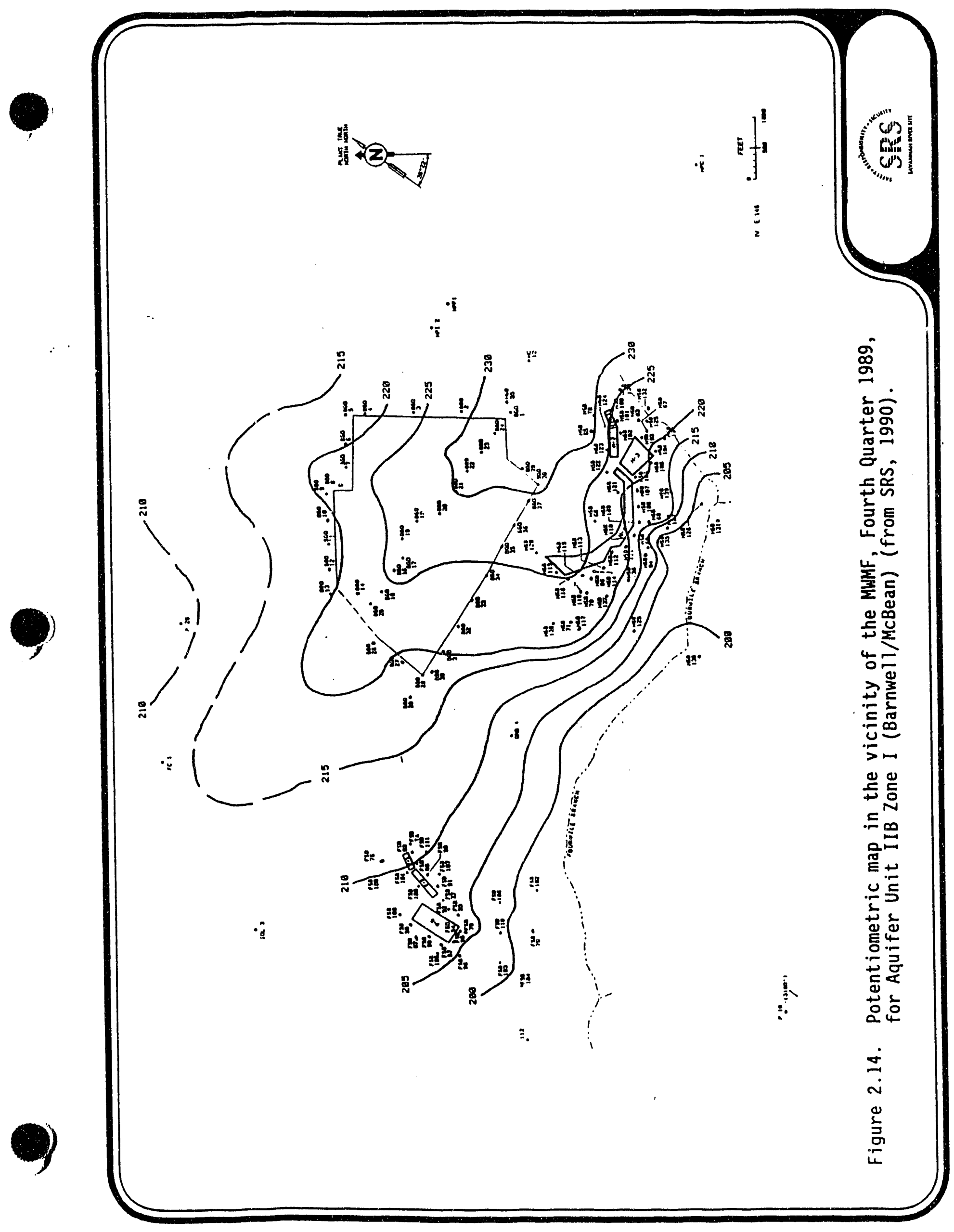


Mile Branch. The divide is not located symmetrically between these two lateral boundaries because of the deep incisement of Upper Three Runs Creek. Instead, the divide is shifted down dip toward Four Mile Branch and runs across the $\mathrm{F}$ - and $\mathrm{H}$-Areas and through the MWMF. The potentiometric surface also declines from east to west toward the Savannah River, which imparts a cross-dip component to the observed flow directions. The potentiometric surface exhibits slight variations in the gradient. Near the groundwater divide and along interstream uplands, the gradient is near $0.01 \mathrm{ft} / \mathrm{ft}$. The gradient steepens by a factor of two $(0.02 \mathrm{ft} / \mathrm{ft})$ upon approaching the bounding streams in response to the increase in topographic relief and convergent flow associated with discharge to the streams.

\subsubsection{Aquifer Unit IIB Zone 2 (Water Table)}

Aquifer Unit IIB Zone 2 (Water Table) is under unconfined conditions. The hydraulic head distribution and flow directions are very similar to the Aquifer Unit IIB Zone 1 (Barnwe11/McBean), and is illustrated in Figures 2.15 and 2.16. A groundwater divide exists in the interstream upland with hydraulic heads decreasing toward the bounding streams. On the northern portion of the study area, Aquifer Unit IIB Zone 2 (Water Table) is unsaturated as the water table occurs in Aquifer Unit IIB Zone 1 (Barnwe11/McBean) in response to discharge to Upper Three Runs Creek. The water table reaches an elevation over $275 \mathrm{ft} \mathrm{msl}$ beneath the $\mathrm{H}$-Area along the trace of the groundwater divide. The water levels decline to the bounding streams reaching elevations between 120 and $150 \mathrm{ft} \mathrm{ms} 1$ along Upper Three Runs Creek and between 190 and $225 \mathrm{ft} \mathrm{msl}$ along Four Mile Branch. In general, the water table follows the topography of the study area occurring approximately 30 to $40 \mathrm{ft}$ below ground level in the uplands and gradually decreasing to zero within the stream valley.

The horizontal gradients observed in the water table are similar to Aquifer Unit IIB Zone 1 (Barnwe11/McBean). Gradients increase in the water table from $0.01 \mathrm{ft} / \mathrm{ft}$ in the interstream upland to $0.02 \mathrm{ft} / \mathrm{ft}$ near the Four Mile Branch. 


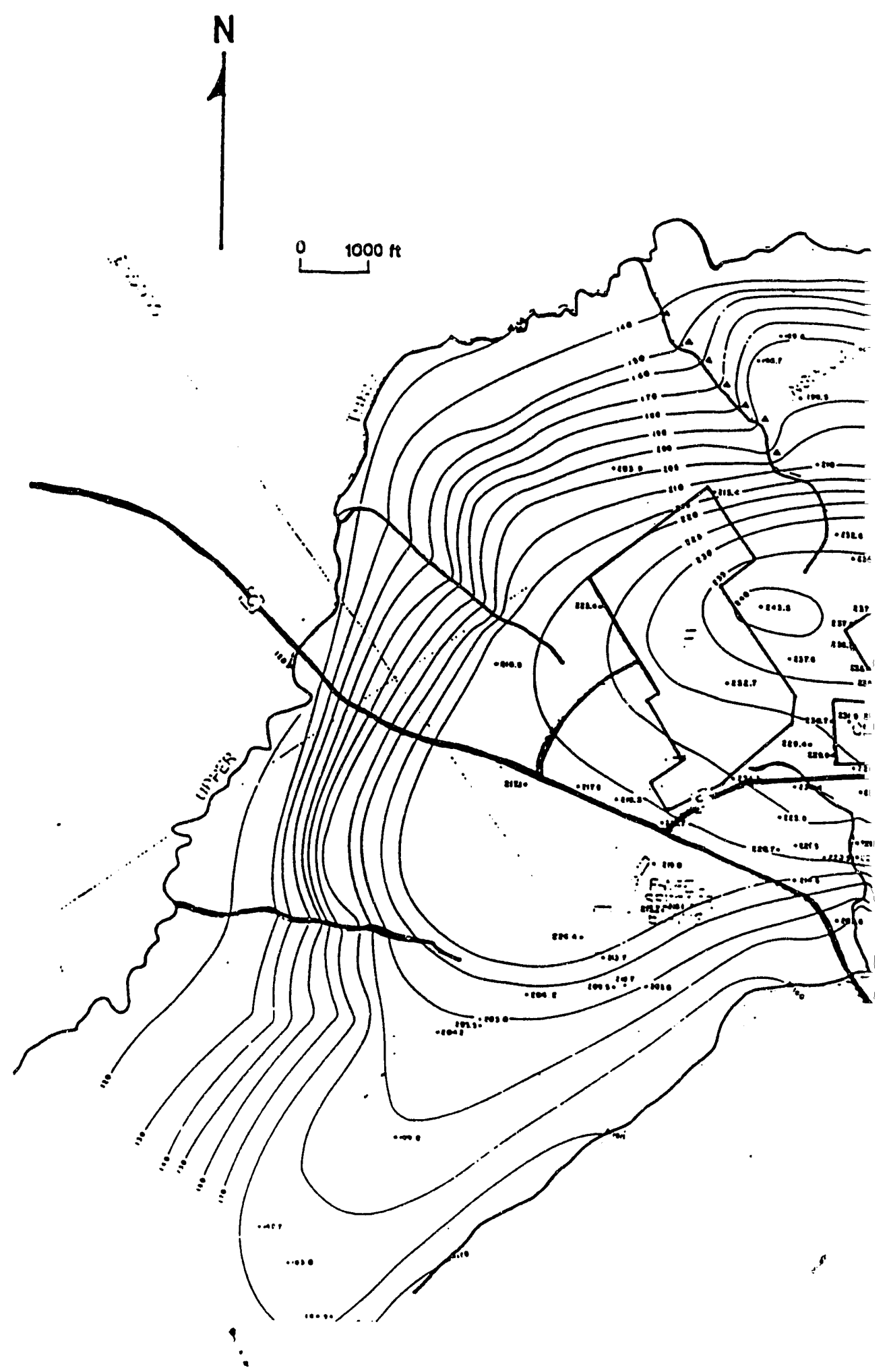

Figure 2.15. Potentiometric map GSA, from Root (19: 


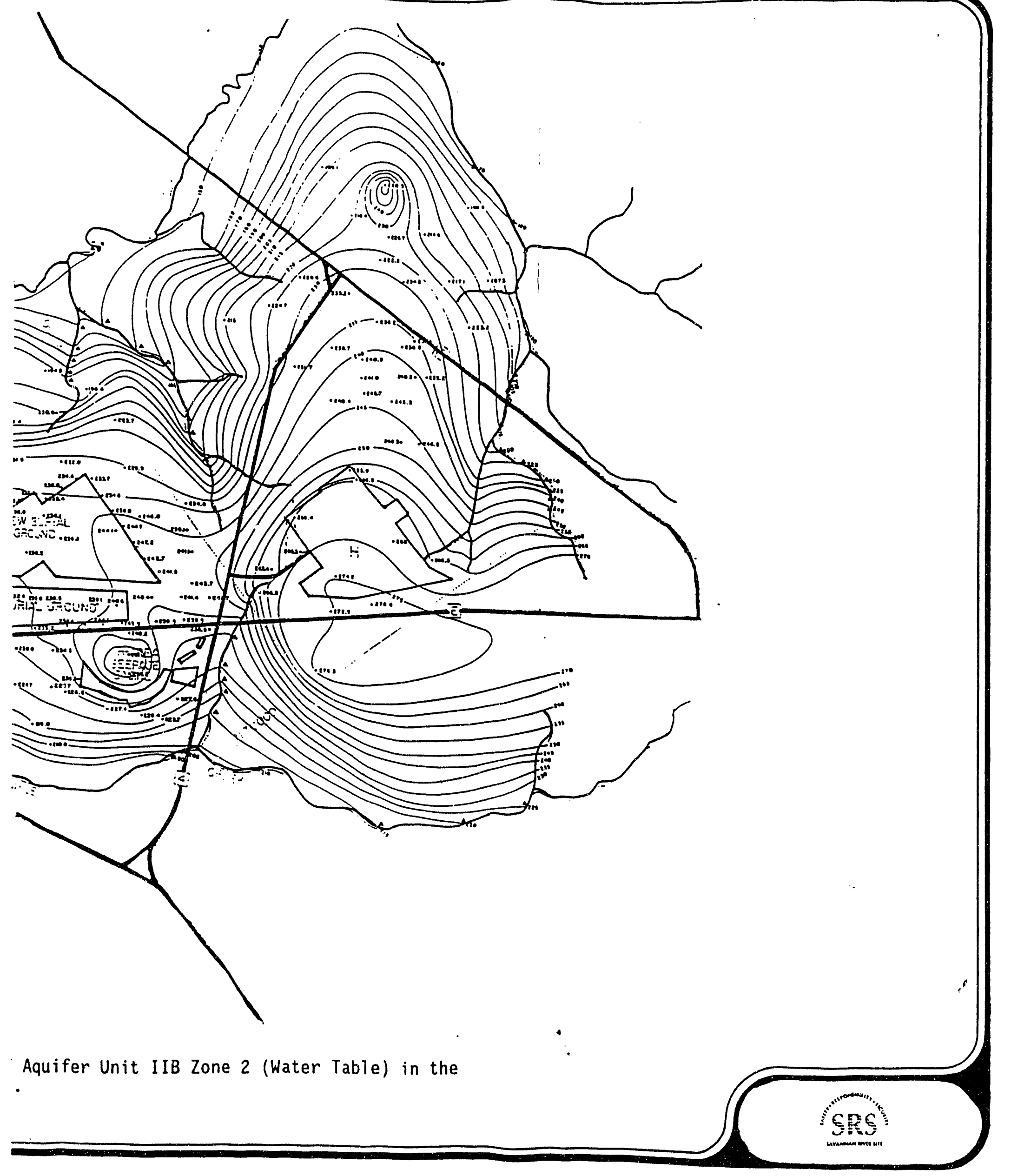




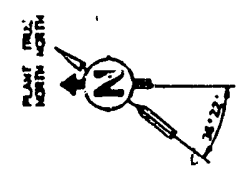

\section{$\tilde{a}$}

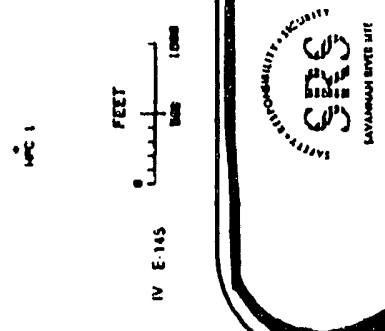
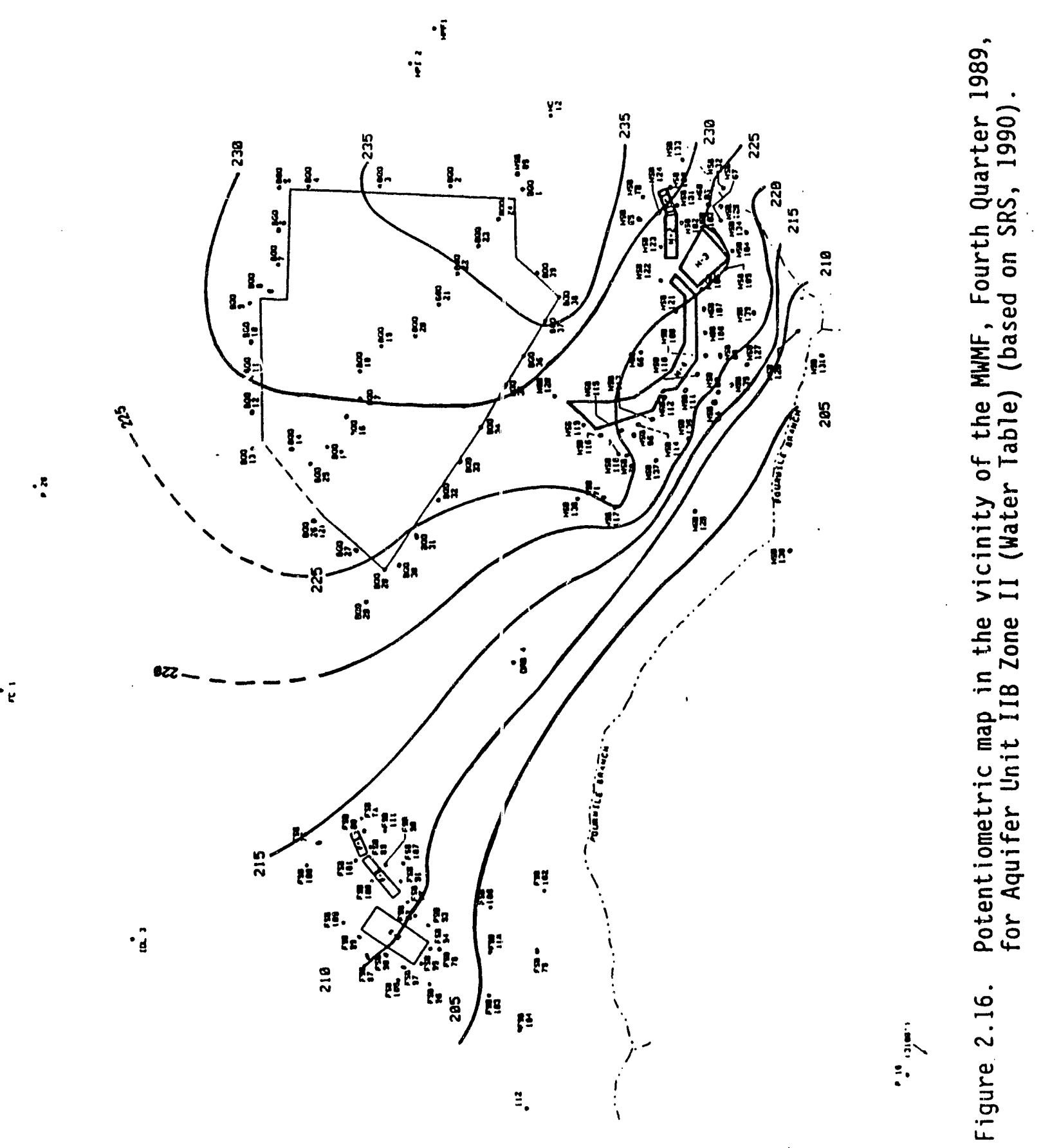


\subsubsection{Vertical Interactions of Aquifers}

Two semi-confining units act to restrict leakage between aquifers in the study area: Confining Unit IIA-IIB (Green Clay) and Confining Unit IIB1-IIB2 (Tan Clay). The volume of leakage between successive aquifers is dependent upon the hydraulic conductivity of the aquitard, the thickness, and the hydraulic gradient across the unit. For the most part, lateral flow dominates within aquifers while vertical flow dominates in aquitards.

Aquifer Unit IIB Zone 2 (Water Table) has a general downward hydraulic potential into lower units. The zone receives recharge primarily in the form of infiltrated precipitation. The vertical component for the flow of water in the water table is downward across Confining Zone IIB1IIB2 (Tan Clay) into Aquifer Unit IIB Zone 1 (Barnwell/McBean). Confining Zone IIB1-IIB2 (Tan Clay) is a leaky aquitard with the degree of leakage across the confining unit being variable. Leakage depends on the magnitude of the head difference across the confining zone and the local competency of the confining unit.

Aquifer Unit IIB Zone 1 (Barnwe11/McBean) is poorly :nnfined and is recharged primarily by downward flow from the Aquifer Unit IIB Zone 2 (Water Table) through Confining Zone IIB1-IIB2 (Tan Clay). The vertical component of flow in Aquifer Unit IIB Zone 1 (Barnwe11/McBean) is downward across the Confining Unit IIA-IIB (Green Clay) into Aquifer Unit IIA (Congaree). Confining Unit IIA-IIB (Green Clay) is more competent than Confining Zone IIBI-IIB2 (Tan Clay), but there is evidence of leakage and areas where the clay has been breached by faults.

Groundwater flow in Aquifer Unit IIA (Congaree) is northwest toward Upper Three Runs Creek. Four Mile Branch to the south does not incise Confining Unit IIA-IIB (Green $\mathrm{Clay}$ ) and therefore does not influence flow in the underlying Aquifer Unit IIA (Congaree). Recharge into Aquifer Unit IIA (Congaree) is primarily from leakage through Confining Unit IIA-IIB (Green $\mathrm{Clay}$ ). In places where the confining unit is breached by faulting, this recharge may be locally increased. Discharge from Aquifer Unit IIA (Congaree) is to Upper Three Runs Creek. Any downward component of flow out of this aquifer unit is believed to be very minor. In most of the GSA, an upward flow potential exists between Aquifer Unit IIA (Congaree) and Aquifer System I across the Confining Unit I-II (Ellenton Clays). In 
addition, the competence of Confining Unit I-II (Ellenton Clays) is quite good. Prior numerical modeling of the entire vertical sequence of aquifers has characterized this unit as having a vertical hydraulic conductivity of $9.4 \times 10^{-10} \mathrm{ft} / \mathrm{d}$ (Duffield, et al., 1986).

\subsubsection{Water Elevation Fluctuations}

Groundwater elevations in the GSA generally recover during the winter and early spring and decline during the remainder of the year. These fluctuations, observed in wells completed in all aquifer units, demonstrate the overall communication between aquifers on a regional scale. Additionally, the amplitude of water-level fluctuations in a particular aquifer unit correspond to the depth of the unit. The shallower units tend to exhibit greater fluctuation than those at greater depth. Parizek and Root (1986) report that the actual lag time between a recharge event at the surface and its impact on the water table is typically between one and two months depending on the depth to the water table. 
3 GROUNDWATER FLOW MODEL OF THE GENERAL SEPARATIONS AREA

\subsection{CODE SELECTION}

The code FTWORK was chosen for simulation of groundwater flow for the GSA. This code was developed for SRS to provide a validated, we11documented, three-dimensional code to simulate the groundwater system at SRS (Faust, et al., 1990). The program has been submitted to the International Groundwater Modeling Center and National Energy Software Center for release as public domain software. GeoTrans, the developer of the code, provides technical support to users and serves as the code custodian for dissemination of updates and enhancements to the code. FTWORK has been benchmarked against several flow and transport models and analytic solutions (Sims, et al., 1989). The code has been applied to several investigations at SRS, to the Paducah Gaseous Diffusion Plant, and several other waste sites.

FTWORK is a finite-difference model for simulation of flow and solute transport processes in fully-saturated porous media in one, two, or threedimensions (Faust, et al., 1990). FTWORK provides an alternative to more comprehensive models such as SWIFT II (Reeves, et al., 1986) and HST3D (Kipp, 1987). Unlike these models, the flow equation is posed in terms of hydraulic head. The hydraulic head formulation is more convenient than the pressure formulation for most groundwater and hazardous waste assessments. FTWORK is easier to use in terms of input and operation because many of the complexities of more comprehensive codes (density dependence, heat transport, deformation, etc.) are not considered. FTWORK is consistent with the well known groundwater flow model, MODFLOW (MCDonald and Harbaugh, 1988), in terms of equation and finite-difference formulation, allowing transfer of input date between the two codes.

The three-dimensional model is based on a finite-difference scheme using the block-centered grid that allows variable spacing and approximation of irregular geometry. The model also allows approximation of layers that have irregular thickness and/or that are not horizontal.

For unconfined conditions, the transmissivity term is a function of the saturated thickness in adjacent blocks. A simple approach for treating non-linear terms is used that is suitable for applications where the non- 
linearity is mild. This model does not include a procedure for resaturation of grid blocks. If a grid block becomes desaturated during any iteration, the grid block is deleted from subsequent solution sets.

This model includes two optional geometrical approximations. The first option permits approximation of aquitards between grid block layers. The second option provides approximation of layers that have variable thickness and variable elevations. The aquitard and variable thickness/elevation options may be specified together or separately.

The equations for flow and solute transport are coupled due to the advective and accumulation terms in the transport equation. These terms are dependent upon head. Because it is assumed that density is independent of concentration, no terms in the flow equation depend on concentration. Thus, the flow equation can be solved independently of solute transport, but the solute transport equation must be solved in conjunction with the flow equation. Many applications involve steady-flow but unsteady solute transport. FTWORK also provides options to simulate a completely unsteady flow and transport situation or to simulate a series of steady flow field with unsteady solute transport. The latter condition is of practical interest for aquifers in which historical pumping has increased in increments. No matter which type of simulation is required, the finitedifference equations are decoupled by first solving the flow equation for heads. The head values required in the transport simulation are then explicitly specified.

For general three-dimensional problems, an iterative method is used to solve the flow and transport equations. This method, Slice Successive Over-Relaxation (SSOR), is a subset of the more general method of block successive over relaxation (Woo and Emanual, 1976). For a detailed description of SSOR, see Wattenbarger and Thurnau (1976). SSOR is similar to 1 ine successive over relaxation in two dimensions, except that instead of solving each row implicitly, each vertical slice of the grid is solved implicitly. For flow, the three-dimensional equations have seven unknowns per equation (grid block). The transport system has 19 unknowns for each grid block. The SSOR method divides the system of equations as follows: five coefficients are treated implicitly for flow and nine coefficients are treated implicitly for transport. 
The matrix equation for each slice is solved using the GaussDoolittle method (Weaver, 1967) for banded coefficient matrices. The coefficient matrix for the flow equation is symmetric, but the coefficient matrix for the transport equation is nonsymmetric. FTWORK includes two alternative equation solvers so that extra computational work is not performed for the flow solution. Also, because the coefficient matrix does not change during a time step or nonlinear iteration, the matrix decomposition is performed only on the first SSOR iteration. On subsequent SSOR iterations, forward and back substitutions are performed. This procedure results in a substantial computational savings because matrix decomposition requires many more computations than forward and backward substitutions. Convergence of the SSOR scheme is checked in absolute terms for flow and normalized terms for solute transport.

Processes considered for solute transport include dispersion, a linear equilibrium adsorption isotherm, and first-order decay. Crossproduct terms for hydrodynamic dispersion can be included in the transport calculations. Inclusion of cross-product terms can provide a significant improvement in the accuracy of transport calculations. The model has an option to use either central or upstream weighting of the advection term and central or backwards weighting of the time derivative.

A Gauss-Newton technique for non-linear least-squares parameter estimation has been incorporated into solution of the flow equation for automatic history matching. A comprehensive mass balance is included in the code for both flow and transport. A layer-by-layer balance is also included for multi-aquifer simulations.

\subsubsection{Version Utilized}

Flow simulations for this project were made with FTWORK Version 2.7, with slight modification. Modifications were required to address special conditions related to dry nodes in areas along stream valleys where aquifers pinch out. This modification is discussed in more detail in section 3.6 . 


\subsection{GEOGRAPHIC INFORMATION SYSTEM}

GIS technology has been used for many aspects of the flow model development, including data storage and retrieval, data analysis, and creation of model input data sets. The GIS software package utilized was Workstation ARC/INFO (Versions 5.0 and 6.0), a powerful software package that includes a sophisticated programming language.

GIS software integrates map-oriented features (rivers, geologic contacts, topography, etc.) with database technology in a graphical environment. This allows for easy visualization of data, such as locations of all monitoring wells screened in a specific formation, with labels indicating well names and water levels during a particular monitoring period. It also allows for sophisticated analysis of spatial and timedependent data, such as intersection of polygonal areas, subtraction of three-dimensional surfaces (such as formation tops and bottoms), and computation of statistics. Graphics containing overlays of diverse data are particularly useful for detailed analysis of data errors and inconsistencies.

\subsubsection{Data Compilation}

Hydrogeologic data stored and analyzed in the GIS are summarized in Figure 3.1. These data include the following:

- Well data (well name, coordinates, date installed, aquifer screened, etc.);

- Water level data (well name, date sampled, water level).

- Stratigraphic data (well name, formation tops, formation bottoms, thicknesses).

The relational database capabilities of the GIS allows all database tables to be related via the well name field. This required well names for all sources of data to be made consistent with one master well list compiled by GeoTrans (with respect to spaces, dashes, case, etc. in the supplied data). The results of the data compilation task are documented in GeoTrans (1992). Although this task required significant effort, the relational database capabilities it afforded justified the effort. 


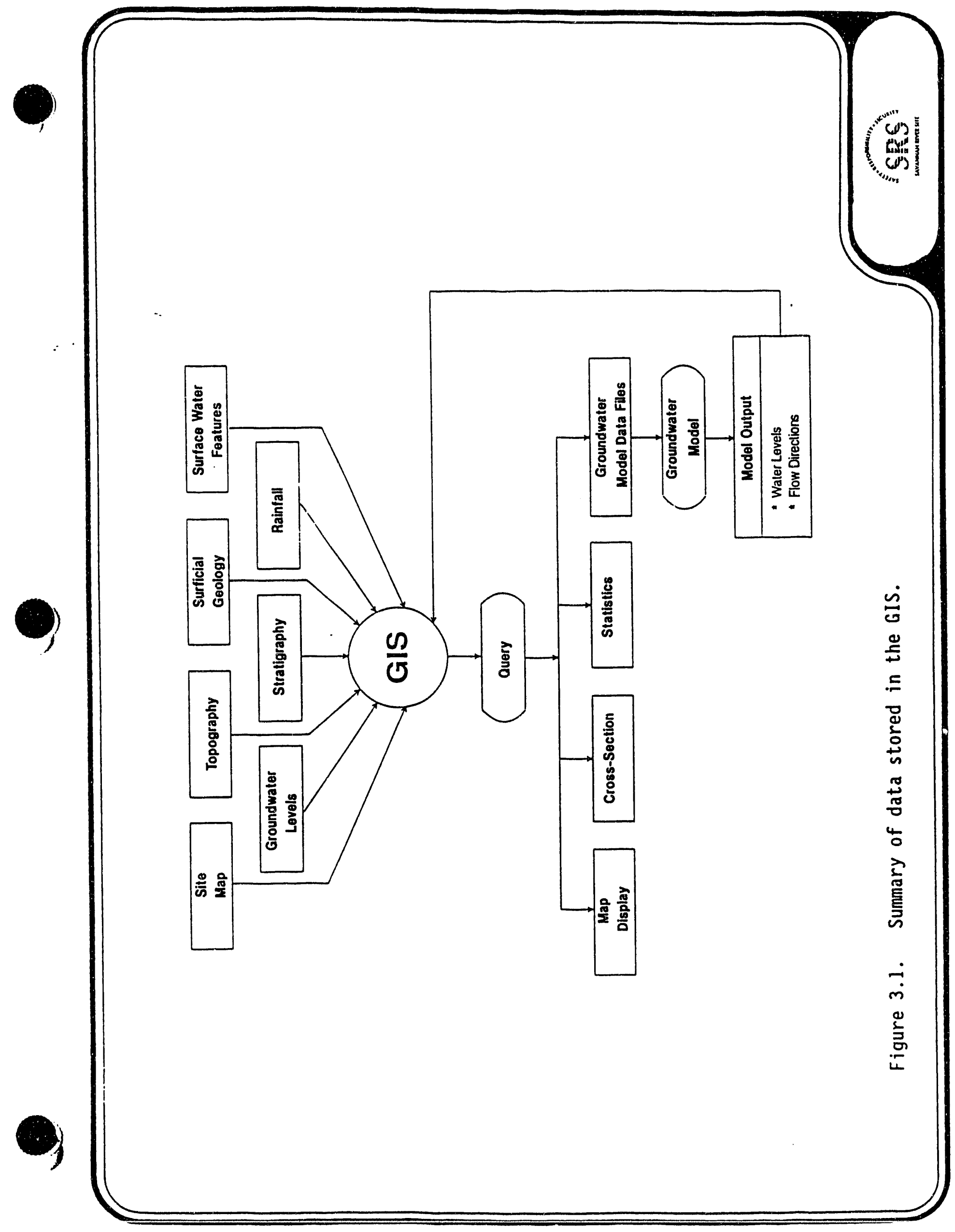




\subsubsection{Integration of Data Compilation With Model Input Data Sets}

The hydrogeologic data were processed with semi-automated techniques to generate the grid-based model input data sets for the simulation code, FTWORK. This was performed utilizing applications developed by GeoTrans for model development via GIS technology. The model grid was efficiently generated in a graphical environment, with other map features set in the background. Each grid cell in the model is represented by a rectangular polygon and a point at the center of the polygon. Grid-based model input for stratigraphy, boundary conditions, and calibration targets were created by intersecting the grid-based polygons or grid-based points with the spatially-variable hydrogeologic data, which was represented in the GIS as polygons, arcs, points, and three-dimensional surfaces.

\subsubsection{Advantages of GIS Approach}

Semi-automated development of model data sets via GIS software is a state-of-the-art technology that offers significant advantages over traditional methods for creating model data sets. Available data (such as stratigraphic and water-level data) are easily displayed to indicate areas of significant data deficiency within the model domain. Data may be analyzed through database query operations in a graphical environment to easily detect data errors and/or data inconsistencies. Perhaps most significantly, cell-specific model input data are derived from spatial GIS operations that are extremely rapid and repeatable. This significantly reduces data input error, and also allows rapid integration of new or revised data into the model input data sets. Another related advantage is that model grids may be easily redefined (to cover more area or increase resolution in areas of concern) with input data easily regenerated with the same repeatable steps.

\subsection{MODEL CONFIGURATION}

Model configuration refers to horizontal discretization, vertical discretization (i.e., implementation of stratigraphy), boundary conditions, and assignment of model parameters. Each of these items is described in detail below. 


\subsubsection{Horizontal Discretization}

The finite-difference grid is presented in Figure 3.2. It contains 91 columns and 75 rows. The upper left corner of the grid is located at SRS coordinates E46750, N87500. The grid is oriented at an angle of 13.285 degrees, clockwise, relative to SRS coordinates. This general orientation was selected to minimize inactive areas within the model domain (i.e., areas north of Upper Three Runs (reek and south of Four Mile Branch). The minimum grid spacing is $200 \mathrm{ft}$; the minimum grid spacing was used to cover the majority of the model area. The maximum grid spacing is 1,246 ft. Grid spacing increases towards the model edges, in areas outside of the immediate study area. The ratio between adjacent grid spacings is less than 1.2.

\subsubsection{Vertical Discretization}

The model is comprised of five layers, which represent three aquifers and two aquitards. The aquifers, from top to bottom, are Aquifer Unit IIB Zone 2 (Water Table), Aquifer Unit IIB Zone I (Barnwell/McBean), and Aquifer Unit IIA (Congaree). Each aquifer is represented by one model layer. The aquitards, from top to bottom, are Confining Unit IIB1-IIB2 ( Tan Clay) and Confining Unit IIA-IIB (Green Clay). Each aquitard is also represented by one model layer.

\subsubsection{Data Sources and Techniques}

Three-dimensional stratigraphic surfaces were generated from the hydrogeologic data to fully define the model input for stratigraphy. The data included two general sources: (1) data provided by SRS; and (2) data provided in Root (1987). Additional data points, called "control points", were added within the GIS to extend data coverage to the edge of the model domain. Elevations or thicknesses at these points were assigned according to trends determined visually from the other two sources of data.

The data from the first two data sources were processed in two ways. The first processing step involved modifying the tops and thicknesses of Confining Unit IIA-IIB (Green Clay) provided by SRS, to remove those portions identified as "carbonate". This was done for two reasons: (1) to make them consistent with thicknesses given by Root (1987), which did not 


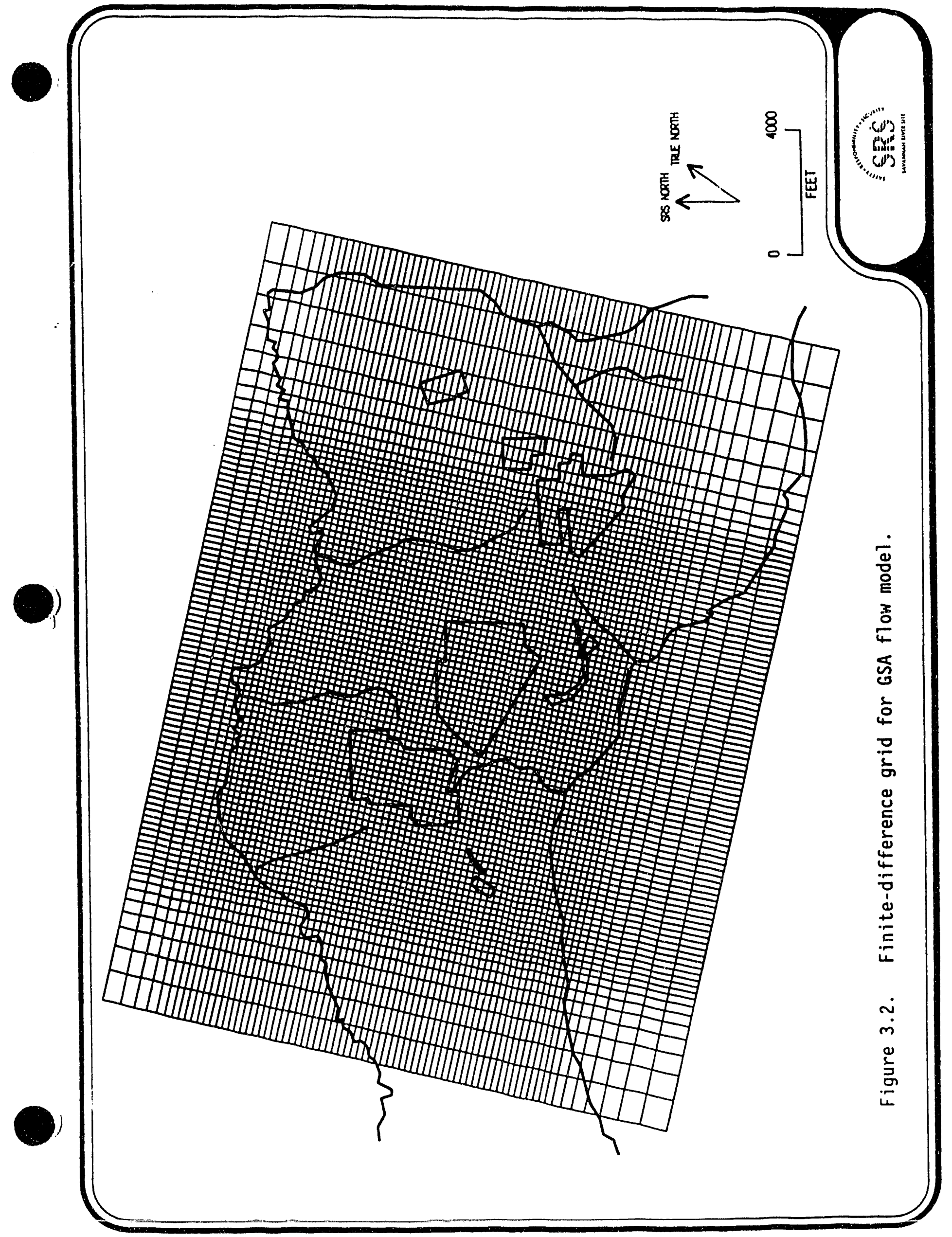


include carbonate thicknesses; and (2) to be consistent for cases where the extreme upper portion of Confining Unit IIA-IIB (Green Clay) was defined as carbonate. The second reason is important because in some cases the SRS classification includes ihese in Confining Unit IIA-IIB (Green Clay) while in others it includes them in Aquifer Unit IIB Zone I (Barnwe11/McBean). The second processing step involved modifying thicknesses provided by Root (1987), such that thickness of Confining Unit IIB1-IIB2 (Tan Clay) could not be less than $5 \mathrm{ft}$ and thickness of Confining Unit IIA-IIB (Green Clay) could not be less than $3 \mathrm{ft}$. This was necessary because much of the Root (1987) thickness data were determined at five foot intervals, which is too coarse to adequately characterize small unit thicknesses. The processed thicknesses were believed to be more representative of actual conditions. Note that no minimum thickness was assigned to data provided by SRS, which were deemed to be more reliable.

Three-dimensional surfaces for the following stratigraphic surfaces were generated from the collected data plus the control data, using the surface modeling features of ARC/INFO:

- Top of Confining Unit IIB1-IIB2 (Tan Clay);

- Thickness of Confining Unit IIBI-IIB2 (Tan Clay);

- Top of Confining Unit IIA-IIB (Green Clay); and

- Thickness of Confining Unit IIA-IIB (Green Clay).

Values of these surfaces were then determined at each model grid center using ARC/INFO commands, to generate cell-based values for the model grid. Grid-based operations (addition and subtraction) were used to define all other required surfaces.

A graphical presentation of stratigraphic data utilized to generate the three-dimensional surfaces are presented in Plates 1 to 6 .

The carbonate sediments identified within the stratigraphic column were not explicitly included in the flow model. Restrictions on the number of vertical layers in the model, limited knowledge of the properties of the carbonates, and their extremely variable distribution (location, thickness, and position in the vertical stratigraphic column) made it difficult to explicitly assign model features to represent these deposits. 


\subsubsection{Stratigraphic Surfaces Implemented in the Model}

Due to the resolution of the model grid, which has a minimum spacing of $200 \mathrm{ft}$, small-scale features such as faults and slumps are not explicitly defined in the model. However, inasmuch as these features affect the overall shape of each stratigraphic surface, they are included. For example, if a fault displaces a confining bed (that otherwise dips consistently) vertically by five $\mathrm{ft}$, that displacement will be evident in the grid-based elevations for that confining unit across a distance of one or two model cells.

The top of layer 1 in the model was set arbitrarily to be $100 \mathrm{ft}$ greater than the top of layer 2. Note that the actual saturated thickness of layer 1 depends on the simulated water levels, and not the stratigraphic top of the unit. Specification of top elevation for layer 1 is required because FTWORK establishes all elevations by successively subtracting thicknesses from the layer 1 top elevation.

The top of layer 2 (bottom of layer 1) was assigned from the data for top of Confining Unit IIB1-IIB2 (Tan C1ay). A structural contour map of this surface is presented in Figure 3.3. This unit dips to the south across the GSA.

The thickness of 1 ayer 2 was assigned from the data for the thickness of Confining Unit IIB1-IIB2 (Tan Clay). An isopach map for Confining Unit IIB1-IIB2 (Tan Clay) is presented in Figure 3.4. The thickness of this confining unit affects the resistance to flow between the aquifers it separates. The confining unit is generally thicker towards Four Mile Branch than towards Upper Three Runs Creek. Although Confining Unit IIB1-IIB2 (Tan Clay) is sometimes absent in the database, a finite thickness is always defined in the model input where this unit is not eroded, with a minimum of $0.1 \mathrm{ft}$ and a maximum of $25.7 \mathrm{ft}$. In areas where the minimum $0.1 \mathrm{ft}$ are assigned, the model treats this as though the Confining Unit IIB1-IIB2 (Tan Clay) were not present. In the model, the hydraulic resistance of these thinned out zones are numerically insignificant. The finite value of thickness is used to avoid numerical problems.

The top of 1 ayer 3 (bottom of layer 2) was calculated by subtracting the surface for the thickness of Confining Unit IIB1-IIB2 (Tan Clay) from 


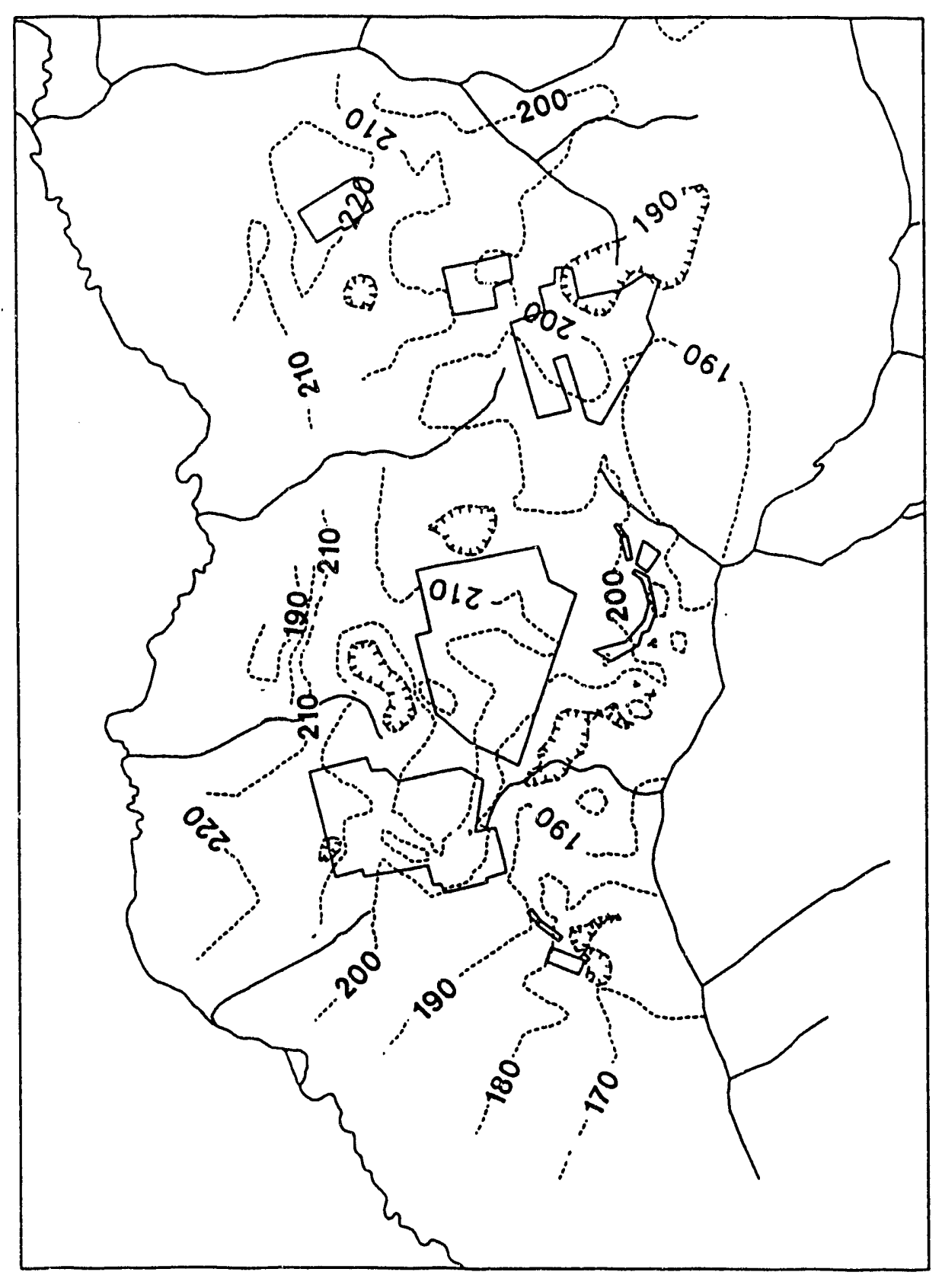

(")

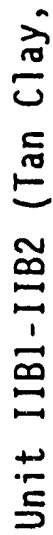

을

的

등 웜

4응

은

๖ั

ㄴํㅇ ฮ

융ㅇ

ED

క气 ง

동

엉

范市

$m$
$m$
$\frac{0}{5}$
$\frac{0}{1}$ 


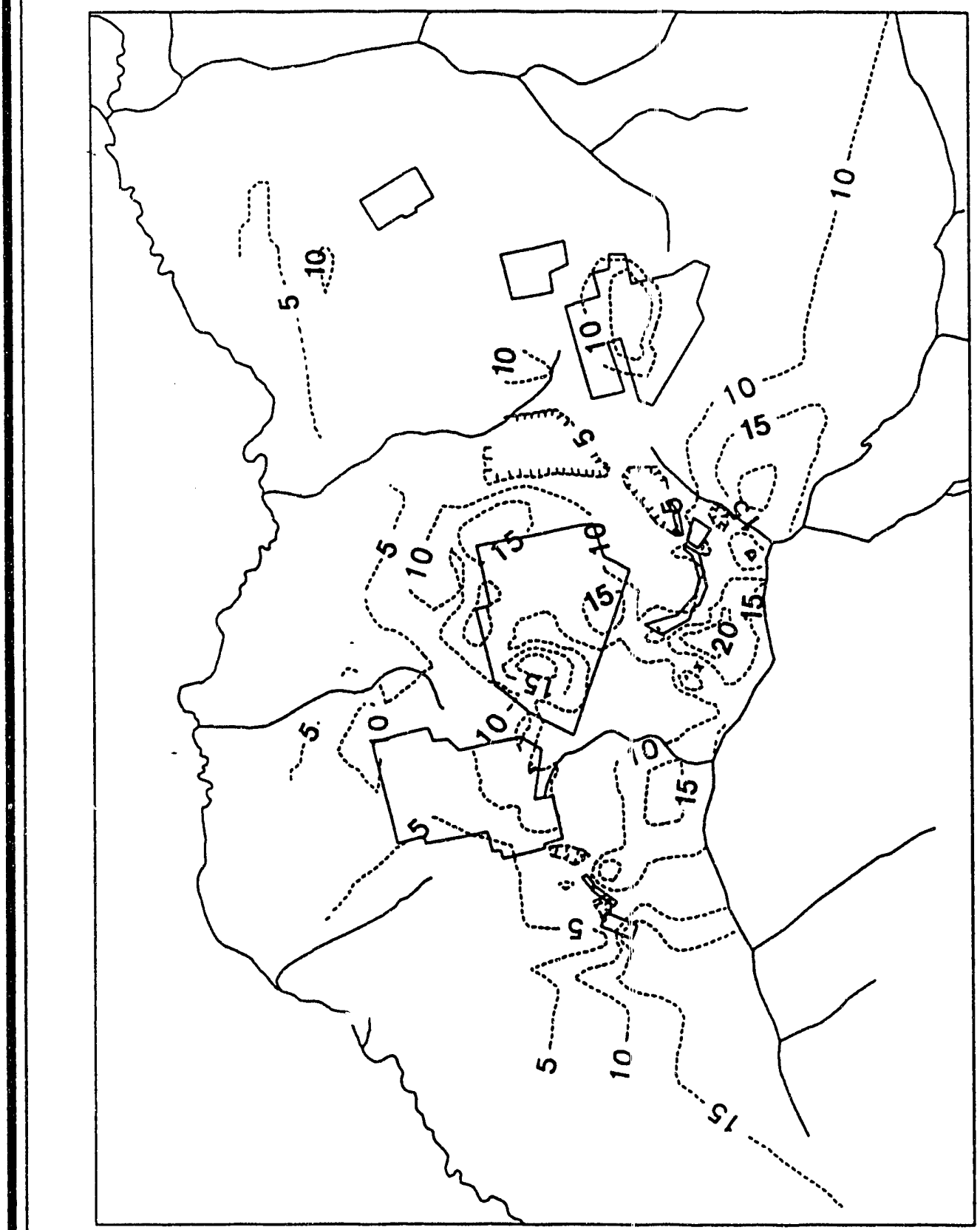

"ל

స

高

号

๓

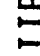

$\frac{1}{0}$

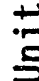

5

.를

E.

등

잍

它

命

ง

崩

훈

엄

독

نं 
the surface for the top of Confining Unit IIB1-IIB2 (Tan Clay). A structural contour map for the top of layer 3 is presented in Figure 3.5 . This layers also dips to the south across the GSA.

The thickness of layer 3 was calculated by subiracting the surface for the top of layer 4 from the top of layer 3. An isopach map for Aquifer Unit IIB Zone I (Barnwell/McBean) is presented in Figure 3.6. This thickness is utilized by the model in conjunction with horizontal hydraulic conductivity to characterize the ability of the aquifer to transmit water. In the model, this layer has a typical thickness of 60 to $96 \mathrm{ft}$, and thins to $20 \mathrm{ft}$ towards Upper Three Runs Creek where it is eroded. The thickness of carbonate in the aquifer were not explicitly accounted for in the model, as was previously discussed.

The top of layer 4 (bottom of layer 3) was assigned from the data for top of Confining Unit IIA-IIB (Green Clay). A structural contour map of this surface is presented in Figure 3.7. As with the overlying units, this unit dips to the south across the GSA.

The thickness of layer 4 was assigned from the data for the thickness of Confining Unit IIA-IIB (Green Clay). An' isopach map for Confining Unit IIA-IIB (Green Clay) is presented in Figure 3.8. In the model, this layer has a typical thickness of 3 to $10 \mathrm{ft}$, with a minimum thickness of $2 \mathrm{ft}$ and a maximum thickness (near the MWMF) of $24 \mathrm{ft}$.

The top of layer 5 (bottom of layer 4) was calculated by subtracting the surface for the thickness of Confining Unit IIA-IIB (Green Clay) from the surface for the top of Confining Unit IIA-IIB (Green Clay). A structural contour map for the top of layer 5 is presented in Figure 3.9. Again, this layer dips to the south across the GSA.

The thickness of 1 ayer 5 was assumed to be $100 \mathrm{ft}$ over the entire model domain.

\subsubsection{Stratigraphic Cross Sections}

Five stratigraphic cross sections were developed from the threedimensional stratigraphic surfaces used to generate the model input. The locations of these sections are presented in Figure 3.10, and correspond to regional cross sections 1 through 5 developed for the RCRA Part B 


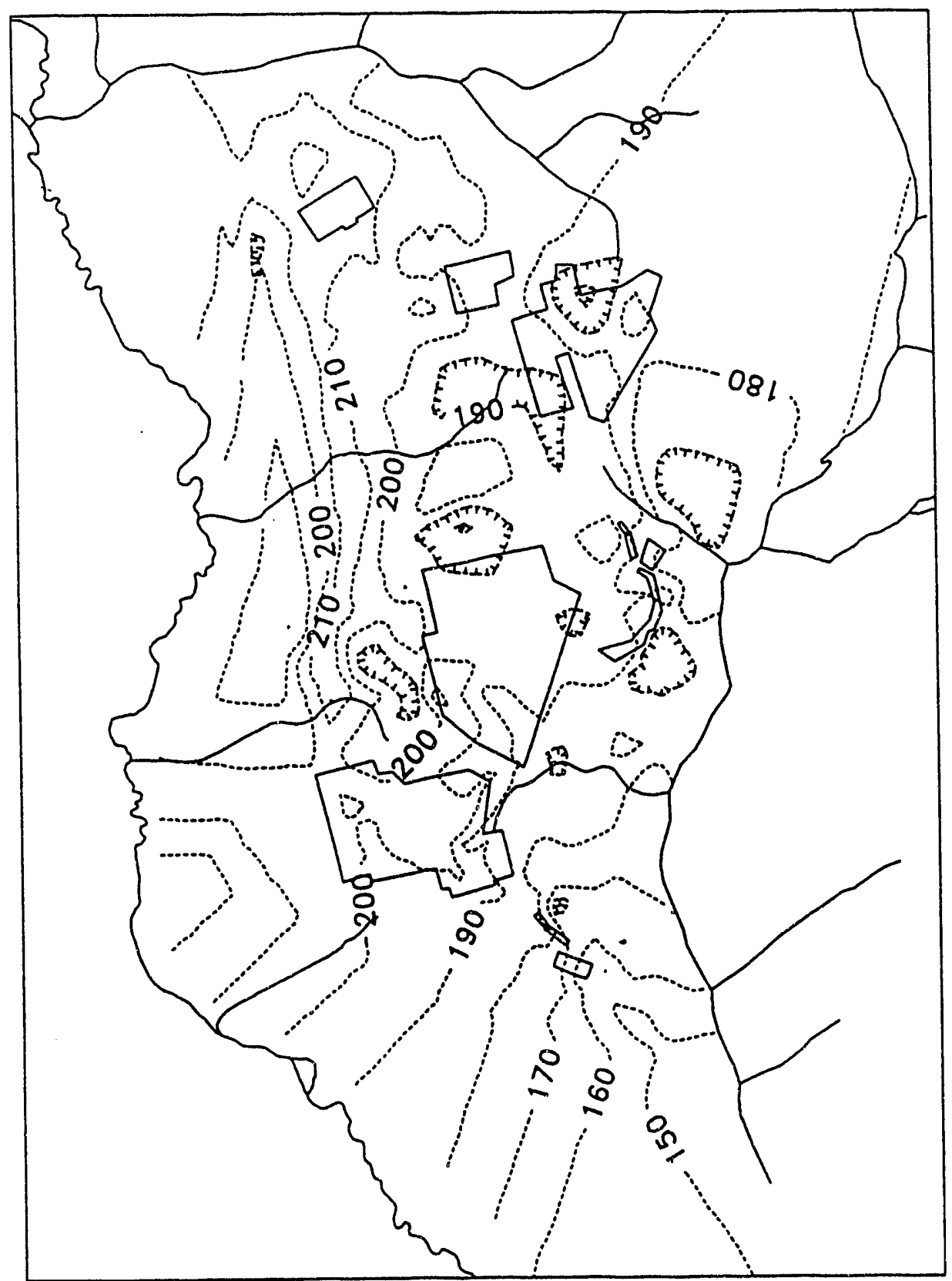

(1)

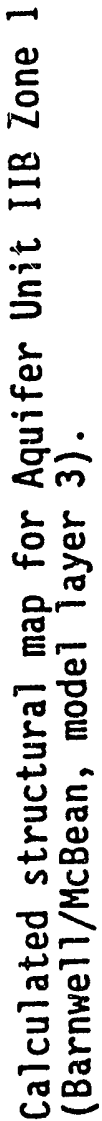

m 


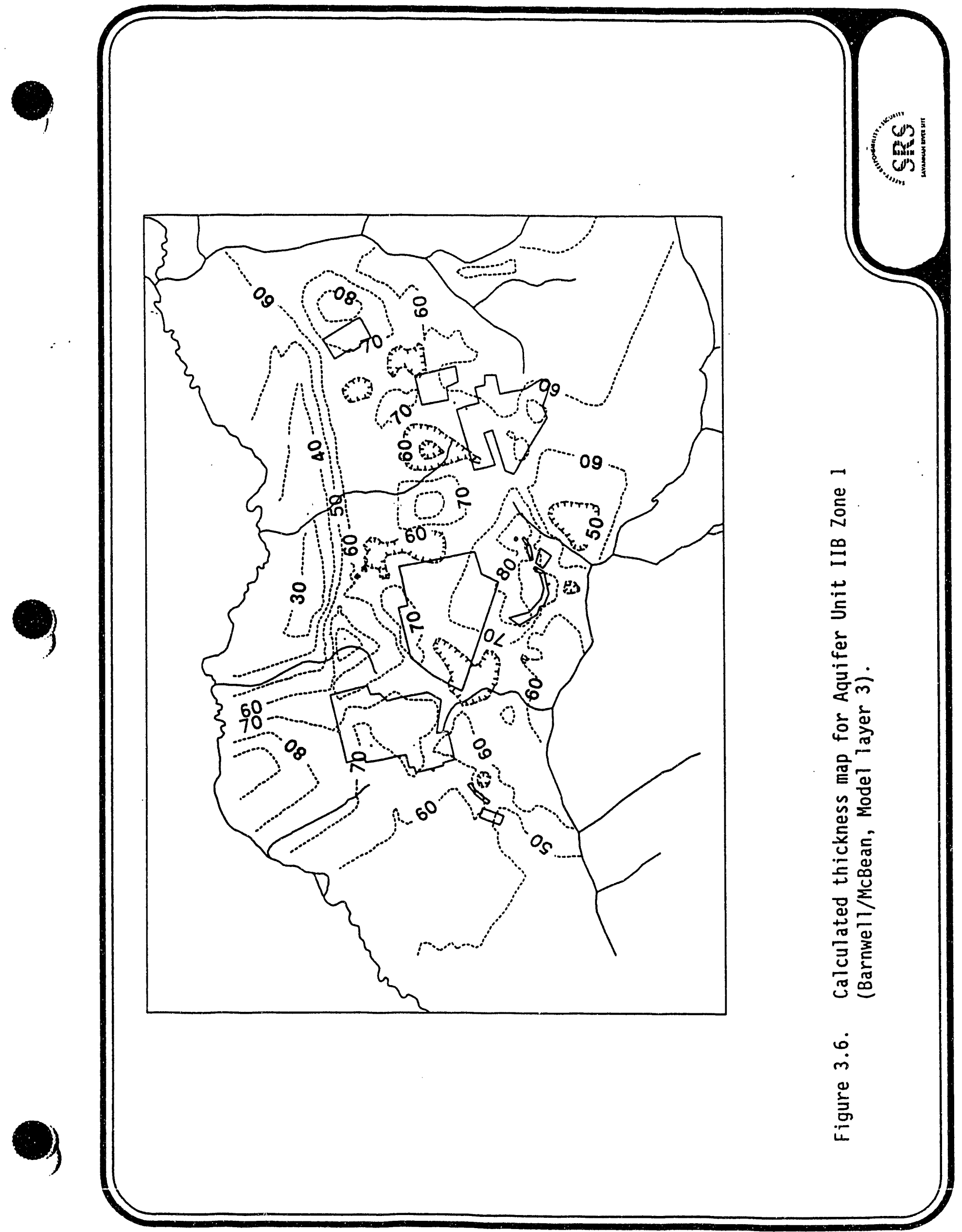




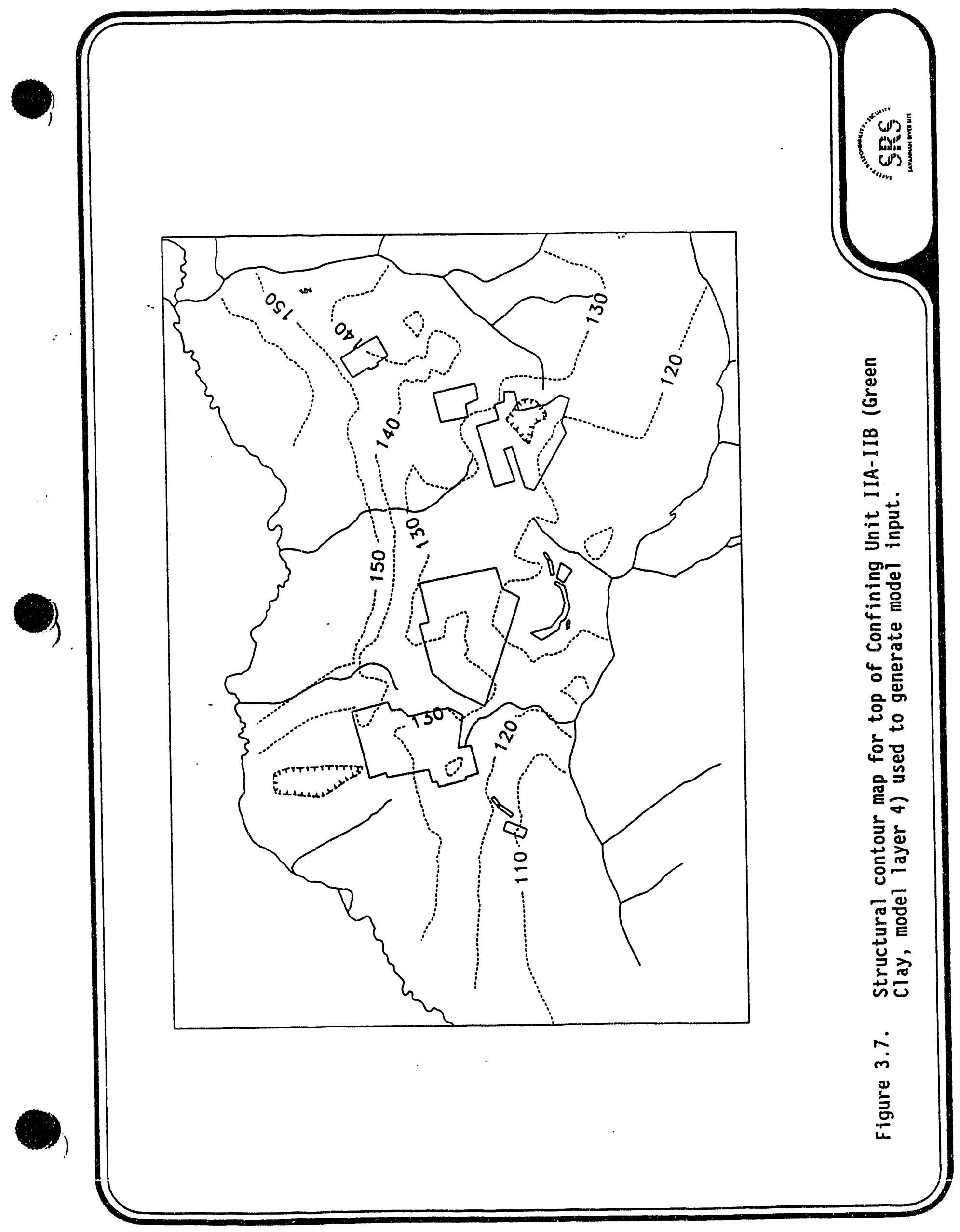




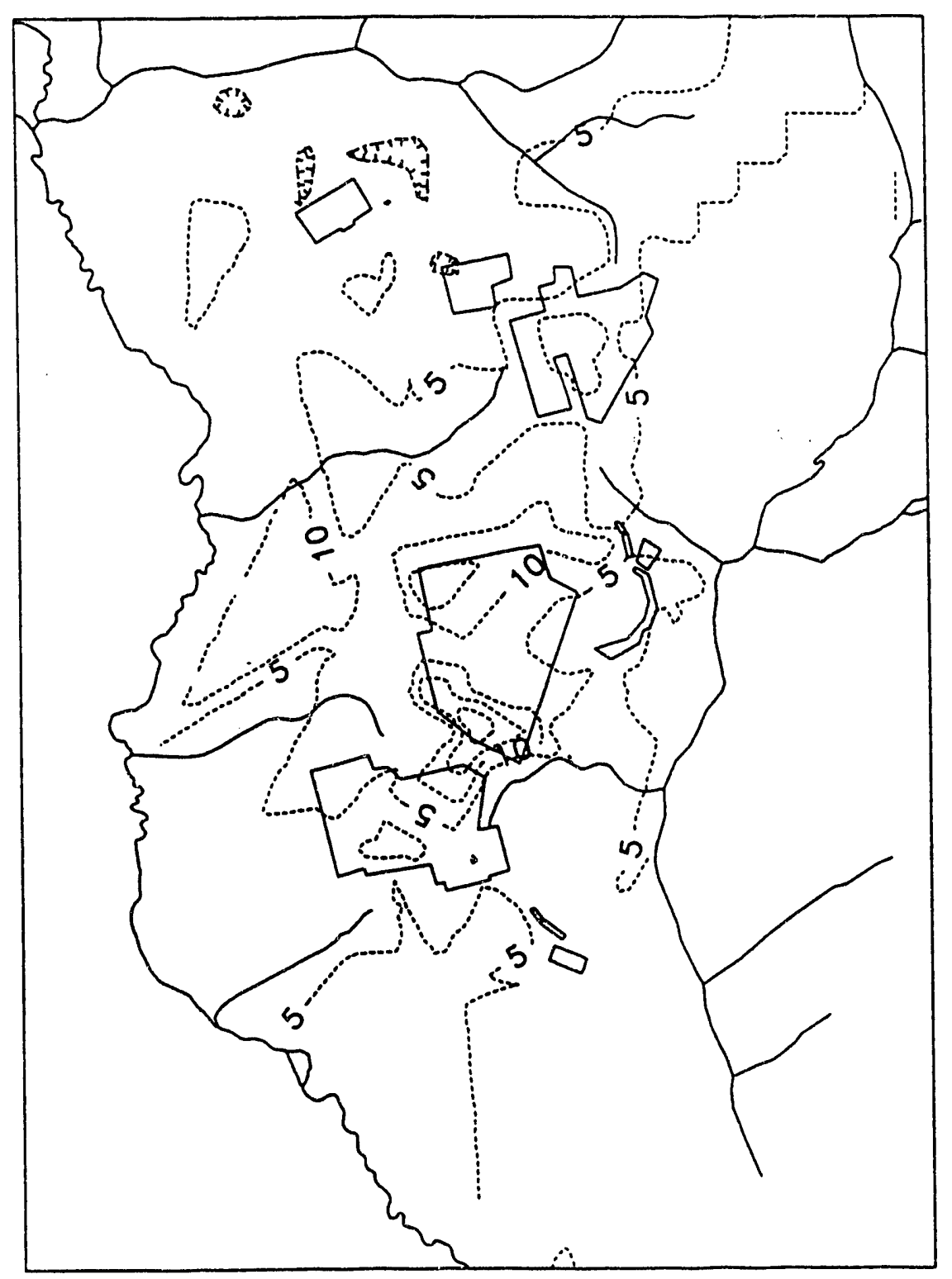

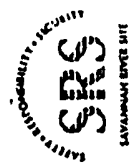

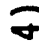

ร

i⿱

동

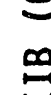

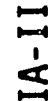

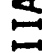

$\stackrel{5}{5}$

올를

E.

둥

ó

4

号过

ฯ ฮ

ม

농ㅎㅁ

占号

$\infty$
$m$
0
$\frac{1}{0}$
$\frac{1}{4}$ 


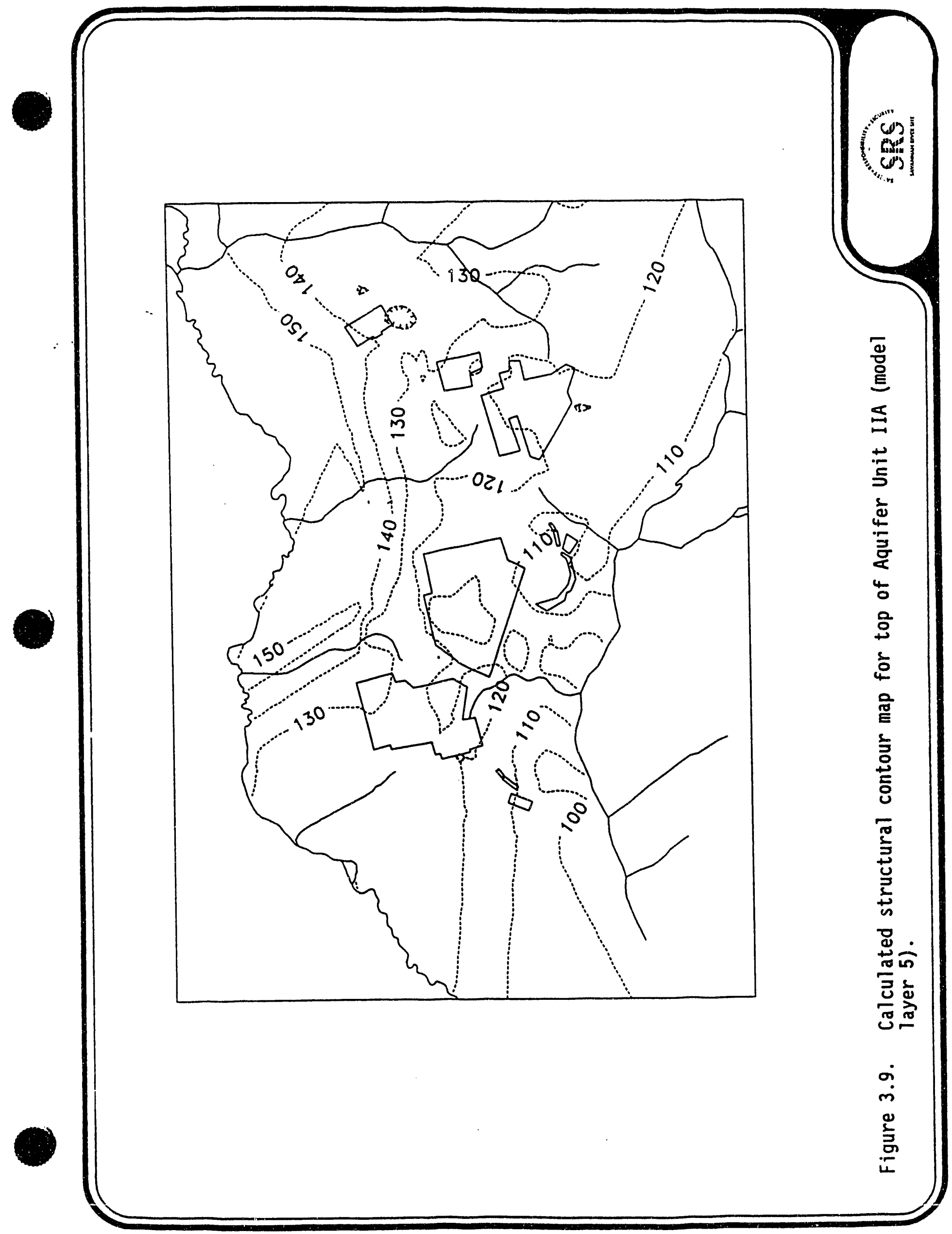




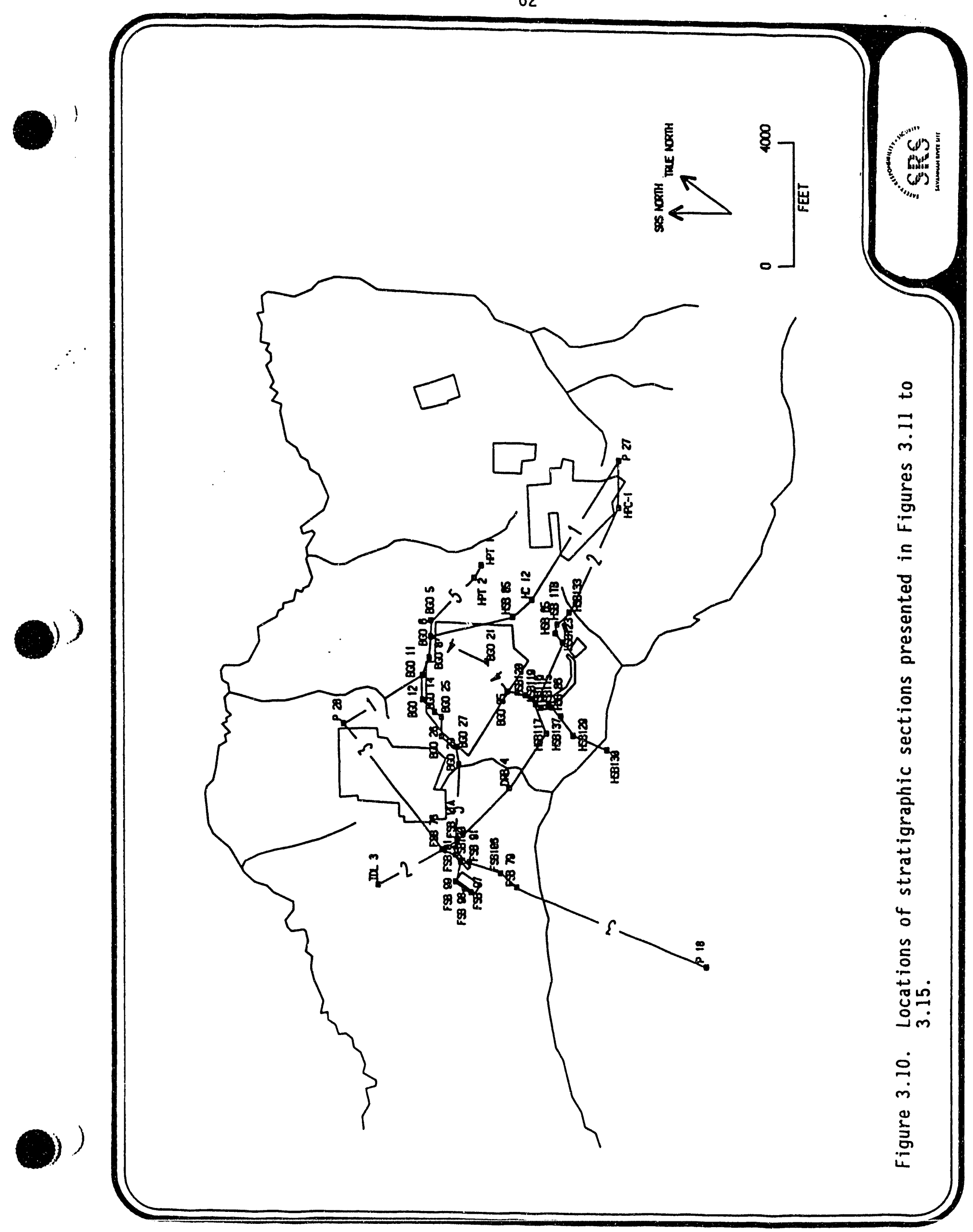


Application (SRS, 1990). The three-dimensional surface representing 1 and surface was based on a topographic map provided by SRS in digital format.

The cross sections, presented in Figures 3.11 to 3.15 , were generated using the GIS which samples each three-dimensional stratigraphic profile at specified points. To generate these sections, points were sampled at intervals of two-hundred ft along each section line, plus at every well used by SRS (1990) in generating their sections (well names are indicated on the sections). Whereas the SRS (1990) sections only utilize stratigraphic data at the wells indicated, the sections presented here are based on all available data as represented by the three-dimensional surfaces. That is the reason these sections sometimes indicate significant features (thinning or thickening of units) between wells indicated on the figures.

The cross sections in SRS (1990) present very fine detail in the vertical, such that a confining bed may include several stringers of clay material separated by sand. For the present analysis, such stringers are grouped as one consistent unit, according to the interpretations in the two data sources utilized, which were described earlier.

\subsubsection{Boundary Conditions}

Boundary conditions of the following types are specified in the flow model :

- $\quad$ specified head;

- no-flow (specified flux of zero);

- river; and

- drain.

A brief description of these types of boundary conditions is given below, followed by a description of rules for boundary condition assignment in the model with the GIS. Then, a description of boundary condition assignments in each model layer is presented. 
SEC 1

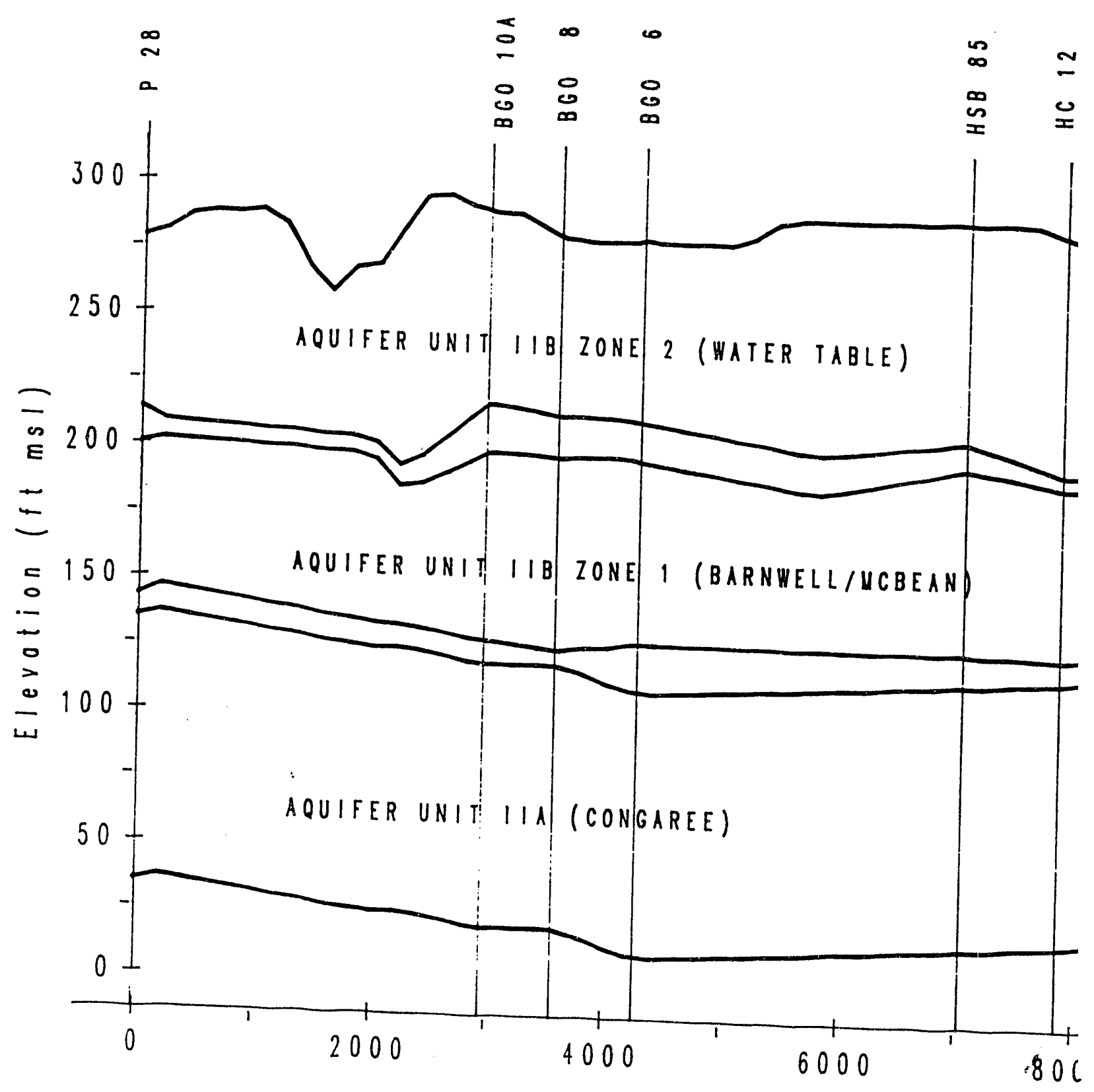

Horizonta Figure 3.11. Stratigraphic section 1, based on three-dimensional st
surfaces used to define model input. 
ON 1

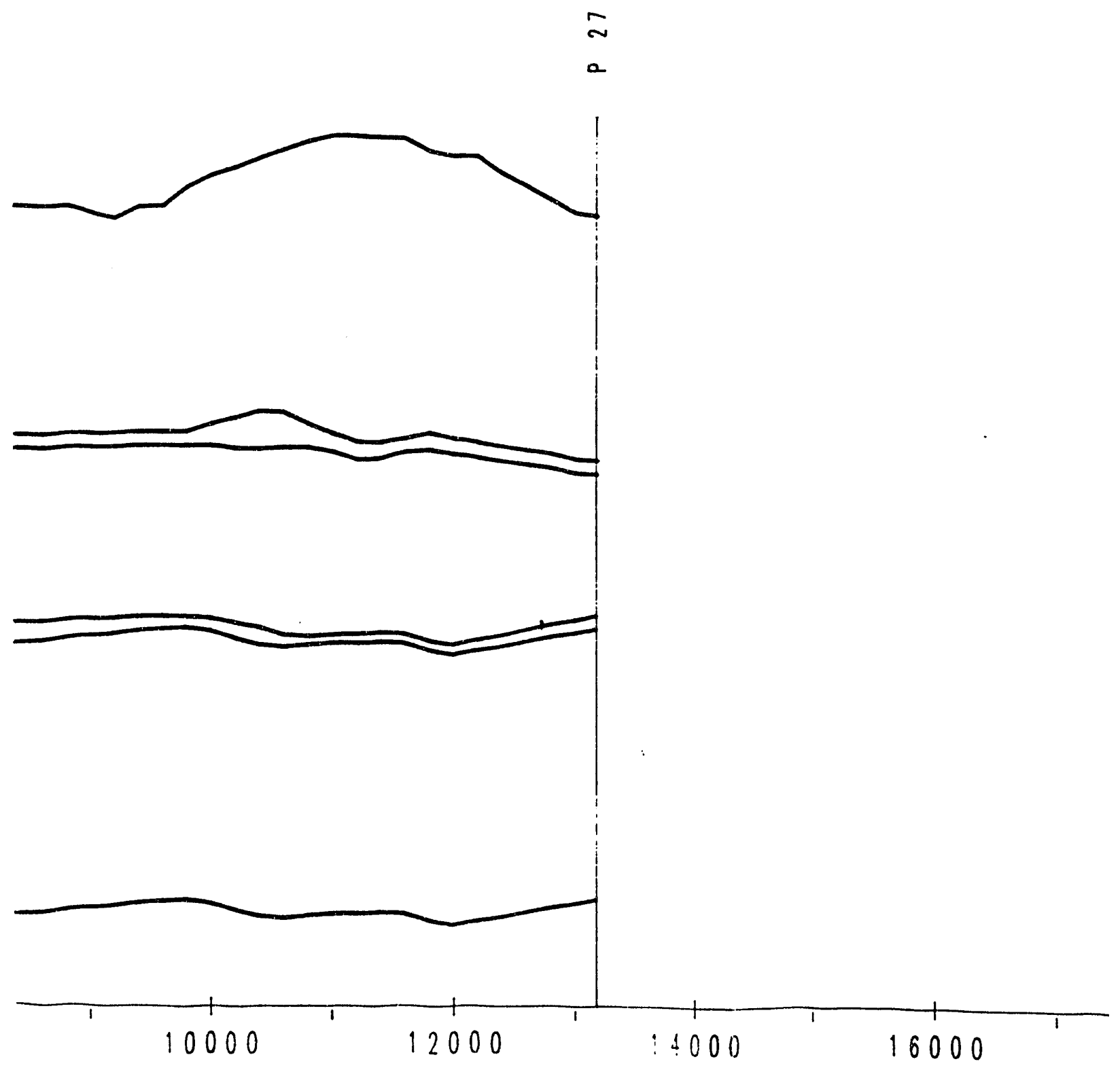

Distance $(f t)$

tigraphic 


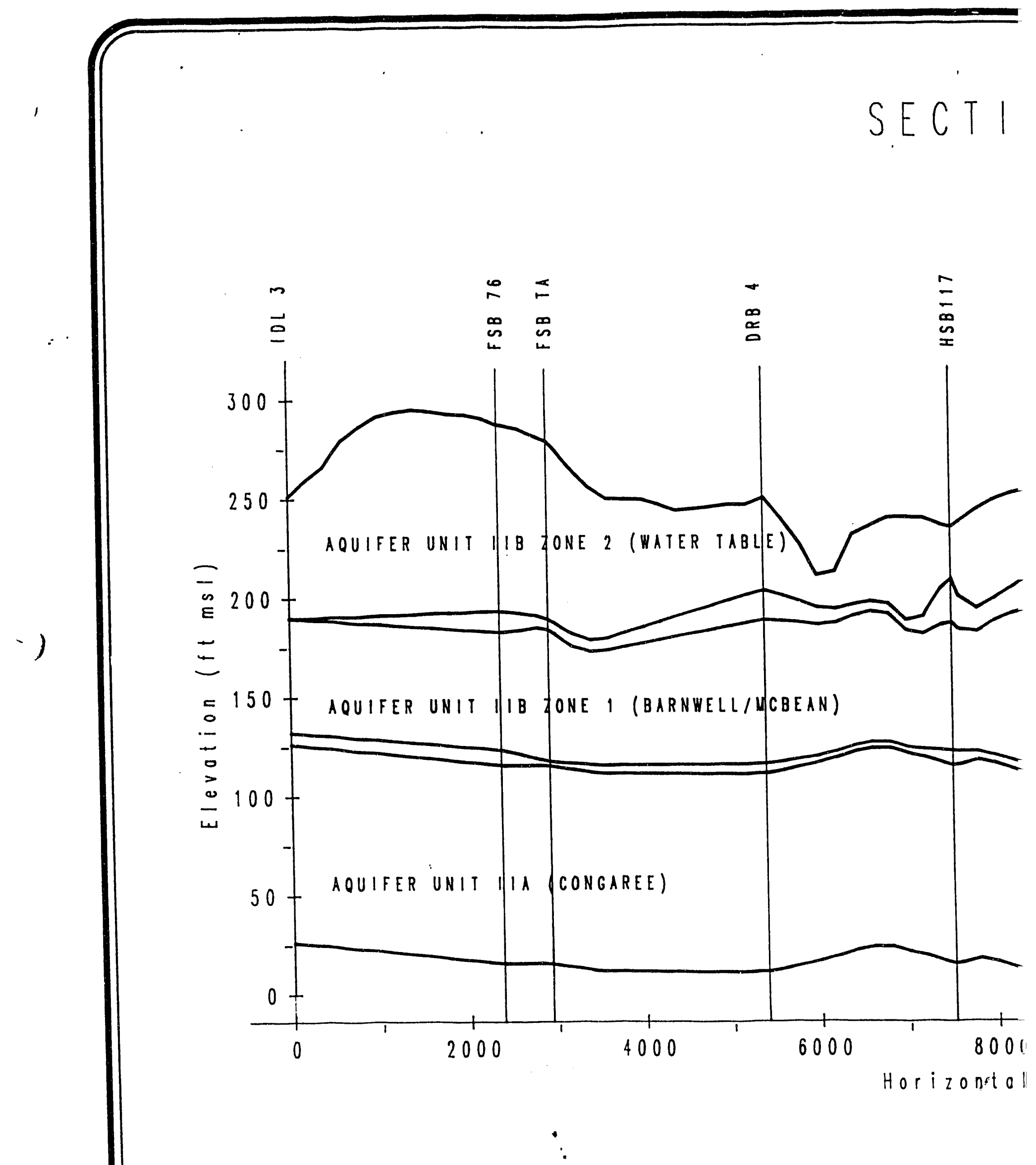

Figure 3.12. Stratigraphic section 2, based on three-dimensional st surfaces used to define model input. 
ION 2

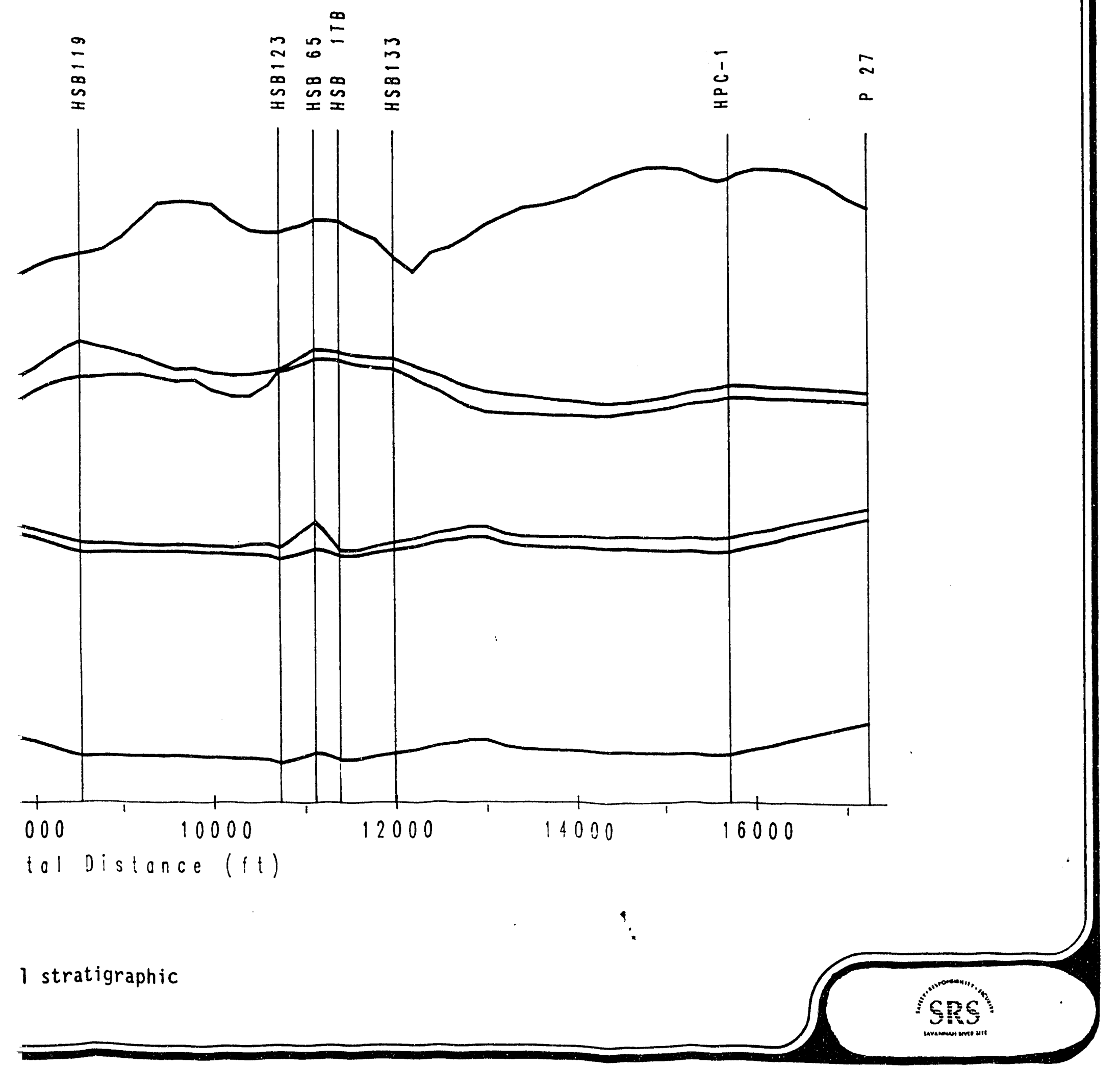




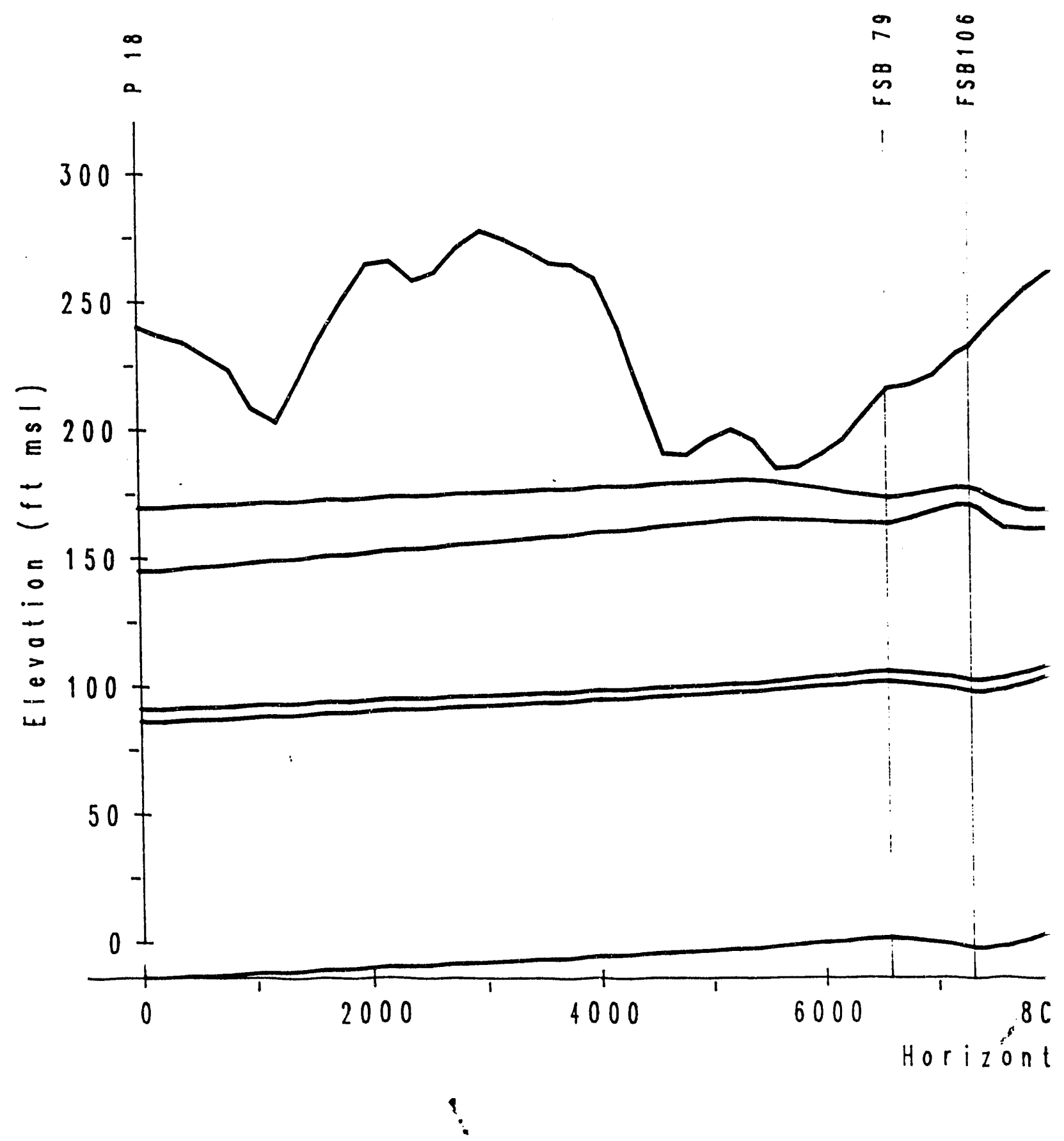

Figure 3.13. Stratigraphic section 3, based on three-dimensior surfaces used to define model input. 
J 3

$\begin{array}{lll}0 & - & 0 \\ 0 & 0 & n \\ \infty & \infty & n\end{array}$

$\infty$

ฉ.

나 나

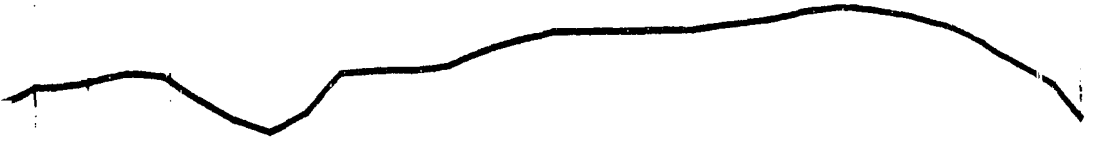

QUU CIFER: UNIT IIB ZONE 2 (WATER TABLE)

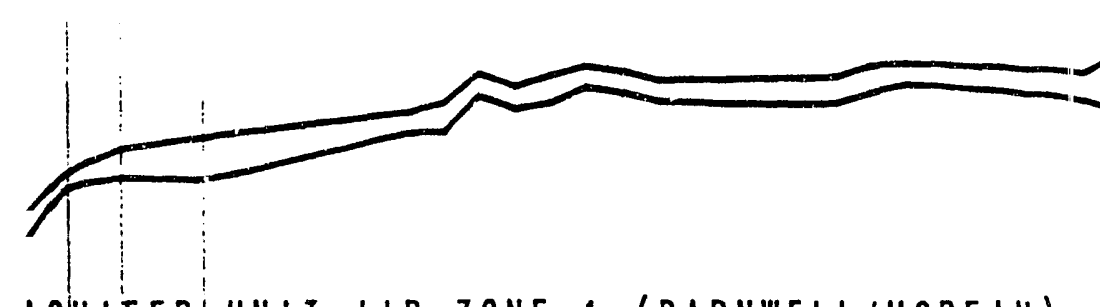

:OUIFER UNIT IIB ZONE I (BARNWELL/NCBEAN) -

AQUIFERI UNIT IIA (CONGAREE)

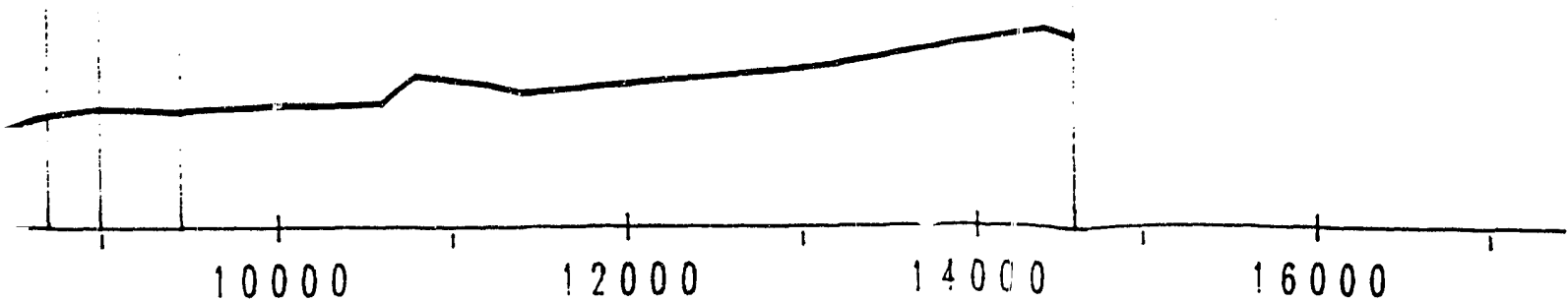

Distancs $(f t)$

tratigraphic 


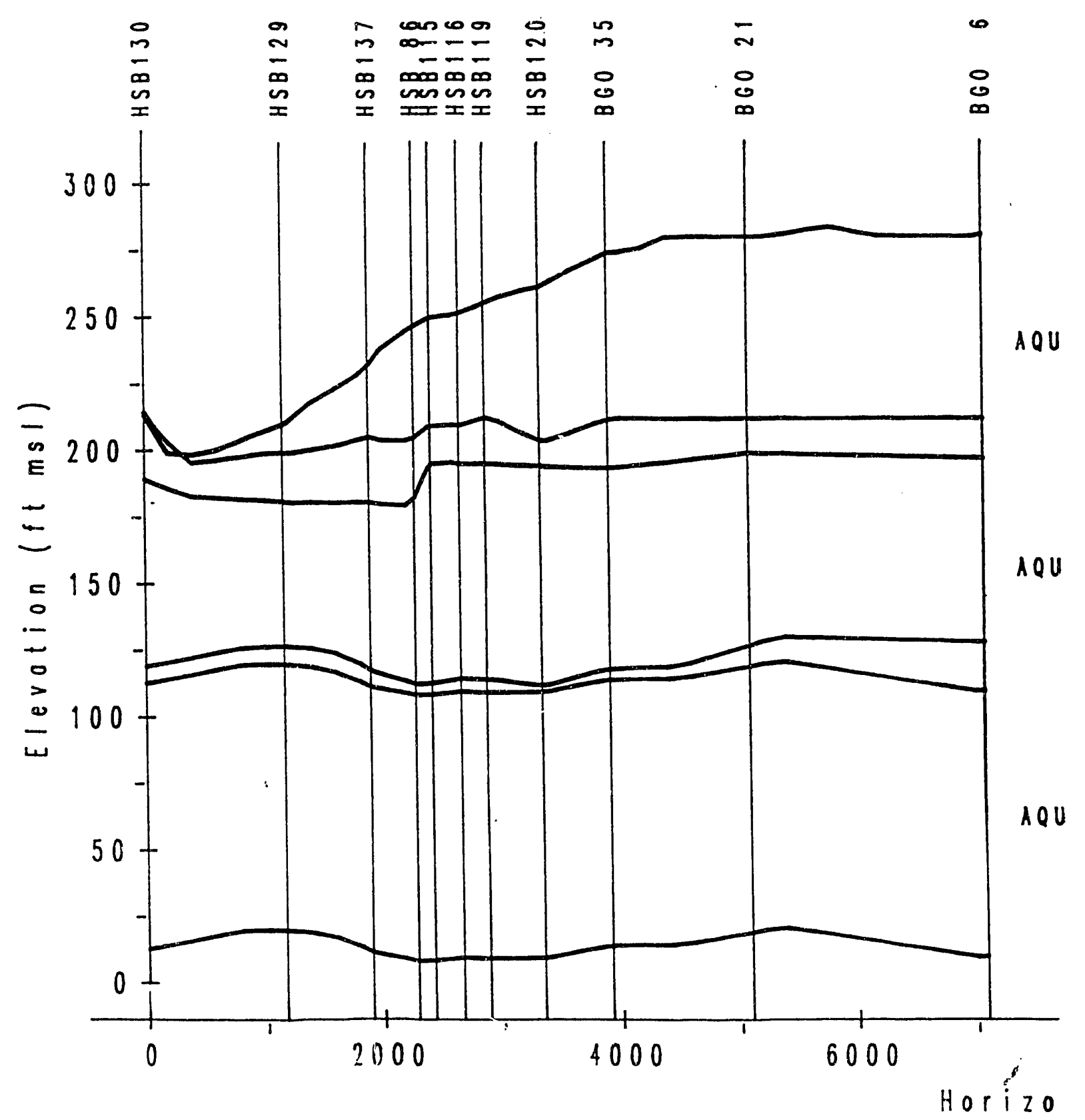

Figure 3.14. Stratigraphic section 4, based on three-dimen surfaces used to define model input. 
ON 4

R UNIT IIB ZONE 2 (WATER TABLE)

:R UNIT IIB ZONE I (BARNWELL/WCBEAN)

ER UNIT IIA (CONGAREE)

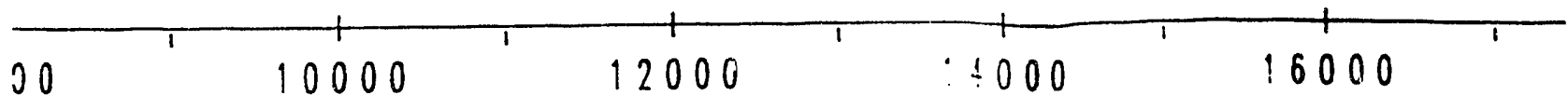

a) Distance $(f t)$

nal stratigraphic

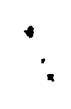




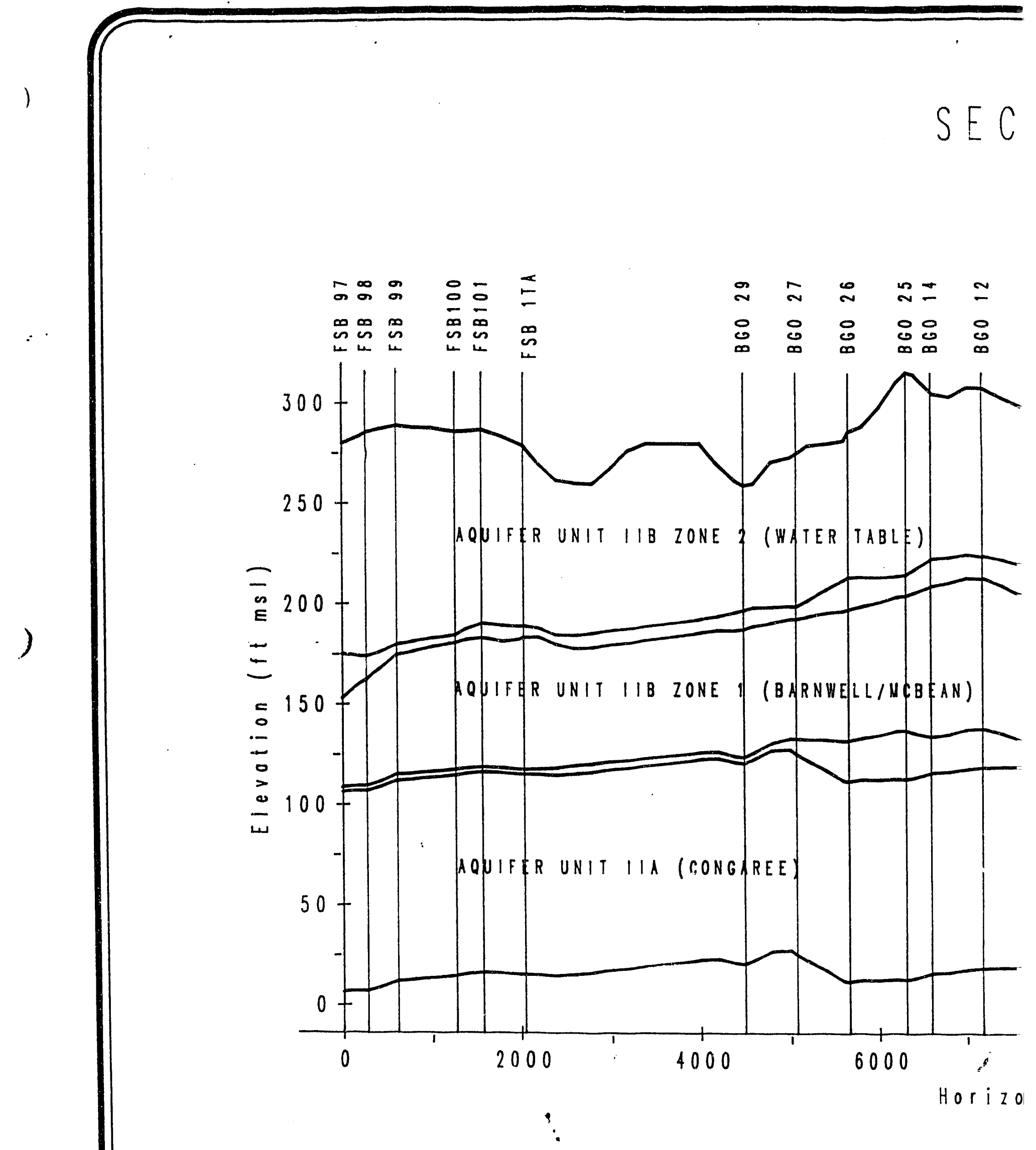

Figure 3.15. Stratigraphic section 5, based on three-dimensional surfaces used to define model input. 
ION 5
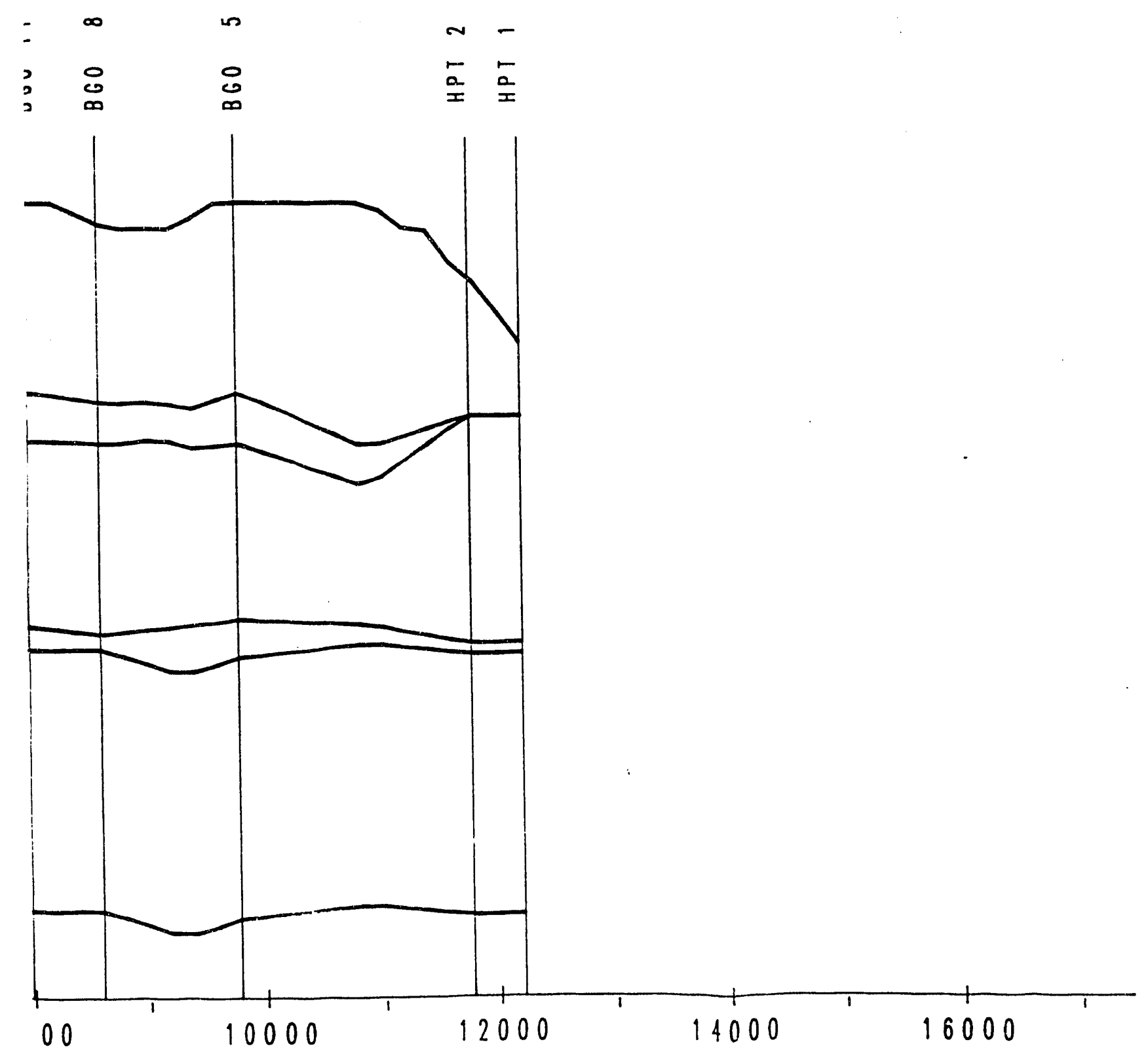

ol Distance $(t t)$

ratigraphic 


\subsubsection{Types of Boundaries}

A specified-head boundary at a model grid cell forces the head in that grid cell to a specified value. Depending on heads in adjacent cells, this boundary serves as an infinite source or sink of water. Specified head boundaries usually represent fully incised streams or rivers, lakes, or sometimes an equipotential line along the edge of a model grid. Calculation of head is never made at these grid cells.

A no-flow boundary at a model grid cell allows no fiux of water into or out of that cell. These cells are also referred to as "inactive". Noflow boundaries usually represent aquifer pinchouts, areas of desaturation, impermeable boundaries, or sometimes flowlines or groundwater divides at the edge of a model grid. The model assumes a no-flow boundary immediately outside of the model grid if no other boundary condition exists at the model grid edge. Model cells that go dry during the simulation are automatically converted to no-flow cells. Calculations of head are never made at inactive grid cells.

A river boundary is a leaky, head-dependant boundary condition that permits flow either into or out of the aquifer, depending upon the calculated head in the cell versus the user-declared stage of the river. This boundary is used to model leakage to or from the aquifer when a stream or river is not directly connected to the aquifer or does not fully incise the aquifer. A river boundary requires the following input for each pertinent grid cell: (1) the bottom elevation of the river; (2) the stage of the river; (3) the area of the river within that cell; and (4) a conductance for the sediments at the river base.

A drain boundary is a leaky, head-dependant boundary condition that only permits flow out of the aquifer, at a rate that depends on the calculated head in the cell versus the elevation of the drain. This type of boundary requires the following input for each pertinent grid cell: (1) the elevation of the drain; (2) the area of the drain within that cell; and (3) a conductance for the material immediately adjacent to the drain.

\subsubsection{Boundary Assignment in the Model with the GIS}

Assignment of boundary conditions in the model required the following basic steps: (1) conceptualization of boundary types throughout the model 
domain; (2) determination of a cell-based representation of each boundary; and (3) operations to insure at most one boundary condition per cell per model layer. This last step is important due to restrictions of the model regarding overlapping boundary conditions (i.e., a river in an inactive cell is inconsistent).

Boundary conditions for model layers 1,3 , and 5 are presented in Figures 3.16 through 3.18 , respectively. Where no boundary condition is specified at the grid edge, a no-flow boundary is assumed by the model immediately outside the model domain. For these areas, it is assumed that equipotentials are generally perpendicular to the model edge.

The only boundaries conditions explicitly defined in model layers 2 and 4 are inactive areas. Inactive areas in layer 2 are identical to those in layer 1 , and inactive areas in layer 4 are identical to those in layer 3.

The process of generating these cell-based boundary conditions for the model is described below, according to boundary type. Then the rules implemented to prevent overlapping boundary conditions are presented.

\section{Specified Head:}

For the GSA flow model, specified heads were only assigned to model layer 5, beneath . Four Mile Brancil and along the east and west edges of the model grid. This boundary represents ir ax and efflux from the more regional Aquifer Unit IIA (Congaree) system. This is not a real hydrogeologic boundary, but is used for convenience of modeling the overlying aquifer systems. Cells were defined to be specified head by interactively drawing a line over the desired cells within the GIS. The actual values of head assigned were derived from the initial heads specified in the model input. Initial heads for layer 5 were determined from a combination of measured water levels (second quarter 1991) and elevations of Upper Three Runs Creek. From these data a three-dimensional surface was generated using the surface modeling module features of ARC/INF0. Elevations of this surface were determined at grid centers to assign cell-based values. 


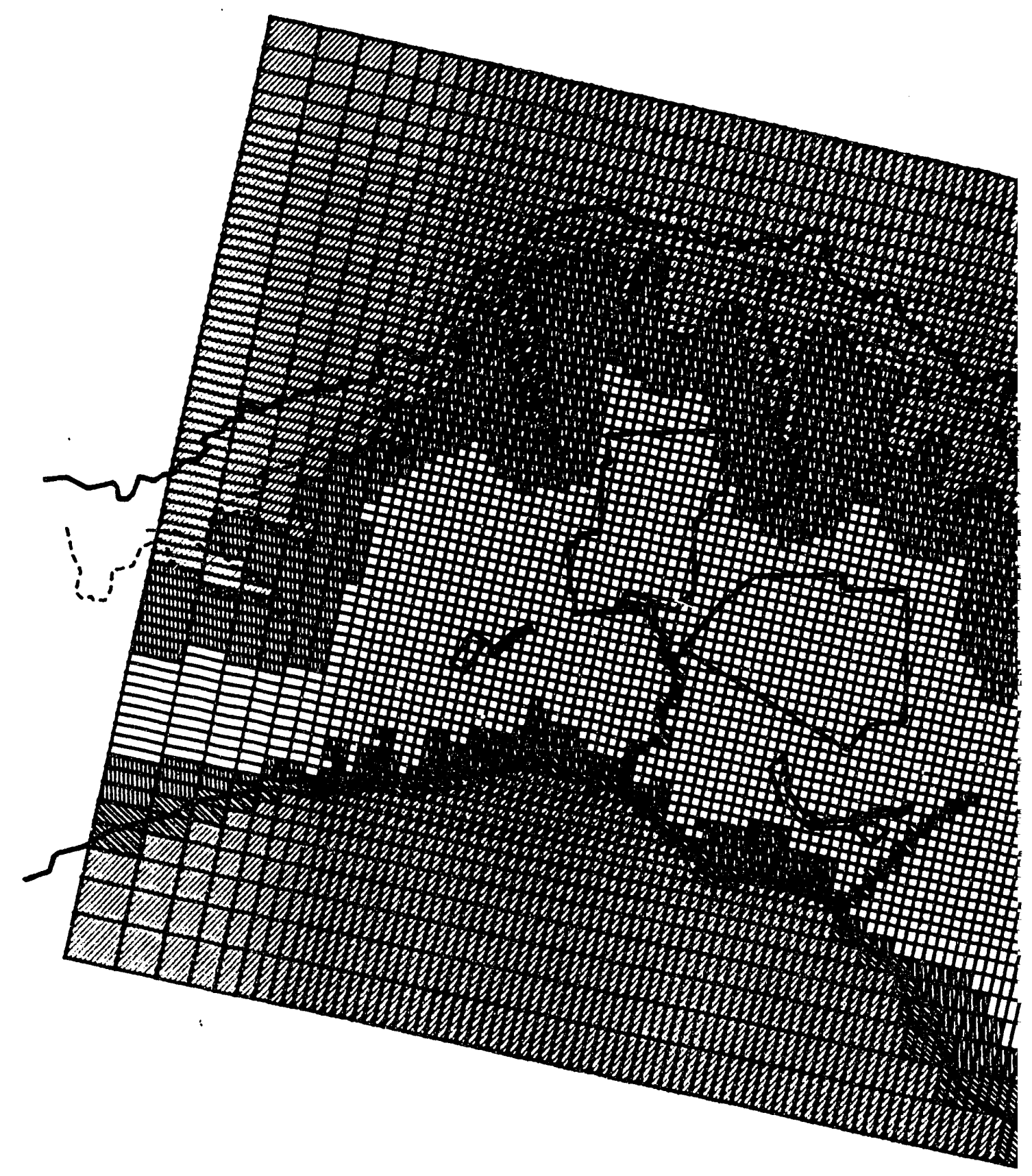




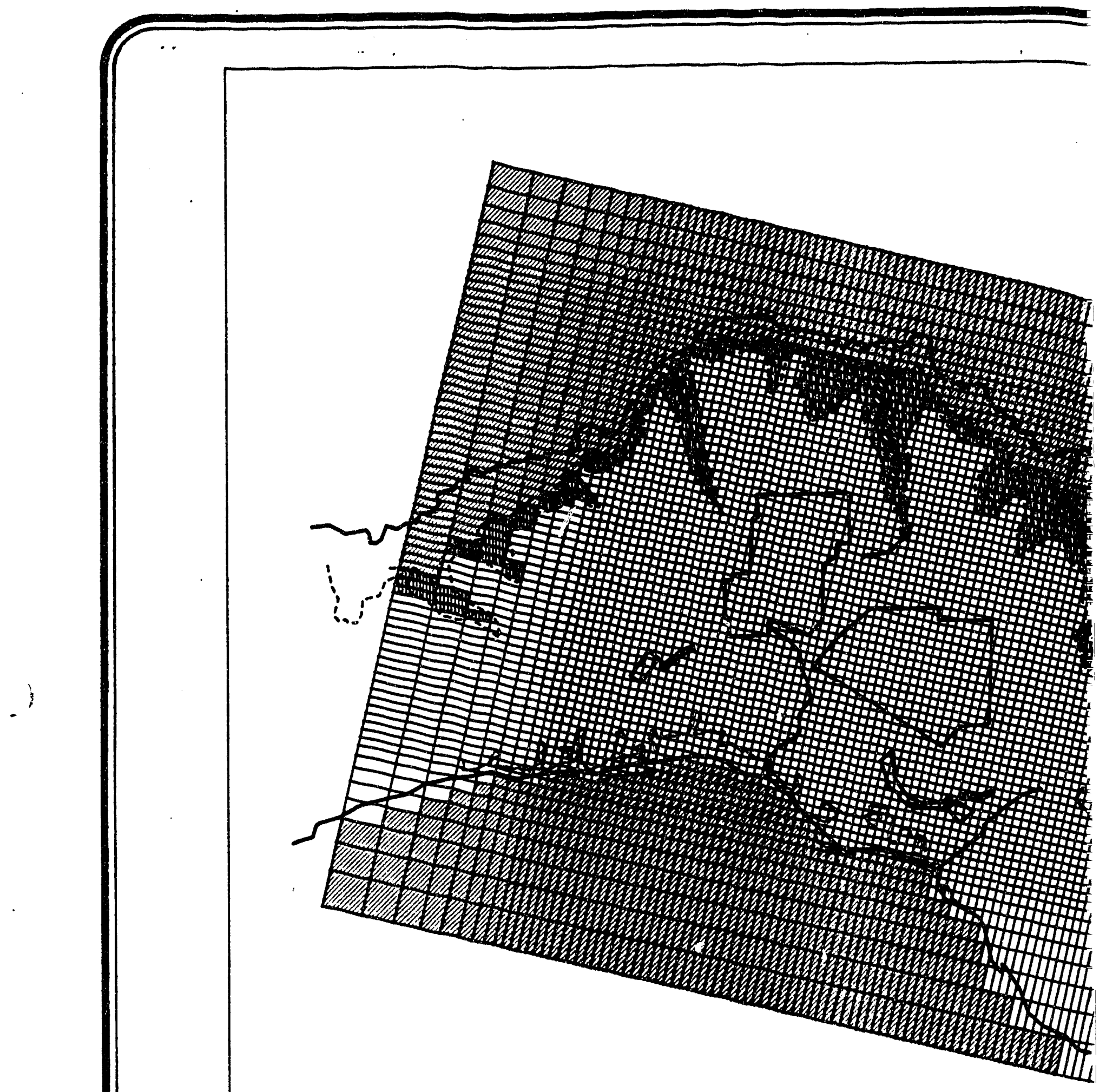


Nodel Loyer 3

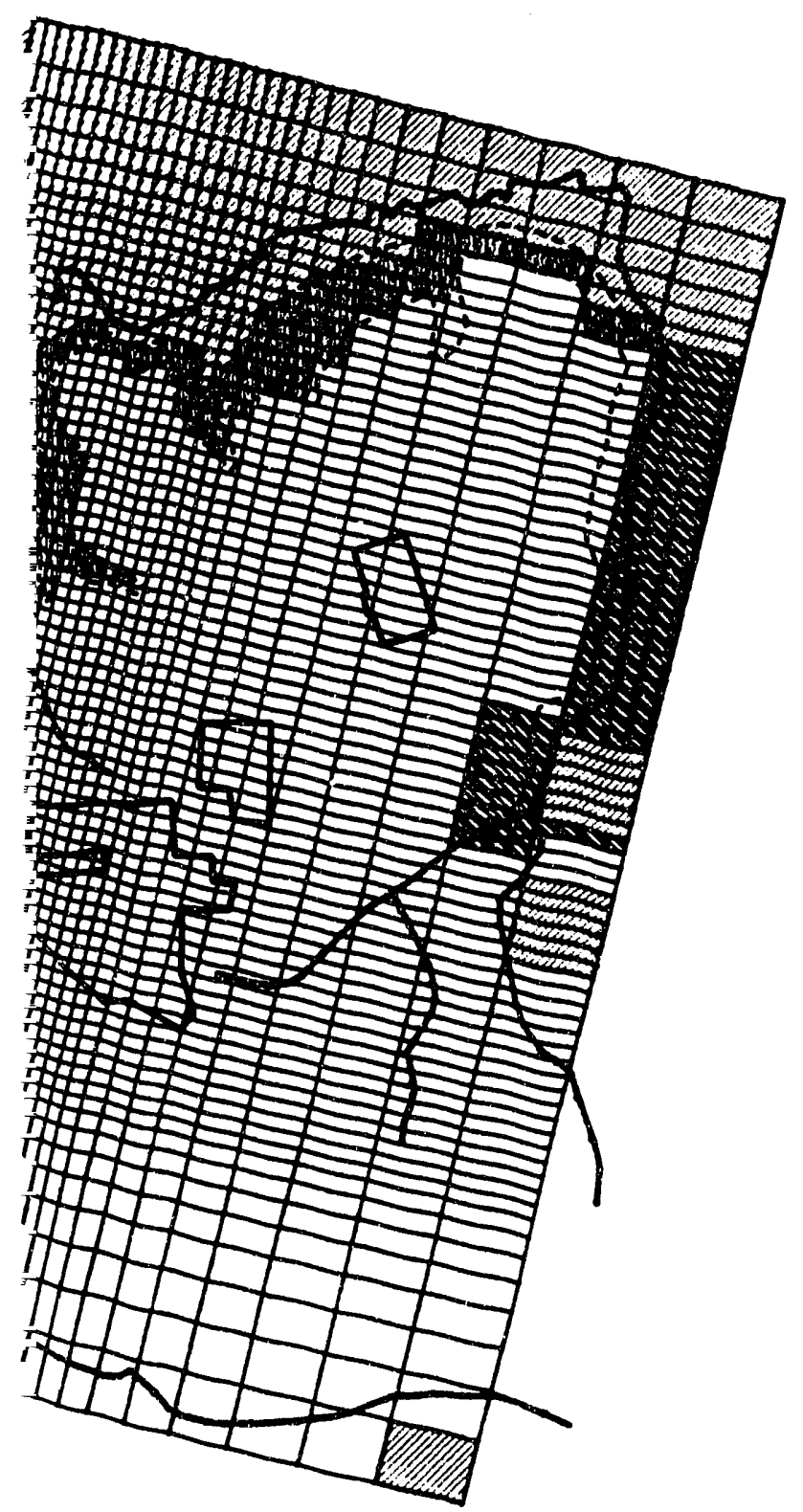

River
Droin
Inters Inoctive
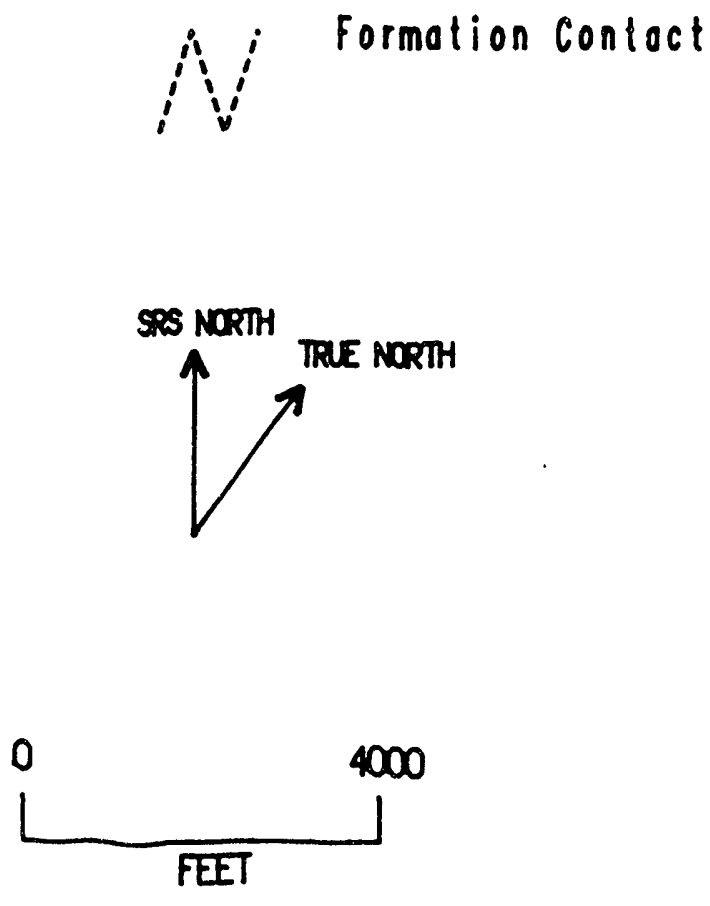

$n$ model layer 3 , which represents :el1/McBean Aquifer). 


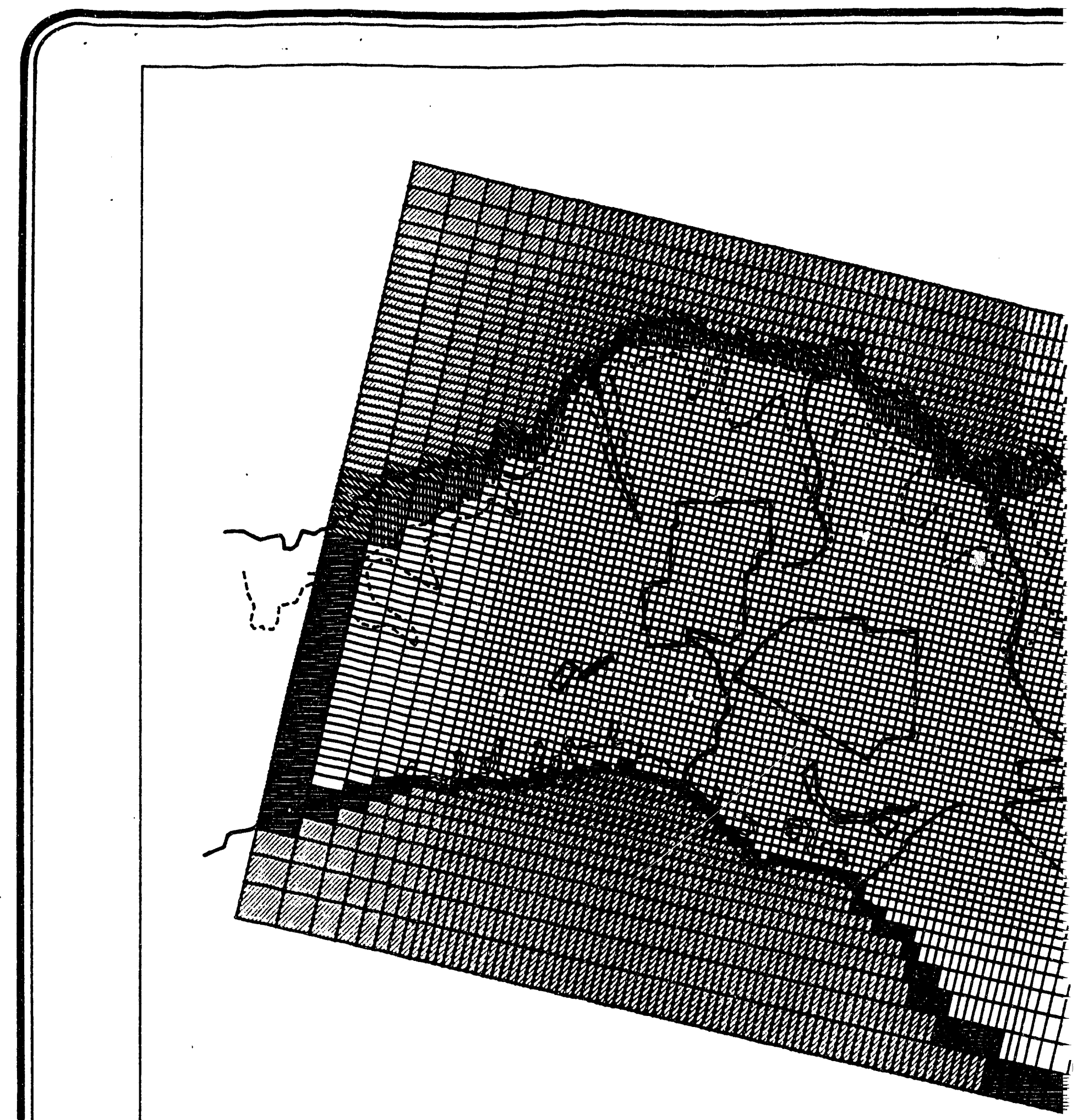

Figure 3.18. Boundary conditions assig Aquifer Unit IIA (Congare 
No Flow:

No-flow boundaries in specific model layers correspond to areas outside of the active model area, or areas where the stratigraphic unit represented by that layer has been eroded away and does not exist. Areas north of Upper Three Runs Creek and South of Four Mile Branch are outside of the active model area, and are assigned as inactive in all model layers. For model layers 1 and 3 (where no specified heads boundaries are assigned), this assumes that the creeks create a flow divide due to their connection with the aquifer. Additional inactive areas, located between these creeks, are based on the top-most stratigraphic unit present, as indicated on Figure 3.19. Units are inactive where they have been eroded away.

The contact between Aquifer Unit IIB Zone 2 (Water Table) and Aquifer Unit IIB Zone 1 (Barnwell/McBean) on Figure 3.19, used to define the inactive area for Aquifer Unit IIB Zone 2 (Water Table), is a modified version of the contact presented by Root (1987). Along Upper Three Runs Creek the contact is the same as given by Root (1987). An analysis of the intersection of surfaces for the 1 and surface and the top of Confining Unit IIB1-IIB2 (Tan Clay) indicated that the contact line drawn by Root (1987) is consistent with current data. However, a contact line for the top of Confining Unit IIB1-IIB2 (Tan Clay) drawn by Root (1987) along Four Mile Branch, just west of the F-Area seepage basins, was not used in this study because the analysis of surface intersections, using the GIS, clearly suggested that Confining Unit IIB1-IIB2 (Tan Clay) was significantiy below land surface in this region.

The contact between Aquifer Unit IIB Zone 1 (Barnwe11/McBean) and Aquifer Unit IIA (Congaree) on Figure 3.19, used to define the inactive area for Aquifer Unit IIB Zone I (Barnwel!/McBean), was not modified from Root (1987). Analysis of the intersection of surfaces for the 1 and surface and the top of Confining Unit IIA-IIB (Green Clay) indicated that this contact line drawn by Root (1987) is consistent with current data.

Desaturated areas are determined by the model, on the basis of stratigraphic elevations versus calculated water-levels. When the calculated water-level in a cell drops below the bottom of that model layer, the model automatically converts that cell to an inactive cell. In 


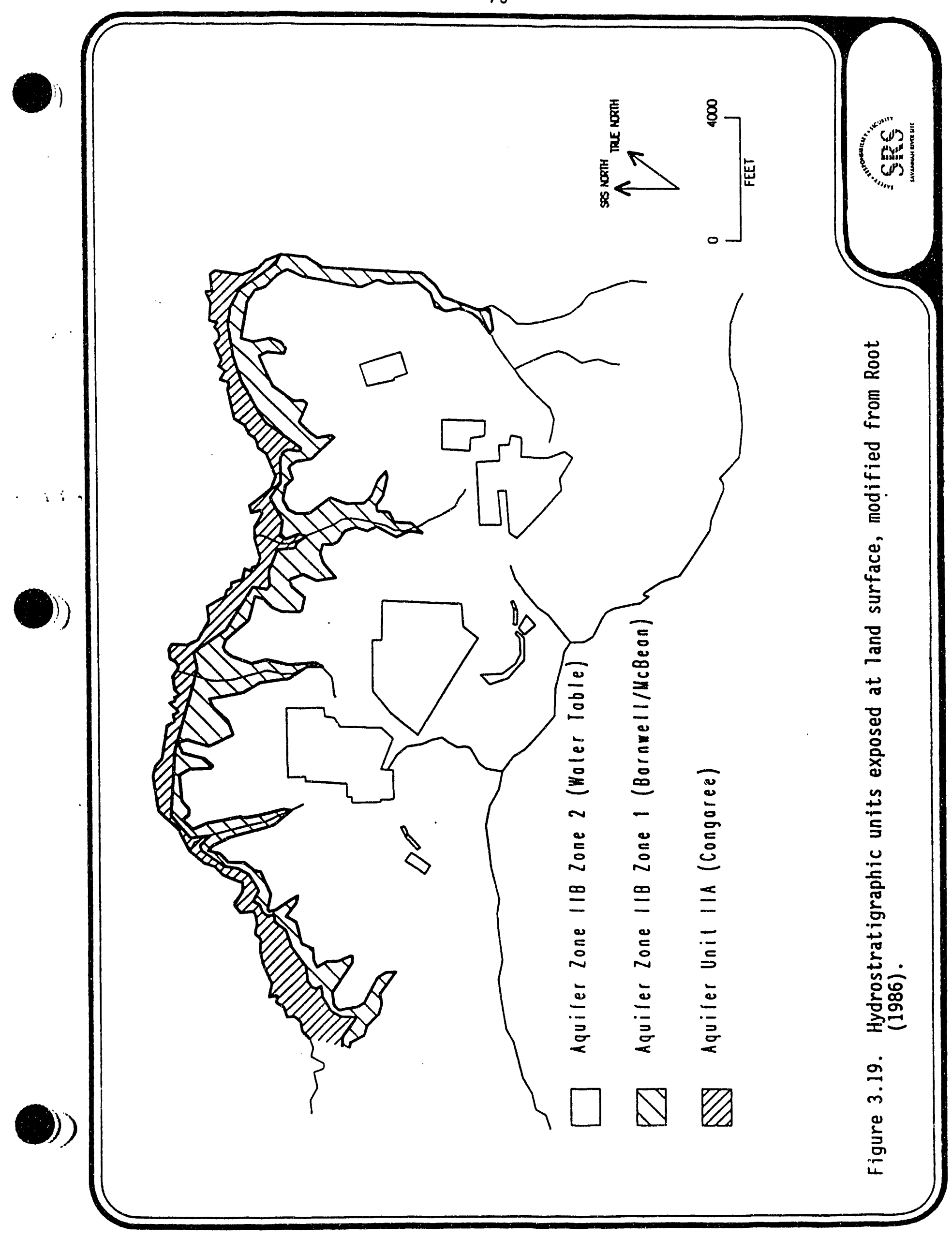


addition, the FTWORK code was modified to insure that, when a confining bed becomes desaturated, the unit above it also becomes desaturated and is converted to an inactive cel1. This prevents errant buildup of water from recharge above the now-inactive confining layer.

No boundary condition was explicitly defined along portions of the eastern and western model grid edges, such that the model assumes no-flow conditions immediately outside the model grid in these layers. For these regions, it was determined that flow should be roughly parallel to the model boundaries, and conceptually this was the most applicable boundary type. Model cells were defined as inactive for each model layer with the GIS by intersecting polygonal areas, representing the inactive areas, with the model grid.

The bottom of model layer 5 is treated as a no-flow boundary in the model. This is consistent with limited vertical flow from Aquifer Unit IIA (Congaree) to underlying units determined in past studies.

\section{River:}

River boundaries were used to represent perennial streams within the model area. Creeks assumed to be intermittent were not included as river cells, but were instead included as drain cells (described later). Intermittent streams were defined according to a dashed representation on the USGS 7.5 minute topographic quadrangle map (1989).

River cells were determined by intersecting arcs representing creeks with the model grid, using the GIS. The model layer for each river cell was determined according to the stratigraphic unit exposed at 1 and surface. The area of the creek within each cell was determined within the GIS by multiplying the length of creek within the cell by an assumed creek width for that creek (see Table 3.1). The stage of the creeks was determined using a linear interpolation algorithm, with known points occurring at 10 foot topographic intervals provided by SRS in digital map form (in some steeper areas, only 50 foot intervals were available). The bottom elevation of creek cells was assigned by subtracting an assumed water depth from the stage for that creek (see Table 3.2). The conductance was treated as a calibration parameter. 
Table 3.1. Assumed creek widths assigned in the model (from $\mathrm{J}$. Haselow, personal communication, 1992).

\begin{tabular}{lc}
\hline Creek & Width (ft) \\
\hline Upper Three Runs Creek & 15 \\
Four Mile Branch & 10 \\
McQueen Branch & 2 \\
All Others & 1 \\
\hline
\end{tabular}


Table 3.2. Depth of water in creeks assigned to the model.

\begin{tabular}{lc}
\hline \hline Creek & Depth of Water $(\mathrm{ft})$ \\
\hline Upper Three Runs Creek & 1 \\
Four Mile Branch & 1 \\
All Others & 0.5 \\
\hline
\end{tabular}


Drain:

Drains were used to represent both intermittent streams and wet1ands. The application of the drain package to each of these was somewhat different, as described below.

Intermittent streams were defined according to a dashed representation on the USGS 7.5 minute topographic quadrangle map (1989). The conceptual model applied here is that these intermittent streams do not act as a source of water to the aquifer, and only flow when the water levels in the aquifer rise enough to permit discharge from the aquifer. This conceptual model is consistent with assignment of intermittent streams as drain cells, which may only remove water from the aquifer. The model layer for each drain cell representing an intermittent stream was determined according to the stratigraphic unit exposed at 1 and surface. The area of the intermittent stream within each cell was generated by the GIS, utilizing the assumed stream widths in Table 3.1. The elevation of these drains was determined according to land surface values. The conductance was set to the same value as for river cells.

Wetland areas are defined as drain cells to permit discharge from the aquifer when water levels exceed 1 and surface. Wetland areas were defined differently along Four Mile Branch and Upper Three Runs Creek. Along a significant portion of Four Mile Branch, the seepline in Aquifer Unit IIB Zone 2 (Water Table) has been previously defined by SRS (Haselow, et al., 1990). In this area, drains were placed between the defined seepline and Four Mile Branch, by intersecting that closed (polygonal) area with the model grid using the GIS. Drain elevations were based on land surface, and the area of the drain within each cell was generated by the GIS. In areas along Four Mile Branch where the seepline was not defined, a seepline was estimated based on the typical width of the defined wetland area. For the entire area along Four Mile Branch, the drains were placed in Aquifer Unit IIB Zone 2 (Water Table), which is consistent with stratigraphy.

Along Upper Three Runs Creek (and its associated tributaries), the drain cells representing wetland areas were defined over an area larger than is expected for the wetland area. The model layer of these cells was defined according to the stratigraphic unit exposed at 1and surface. Thus, for a given row and column in the model, a drain will be assigned in only 
one layer (the layer exposed at the surface). Drain elevations were based on land surface, and the area of the drain within each cell was generated by the GIS. Drains will only remove water from the aquifer when the calculated water-level exceeds the drain elevation (i.e., average land surface) in the cell. This conceptual model allows the wetlands to occur in any of the model units exposed along the valley walls of Upper Three Runs Creek, according to the unit exposed at the land surface, the calculated water level in that unit, and the land surface elevation specified for that cell.

\section{Rules for Overlapping Boundaries:}

A series of operations was performed within the GIS to prevent overlapping of inconsistent boundary conditions, and to conform to input requirements of the FTWORK model. These operations, based on rules, are repeatable such that future revisions to model data or the model grid will utilize consistent logic for data-set generation.

The operations performed are as follows, in this order:

1. If a cell has a river in it, it must be active and contain no other boundaries.

2. If a cell has a river in it, all cells beneath it must be active.

3. Given the overriding conditions of (1) and (2), a cell is inactive if more than 50 percent of the cell is in an inactive zone.

4. If a specific row/column pair contains drains in more than one model layer (i.e. a stratigraphic contact passes through the cell), only assign a drain in the layer represented by the greatest drain area.

5. If a cell is defined as both specified head and a drain, only assign it as a specified head node.

For this model, if a grid cell contains both a seepage drain and an intermittent stream drain, the parameters (elevation, conductance) are averaged and the area summed. For models with finer horizontal 
discretization, using only the intermittent stream drains (which have lower elevations due to the stream incisement) may perhaps be more appropriate. For the discretization of the current model, however, such detail is not meaningful because the width of the intermittent stream is small compared to the overall width of the cell.

\subsubsection{Other Model Parameters}

In addition to boundary conditions, the following parameters are required as input data for the groundwater flow model:

- Horizontal hydraulic conductivity;

- Vertical hydraulic conductivity;

- Net recharge

These parameters are assigned in FTWORK in one of two ways: (1) as a uniform value for a specific model layer; or (2) as a series of zones with different values for a specific model layer. These parameters were all treated as calibration parameters in the flow model calibration, such that values for each parameter were not pre-determined, but instead were estimated during the calibration process. This process is discussed in detail in the next section.

In FTWORK, net recharge is applied to the highest active model layer for a specific row/column pair. A reduced value (assuming a 95 percent efficient cap) was assigned to areas corresponding to capped areas, which include the MWMF, the F-Area seepage basins, and the H-Area seepage basins. This entailed assigning net recharge at 5 percent of its rate over typical grid cells. In some cases, small caps were not represented by any grid cells due to the size of the grid cell relative to the size of the capped area. The representation of capped areas in the model data set is presented in Figure 3.20.

\subsection{MODEL CALIBRATION}

Model calibration refers to the process of determining model parameters such that the flow model satisfactorily reproduces observed groundwater flow conditions. Due to simplifications inherent in the 


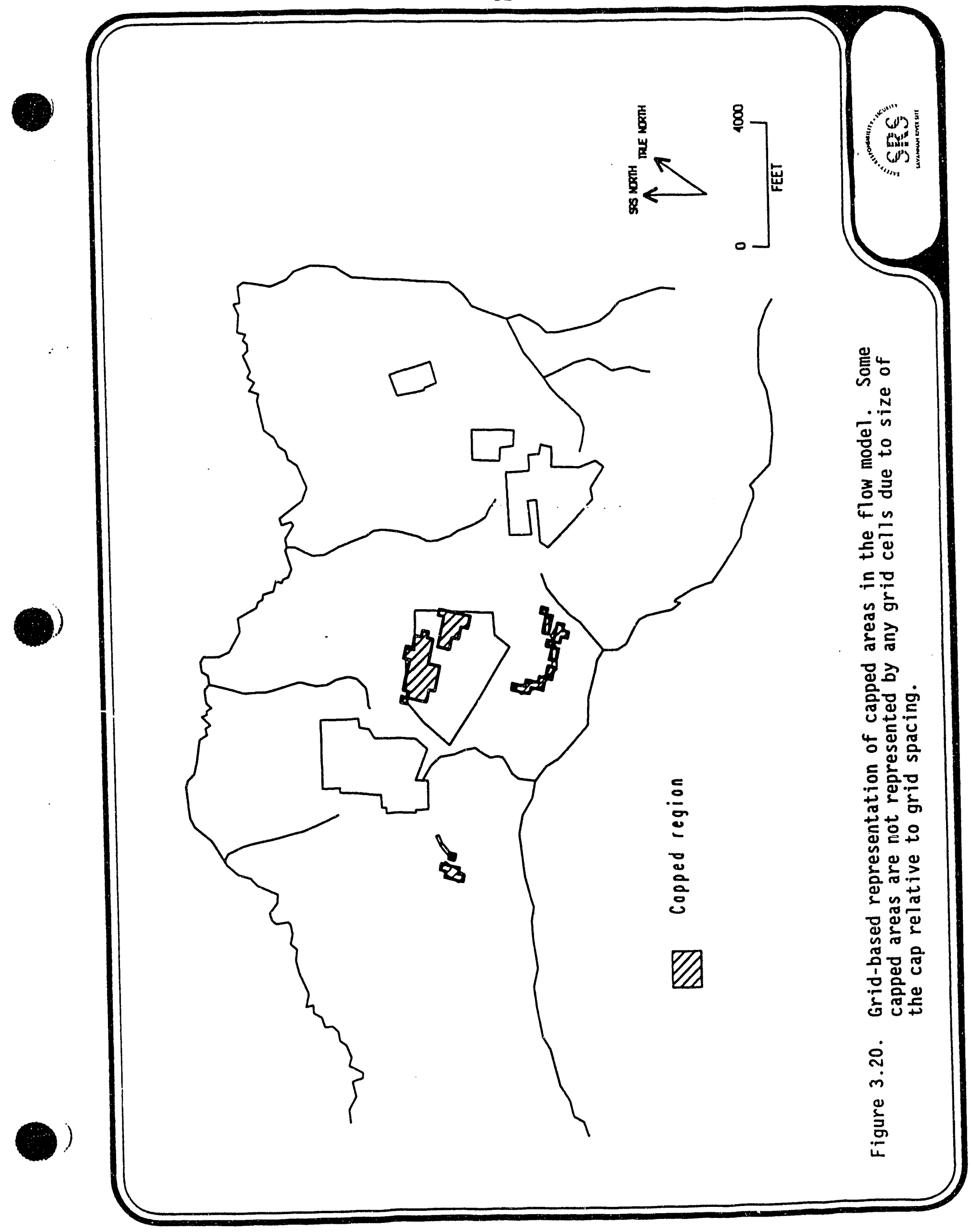


representation of a groundwater system with a numerical mode1, observed conditions can never be matched exactly. Typically, calibration criteria are developed and utilized to compare results of different simulations, based on different parameter values, with observed conditions. It is important to note that different combinations of parameter values frequently yield similar results with a groundwater flow model, such that many satisfactory combinations of parameter values may be found with respect to the calibration criteria.

Five types of model inputs were treated as calibration parameters for this groundwater flow model:

- Horizontal hydraulic conductivity in each model layer;

- Vertical hydraulic conductivity in each model layer;

- Net recharge;

- River Conductance; and

- Drain Conductance.

The calibration approach and calibration results are described below.

\subsubsection{Approach}

The following approach was utilized to calibrate steady-state groundwater flow model for the GSA:

1. Develop calibration criteria;

2. Attempt to satisfactorily meet the calibration criteria by first assigning uniform values to each calibration parameter (with the exception of net recharge, for which a reduced value was utilized for capped areas assuming 95 percent efficient caps);

3. Identify regions where observed conditions appear inconsistent with respect to uniform parameter values; and

4. Develop zones for parameter values to improve the performance of the simulation model with respect to calibration criteria.

The semi-automated history matching feature of the FTWORK was utilized code to assist in the calibration process. FTWORK compares water levels at 
known locations (wells) to simulated water levels at equivalent model locations, and adjusts specified calibration parameters to minimize the sum of squares difference between simulated and observed water levels. However, for this investigation, a residual sum of squares minimization for water-level targets was not used as the primary calibration criterion. Although many measured water-levels were available, the spatial and vertical distribution of targets introduced significant bias in the parameter estimation procedure. Because all targets are treated with equal weight by the semi-automated procedure, the model would seek to achieve the best match in model layer 1 , for example, because that layer contained significantly more targets than any other model layer. A similar problem existed with clustering of data around $\mathrm{F}$ - and $\mathrm{H}$-areas, which led to improved matches in those areas at the expense of other locations with fewer data points.

\subsubsection{Calibration Criteria}

The primary criterion for assessing the steady-state flow model calibration was to reproduce measured water-levels from the second quarter 1991. This period, corresponding to April 1 to June 30 inclusive, was selected primarily because it was the quarter for which the most data were available (for this study, it was also the most recent data available). There was a trade-off involved between data quantity and representation of steady-state conditions, because hydrographs for selected wells indicated that measured water-levels were upward-trending by several $\mathrm{ft}$ over the first six months of 1991.

As previously mentioned, direct use of a semi-automated parameter estimation technique as the primary calibration criterion was not appropriate for this model, given that statistical biases would potentially be introduced by the data distribution. This left three general options: (1) modify the semi-automated procedure to allow for weighting of data points; (2) remove many of the data points in the top model layer and from clustered data to increase the utility of the parameter estimation module; or (3) rely on a more visual approach to history-matching in conjunction with manual perturbation of parameter values. Rather than remove 
significant quantities of measured data or perform significant technical modification to the code, the last option was selected.

The primary calibration criteria for the flow model were defined as follows:

- Reproduce water levels within all areas of concern, and all areas with reliable data, generally within $2 \mathrm{ft}$;

- $\quad$ Reproduce general flow patterns indicated by measured water levels and indicated in previous studies; and

- Produce residuals (the difference between measured and simulated water-levels) that are generally well distributed about zero error for each model layer.

To achieve these goals, the semi-automated procedure was used to guide initial estimates for parameter values. Then parameters values were varied, and in some cases zoned, until a satisfactory simulation with respect to the calibration criteria was achieved.

Stream flow measurements are often a valuable tool for model calibration. Gaging stations with available data near the GSA are illustrated in Figure 3.21. Ideally, net discharge to the stream over specific reaches can be compared to net discharge to the stream simulated by the model over the same reach. Typically, when the stream is a boundary for the model (as in this model) an assumption is required to quantify the net stream discharge (or percentage of net stream discharge) from the other side of the river.

This type of calibration exercise is problematic for this flow model for several reasons. First, along Upper Three Runs Creek, only one gaging station is within the model domain. Other stations are significantly removed from the model area, such that net discharge from the modeled area to Upper Three Runs Creek is only a small component of overall net discharge between gaging locations. Secondly, calculations of simulated net discharge to streams is complicated by discharge from the aquifer to 1 and surface in wetland areas, which is represented in the model with drains. Thirdly, the available record of net stream discharge (presented in Chapter 2) available for this report is through 1989 only, and does not 


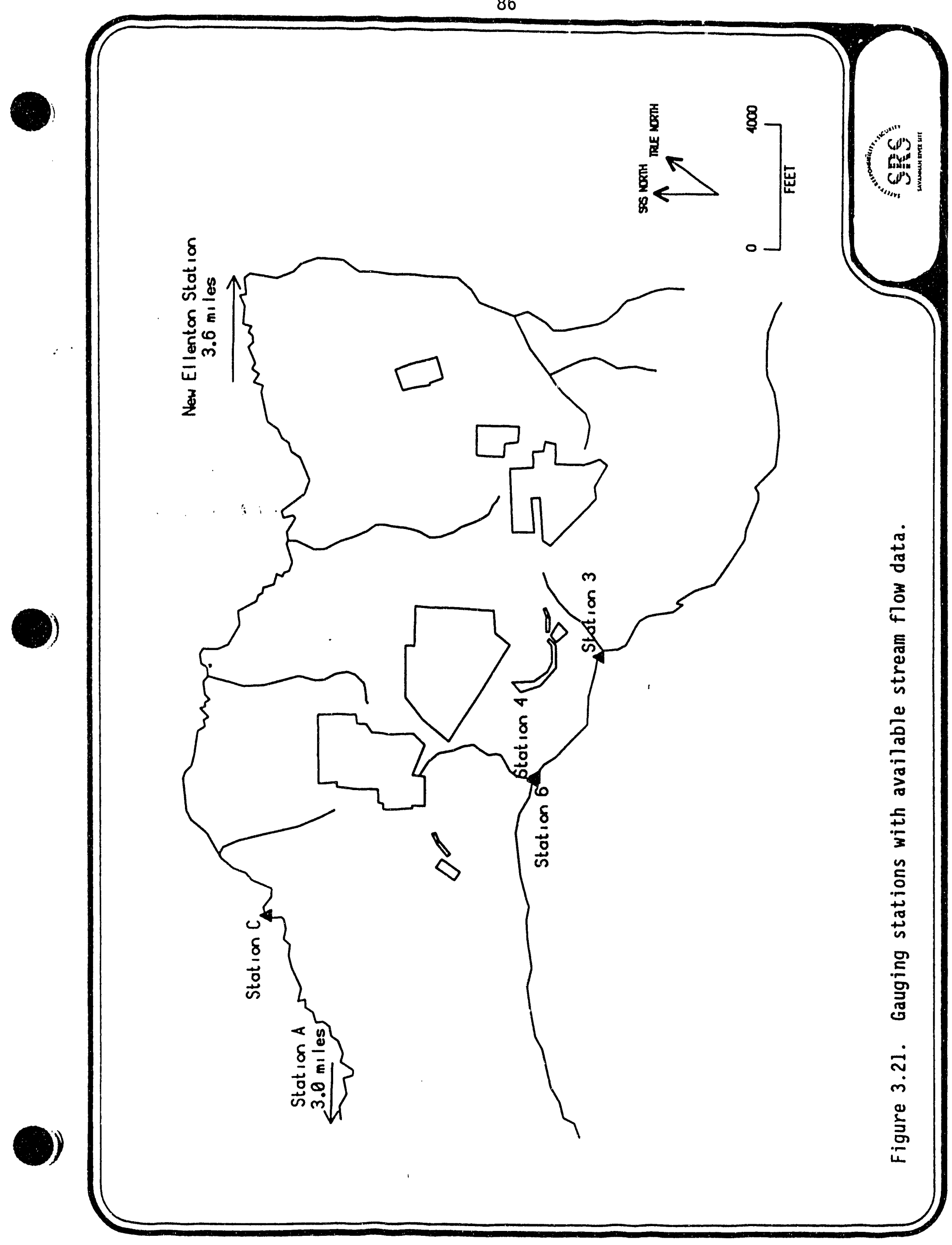


include the calibration period for this study (second quarter 1991). As a result, low emphasis was placed on net discharge to streams for calibration purposes.

\subsubsection{Issues Pertaining To Water Level Targets}

Measured water-levels utilized in the calibration process are listed in Table 3.3 and are illustrated in Plates 7 to 9 . These water levels pertain to second quarter, 1991 (April 1 to June 30 inclusive). Water levels removed due to apparent errors in the data are not included in the table or the plate, but are documented in Table 3.4. Well desaturated in model results were removed to avoid problems with the semi-automated history matching procedures in FTWORK. For wells with multiple measurement dates within this time period, all water-levels were utilized. These wells are documented in Table 3.5 .

Variability of measured water-levels among wells in close proximity often precluded any possibility of matching all water levels within $2 \mathrm{ft}$. In some cases, measured water-levels at two wells within the same grid cell or adjacent cells vary by more than $5 \mathrm{ft}$ with respect to measured waterlevel. When a water-level measurement error was clearly indicated, that measurement was removed from the analysis. In some cases, however, a clear error was not apparent. For instance, the following three wells are located in the same grid cell in the model (1ayer 1, column 28, row 38), had water-levels measured on the same date (May 7, 1991), and have similar screened intervals:

$\begin{array}{lc}\text { WELL } & \begin{array}{c}\text { MEASURED WATER } \\ \text { ELEVATION (ft } \mathrm{ms} \text { ) })\end{array} \\ \text { FTF } 12 & 226.90 \\ \text { FTF 24A } & 220.50 \\ \text { FTF 27 } & 220.70\end{array}$

Clearly, no water level predicted by the model will satisfy all three targets for this grid cell, yet at the same time, there is no clear indication that the measured water level at FTF 12 is in error. 
Table 3.3. Observed water elevations for second quarter 1991 used for model calibration.

\begin{tabular}{|c|c|c|c|c|c|c|}
\hline \multicolumn{2}{|c|}{ WELL } & \multicolumn{2}{|c|}{$\begin{array}{l}\text { MEASURED WATER } \\
\text { DATE ELEV (FT ms } \mathrm{l} \text { ) }\end{array}$} & NORTH & EAST & $\begin{array}{l}\text { MODEL } \\
\text { LAYER }\end{array}$ \\
\hline 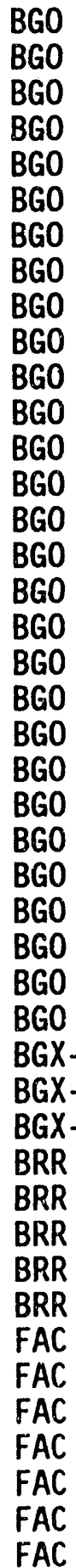 & $\begin{array}{l}1 D \\
2 D \\
6 D \\
7 D \\
8 D \\
9 D \\
11 D \\
12 D \\
13 D \\
15 D \\
16 D \\
18 D \\
20 D \\
21 D \\
22 D \\
23 D \\
24 D \\
26 D \\
27 D \\
28 D \\
30 D \\
31 D \\
32 D \\
34 D \\
35 D \\
36 D \\
37 D \\
38 D \\
39 D \\
-10 D \\
-12 D \\
-9 D \\
1 D \\
2 D \\
3 D \\
4 D \\
5 D \\
3 \\
4 \\
5 \\
6 \\
6 \\
7 \\
8\end{array}$ & $\begin{array}{l}5 / 03 / 91 \\
5 / 03 / 91 \\
5 / 07 / 91 \\
5 / 06 / 91 \\
5 / 10 / 91 \\
5 / 03 / 91 \\
5 / 03 / 91 \\
5 / 07 / 91 \\
5 / 10 / 91 \\
5 / 06 / 91 \\
5 / 13 / 91 \\
5 / 13 / 91 \\
5 / 31 / 91 \\
5 / 31 / 91 \\
5 / 13 / 91 \\
5 / 13 / 91 \\
5 / 13 / 91 \\
5 / 08 / 91 \\
5 / 08 / 91 \\
5 / 08 / 91 \\
5 / 08 / 91 \\
5 / 08 / 91 \\
5 / 08 / 91 \\
5 / 09 / 91 \\
5 / 09 / 91 \\
5 / 09 / 91 \\
5 / 09 / 91 \\
5 / 09 / 91 \\
5 / 09 / 91 \\
6 / 11 / 91 \\
6 / 11 / 91 \\
6 / 10 / 91 \\
5 / 02 / 91 \\
5 / 02 / 91 \\
5 / 02 / 91 \\
5 / 02 / 91 \\
5 / 02 / 91 \\
5 / 30 / 91 \\
5 / 30 / 91 \\
5 / 30 / 91 \\
4 / 04 / 91 \\
5 / 30 / 91 \\
5 / 30 / 91 \\
5 / 30 / 91\end{array}$ & $\begin{array}{l}238.01 \\
237.29 \\
230.73 \\
226.59 \\
226.74 \\
231.71 \\
230.57 \\
230.33 \\
230.04 \\
229.47 \\
230.58 \\
231.63 \\
234.75 \\
234.70 \\
232.86 \\
235.46 \\
236.53 \\
227.38 \\
227.43 \\
226.34 \\
226.07 \\
227.13 \\
227.99 \\
233.39 \\
234.41 \\
236.27 \\
237.42 \\
235.21 \\
234.54 \\
226.64 \\
240.03 \\
227.42 \\
215.51 \\
214.66 \\
214.26 \\
214.11 \\
213.74 \\
229.02 \\
228.37 \\
224.12 \\
218.54 \\
219.76 \\
220.16 \\
228.86\end{array}$ & $\begin{array}{l}73737.90 \\
74552.90 \\
76487.30 \\
76494.50 \\
76588.00 \\
76811.60 \\
76805.09 \\
76805.24 \\
76805.26 \\
75973.54 \\
75751.35 \\
75599.98 \\
74962.24 \\
74688.53 \\
74482.20 \\
74238.09 \\
74012.39 \\
76128.00 \\
75677.30 \\
75348.30 \\
75187.70 \\
74985.30 \\
74727.00 \\
74228.80 \\
73946.00 \\
73743.80 \\
73490.80 \\
73329.30 \\
73583.50 \\
76183.33 \\
74410.88 \\
76935.98 \\
77365.20 \\
77431.40 \\
77398.30 \\
77360.50 \\
77266.70 \\
78018.30 \\
78223.80 \\
77960.30 \\
78129.00 \\
78129.00 \\
78123.40 \\
78090.90\end{array}$ & $\begin{array}{l}58779.30 \\
58809.70 \\
58297.10 \\
57917.20 \\
57617.00 \\
57478.94 \\
56651.26 \\
56231.08 \\
55840.01 \\
55859.11 \\
56202.12 \\
56711.17 \\
57113.81 \\
57470.66 \\
57817.30 \\
58132.96 \\
58438.76 \\
55015.20 \\
54680.20 \\
54457.90 \\
54499.20 \\
54841.70 \\
55250.20 \\
56082.60 \\
56556.50 \\
56888.10 \\
57292.90 \\
57557.50 \\
57831.00 \\
59765.48 \\
59674.29 \\
59522.11 \\
50588.20 \\
50306.30 \\
50203.50 \\
50104.50 \\
50009.00 \\
55322.70 \\
55472.90 \\
55241.30 \\
55335.50 \\
55335.50 \\
55356.20 \\
55366.00\end{array}$ & $\begin{array}{l}1 \\
1 \\
1 \\
1 \\
1 \\
1 \\
1 \\
1 \\
1 \\
1 \\
1 \\
1 \\
1 \\
1 \\
1 \\
1 \\
1 \\
1 \\
1 \\
1 \\
1 \\
1 \\
1 \\
1 \\
1 \\
1 \\
1 \\
1 \\
1 \\
1 \\
1 \\
1 \\
1 \\
1 \\
1 \\
1 \\
1 \\
1 \\
1 \\
1\end{array}$ \\
\hline
\end{tabular}


Table 3.3. Observed water elevations for second quarter 1991 used for model calibration (Continued).

\begin{tabular}{|c|c|c|c|c|c|}
\hline WELL & \multicolumn{2}{|c|}{$\begin{array}{c}\text { MEASURED WATER } \\
\text { DATE ELEV (FT ms } 1 \text { ) }\end{array}$} & & EAST & $\begin{array}{l}\text { MODEL } \\
\text { LAYER }\end{array}$ \\
\hline $\begin{array}{ll}\text { FAL } & 1 \\
\text { FAL } & 2 \\
\text { FCA } & 2 D \\
\text { FCA } & 9 D \\
\text { FCA } 10 A \\
\text { FCA } 16 A \\
\text { FCA } 16 D \\
\text { FCA } 19 D \\
\text { FCB } 2 \\
\text { FCB } & 4 \\
\text { FCB } & 5 \\
\text { FCB } & 6 \\
\text { FET } & 10 \\
\text { FET } 2 D \\
\text { FET } & 3 D \\
\text { FET } & 4 D \\
\text { FSB } & 76 \\
\text { FSB } & 77 \\
\text { FSB } & 77 \\
\text { FSB } & 78 D \\
\text { FSB } & 78 D \\
\text { FSB } & 78 D \\
\text { FSB } & 79 D \\
\text { FSB } & 79 D \\
\text { FSB } & 88 D \\
\text { FSB } & 89 D \\
\text { FSB } & 90 D \\
\text { FSB } & 910 \\
\text { FSB } & 92 D \\
\text { FSB } & 93 D \\
\text { FSB } & 940 R \\
\text { FSB } & 950 R \\
\text { FSB } & 98 D \\
\text { FSB } & 99 D \\
\text { FSB } & 99 D \\
\text { FSB104D } \\
\text { FSB105DR } \\
\text { FSB106D } \\
\text { FSB107D } \\
\text { FSB107D } \\
\text { FSB108D } \\
\text { FSB109D } \\
\text { FSB110D } \\
\text { FSB110D }\end{array}$ & $\begin{array}{l}5 / 15 / 91 \\
5 / 15 / 91 \\
5 / 15 / 91 \\
5 / 15 / 91 \\
6 / 06 / 91 \\
6 / 06 / 91 \\
5 / 15 / 91 \\
5 / 15 / 91 \\
5 / 29 / 91 \\
5 / 15 / 91 \\
5 / 30 / 91 \\
5 / 30 / 91 \\
5 / 01 / 91 \\
4 / 30 / 91 \\
4 / 30 / 91 \\
4 / 30 / 91 \\
4 / 01 / 91 \\
4 / 25 / 91 \\
4 / 01 / 91 \\
4 / 02 / 91 \\
4 / 05 / 91 \\
4 / 24 / 91 \\
4 / 02 / 91 \\
4 / 24 / 91 \\
4 / 04 / 91 \\
4 / 03 / 91 \\
4 / 04 / 91 \\
4 / 04 / 91 \\
4 / 04 / 91 \\
4 / 04 / 91 \\
4 / 04 / 91 \\
4 / 04 / 91 \\
4 / 09 / 91 \\
4 / 08 / 91 \\
4 / 24 / 91 \\
4 / 10 / 91 \\
4 / 09 / 91 \\
4 / 09 / 91 \\
4 / 09 / 91 \\
4 / 25 / 91 \\
4 / 09 / 91 \\
4 / 09 / 91 \\
4 / 10 / 91 \\
4 / 24 / 91\end{array}$ & $\begin{array}{l}218.80 \\
217.08 \\
224.39 \\
224.70 \\
224.49 \\
224.54 \\
224.43 \\
217.04 \\
229.18 \\
227.82 \\
228.10 \\
228.41 \\
222.97 \\
221.64 \\
221.60 \\
222.26 \\
215.81 \\
211.71 \\
211.63 \\
208.84 \\
208.95 \\
209.07 \\
203.30 \\
202.94 \\
215.36 \\
214.69 \\
213.73 \\
212.79 \\
211.29 \\
210.40 \\
209.56 \\
209.37 \\
210.77 \\
211.85 \\
212.02 \\
205.63 \\
209.89 \\
206.89 \\
213.65 \\
213.61 \\
215.95 \\
212.49 \\
206.28 \\
206.06\end{array}$ & $\begin{array}{l}78115.90 \\
78231.90 \\
78295.80 \\
78600.50 \\
78640.40 \\
78899.50 \\
78898.50 \\
78271.90 \\
76679.70 \\
76780.40 \\
76492.60 \\
76582.10 \\
76165.60 \\
76045.80 \\
75961.00 \\
75959.30 \\
76141.60 \\
75129.40 \\
75129.40 \\
74764.00 \\
74764.00 \\
74764.00 \\
73663.10 \\
73663.10 \\
75621.80 \\
75548.30 \\
75376.90 \\
75207.60 \\
75045.80 \\
74888.50 \\
74869.08 \\
74991.68 \\
75371.90 \\
75691.70 \\
75691.70 \\
73865.10 \\
75258.10 \\
74193.00 \\
75177.20 \\
75177.20 \\
76260.70 \\
75855.90 \\
74193.30 \\
74193.30\end{array}$ & $\begin{array}{l}53756.40 \\
53757.40 \\
53715.20 \\
53733.10 \\
53571.90 \\
53568.80 \\
53719.50 \\
53719.10 \\
55046.70 \\
54605.90 \\
54773.00 \\
54733.40 \\
53299.90 \\
52981.20 \\
53025.70 \\
53149.00 \\
51388.80 \\
50713.10 \\
50713.10 \\
50164.70 \\
50164.70 \\
50164.70 \\
50139.70 \\
50139.70 \\
51527.00 \\
51335.80 \\
51140.70 \\
50946.60 \\
50557.60 \\
50452.40 \\
50162.88 \\
49996.02 \\
50111.60 \\
50326.90 \\
50326.90 \\
49255.40 \\
49841.00 \\
50636.80 \\
51149.80 \\
51149.80 \\
51142.30 \\
50488.60 \\
50141.60 \\
50141.60\end{array}$ & $\begin{array}{l}1 \\
1 \\
1 \\
1 \\
1 \\
1 \\
1 \\
1 \\
1 \\
1 \\
1 \\
1 \\
1 \\
1 \\
1 \\
1 \\
1 \\
1 \\
1 \\
1 \\
1 \\
1 \\
1 \\
1 \\
1 \\
1 \\
1 \\
1 \\
1 \\
1 \\
1 \\
1 \\
1 \\
1 \\
1 \\
1 \\
1 \\
1 \\
1 \\
1 \\
1 \\
1 \\
1 \\
1\end{array}$ \\
\hline
\end{tabular}


Table 3.3. Observed water elevations for second quarter 1991 used for model calibration (Continued).

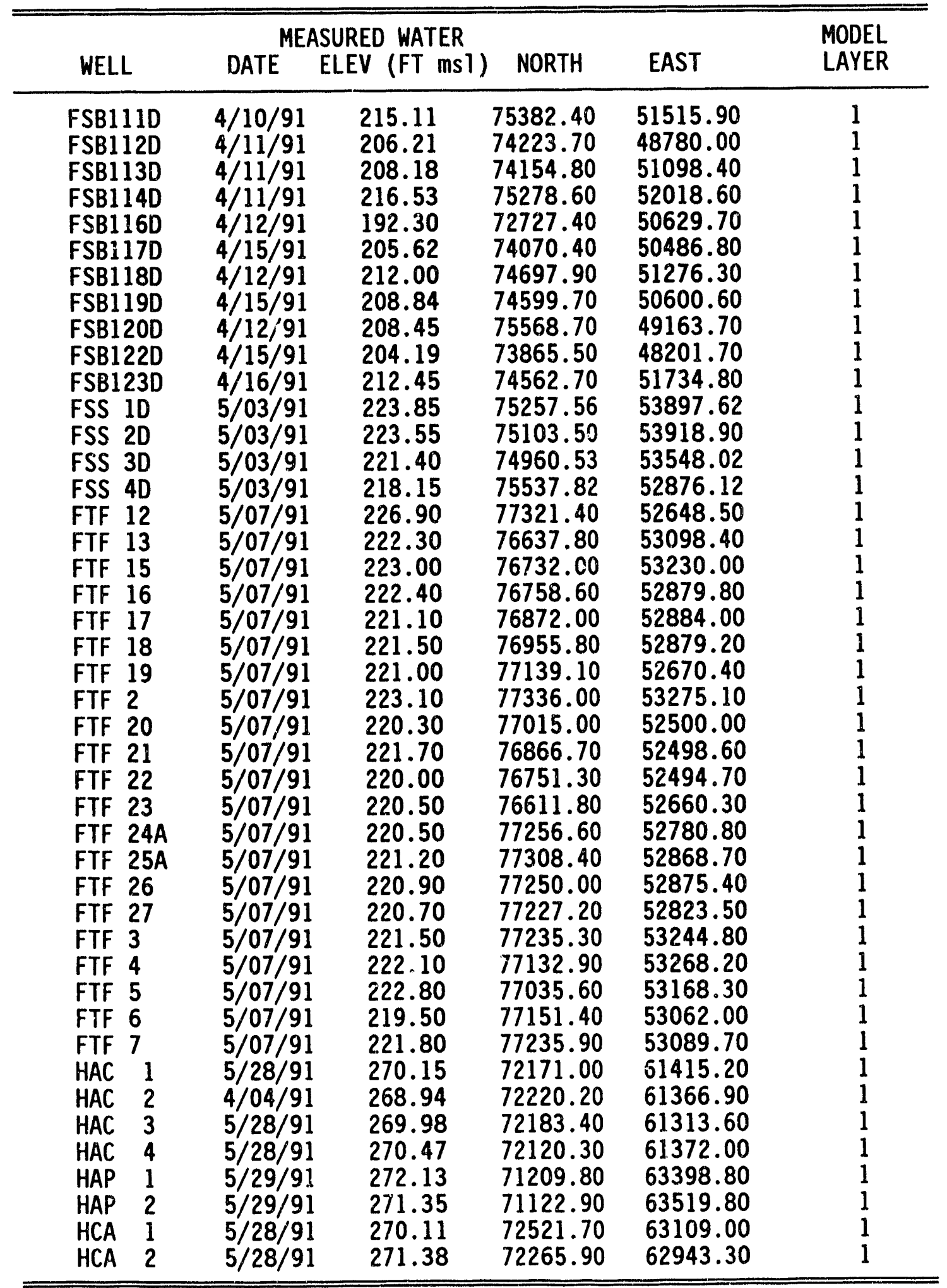


Table 3.3. Observed water elevations for second quarter 1991 used for model calibration (Continued).

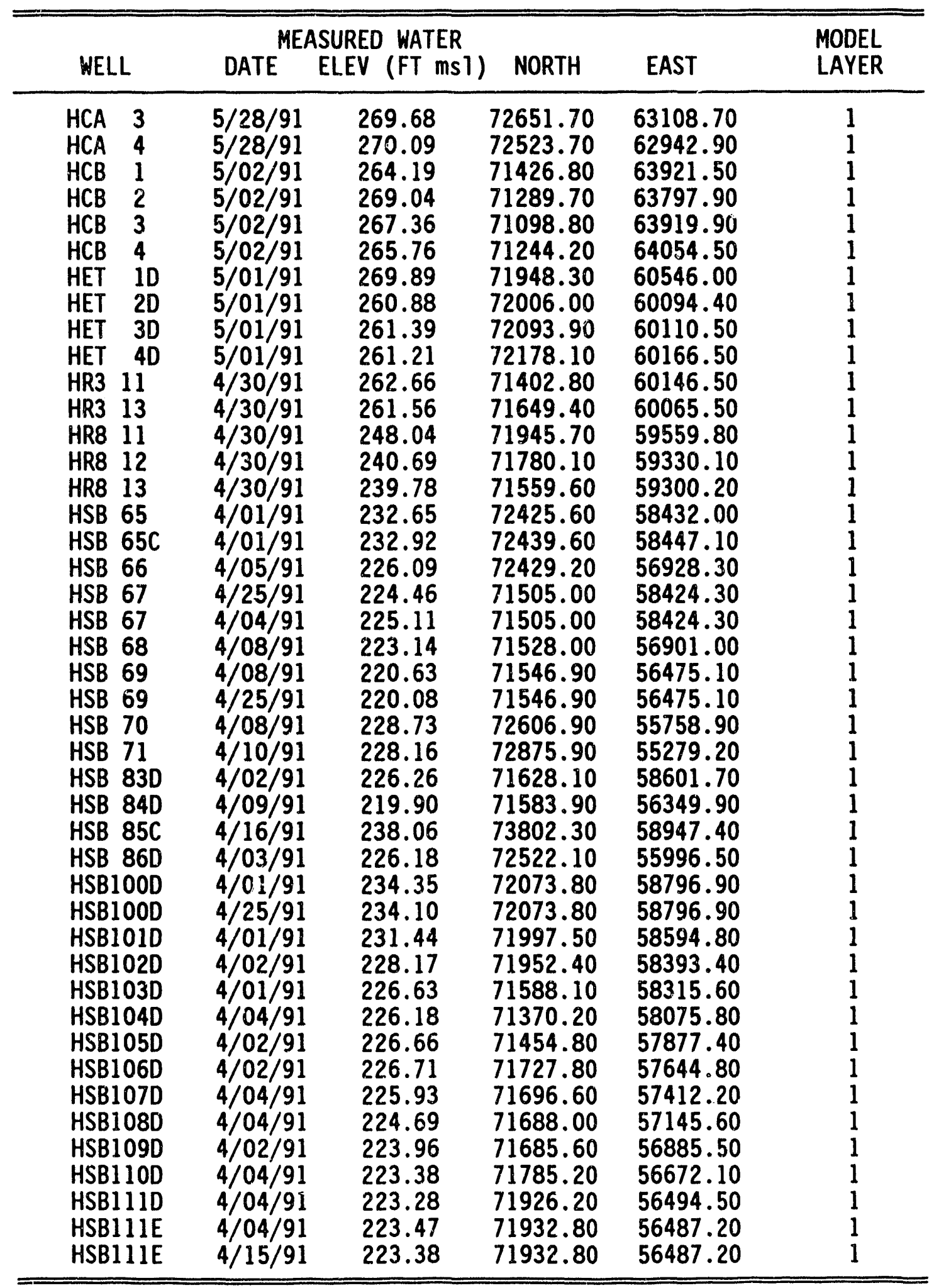


Table 3.3. Observed water elevations for second quarter 1991 used for model calibration (Continued).

\begin{tabular}{|c|c|c|c|c|c|}
\hline WELL & DATE $^{\text {MEA }}$ & $\begin{array}{l}\text { ASURED WATER } \\
\text { ELEV (FT msl) }\end{array}$ & NORTH & EAST & $\begin{array}{l}\text { MODEL } \\
\text { LAYER }\end{array}$ \\
\hline 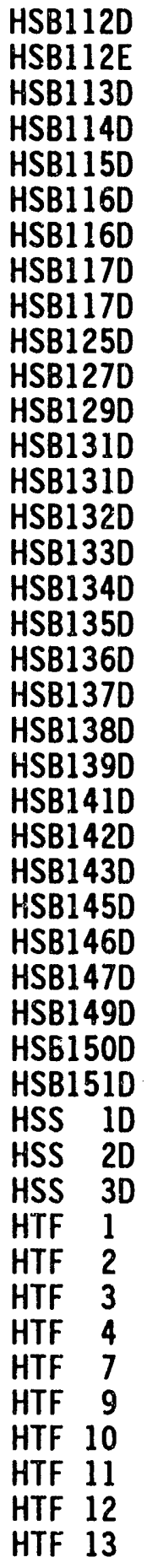 & $\begin{array}{l}4 / 08 / 91 \\
4 / 09 / 91 \\
4 / 04 / 91 \\
4 / 03 / 91 \\
4 / 03 / 91 \\
4 / 03 / 91 \\
4 / 25 / 91 \\
4 / 10 / 91 \\
4 / 25 / 91 \\
4 / 11 / 91 \\
4 / 09 / 91 \\
4 / 15 / 91 \\
4 / 15 / 91 \\
4 / 25 / 91 \\
5 / 20 / 91 \\
4 / 16 / 91 \\
4 / 11 / 91 \\
4 / 09 / 91 \\
4 / 11 / 91 \\
4 / 08 / 91 \\
4 / 10 / 91 \\
4 / 08 / 91 \\
4 / 17 / 91 \\
4 / 10 / 91 \\
4 / 12 / 91 \\
4 / 15 / 91 \\
4 / 17 / 91 \\
4 / 17 / 91 \\
4 / 15 / 91 \\
4 / 15 / 91 \\
4 / 10 / 91 \\
5 / 03 / 91 \\
5 / 02 / 91 \\
5 / 02 / 91 \\
4 / 17 / 91 \\
4 / 29 / 91 \\
4 / 29 / 91 \\
4 / 29 / 91 \\
4 / 24 / 91 \\
4 / 17 / 91 \\
4 / 17 / 91 \\
4 / 17 / 91 \\
4 / 24 / 91 \\
4 / 24 / 91\end{array}$ & $\begin{array}{l}224.40 \\
224.38 \\
224.85 \\
225.72 \\
226.88 \\
228.54 \\
227.81 \\
227.35 \\
225.55 \\
221.75 \\
218.95 \\
209.10 \\
205.63 \\
205.13 \\
221.81 \\
235.97 \\
223.40 \\
219.33 \\
222.32 \\
224.81 \\
227.05 \\
224.56 \\
245.35 \\
198.59 \\
213.81 \\
221.59 \\
225.63 \\
233.44 \\
224.46 \\
227.62 \\
208.29 \\
272.22 \\
271.57 \\
284.73 \\
274.00 \\
275.60 \\
276.20 \\
275.40 \\
276.50 \\
274.20 \\
273.70 \\
274.30 \\
273.80 \\
274.50\end{array}$ & $\begin{array}{l}72161.60 \\
72166.60 \\
72302.70 \\
72474.20 \\
72662.30 \\
72898.10 \\
72898.10 \\
72747.60 \\
72747.60 \\
71498.20 \\
71218.90 \\
71837.10 \\
70365.00 \\
70365.00 \\
71469.50 \\
71943.50 \\
71217.30 \\
71396.70 \\
71906.00 \\
72278.90 \\
73160.20 \\
71133.20 \\
71184.40 \\
73113.00 \\
73754.00 \\
71088.00 \\
70469.70 \\
73827.90 \\
71338.80 \\
71692.60 \\
72997.80 \\
67610.30 \\
67355.90 \\
68257.50 \\
71745.00 \\
71610.00 \\
71510.00 \\
71630.00 \\
71130.00 \\
71652.00 \\
71520.00 \\
71398.00 \\
71520.00 \\
71856.00\end{array}$ & $\begin{array}{l}56408.10 \\
56399.50 \\
56164.30 \\
56104.60 \\
56039.80 \\
55988.20 \\
55988.20 \\
55155.60 \\
55155.60 \\
58584.10 \\
56788.00 \\
55103.40 \\
56891.10 \\
56891.10 \\
58799.30 \\
59102.30 \\
58296.50 \\
56552.80 \\
55941.70 \\
55696.10 \\
55260.70 \\
57384.40 \\
59170.90 \\
53493.10 \\
52774.50 \\
57753.90 \\
58493.00 \\
55804.40 \\
57286.30 \\
58692.80 \\
54026.40 \\
64675.60 \\
64785.90 \\
64709.50 \\
62067.00 \\
62175.00 \\
62067.00 \\
61942.00 \\
62112.00 \\
61698.00 \\
61838.00 \\
61722.00 \\
61593.00 \\
61586.00\end{array}$ & $\begin{array}{l}1 \\
1 \\
1 \\
1 \\
1 \\
1 \\
1 \\
1 \\
1 \\
1 \\
1 \\
1 \\
1 \\
1 \\
1 \\
1 \\
1 \\
1 \\
1 \\
1 \\
1 \\
1 \\
1 \\
1 \\
1 \\
1 \\
1 \\
1 \\
1 \\
1 \\
1 \\
1 \\
1 \\
1 \\
1 \\
1 \\
1 \\
1 \\
1 \\
1 \\
1 \\
1 \\
1\end{array}$ \\
\hline
\end{tabular}


Table 3.3. Observed water elevations for second quarter 1991 used for model calibration (Continued).

\begin{tabular}{|c|c|c|c|c|c|}
\hline WELL & DATE & $\begin{array}{l}\text { SURED WATER } \\
\text { ELEV (FT ms l) }\end{array}$ & NORTH & EAST & $\begin{array}{l}\text { MODEL } \\
\text { L.AYER }\end{array}$ \\
\hline $\begin{array}{ll}\text { HTF } & 14 \\
\text { HTF } & 15 \\
\text { HTF } & 16 \\
\text { HTF } & 17 \\
\text { HTF } & 18 \\
\text { HTF } & 19 \\
\text { HTF } & 20 \\
\text { HTF } & 21 \\
\text { HTF } & 22 \\
\text { HTF } & 23 \\
\text { HTF } & 24 \\
\text { HTF } & 25 \\
\text { HTF } & 26 \\
\text { HTF } & 27 \\
\text { HTF } & 28 \\
\text { HTF } & 29 \\
\text { HTF } & 31 \\
\text { HTF } & 32 \\
\text { NBG } & 1 \\
\text { NBG } & 2 \\
\text { NBG } & 3 \\
\text { SBG } & 1 \\
\text { SBG } & 2 \\
\text { SBG } & 3 \\
\text { SBG } & 4 \\
\text { SBG } & 5 \\
\text { SBG } & 6 \\
\text { SCA } & 2 \\
\text { SCA } & 3 \\
\text { SCA } & 4 \\
\text { SCA } & 5 \\
\text { SCA } & 6 \\
\text { SLT } & 1 \\
\text { SLP } & 2 \\
\text { ZBG } & 1 \\
\text { ZDT } & 1 \\
\text { ZDT } & 2 \\
\text { BGO } & 6 C \\
\text { BGO } & 8 C \\
\text { BGO } & 10 C \\
\text { BGO } & 14 C \\
\text { BGO } & 27 C \\
\text { BGO } & 30 C \\
\text { BGO } & 31 C\end{array}$ & $\begin{array}{l}4 / 24 / 91 \\
4 / 24 / 91 \\
4 / 17 / 91 \\
4 / 17 / 91 \\
4 / 29 / 91 \\
4 / 29 / 91 \\
4 / 29 / 91 \\
4 / 29 / 91 \\
4 / 24 / 91 \\
4 / 24 / 91 \\
4 / 24 / 91 \\
4 / 24 / 91 \\
4 / 29 / 91 \\
4 / 24 / 91 \\
4 / 24 / 91 \\
4 / 24 / 91 \\
4 / 24 / 91 \\
4 / 24 / 91 \\
5 / 15 / 91 \\
5 / 15 / 91 \\
5 / 15 / 91 \\
5 / 23 / 91 \\
6 / 07 / 91 \\
6 / 07 / 91 \\
5 / 23 / 91 \\
5 / 23 / 91 \\
5 / 23 / 91 \\
6 / 07 / 91 \\
5 / 20 / 91 \\
5 / 20 / 91 \\
5 / 20 / 91 \\
5 / 20 / 91 \\
5 / 20 / 91 \\
5 / 20 / 91 \\
6 / 05 / 91 \\
5 / 29 / 91 \\
5 / 29 / 91 \\
5 / 06 / 91 \\
5 / 10 / 91 \\
5 / 07 / 91 \\
5 / 10 / 91 \\
5 / 03 / 91 \\
5 / 08 / 91 \\
5 / 08 / 91\end{array}$ & $\begin{array}{l}273.70 \\
274.00 \\
270.50 \\
263.20 \\
272.50 \\
270.20 \\
269.60 \\
270.20 \\
276.50 \\
275.50 \\
274.80 \\
274.60 \\
275.10 \\
277.10 \\
276.80 \\
277.20 \\
276.80 \\
275.40 \\
223.54 \\
223.93 \\
217.53 \\
238.76 \\
237.46 \\
237.47 \\
241.35 \\
249.91 \\
244.72 \\
241.63 \\
240.10 \\
240.42 \\
239.75 \\
240.47 \\
245.23 \\
244.86 \\
234.45 \\
240.02 \\
241.59 \\
220.41 \\
218.60 \\
220.44 \\
222.91 \\
220.35 \\
219.31 \\
226.04\end{array}$ & $\begin{array}{l}71858.00 \\
71700.00 \\
72150.00 \\
72600.00 \\
71771.80 \\
71902.50 \\
72073.30 \\
71998.20 \\
71363.40 \\
71363.10 \\
71362.60 \\
71224.30 \\
71090.70 \\
71057.90 \\
71080.10 \\
71229.90 \\
70747.00 \\
70880.60 \\
79300.40 \\
79099.80 \\
78939.60 \\
74619.40 \\
74570.20 \\
73699.90 \\
72399.80 \\
72208.30 \\
73599.30 \\
73850.60 \\
73959.30 \\
73856.50 \\
74092.90 \\
73706.20 \\
72958.40 \\
72863.40 \\
76584.20 \\
71644.40 \\
71696.50 \\
76487.10 \\
76579.20 \\
76805.00 \\
76367.67 \\
75666.30 \\
75181.00 \\
74978.00\end{array}$ & $\begin{array}{l}61462.00 \\
61353.00 \\
61950.00 \\
61188.00 \\
61223.30 \\
61079.20 \\
61086.40 \\
61261.00 \\
62553.60 \\
62670.30 \\
62775.60 \\
62902.00 \\
62815.70 \\
62660.30 \\
62515.70 \\
62414.90 \\
62662.50 \\
62807.90 \\
53879.30 \\
53958.40 \\
54068.10 \\
63749.10 \\
64939.60 \\
65265.60 \\
65010.20 \\
64499.00 \\
63860.00 \\
64697.10 \\
64571.20 \\
64563.50 \\
64630.80 \\
64637.50 \\
64449.10 \\
64529.70 \\
65584.10 \\
65114.80 \\
65059.90 \\
58307.00 \\
57618.70 \\
57041.00 \\
55839.01 \\
54671.40 \\
54512.30 \\
54816.20\end{array}$ & $\begin{array}{l}1 \\
1 \\
1 \\
1 \\
1 \\
1 \\
1 \\
1 \\
1 \\
1 \\
1 \\
1 \\
1 \\
1 \\
1 \\
1 \\
1 \\
1 \\
1 \\
1 \\
1 \\
1 \\
1 \\
1 \\
1 \\
1 \\
1 \\
1 \\
1 \\
1 \\
1 \\
1 \\
1 \\
1 \\
1 \\
1 \\
1 \\
3 \\
3 \\
3 \\
3 \\
3 \\
3 \\
3\end{array}$ \\
\hline
\end{tabular}


Table 3.3. Observed water elevations for second quarter 1991 used for model calibration (Continued).

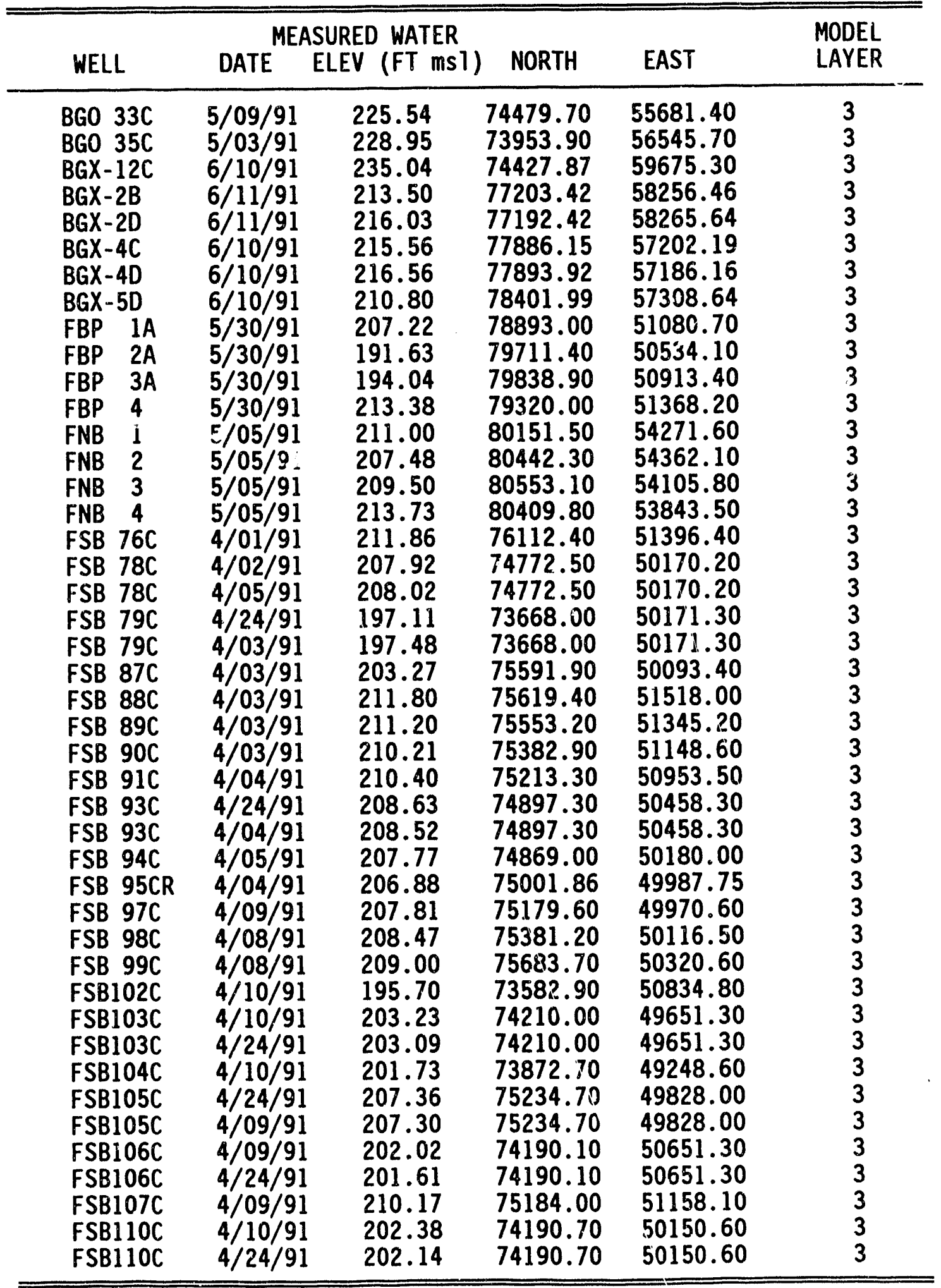


Table 3.3. Observed water elevations for second quarter 1991 used for model calibration (Continued).

\begin{tabular}{|c|c|c|c|c|c|}
\hline WELL & DATE & $\begin{array}{l}\text { ASURED WATER } \\
\text { ELEV (FT msl) }\end{array}$ & NORTH & EAST & $\begin{array}{l}\text { MODEL } \\
\text { LAYER }\end{array}$ \\
\hline $\begin{array}{l}\text { FSB111C } \\
\text { FSB112C } \\
\text { FSB113C } \\
\text { FSB114C } \\
\text { FSB116C } \\
\text { FSB120C } \\
\text { FSB121C } \\
\text { FSB122C } \\
\text { FSB123C } \\
\text { HMD-1DC } \\
\text { HMD-2DC } \\
\text { HMD-3DC } \\
\text { HMD-4DC } \\
\text { HSB } 65 B \\
\text { HSB } 68 B \\
\text { HSB } 68 C \\
\text { HSB } 70 C \\
\text { HSB } 71 C \\
\text { HSB } 83 B \\
\text { HSB 83C } \\
\text { HSB 84B } \\
\text { HSB } 84 C \\
\text { HSB 85B } \\
\text { HSB 86B } \\
\text { HSB 86C } \\
\text { HSB100C } \\
\text { HSB101C } \\
\text { HSB102C } \\
\text { HSB103C } \\
\text { HSB104C } \\
\text { HSB105C } \\
\text { HSB106C } \\
\text { HSB107C } \\
\text { HSB108C } \\
\text { HSB109C } \\
\text { HSB110C } \\
\text { HSB111C } \\
\text { HSB112C } \\
\text { HSB113C } \\
\text { HSB114C } \\
\text { HSB115C } \\
\text { HSB116C } \\
\text { HSB117C } \\
\text { HSB125C }\end{array}$ & $\begin{array}{l}4 / 10 / 91 \\
4 / 11 / 91 \\
4 / 11 / 91 \\
4 / 11 / 91 \\
4 / 12 / 91 \\
4 / 15 / 91 \\
4 / 15 / 91 \\
4 / 15 / 91 \\
4 / 16 / 91 \\
5 / 02 / 91 \\
5 / 02 / 91 \\
5 / 02 / 91 \\
5 / 02 / 91 \\
4 / 01 / 91 \\
4 / 09 / 91 \\
4 / 09 / 91 \\
4 / 09 / 91 \\
4 / 10 / 91 \\
4 / 02 / 91 \\
4 / 02 / 91 \\
4 / 09 / 91 \\
4 / 09 / 91 \\
4 / 16 / 91 \\
4 / 03 / 91 \\
4 / 03 / 91 \\
4 / 01 / 91 \\
4 / 01 / 91 \\
4 / 02 / 91 \\
4 / 01 / 91 \\
4 / 04 / 91 \\
4 / 02 / 91 \\
4 / 02 / 91 \\
4 / 04 / 91 \\
4 / 04 / 91 \\
4 / 02 / 91 \\
4 / 04 / 91 \\
4 / 04 / 91 \\
4 / 08 / 91 \\
4 / 04 / 91 \\
4 / 03 / 91 \\
4 / 03 / 91 \\
4 / 03 / 91 \\
4 / 10 / 91 \\
4 / 11 / 91\end{array}$ & $\begin{array}{l}211.62 \\
202.15 \\
203.21 \\
212.55 \\
189.07 \\
205.43 \\
204.01 \\
200.30 \\
210.06 \\
210.83 \\
202.98 \\
202.50 \\
202.45 \\
224.93 \\
217.95 \\
218.78 \\
226.15 \\
225.98 \\
223.68 \\
225.41 \\
211.60 \\
214.67 \\
233.07 \\
223.55 \\
226.15 \\
227.11 \\
225.96 \\
225.19 \\
224.36 \\
221.37 \\
220.61 \\
222.50 \\
220.21 \\
219.27 \\
219.78 \\
220.20 \\
221.43 \\
223.10 \\
223.75 \\
225.64 \\
226.72 \\
227.63 \\
224.45 \\
224.40\end{array}$ & $\begin{array}{l}75383.30 \\
74227.50 \\
74160.70 \\
75288.50 \\
72725.50 \\
75549.80 \\
75155.70 \\
73881.80 \\
74566.70 \\
78731.72 \\
79665.80 \\
79578.71 \\
79160.40 \\
72445.60 \\
71525.50 \\
71524.10 \\
72597.30 \\
72866.60 \\
71639.60 \\
71636.90 \\
71603.30 \\
71597.10 \\
73789.30 \\
72519.00 \\
72529.70 \\
72077.20 \\
72001.90 \\
71960.10 \\
71593.90 \\
71376.80 \\
71447.30 \\
71720.90 \\
71698.50 \\
71688.70 \\
71684.80 \\
71779.30 \\
71919.40 \\
72156.40 \\
72312.30 \\
72464.60 \\
72653.20 \\
72888.10 \\
72740.70 \\
71503.60\end{array}$ & $\begin{array}{l}51526.30 \\
48794.80 \\
51084.20 \\
52033.80 \\
50645.90 \\
49171.10 \\
48413.10 \\
48195.00 \\
51750.50 \\
56973.32 \\
57269.74 \\
57745.22 \\
58188.49 \\
58439.40 \\
56882.10 \\
56872.70 \\
55757.10 \\
55281.50 \\
58594.90 \\
58614.80 \\
56352.40 \\
56360.10 \\
58953.30 \\
55976.90 \\
55984.60 \\
58806.50 \\
58604.40 \\
58399.70 \\
58323.60 \\
58082.60 \\
57883.80 \\
57651.50 \\
57432.00 \\
57155.50 \\
56895.60 \\
56680.70 \\
56501.90 \\
56417.40 \\
56160.40 \\
56107.00 \\
56043.20 \\
55989.10 \\
55162.90 \\
58592.80\end{array}$ & $\begin{array}{l}3 \\
3 \\
3 \\
3 \\
3 \\
3 \\
3 \\
3 \\
3 \\
3 \\
3 \\
3 \\
3 \\
3 \\
3 \\
3 \\
3 \\
3 \\
3 \\
3 \\
3 \\
3 \\
3 \\
3 \\
3 \\
3 \\
3 \\
3 \\
3 \\
3 \\
3 \\
3 \\
3 \\
3 \\
3 \\
3 \\
3 \\
3 \\
3 \\
3 \\
3 \\
3 \\
3 \\
3\end{array}$ \\
\hline
\end{tabular}


96

Table 3.3. Observed water elevations for second quarter 1991 used for model calibration (Continued).

\begin{tabular}{|c|c|c|c|c|c|}
\hline WELL & DATE $^{\text {MEA }}$ & $\begin{array}{l}\text { SURED WATER } \\
\text { ELEV (FT ms I) }\end{array}$ & NORTH & EAST & $\begin{array}{l}\text { MODEL } \\
\text { LAYER }\end{array}$ \\
\hline $\begin{array}{l}\text { HSB127C } \\
\text { HSB129C } \\
\text { HSB130C } \\
\text { HSB131C } \\
\text { HSB133C } \\
\text { HSB134C } \\
\text { HSB134C } \\
\text { HSB135C } \\
\text { HSB136C } \\
\text { HSB137C } \\
\text { HSB139C } \\
\text { HSB141C } \\
\text { HSB142C } \\
\text { HSB143C } \\
\text { HSB145C } \\
\text { HSB146C } \\
\text { HSB151C } \\
\text { HSB152C } \\
\text { YSC } 1 C \\
\text { YSC } \\
\text { BGC } \\
\text { BGO } 6 A \\
\text { BGO 14A } \\
\text { BGO 16A } \\
\text { BGO 18A } \\
\text { BGO 25A } \\
\text { BGO 26A } \\
\text { BGO 29A } \\
\text { BGX-4A } \\
\text { FSB 76A } \\
\text { FSB 76B } \\
\text { FSB 78A } \\
\text { FSB 78B } \\
\text { FSB 79B } \\
\text { FSB 87A } \\
\text { FSB 87B } \\
\text { FSB 96AR } \\
\text { FSB 97A } \\
\text { FSB 98A } \\
\text { FSB 99A } \\
\text { FSB100A } \\
\text { FSB101A } \\
\text { FSB112A } \\
\text { FSB113A } \\
\text { FSB114A }\end{array}$ & $\begin{array}{l}4 / 09 / 91 \\
4 / 15 / 91 \\
4 / 12 / 91 \\
4 / 15 / 91 \\
4 / 16 / 91 \\
5 / 20 / 91 \\
4 / 11 / 91 \\
4 / 09 / 91 \\
4 / 11 / 91 \\
4 / 08 / 91 \\
4 / 09 / 91 \\
4 / 17 / 91 \\
4 / 10 / 91 \\
4 / 12 / 91 \\
4 / 15 / 91 \\
4 / 17 / 91 \\
4 / 10 / 91 \\
4 / 10 / 91 \\
6 / 06 / 91 \\
6 / 04 / 91 \\
5 / 06 / 91 \\
5 / 10 / 91 \\
5 / 31 / 91 \\
5 / 13 / 91 \\
5 / 07 / 91 \\
5 / 08 / 91 \\
5 / 08 / 91 \\
6 / 10 / 91 \\
4 / 01 / 91 \\
4 / 01 / 91 \\
4 / 02 / 91 \\
4 / 02 / 91 \\
4 / 02 / 91 \\
4 / 03 / 91 \\
4 / 03 / 91 \\
4 / 05 / 91 \\
4 / 08 / 91 \\
4 / 05 / 91 \\
4 / 08 / 91 \\
4 / 08 / 91 \\
4 / 12 / 91 \\
4 / 11 / 91 \\
4 / 11 / 91 \\
4 / 11 / 91\end{array}$ & $\begin{array}{l}210.83 \\
206.44 \\
200.08 \\
203.79 \\
231.12 \\
220.11 \\
221.77 \\
207.19 \\
218.93 \\
222.61 \\
215.26 \\
229.95 \\
198.96 \\
209.70 \\
214.09 \\
210.43 \\
208.92 \\
199.06 \\
223.30 \\
226.95 \\
159.49 \\
158.81 \\
161.44 \\
161.48 \\
161.30 \\
160.82 \\
159.53 \\
155.11 \\
155.41 \\
151.67 \\
156.06 \\
154.41 \\
157.96 \\
153.96 \\
150.80 \\
152.95 \\
152.19 \\
151.37 \\
150.78 \\
151.65 \\
151.75 \\
154.34 \\
157.99 \\
155.32\end{array}$ & $\begin{array}{l}71210.10 \\
71830.40 \\
70762.40 \\
70374.70 \\
71949.50 \\
71210.30 \\
71210.30 \\
71390.20 \\
71900.30 \\
72269.90 \\
71129.80 \\
71196.70 \\
73119.00 \\
73738.20 \\
71098.90 \\
70471.60 \\
72997.90 \\
72012.00 \\
78186.20 \\
77059.70 \\
76487.20 \\
76377.54 \\
75756.95 \\
75599.89 \\
76158.50 \\
76144.60 \\
75560.00 \\
77879.18 \\
76131.90 \\
76122.40 \\
74757.70 \\
74765.90 \\
73666.10 \\
75601.70 \\
75597.00 \\
74914.91 \\
75171.20 \\
75389.80 \\
75675.60 \\
75534.40 \\
75719.00 \\
74231.40 \\
74167.50 \\
75297.40\end{array}$ & $\begin{array}{l}56792.10 \\
55110.00 \\
54643.60 \\
56894.90 \\
59110.30 \\
58289.90 \\
58289.90 \\
56560.80 \\
55949.60 \\
55700.20 \\
57374.50 \\
59170.20 \\
53505.30 \\
52773.20 \\
57769.00 \\
58473.10 \\
54014.90 \\
54346.70 \\
65855.50 \\
65901.90 \\
58316.80 \\
55838.32 \\
56194.15 \\
56699.67 \\
55668.08 \\
55014.20 \\
54103.50 \\
57215.58 \\
51391.60 \\
51394.00 \\
50172.80 \\
50178.80 \\
50159.20 \\
50115.80 \\
50104.90 \\
49746.64 \\
49965.70 \\
50121.60 \\
50314.80 \\
50958.40 \\
51191.30 \\
48809.10 \\
51068.10 \\
52046.60\end{array}$ & $\begin{array}{l}3 \\
3 \\
3 \\
3 \\
3 \\
3 \\
3 \\
3 \\
3 \\
3 \\
3 \\
3 \\
3 \\
3 \\
3 \\
3 \\
3 \\
3 \\
3 \\
3 \\
5 \\
5 \\
5 \\
5 \\
5 \\
5 \\
5 \\
5 \\
5 \\
5 \\
5 \\
5 \\
5 \\
5 \\
5 \\
5 \\
5 \\
5 \\
5 \\
5 \\
5 \\
5 \\
5 \\
5\end{array}$ \\
\hline
\end{tabular}


Table 3.3. Observed water elevations for second quarter 1991 used for model calibration (Continued).

\begin{tabular}{lccccc}
\hline \multicolumn{7}{c}{ MEASURED WATER } & & \\
WELL & DATE & ELEV $(\mathrm{FT}$ ms 1$)$ & NORTH & EAST & MODEL \\
LAYER \\
\hline FSB120A & $4 / 12 / 91$ & 148.35 & 75538.90 & 49175.70 & 5 \\
HSB 65A & $4 / 01 / 91$ & 170.99 & 72436.20 & 58436.00 & 5 \\
HSB 68A & $4 / 08 / 91$ & 171.43 & 71526.90 & 56892.10 & 5 \\
HSB 69A & $4 / 05 / 91$ & 171.73 & 71549.40 & 56465.10 & 5 \\
HSB 83A & $4 / 02 / 91$ & 172.92 & 71648.60 & 58606.10 & 5 \\
HSB 84A & $4 / 09 / 91$ & 171.48 & 71586.20 & 56359.10 & 5 \\
HSB 85A & $4 / 16 / 91$ & 168.62 & 73791.90 & 58943.40 & 5 \\
HSB 86A & $4 / 03 / 91$ & 168.19 & 72520.20 & 55985.90 & 5 \\
HSB117A & $4 / 10 / 91$ & 165.96 & 72733.60 & 55170.10 & 5 \\
HSB118A & $4 / 02 / 91$ & 167.29 & 72696.40 & 55775.60 & 5 \\
HSB119A & $4 / 17 / 91$ & 166.69 & 73082.50 & 56100.20 & 5 \\
HSB120A & $4 / 03 / 91$ & 165.92 & 73395.10 & 56431.90 & 5 \\
HSB121A & $4 / 05 / 91$ & 171.24 & 72024.80 & 57389.60 & 5 \\
HSB122A & $4 / 05 / 91$ & 171.08 & 72195.90 & 57747.40 & 5 \\
HSB123A & $4 / 09 / 91$ & 171.33 & 72189.80 & 58124.80 & 5 \\
HSB139A & $4 / 08 / 91$ & 173.18 & 71127.40 & 57365.40 & 5 \\
HSB141A & $4 / 16 / 91$ & 174.29 & 71213.60 & 59168.70 & 5 \\
HSB144A & $4 / 11 / 91$ & 170.25 & 71892.10 & 56200.50 & 5 \\
YSC 2A & $6 / 06 / 91$ & 162.88 & 78311.50 & 66100.10 & 5 \\
YSC 5A & $6 / 06 / 91$ & 178.95 & 74295.90 & 67134.90 & 5 \\
\hline \hline
\end{tabular}


Table 3.4. Wells with measured water-levels in second quarter 1991 removed from the calibration process.

\begin{tabular}{|c|c|c|c|c|}
\hline WELL & DATE & $\begin{array}{l}\text { MODEL } \\
\text { LAYER }\end{array}$ & $\begin{array}{l}\text { MEASURED } \\
\text { WATER } \\
\text { ELEVATION } \\
\text { (FT MSL) }\end{array}$ & REASON FOR OMITTING \\
\hline FCB 3 & $5 / 29 / 91$ & 1 & 221.86 & $\begin{array}{l}\text { Apparently screened across Confining } \\
\text { Unit IIB1-IIB2 (Tan Clay) }\end{array}$ \\
\hline FSB 930 & $4 / 16 / 91$ & 1 & 216.52 & $\begin{array}{l}\text { Inconsistent with time series data } \\
\text { for that well }\end{array}$ \\
\hline FSB115 & $4 / 12 / 91$ & 1 & 192.70 & Inactive portion of model \\
\hline HSB130D & $4 / 12 / 91$ & 1 & 200.99 & Inactive portion of model \\
\hline HSB140D & $4 / 12 / 91$ & 1 & 216.80 & Inactive portion of model \\
\hline HSB148D & $4 / 16 / 91$ & 1 & 215.76 & Inactive portion of model \\
\hline NBG 4 & $5 / 15 / 91$ & 1 & 217.05 & Desaturated in model results \\
\hline NBG 5 & $5 / 15 / 91$ & 1 & 217.70 & Desaturated in model results \\
\hline ZBG 2 & $6 / 5 / 91$ & 1 & 241.59 & Desaturated in model results \\
\hline FCA 2 & $5 / 15 / 91$ & 1 & 298.49 & Perched zone \\
\hline FCA $16 B$ & $6 / 6 / 91$ & 1 & 298.17 & Perched zone \\
\hline SCA $3 A$ & $5 / 20 / 91$ & 1 & 271.61 & Perched zone \\
\hline SCA $4 A$ & $5 / 20 / 91$ & 1 & 269.08 & Perched zone \\
\hline ZBG $\quad 1 A$ & $6 / 6 / 91$ & 1 & 276.16 & Perched zone \\
\hline FSB115C & $4 / 12 / 91$ & 3 & 184.89 & Inactive portion of model \\
\hline FSB140C & $4 / 12 / 91$ & 3 & 206.52 & Inactive portion of model \\
\hline HSB148C & $4 / 16 / 91$ & 3 & 201.78 & Inactive portion of model \\
\hline FSB $79 A$ & $4 / 2 / 91$ & 5 & 167.74 & $\begin{array}{l}\text { Inconsistent with time-series data } \\
\text { for that well }\end{array}$ \\
\hline BGO $10 A$ & $5 / 7 / 91$ & 5 & 165.28 & $\begin{array}{l}\text { Replacement we11 in third quarter } \\
1991 \text { indicates substantially lower } \\
\text { water-level }\end{array}$ \\
\hline
\end{tabular}


Table 3.4. Wells with measured water-levels in second quarter 1991 removed from the calibration process (Continued).

\begin{tabular}{|c|c|c|c|c|}
\hline WELL & DATE & $\begin{array}{l}\text { MODEL } \\
\text { LAYER }\end{array}$ & $\begin{array}{l}\text { MEASURED } \\
\text { WATER } \\
\text { ELEVATION } \\
\text { (FT MSL) }\end{array}$ & REASON FOR OMITTING \\
\hline BGO $12 A$ & $5 / 7 / 91$ & 5 & 175.25 & $\begin{array}{l}\text { Replacement well in third quarter } \\
1991 \text { indicates substantially lower } \\
\text { water-level }\end{array}$ \\
\hline HSB124A & $4 / 16 / 91$ & 5 & 193.77 & $\begin{array}{l}\text { Inconsistent with other water levels } \\
\text { in that mode? layer }\end{array}$ \\
\hline HSB140A & $4 / 12 / 91$ & 5 & 206.52 & Inactive portion of model \\
\hline
\end{tabular}


100

Table 3.5. Wells sampled multiple times in second quarter 1991.

\begin{tabular}{|c|c|c|c|}
\hline WELL & DATE & $\begin{array}{l}\text { MODEL } \\
\text { LAYER }\end{array}$ & $\begin{array}{l}\text { MEASURED WATER } \\
\text { ELEVATION (ft } \mathrm{ms} 1)\end{array}$ \\
\hline $\begin{array}{ll}\text { FAC } & 6 \\
\text { FAC } & 6\end{array}$ & $\begin{array}{l}4 / 04 / 91 \\
5 / 30 / 91\end{array}$ & $\begin{array}{l}1 \\
1\end{array}$ & $\begin{array}{l}218.54 \\
219.76\end{array}$ \\
\hline $\begin{array}{l}\text { FSB } 77 \\
\text { FSB } 77\end{array}$ & $\begin{array}{l}4 / 01 / 91 \\
4 / 25 / 91\end{array}$ & $\begin{array}{l}1 \\
1\end{array}$ & $\begin{array}{l}211.63 \\
211.71\end{array}$ \\
\hline $\begin{array}{ll}\text { FSB } & 78 D \\
\text { FSB } & 780 \\
\text { FSB } & 78 D\end{array}$ & $\begin{array}{l}4 / 02 / 91 \\
4 / 05 / 91 \\
4 / 24 / 91\end{array}$ & $\begin{array}{l}1 \\
1 \\
1\end{array}$ & $\begin{array}{l}208.84 \\
208.95 \\
209.07\end{array}$ \\
\hline $\begin{array}{l}\text { FSB } 790 \\
\text { FSB } 790\end{array}$ & $\begin{array}{l}4 / 02 / 91 \\
4 / 24 / 91\end{array}$ & $\begin{array}{l}1 \\
1\end{array}$ & $\begin{array}{l}203.30 \\
202.94\end{array}$ \\
\hline $\begin{array}{ll}\text { FSB } & 99 D \\
\text { FSB } & 99 D\end{array}$ & $\begin{array}{l}4 / 08 / 91 \\
4 / 24 / 91\end{array}$ & $\begin{array}{l}1 \\
1\end{array}$ & $\begin{array}{l}211.85 \\
212.02\end{array}$ \\
\hline $\begin{array}{l}\text { FSB107D } \\
\text { FSB107D }\end{array}$ & $\begin{array}{l}4 / 09 / 91 \\
4 / 25 / 91\end{array}$ & $\begin{array}{l}1 \\
1\end{array}$ & $\begin{array}{l}213.65 \\
213.61\end{array}$ \\
\hline $\begin{array}{l}\text { FSB110D } \\
\text { FSB110D }\end{array}$ & $\begin{array}{l}4 / 10 / 91 \\
4 / 24 / 91\end{array}$ & $\begin{array}{l}1 \\
1\end{array}$ & $\begin{array}{l}206.28 \\
206.06\end{array}$ \\
\hline $\begin{array}{ll}\text { HSB } & 67 \\
\text { HSB } & 67\end{array}$ & $\begin{array}{l}4 / 04 / 91 \\
4 / 25 / 91\end{array}$ & $\begin{array}{l}1 \\
1\end{array}$ & $\begin{array}{l}225.11 \\
224.46\end{array}$ \\
\hline $\begin{array}{ll}\text { HSB } & 69 \\
\text { HSB } & 69\end{array}$ & $\begin{array}{l}4 / 08 / 91 \\
4 / 25 / 91\end{array}$ & $\begin{array}{l}1 \\
1\end{array}$ & $\begin{array}{l}220.63 \\
220.08\end{array}$ \\
\hline $\begin{array}{l}\text { HSB100D } \\
\text { HSB100D }\end{array}$ & $\begin{array}{l}4 / 01 / 91 \\
4 / 25 / 91\end{array}$ & $\begin{array}{l}1 \\
1\end{array}$ & $\begin{array}{l}234.35 \\
234.10\end{array}$ \\
\hline $\begin{array}{l}\text { HSB111E } \\
\text { HSB111E }\end{array}$ & $\begin{array}{l}4 / 04 / 91 \\
4 / 15 / 91\end{array}$ & $\begin{array}{l}1 \\
1\end{array}$ & $\begin{array}{l}223.47 \\
223.38\end{array}$ \\
\hline $\begin{array}{l}\text { HSB116D } \\
\text { HSB116D }\end{array}$ & $\begin{array}{l}4 / 03 / 91 \\
4 / 25 / 91\end{array}$ & $\begin{array}{l}1 \\
1\end{array}$ & $\begin{array}{l}228.54 \\
227.81\end{array}$ \\
\hline $\begin{array}{l}\text { HSB117D } \\
\text { HSB117D }\end{array}$ & $\begin{array}{l}4 / 10 / 91 \\
4 / 25 / 91\end{array}$ & $\begin{array}{l}1 \\
1\end{array}$ & $\begin{array}{l}227 \cdot 35 \\
225.55\end{array}$ \\
\hline $\begin{array}{l}\text { HSB131D } \\
\text { HSB131D }\end{array}$ & $\begin{array}{l}4 / 15 / 91 \\
4 / 25 / 91\end{array}$ & $\begin{array}{l}1 \\
1\end{array}$ & $\begin{array}{l}205.63 \\
205.13\end{array}$ \\
\hline $\begin{array}{l}\text { HSB134C } \\
\text { HSB134C }\end{array}$ & $\begin{array}{l}4 / 11 / 91 \\
5 / 20 / 91\end{array}$ & $\begin{array}{l}3 \\
3\end{array}$ & $\begin{array}{l}221.77 \\
220.11\end{array}$ \\
\hline
\end{tabular}


Table 3.5. Wells sampled multiple times in second quarter 1991 (Continued).

\begin{tabular}{lccc}
\hline \hline WELL & DATE & $\begin{array}{c}\text { MODEL } \\
\text { LAYER }\end{array}$ & $\begin{array}{c}\text { MEASURED WATER } \\
\text { ELEVATION (ft ms } 1)\end{array}$ \\
\hline FSB 78C & $4 / 02 / 91$ & 3 & 207.92 \\
FSB 78C & $4 / 05 / 91$ & 3 & 208.02 \\
FSB 79C & $4 / 03 / 91$ & 3 & 197.48 \\
FSB 79C & $4 / 24 / 91$ & 3 & 197.11 \\
FSB 93C & $4 / 04 / 91$ & 3 & 208.52 \\
FSB 93C & $4 / 24 / 91$ & 3 & 208.63 \\
FSB103C & $4 / 10 / 91$ & 3 & 203.23 \\
FSB103C & $4 / 24 / 91$ & 3 & 203.09 \\
FSB105C & $4 / 09 / 91$ & 3 & 207.30 \\
FSB105C & $4 / 24 / 91$ & 3 & 207.36 \\
FSB106C & $4 / 09 / 91$ & 3 & 202.02 \\
FSB106C & $4 / 24 / 91$ & 3 & 201.61 \\
FSB110C & $4 / 10 / 91$ & 3 & 202.38 \\
FSB110C & $4 / 24 / 91$ & 3 & 202.14 \\
\hline \hline
\end{tabular}


This type of calibration problem occurs with great frequency for water level data within the GSA. In some cases, these variabilities in measurements may indicate significant local heterogeneity that is at too small of a scale to be represented in the regional flow model. In some cases, it may be a result of well location within the grid block, relative to the location of the grid block center (where calculations are made). In some cases, it may be a temporal phenomenon, where nearby wells are measured several days or months apart. In some cases it may be a function of vertical gradients, where wells are screened at different vertical intervals within the same model layer (downward vertical gradients exist through most of the model domain).

Rather than remove data points without apparent errors, all such data points were kept within the analysis, recognizing that significant residuals would occur at many locations irregardless of the parameter values assigned.

\subsubsection{Summary of Model Calibration Procedure and Results}

\subsubsection{Initial Efforts}

Initial simulations were made to determine if parameter values could be assigned in a non-zoned manner to achieve an adequate calibration with respect to the calibration criteria. The semi-automated parameter estimation technique was utilized to minimize the sum of squares for modeled residuals. The initial simulations were also used to determine appropriate values for drain and river conductance such that the connecion between these features and the aquifer was good (which is indicated by measured water levels with respect to river stages and land surface elevations).

When it became evident that the distribution of measured water levels was biasing the results of the semi-automated procedure, additional perturbation of parameters was performed manually, still utilizing uniform parameter values. It became apparent that a sufficient match could not be obtained in all regions of the GSA utilizing uniform parameters. In particular, the following was noted: 
1. Near H-Area, water levels in Aquifer Unit IIB Zone 2 (Water Table, model layer 1) were simulated too low when other areas matched we11;

2. In the northern part of the MWMF (and to the north towards Upper Three Runs (reek), water levels in Aquifer Unit IIB Zone 1 (Barnwel1/McBean, model layer 3) and Aquifer Unit IIB Zone 2 (Water Table, model layer 1) were simulated too high when other areas matched well;

3. Near the F-Area seepage basins, water levels in Aquifer Unit IIB Zone 1 (Barnwe11/McBean, model layer 3) and Aquifer Unit IIB Zone 2 (Water Table, model layer 1) were simulated too low when other areas matched well; and

4. Near the H-Area seepage basins (and to the south) a steeper hydraulic gradient in Aquifer Unit IIB Zone 1 (Barnwe11/McBean, model 1ayer 3 ) was indicated by measured values than could be simulated with uniform parameters.

These results indicated a need for one or more parameters to be assigned in zones, as opposed to uniformly.

\subsubsection{Addition of Zones}

Simulations were performed to assess the general impact of zones for the vertical hydraulic conductivity in model layers 2 and 4 (the confining units). The following general conclusions were made from these simulations:

- Water levels in layer 5 are relatively insensitive to modifications in the vertical hydraulic conductivity of layers 2 or 4;

- Water levels in layers 1 and 3 are quite sensitive to zoned values for vertical hydraulic conductivity of the confining beds (layers 2 and 4 ) in the vicinity of the zones, and are relatively insensitive away from the zones;

- In the vicinity of a zone of lower vertical hydraulic conductivity in layer 2, water-levels increase in layer 1 and decrease in layer 3 ; and

- In the vicinity of a zone of lower vertical hydraulic conductivity in layer 4 , water-levels increase in layer 1 and increase even more in layer 3. 
Based on these results, simple geometric shapes were added to the confining units to address problems (1) through (3) three detailed above.

To address problem (4), which pertained to horizontal gradients in layer 3, a zone of reduced horizontal hydraulic conductivity was specified in 1ayer 3 .

The exact shapes and positions of zones were varied during the calibration process to improve the overall match with observed waterlevels. Net recharge was also varied as zones were added to improve the overall match. An attempt was made to keep the geometric shapes of the zones simple, recognizing that available data do not allow easy definition of detailed parameter zones.

\subsubsection{Calibration Results}

Final values for calibrated parameters are presented in Table 3.6. The zonation of parameters in layers 2,3 and 4 is presented in Figures 3.22 to 3.24. The calibrated values for net recharge, in both capped and uncapped areas, is.presented in Figure 3.25.

The calibrated equipotential surface for Aquifer Unit IIB Zone 2 (Water Table, model layer 1 ) is presented in Figure 3.26. Flow directions, including a flow divide, are consistent with previous studies in the GSA. Residuals, calculated as simulated minus observed water-levels, are presented areally for this model layer in Figure 3.27. A positive value indicates that simulated values are too high, and a negative value indicates that simulated values are too low. Although water-levels are not predicted within $2 \mathrm{ft}$ at all points, for reasons detailed previously, that particular criterion is met with regularity in all major areas of concern within the GSA.

The calibrated equipotential surface for Aquifer Unit IIB Zone 1 (Barnwel1/McBean, model layer 3 ) is presented in Figure 3.28. Flow directions, including a flow divide, are again consistent with previous studies in the GSA. As shown in the figure, a relatively steep gradient exists in the vicinity of the $\mathrm{H}$-Area seepage basins, resulting from the zonation in horizontal hydraulic conductivity. Residuals, calculated as 


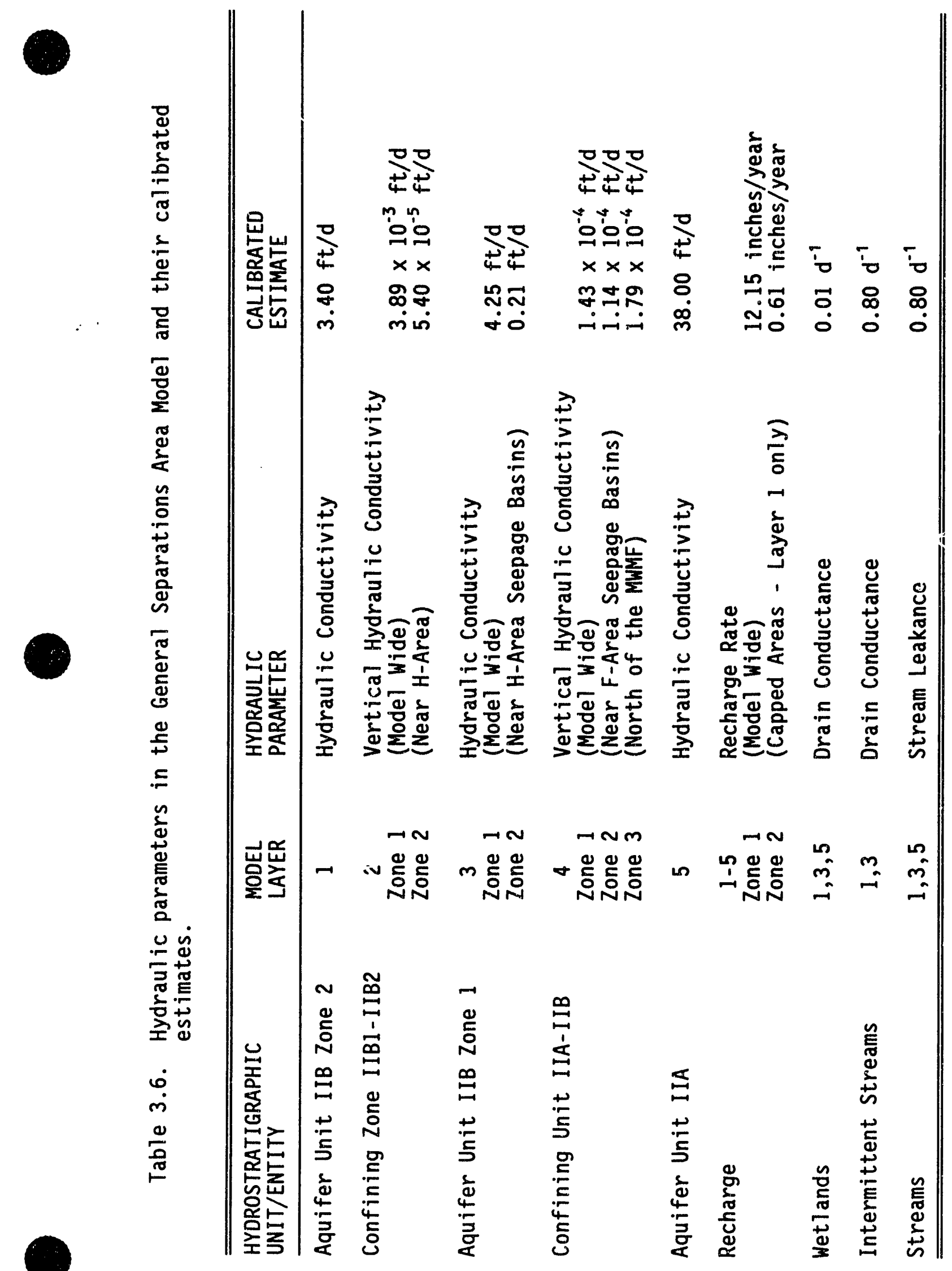




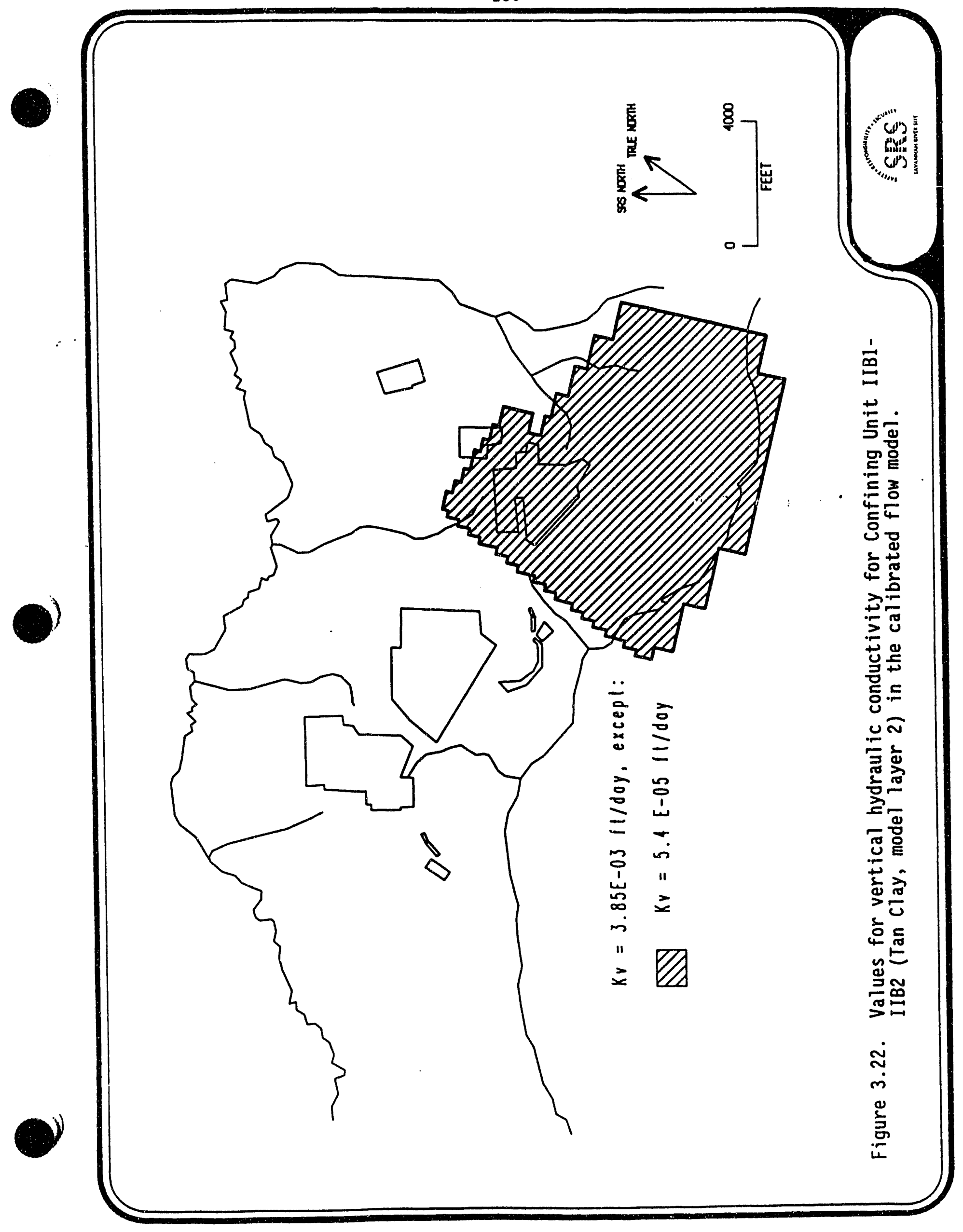




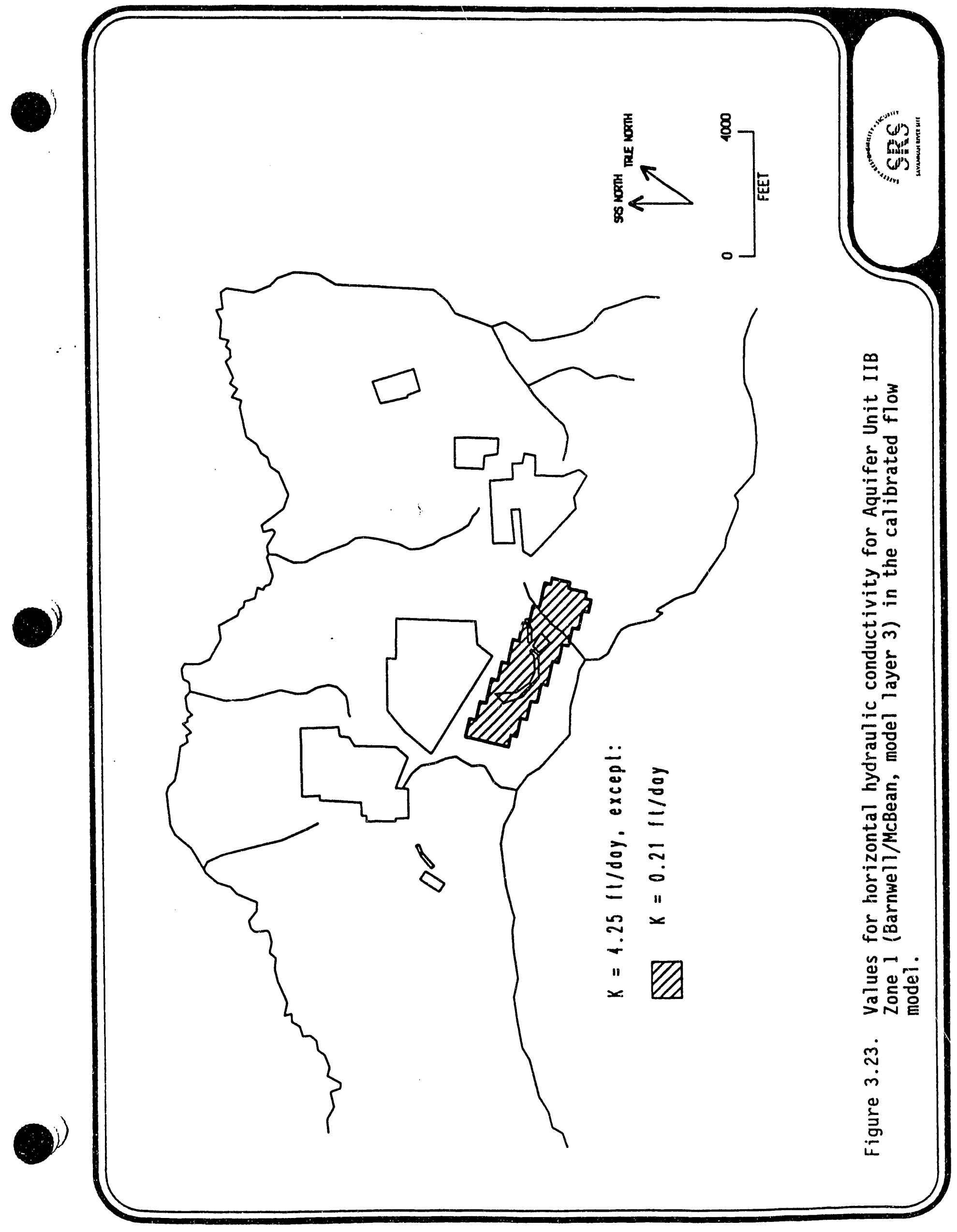




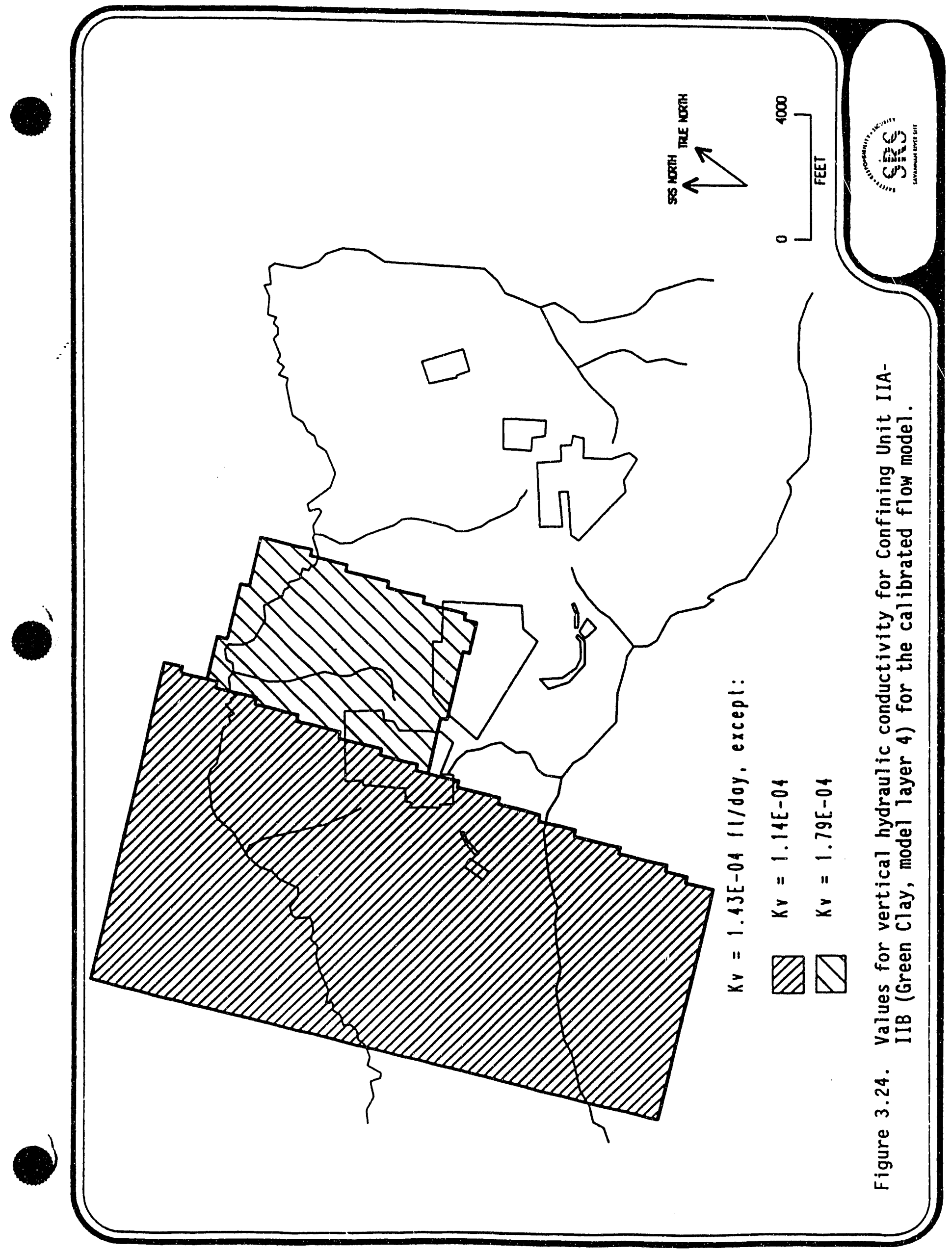




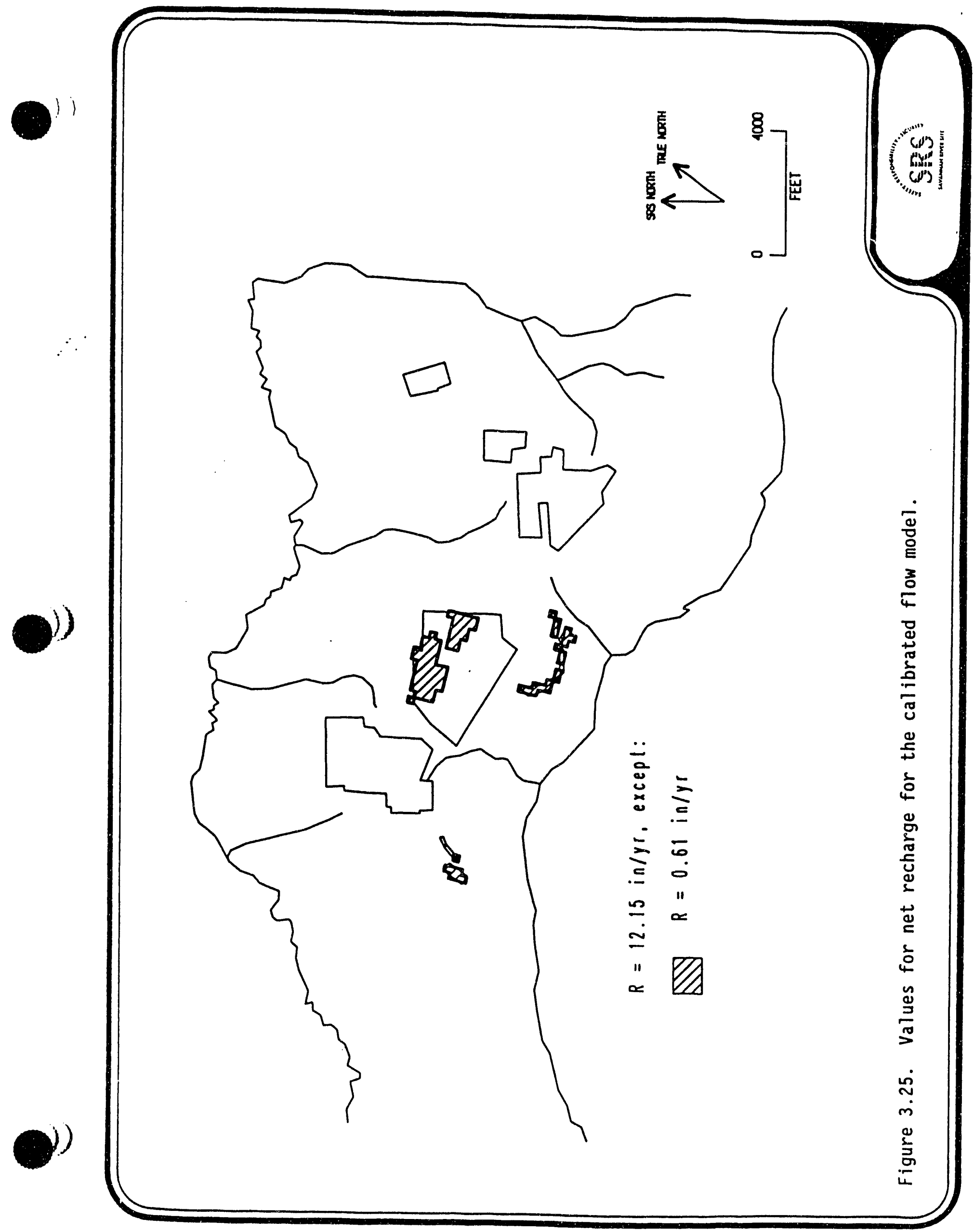



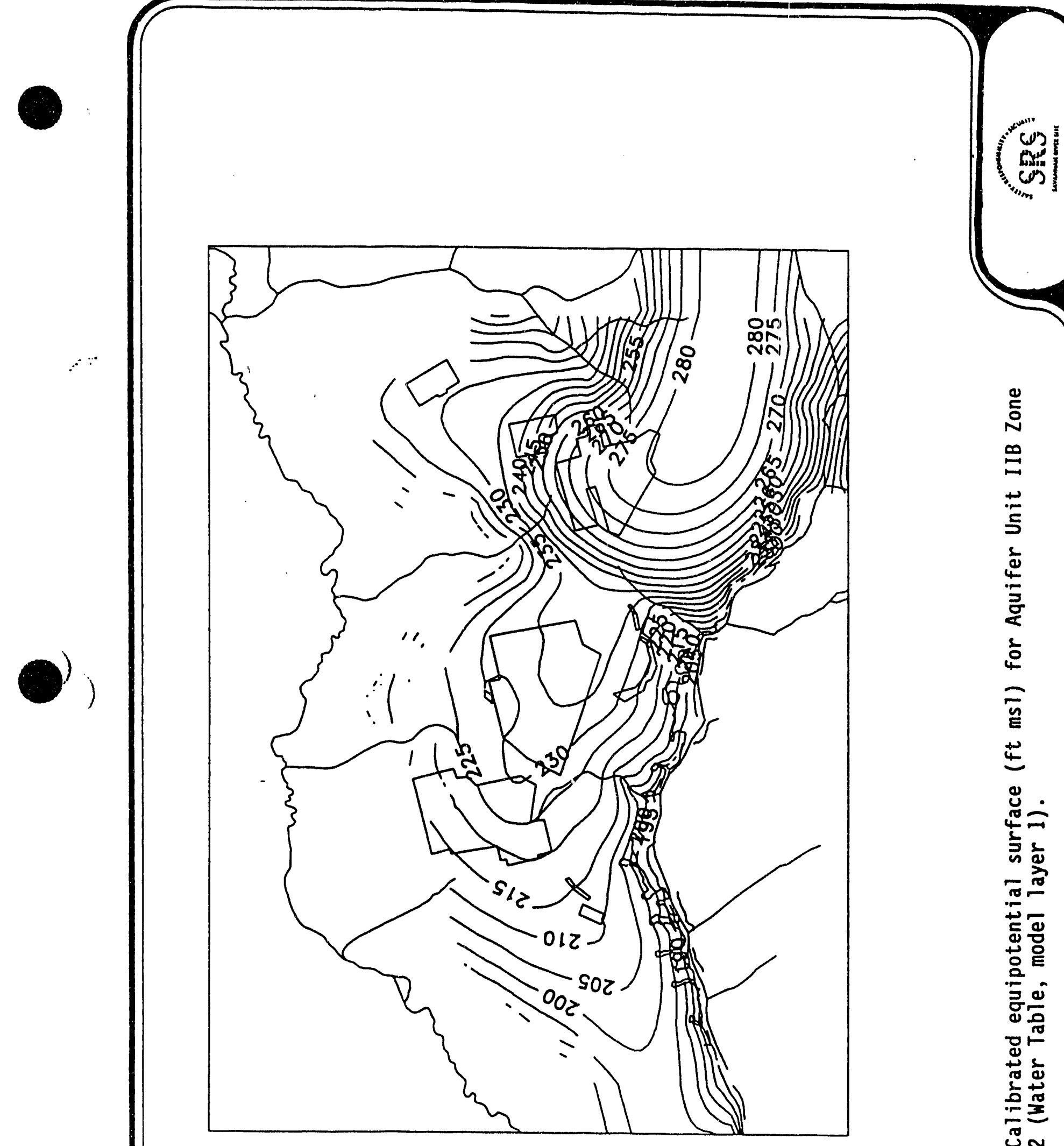

告 


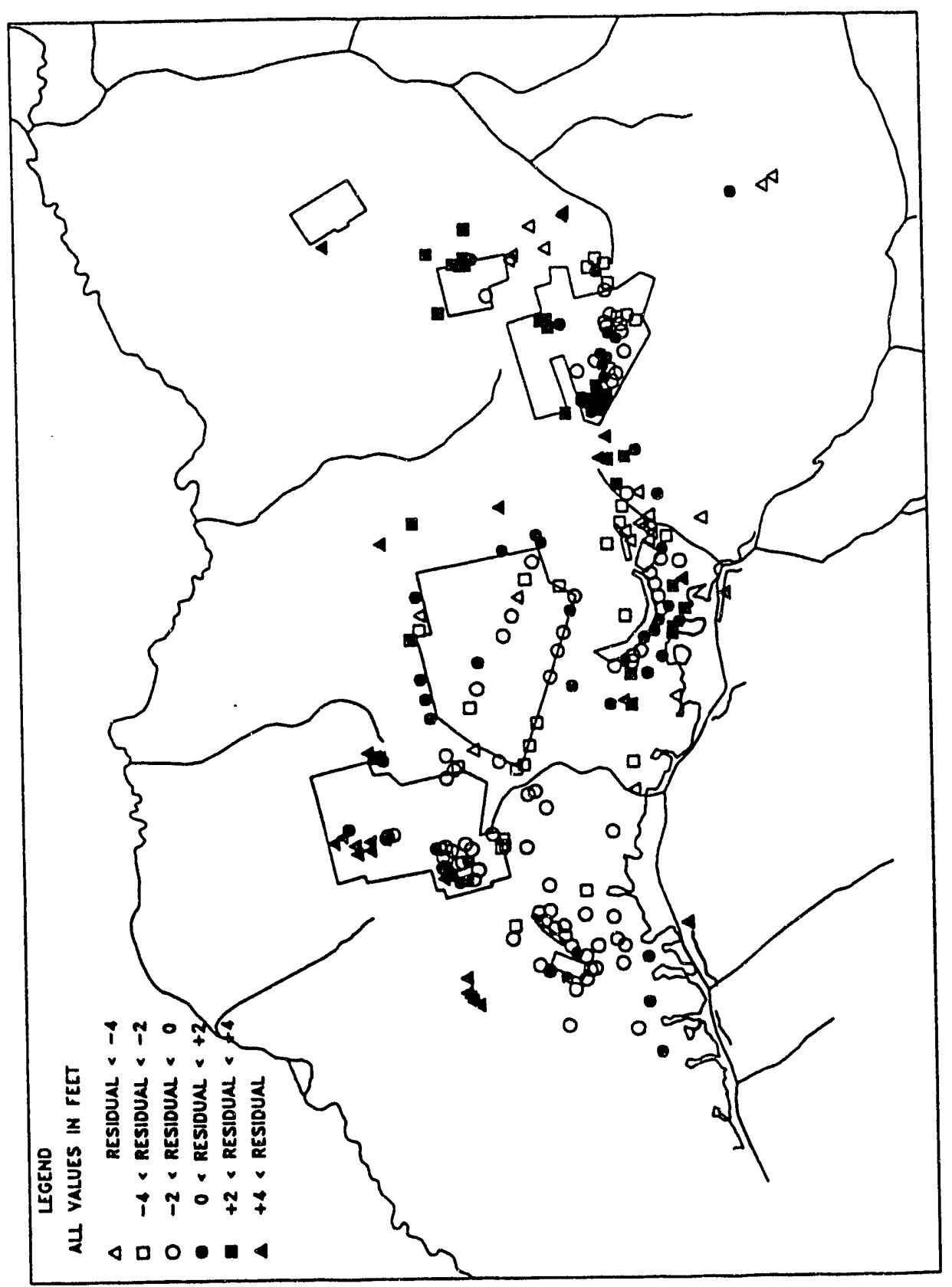

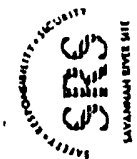

E

a

$\frac{4}{2}$

ธิ์

$=$

อ

งิ

我

ఫั ฮั

ญे

जิ-

造守

읕

.

Eั

Ð્

뜬

릍

n

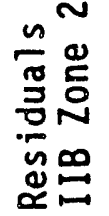

$\approx$

m

告 

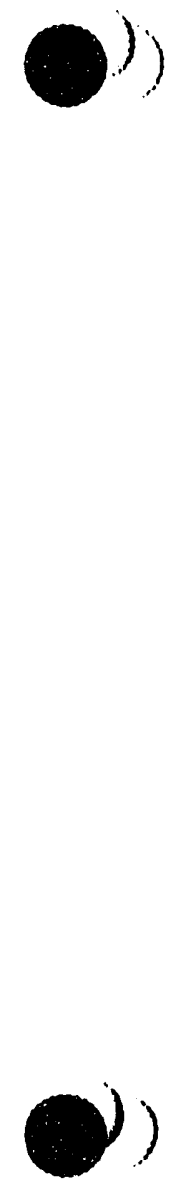
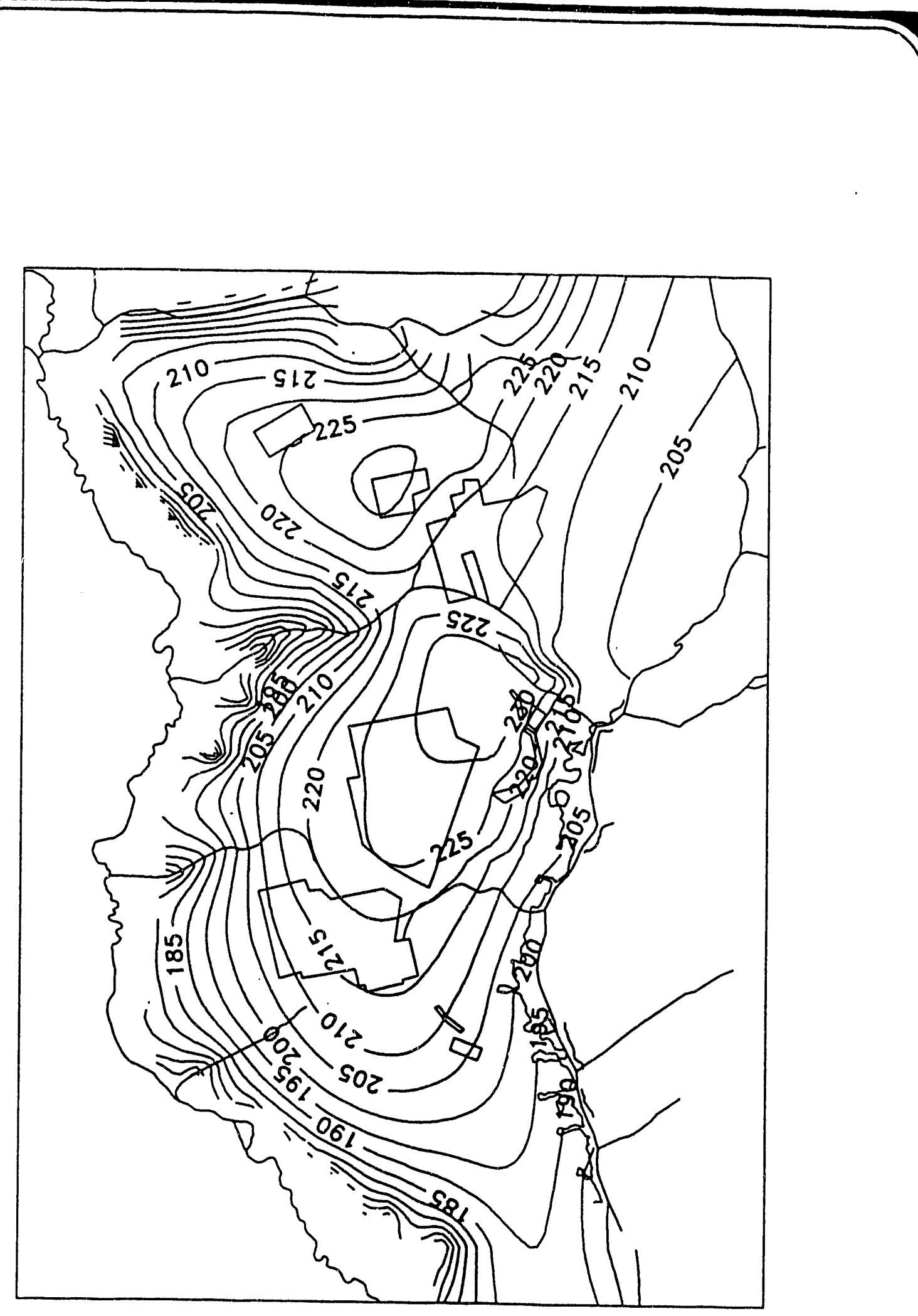
simulated minus observed water-levels, are presented areally for this model layer in Figure 3.29. A smaller percentage of points satisfy the 2-foot residual criterion in this model layer than in model layer 1 , although that criterion is frequently met in diverse areas of the GSA. The variability in data among wells in close proximity made it difficult to achieve an excellent match at all wells, given the grid discretization and simplification of parameter values into only a few discrete zones. For instance, near the $\mathrm{H}$-Area seepage basins, many points meeting the 2-foot residual criterion are immediately adjacent to wells with residuals of greater than $4 \mathrm{ft}$.

The calibrated equipotential surface for Aquifer Unit IIA (Congaree, model layer 5) is presented in Figure 3.30. Flow directions, which are towards Upper Three Runs Creek, are consistent with previous studies in the GSA. Residuals, calculated as simulated minus observed water-levels, are presented for this model layer in map form in Figure 3.31. The match of simulated and observed water levels is excellent in this model layer with respect to the 2-foot residual criterion, which is in part a result of the specified head boundary conditions assigned in this model layer.

Additional analysis was performed to assess the groundwater flow calibration. Line graphs of measured versus simulated head for model layers 1,3 and 5 are presented in Figures 3.32 to 3.34. Superimposed on these plots is a 45-degree line (where measured and simulated head are equivalent) on which all data points would fall if the calibration was perfect. Typically, a calibration is considered to be better when data points fall in a somewhat random distribution about this line. Otherwise, bias in the simulation relative to measured water levels is indicated. Also presented on these plots are lines of best fit according to the data points. Again, deviation of this line from the 45-degree line indicates bias in the simulated results.

The figures for 1 ayers 1 and 3 indicate that data points are well distributed about the 45-degree line, and the best-fit line indicates little bias. These two figures indicate that, in general, water levels are more accurately simulated in model layer 1 than model layer 3 . The line graph for layer 5 indicates an excellent match with water-levels, slightly biased, however, towards lower simulated values than measured water 


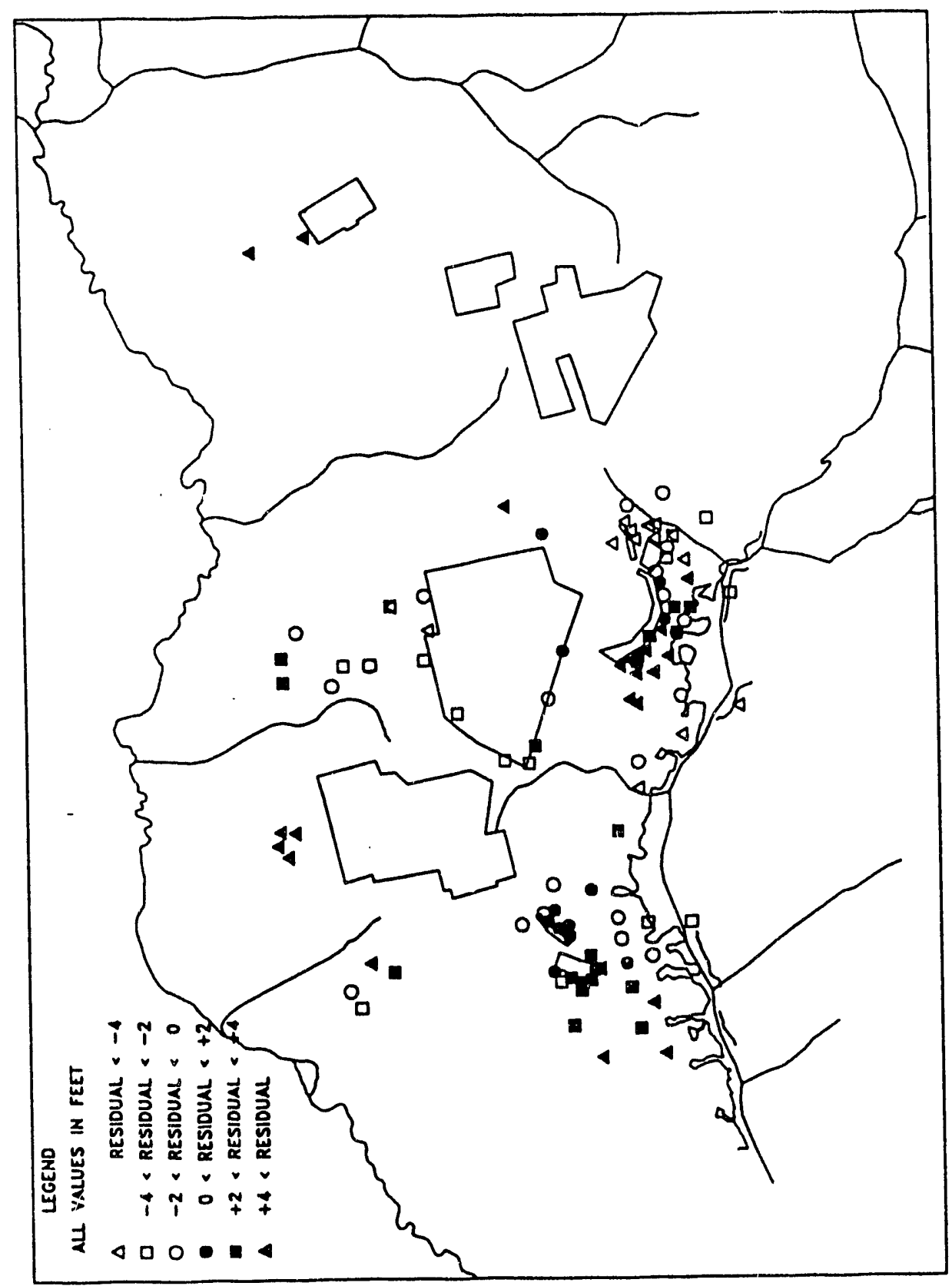

")
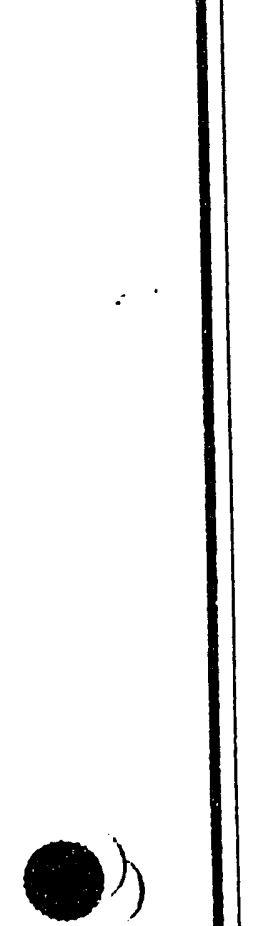


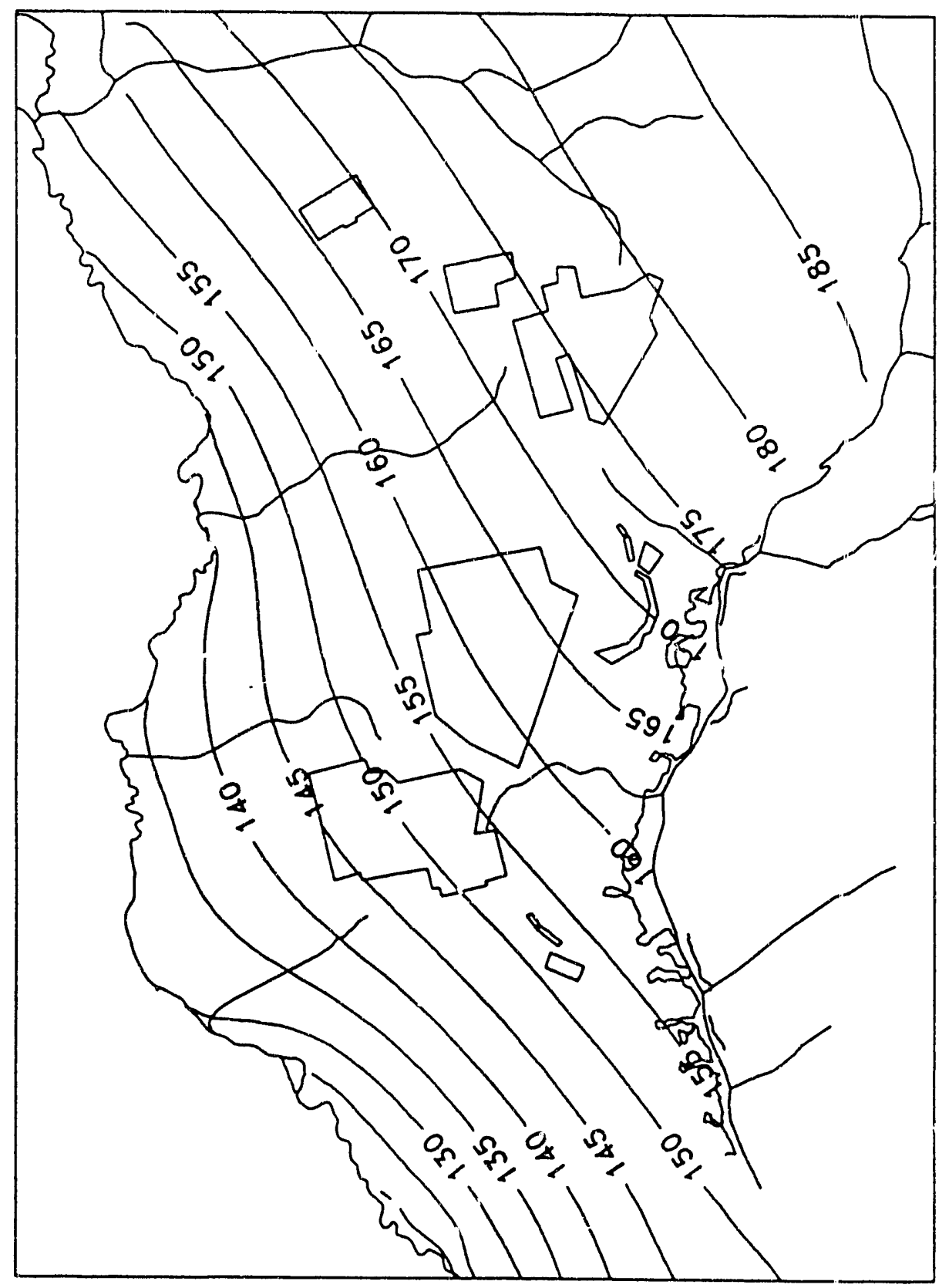

"3)

$\Xi$

$\stackrel{ \pm}{5}$

高

8

$\widehat{\bar{E}}$

屶

I

4

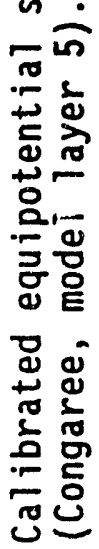

요

m.

光 


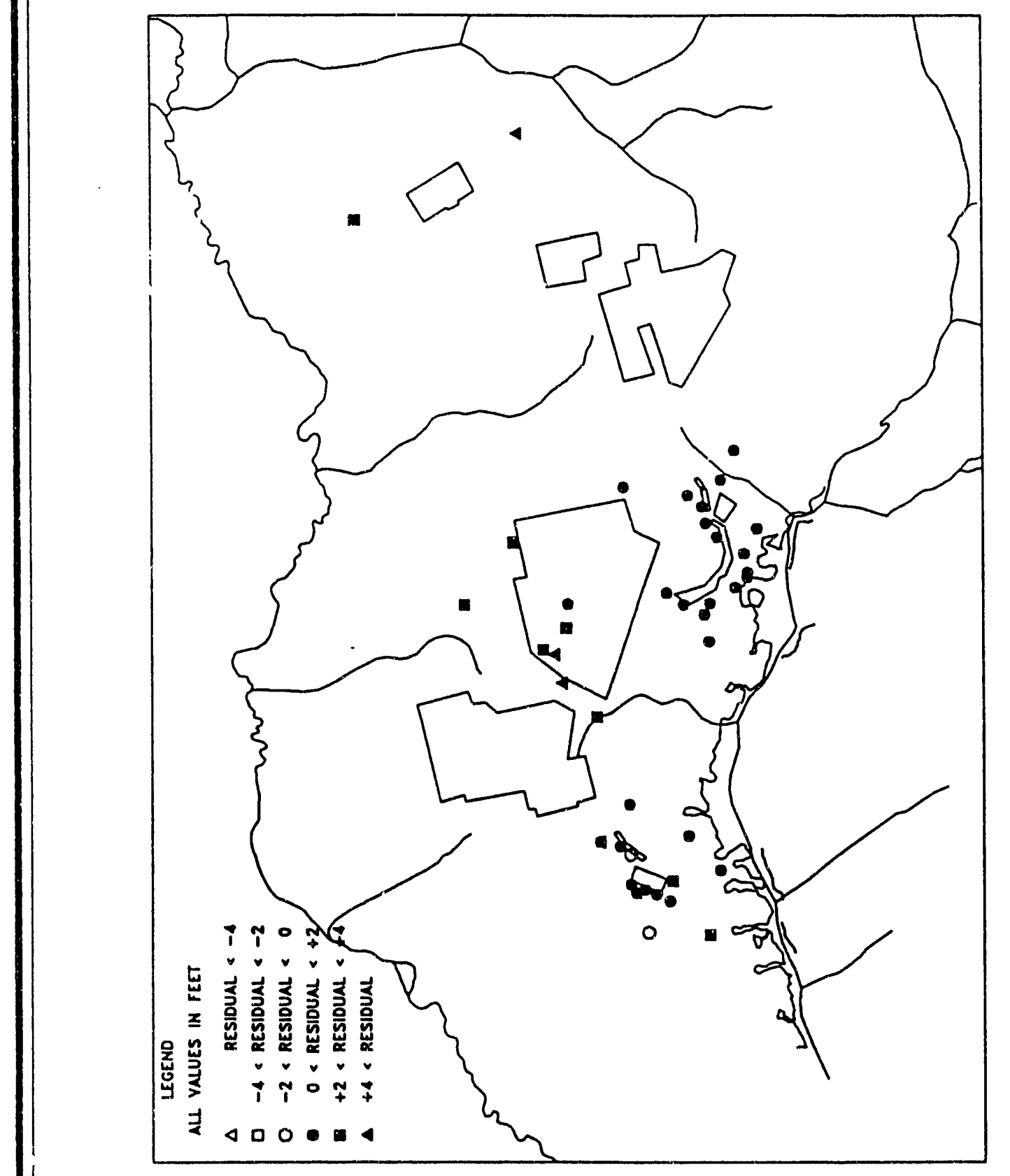

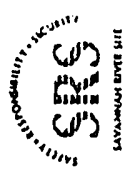

$\pm$

4

3

ริ

.

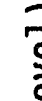

- ) 


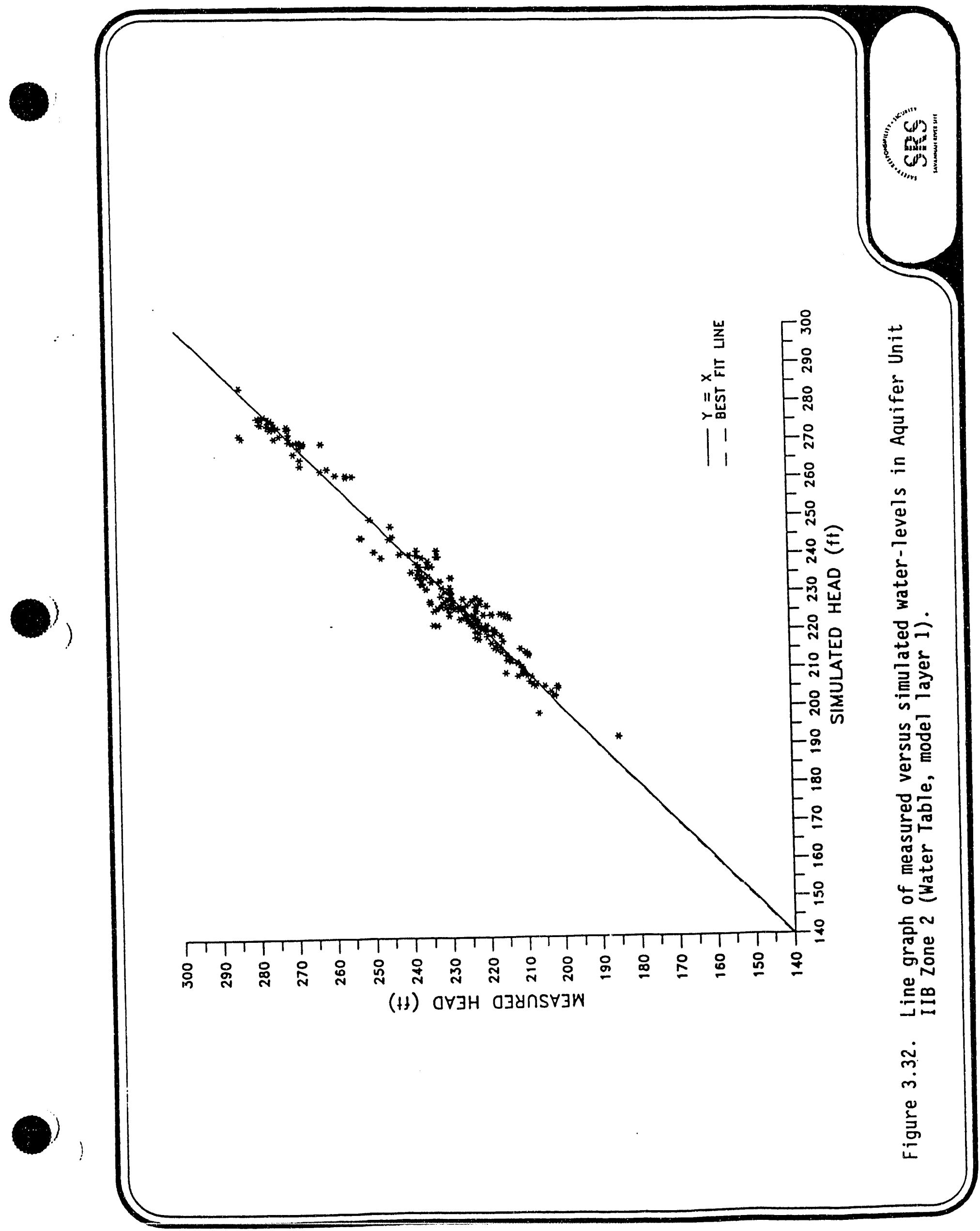




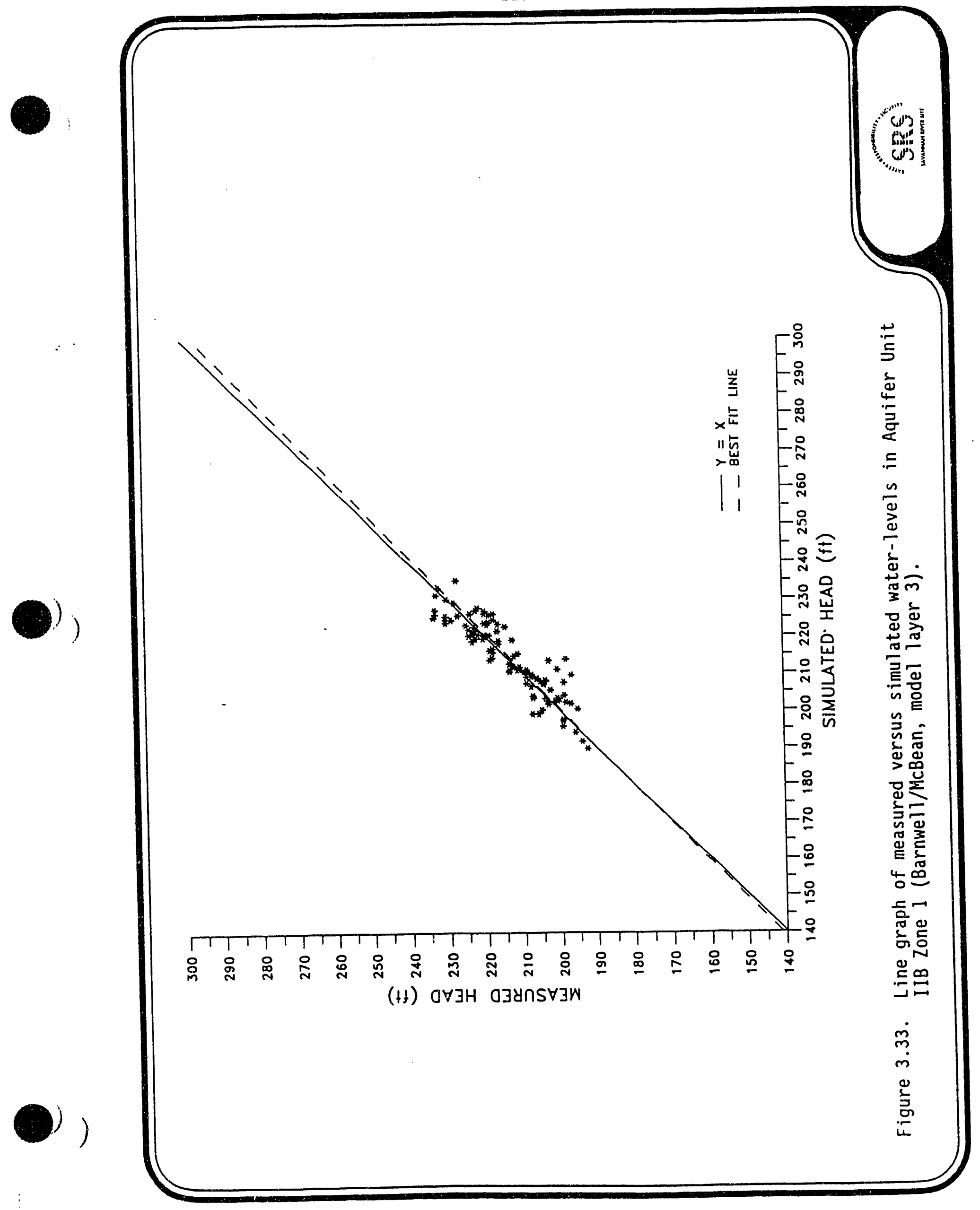




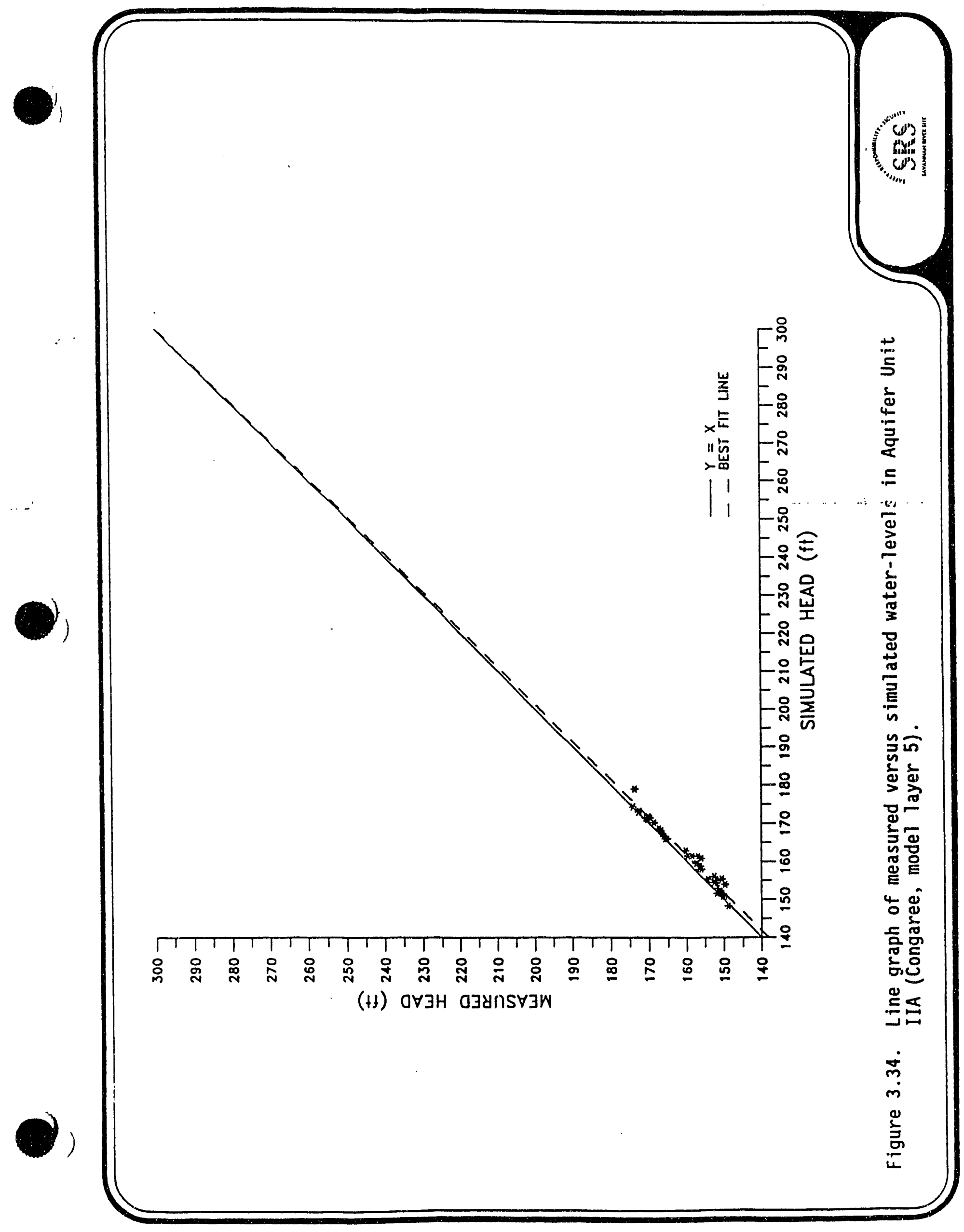


levels (indicated by the location and orientation of the best-fit line relative to the 45-degree line). Such a bias in the Congaree is insignificant with respect to the modeling objectives, because the bias (on the order of 1 foot) does not significantly affect either horizontal gradients within this layer or vertical gradients between this aquifer and the overlying aquifer (head differences between Aquifer Unit IIB Zone 1 (Barnwe11/McBean) and Aquifer Unit IIA (Congaree) are on the order of 40 to $60 \mathrm{ft}$ or more).

A histogram of residuals in all model layers is presented in Figure 3.35. Generally, a calibration is considered better if the histogram is randomly distributed and clustered around a residual of zero. The appropriate shape is indicated by this figure. The flattened shape of this curve results from the presence of many relatively high residuals, for reasons discussed previously.

A figure illustrating the layer-by-layer mass balance for the calibrated flow model is presented in Figure 3.36. Major model features indicated by this figure include:

- Recharge is applied to all three aquifers, according to the highest active model layer;

- Significant net downward flow exists throughout the entire GSA;

- Discharge to wetlands occurs from all three aquifers; and

- Streams are recharged from the aquifers, and almost never discharge water to the aquifers.

The significant downward gradients across the GSA, evident from the simulated water-levels and the layer-by-layer mass balance, are discussed in more detail in Chapter 4 of this report.

An analysis was performed to compare the simulated net discharge to Four Mile Branch between Stations 3 and 4 (see Figure 3.21) with measured values for net discharge (see Figure 2.9). This is the only pair of stations for which a meaningful comparison may be made, given the orientation of stations relative to the modeled area. 


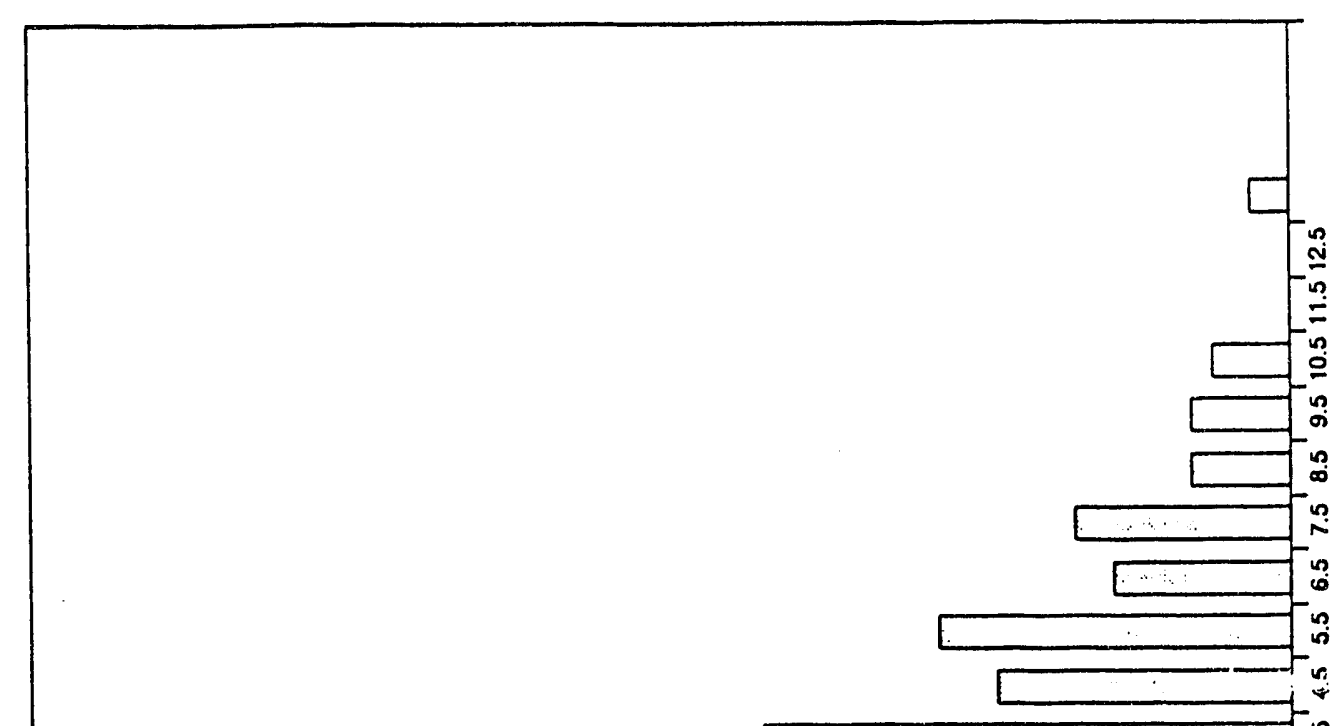

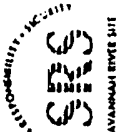

\%

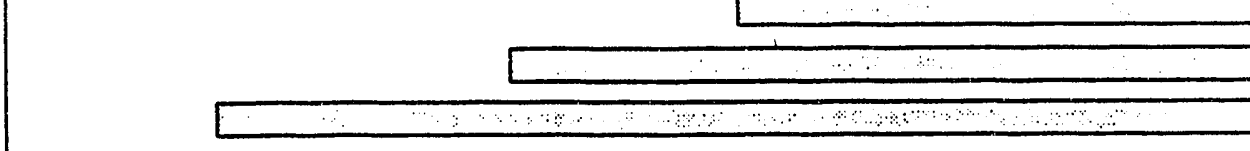

电

แ

국

$\$$

:

品

م

ऽ

岃

崩
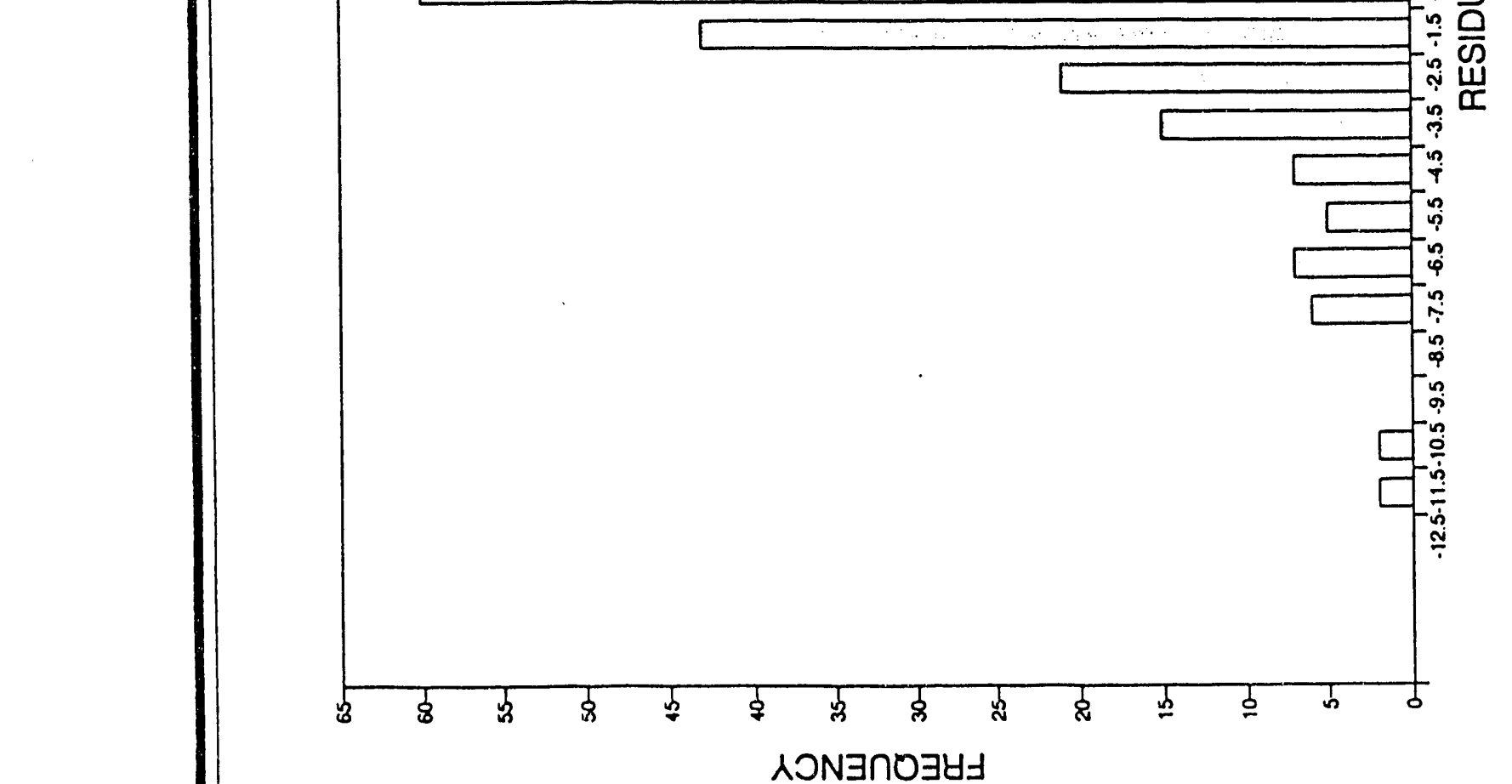

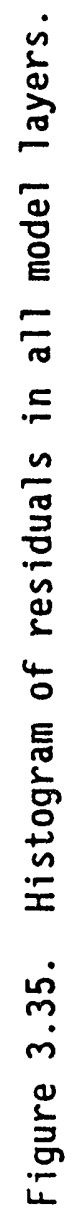




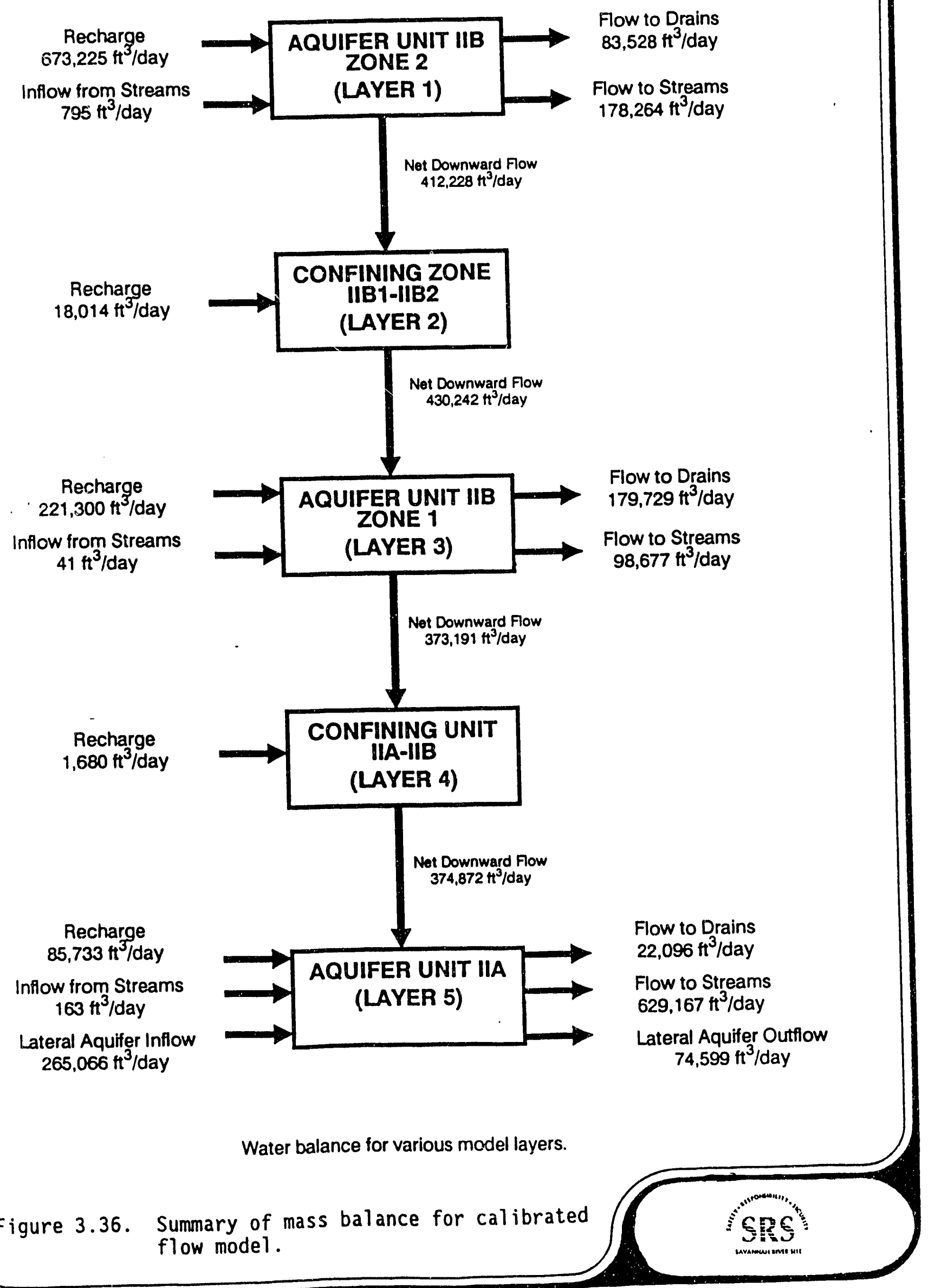


The model indicates approximately $0.1 \mathrm{cfs}$ is discharged along this reach via the river package, and another $0.1 \mathrm{cfs}$ is discharged to wetlands along that reach (and presumably discharges to the creek ultimately). This yields a total simulated net discharge of 0.2 cfs from the GSA along that reach.

Measured values of net discharge for this reach average approximately $1.0 \mathrm{cfs}$, and accounting for symmetry, approximately $0.5 \mathrm{cfs}$ should come from the GSA along this reach. However, Figure 2.1 indicates net discharge of $0.5 \mathrm{cfs}$ for some later periods of measurement, and the record does not include the model calibration period (second quarter, 1991). If this lower net discharge is more accurate for the model calibration period, and accounting for symmetry, only 0.25 cfs should come from the GSA along this reach. This is consistent with the $0.2 \mathrm{cfs}$ of net discharge predicted by the model.

Updated net discharge calculations will be necessary to determine how closely the model actually matches measured values, but in either case, given the limitations and assumptions of this calibration method, the simulation values are within an appropriate range.

\subsection{SENSITIVITY ANALYSIS}

The response of the flow model to variation in key hydraulic parameters was evaluated by performing a sensitivity analysis. Sensitivity analysis provides insight to the relative importance of parameters in governing flow conditions. It also may reveal those parameters for which uncertainty is an important issue. Model sensitivity is usually evaluated by noting model response for a systematic, independent variation within reasonable limits of key parameters.

Model sensitivity to horizontal hydraulic conductivities in Aquifer Unit IIB Zone 2 (Water Table), horizontal conductivities in Aquifer Unit IIB Zone 1 (Barnwel1/McBean), vertical hydraulic conductivities in Confining Zone IIB1-IIB2 (Tan Clay), vertical conductivities in Confining Unit IIA-IIB (Green Clay), and recharge was investigated using the FTWORK parameter estimation algorithm. Included in this analysis was a separate treatment of each of the horizontal and vertical conductivity zones delineated during the calibration phase. The model computed the resulting 
head distributions in each model layer for a 10 percent increase in each horizontal hydraulic conductivity zone, a 10 percent decrease in each vertical hydraulic conductivity zone, and a 10 percent increase in recharge. A 10 percent change was used in this analysis as this reasonably approximates the general level of uncertainty that exists in the horizontal hydraulic conductivity and recharge parameters. Greater than 10 percent uncertainty exists, however, for the vertical hydraulic conductivity values specified in the model. This increment of change was nonetheless used in vertical hydraulic conductivity perturbations for comparability among all sensitivity simulations.

The FTWORK parameter estimation option assumes that a linear response is produced by a given change in parameter value. For example, a 10 percent increase in a given parameter is assumed to produce a change in computed heads equal and opposite in sign to the model response resulting from a 10 percent decrease in the same parameter. The choice to increase recharge and horizontal hydraulic conductivities and decrease vertical hydraulic conductivities was made in accordance with the configuration of FTWORK to increase and decrease these respective parameters with in their defined ranges.

\subsubsection{Sensitivity to Horizontal Hydraulic Conductivity}

The analysis of model sensitivity to horizontal hydratic ic conductivity was limited to Aquifer Unit IIB Zone 2 (Water Table) and Aquifer Unit IIB Zone 1 (Barnwell/McBean). These units are represented in the model by layers 1 and 3 , respectively. With regard to this parameter, Layer 1 is defined as consisting of one zone that encompasses the entire

model area. Layer 3, however, is partitioned between two zones (see Figure 3.23). One zone is restricted to the general vicinity of the H-Area seepage basins, and the other zone includes the remainder of the model area.

The overall sensitivity of the model to the 10 percent increase in layer 1 horizontal hydraulic conductivity is primarily restricted to layer 1. The change produced a localized 3 foot decrease in hydraulic head in model layer 1 in the vicinity of $\mathrm{H}$-Area (Figure 3.37 ). 

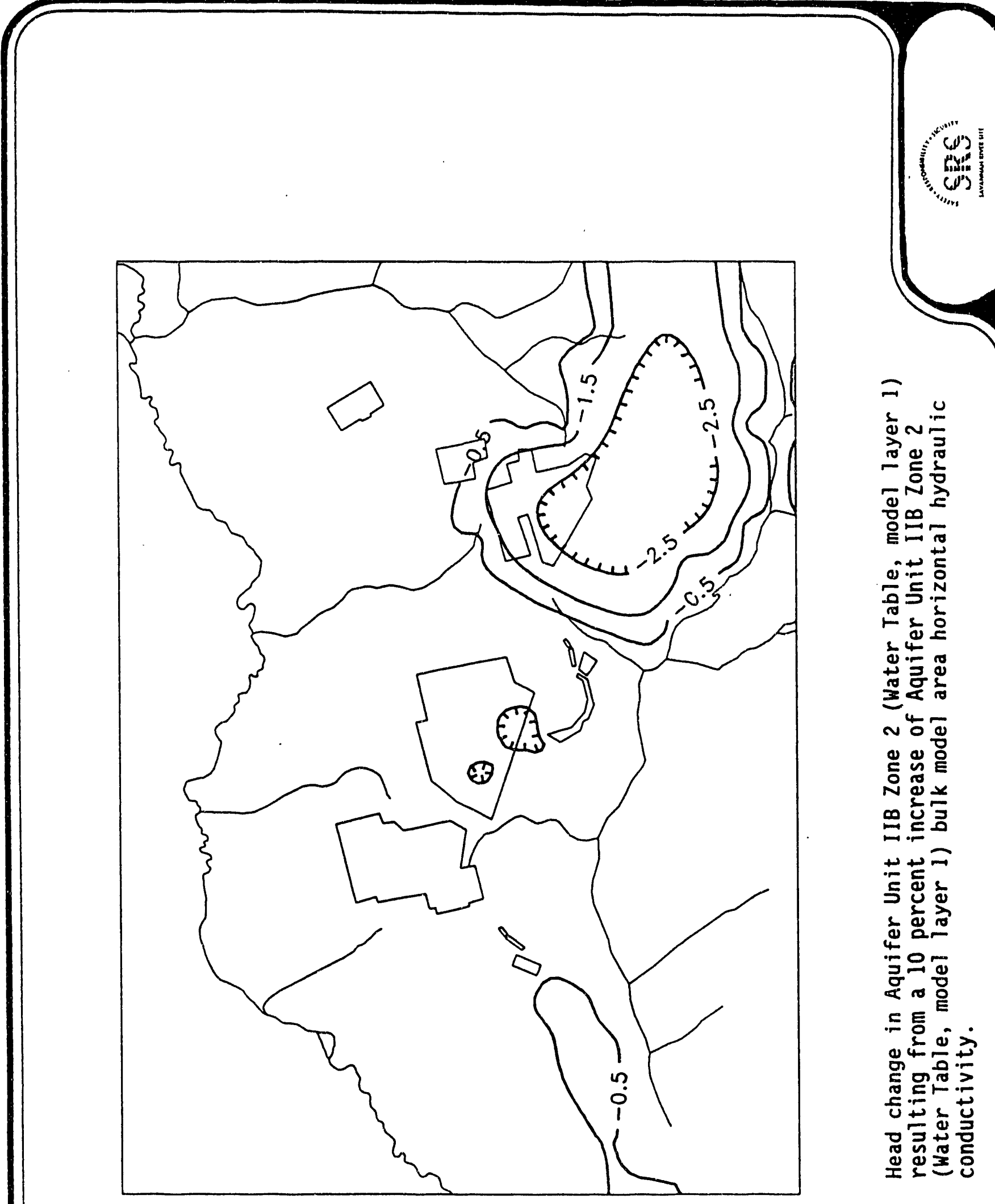

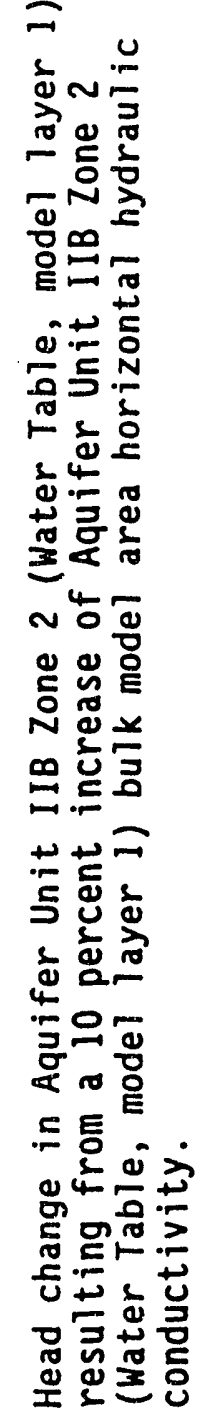

ตั 
The model exhibits significantly greater sensitivity to changes in layer 3 horizontal hydraulic conductivity. Head changes resulting from a 10 percent increase in the layer 3 horizontal hydraulic conductivity zone covering the majority of the model area are shown in Figures 3.38 and 3.39 for layers 1 and 3 , respectively. Widespread head declines of more than 1 $\mathrm{ft}$ in 1 ayer 1 and more than $1.5 \mathrm{ft}$ in layer 3 resulted. As expected, most of the declin? occurs in the central part of the model, furthest from the boundary condi.ions.

\subsubsection{Sensitivity to Vertical Hydraulic Conductivity}

Model sensitivity to the vertical hydraulic conductivity of Confining Zone IIBI-IIB2 (Tan Clay) and Confining Unit IIA-IIB (Green Clay) was investigated. These hydrostratigraphic units are represented in the model by layers 2 and 4 , respectively. Relative to layer 1 and 3 horizontal hydraulic conductivities, the model shows greater sensitivity to the vertical hydraulic conductivities of layers 2 and 4 .

Layer 2 vertical hydraulic conductivities are partitioned into 2 zones. One of the zones is defined in the eastern portion of the model, in the vicinity of H-Area (Figure 3.22). The second zone encompasses the remainder of the model area. A 10 percent decrease of vertical hydraulic conductivity in the zone representing the majority of the model area produced head increases of less then $0.5 \mathrm{ft}$ in layer 1 (Figure 3.40) and head declines in layer 3 of roughly the same order of magnitude (Figure 3.41). Note that the response in layer 3 is generally to lower heads, however there is an increase in head near Four Mile Branch. This results from increased restriction of flow toward the outlet point. The response of the model to a 10 percent decrease in vertical hydraulic conductivity in the eastern zone of layer 2 is generally restricted to the extent of this zone. Heads in layer 1 (Figure 3.42) increased by as much as $0.75 \mathrm{ft}$ in this area and a roughly equal head decline was observed in layer 3 (Figure 3.43 ). None of the analyses of the model sensitivity of layer 2 vertical hydraulic conductivity had significant impact on the computed heads for layer 5, which represents Aquifer Unit IIA (Congaree). 


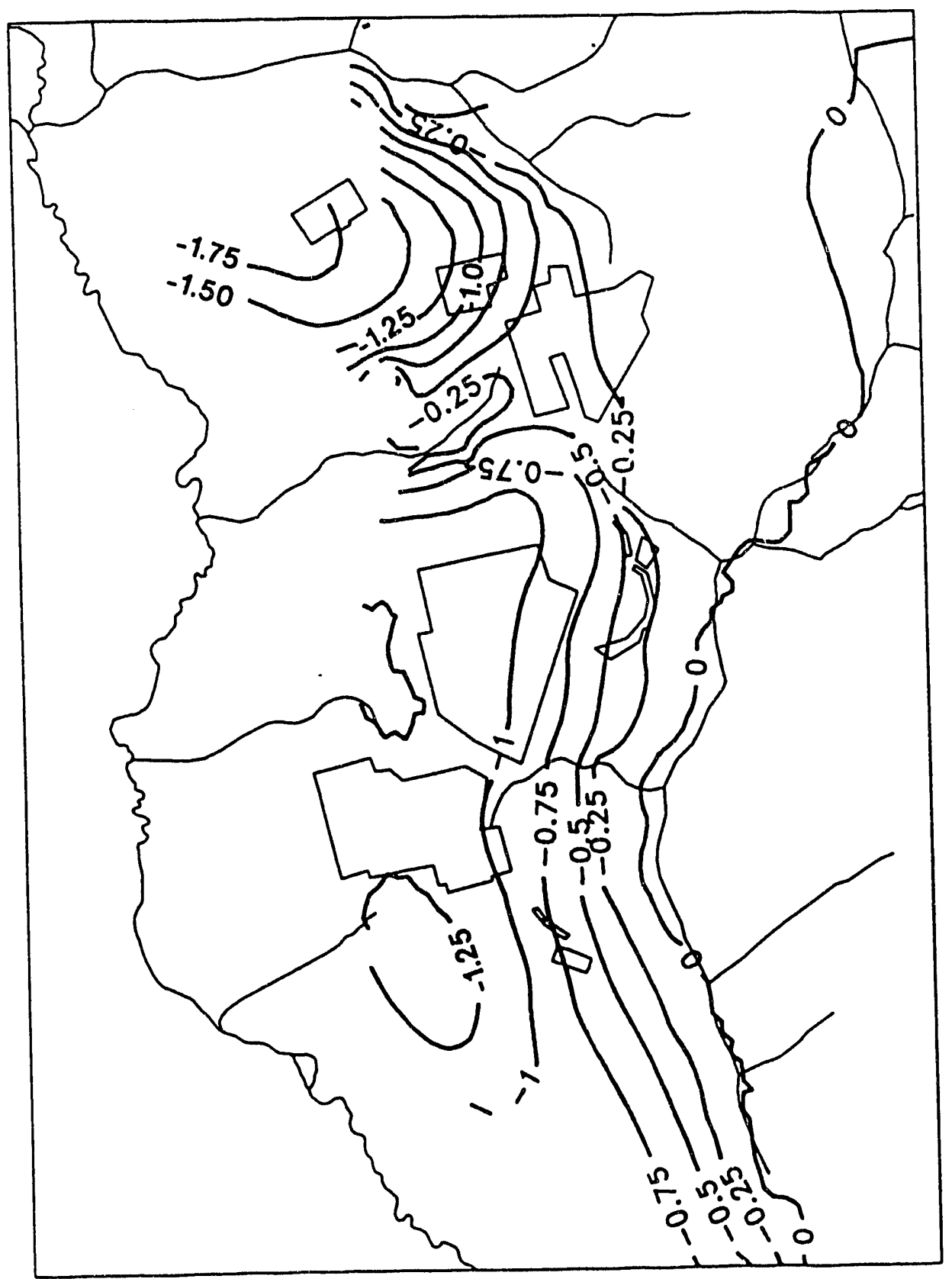

(1)

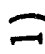

ธิ-

ฮั

豙

嗼莒

ㅁN

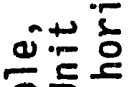

吾

๘

ธิ

풍

争

N4

Ф

ธิ

No

就

口.E

농

डิ

屯这客

4 을

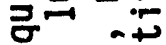

的 至

트응

व 4

g음

过些

可

웅

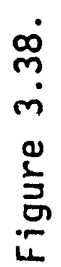



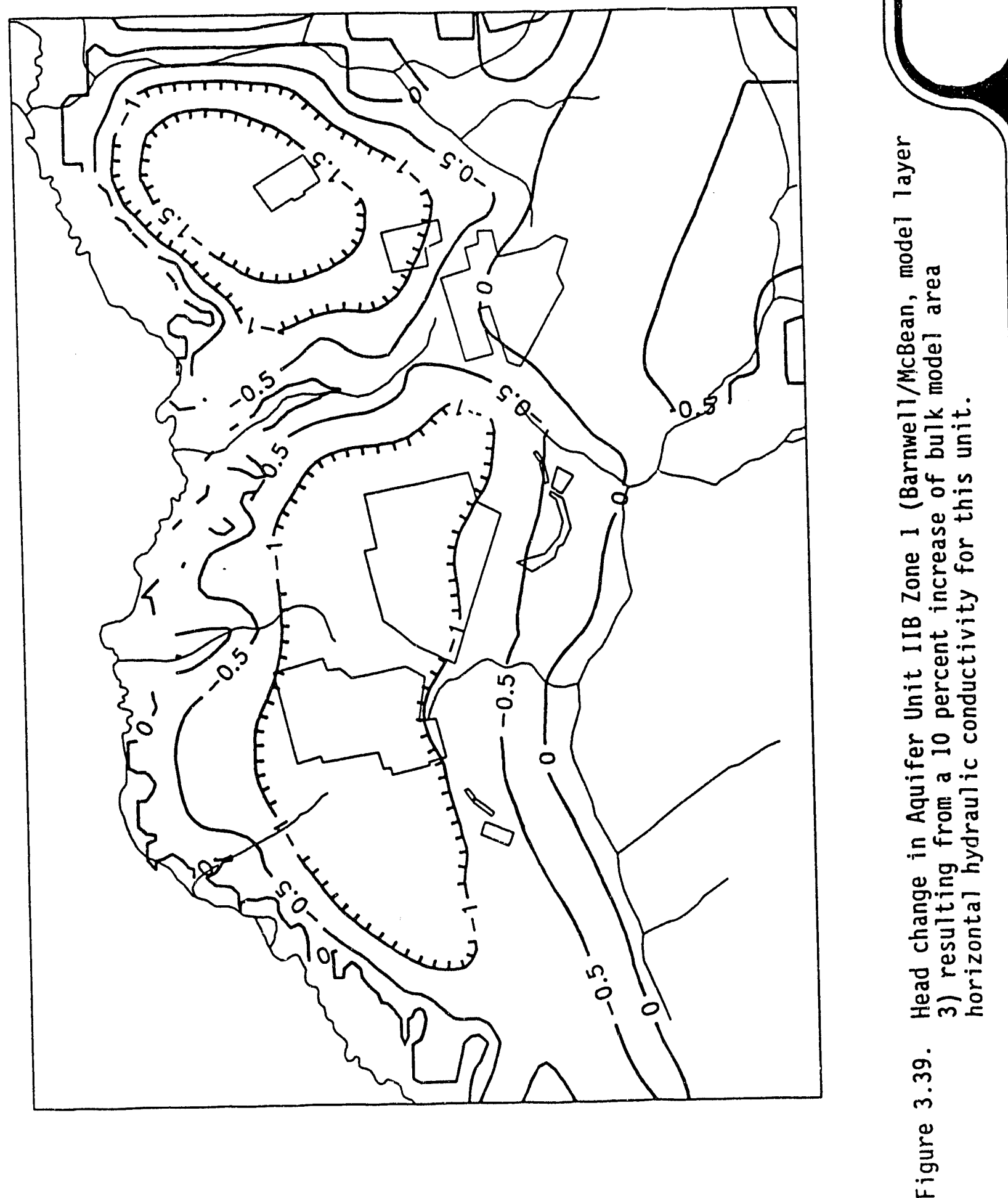


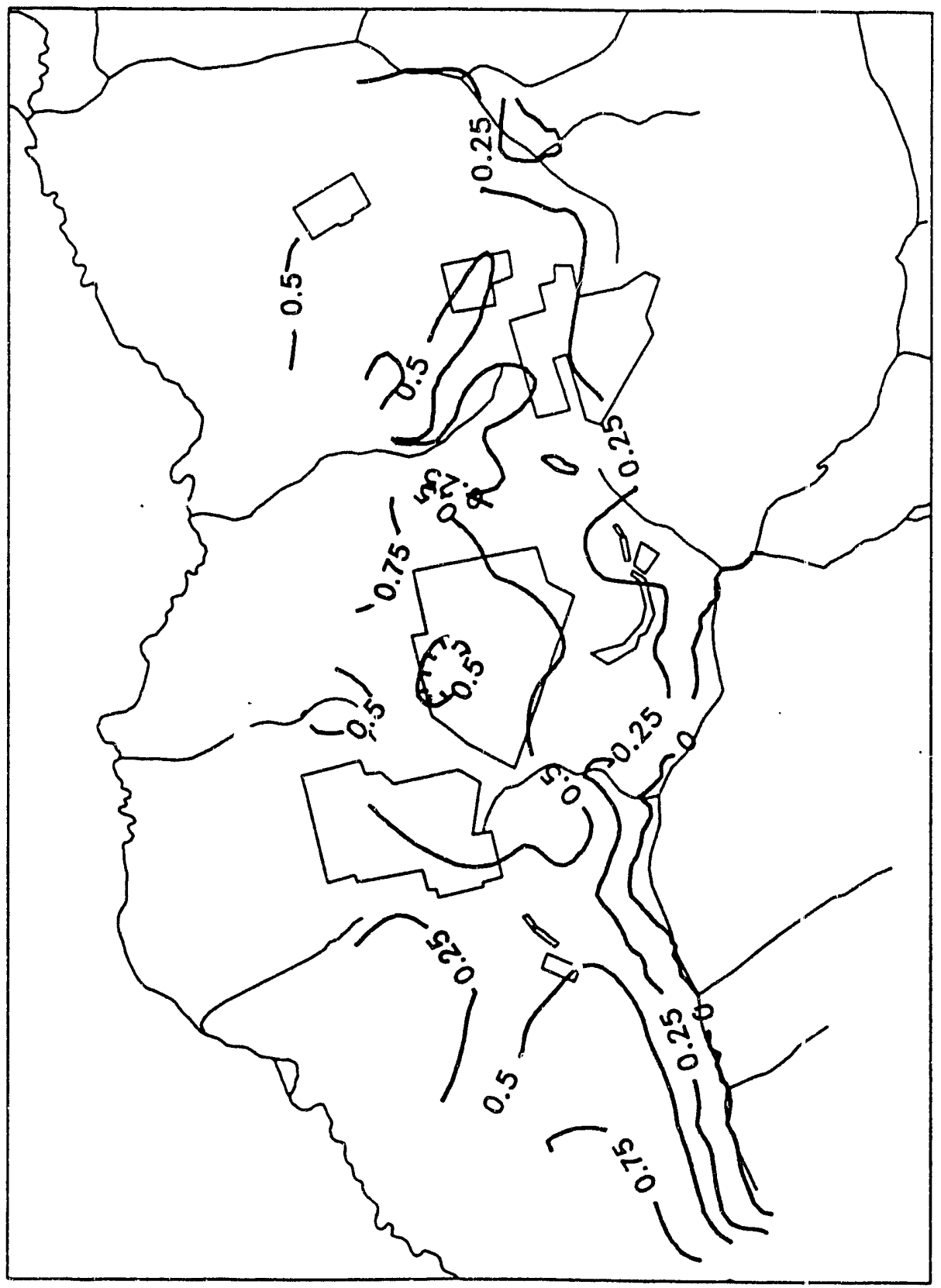

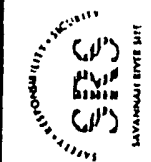

$\overline{1}$

कळ

무

- $\frac{1}{-\infty}$

ธ。ํํ

일 원

옹ㄹ

음 을

들.

$\leq .5+$

可䗆

ro

ت.

NO

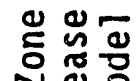

N

$\infty$ ป

四些

قد

ธิธี้

ธิ ฮे के

4

름으

$<0$

드틍응

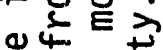

몽

든든

율동

똥ㅇㅇ

$\dot{8}$
$\dot{0}$
$\dot{\sigma}$
$\stackrel{\sigma}{5}$ 


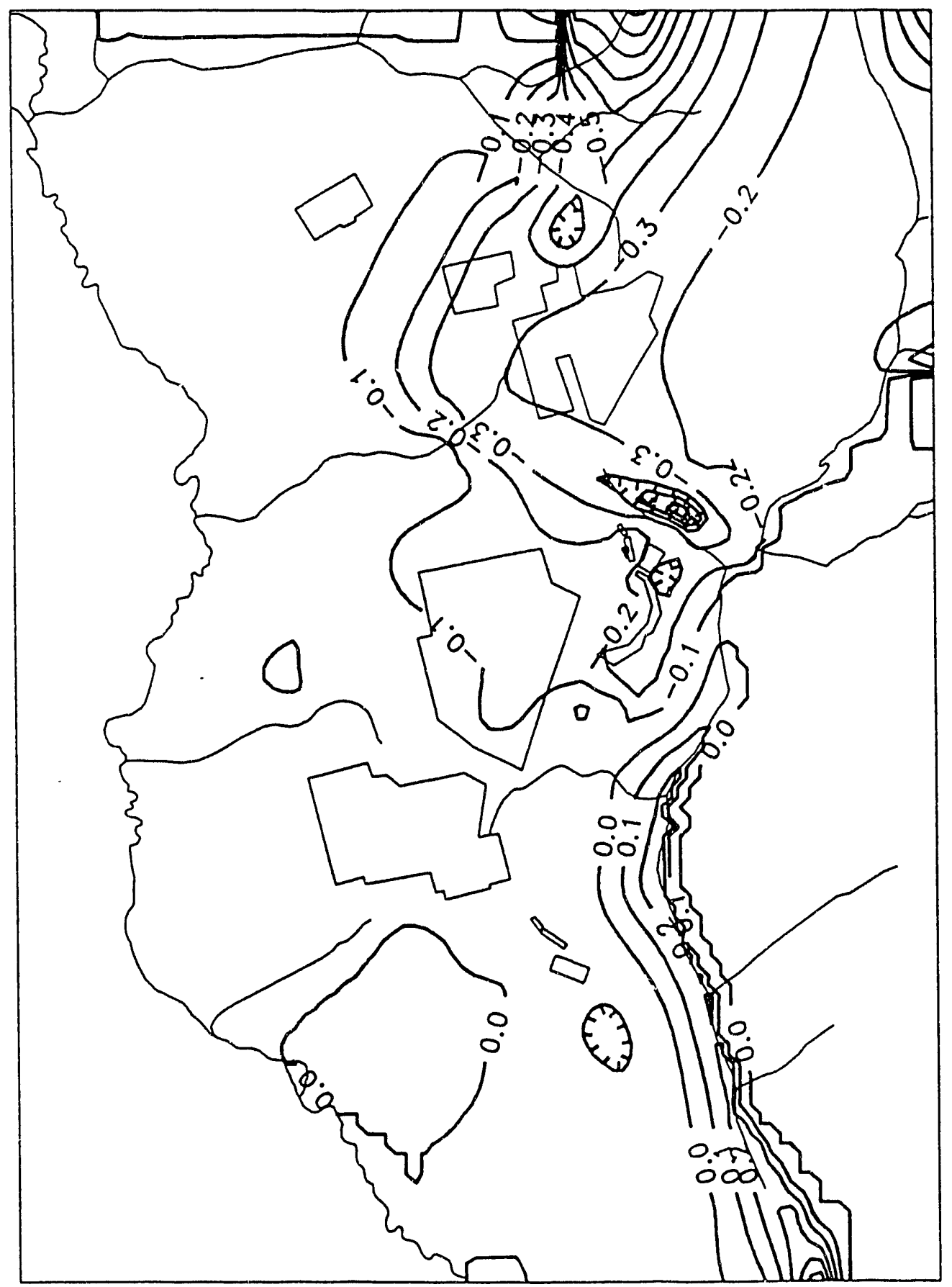

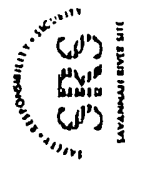

\ั๊

$-\frac{1}{\infty}$

응븐

E

동ํำ

岕

足忐正

프

인동

क्ष 4

造品

$-\stackrel{0}{\sim} \frac{1}{\pi}$

(1) ฮี

ธํㅇㄴ웡

웡을

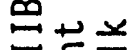

ق

동

넌으 닌

号宁

군 틍

$\therefore \leftarrow$ 잉

일을

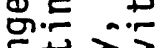

ह

它寻它

잉 동

㧘我

J 


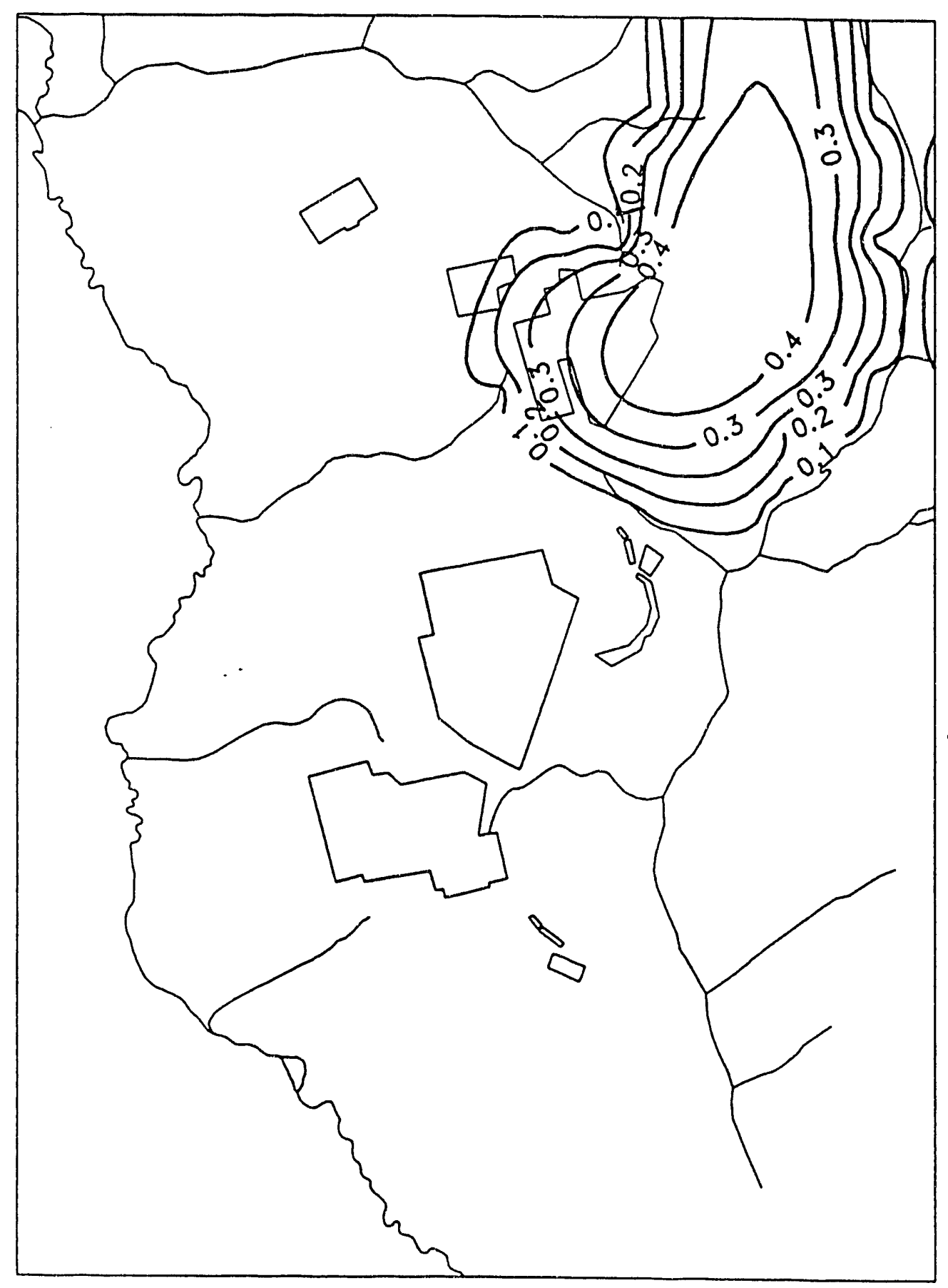

I

\ัญ

몯

曲点

응뻬

을 은

웅

음

등

어

के

눙

王宁

ㄴํㅇ ?

ט

的

只西。

넌

舟元

四它

ث\$

동 ్ㅜ을

ธ。ิ

屯ั ฮす

응

쿤은

叮

드응ㅇㅇㅇ

난든

它

동무음

든 든

호웜

生上品

范 


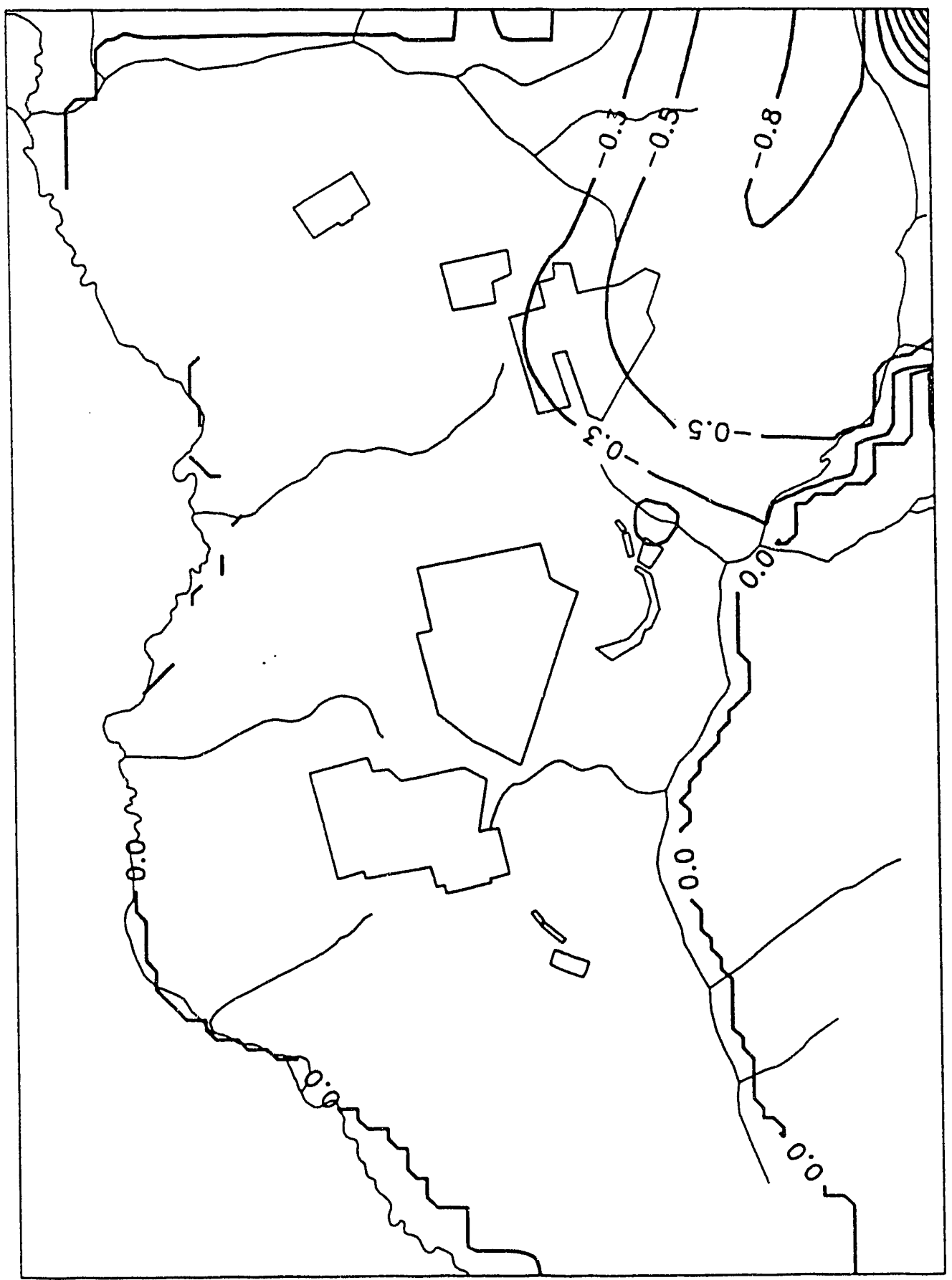

\ั)

붐물

홍

흠두

히

ํํำ

ชำ

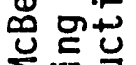

立正要

푼

唫

叫告

00

一咢

율

은

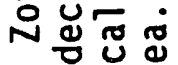

$\infty$ 인

四奆总。

닌

ㅎํㅇㅇㅇㅎํ

4

可西4

하응잉

ㄷㄴㄴ웡웡

䶸虽

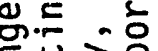

芯市市

돈

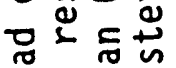

的上要

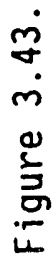


Three zones represent the vertical hydraulic conductivity distribution in model layer 4. The first zone begins in the vicinity of $F$ Area and extends to the western boundary of the model (Figure 3.24). Located in the central portion of the model area, the second zone begins in the vicinity of MWMF and extends to the northern model boundary. The remaining portions of these layers are encompassed in the third zone, covering the south-central and western portion of the model area.

The model exhibited significant sensitivity to all of the layer 4 zones. Without exception, reducing the vertical hydraulic conductivity of this layer produced increases in the heads of layers 1 and 3 . Additionally, these impacts were generally confined to the respective areas where the zones are defined. A 10 percent decrease of the vertical hydraulic conductivity in the western zone produced a head increases in excess of $1.75 \mathrm{ft}$ in layer 1 (Figure 3.44) and an increase in excess of $1.80 \mathrm{ft}$ in layer 3 (Figure 3.45). For the zone defined in the northcentral portion of the model area, a 10 percent decrease of the vertical hydraulic conductivity produced a head increase of more than $1.25 \mathrm{ft}$ in layer 1 (Figure 3.46) and roughly equal in layer 3 (Figure 3.47). In the vicinity of the south-central eastern zone, the 10 percent decrease in vertical hydraulic conductivity resulted in roughly equivalent head declines ranging up to roughly $1.5 \mathrm{ft}$ in both layer 1 (Figure 3.48 ) and 3 (Figure 3.49).

Reductions in the vertical conductivity of Confining Unit IIA-IIB at all locations in the model area produced negligible changes in the computed heads of Aquifer Unit IIA (Congaree).

\subsubsection{Sensitivity to Recharge}

Model sensitivity to recharge was investigated by increasing recharge uniformly by 10 percent and evaluating the resulting head changes in the model layers 1, 3, and 5 which represent Aquifer Unit IIA Zone 2 (Water Table), Aquifer Unit IIB Zone 1 (Barnwell/McBean), and Aquifer Unit IIA (Congaree), respective?y. Recharge is assigned to the uppermost active cell in a vertical projection over the entire model domain. The 10 percent increase in recharge produced layer 1 and layer 3 head increases up to 4 $\mathrm{ft}$. The maximum head increase in layer 5 , however, was only $0.1 \mathrm{ft}$. 


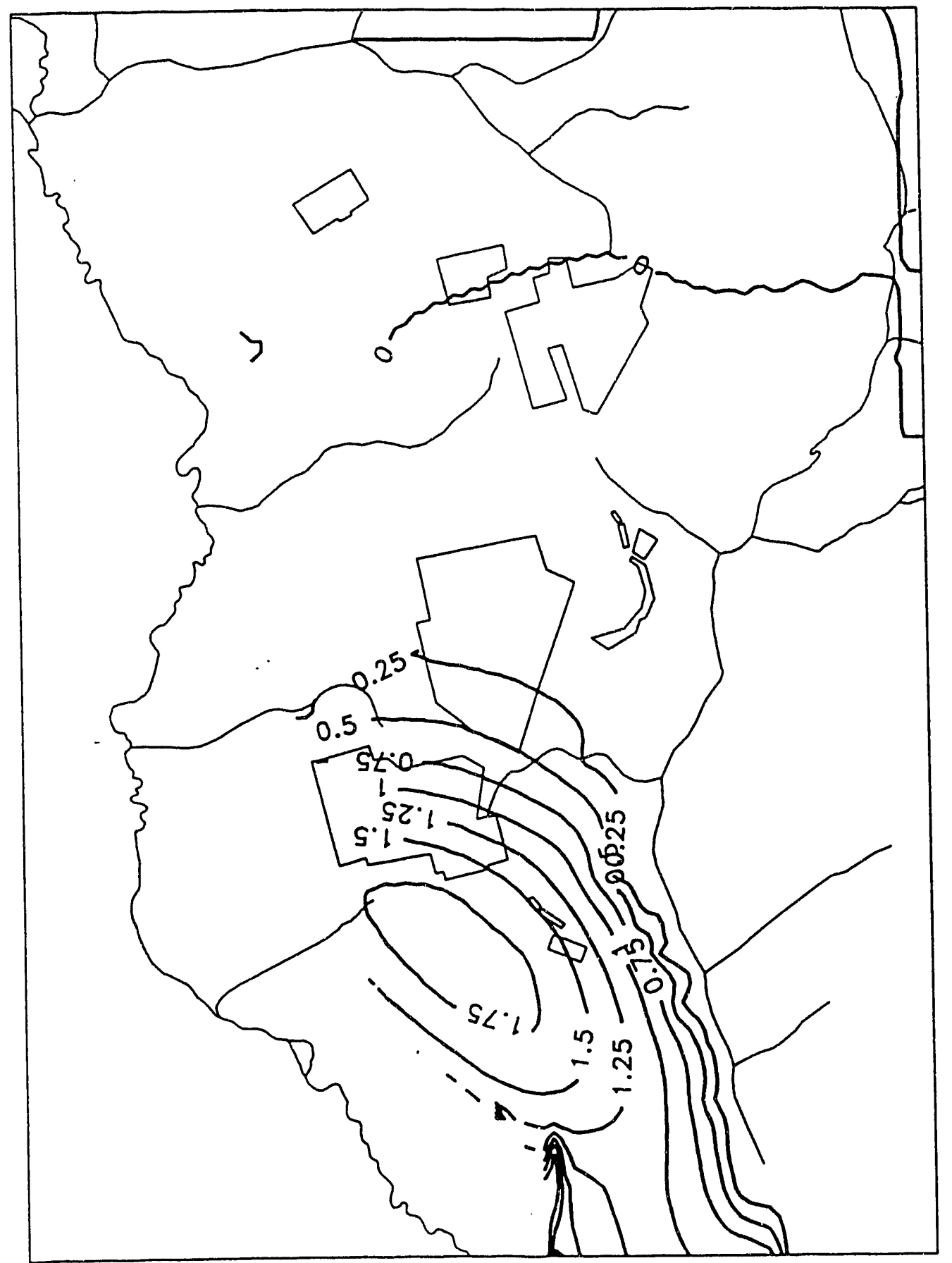

I خัง 듬 㕸立 묠 EN 동흥 훙모 드

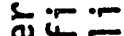
눙등 궁 넌 능

步

ธิ์ N正

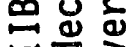
망

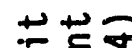
돈원

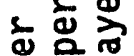

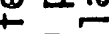
뭉워

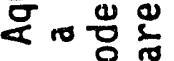
ᄃ EE E क 난 बัँे 믈 든 ง๋ 웡

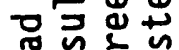
吕 ⿺辶寸

过 


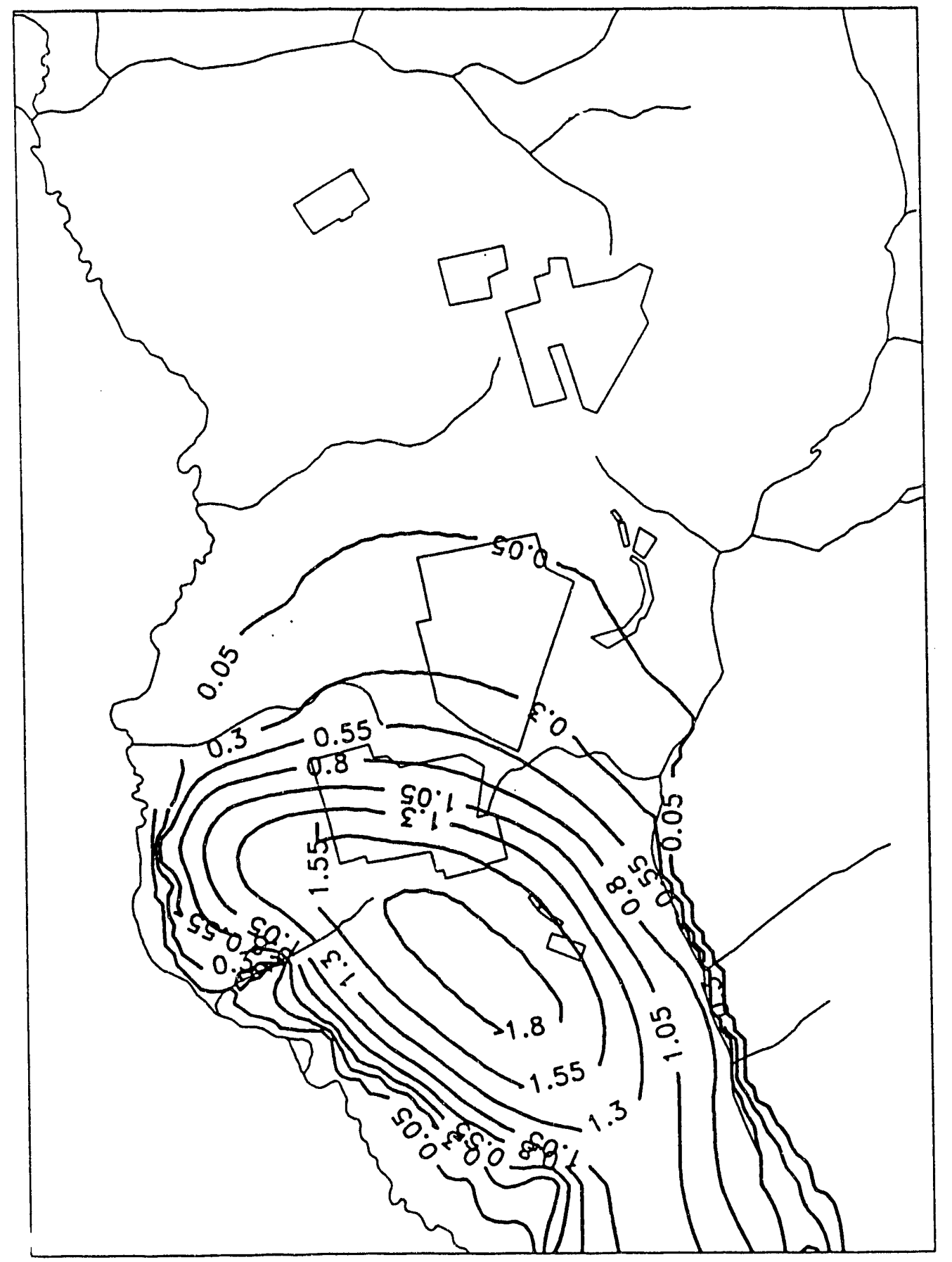

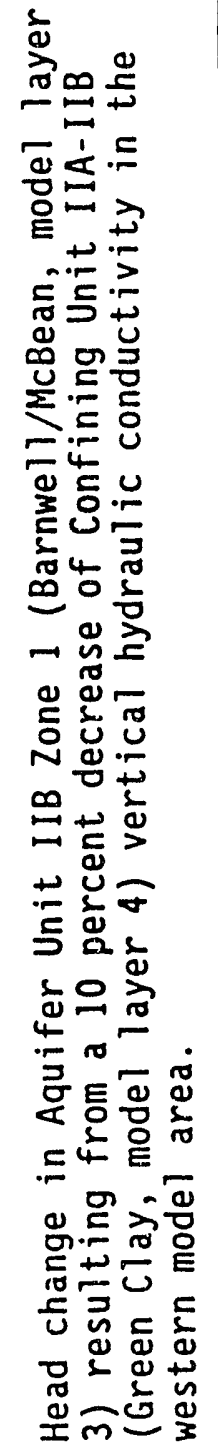

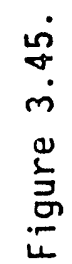




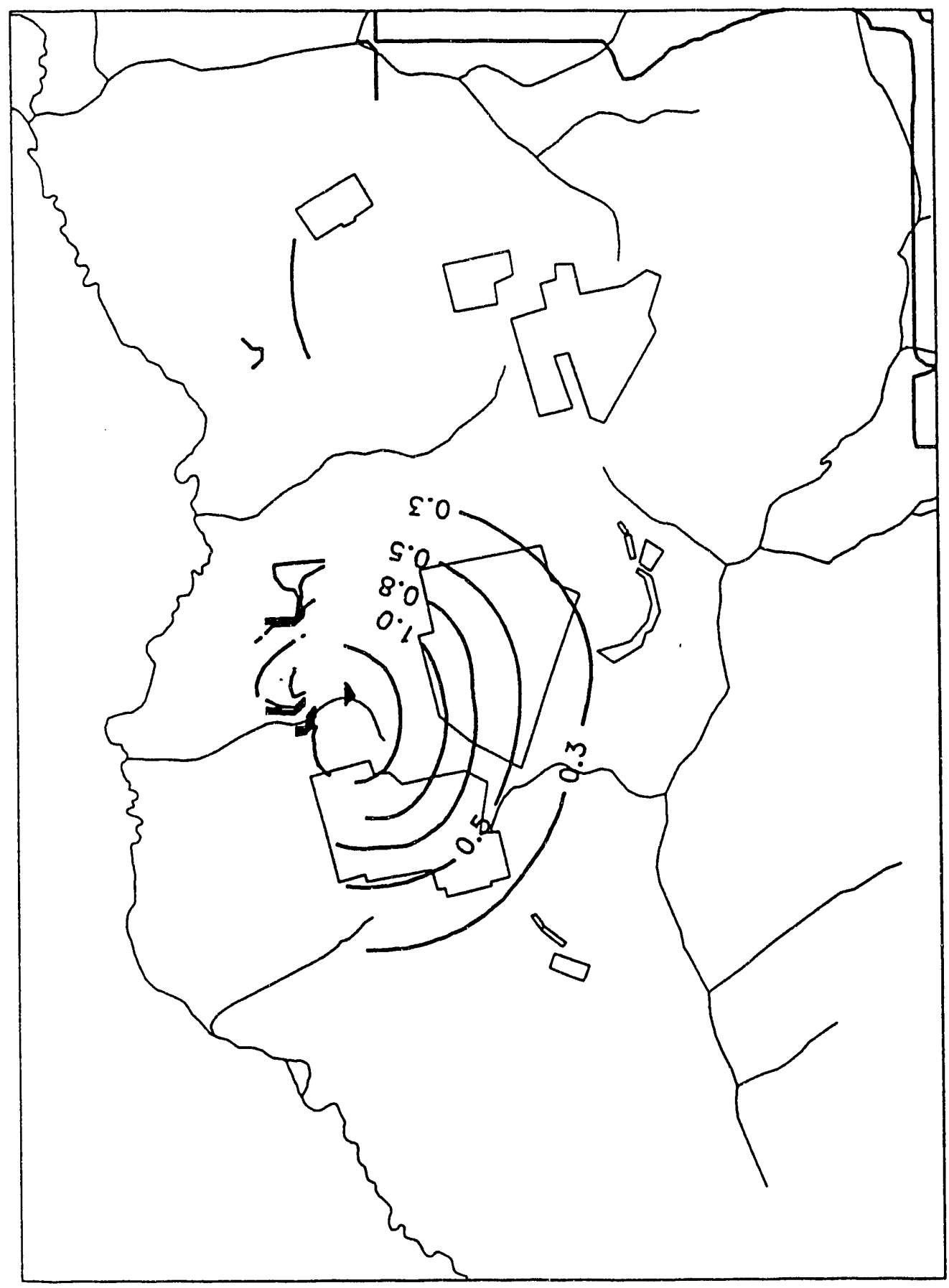

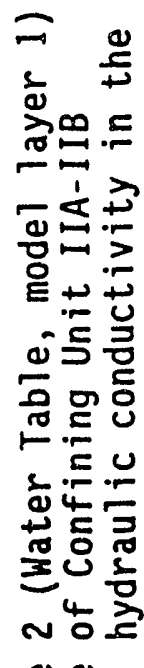

过 崩

N.-

ص就交

녕

동 웡

ธ ฮे ญ

4 西

군웜

的告员

드응

ข

믿ㅎㄷ

员.

它声的

㖊寻文

온히응

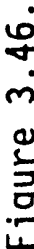




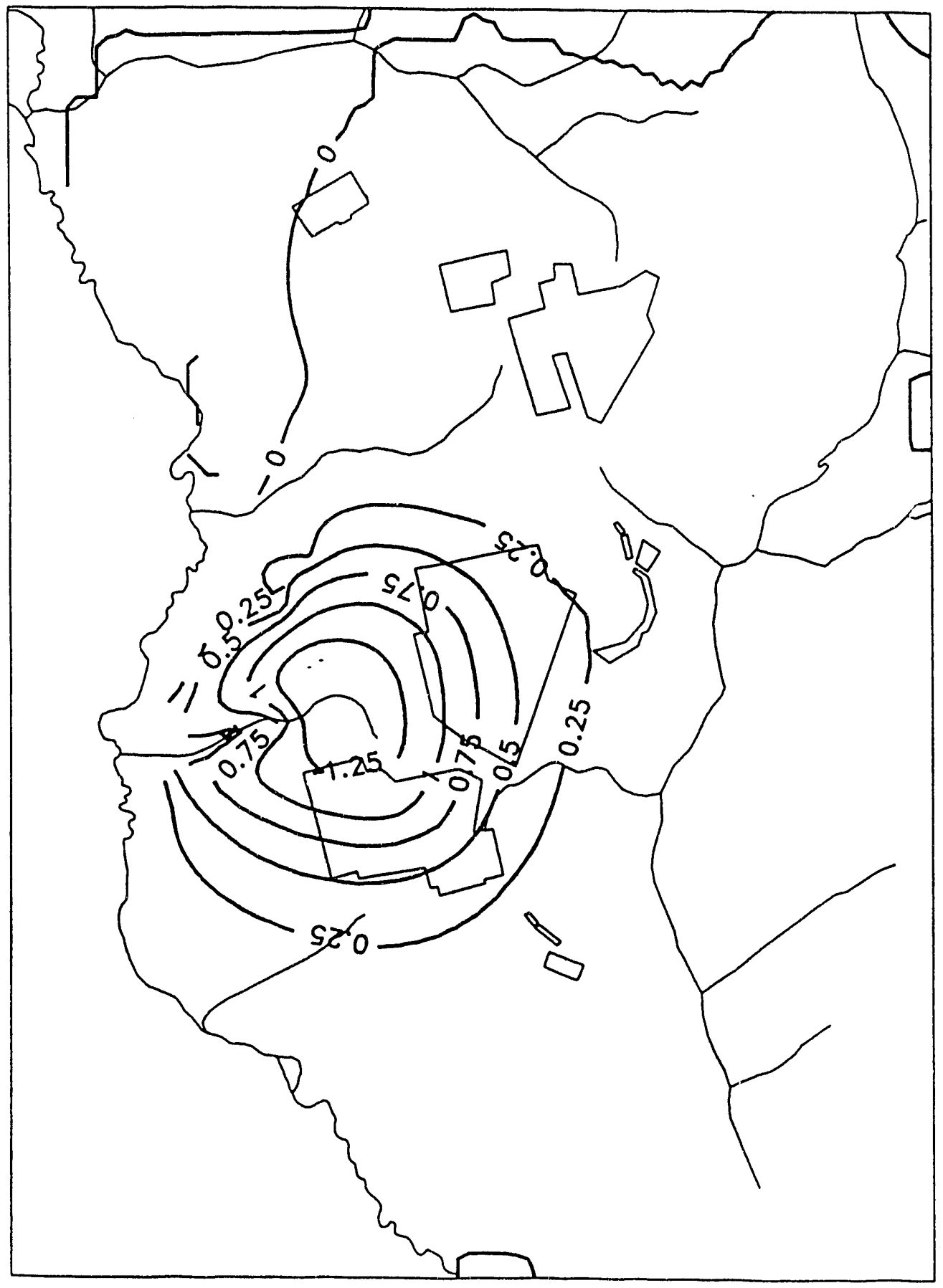

(1)

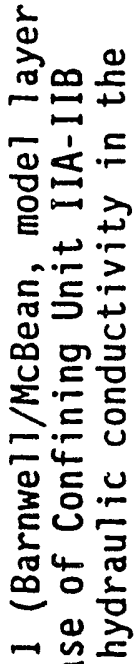

๑

ธิ㇒兀

Nบ엄

$\infty$

击节

넌

동

与ั

흐음

4

훙ㅎㅇㅇㅎㅇ

인응 을

印关

西

ब․ ㅎํ

픈도

군

원

品克

xm응

نे 


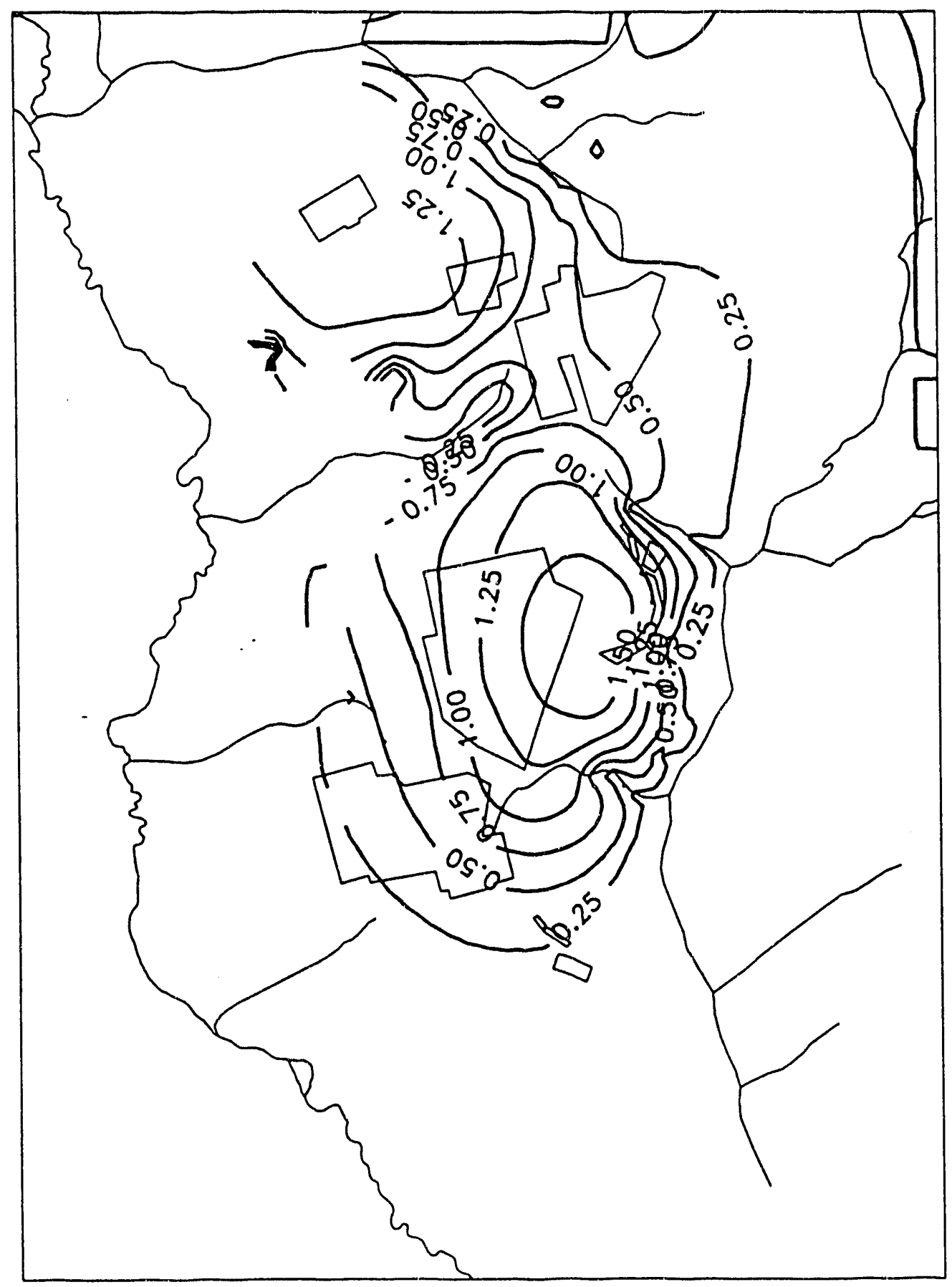

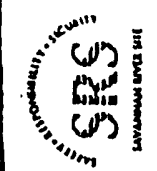

ప

굠드.

-

믄

E

독ํํำ

동ㅇํㅇ

คE

\&

등

ㄴํㄴ

능

幽

엉

效范

元す

芯层

与 원

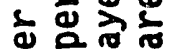

$40-$

군

ᄃ

$\therefore$ 인

品 市

일 원

ฮ.

U士口

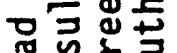

똔븡

年 


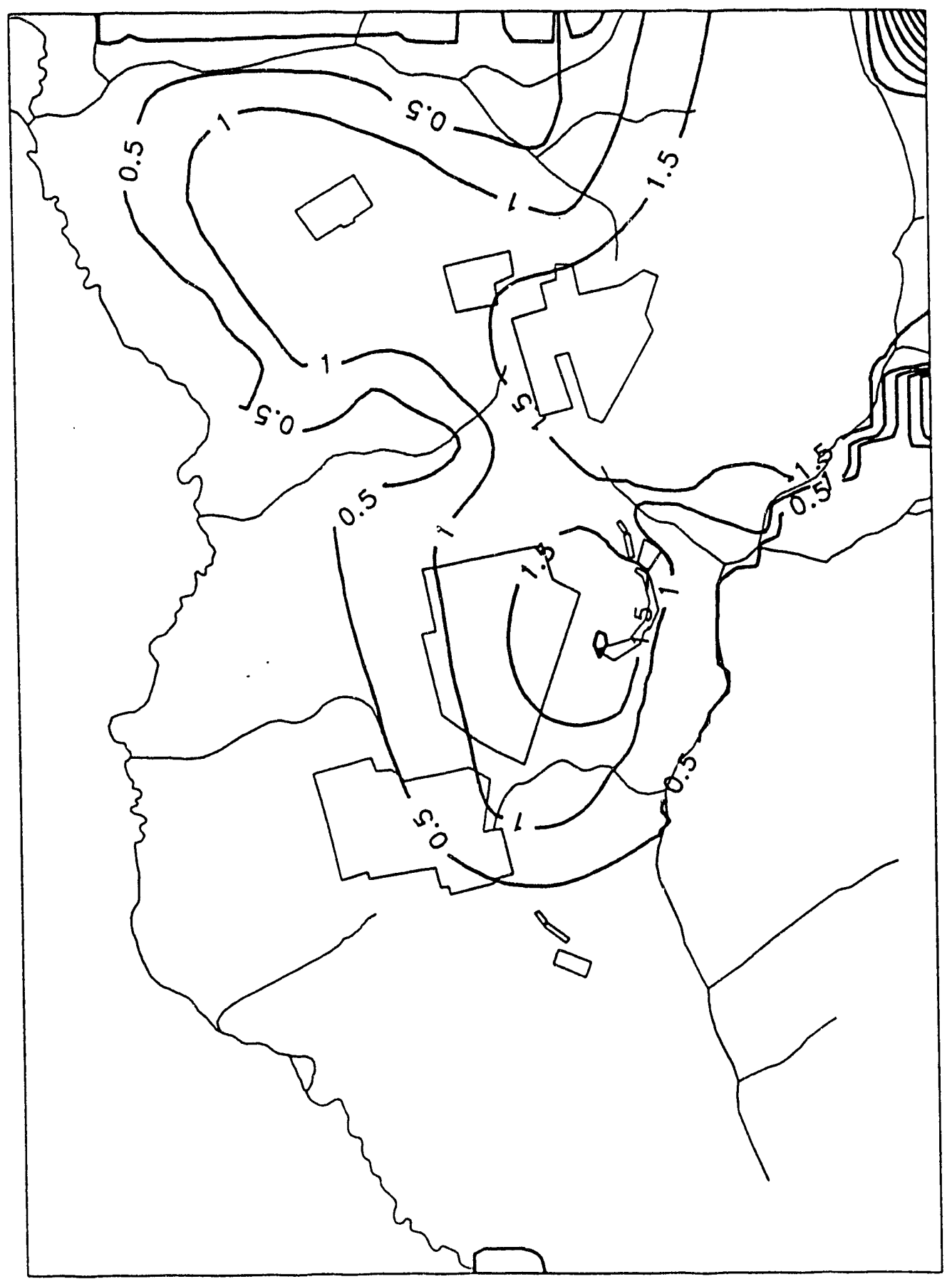

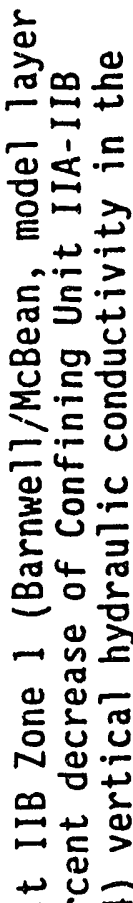

比

与ั

㐫음 希市

흐웧

중형ㅎㅁ임

二驼晨

용

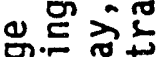

跣它

领

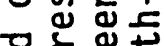

品它

壬的宪

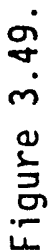




\subsubsection{Sensitivity Analysis Conclusions}

The principal conclusions of the sensitivity analysis are as follows:

- Given a similar percentage change in parameter value, the model exhibits comparatively gre . :er sensitivity to recharge than to vertical hydraulic conductivity and horizontal hydraulic conductivity. Similarly, heads are more sensitive to vertical hydraulic conductivity than to horizontal hydraulic conductivity for an equal percentage change.

- Because the model is fairly sensitive to a ten-percent change in vertical hydraulic conductivity of the aquitards, it is likely that a change that is more consistent with the level of uncertainty and heterogeneity of this parameter will produce large changes in hydraulic heads. This underscores the importance of accurate quantification of vertical hydraulic conductivity and its spatial variation.

- Variations of 10 percent in the vertical hydraulic conductivity of Confining Unit IIA-IIB (Green Clay) exert greater control on computed heads than similar percentage variations of the vertical hydraulic conductivity of Confining Zone IIBI-IIB2 (Tan Clay).

- Changes in the vertical hydraulic conductivity of layer 2, which represents Confining Zone IIB1-IIB2 (Tan C1ay), affect heads in the over- and underlying model layers inversely. For example, a decrease in this parameter produces an increase in layer 1 heads and a decrease in layer 3 heads.

- Localized changes in parameters generally produce changes in head in the same locality. This observation emphasizes the importance of localized heterogeneity in producing head distributions.

- Changes in the vertical hydraulic conductivity of layer 4, which represents Confining Unit IIA-IIB (Green Clay), affects heads in the over- and underlying model layers in the same sense. A decrease in this parameter, for example, results in increases in heads in layers 1 and 3 .

- Aquifer Unit IIA is relatively insensitive to changes in the selected parameters investigated.

\subsection{CODE MODIFICATIONS}

A modification to the FTWORK code was made to insure that, when a confining bed becomes desaturated, the unit above it also becomes desaturated and is converted to an inactive cell. This modification 


\section{1}

prevents errant buildup of water from recharge above the now-inactive confining layer. This code change was made because problems of this type were encountered in desaturated areas, near the creeks, during the initial simulations. 
4 DESCRIPTION OF FLOW NEAR THE MIXED WASTE MANAGEMENT FACILITY

The next phase of this study will involve simulation of transport of contaminants introduced to the groundwater system from the MWMF. As a precursor to that phase of the study, this chapter focuses on details of the simulated flow system near the MWMF, and describes a preliminary transport analysis in the form of particle-tracking.

\subsection{SIMULATED FLOW DIRECTIONS}

Transport of dissolved contaminants is potentially affected by groundwater flow in both the horizontal and vertical directions. The simulated equipotential surfaces in the vicinity of the MWMF provide insight into the eventual fate of contaminants introduced in that area.

Simulated equipotentials for model layers 1,3 and 5 in the vicinity of the MWMF are presented in Figures 4.1 to 4.3. These figures indicate the presence of a flow divide across the MWMF in model layers 1 and 3 . Without the influence of vertical flow, contaminants would ultimately discharge either to Upper Three Runs Creek or Four Mile Branch, depending on the where they were introduced to the groundwater system relative to the groundwater divide.

Inspection of the equipotential surfaces indicates significant potential for downward flow across confining units in the vicinity of the MWMF. There is approximately 6 to $8 \mathrm{ft}$ of downward head difference between model layers 1 and 3 directly below the MWMF, and approximately $65 \mathrm{ft}$ of downward head difference between model layers 3 and 5 in the same area.

Simulated flow directions in the model layer 5 are towards Upper Three Runs Creek. If contaminants are transported downward to this layer from the overlying aquifers, and are then transported horizontally in the direction of groundwater flow, the ultimate discharge points will be along Upper Three Runs Creek (the model assumes that vertical flow between the Congaree and underlying units is relatively insignificant). 


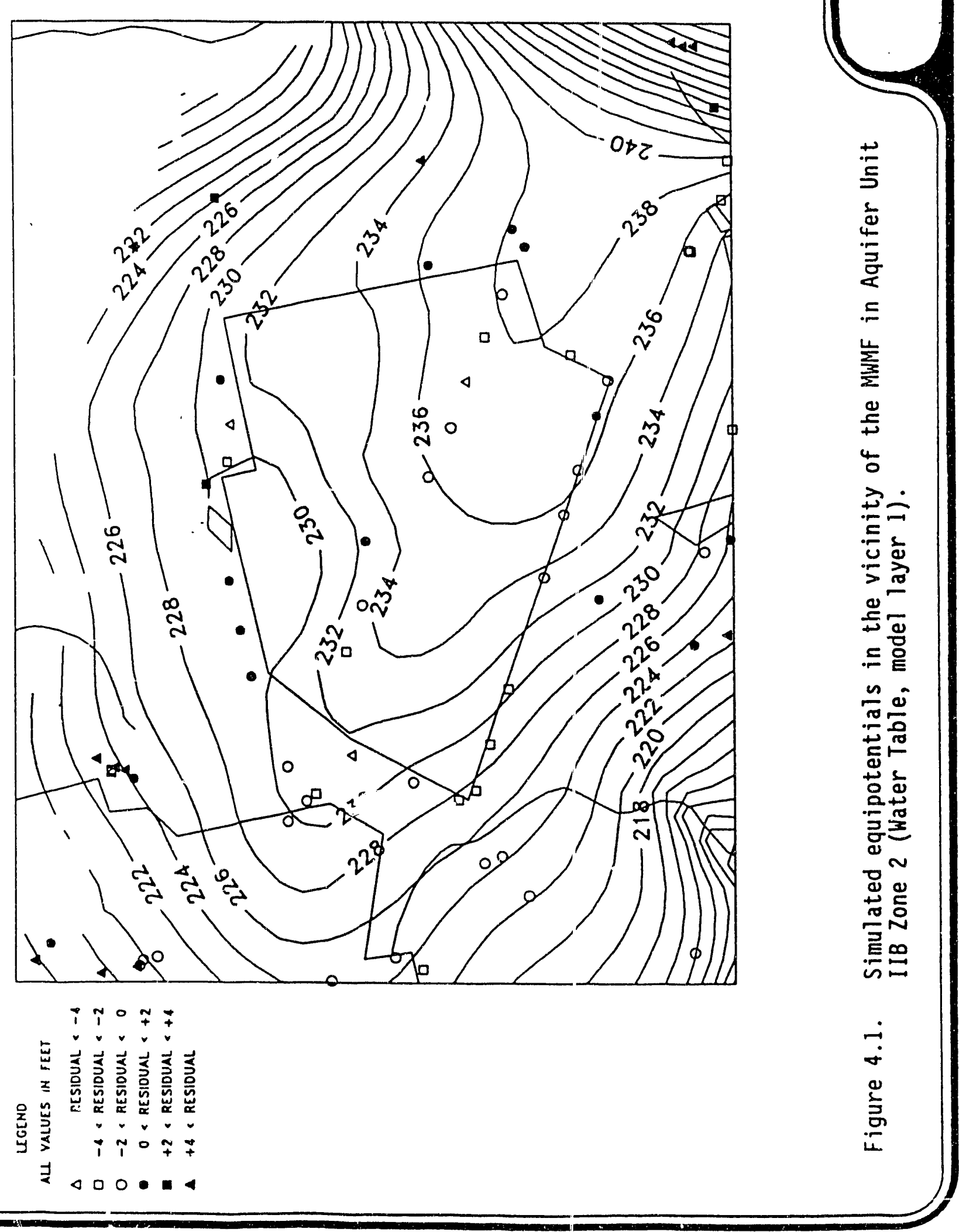




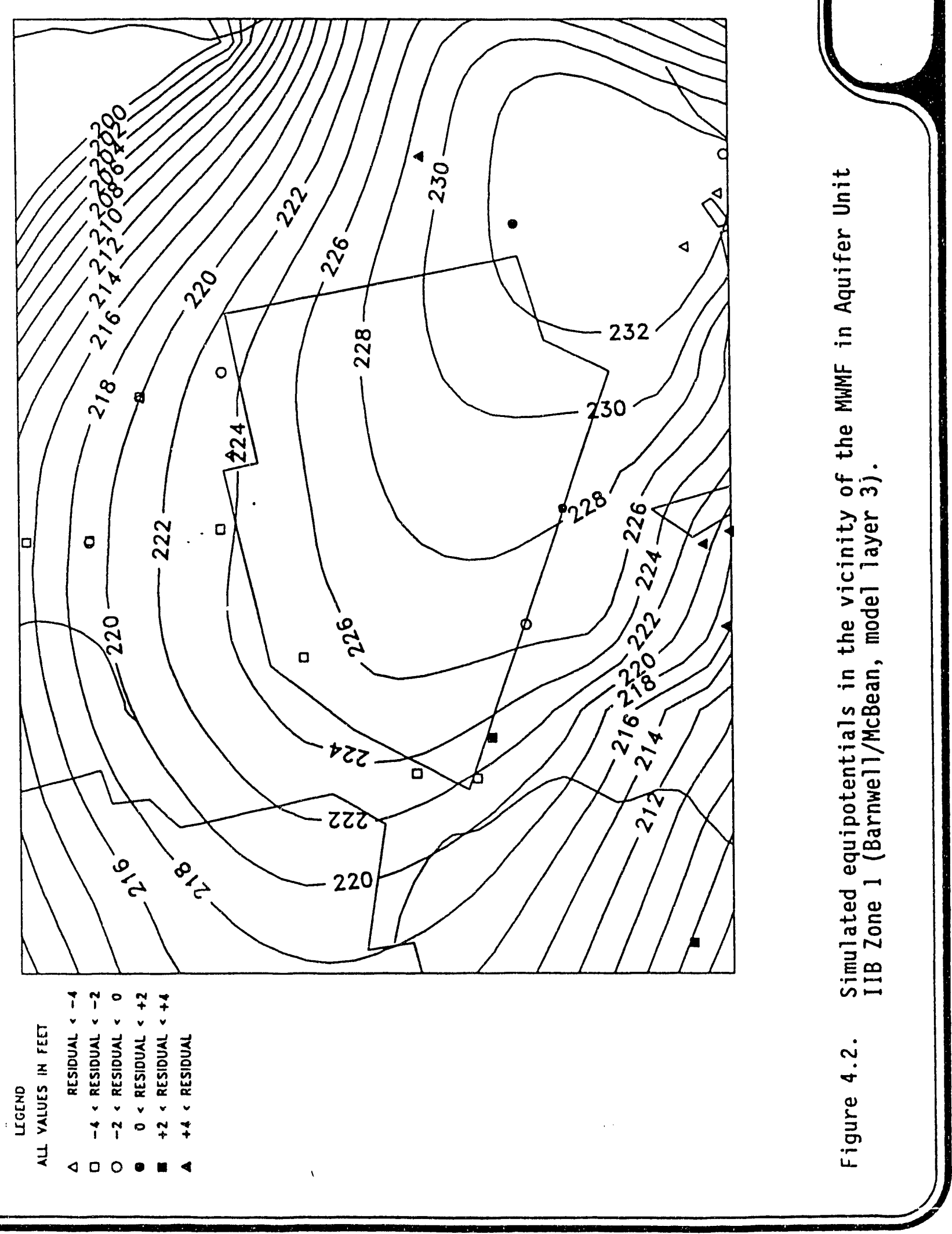




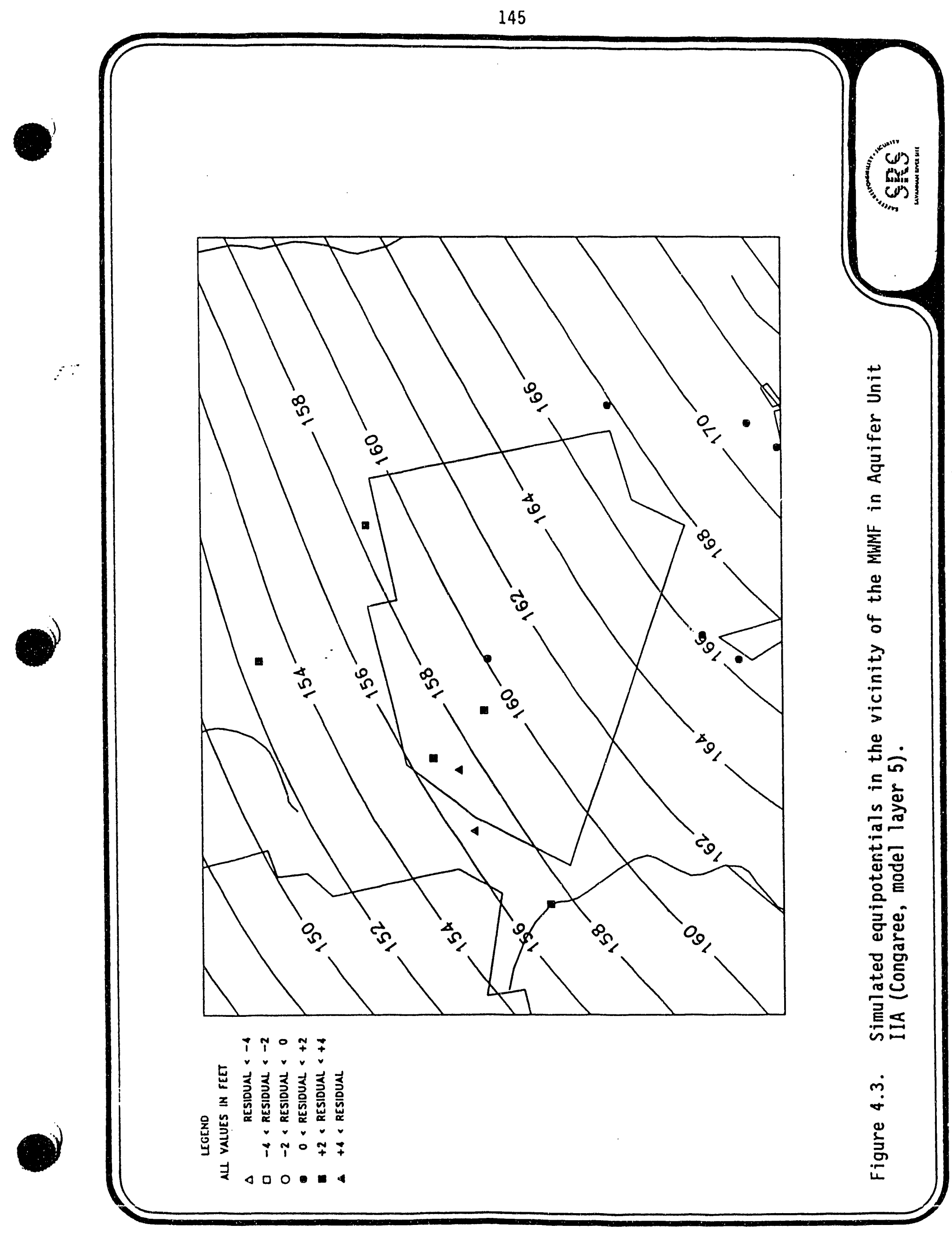




\subsection{PARTICLE TRACKING}

A particle tracking analysis was performed to make a preliminary assessment of contaminant transport for the MWMF. The flow paths and travel times for discrete particles originating from the MWMF was calculated with MODPATH, a publicly available particle-tracking code developed by the United States Geological Survey (Pollock, 1989). This analysis predicts movement of water molecules through the groundwater flow system. Although this simplified analysis ignores many transport phenomena, such as dispersion and adsorption, it is useful for estimating general patterns of transport movement according to groundwater flow.

Figure 4.4 presents a summary of the particle-tracking analysis. On this figure, initial locations of particles are represented by circles. Arrowheads on the figure indicate that a particle has moved into another layer. Approximately 50 particles were introduced across the MWMF in the uppermost saturated portion of the model (i.e., the within model layer 1).

Although some horizontal flow is indicated in model layer 1 outward from the groundwater divide, vertical flow is more significant. Before particles reach a discharge point they move downward. Particles first enter model layer 2 after 6 years, and first enter model layer 3 after 8 years. Again, although some horizontal movement is indicated in model layer 3, particles migrate downward before reaching any discharge points. Particles first enter model layer 4 in 20 years, and first enter layer 5 after 22 years.

Once particles enter model layer 5 , movement is to the northwest towards Upper Three Runs Creek. Particles reach Upper Three Runs Creek during a period spanning from 38 to 90 years from the time of entry into the uppermost saturated portion of the model. The initial discharge point in Upper Three Runs Creek is immediately downstream of where Crouch Branch flows into Upper Three Runs Creek. 


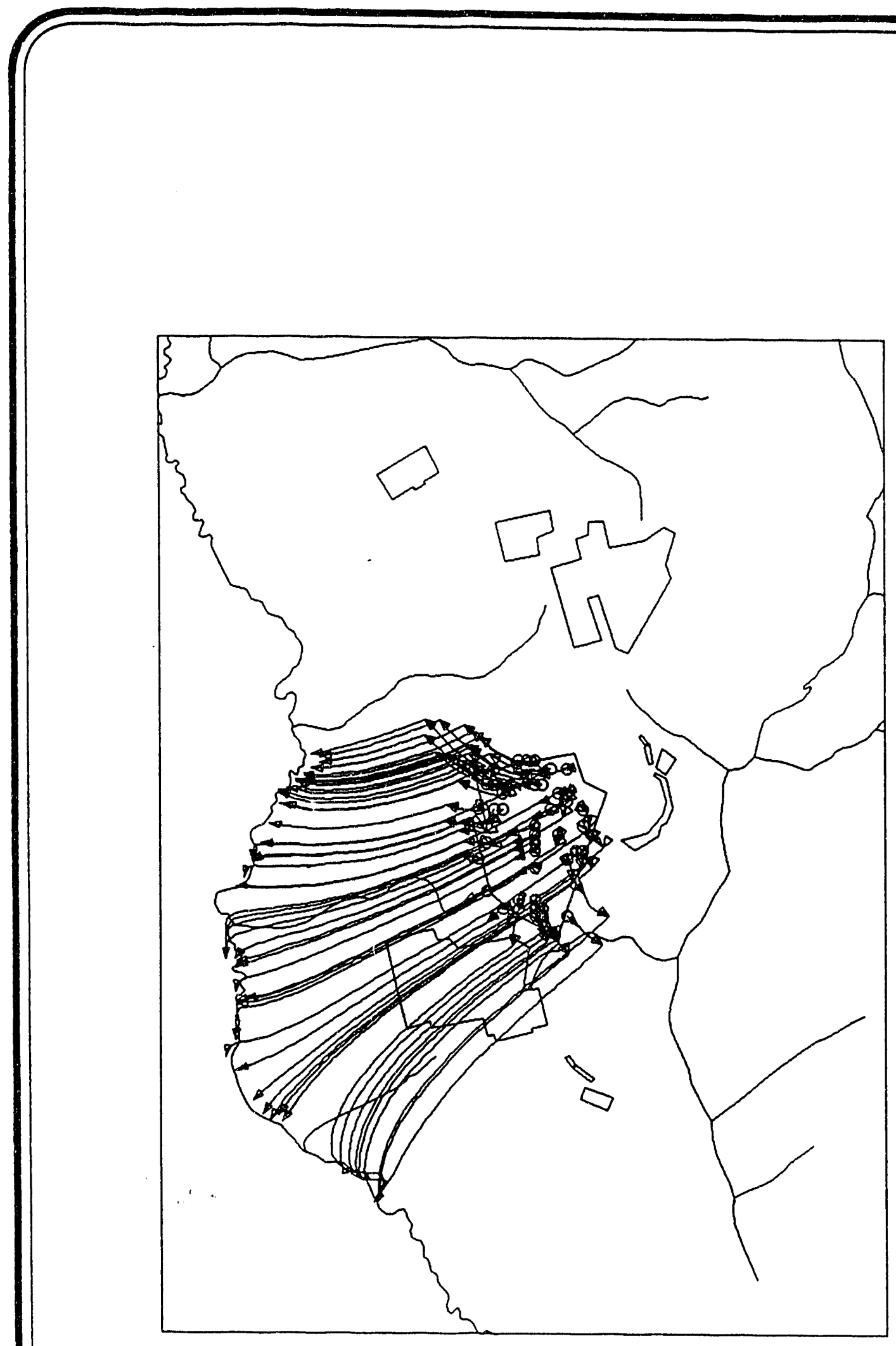

(4)

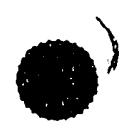

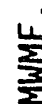

委

4

.

$\frac{n}{\infty}$

.

단

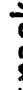

$+$

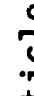

范

วิ

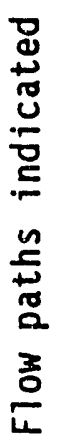

$\dot{0}$
$\dot{0}$
$\frac{0}{3}$ 


\section{CONCLUSIONS}

\subsection{MODEL ASSESSMENT}

The calibrated flow model for the GSA is a useful tool for prediction of groundwater flow, and ultimately for prediction of solute transport. Given the variability of measured water level data and complex hydrostratigraphy, this model adequately simulates regional groundwater flow conditions across the GSA.

Advances represented by this model relative to previous groundwater flow models for the GSA include the following:

- Horizontal grid spacing has been reduced to $200 \mathrm{ft}$ over much of the model domain;

- Confining units have been explicitly defined as model layers (compared to the quasi-3D approach previously used), which is more consistent with transition to solute transport modeling;

- $\quad$ Stratigraphy has been more rigorously included by accounting for variable thicknesses of aquifers and confining units, which in turn are based upon a database with substantially increased numbers of data points;

- Effects of geologic features such as slumps and faults are implicitly included over several grid blocks due to the variable stratigraphy incorporated in the model (although such features are not explicitly defined in the model);

- Net discharge to rivers and seepage to wetlands are represented with more appropriate (leaky) boundary conditions than previously utilized;

- Calibration has been based on a substantially increased number of well locations with measurements of water elevation;

- Model features have been updated in accordance with recent features, such as reduced-permeability caps at the MWMF and the seepage basins;

- A substantial graphics-based database for all aspects of the model input and output has been compiled in a GIS, which has allowed more significant error analysis of data received than previously possible, and which will allow future data to be incorporated into the modeling analysis in a straightforward and efficient manner; 
- The model data sets have been created within the GIS using semi-automated techniques based on a repeatable series of procedures, such that any future modifications to the model (including potential grid refinement) will be performed consistently; and

- The flow model has been created with the FTWORK code, a solute transport code, such that future transition to solute transport analys is will be relatively simple.

The combination of increased data, improved representation of stratigraphy and boundary conditions, and the incorporation of powerful GIS technology in the modeling process are all significant with respect to present and future applications of the groundwater flow model.

Due to the regional nature of the model and the limited zonation of parameter values in the model relative to inherent natural heterogeneities in the geologic system, an inexact match of simulated to observed water levels is expected. Future modeling efforts may possibly include more zones, or perhaps even a stochastic representation of certain parameters, to account for such heterogeneities in a more rigorous manner. Given the sensitivity displayed in model results to zonation of horizontal and vertical hydraulic parameters, accounting for such heterogeneities in analyses performed at more localized scales may be a significant component.

Despite the increase in available data relative to past modeling studies, additional data needs still exist, and are documented in the next section.

\subsection{DATA NEEDS}

The following is a list of data needs (or in some cases data suggestions) required for continued improvement of the modeling process for the GSA:

1. More stratigraphic data south of $\mathrm{H}$-Area, in addition to measured water levels in Aquifer Unit IIB Zone 1

(Barnwe11/McBean) in that area, will enable improved assessment of the model in that area. In the present model, a zone of substantially reduced vertical hydraulic conductivity is assigned to Confining Unit IIBI-IIB2 (Tan Clay) in that region to simulate the observed groundwater mound in Aquifer Unit IIB 
Zone 2 (Water Table). Additional data might help verify the appropriateness of this representation.

2. Additional water level measurements north of the F-Area seepage basins will allow better representation of the position of the groundwater flow divide in Aquifer Unit IIB Zone 2 (Water Table) and Aquifer Unit IIB Zone 1 (Barnwell/McBean). This is a critical area with respect to ultimate discharge point of contaminants, and the effect of potential pump-and-treat operations on this groundwater flow divide are important.

3. Continued testing of hydraulic parameters for aquifers and confining units is suggested, particularly in zones with substantial carbonate materials and where zones have been included in this model.

4. Net discharge data to Upper Three Runs Creek over the limits of the model domain will allow a comparison with simulated net discharge to be performed. Currently, data is only available for one station within the extent of the GSA, such that net discharge to the stream within the model extent cannot be calculated.

5. Quantification of process water flow via effluent ditches to Upper Three Runs Creek and Four Mile Branch will allow their inclusion into the modeling process.

6. An updated water budget study to confirm long-term net recharge assigned in the model will be useful.

7. The geologic interpretation of aquifer extent near Upper Three Runs Creek, and conceptual model of seepage to wetlands in this region, needs to be verified.

8. Improved data regarding limits of saturation above Confining Unit IIB1-IIB2 (Tan Clay) towards Upper Three Runs Creek wiII aid in future model calibration.

9. Regional Congaree water levels will allow more accurate specified head boundary assignments.

The priority for collecting the data described above will vary depending upon area of regulatory concern and proposed corrective measures. For purposes of quantifying flow in the entire GSA, collection of data south of $\mathrm{H}$-area (data need 1 ) is important because this area represents a significant portion of the GSA. Accurate quantification of 
the cause of the head buildup may not be important if studies focus only on the Burial Grounds and F- and H-area seepage basins.

Collecting additional water levels north of the F-area seepage basins (data need 2) should be done immediately. Quantifying flow directions and position of the groundwater divide is crucial for several ongoing studies.

Testing of aquifer parameters (data need 3 ) should be an ongoing task. It is particularly important to note that numerical models require data and hence site characterization in areas that may be distant from various facilities.

Data needs 4, 5, and 6 all pertain to water budget considerations. Siting discharge stations on Upper Three Runs Creek (data need 4) is fairly important and could be done immediately with a very limited budget. After Upper Three Runs Creek discharge has been quantified, this should be broken down further to assess contributions from other surface waters (data need 5). Because recharge is such an influential parameter, its accurate quantification is important (data need 6 ). This type of study could be accomplished using standard stream gaging and basin delineation techniques or could involve complex instrumentation. A combination of both would be useful because it is important to know overall recharge rates (stream gaging techniques) as well as spatial distribution of recharge (instrumentation at various sites).

Very little data exist on the extent of aquifers near Upper Three Runs Creek and the configuration of wetlands. Continued seepline studies with emphasis on the geology and hydraulic effects would help define this boundary of the model better. Like data need 1 , this is a site characterization issue, but involves nearly all facilities in the GSA because Upper Three Runs is the ultimate discharge point.

The final data need, inclusion of regional Aquifer IIA (Congaree) water levels, can be done without time consuming data collection. Wells exist near the proposed New Production Reactor site and at other locations sitewide that, if measured contemporaneously, could improve subsequent updates to the model.

In addition, significant effort should be made at SRS to standardize well names. The powerful relational database features of the GIS, which allow different types of data to be analyzed in a graphical environment, 
requires database tables to be related via the well name or some other identifying feature. Perhaps all wells could be assigned a unique identification number (digits only) in addition to the well name, such that many of the problems related to character strings in digital format (i.e., case dependency, spaces, dashes, etc.) can be avoided.

\subsection{TRANSPORT MODEL CONSIDERATIONS}

The transport modeling for MWMF will likely require a refinement of grid discretization. This will be more easily achieved than in the past due to the semi-automated procedures available with the GIS.

The preliminary transport analysis based on particle tracking presented in this report indicates that particles introduced to the groundwater system from the MWMF ultimately discharge to Upper Three Runs Creek from Aquifer Unit IIA (Congaree). This suggests that inclusion of some areas south of the MWMF, toward Four Mile Branch, may not be required in the soiute transport modeling.

Representation of confining beds with one model layer can sometimes lead to inaccurate predications of vertical contaminant transport. This results from the fact that, once a contaminant is introduced to a model layer representing the confining unit, it is automatically mixed throughout the model layer. This allows contaminants to migrate vertically more rapidly in the model than in the actual system. Increased vertical discretization of confining beds may be necessary in the transport model to prevent such "smearing" of concentration fronts across the confining beds. Typically, three model layers for each confining bed are sufficient to minimize this problem. This would indicate that the solute transport model will likely contain at least 9 layers, as opposed to 5 model layers for the flow model.

Additional parameters need to be characterized for the transport mode1. These include source terms, concentration distributions, and distribution coefficients. In many cases, the results of the transport simulations may be more sensitive to specification of these parameters than to the hydraulic parameters. 
Finally, the transport model calibration process may lead to improved understanding of flow conditions within the GSA, which may require revisions to the calibrated flow model presented in this report. 


\section{REFERENCES}

Aadland, R.K., 1990. Classification of Hydrostratigraphic Units at Savannah River Site, South Carolina. Savannah River Laboratory, WSRC-RP-90-987, Westinghouse Savannah River Company, Aiken, SC.

Beaudoin, C.M., Schreuder, P.J., and J.S. Haselow, 1991. A Ground Water Flow Model for the A/M Area of the SRS, Savannah River Site, Savannah River Laboratory, WSRC-RP-91-0585, Westinghouse Savannah River Company.

Bledsoe, H.W., 1988. SRP Baseline Hydrogeologic Investigation - Phase III DEPST-88-627; E.I. du Pont de Nemours \& Co. Savannah River Laboratory, Aiken, South Carolina.

Buss, D.R., G.M. Duffield, R.W. Root, Jr., S.S. Hughes, and J.W. Mercer, 1986. Characterization of groundwater flow and transport in the General Separations Areas, Savannah River Plant: Flow model calibration report, GeoTrans, Inc.

Cahill, J.M., 1982. Hydrology of the Low - Level Radioactive - Solid Waste Burial Site and Vicinity near Barnwel1, South Carolina, U.S. Geological Survey, Open - File Report 82-863.

CH2M Hil1, 1989. Congaree Aquifer Test, Savannah River Site, April 1989.

Colquhoun, D.J., I.D., Woollen, D.S. Van Nieuwenhuise, G.G. Padgett, R.W. 01dham, D.C. Boylan, J.W. Bishop, and P.D. Howe11, 1983. Surface and Subsurface Stratigraphy Structure, and Aquifers of the South Carolina Coastal Plain: Report for the Department of Health and Environmental Control, Ground Water Protection Division, $78 \mathrm{pp}$.

Duffield, G.M., D.R. Buss, R.W. Root, Jr., S.S. Hughes, and J.W. Mercer, 1986. Characterization of groundwater flow and transport in the General Separations Areas, Savannah River Plant: Flow model refinement and particle-tracking analysis report, GeoTrans, Inc.

Duffield, G.M., D.R. Buss, and C.P. Spalding, 1987. Characterization of groundwater flow and transport in the General Separations Areas, Savannah River Plant: Evaluation of closure cap effectiveness Mixed Waste Management Facility (643-28G), Phase I, Final Report, GeoTrans, Inc.

Evans, E.K. and R.R. Parizek, 1991. Characterization of Hydraulic Conductivity Heterogeneity in Tertiary Sediments within the General Separations Area, Savannah River Site, South Carolina, Department of Geosciences, The Pennsylvania State University. 
Faust, C.R., P.N. Sims, C.P. Spalding, P.F. Andersen, and D.E. Stephenson, 1990. FTWORK: A three-dimensional groundwater flow and solute transport code, Westinghouse Savannah River Company report WSRC-RP89-1085.

GeoTrans, Inc., 1992. Data retrieval and organization for integration into numerical models of the General Separations Area, Savannah River Site, prepared for Westinghouse Savannah River Company, Augusta, Georgia.

GeoTrans, Inc., 1991. Groundwater modeling of remedial alternatives for the F-and H-Area Seepage Basins, prepared for Westinghouse Savannah River Company, Environmental Restoration Group, Augusta, Georgia.

GeoTrans, Inc., 1990. Preliminary evaluation of remedial alternatives for the F-Area Seepage Basins, prepared for Westinghouse Savannah River Company, Aiken, South Carolina.

GeoTrans, Inc., 1988a. Characterization of groundwater flow and transport in the General Separations Area Savannah River Plant: Effect of closure options on groundwater flow F-Area Seepage Basins, Phase I Final Report.

GeoTrans, Inc., 1988b. Characterization of groundwater flow and transport in the General Separations Area Savannah River Plant: Effect of closure options on groundwater flow H-Area Seepage Basins, Phase I Final Report.

GeoTrans, Inc., 1988c. Characterization of groundwater flow and transport in the General Separations Area Savannah River Plant: Effect of closure options on solute transport F-Area Seepage Basins, Phase 2, Final Report.

GeoTrans, Inc., 1988d. Characterization of groundwater flow and transport in the General Separations Area Savannah River P1ant: Effect of closure options on solute transport H-Area Seepage Basins, Phase 2, Final Report.

GeoTrans, Inc., 1988e. Characterization of groundwater flow and transport in the General Separations Area Savannah River Plant: Effect of closure cap in tritium migration, Mixed Waste Management Facility (643-28G), Phase II, Final Report.

Geraghty \& Miller, Inc., 1990. Evaluation of integrated waste facility closure capping on groundwater flow and solute transport in General Separations Area, Savannah River: Flow model and particle-tracking analysis, Final Report.

Haselow, J.S., Savannah River Laboratory, telephone conversation, 1992. 
Haselow, J.S., B.B. Looney, N.V. Halverson, and J.B. Gladden, 1990. Analysis of Soil and Water at the Four Mile Seepline near F \& H Areas of SRS, Westinghouse Savannah River Co.

Hubbard, J.E., 1986. An update on the SRP Burial Ground Area Water Balance and Hydrology, DPST-85-958.

Kipp, K.L., Jr., 1987. HST3D: A computer code for simulation of heat and solute transport in three-dimensional ground-water flow systems, U.S. Geological Survey Water Resources Investigations Report 86-4095, 517 pp.

McDonald, M.G. and A.W. Harbaugh, 1988. A three-dimersional finitedifference groundwater flow model, Techniques of Water Resource Investigations of the U.S. Geological Survey, Book 6, Chapter Al.

Parizek, R.R., and R.W. Root, Jr., 1986. Development of a groundwater velocity model for the radioactive waste management facility, Savannah River Plant, South Carolina -- Final Report and report on aquifer testing and geostatistical modeling, DPST-86-658, U.S. Dept. of Energy.

Pollock, D.W., 1989. Documentation of computer programs to compute and display pathlines using results form the U.S. Geological Survey modular three-dimensional finite-difference ground-water flow model, U.S. Geological Survey Open File Report 89-381.

Price, V., S.J. Bohannon, J. Marsh, W.C. Fallaw, and K.A. Sargent, 1988. Geology and Hydrology of the F-Area Seepage Basins, DRAFT.

Reeves, M., D.S. Ward, N.D. Johns, and R.M. Cranwe11, 1986. Theory and implementation for SWIFT II, the Sandia waste-isolation flow and transport model for fractured media, Release 8.84 .

Root, R.W., Jr., 1987. Numerical simulation of groundwater flow at Savannah River Plant, South Carolina, Doctor of Philosophy dissertation, Pennsylvania State University.

Sims, P.N., P.F. Andersen, D.E. Stephenson, and C.R. Faust, 1989. Testing and benchmarking of a three-dimensional groundwater flow and transport mode1, Proceedings of the Solving Groundwater Problems with Models Conference, National Water Well Association.

Siple, G.E., 1967. Geology and Ground-water of the Savannah River Plant and Vicinity, South Carolina, U.S. Geological Survey Water Supply Paper 1841,113 p., Reston, VA.

Sirrine Environmental, Inc., 199la. Burial Ground Expansion, Hydrogeologic Characterization, Savannah River Site, WSRC-RP-91866.

Sirrine Environmental, Inc., 1991b. Hydrogeologic Characterization, HW/MW Disposal Facility, Savannah River Site, WSRC-RP-91-423. 
SRS, 1990. App? ication for a Hazardous Waste Part B Post-Closure Care Permit, Savannah River Site, United States Department of Energy.

U.S. Environmental Protection Agency, 1984. The hydrologic evaluation of 1 andfil1 performance (HELP) mode1, EPA \530-SW-84-009, Volume I, User's Guide for Version 1.

Wattenbarger, R.A., and D.H. Thurnau, 1976. Application of SSOR to threedimensional reservoir problems, Paper presented at 4 th Symposium on Numerical Simulation of Reservoir Performance, Soc. of Petrol. Eng., AIME, Los Angeles, Cal ifornia, (Feb. 19-20).

Weaver, W., Jr., 1967. Computer Programs for Structural Analysis, D. Van Norstrand Company, Inc., Princeton, New Jersey.

Westinghouse Environmental and GeoTechnical Services, Inc., 1990. Hydrogeologic Characterization of the Proposed Waste Solidification and Disposal Facility Site, Y-Area, Savarnah River Site, Aiken, South Carolina.

Woo, P.T., and A.S. Emanual, 1976. A block successive over-relaxation method for coupled equations, Paper presented at East Annual Fall Meeting, Society of Petroleum Engineers, AIME, New Orleans, Louisiana, (0ct. 3-6). 


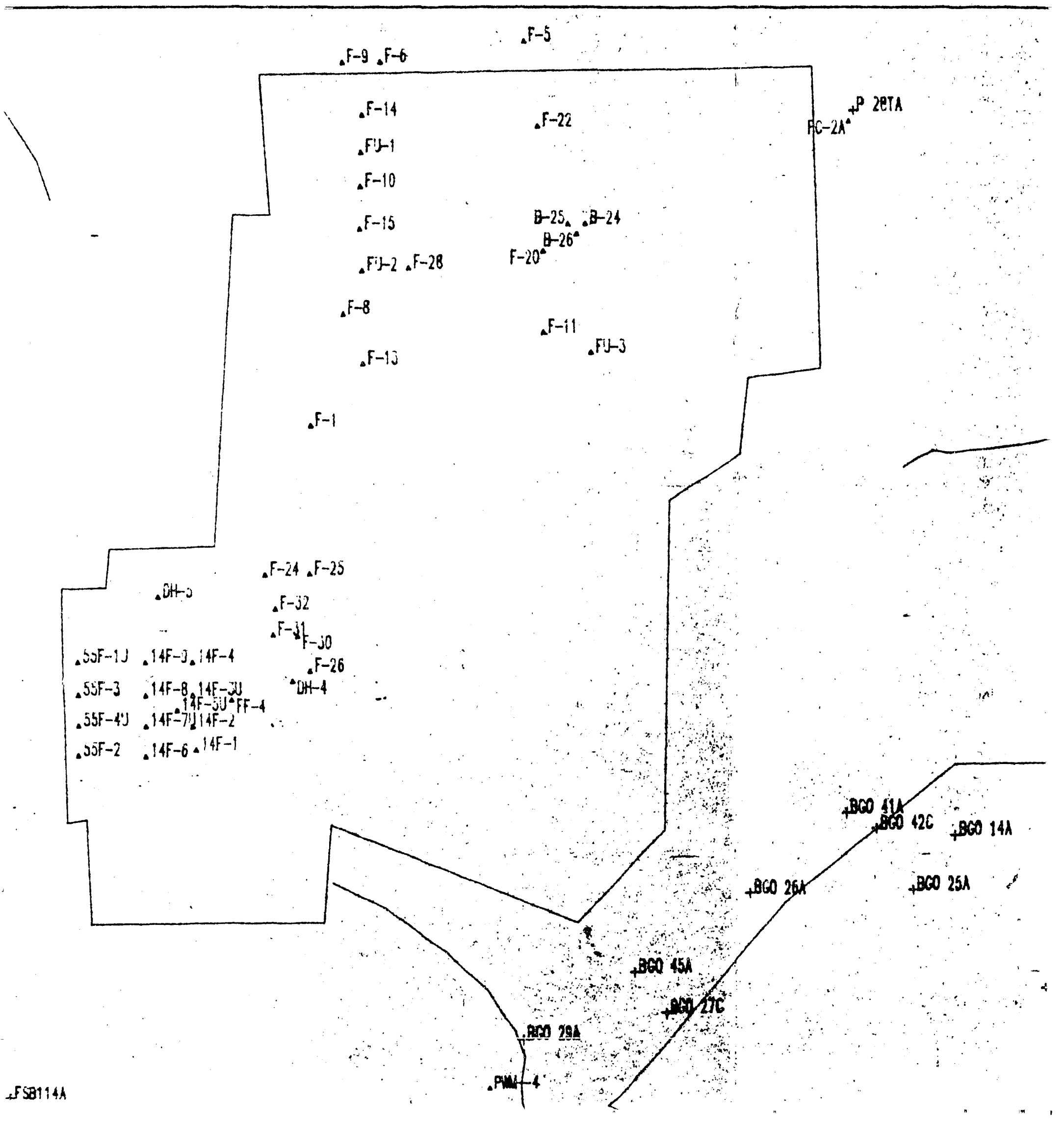




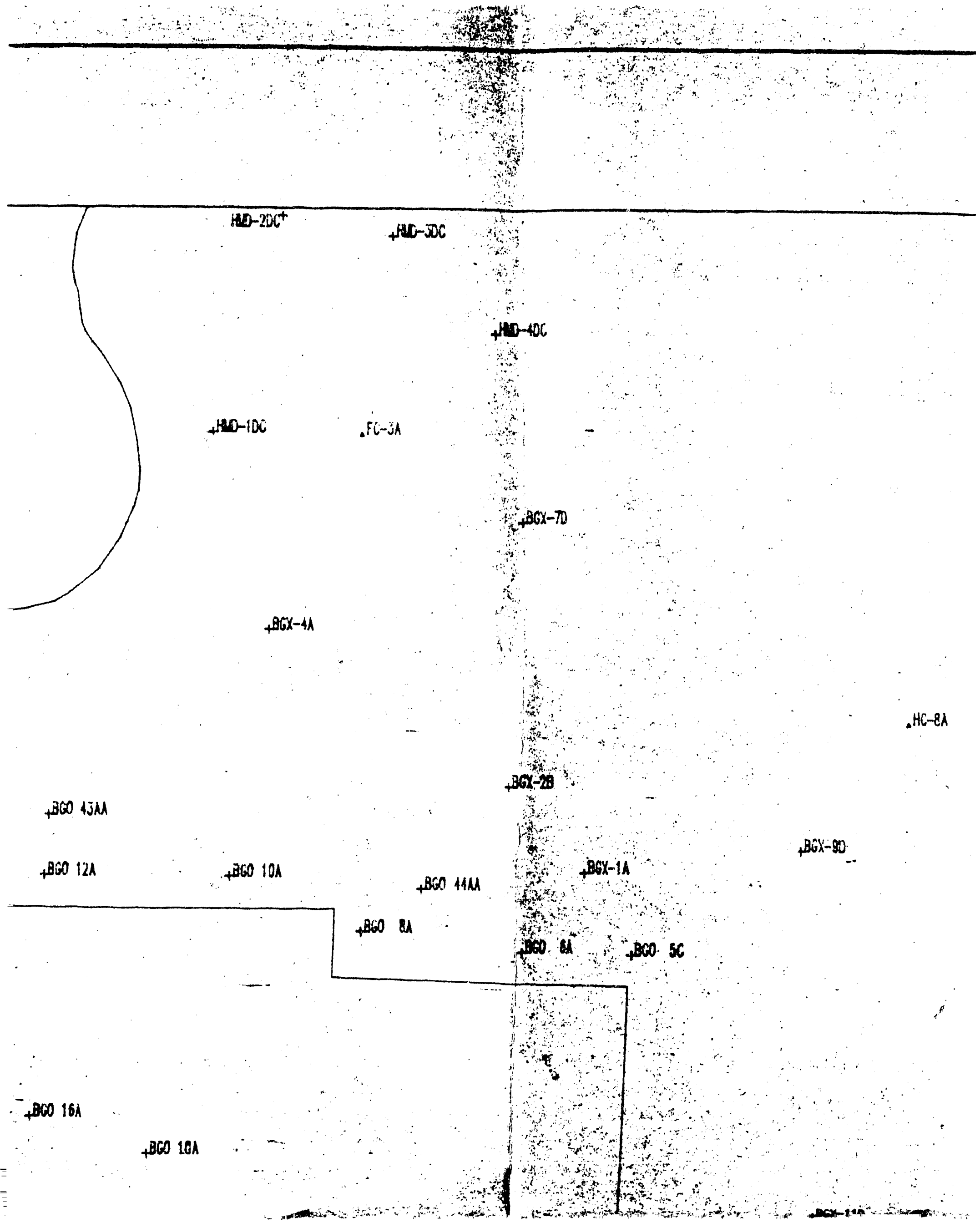




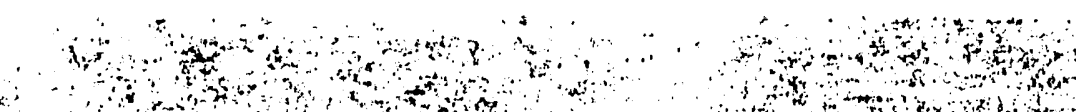
2) $\quad$ a

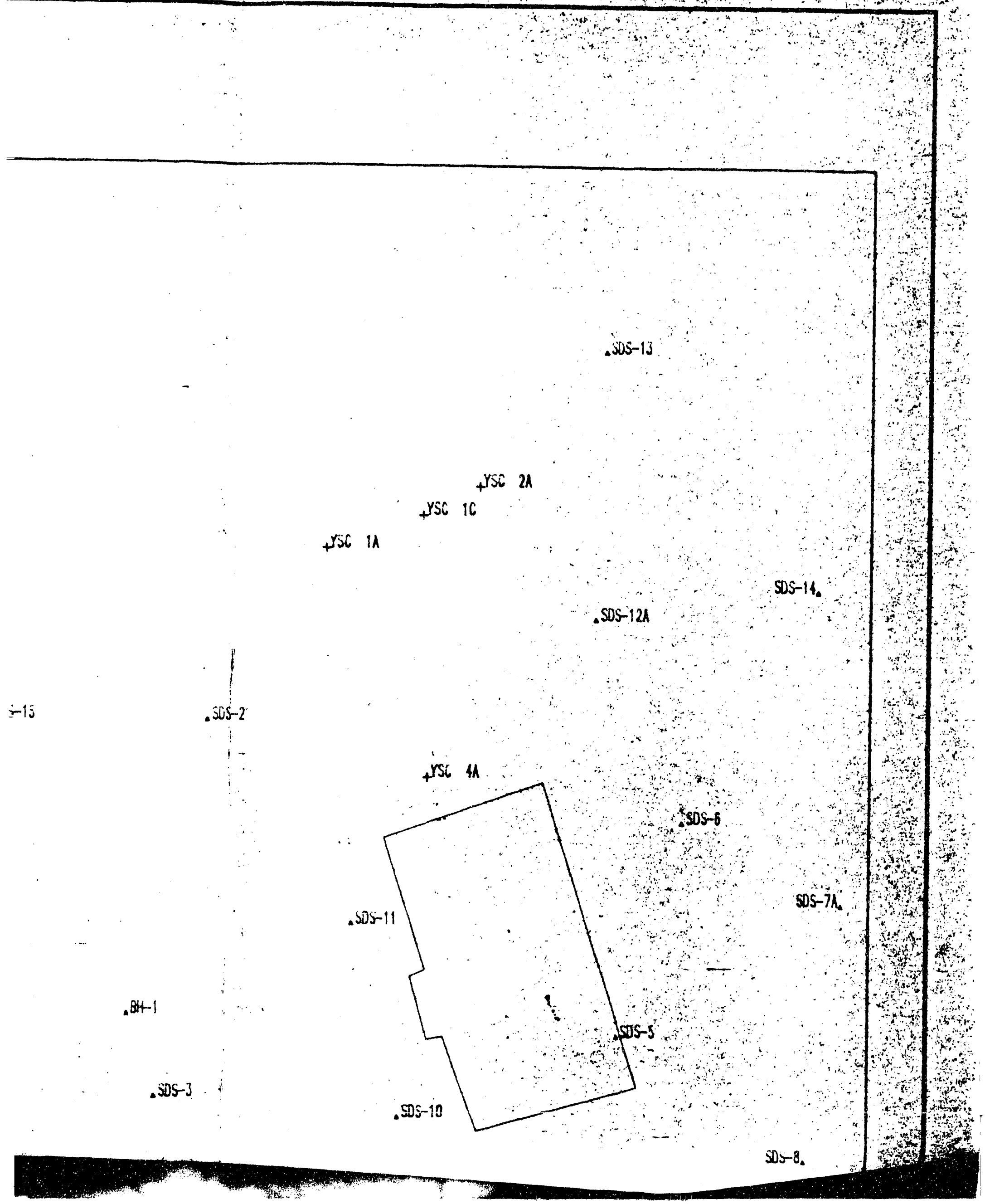




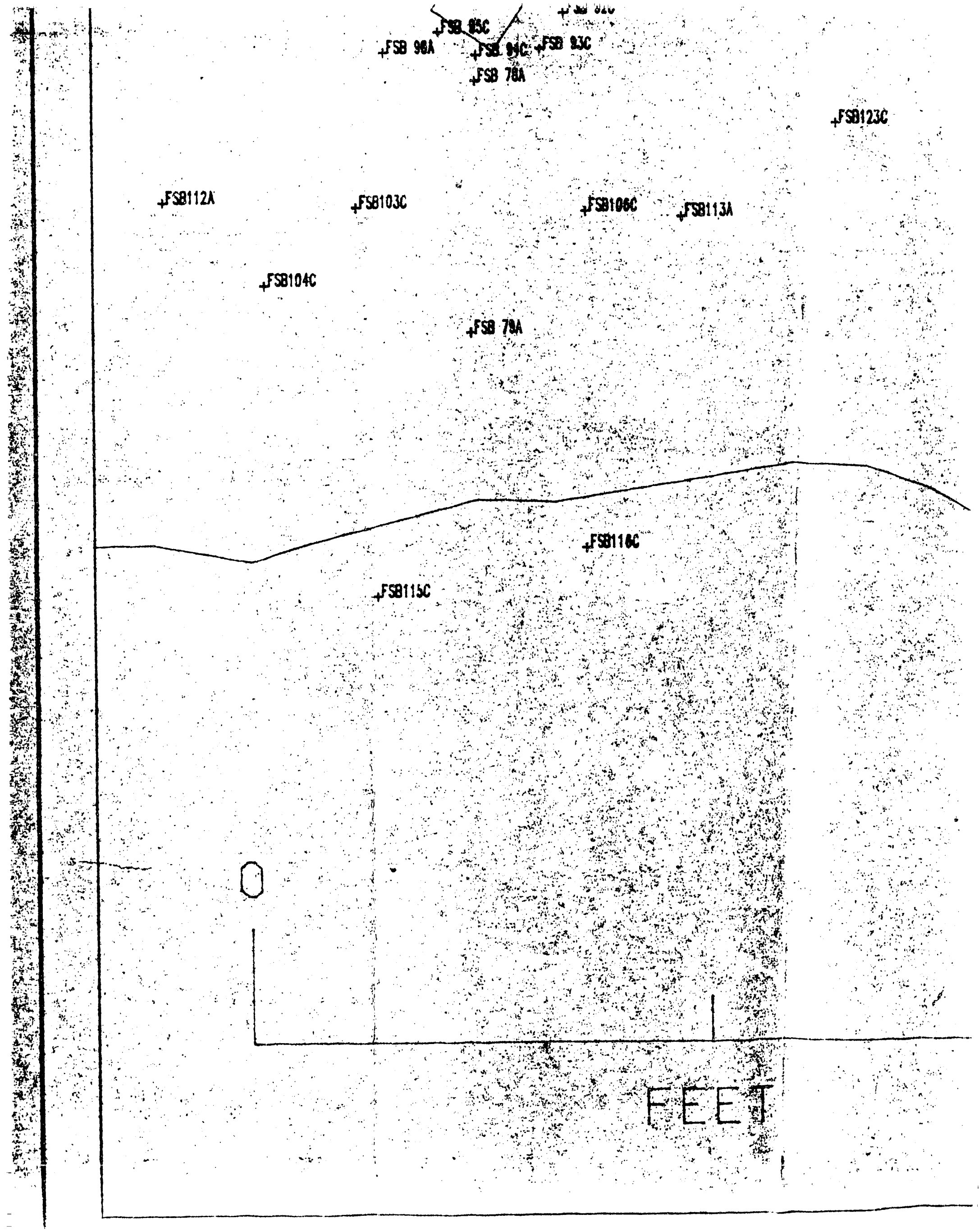




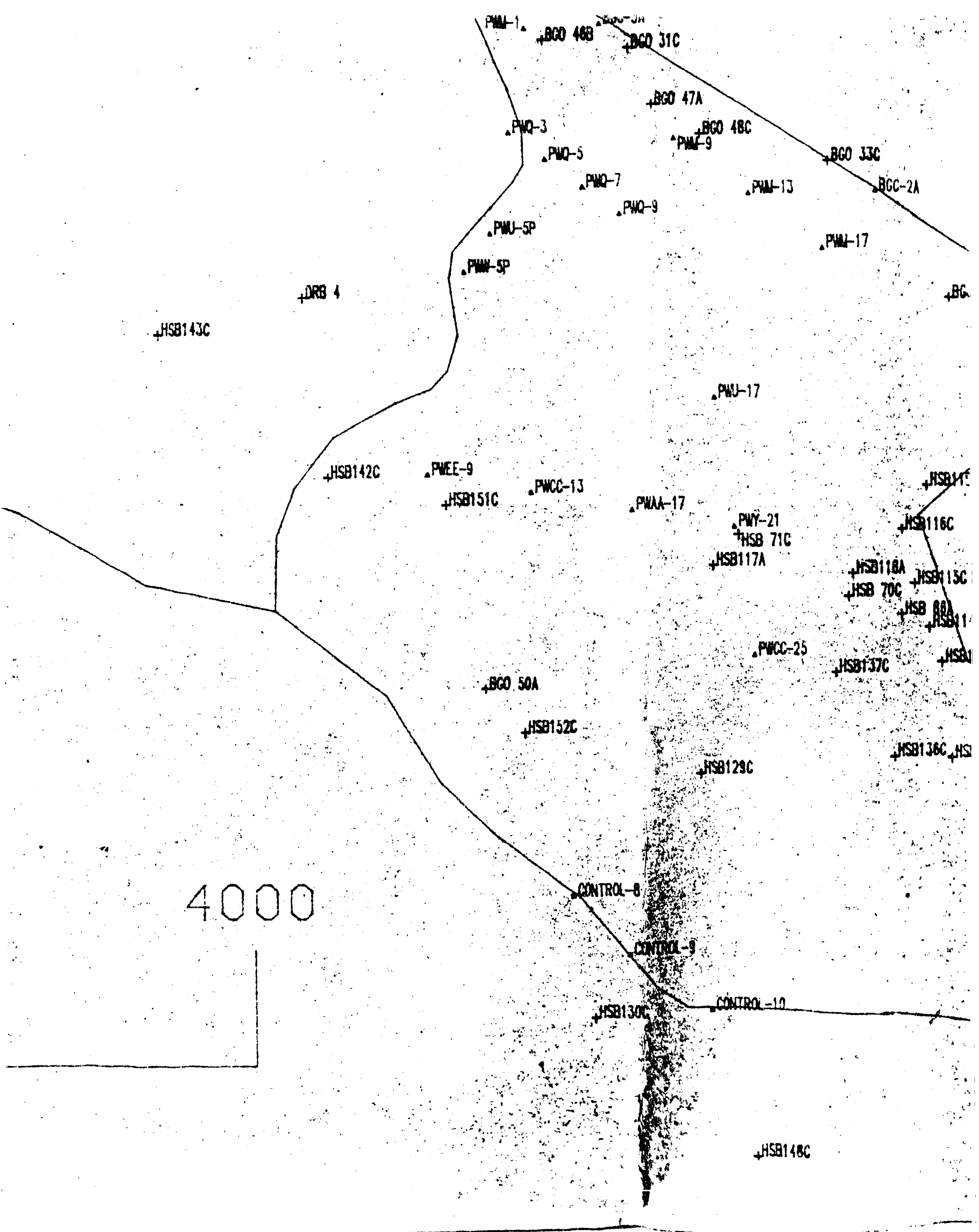




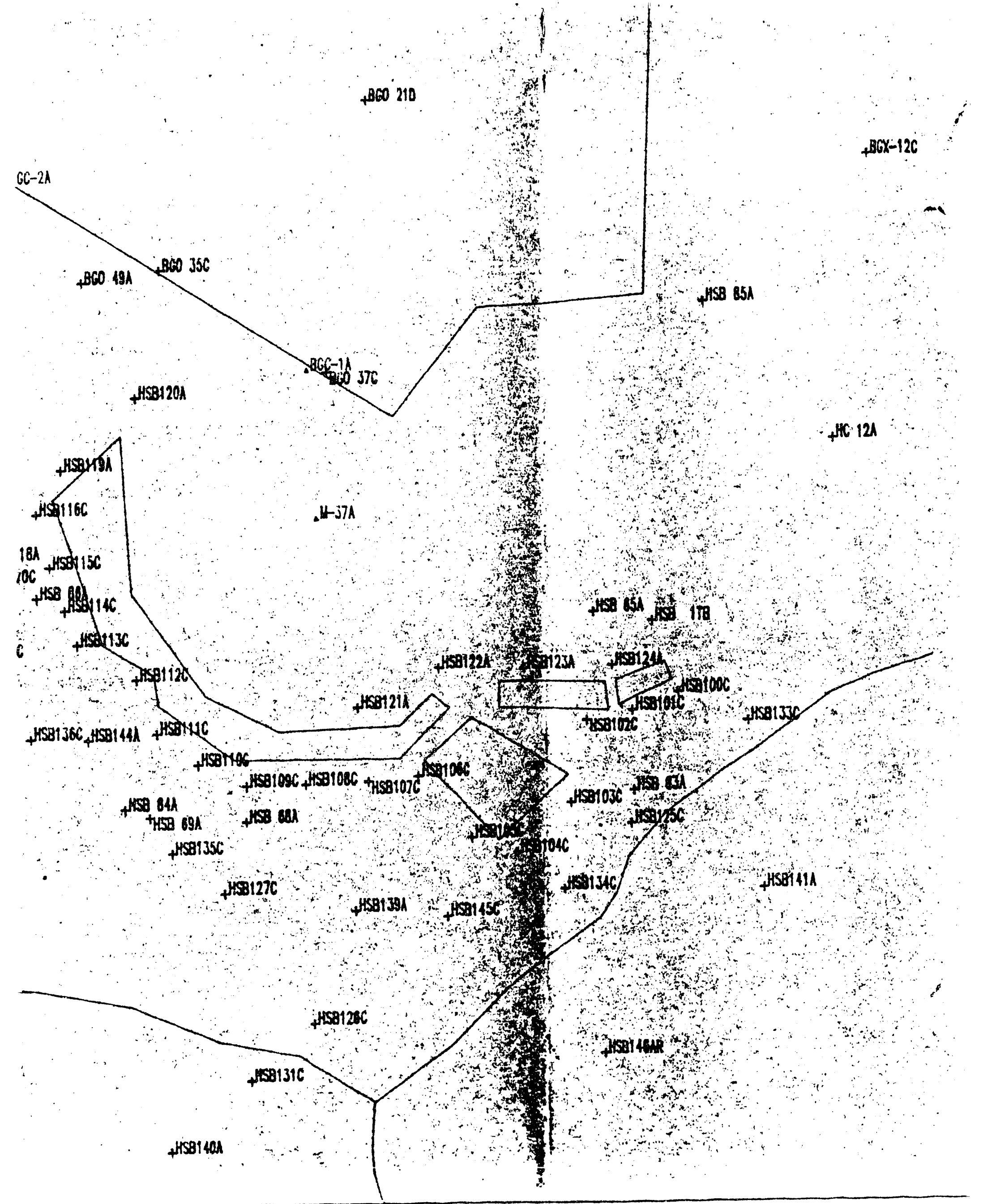




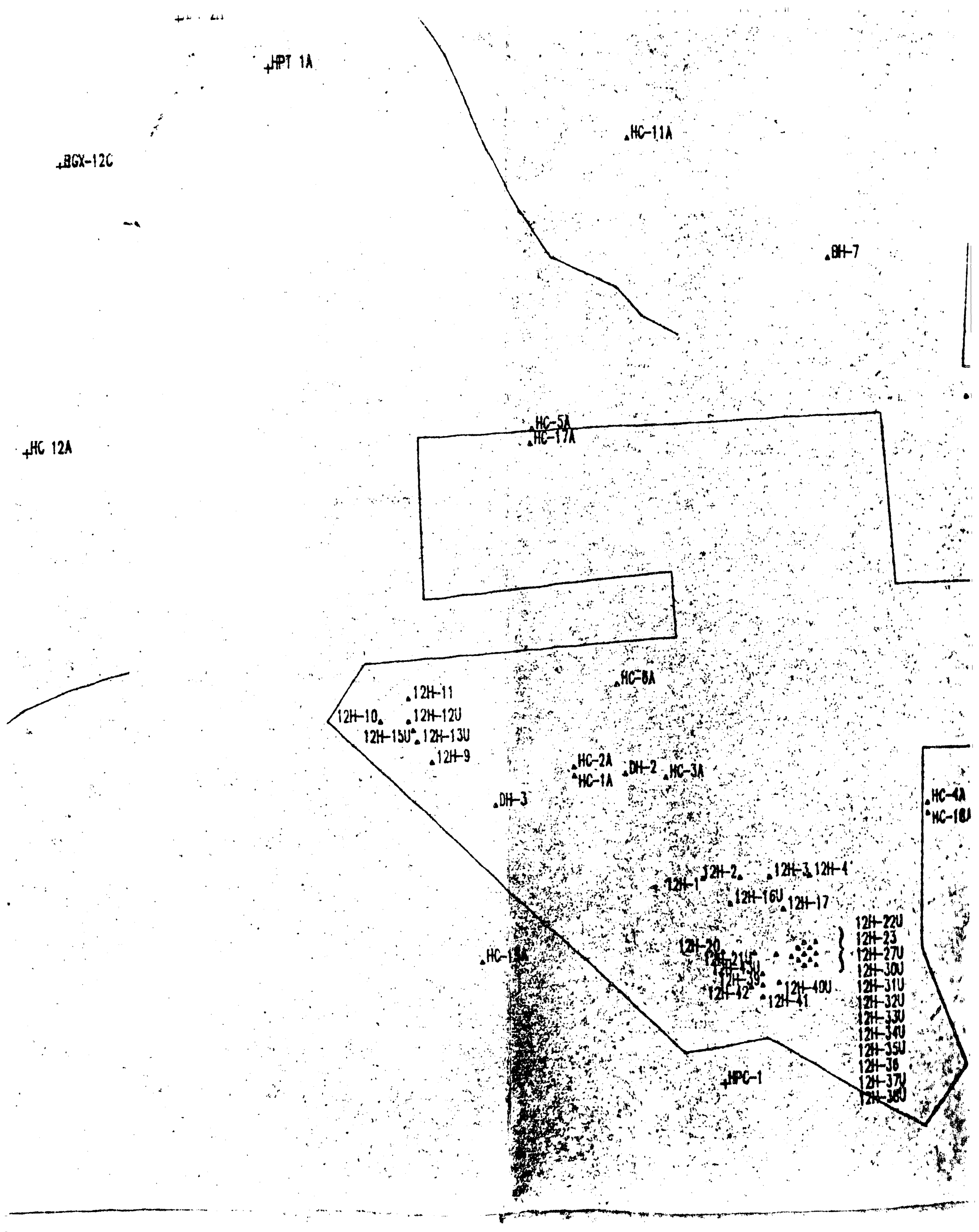




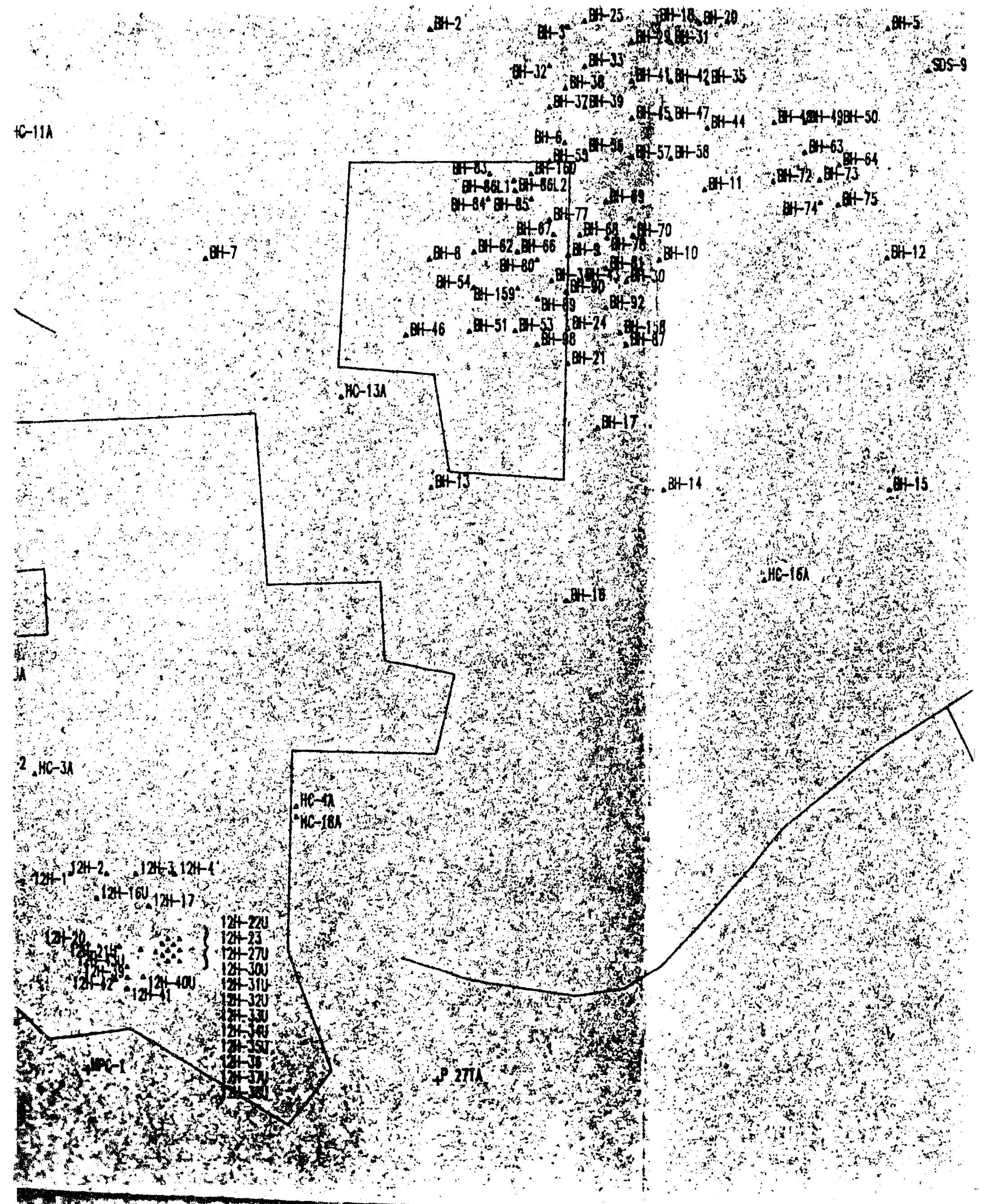




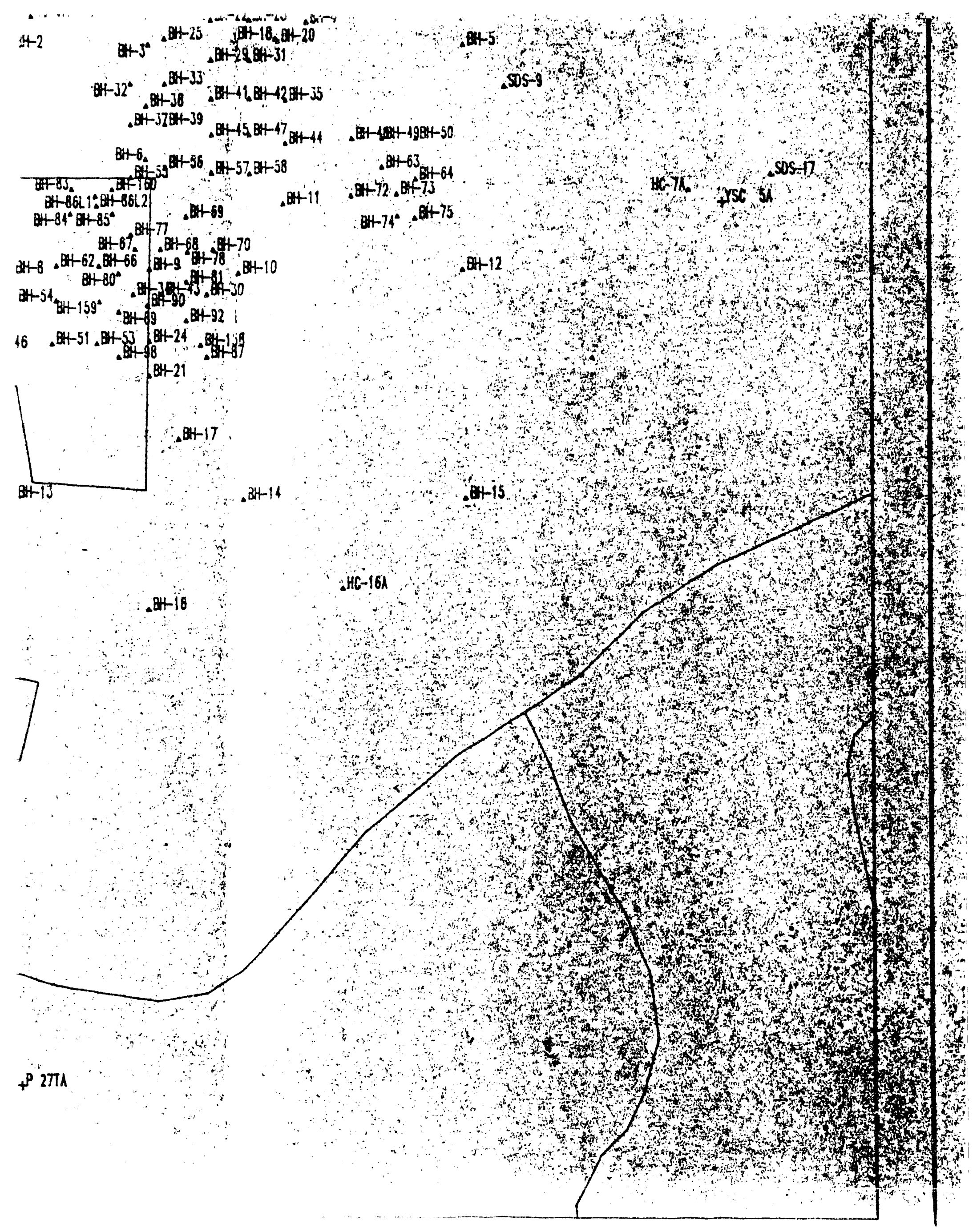




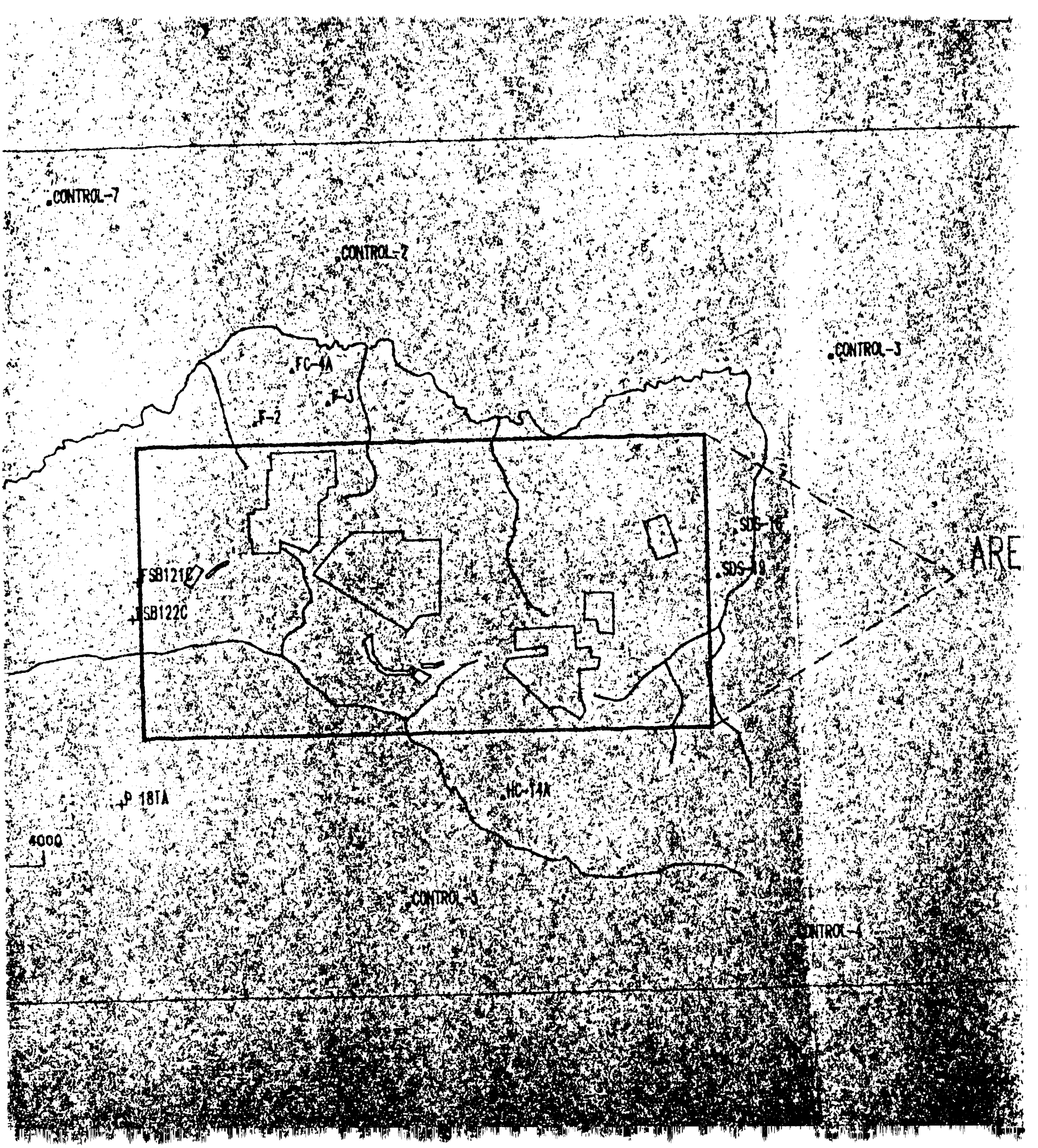




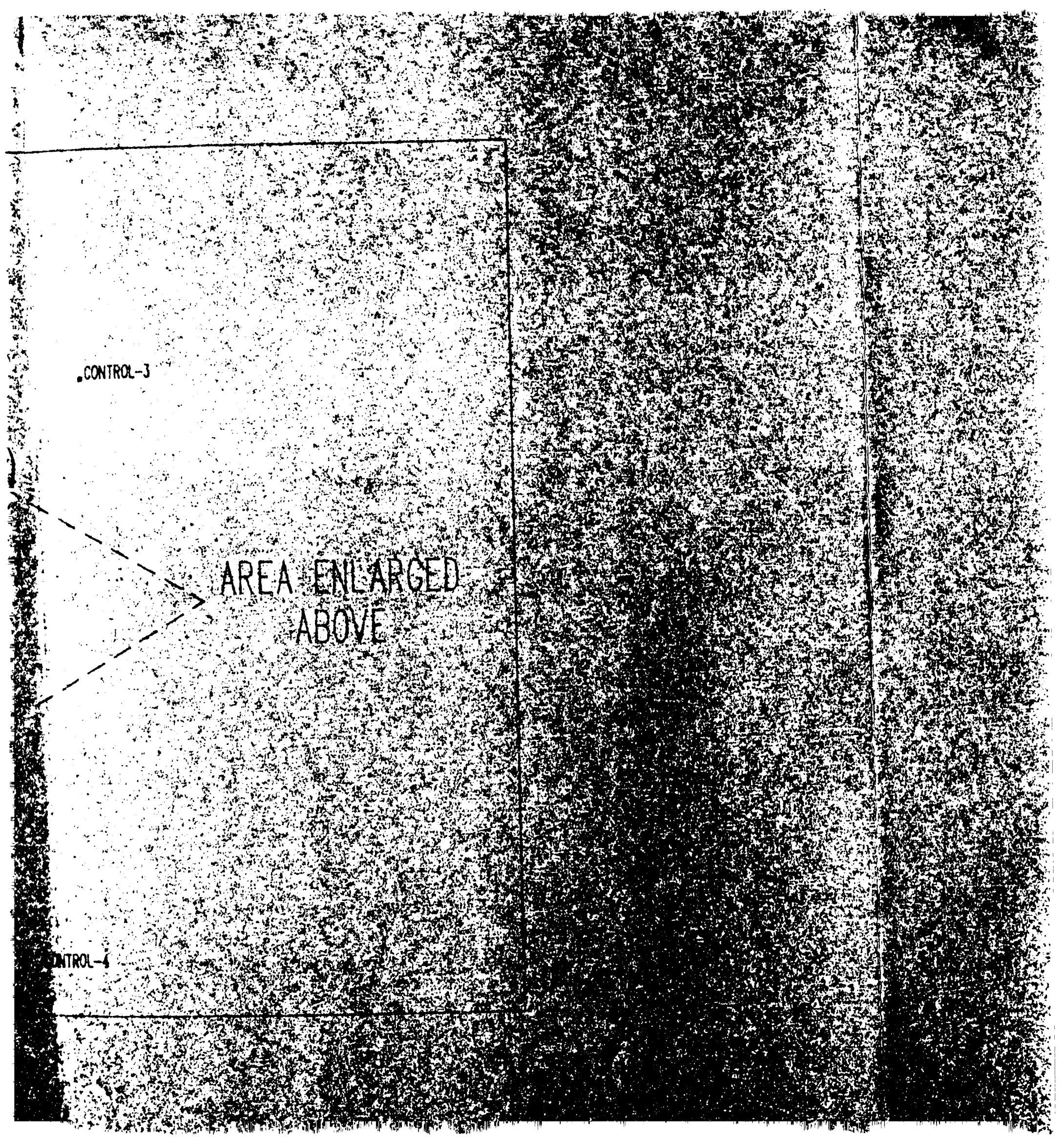



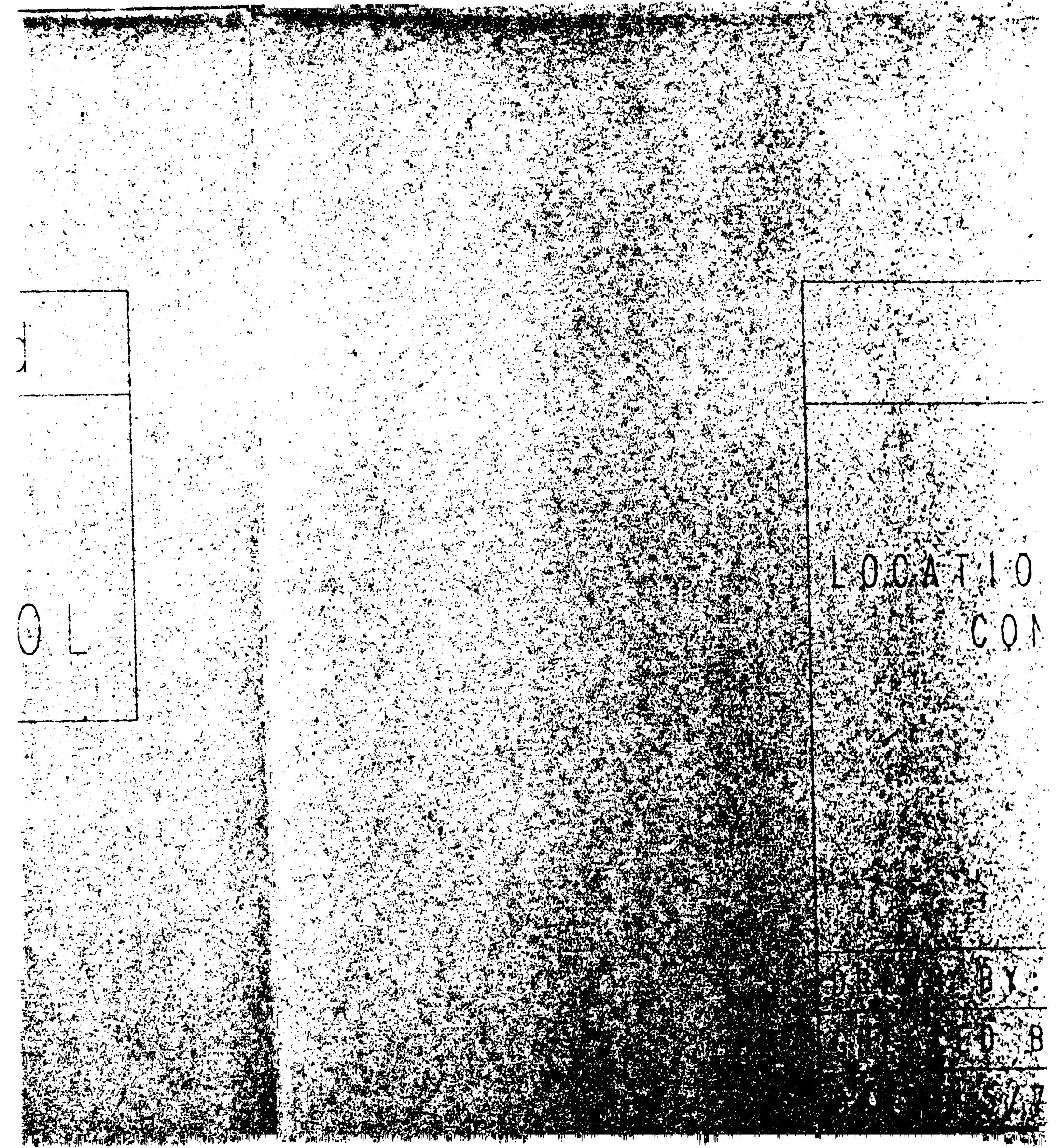
7f

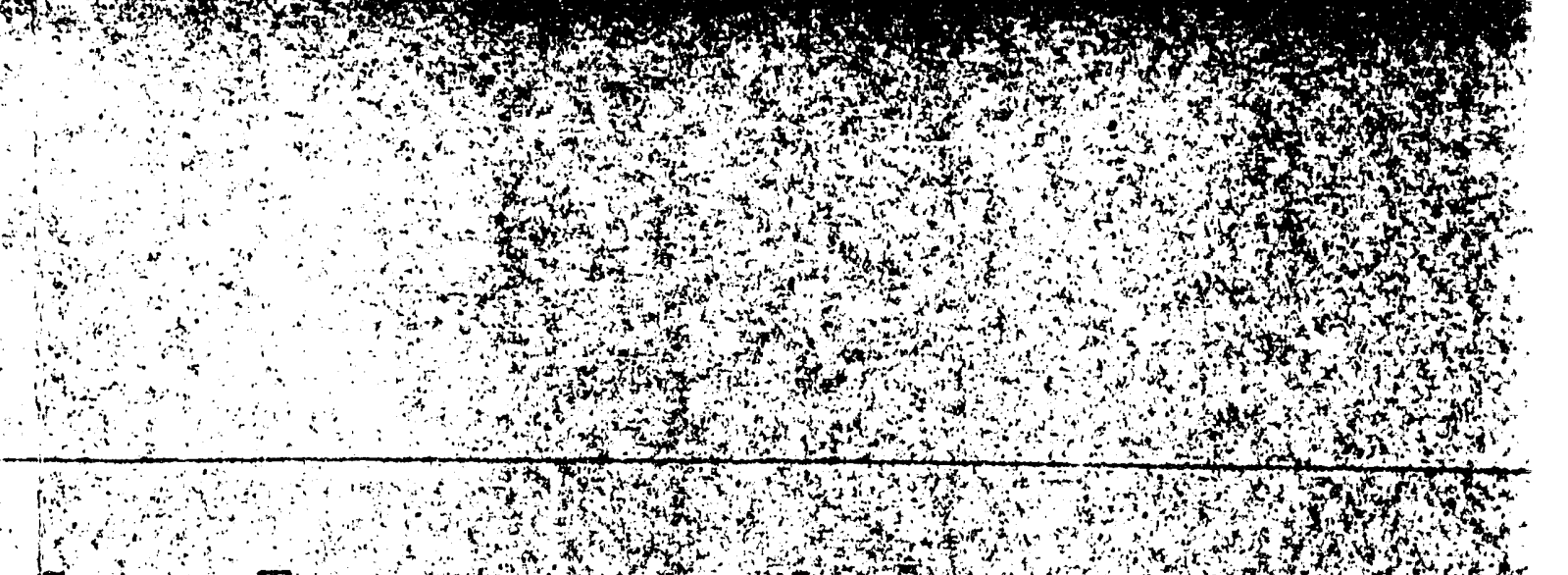

\section{$\mathrm{GeoTrans} / \mathrm{hc}$. Wh}

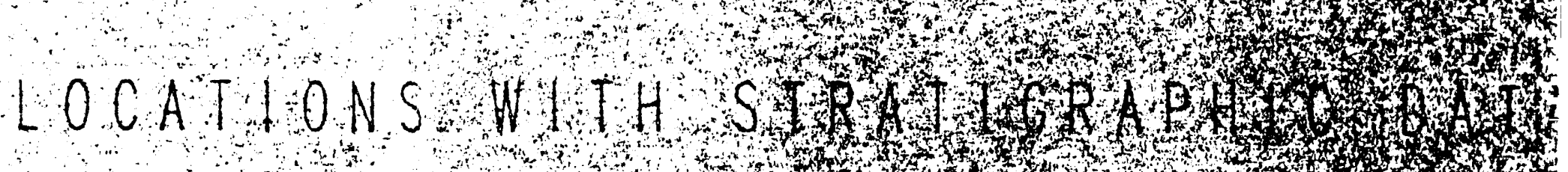

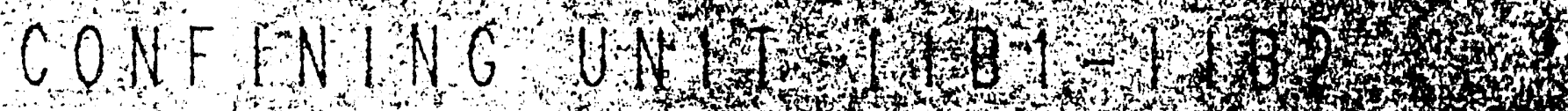

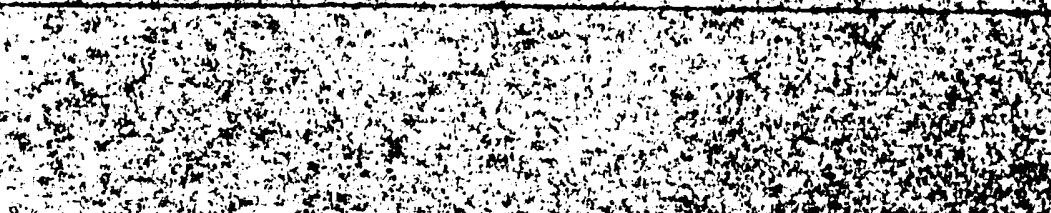
.

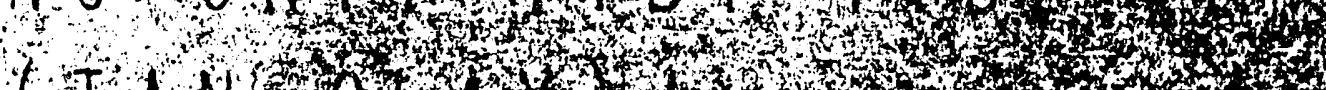

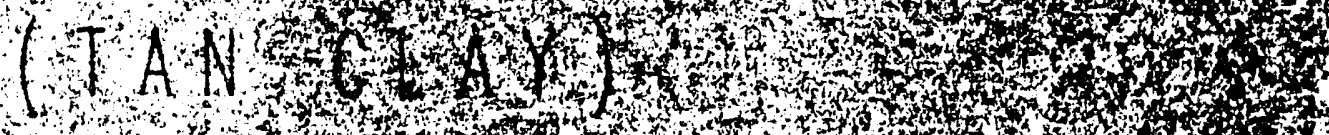

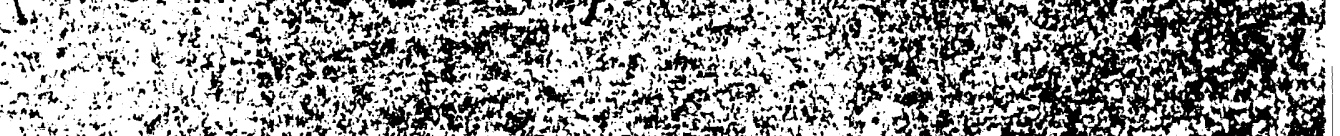

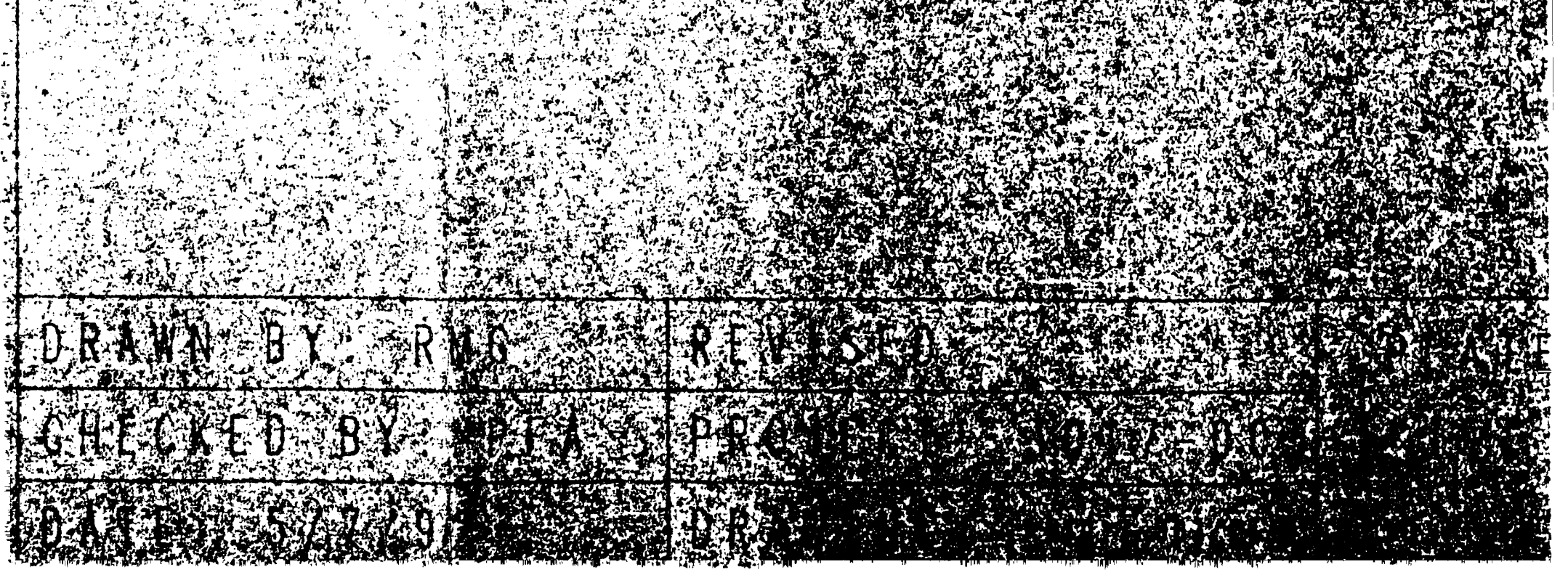




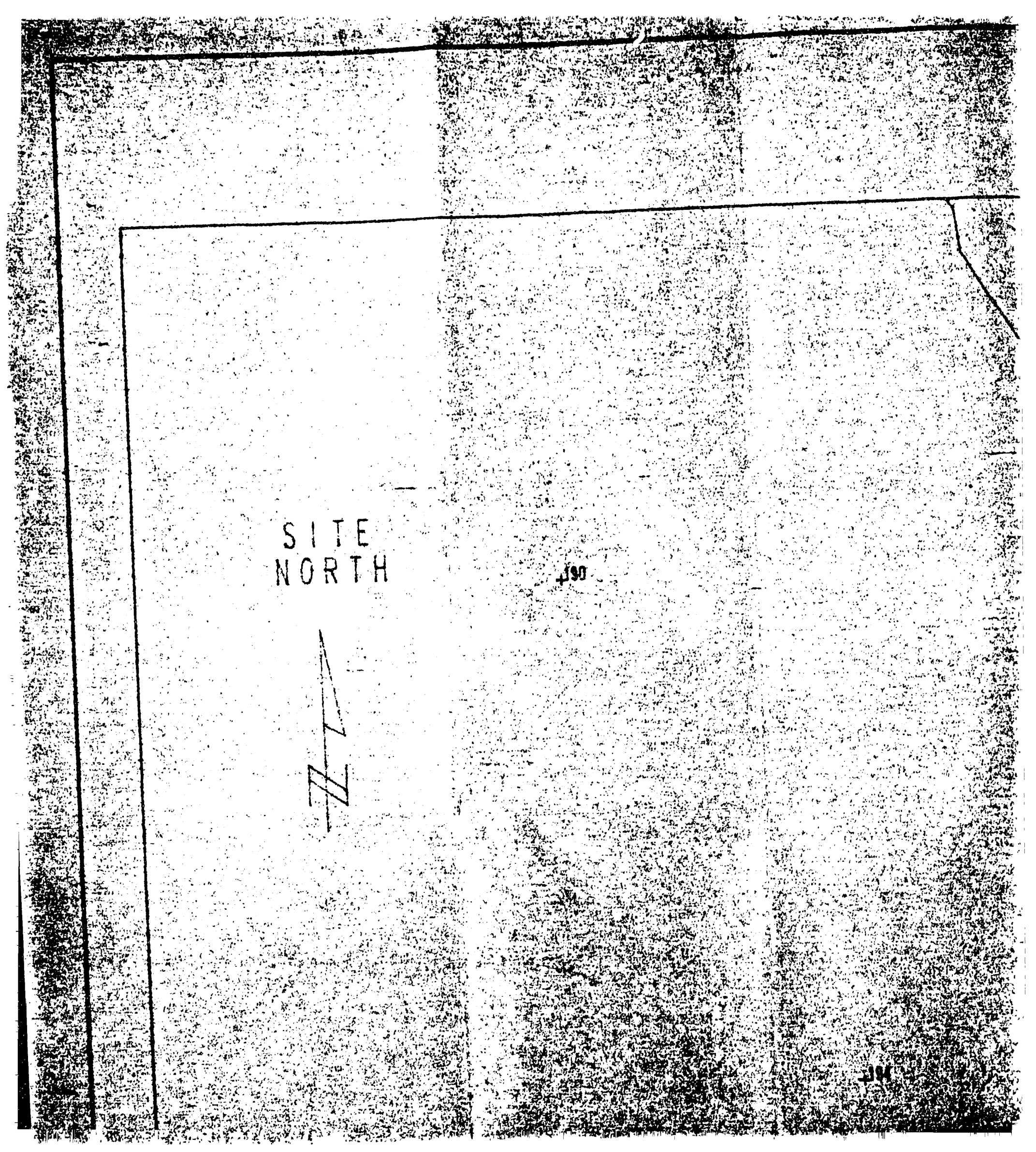





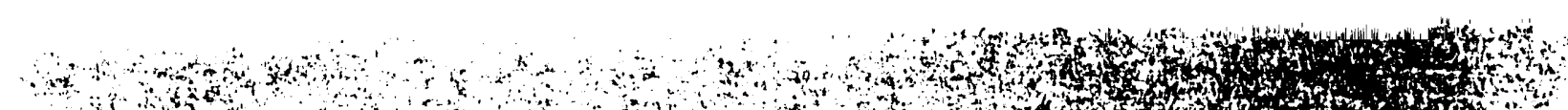

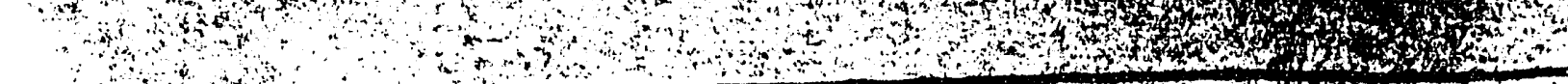

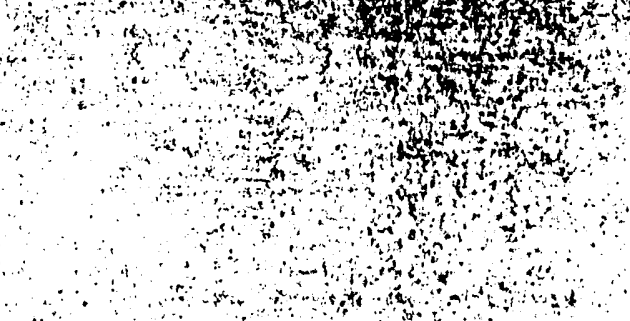

\section{$+222$}

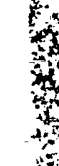

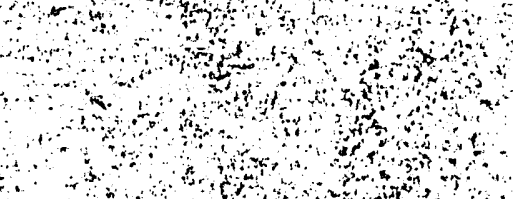

कासेकी

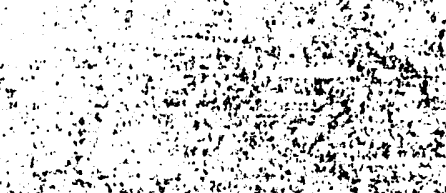
monts of

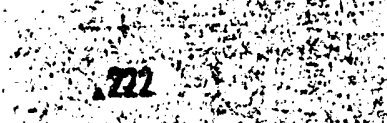

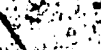
? . and

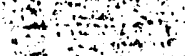




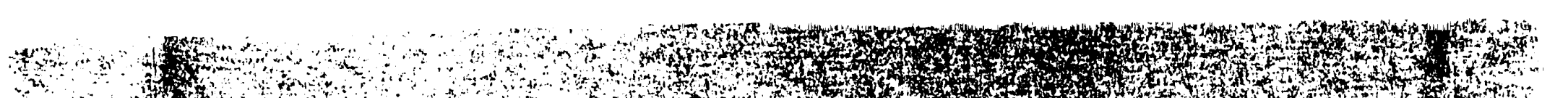

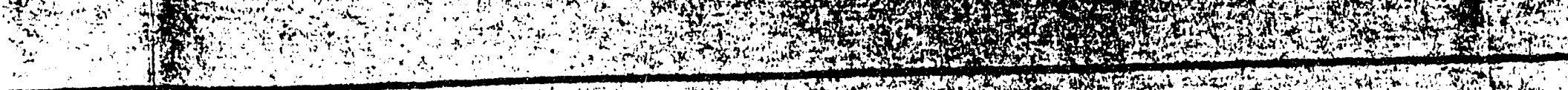
45

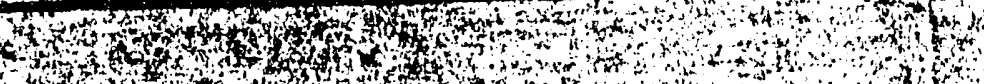

intis

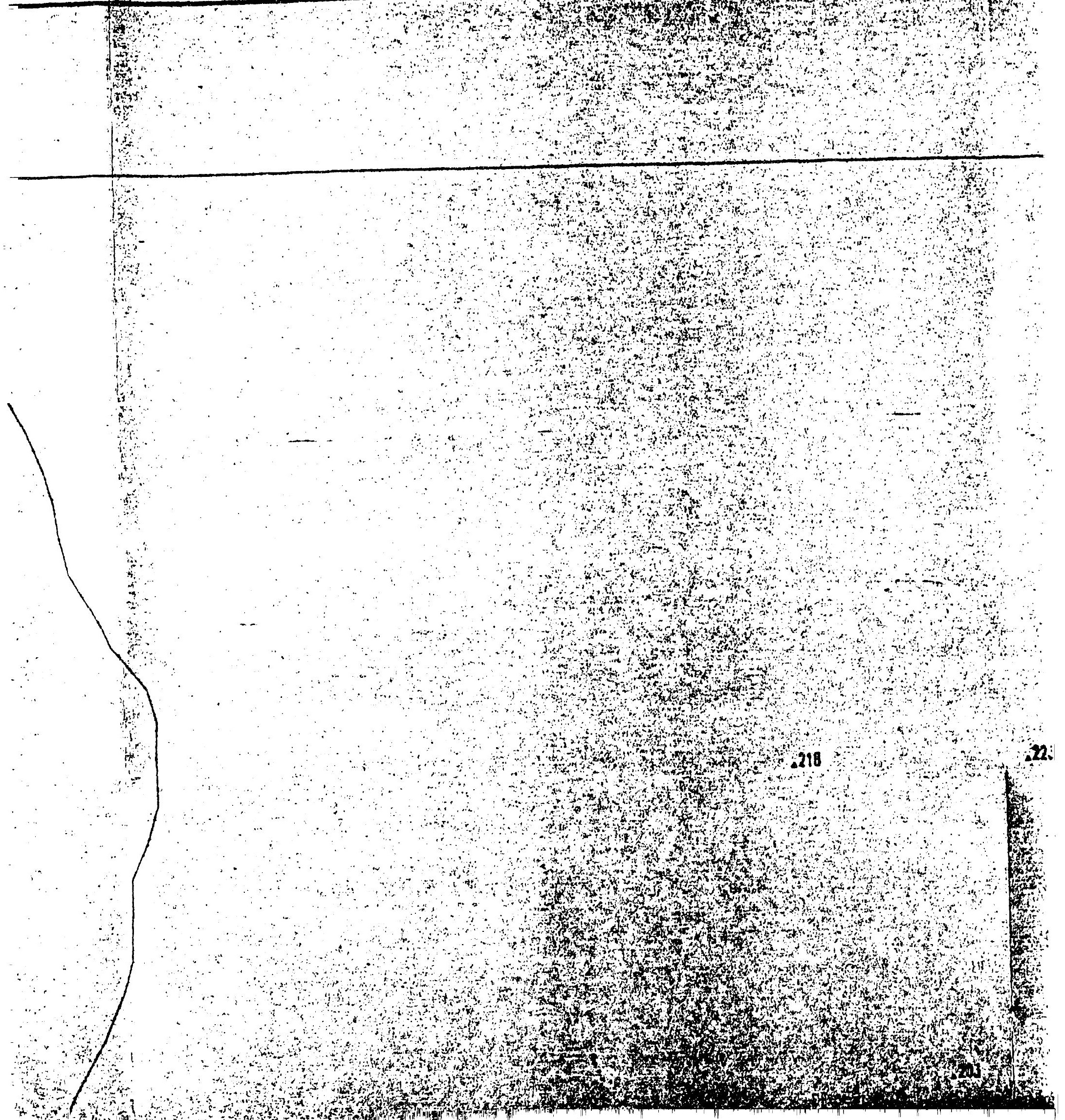




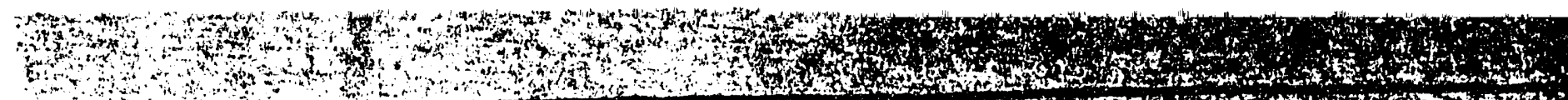

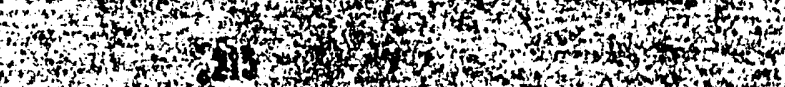

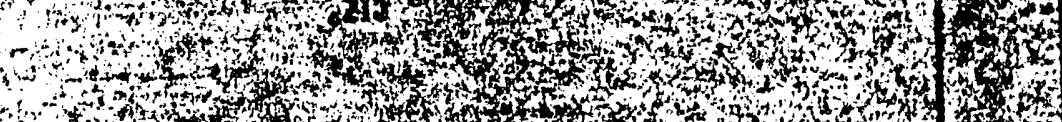




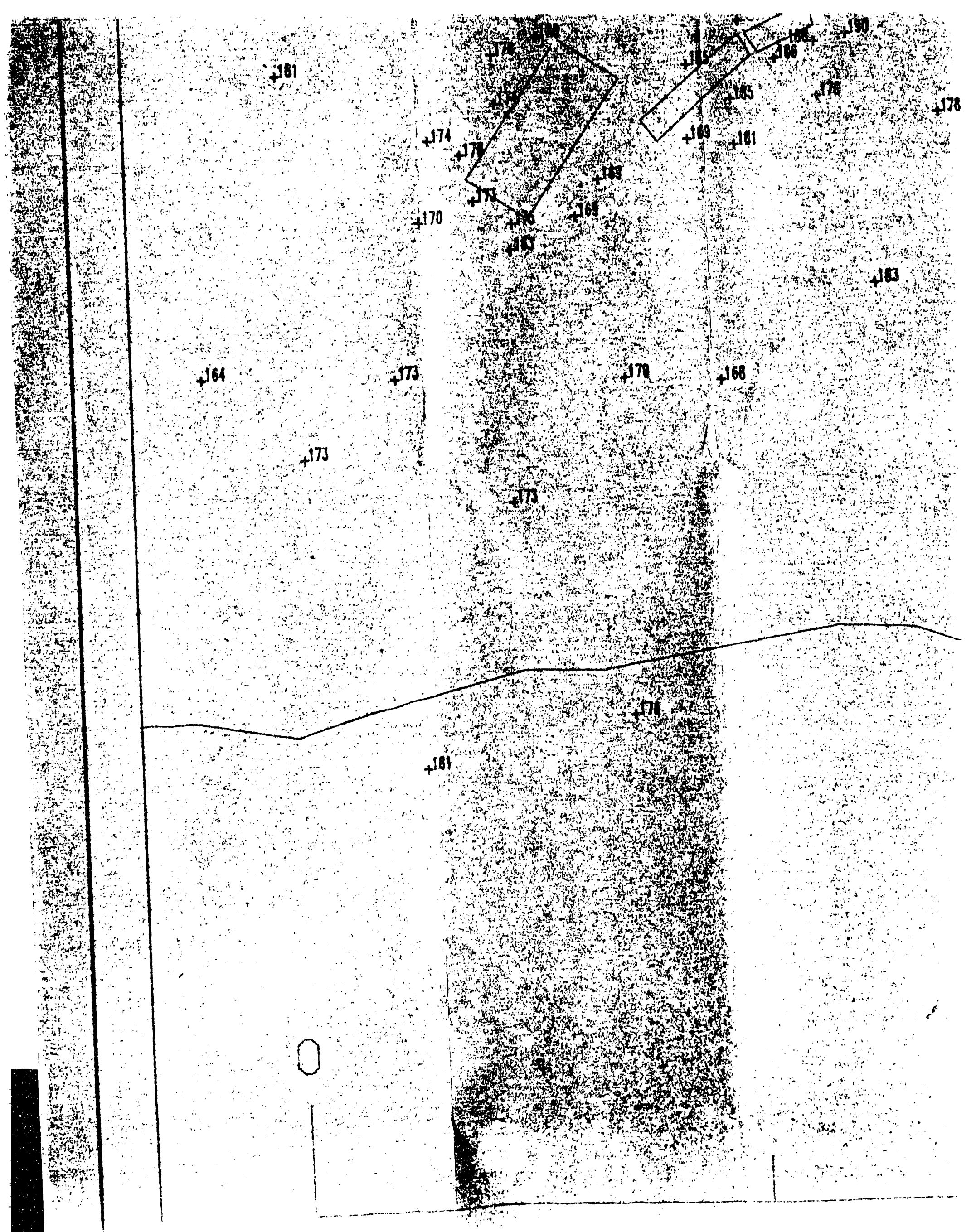




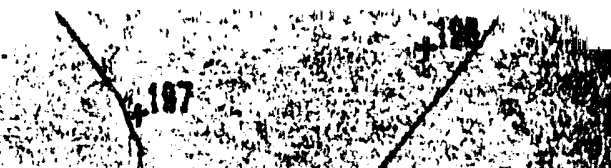

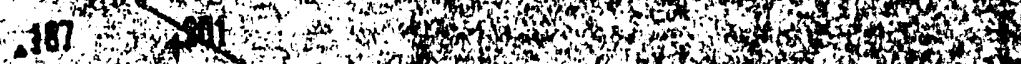

185. $10 \mathrm{xl}$

2ois

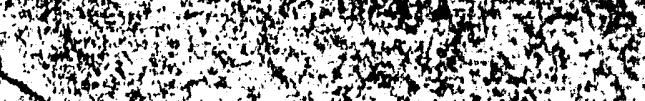

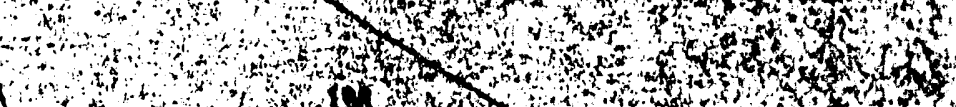

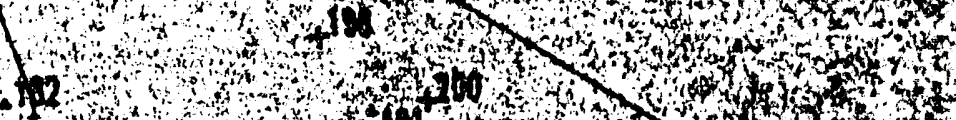

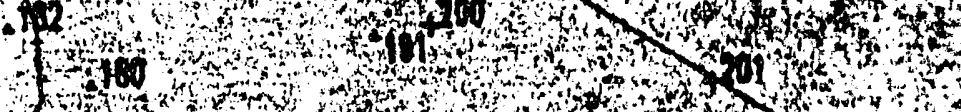

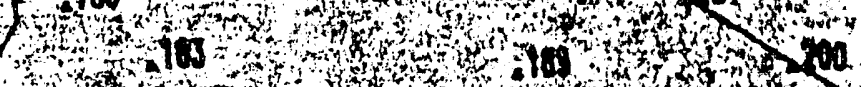

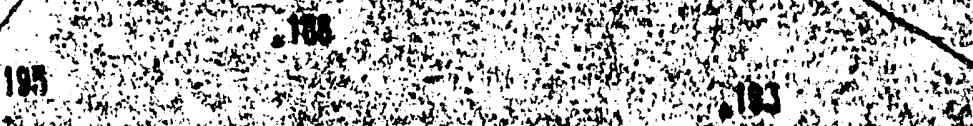

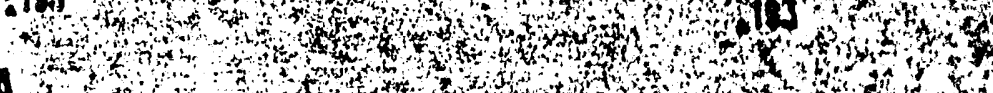

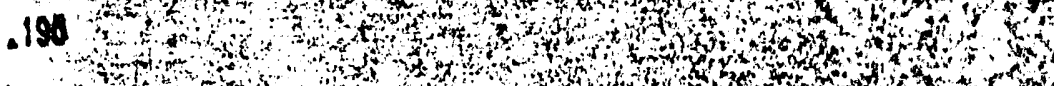

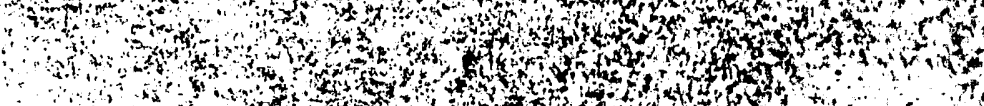

3

$+998$

\section{0}

.195

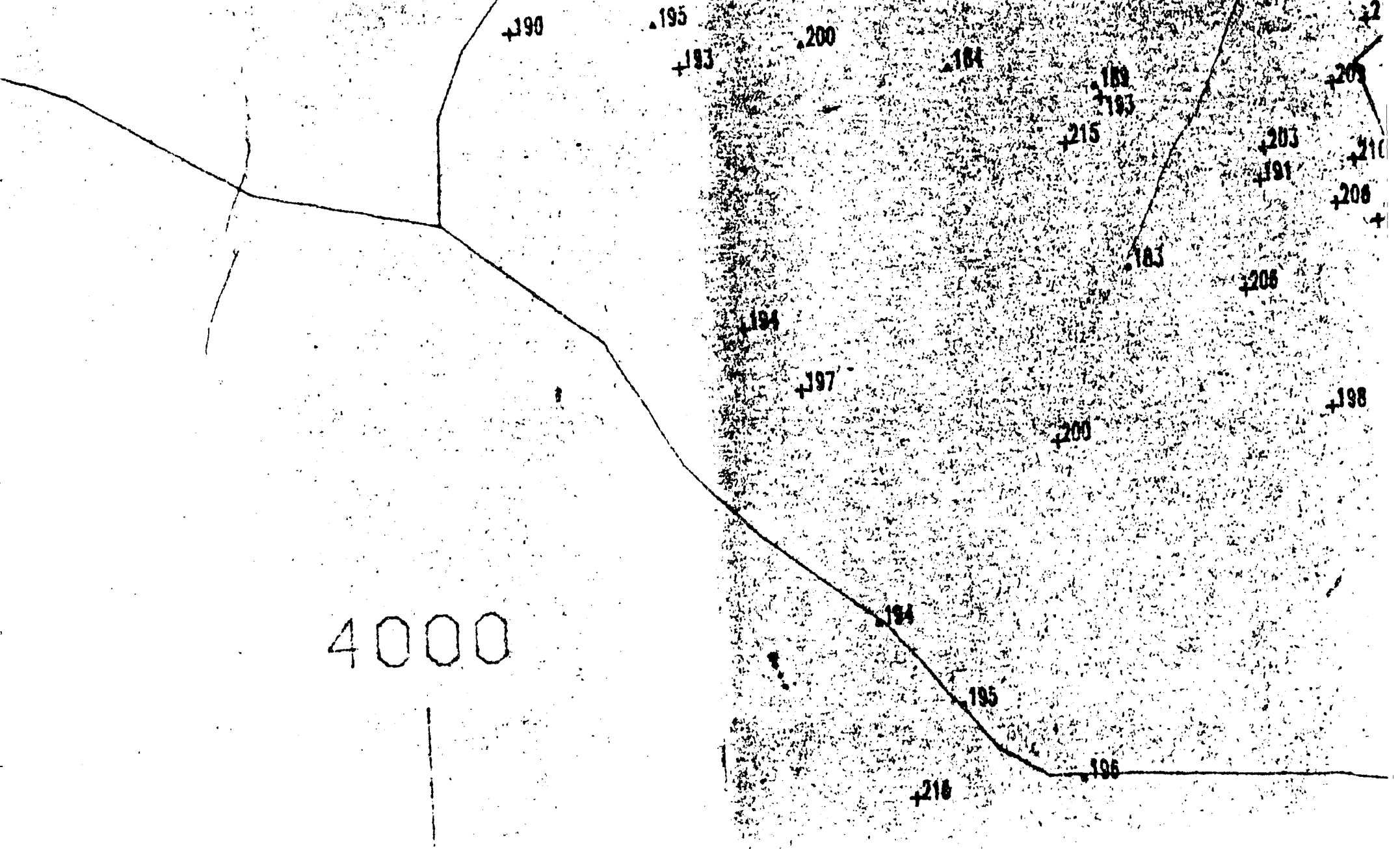




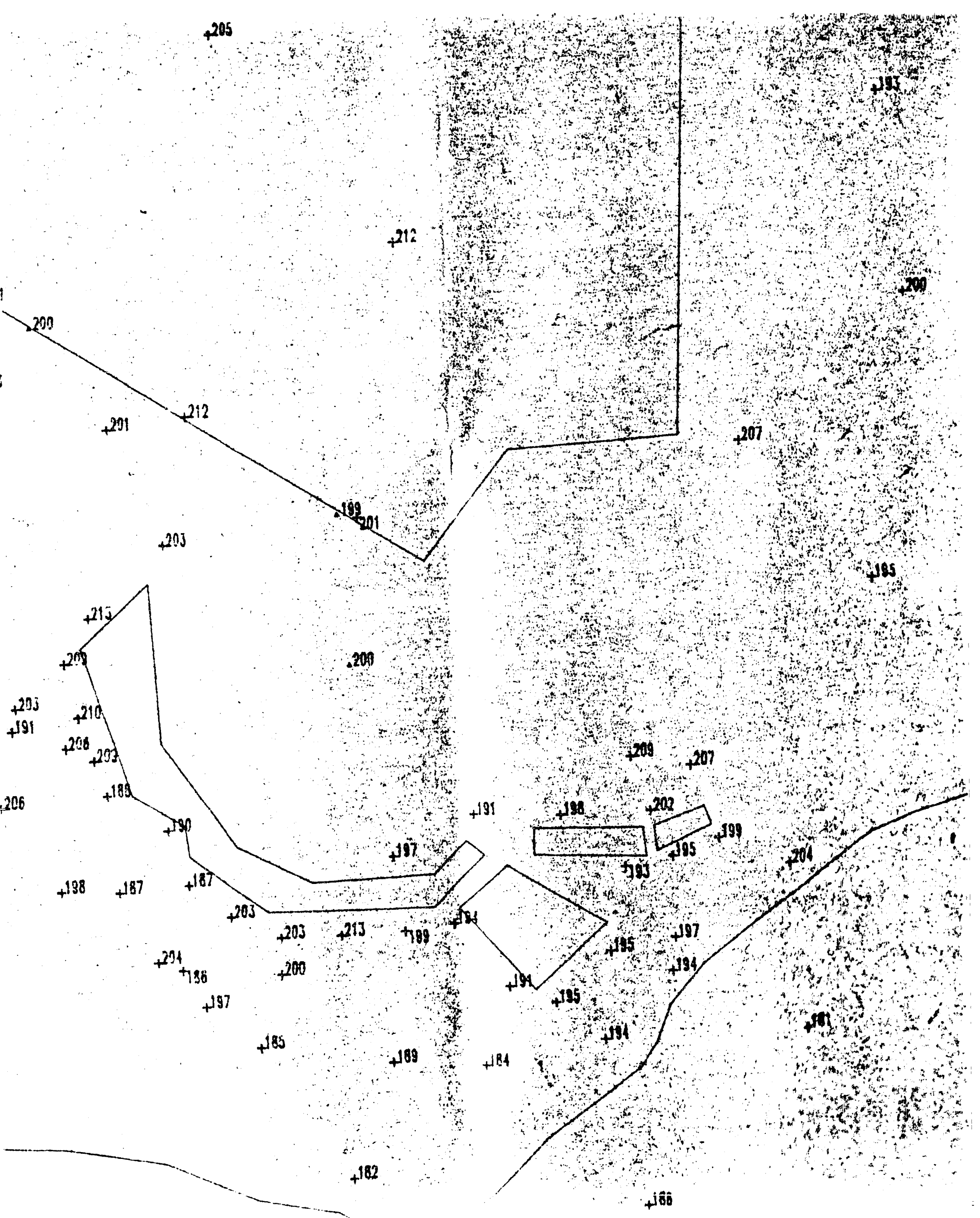




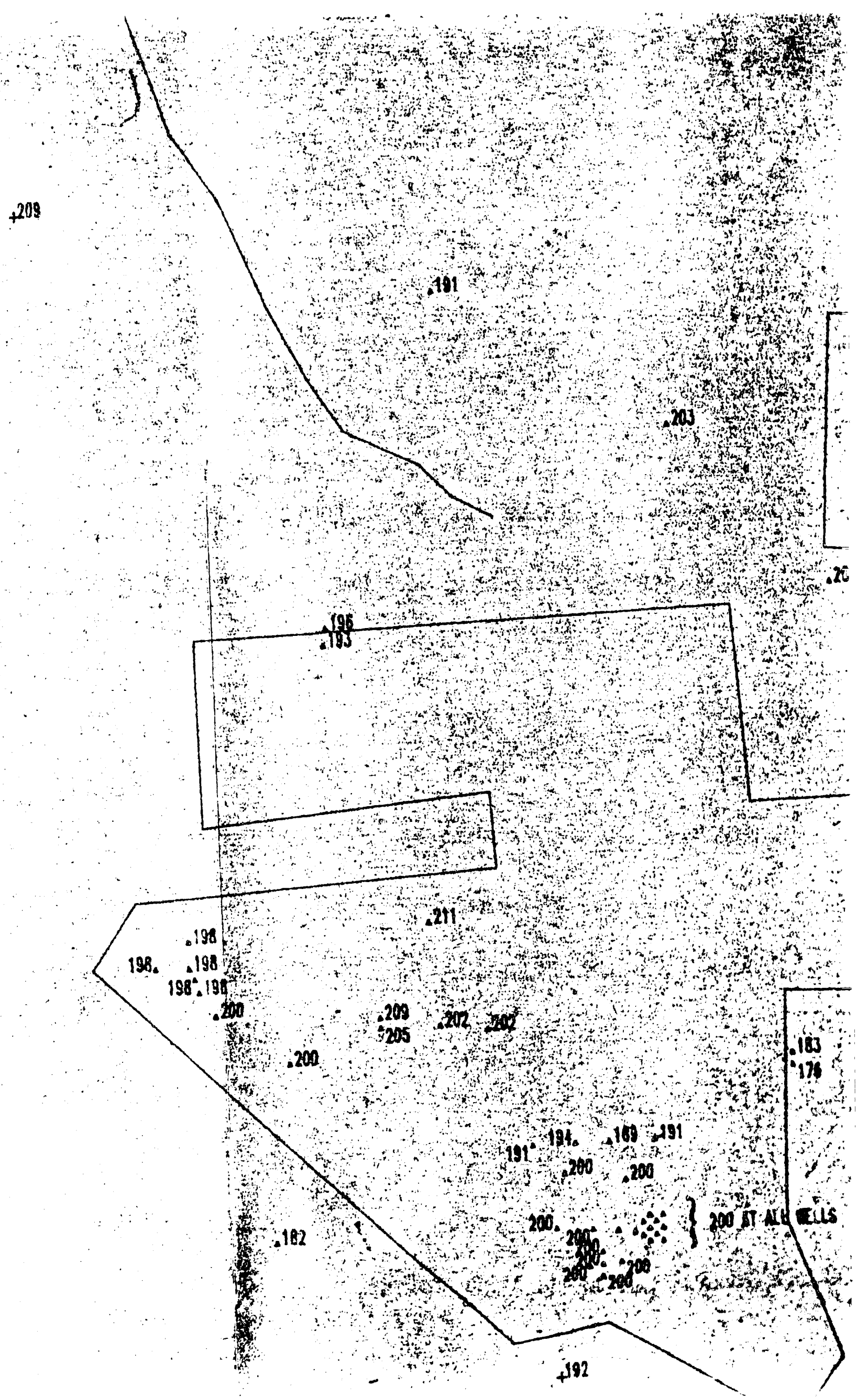




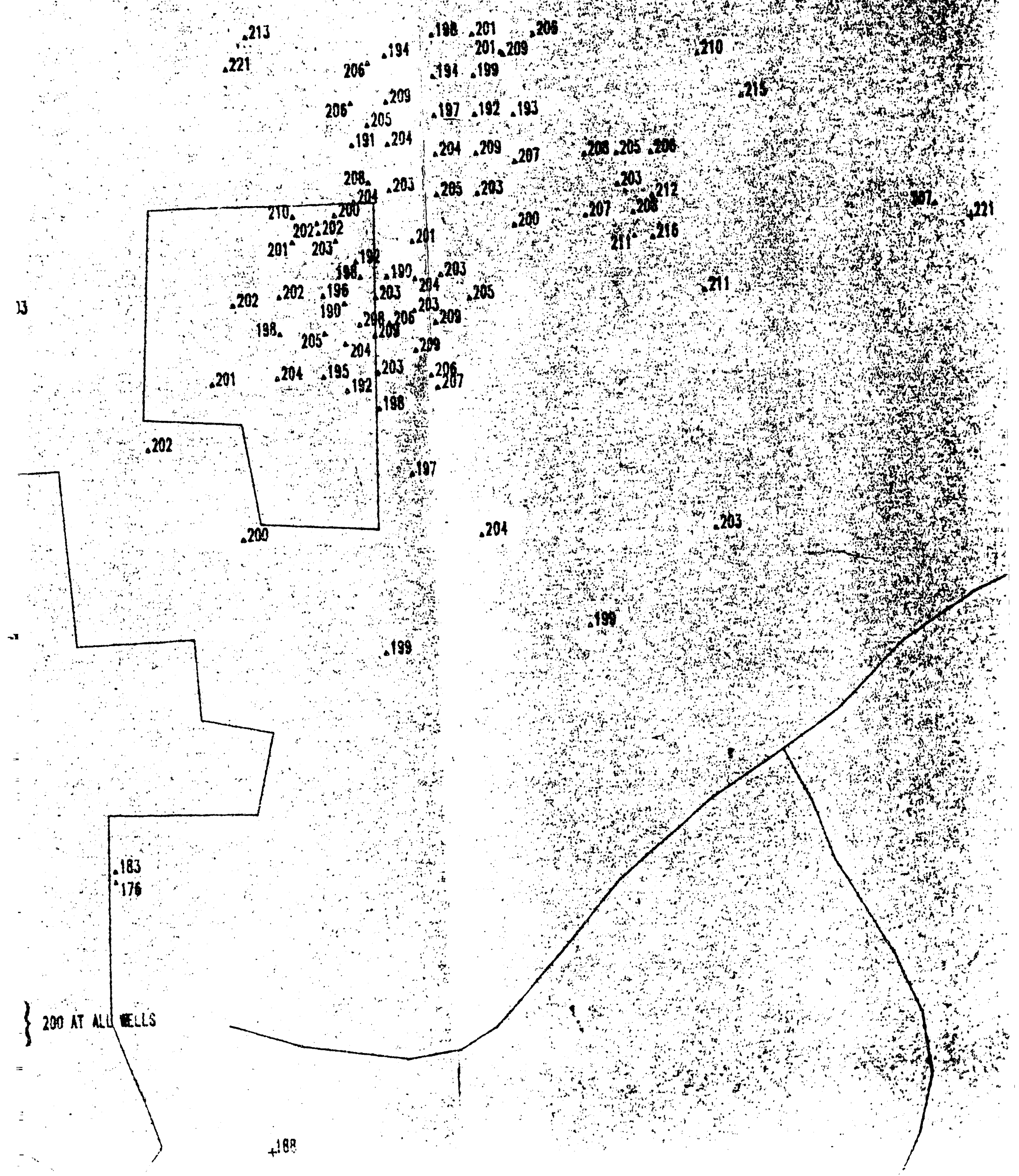


.213

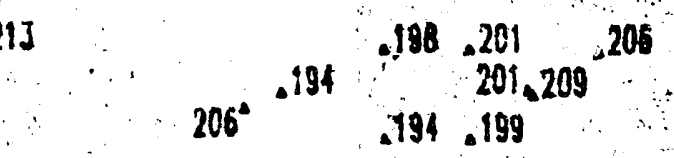

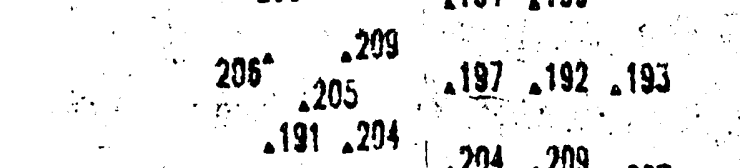

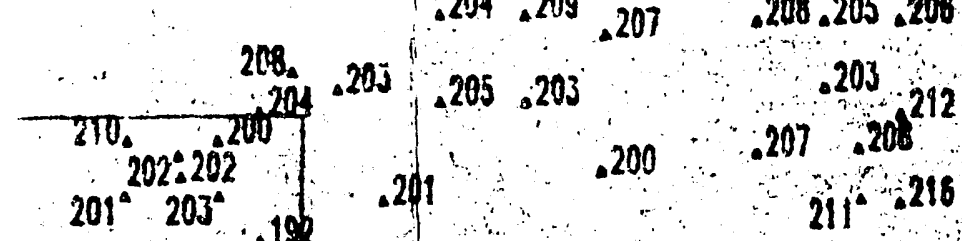

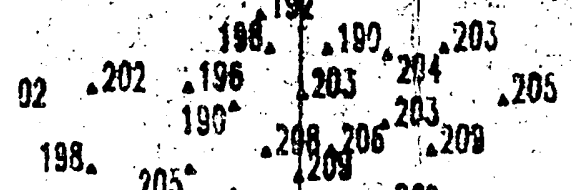

198. $205^{\circ}=\left.204\right|^{2009} \cdot 2209$

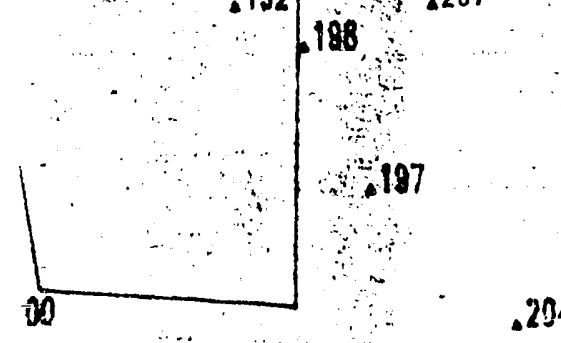

208.205 .200

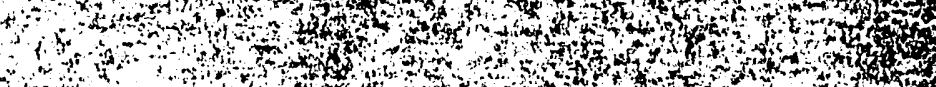

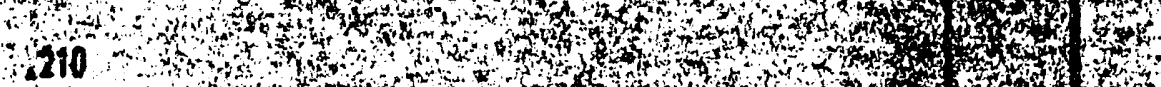

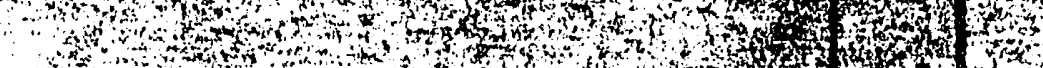

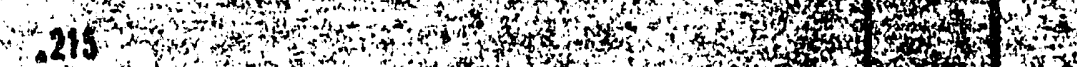

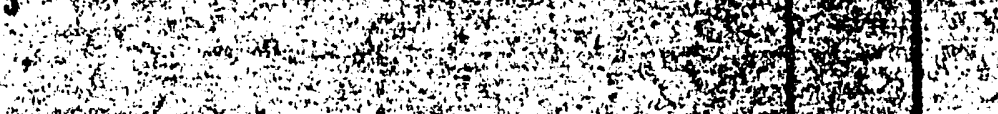

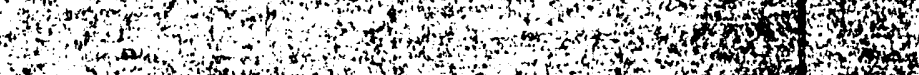

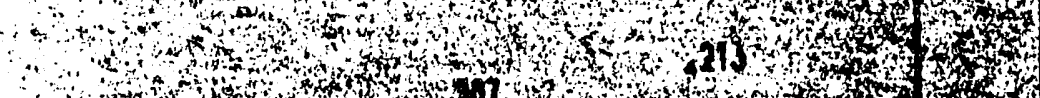

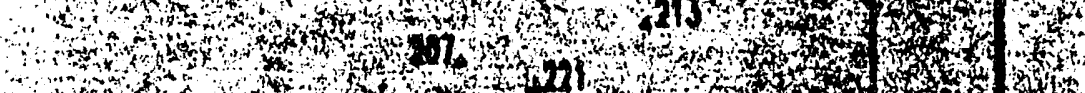

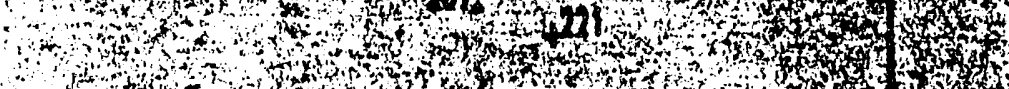

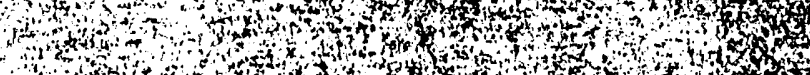

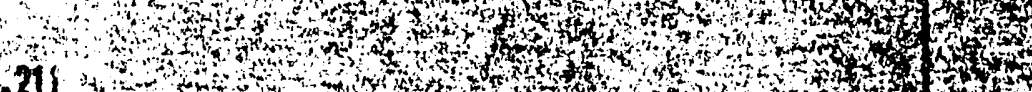

-

294

.199

.199
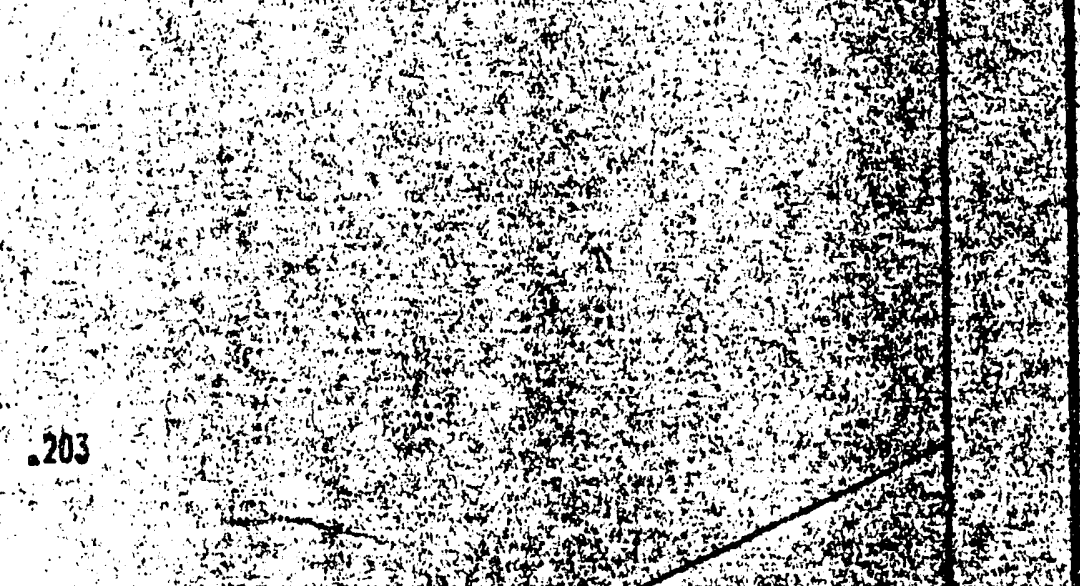

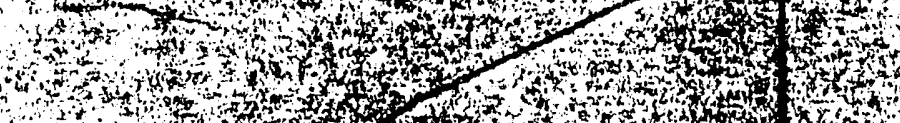

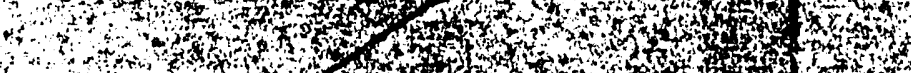


$4000, y+1)$ 


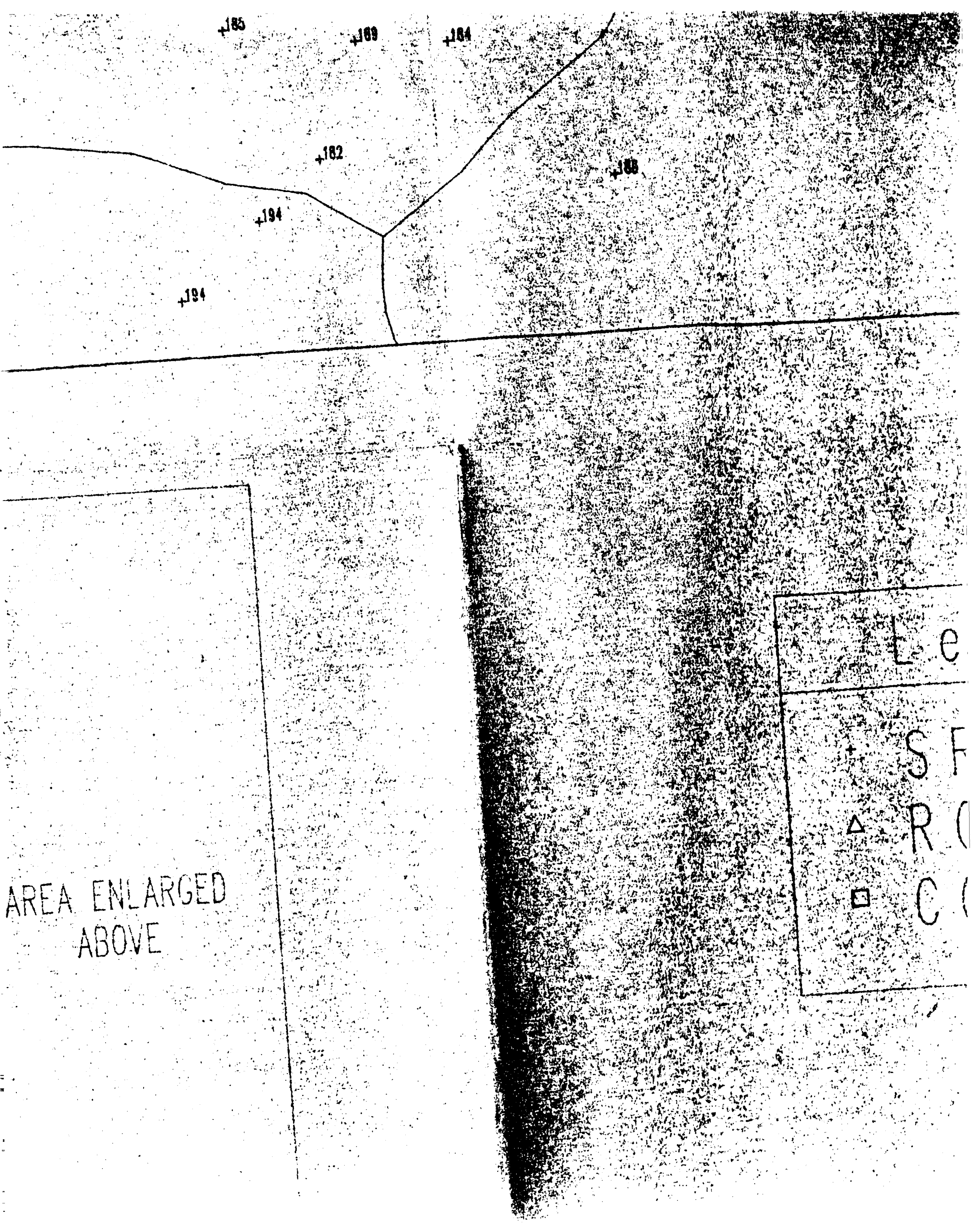




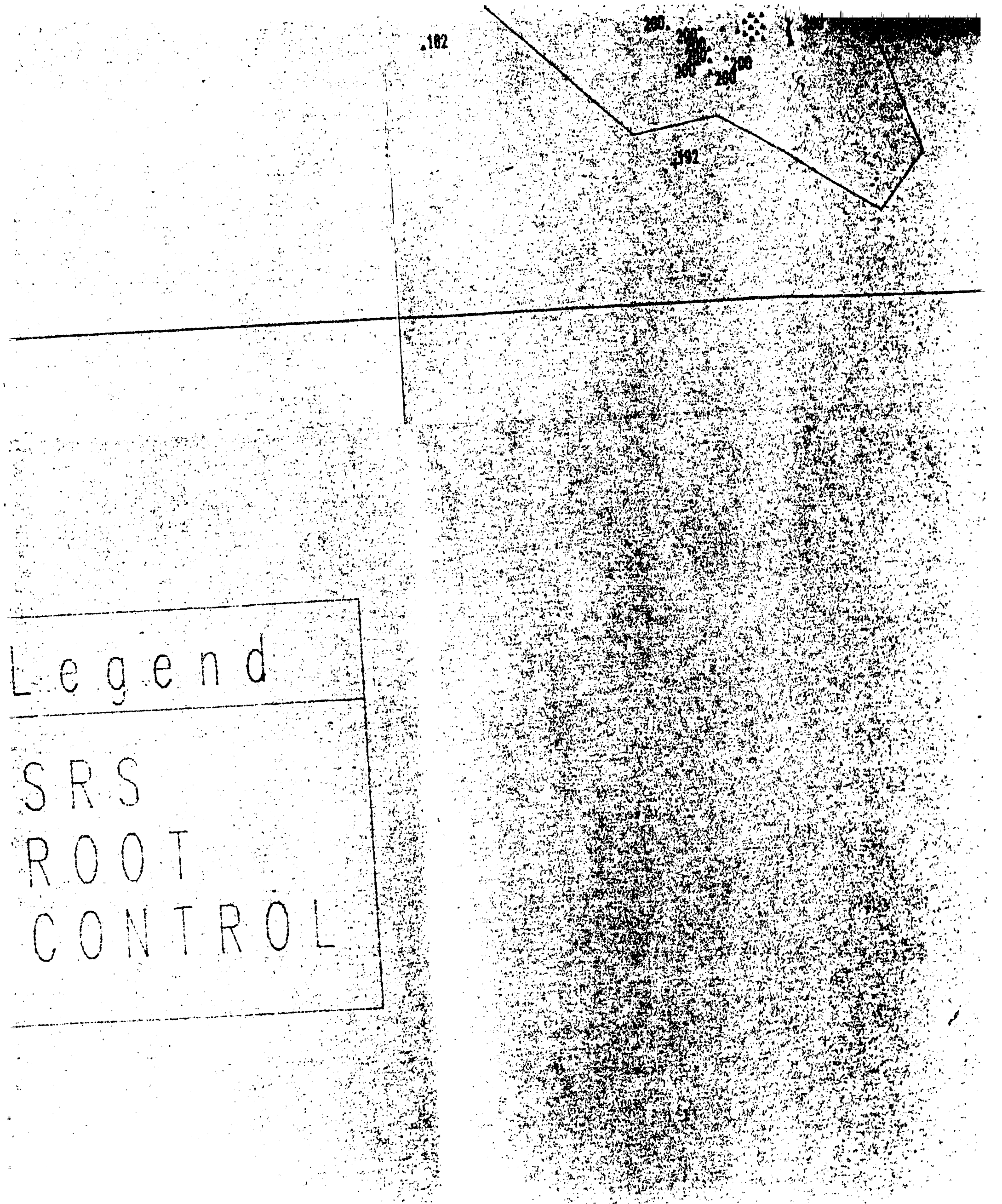




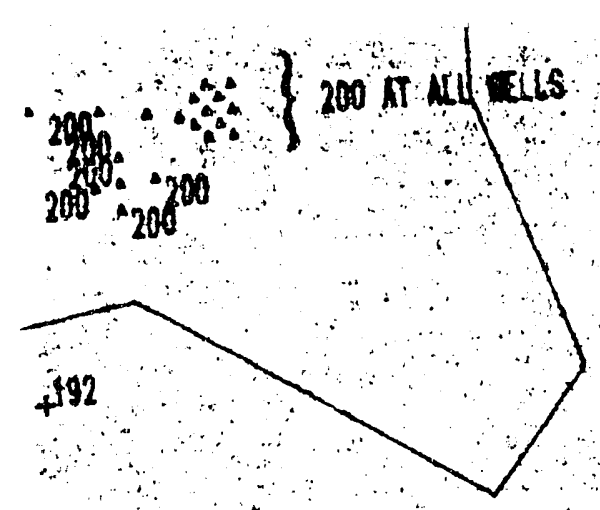

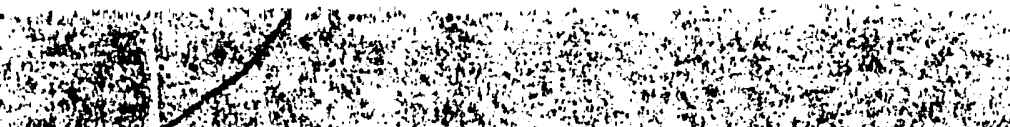

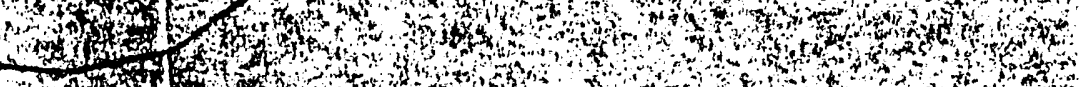

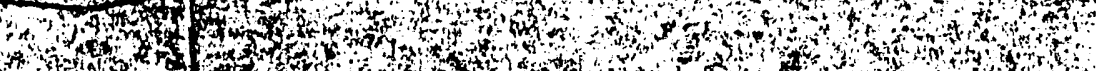

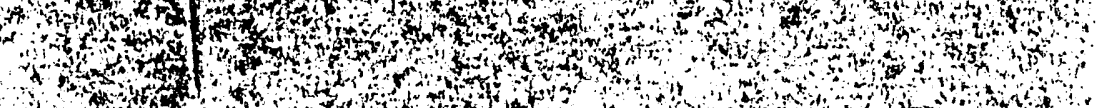

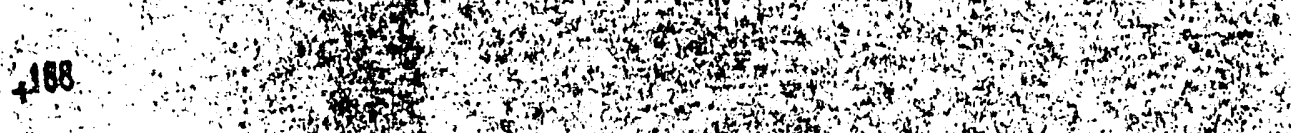

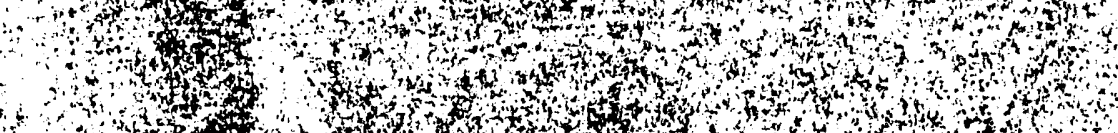

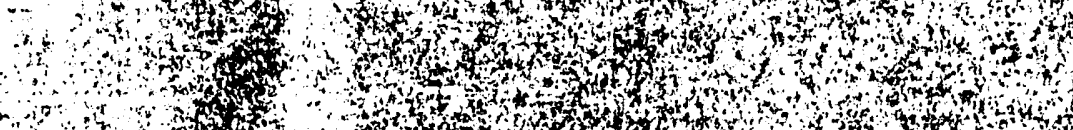
of

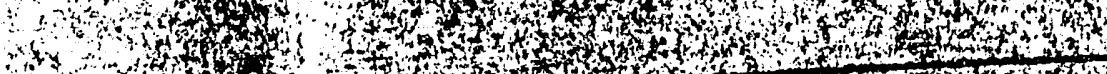

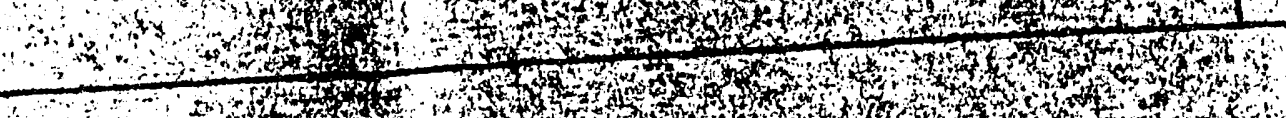

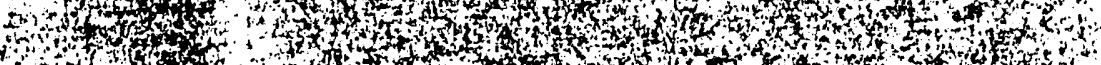

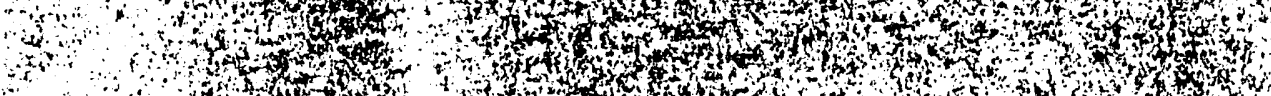

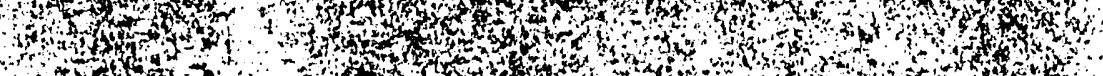

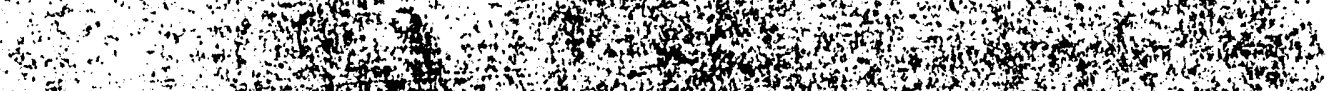

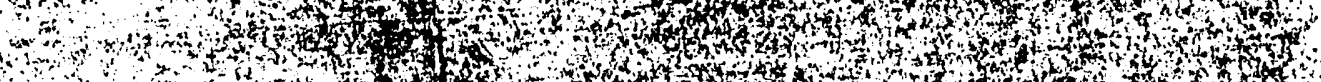

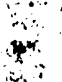

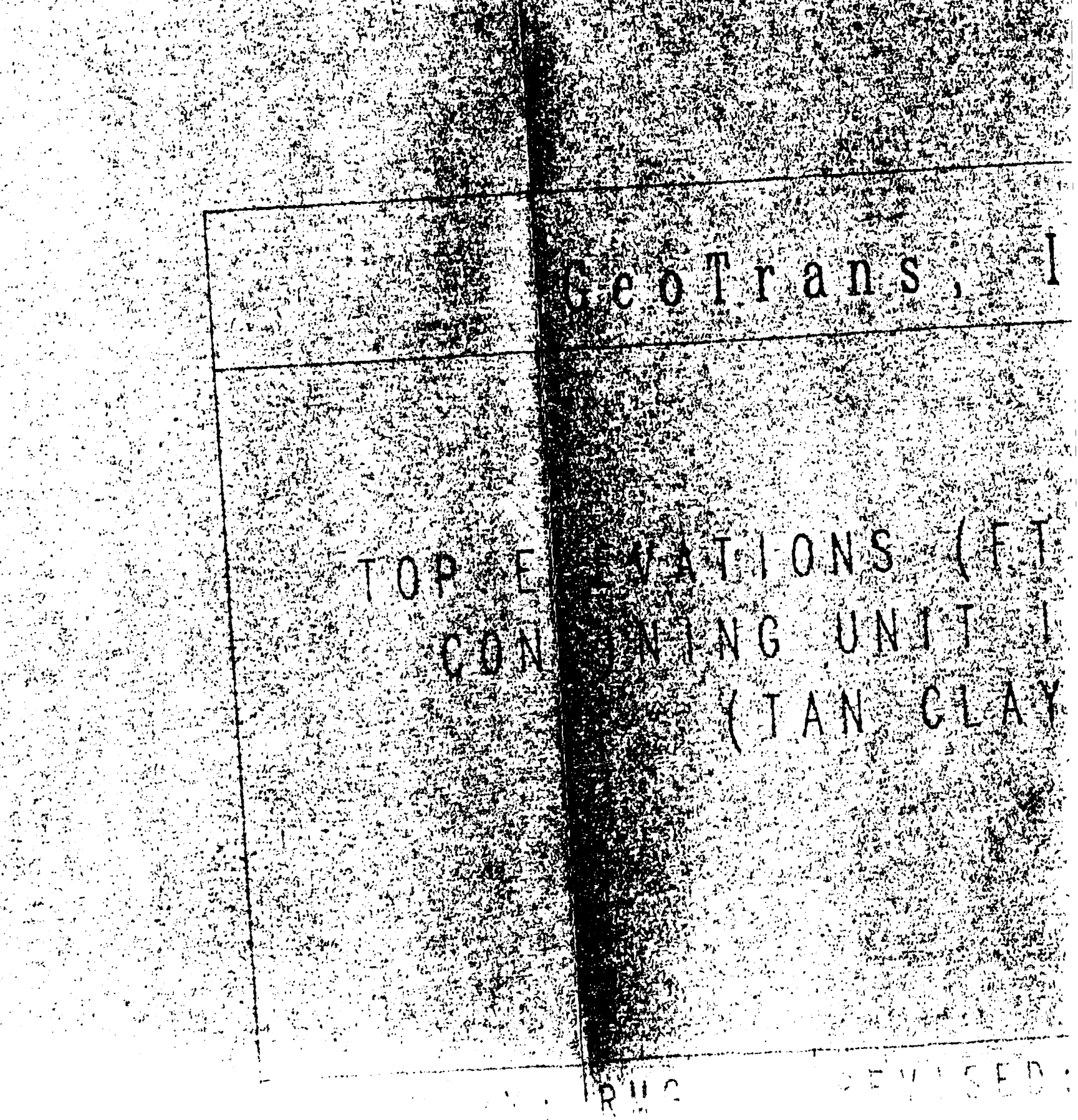



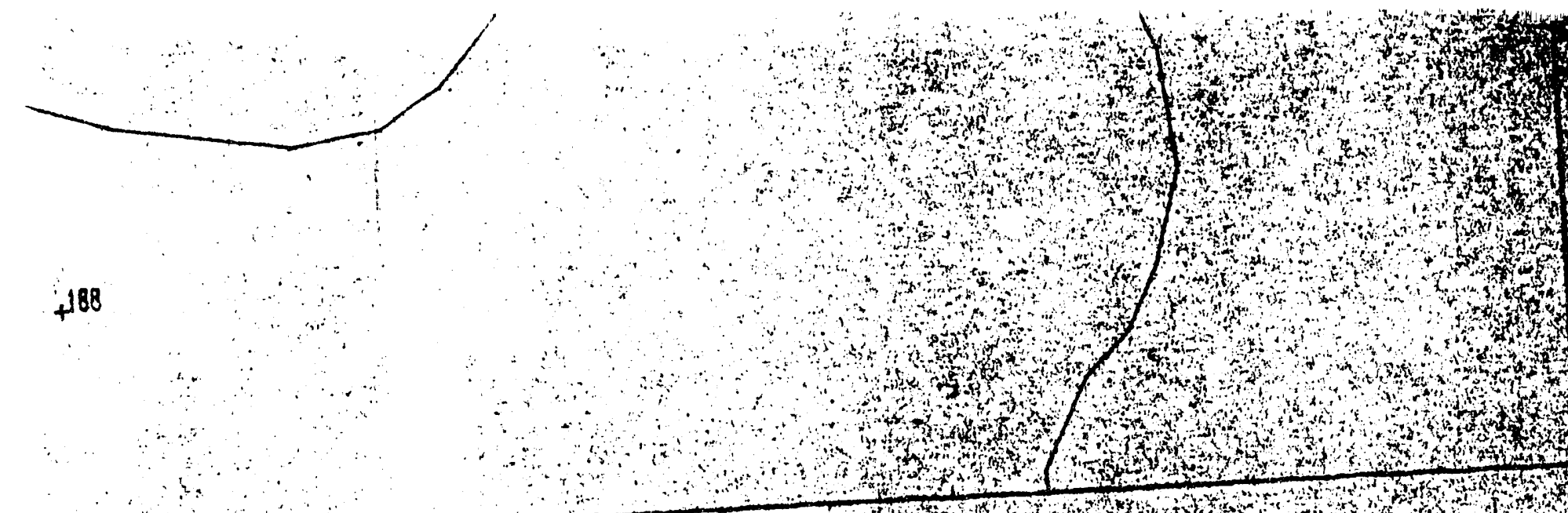

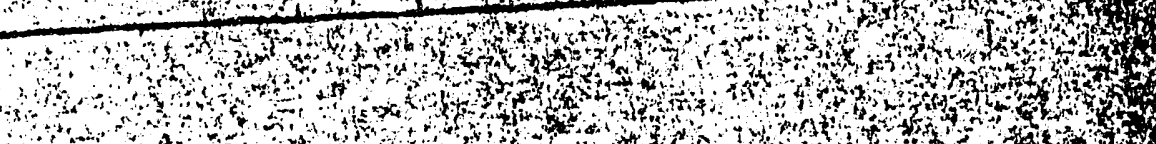

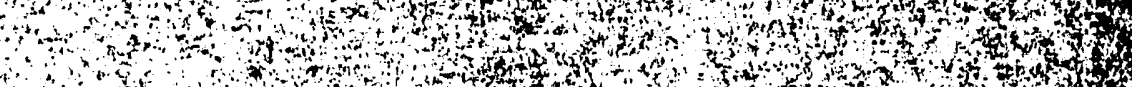

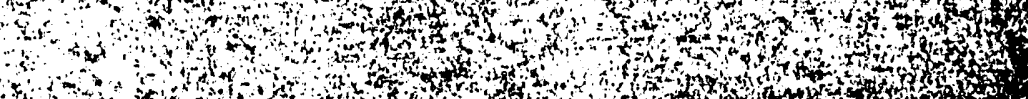

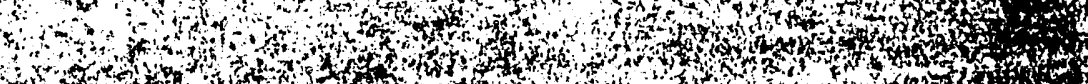

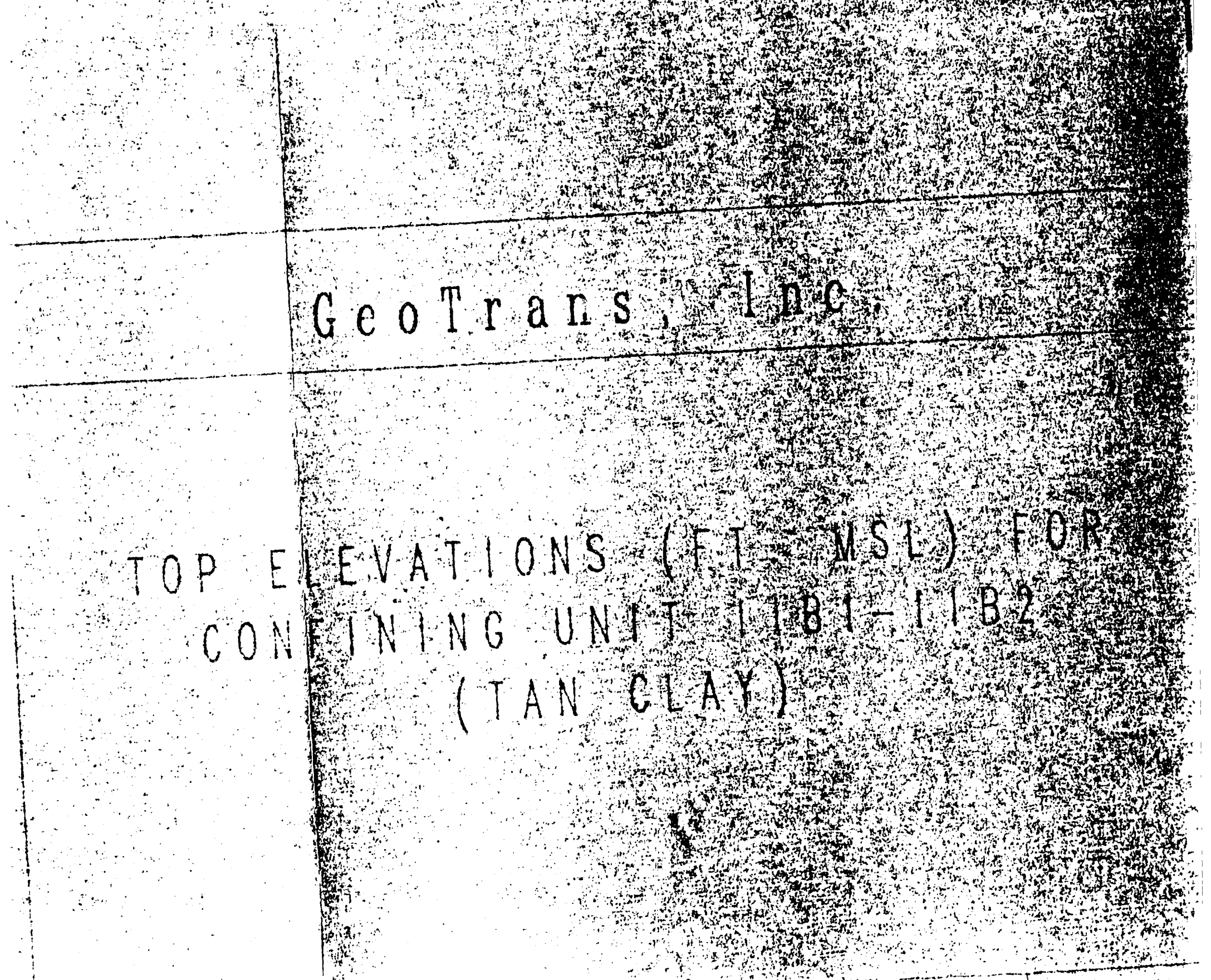




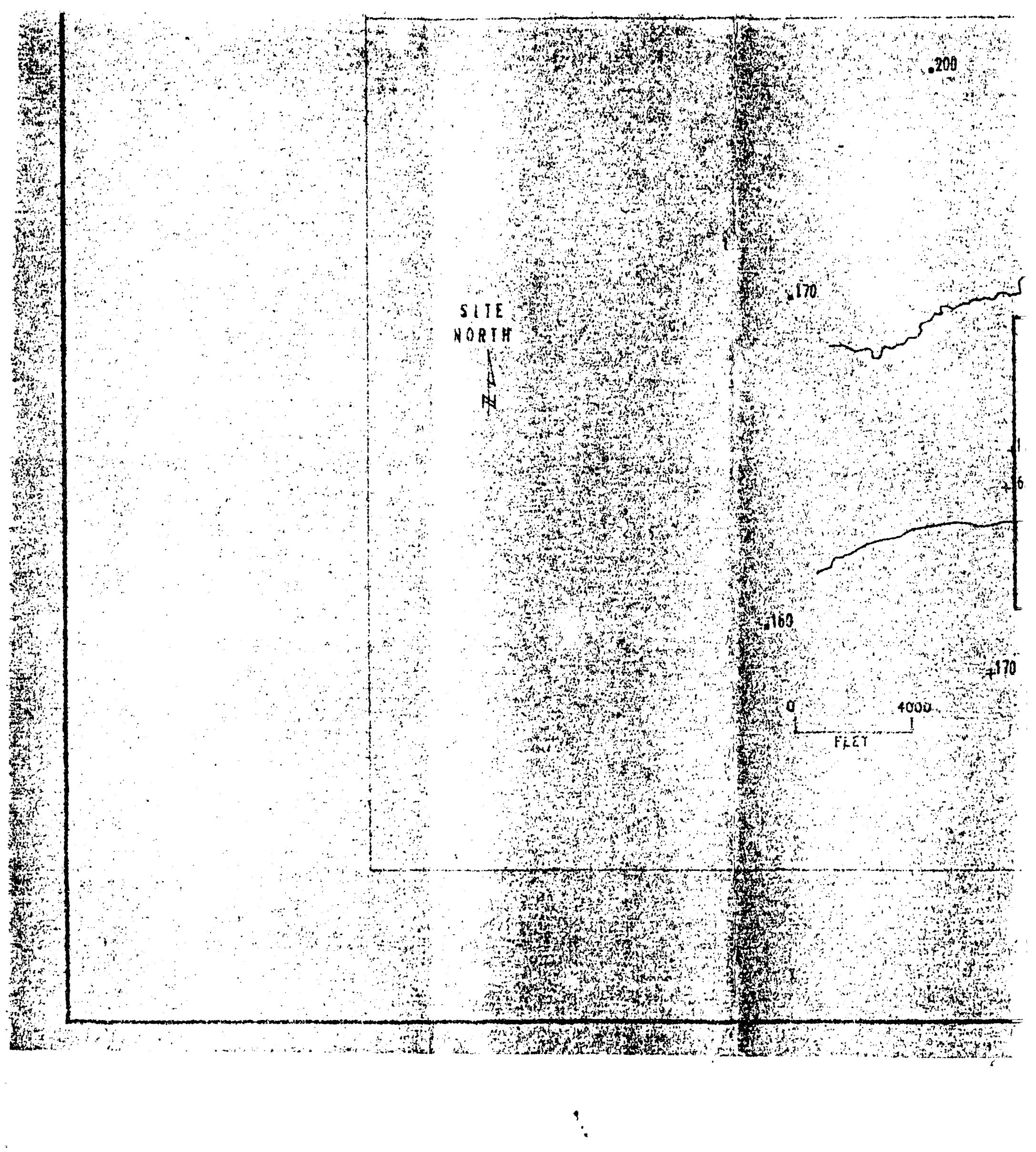




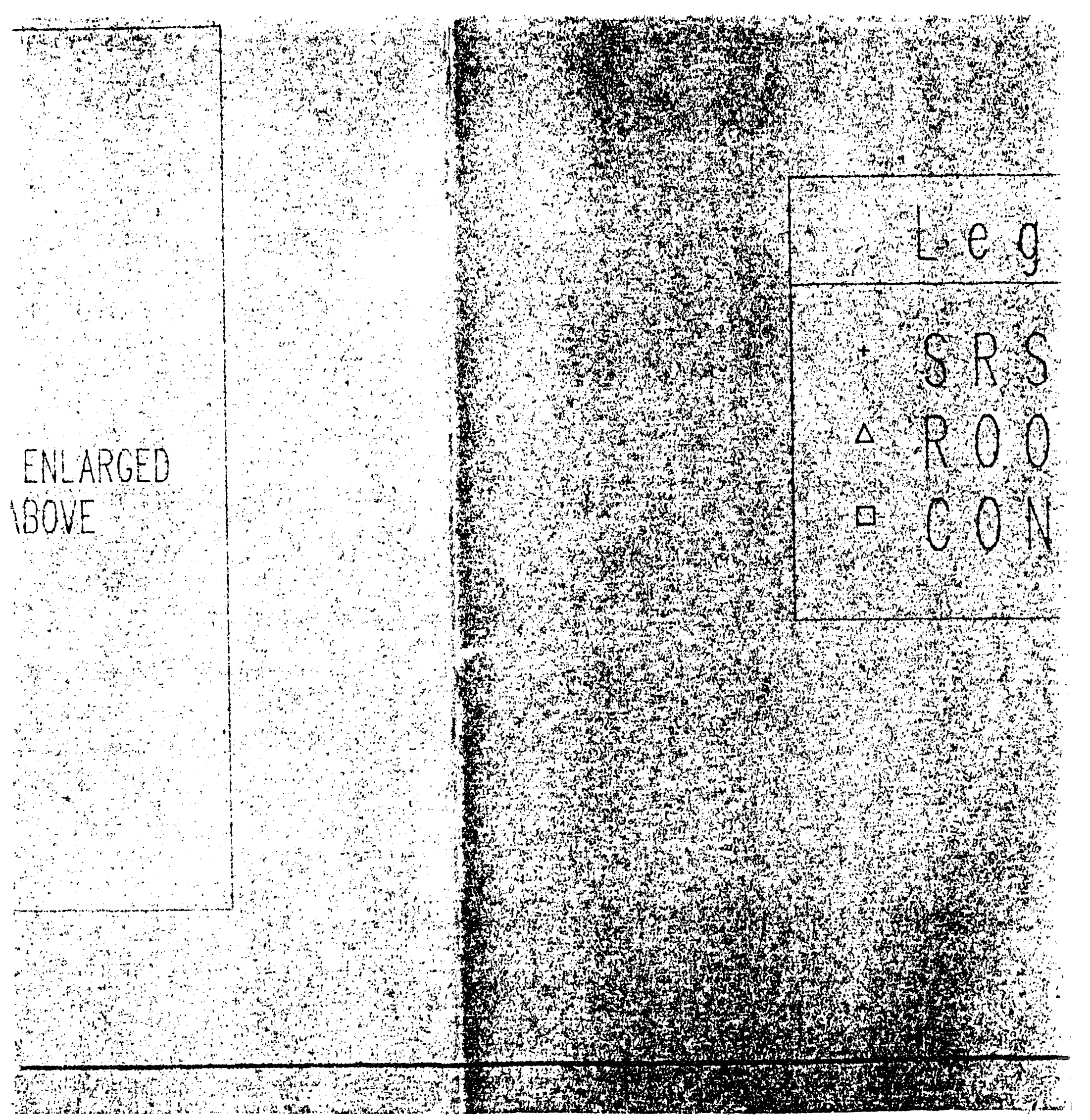




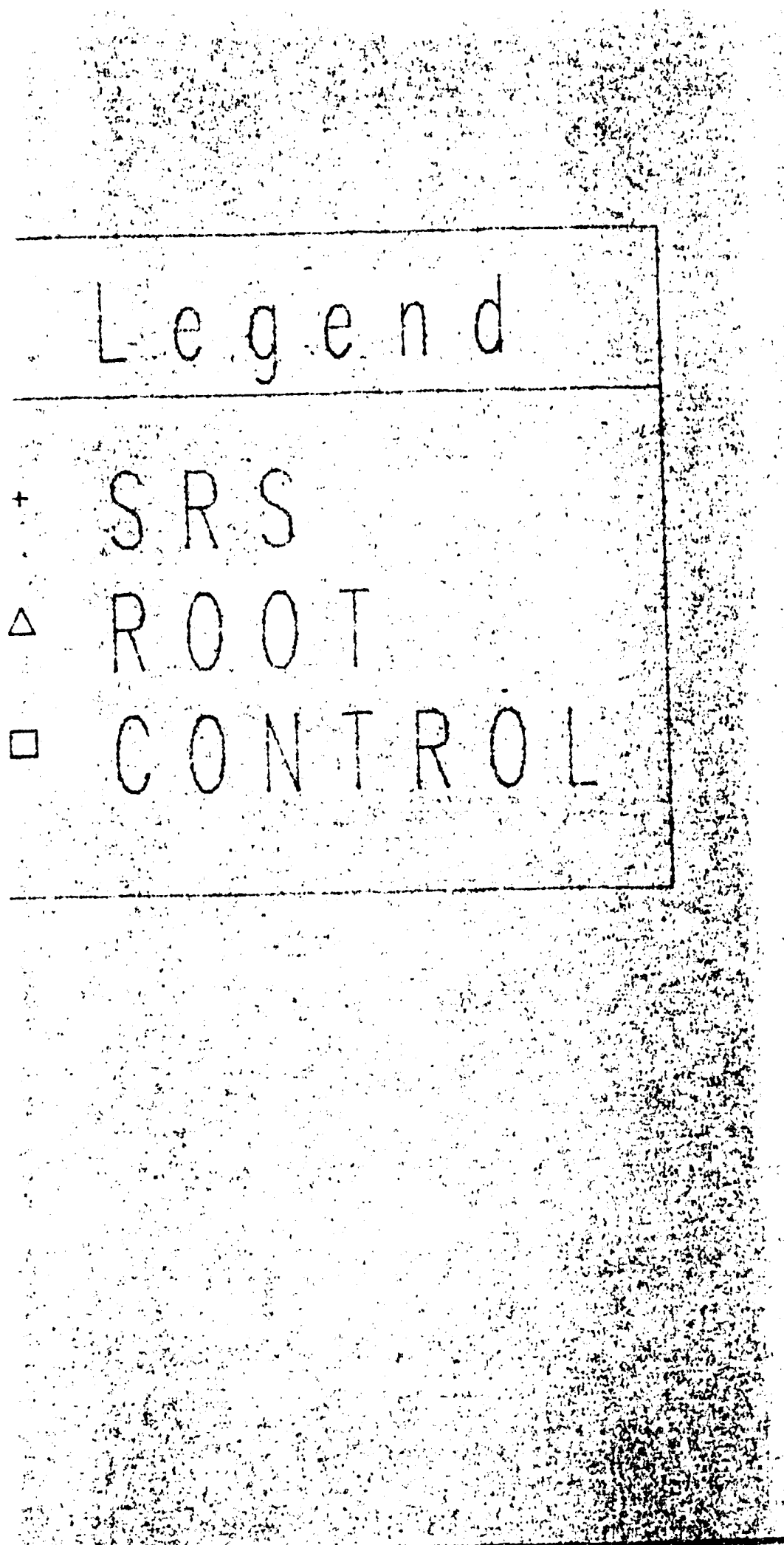

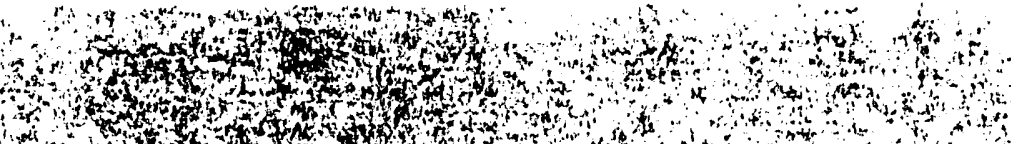

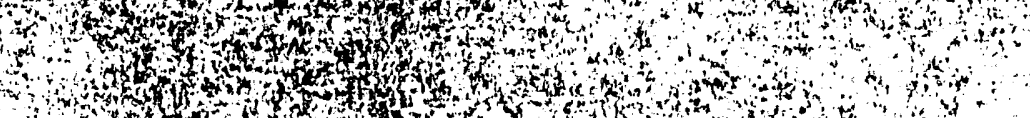
,

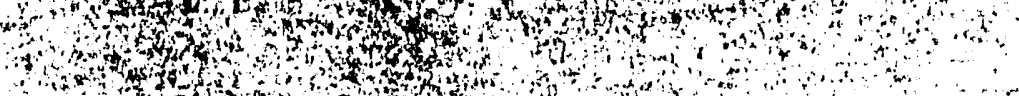

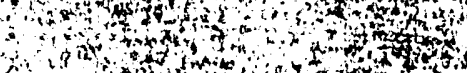

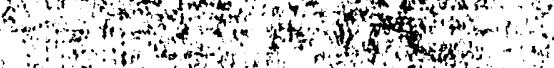

ac.

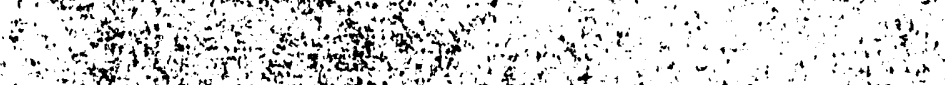

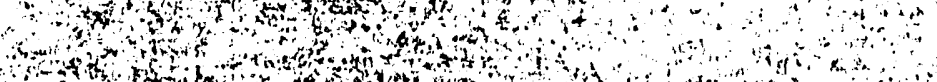

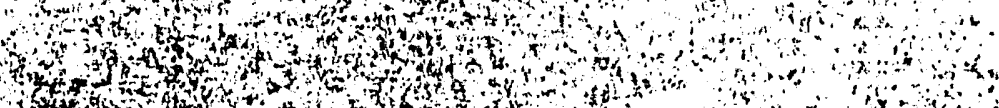

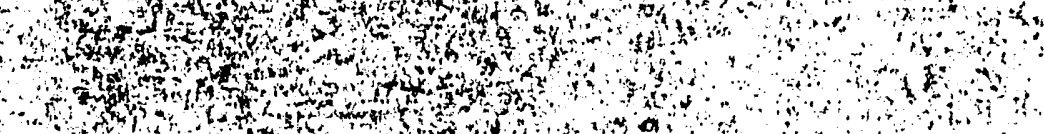

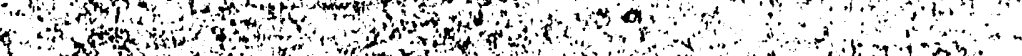

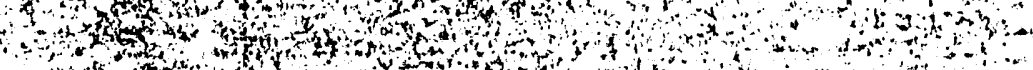

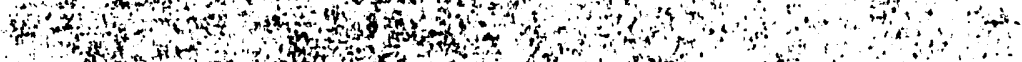

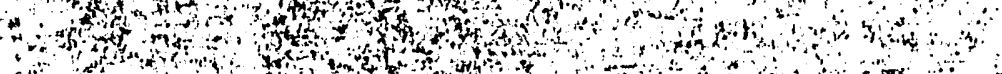

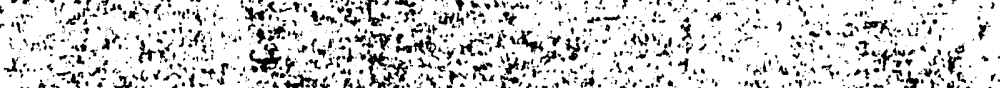

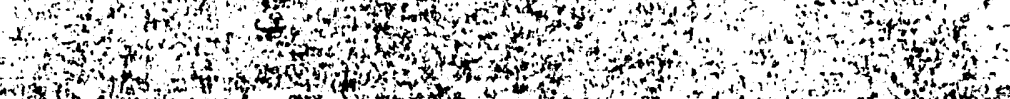

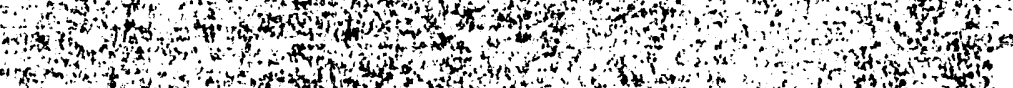

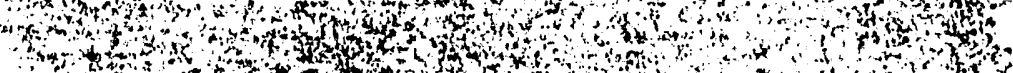

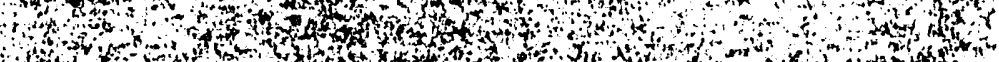

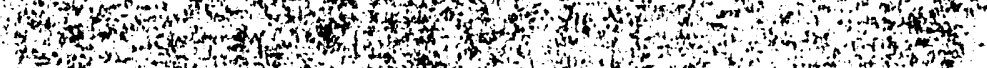

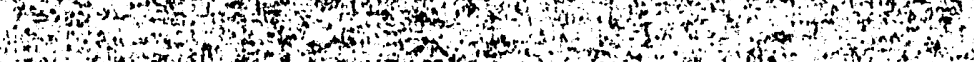

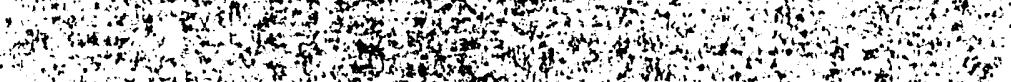

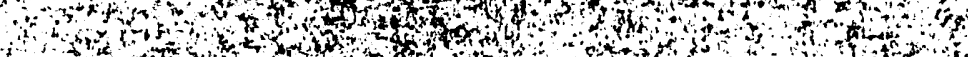

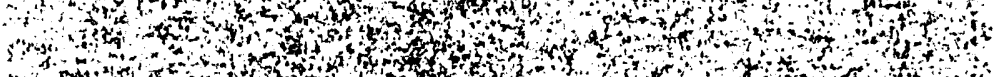

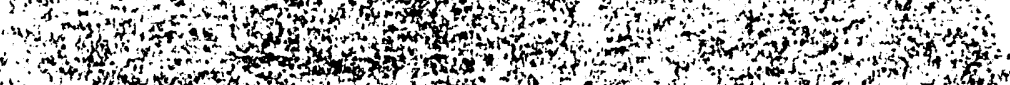

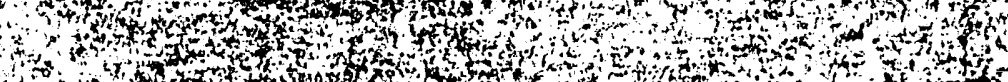
$n$
$n$

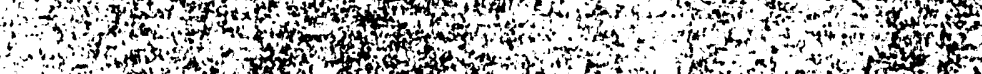

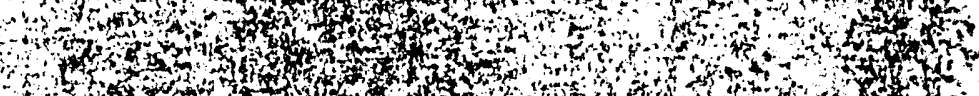

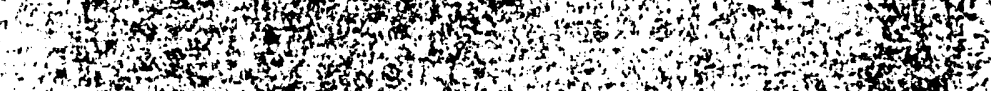

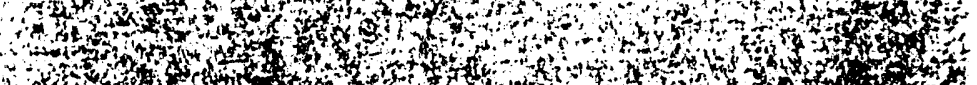

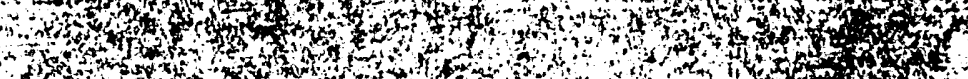

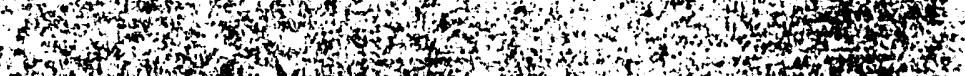

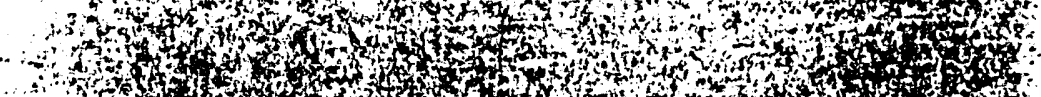
7. t in

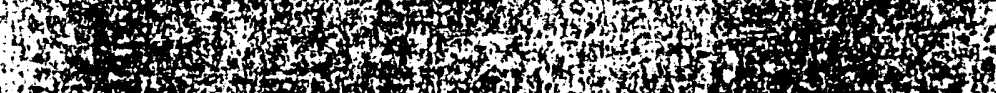

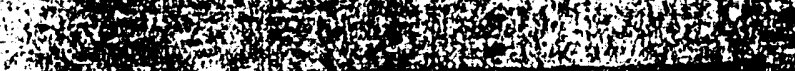

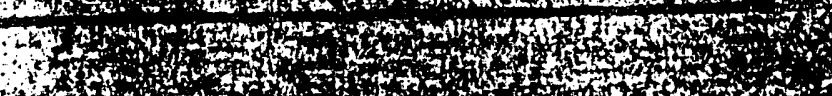

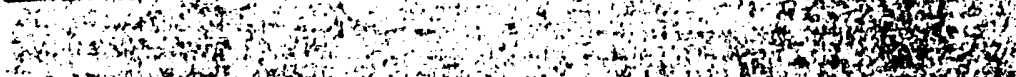

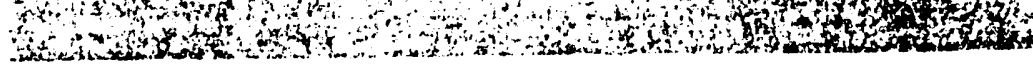




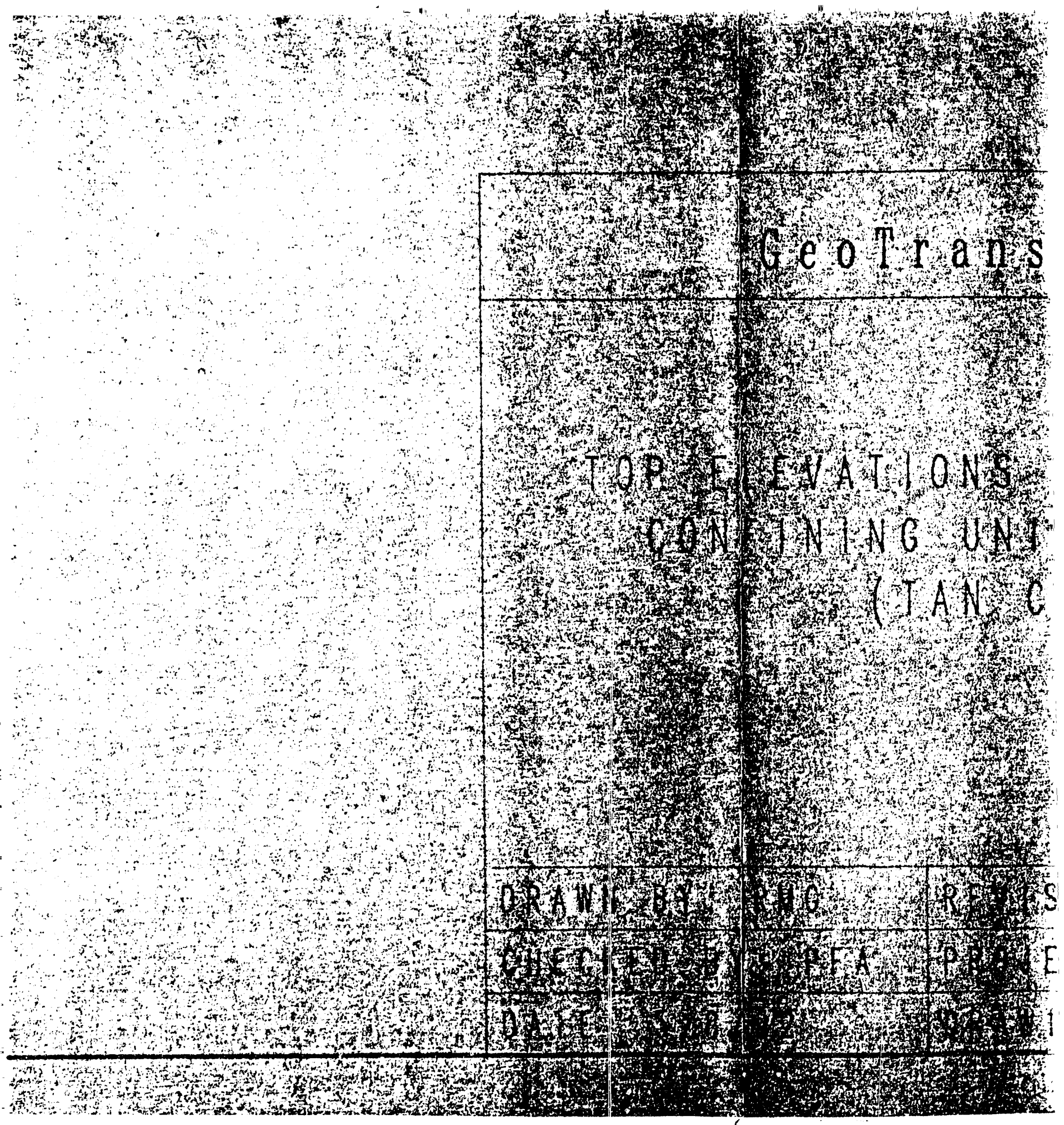




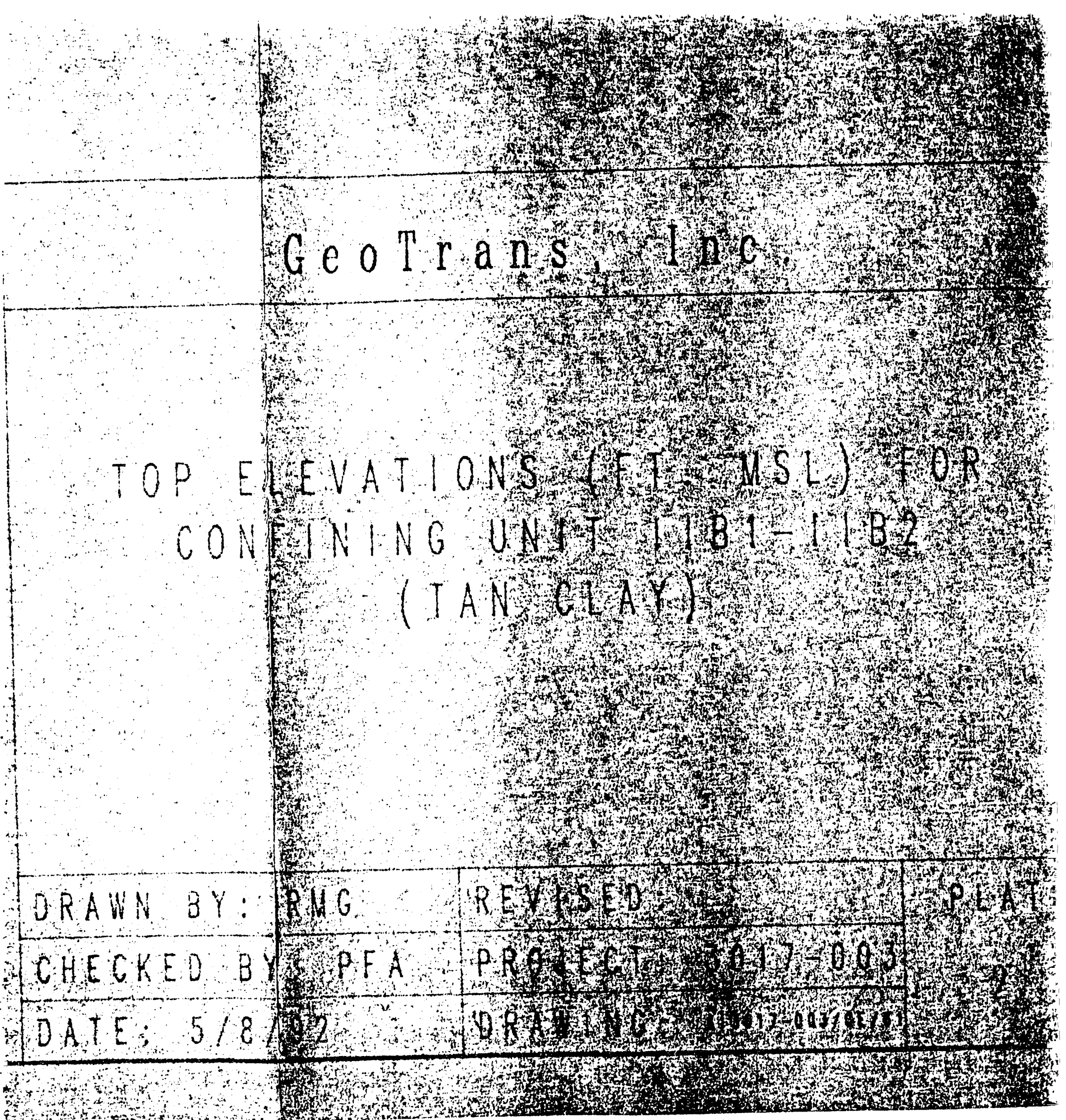




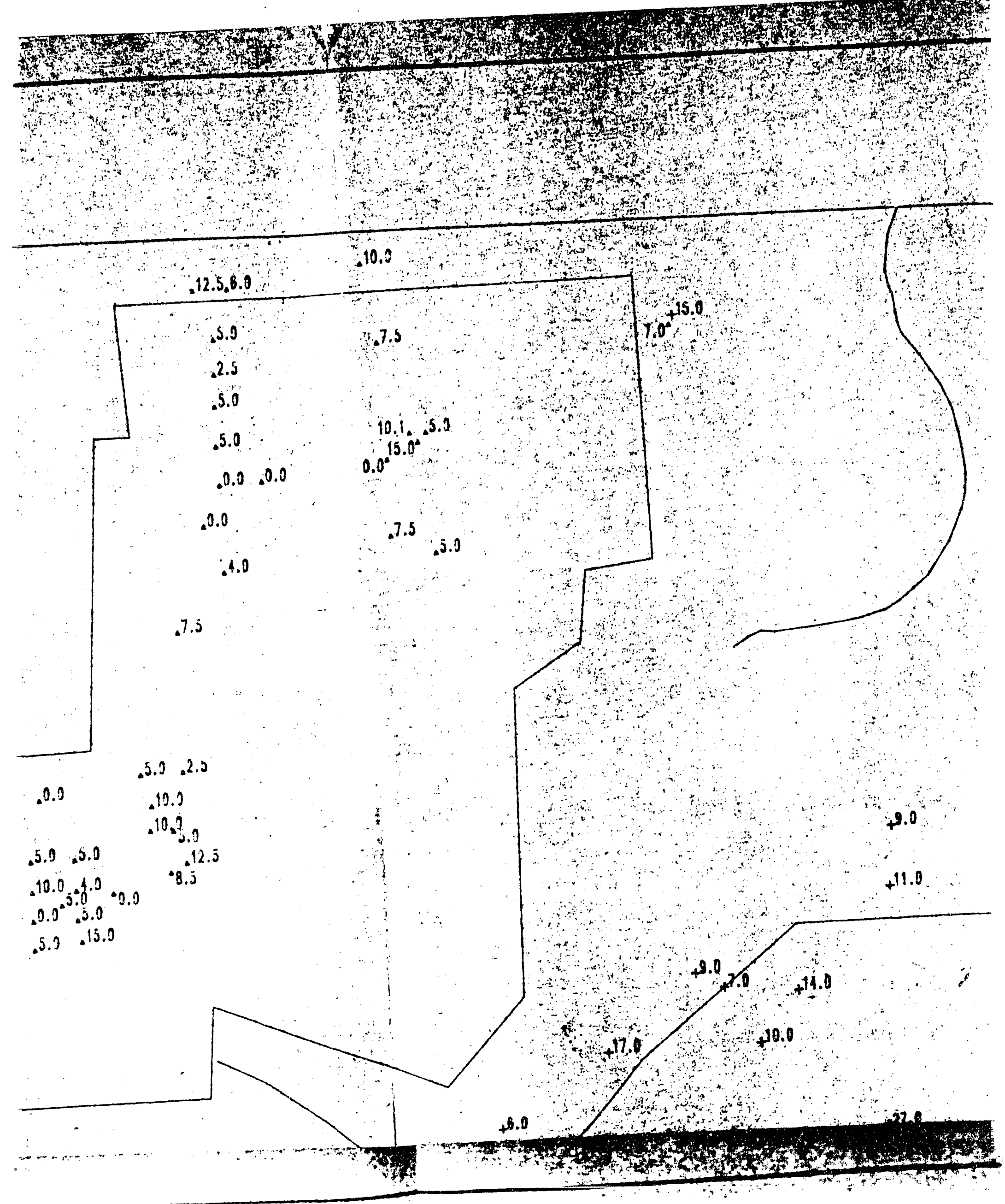




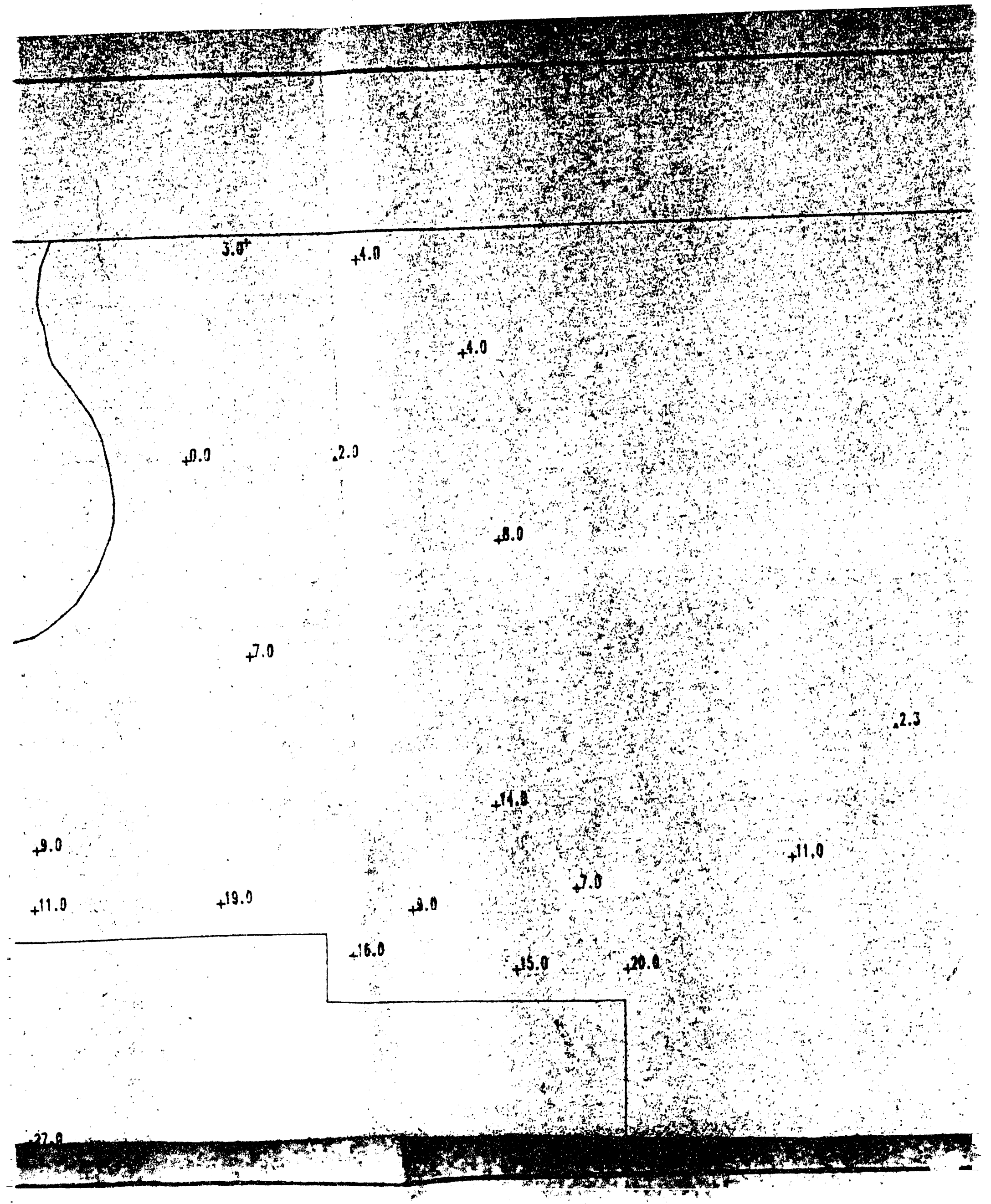




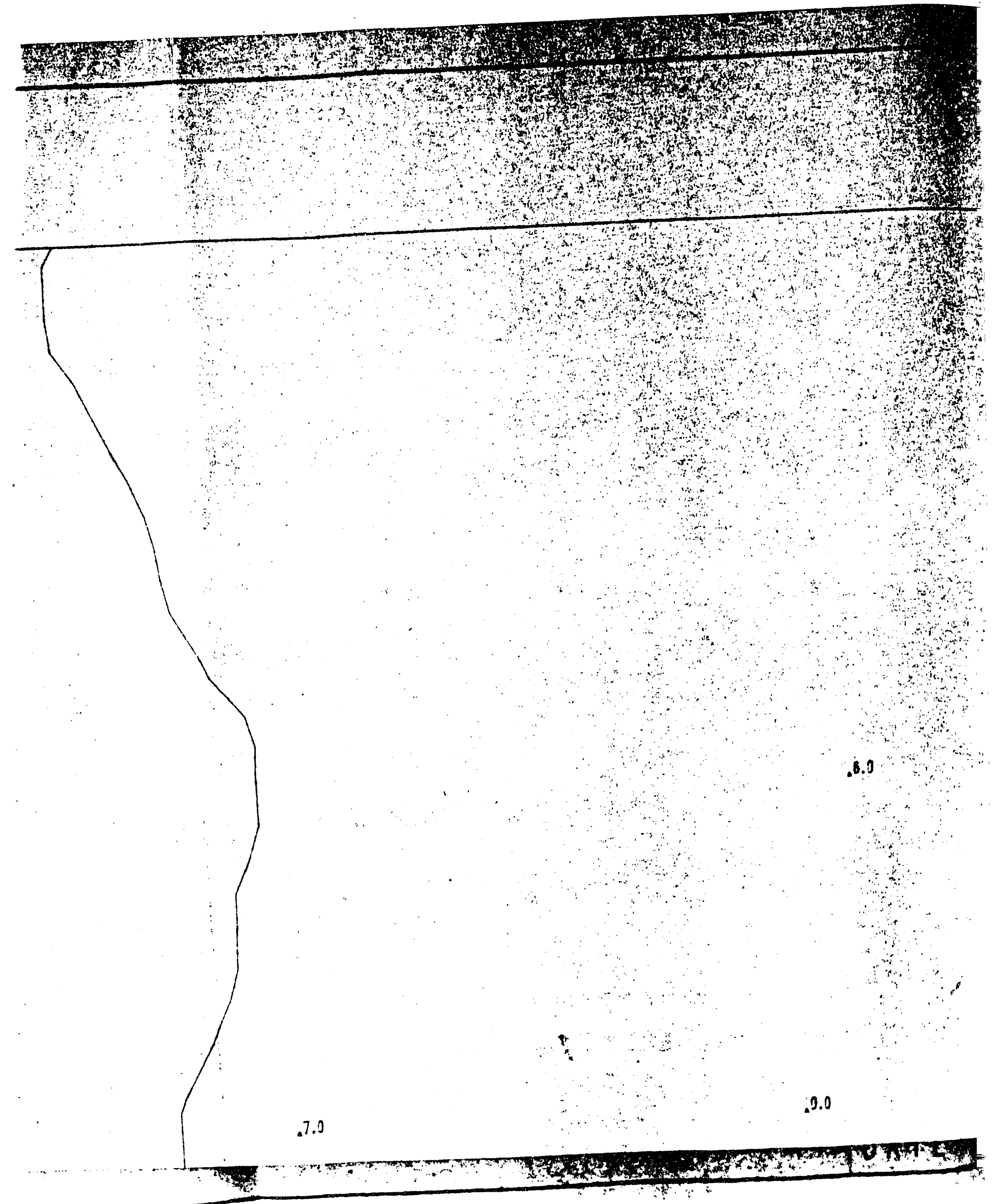




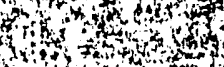




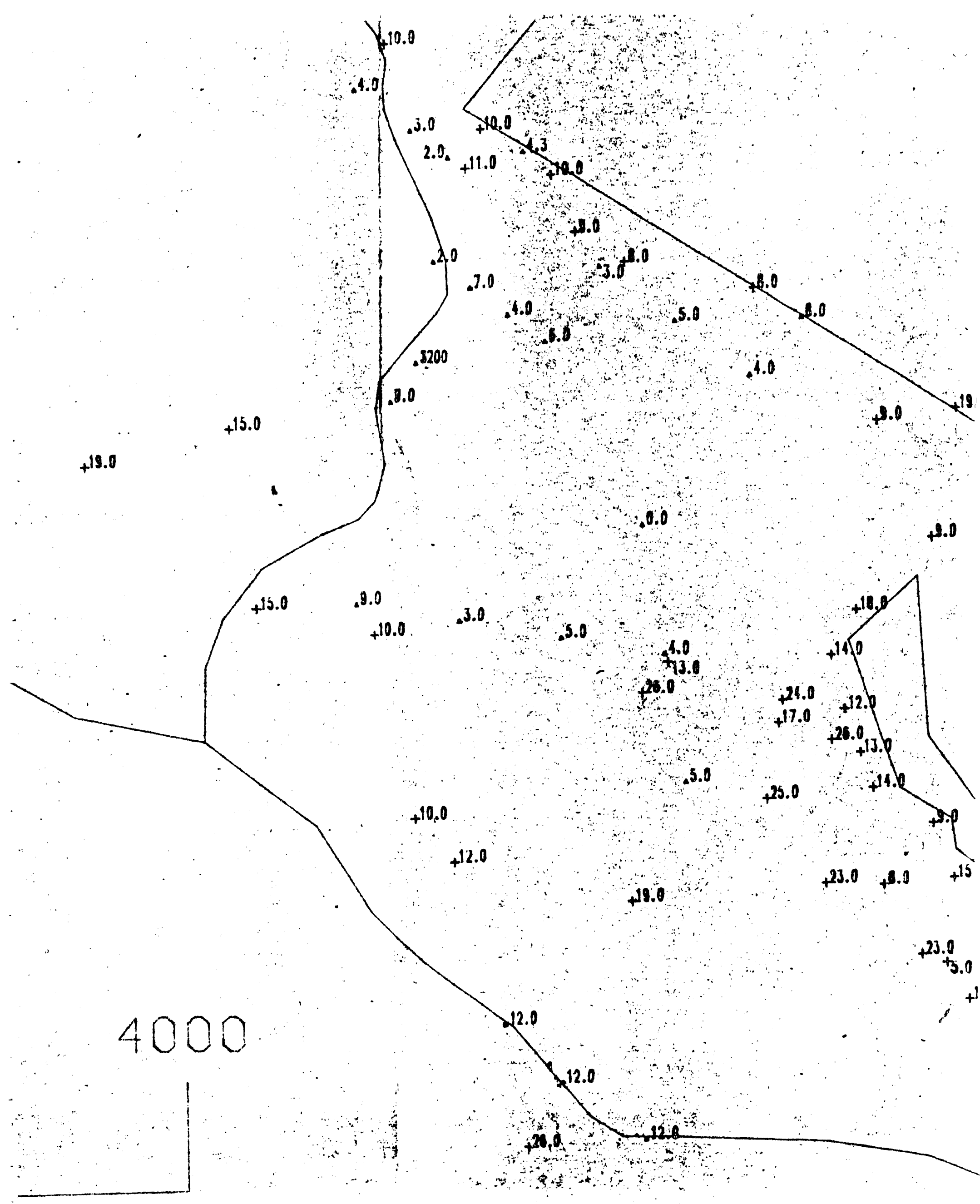


$+$

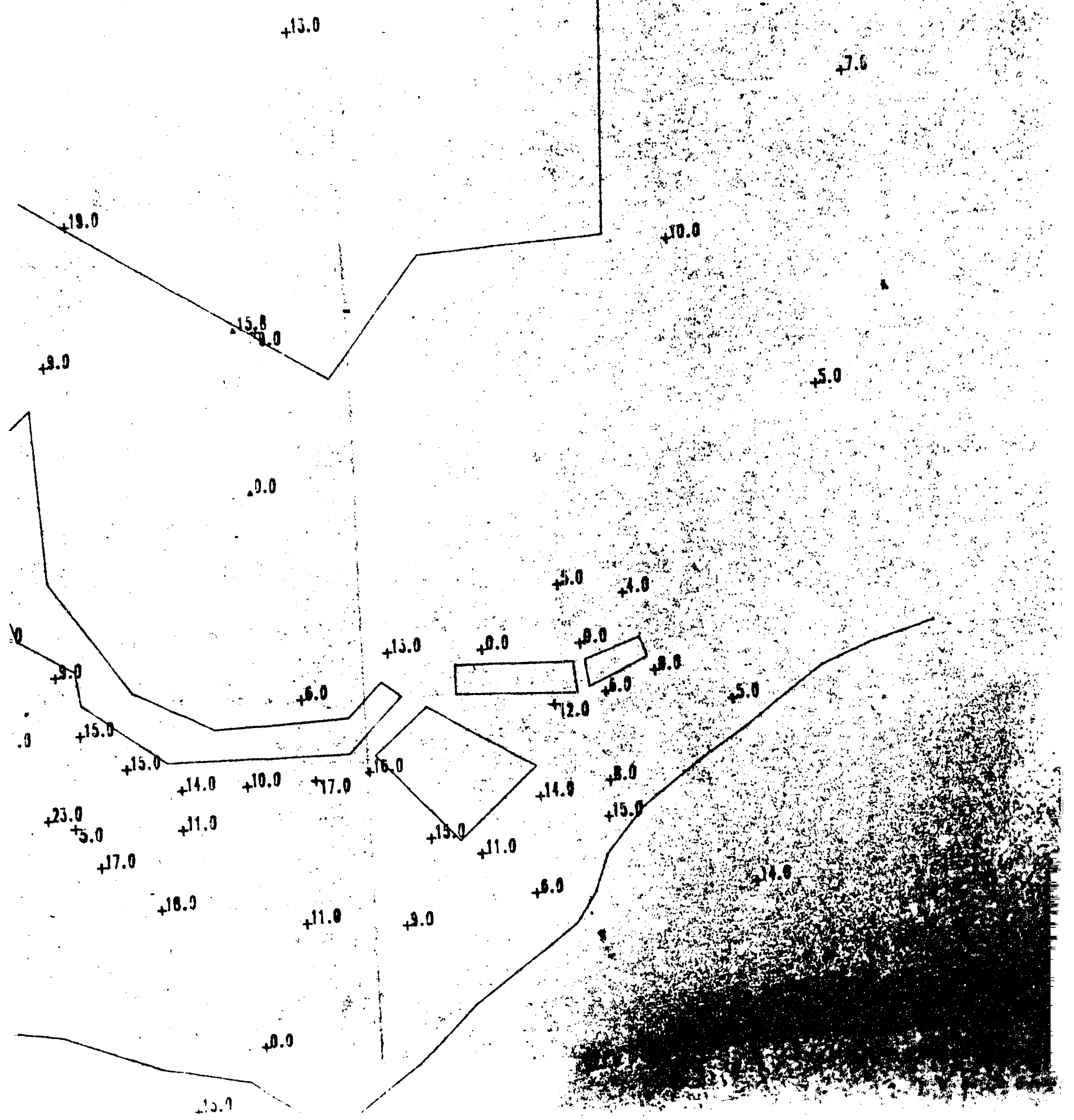


$+0.9$

0.0
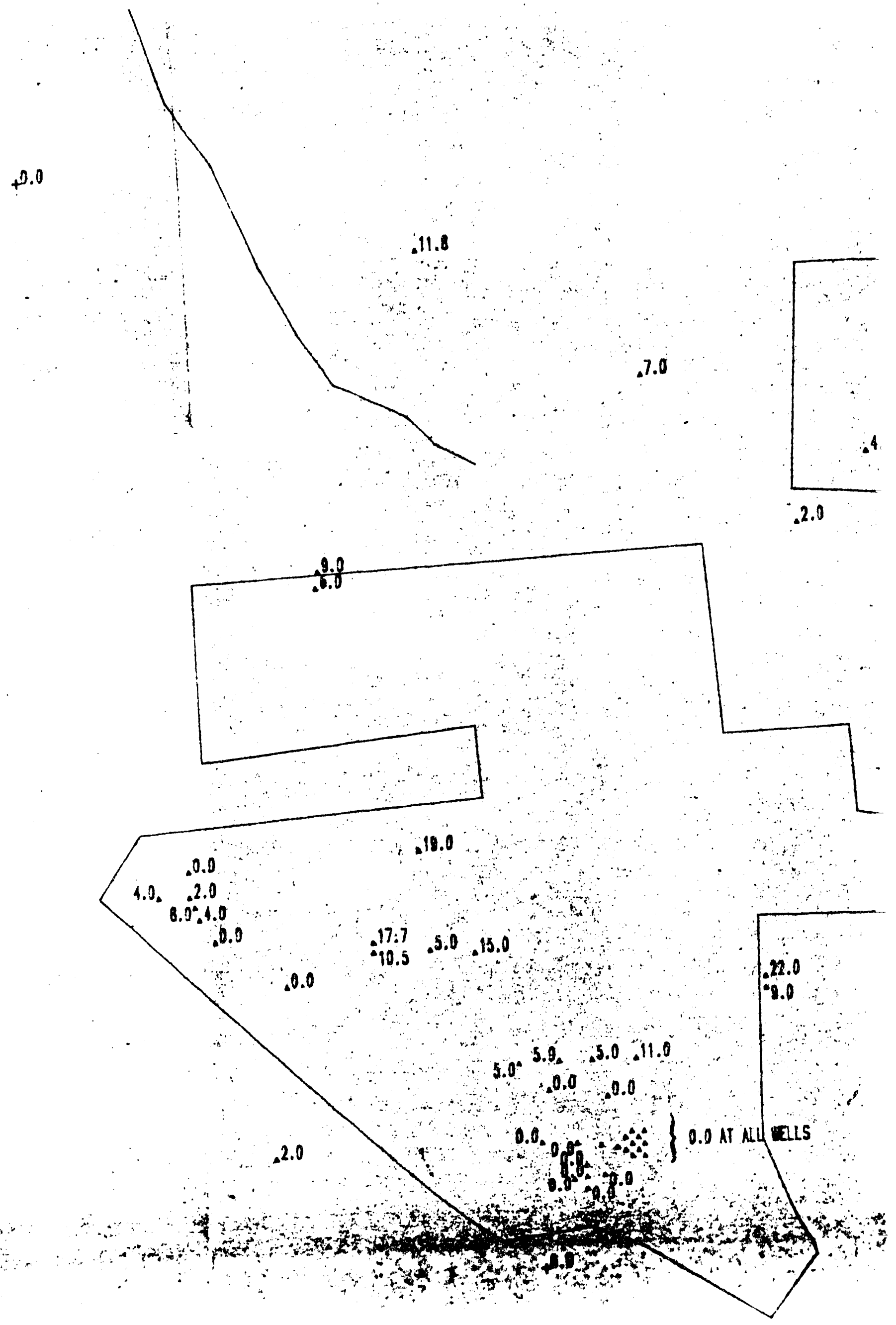


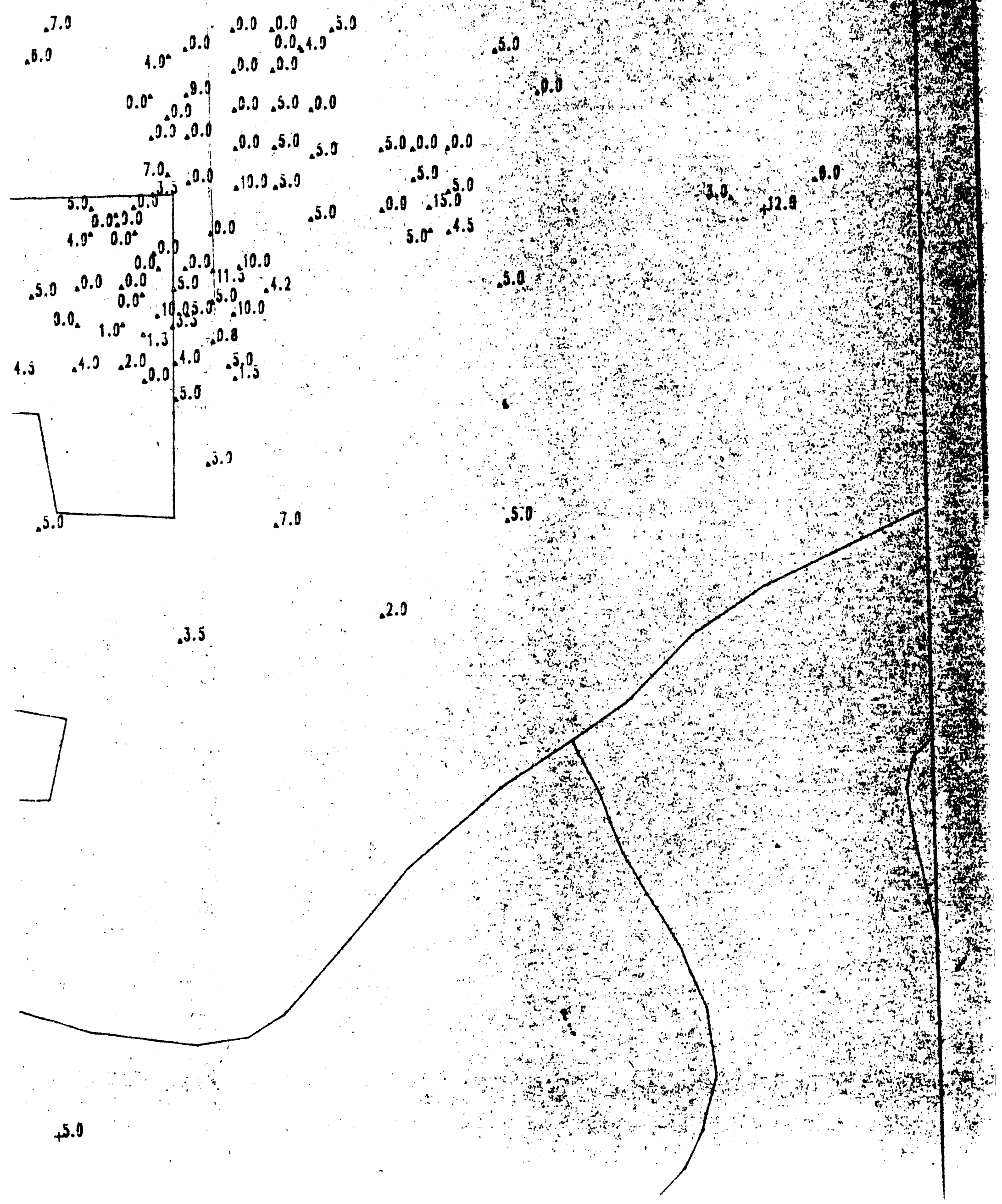




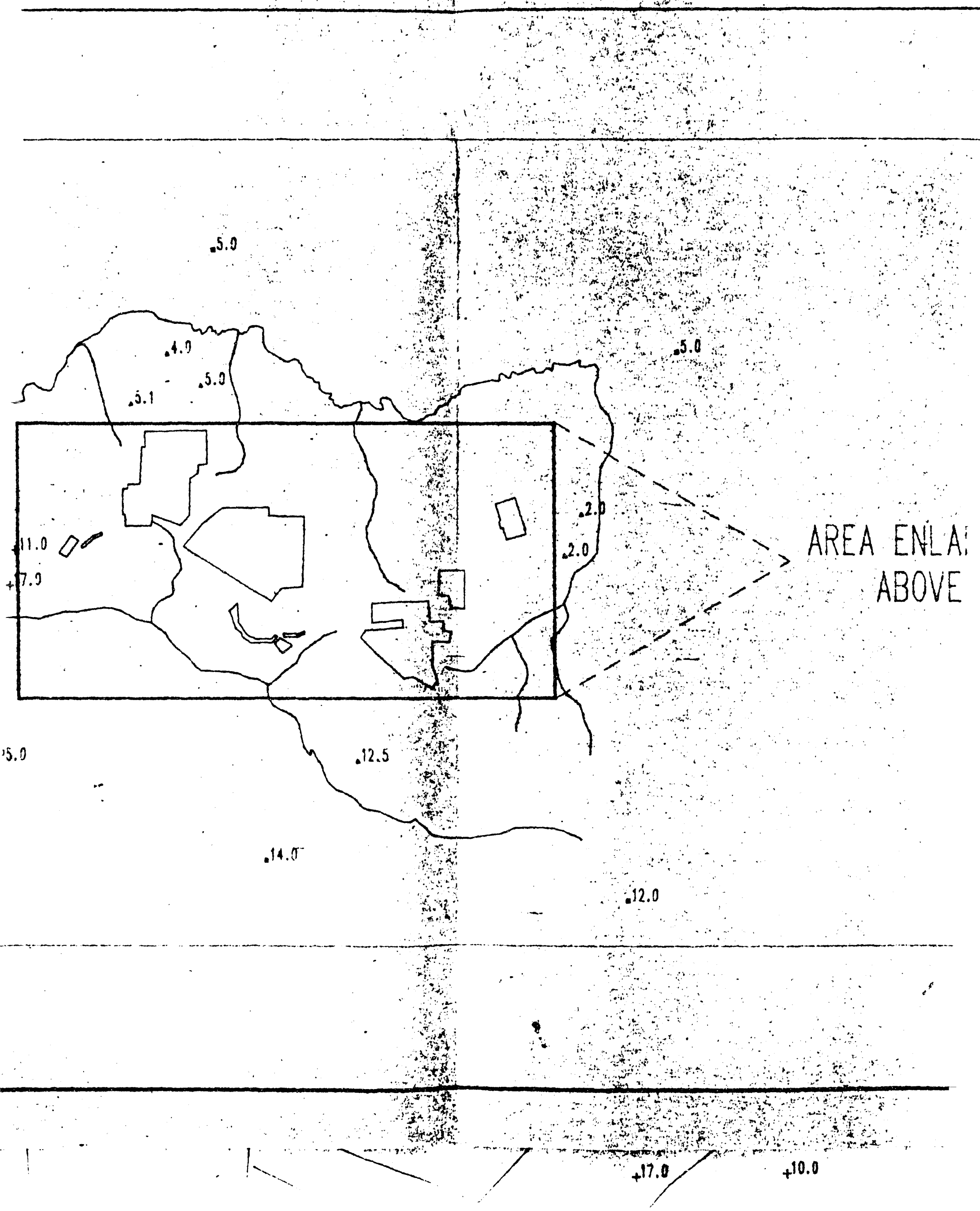




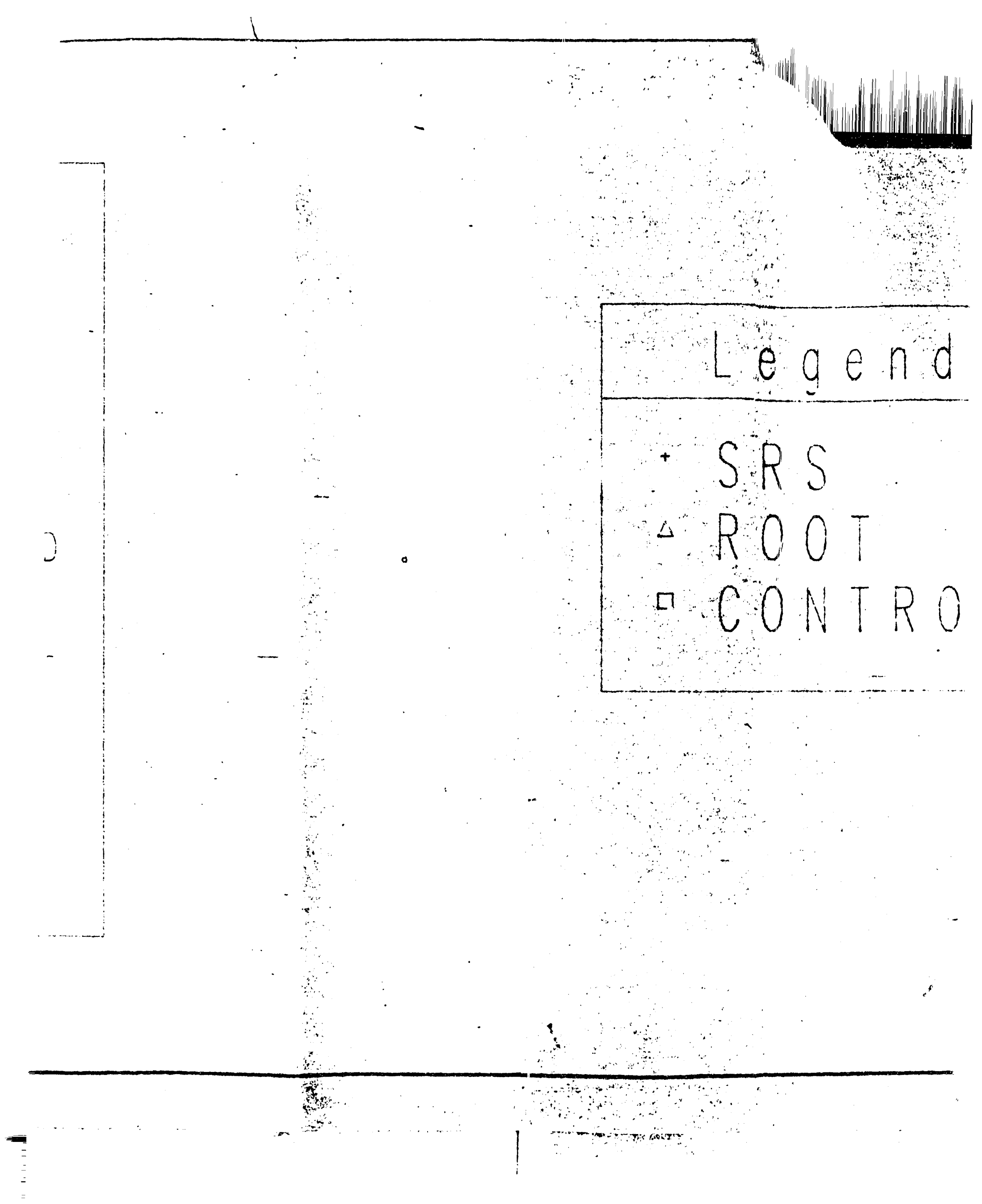




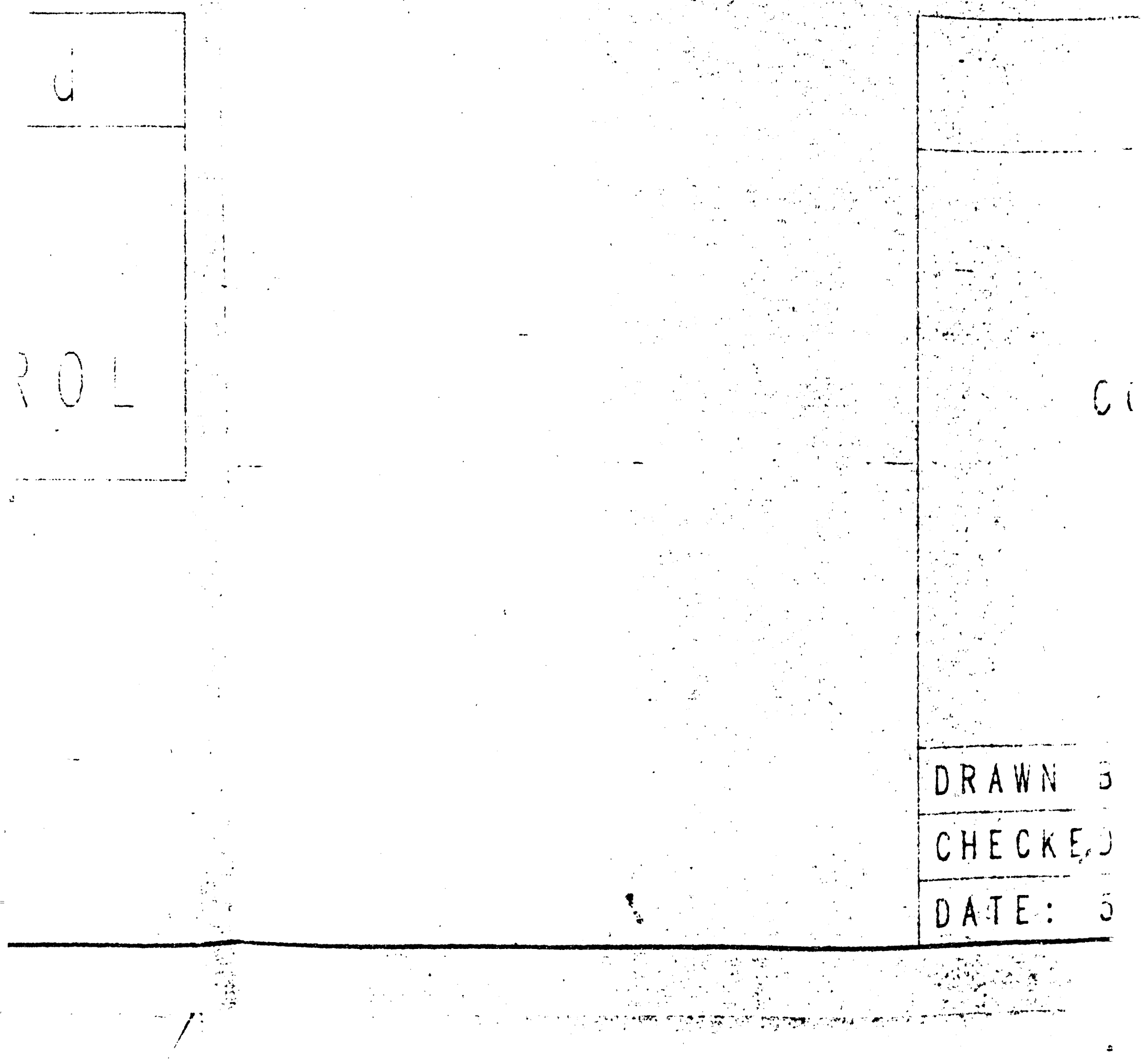




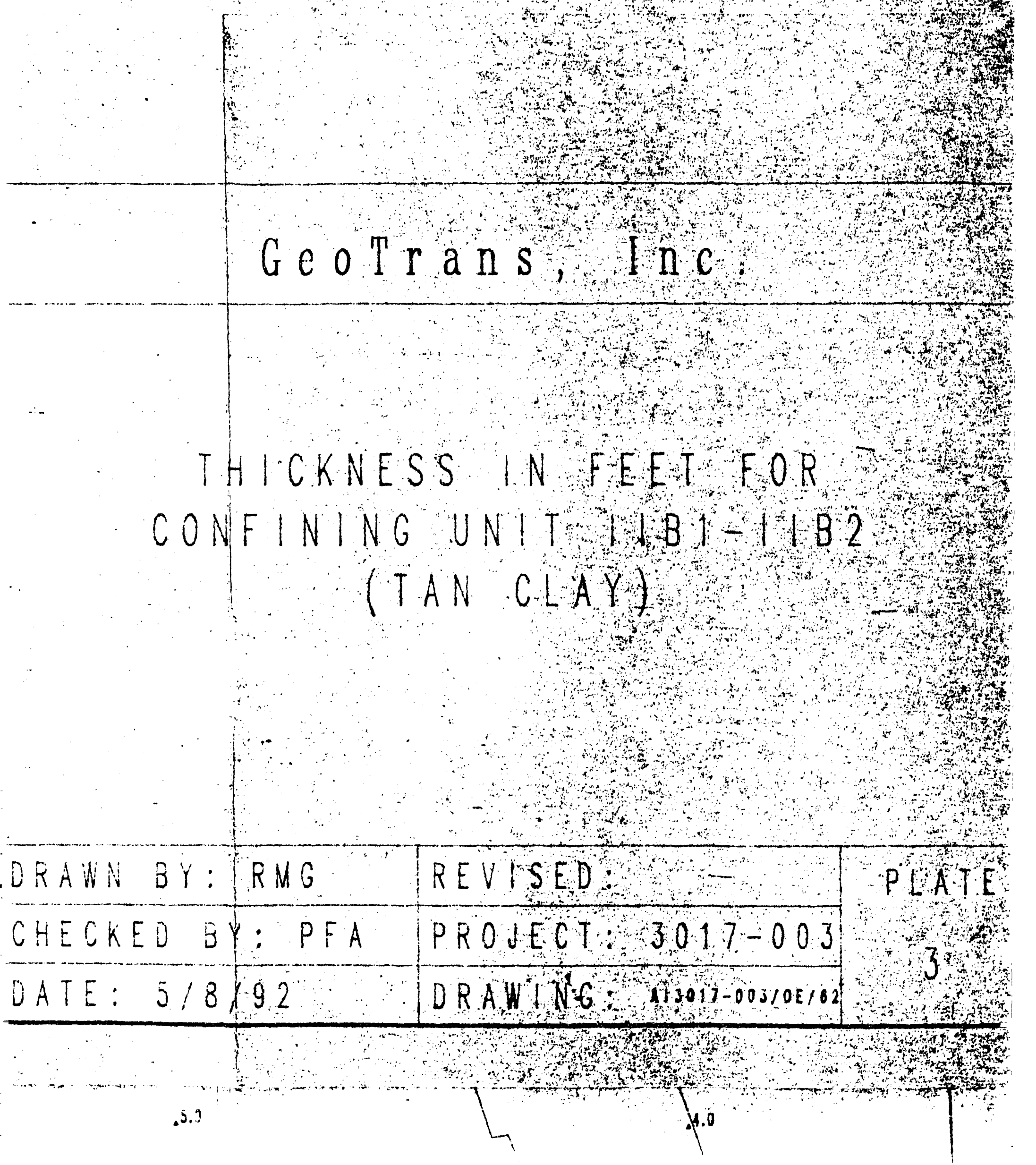




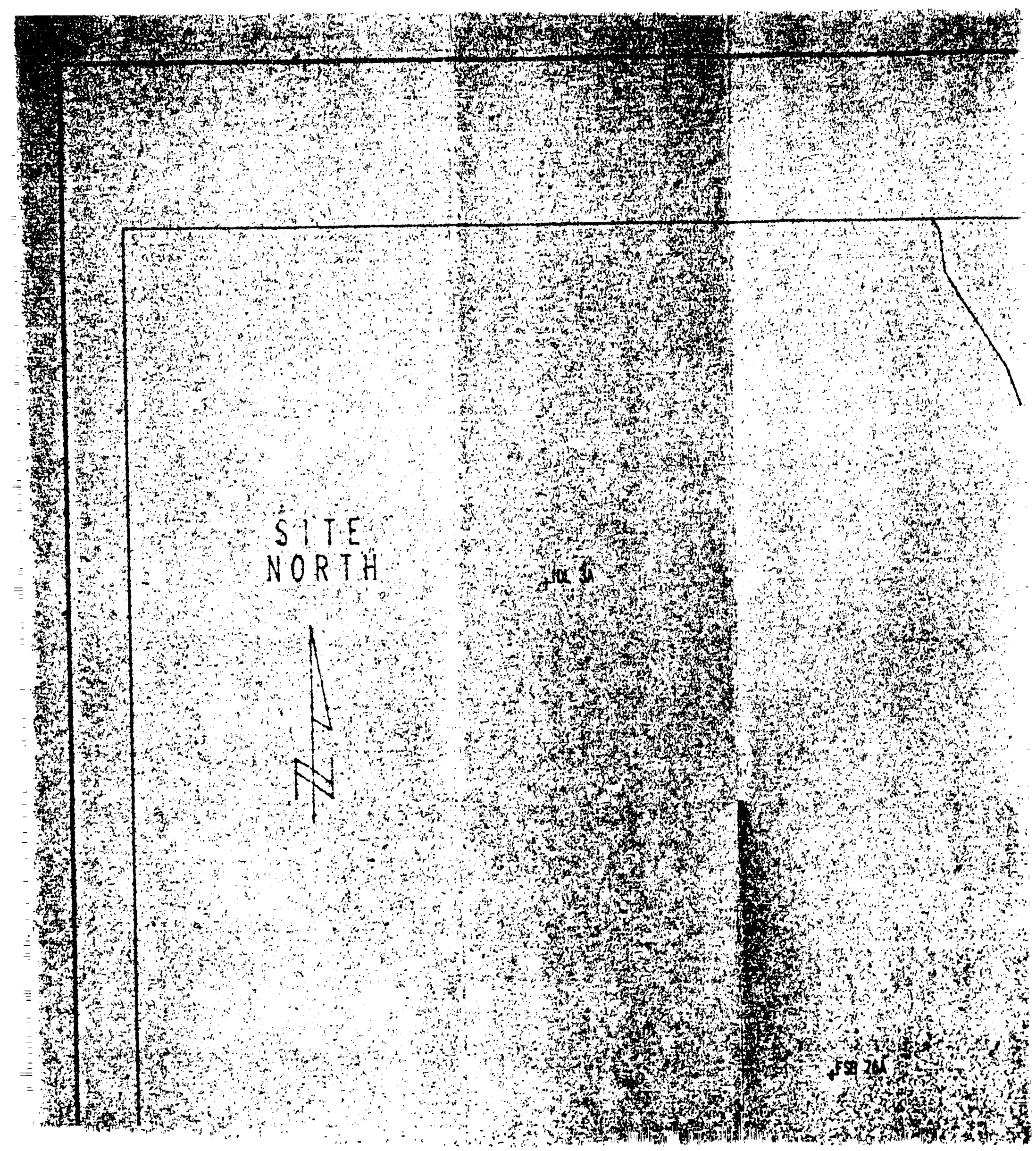




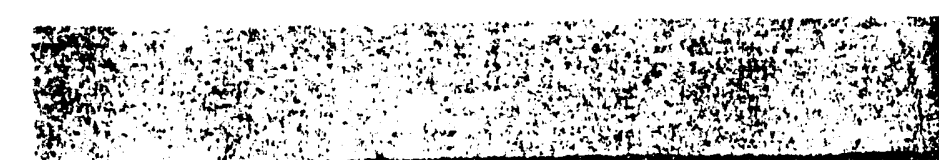

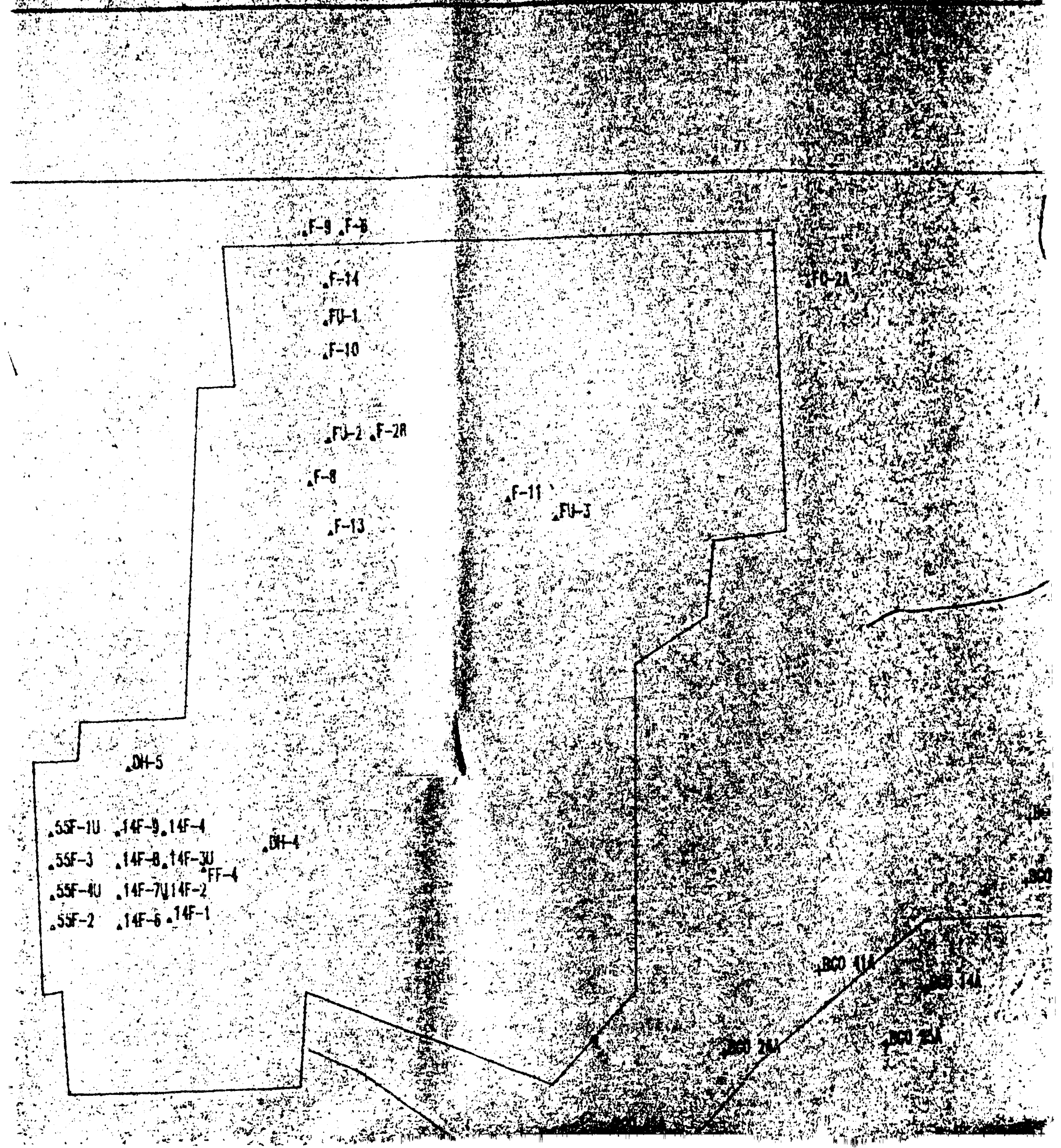




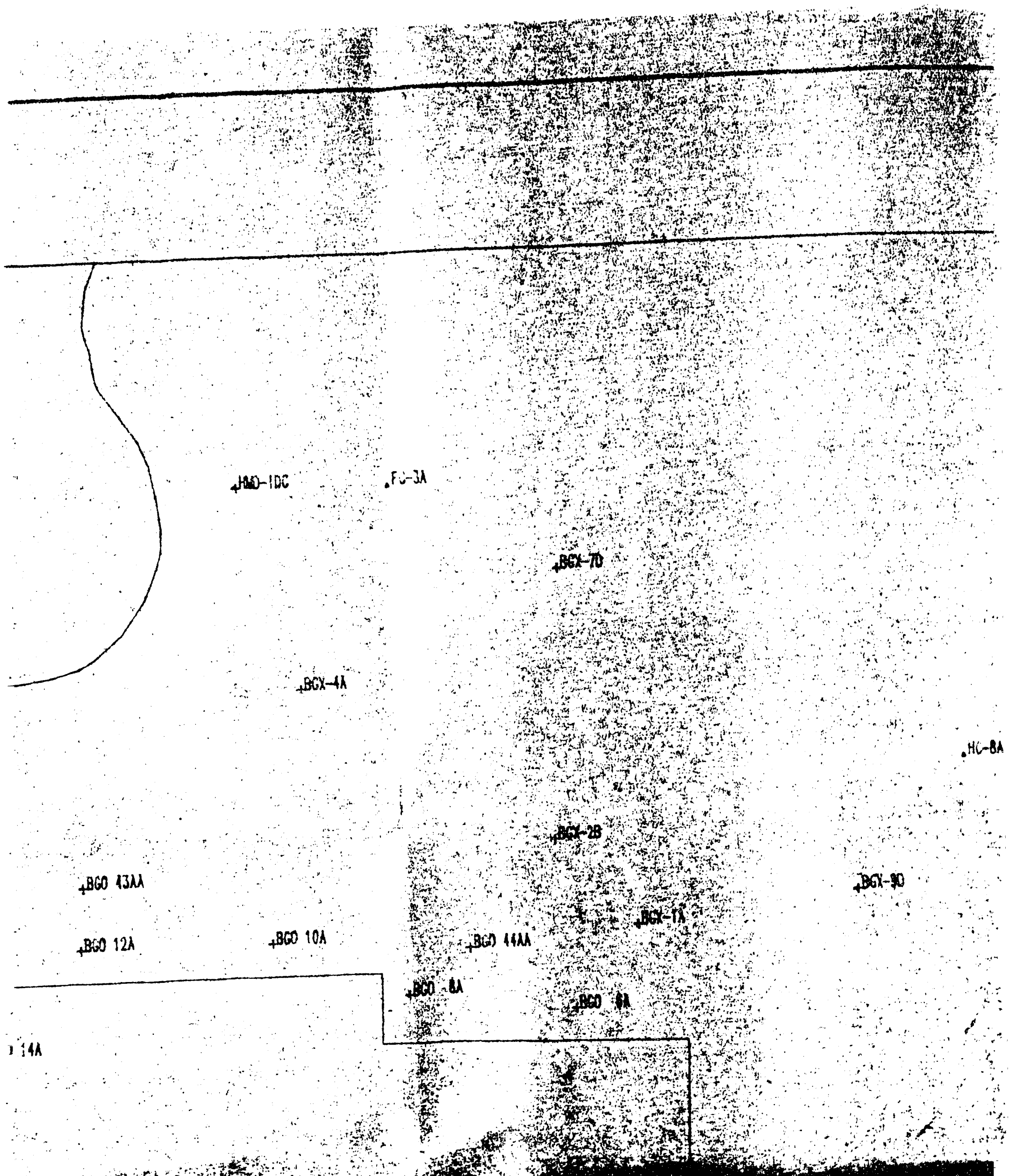




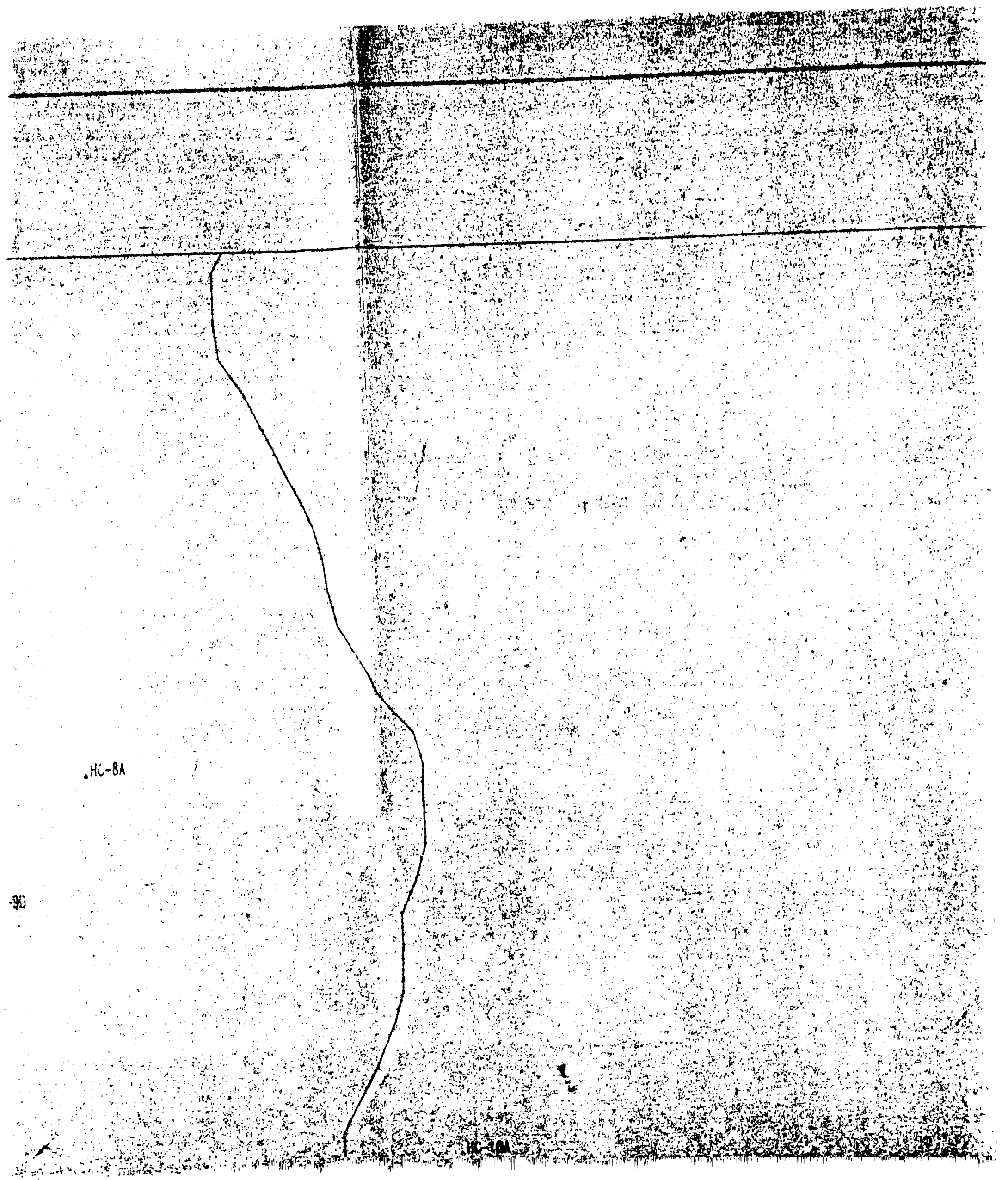




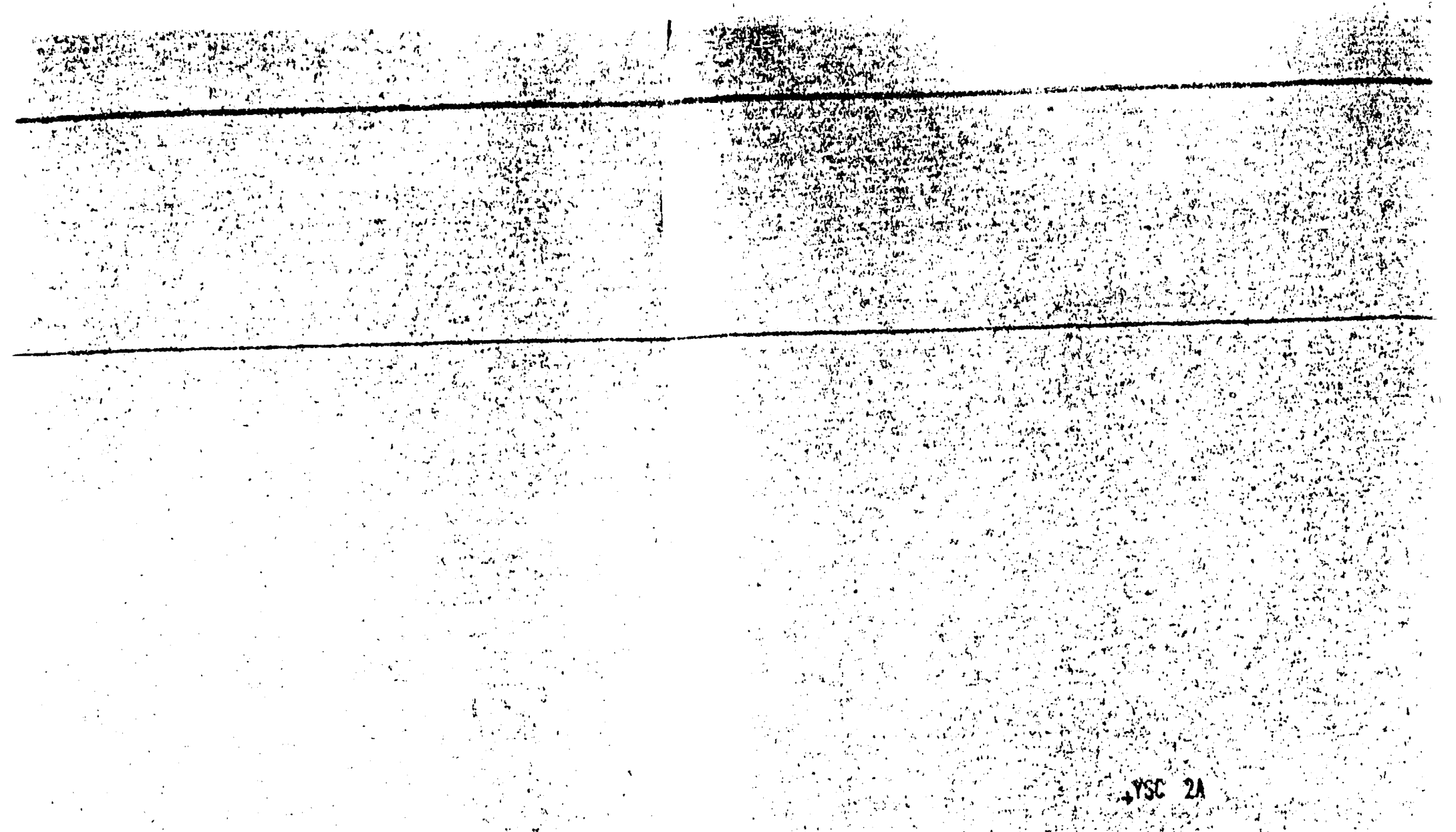




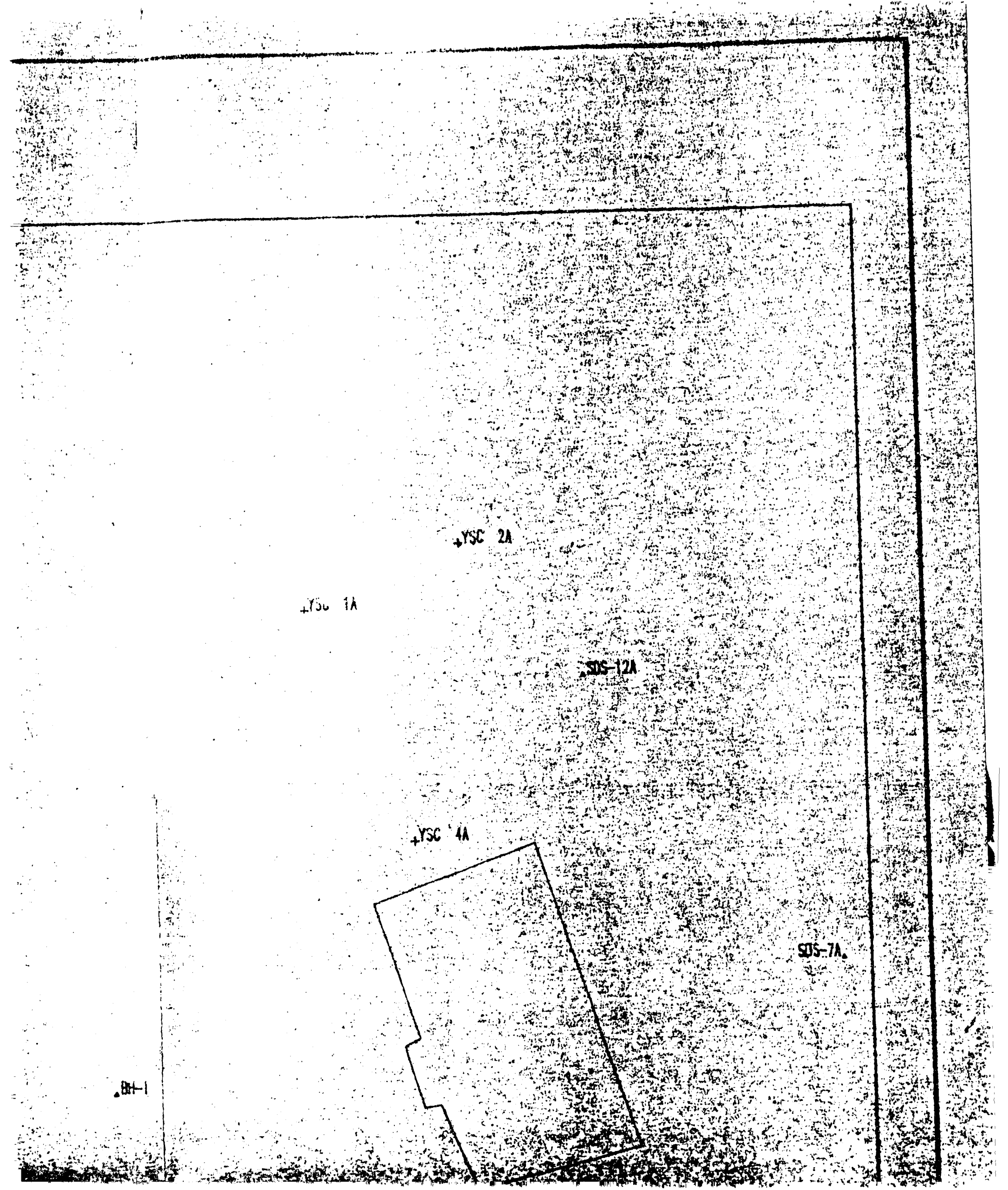




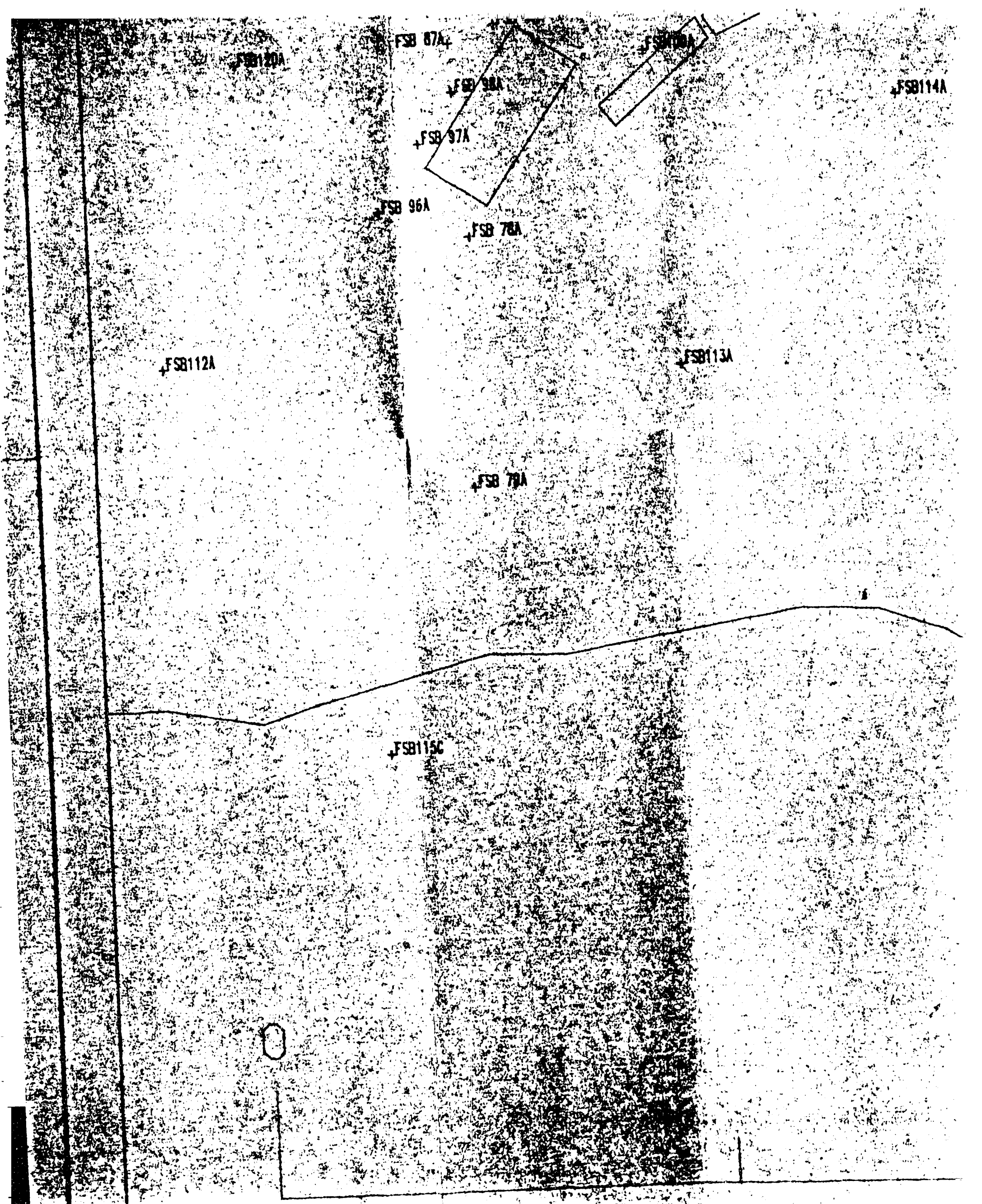




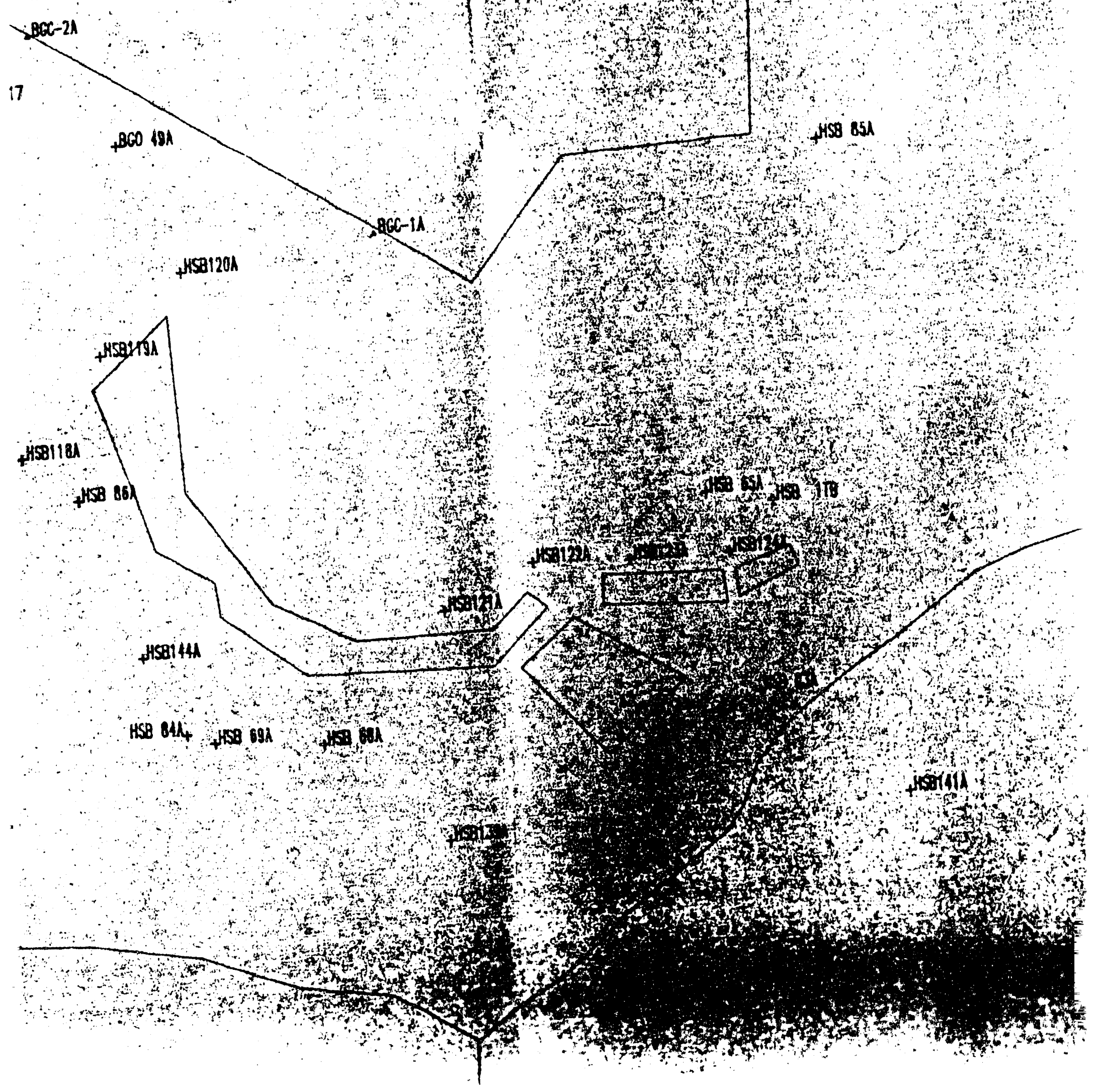




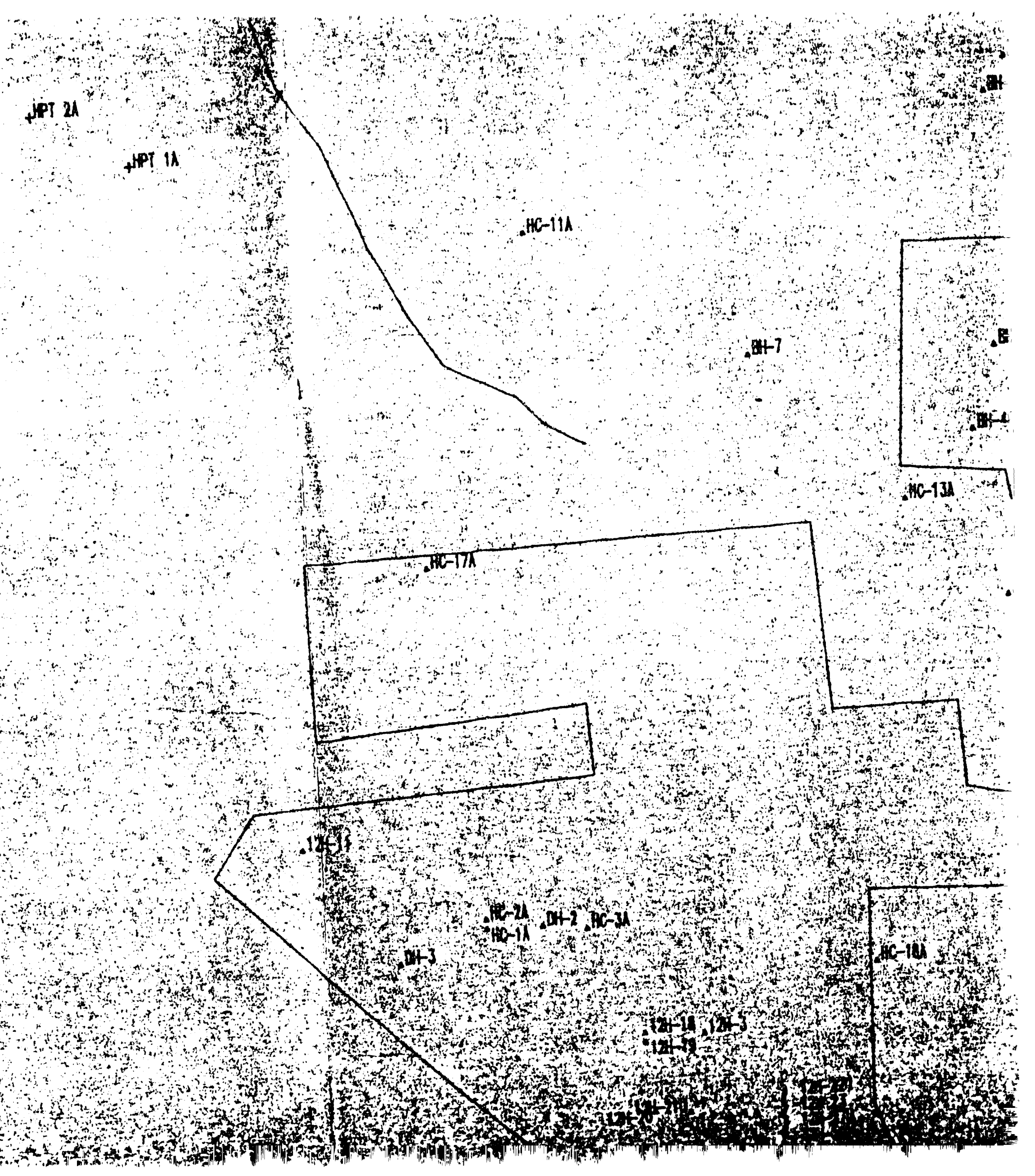




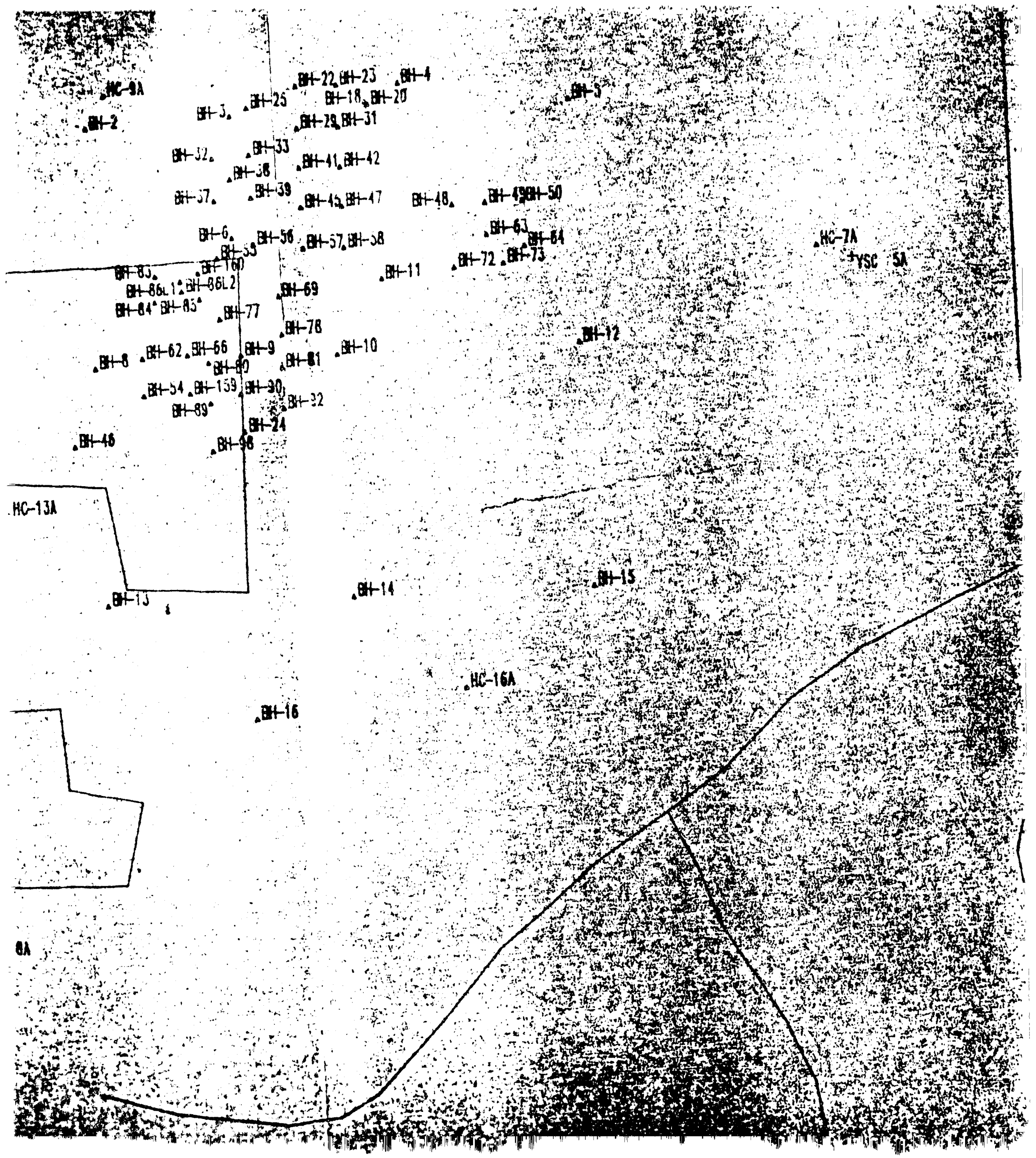




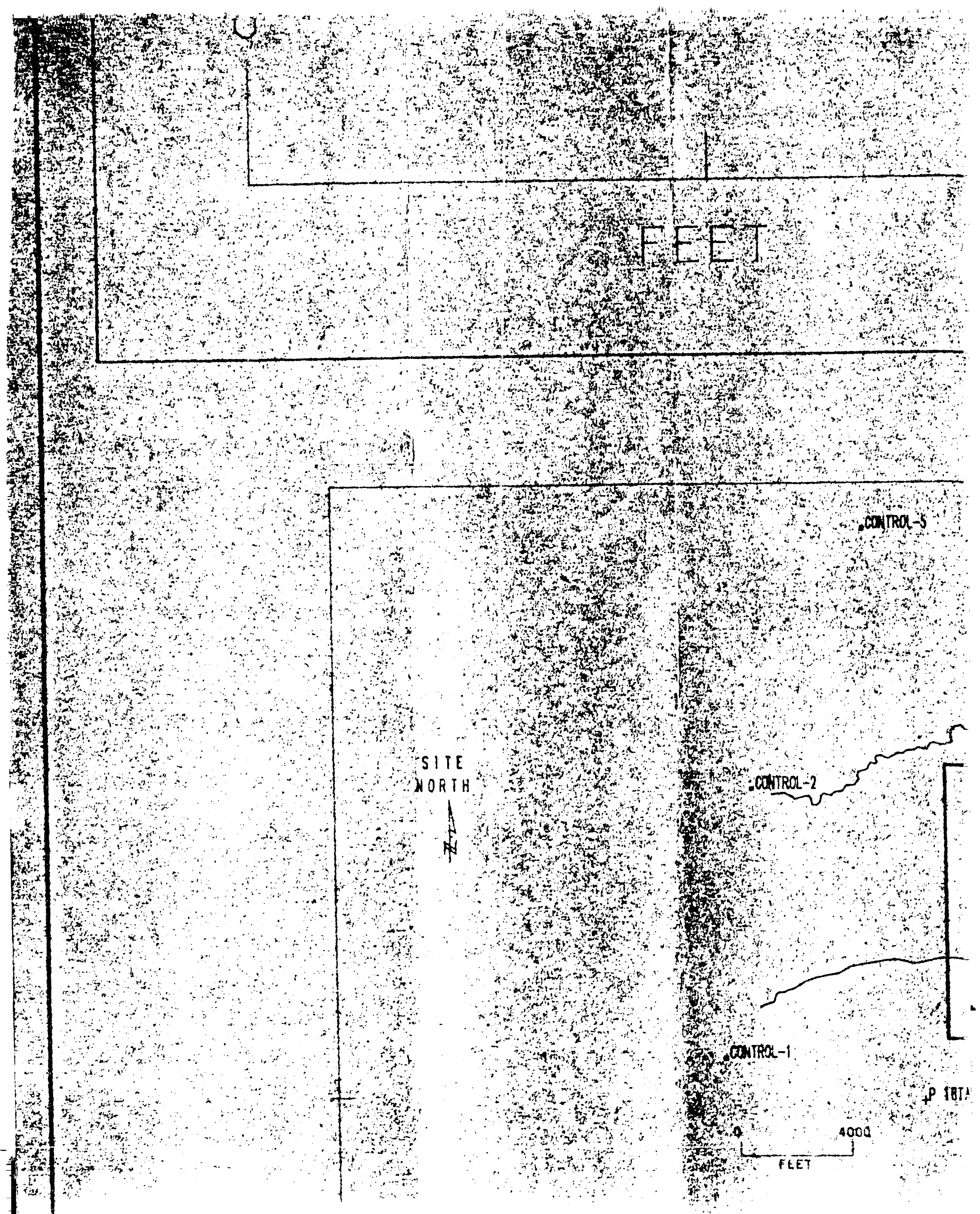




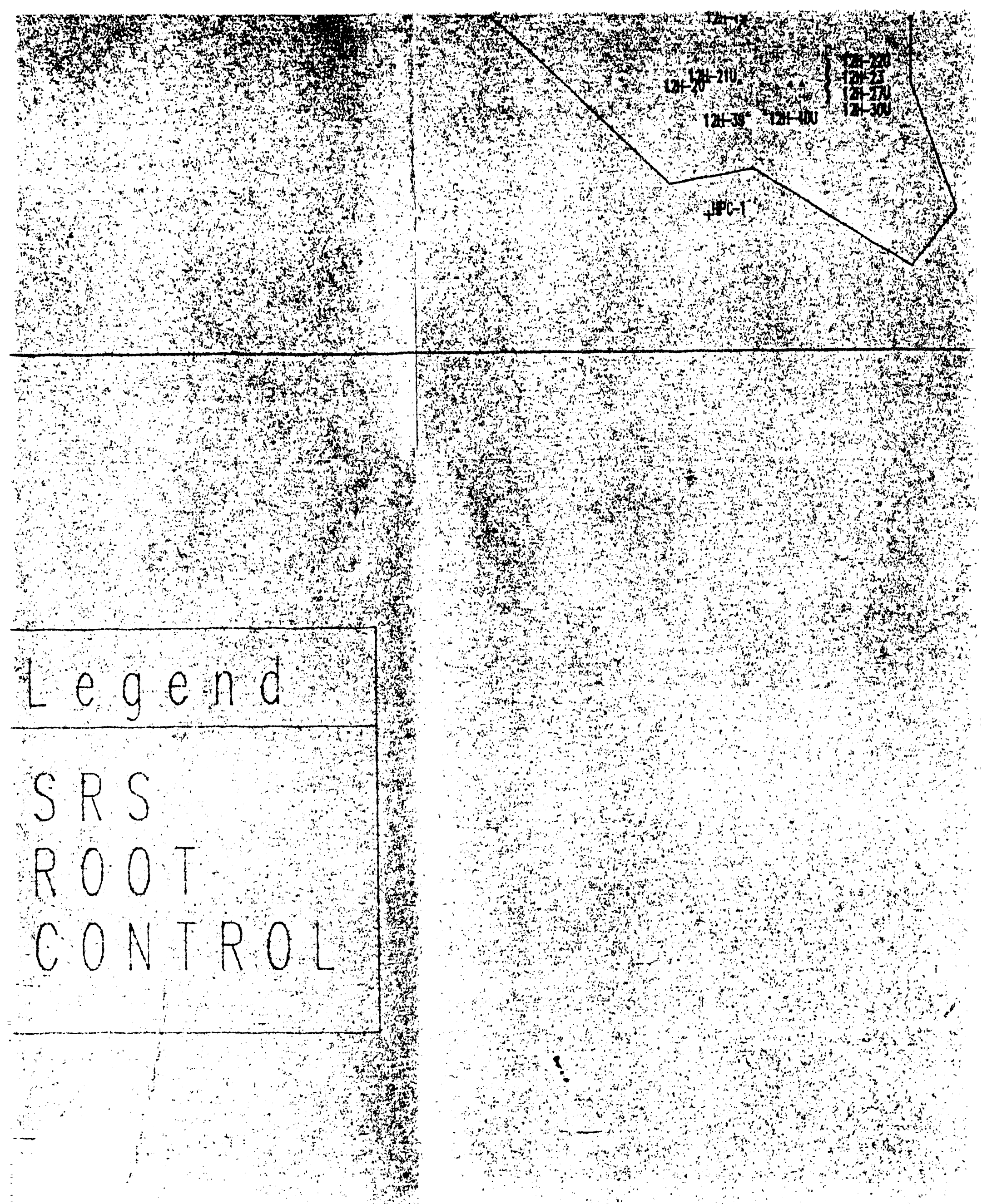




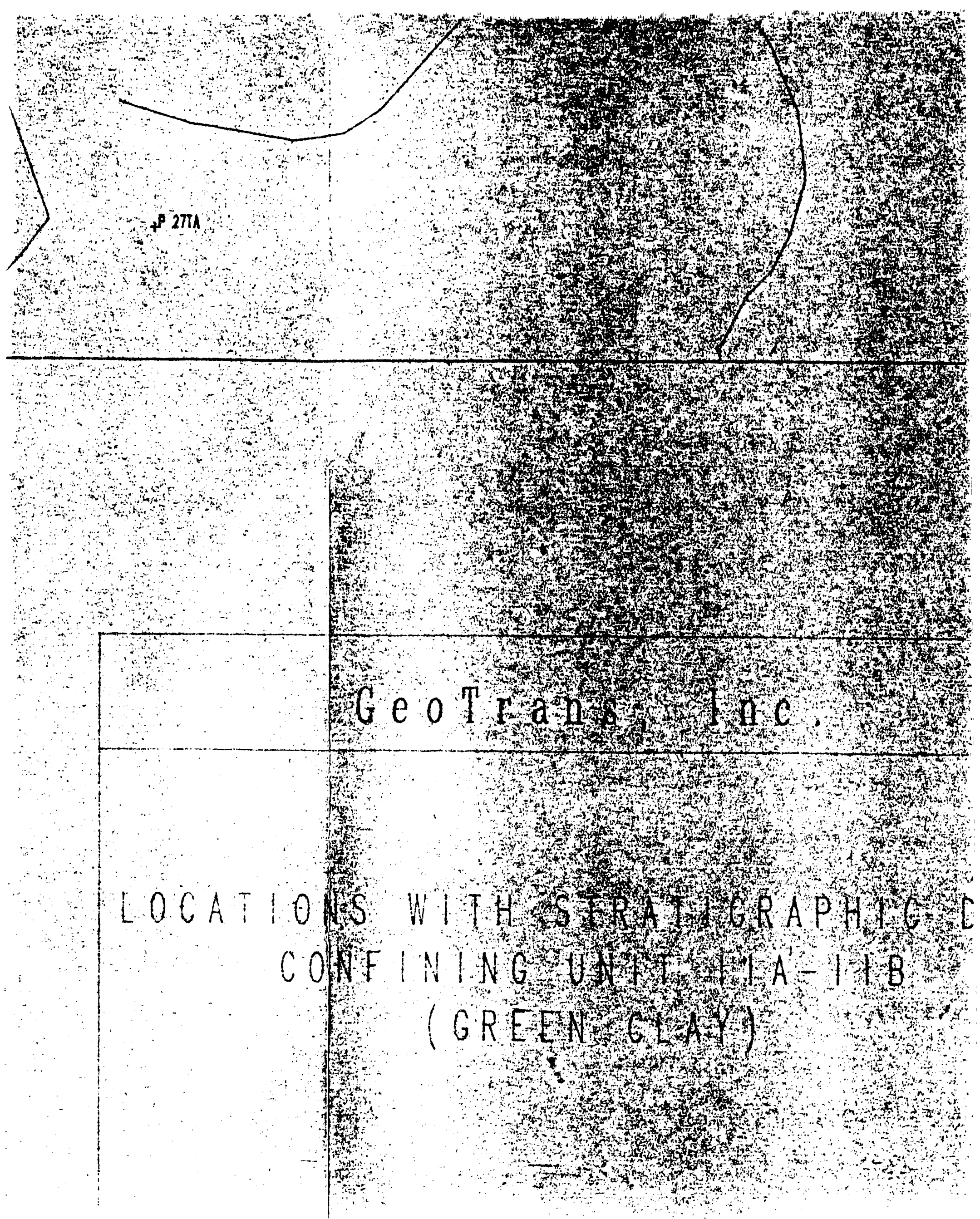


H

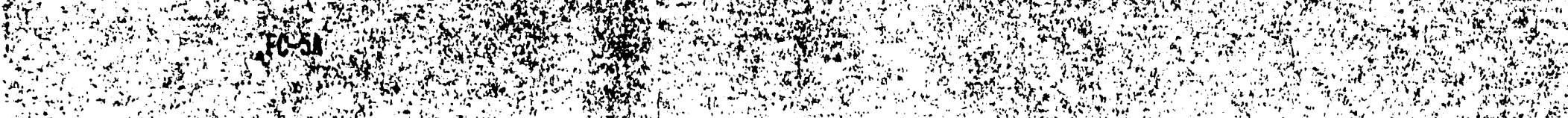

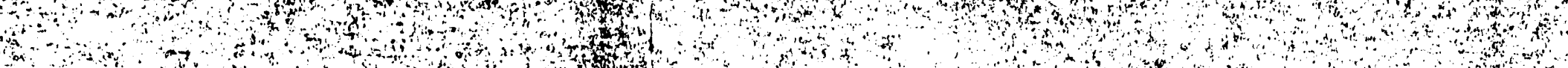

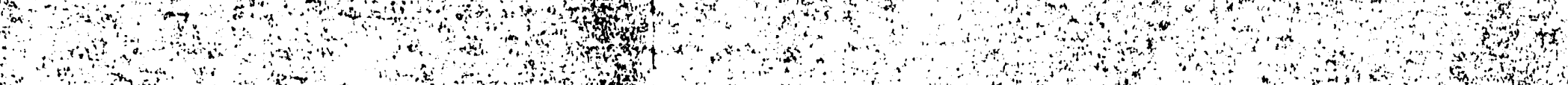
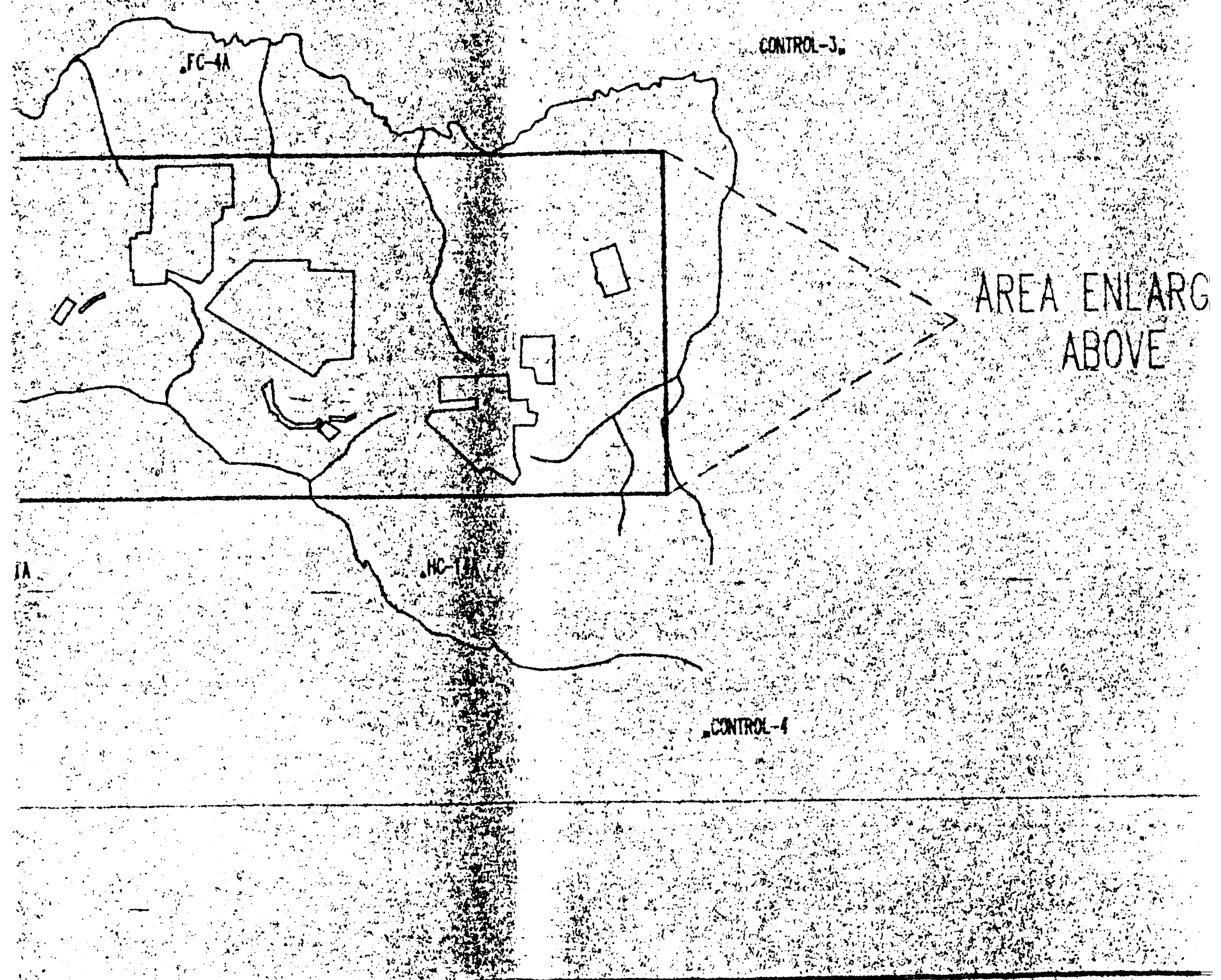
का

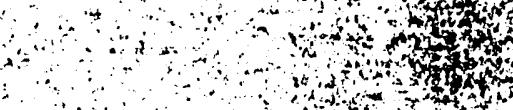
The Wot

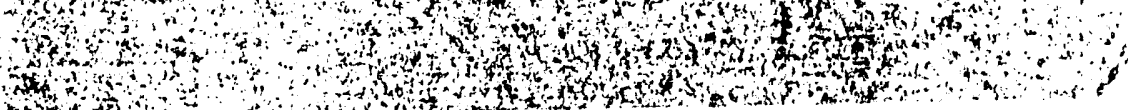

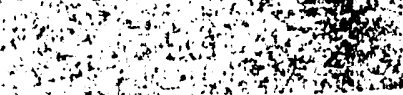




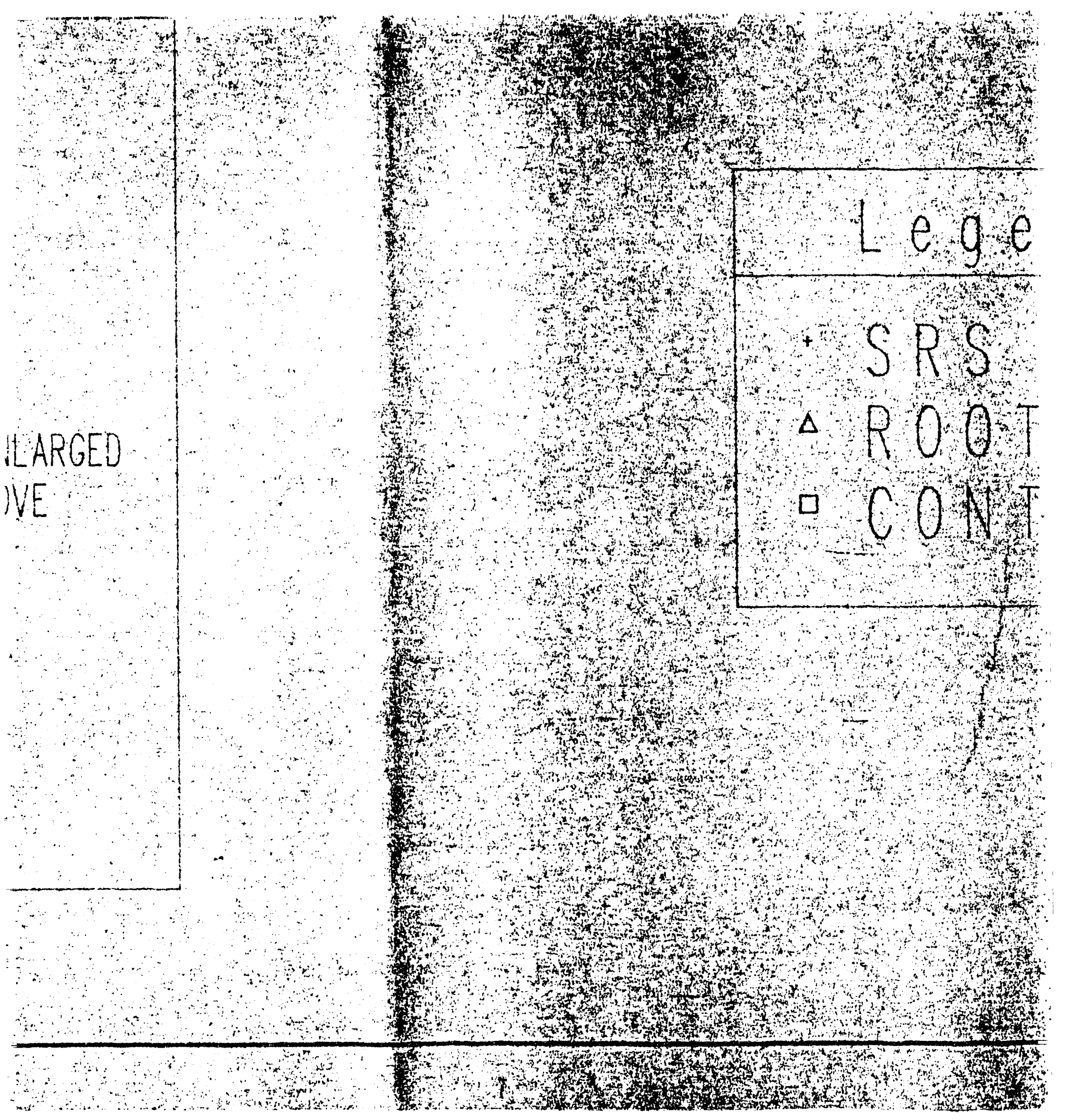




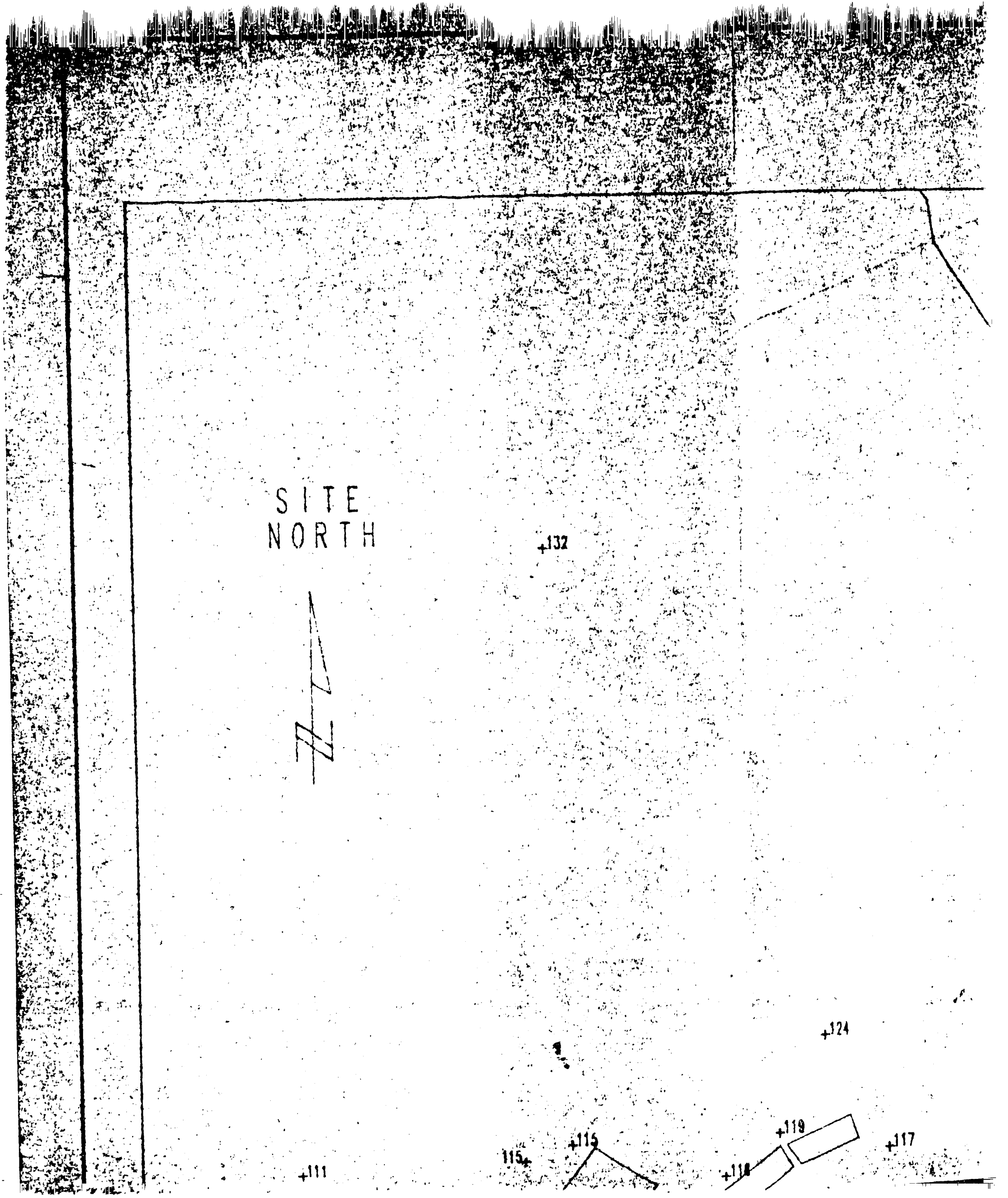




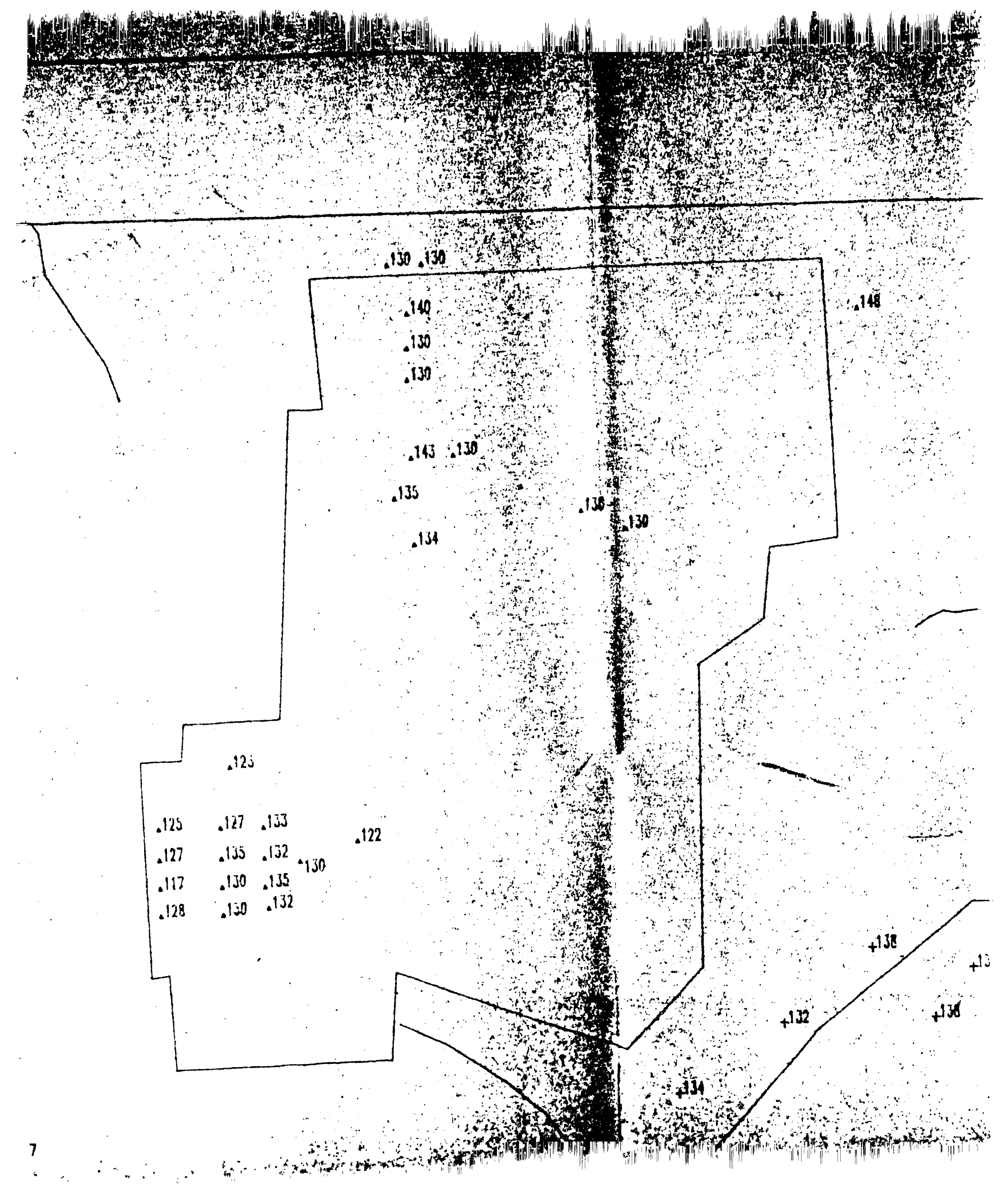




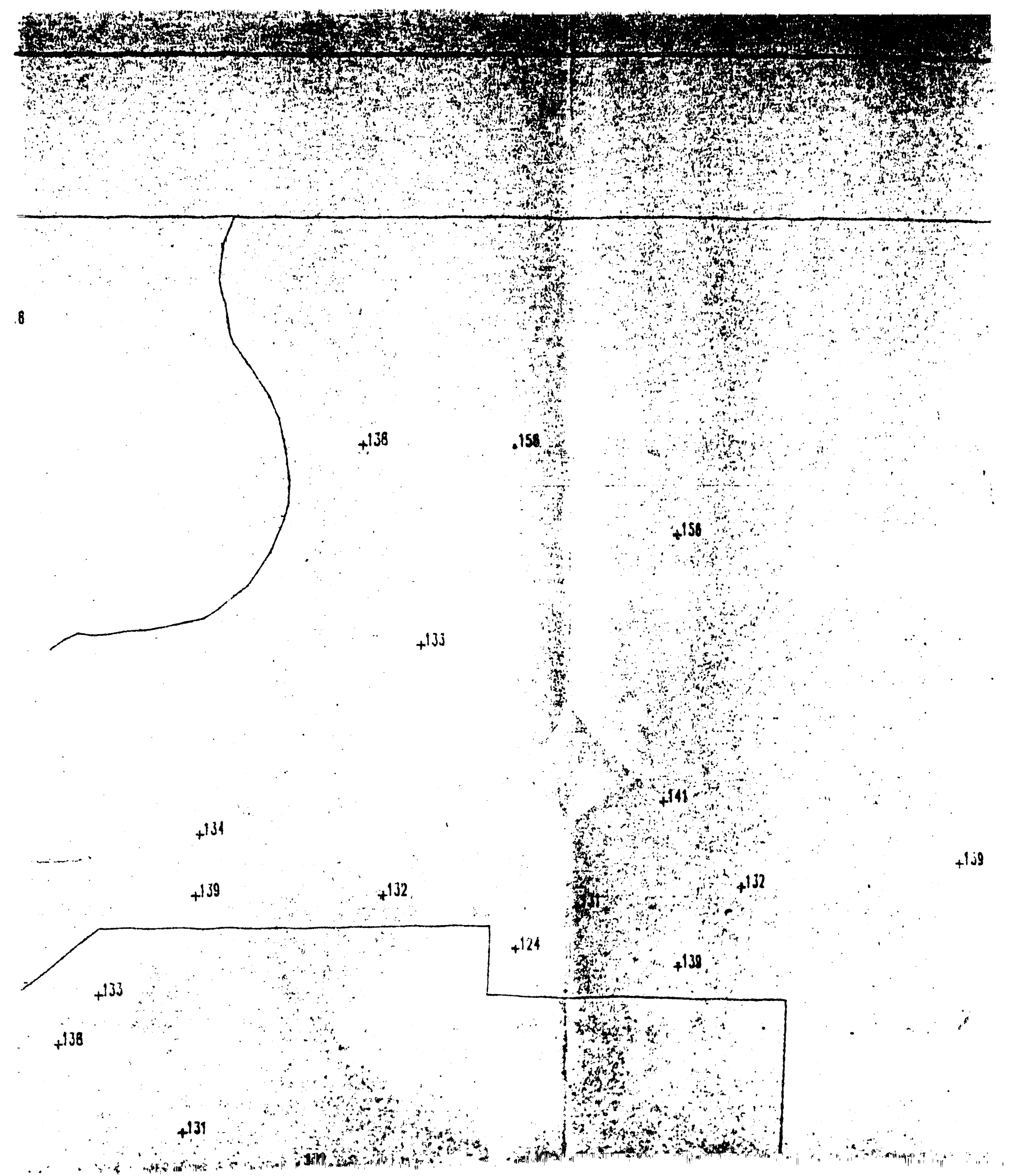


How

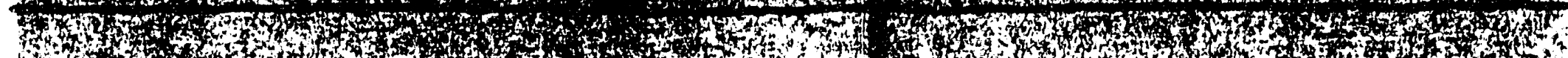

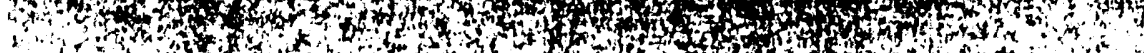

ar

sor

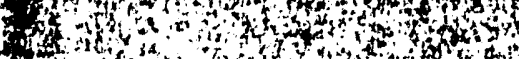

and

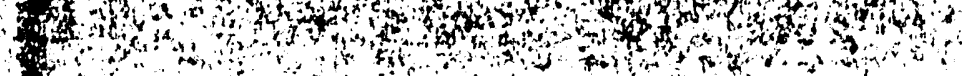

an a n a

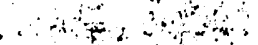

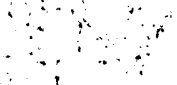

.153

$+139$

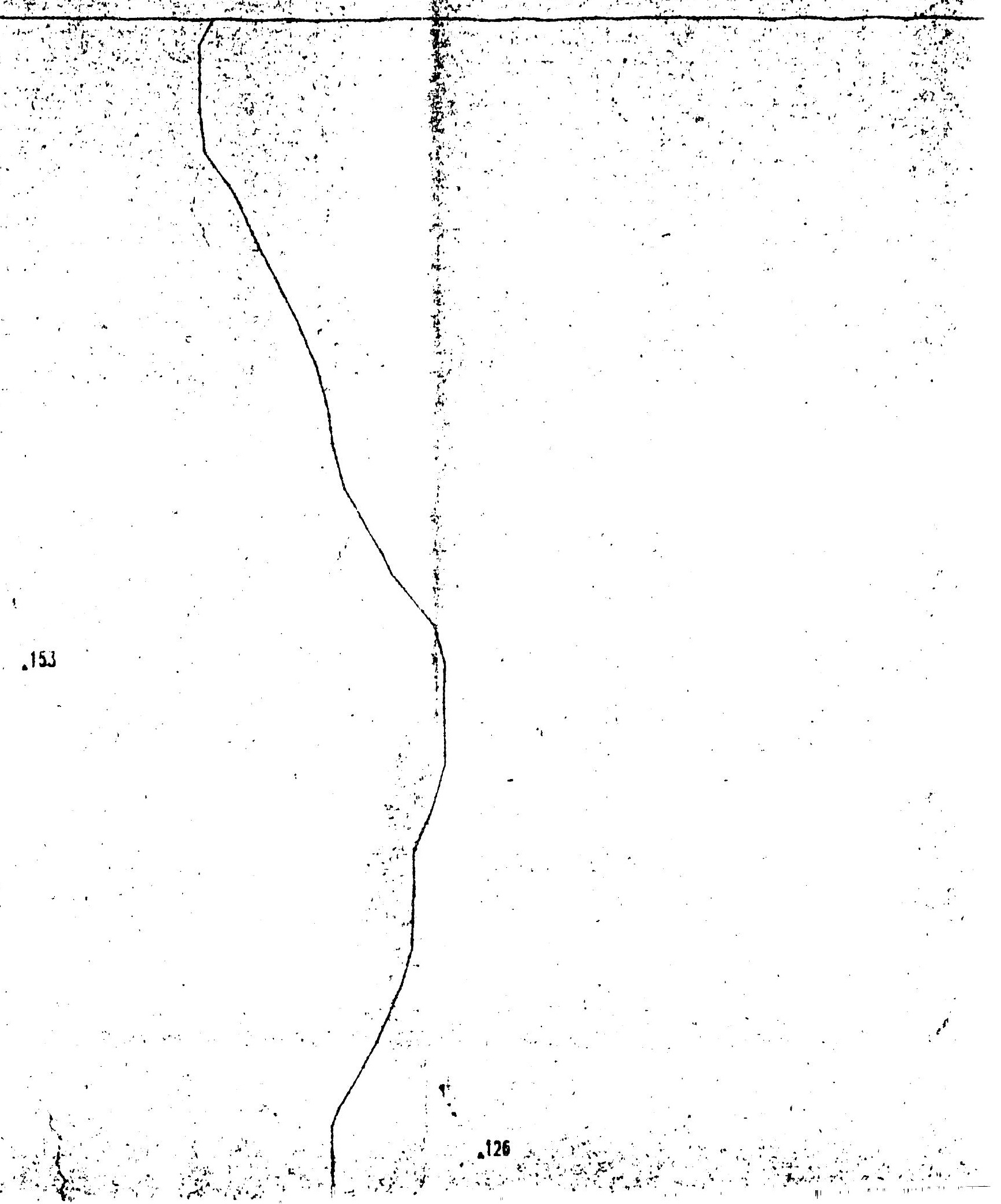

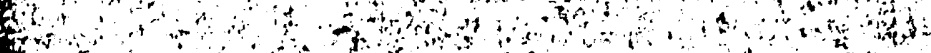




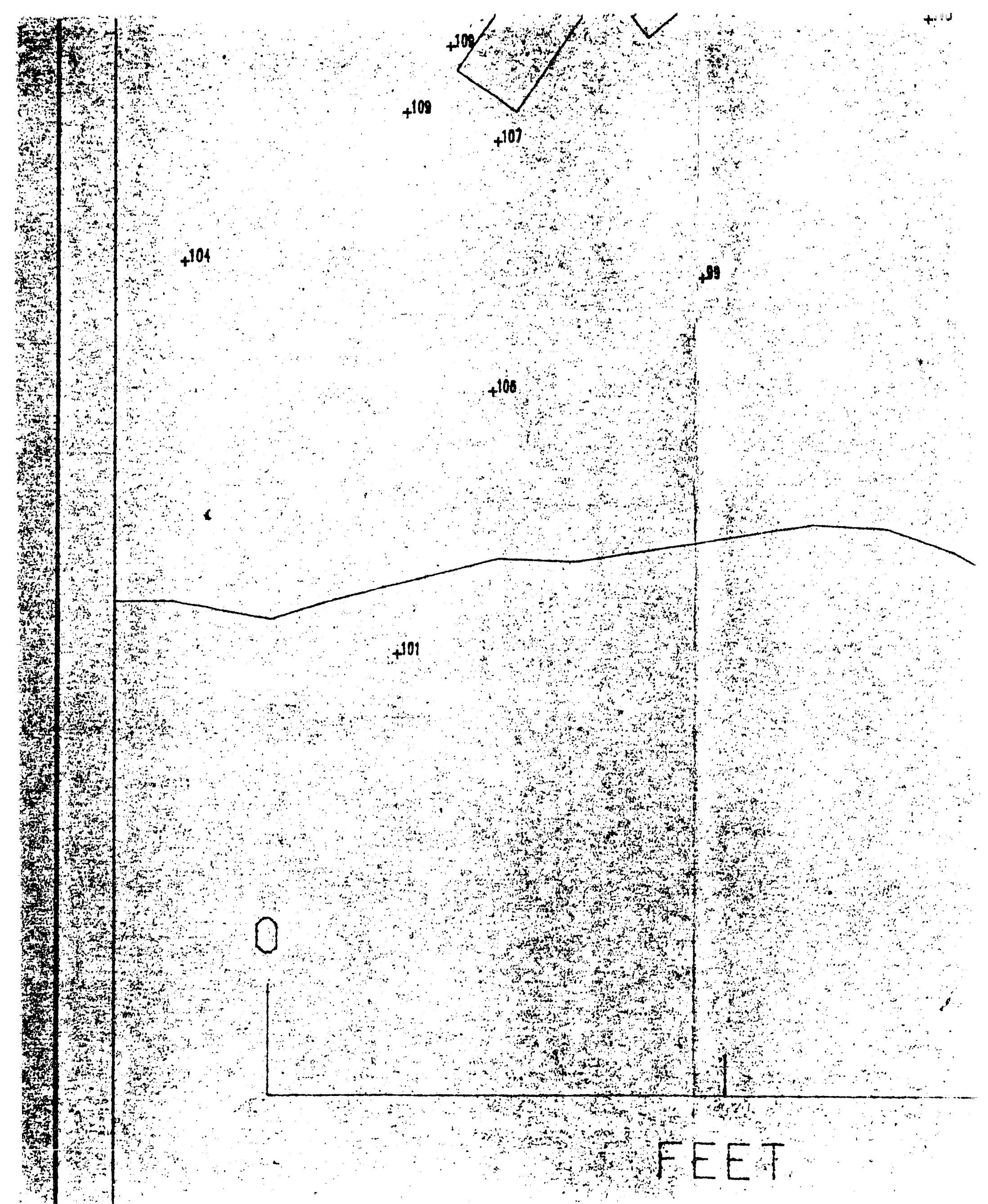




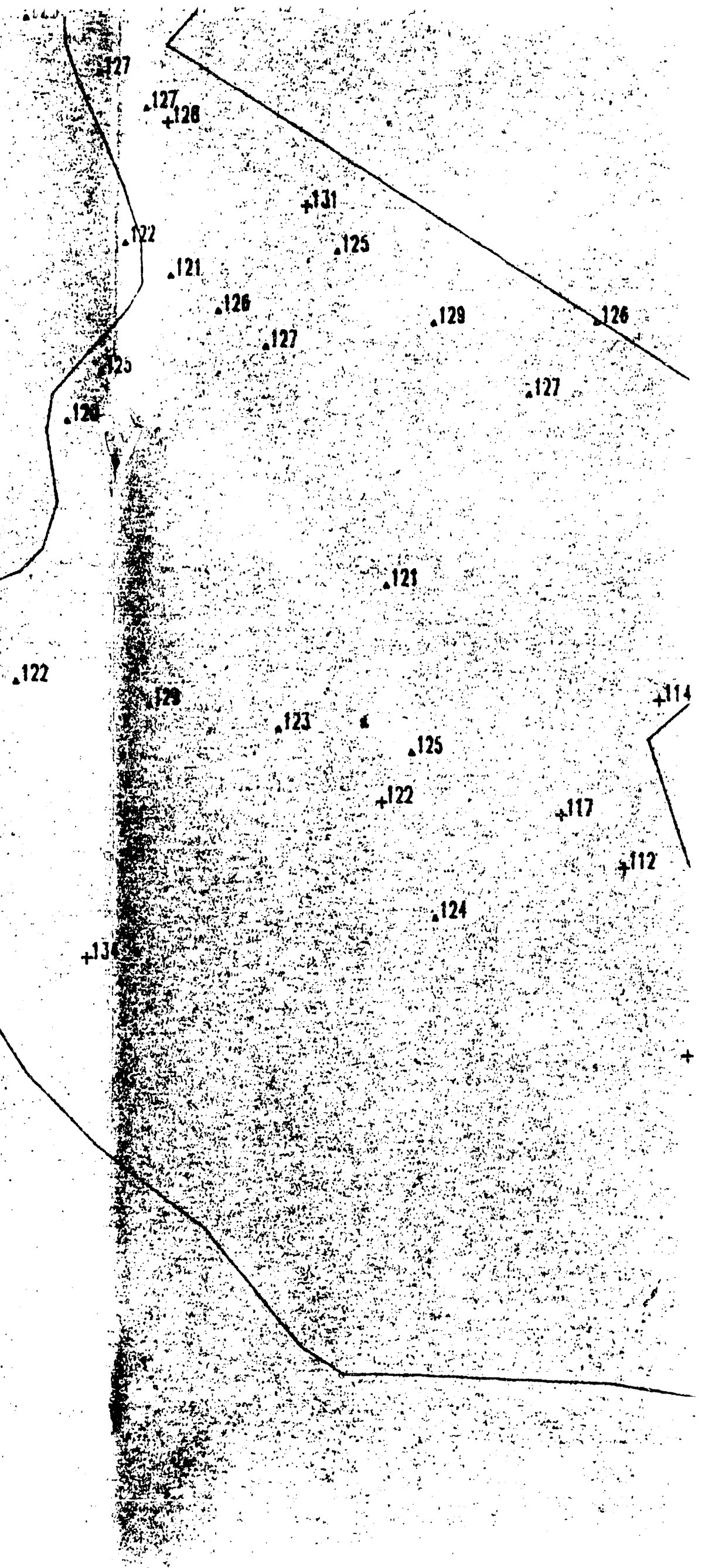




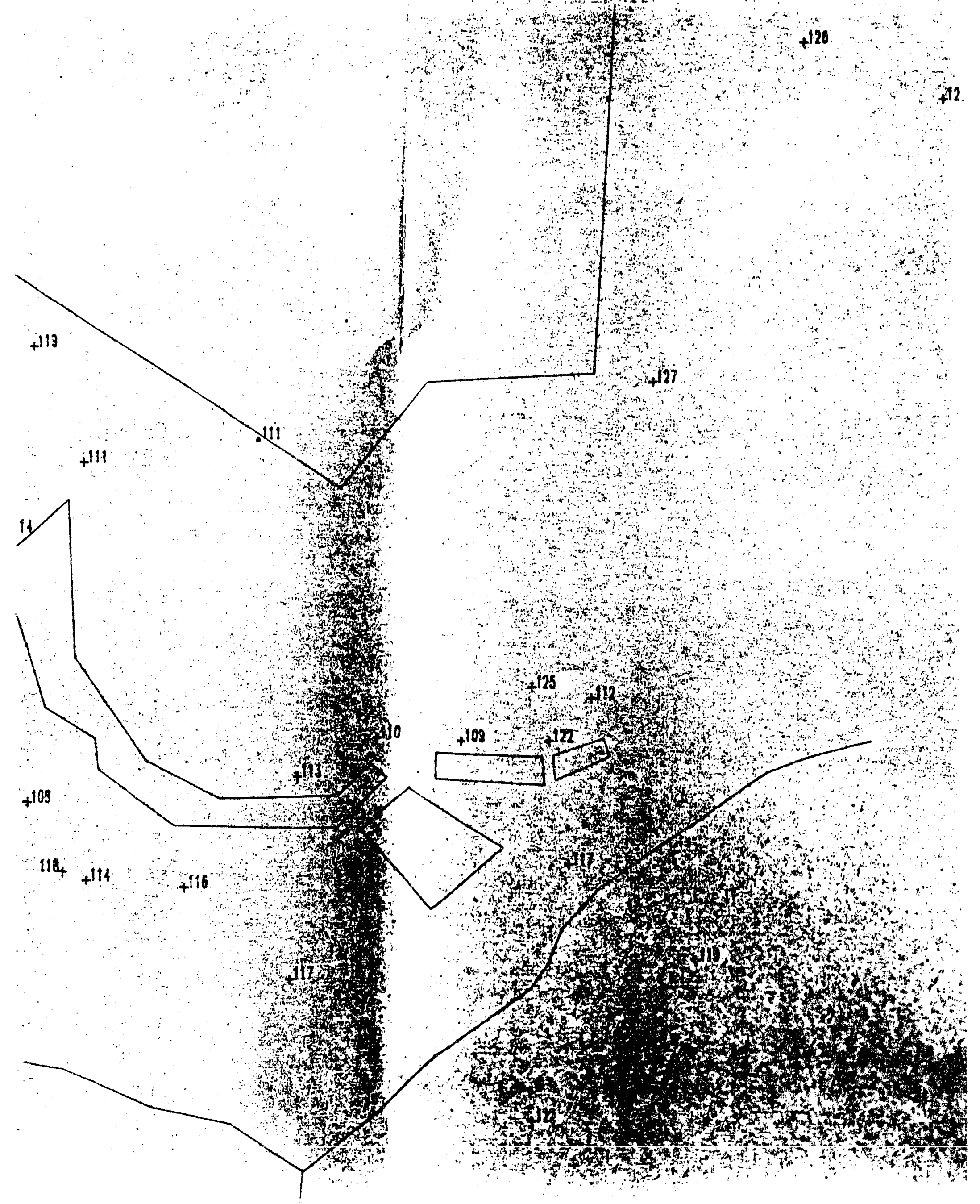




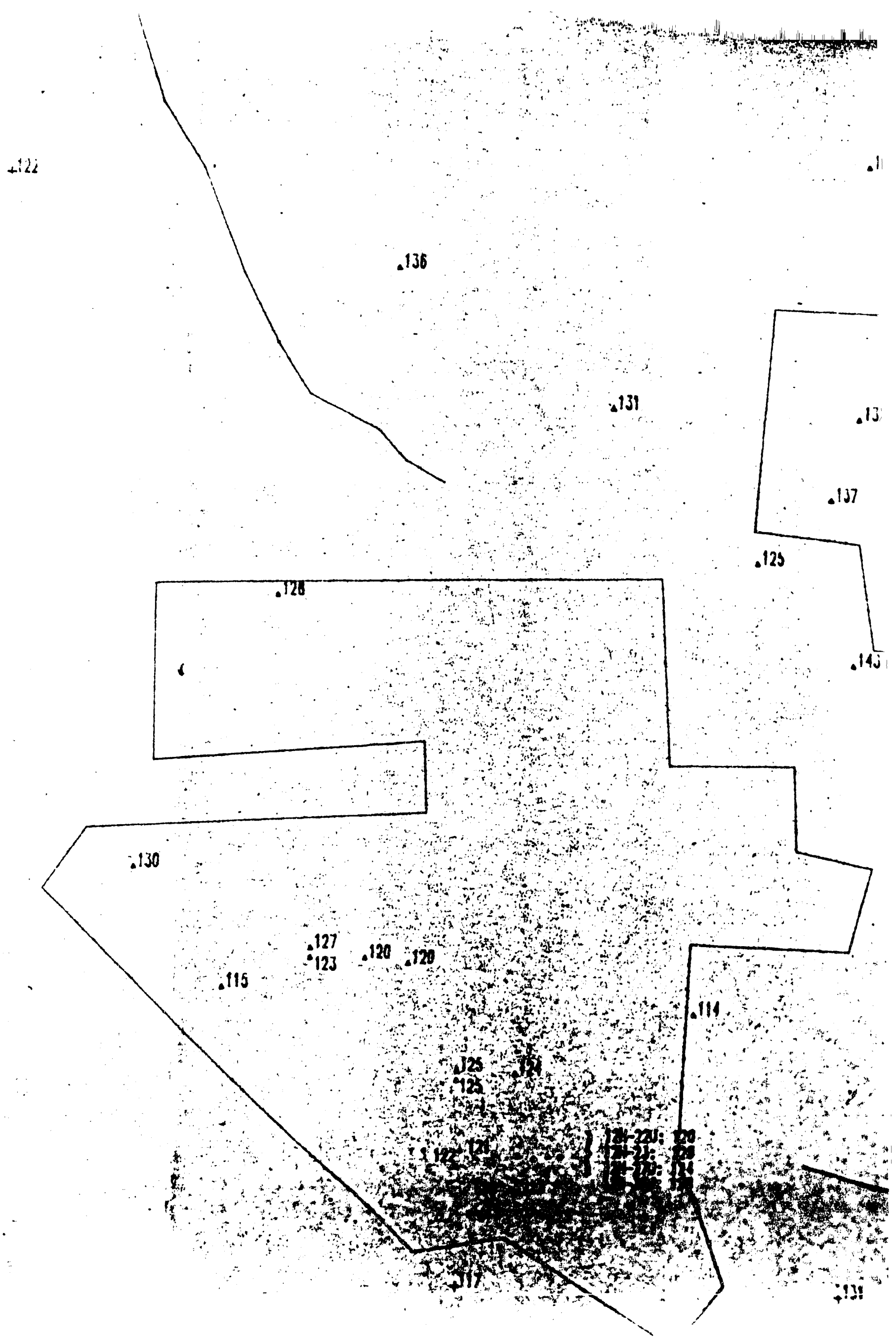




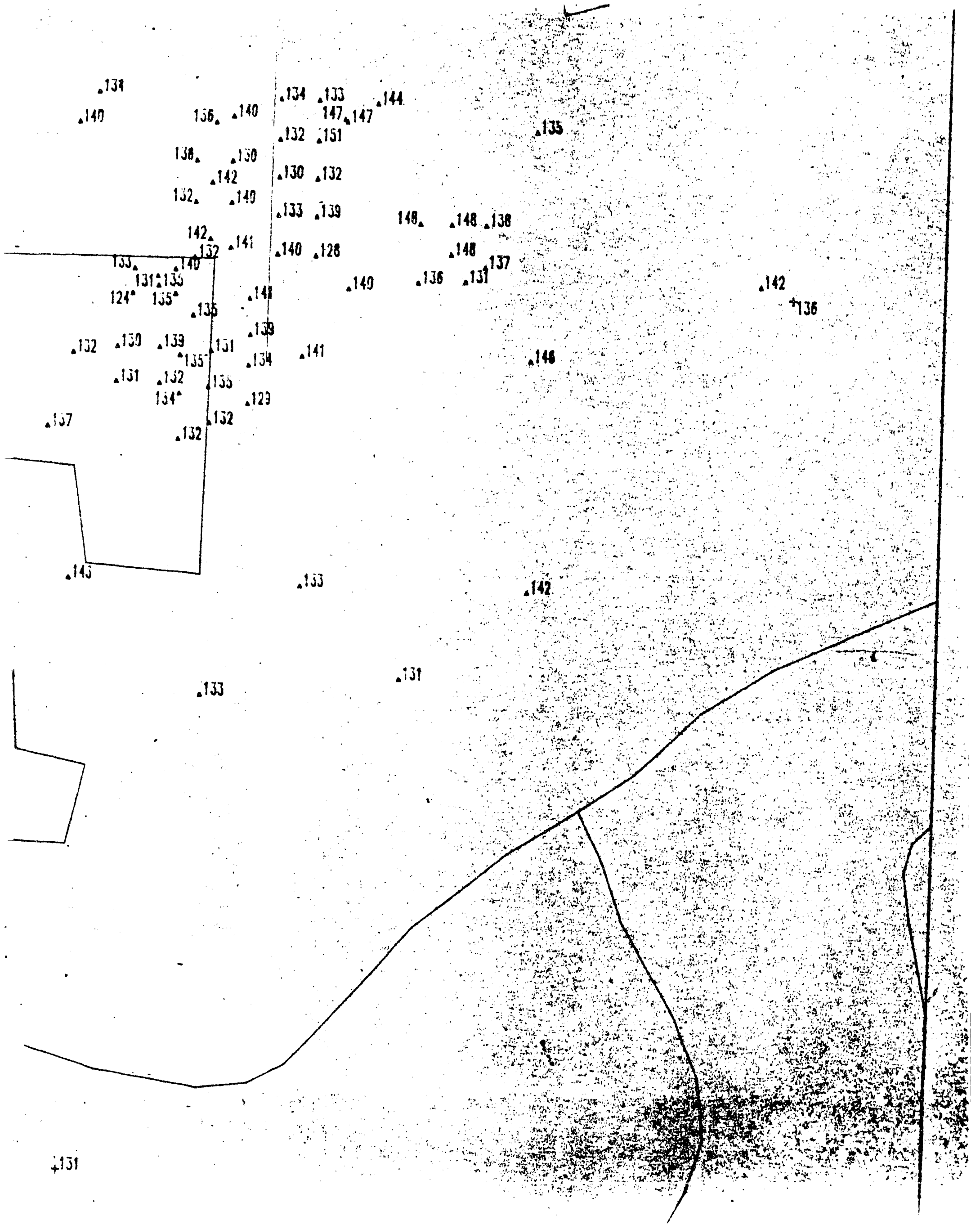



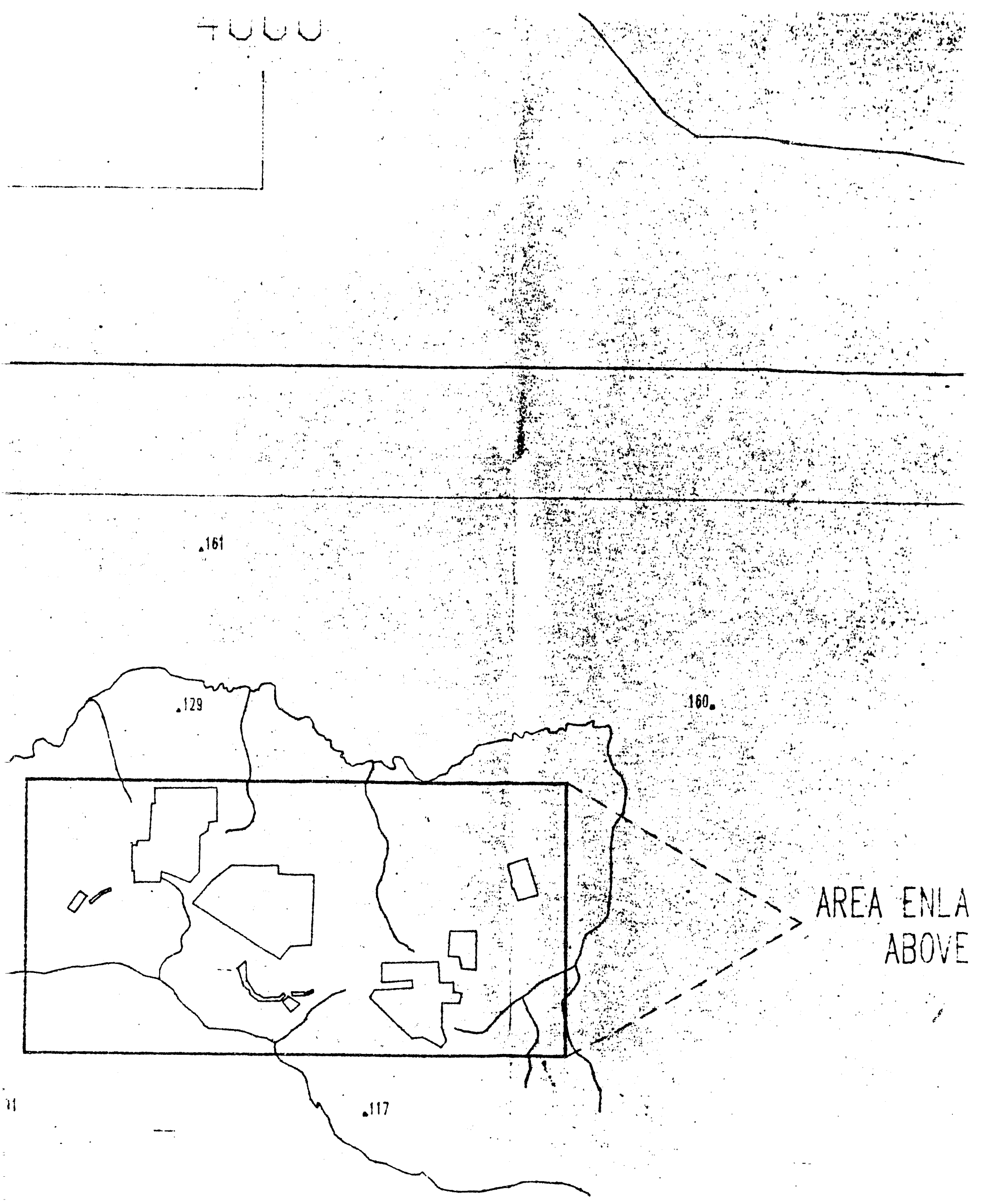


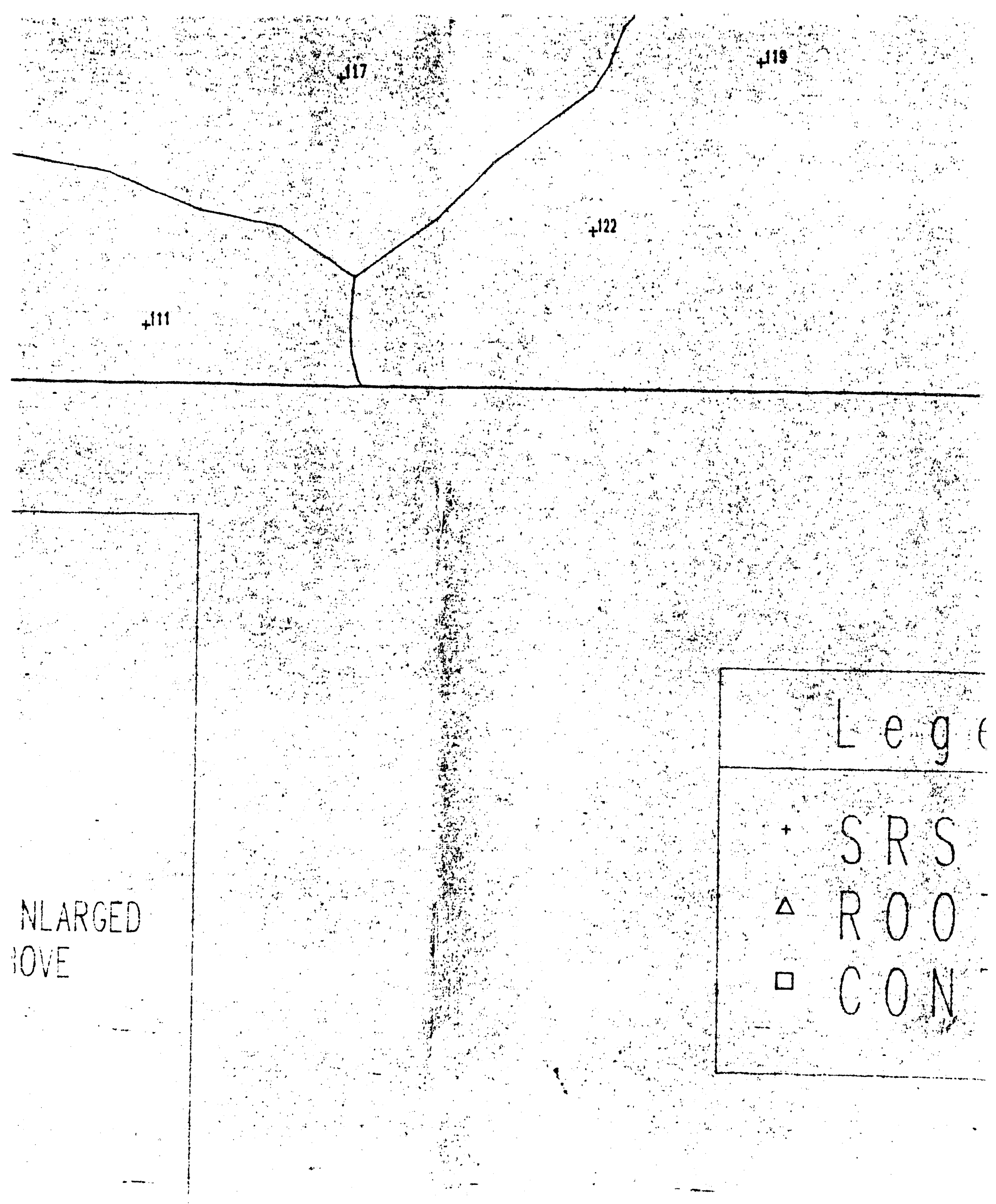




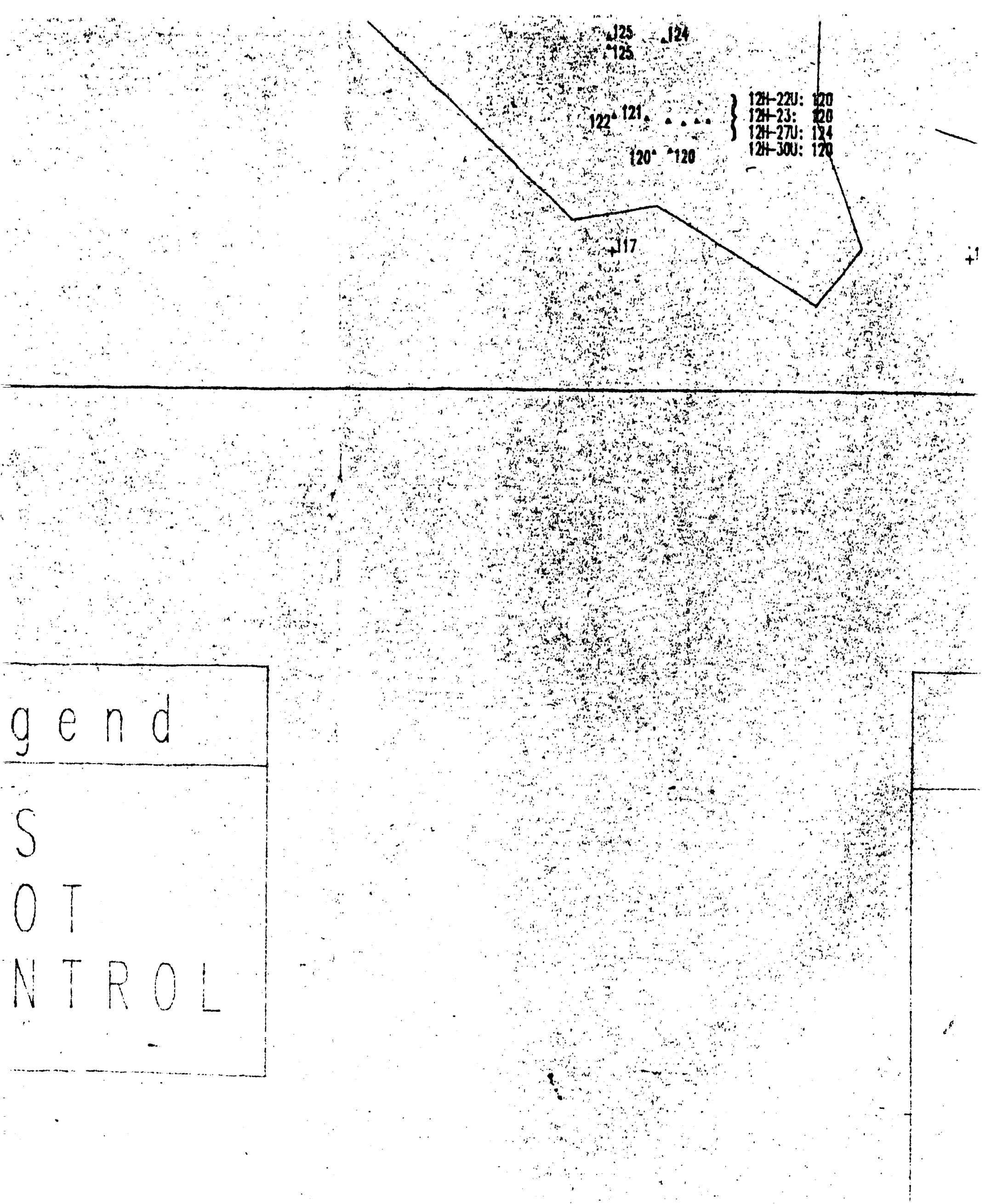




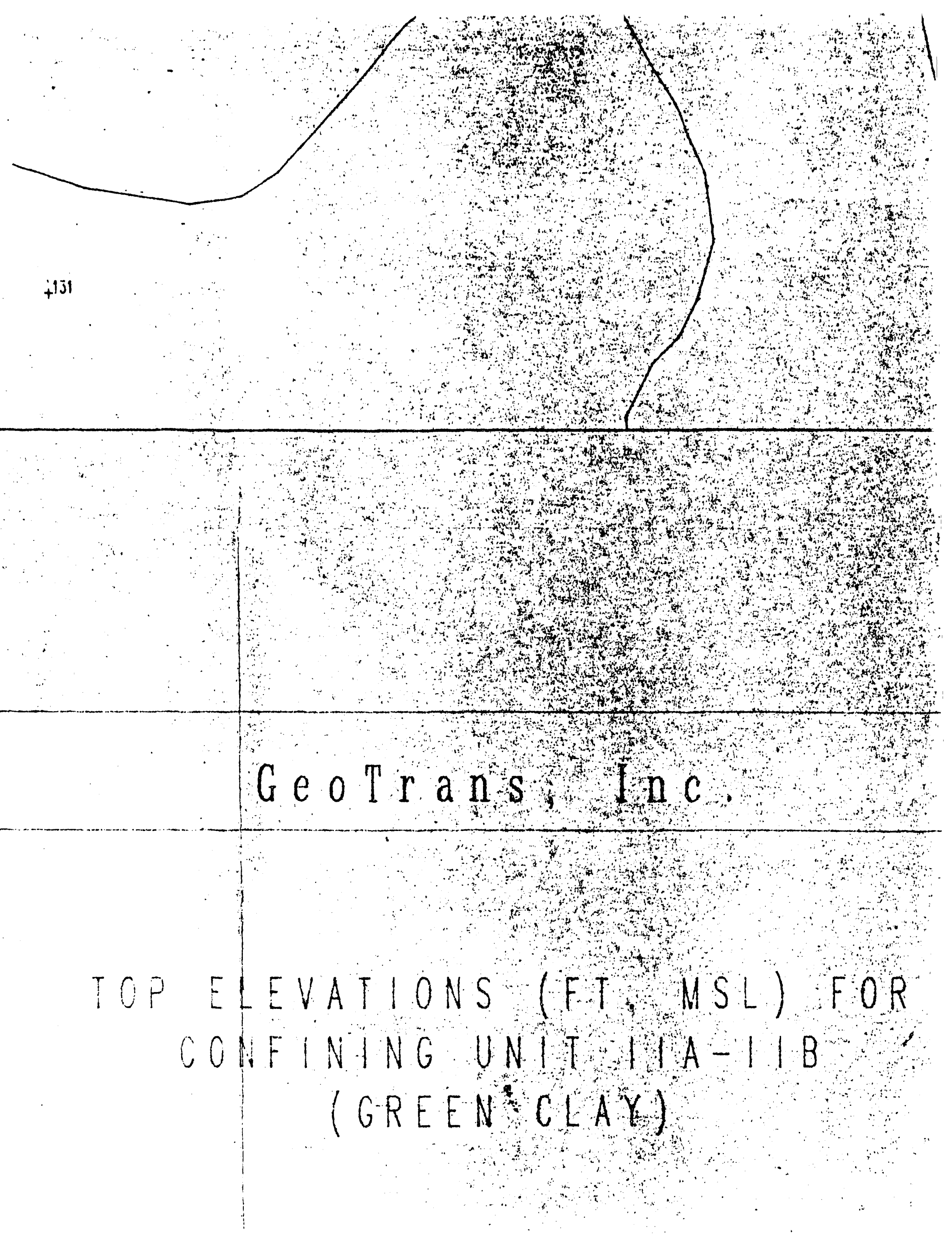




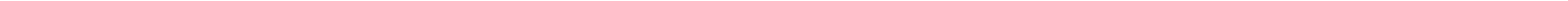




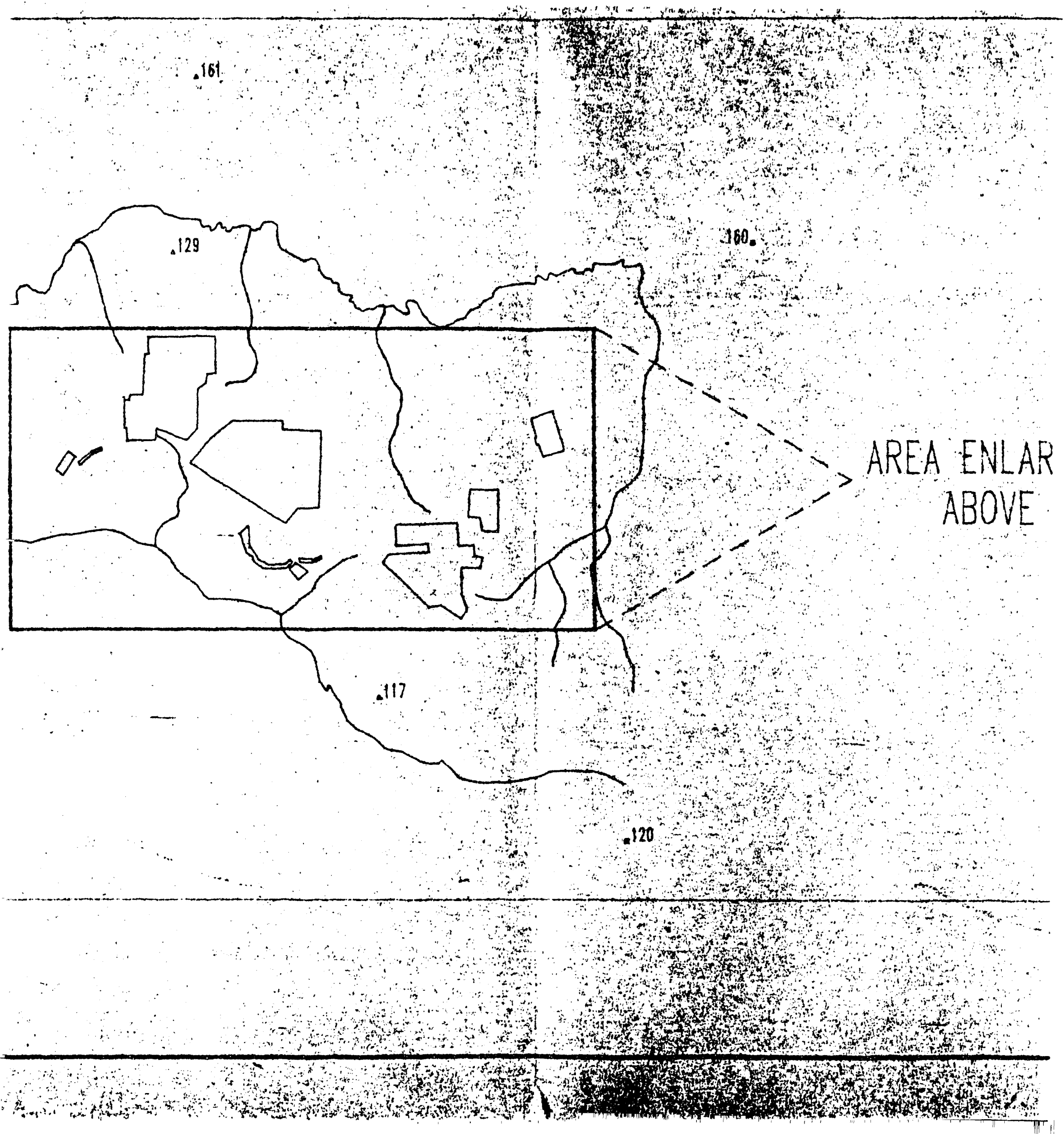




\section{Ge o Trans $1 \mathrm{nc}$.}

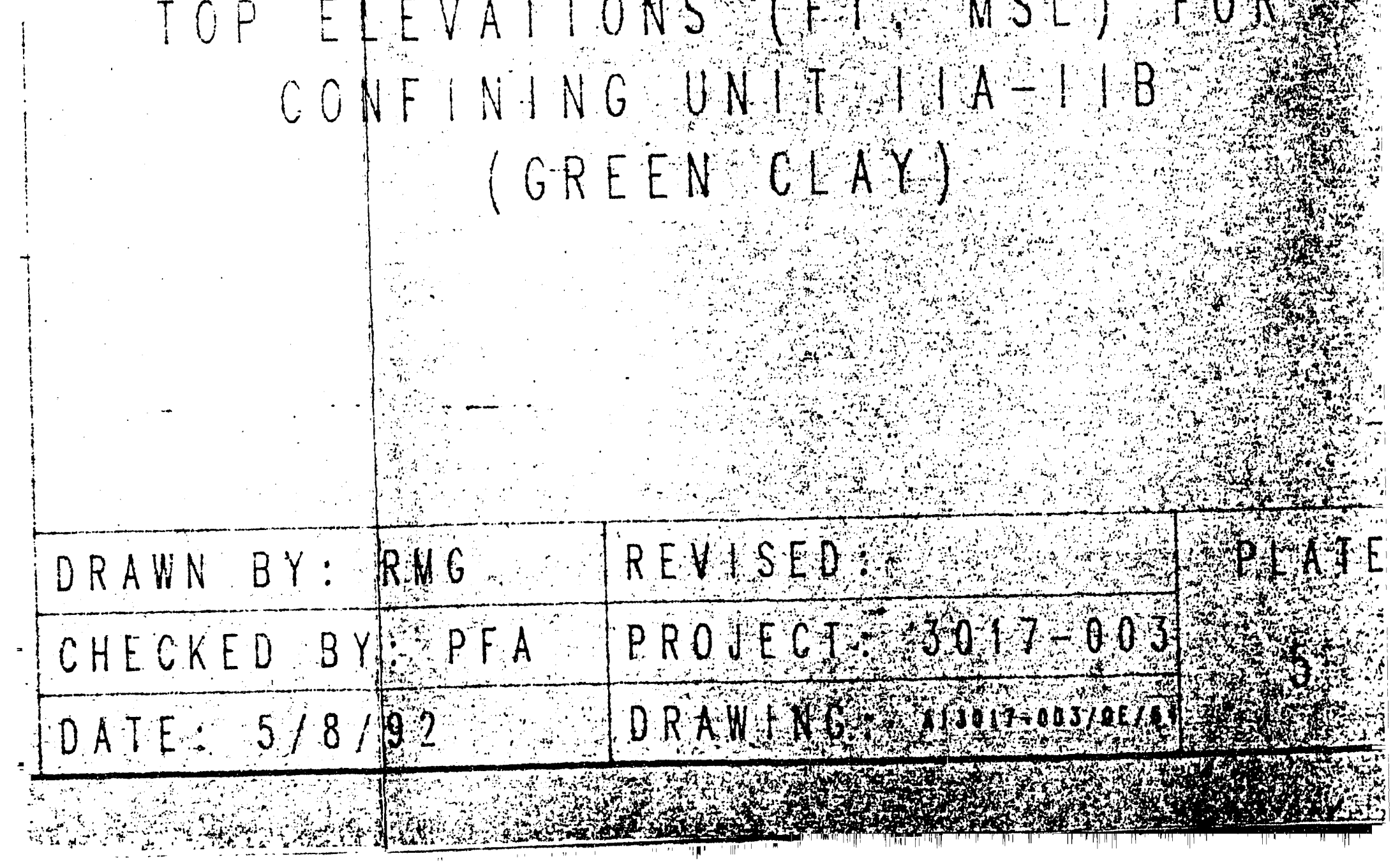




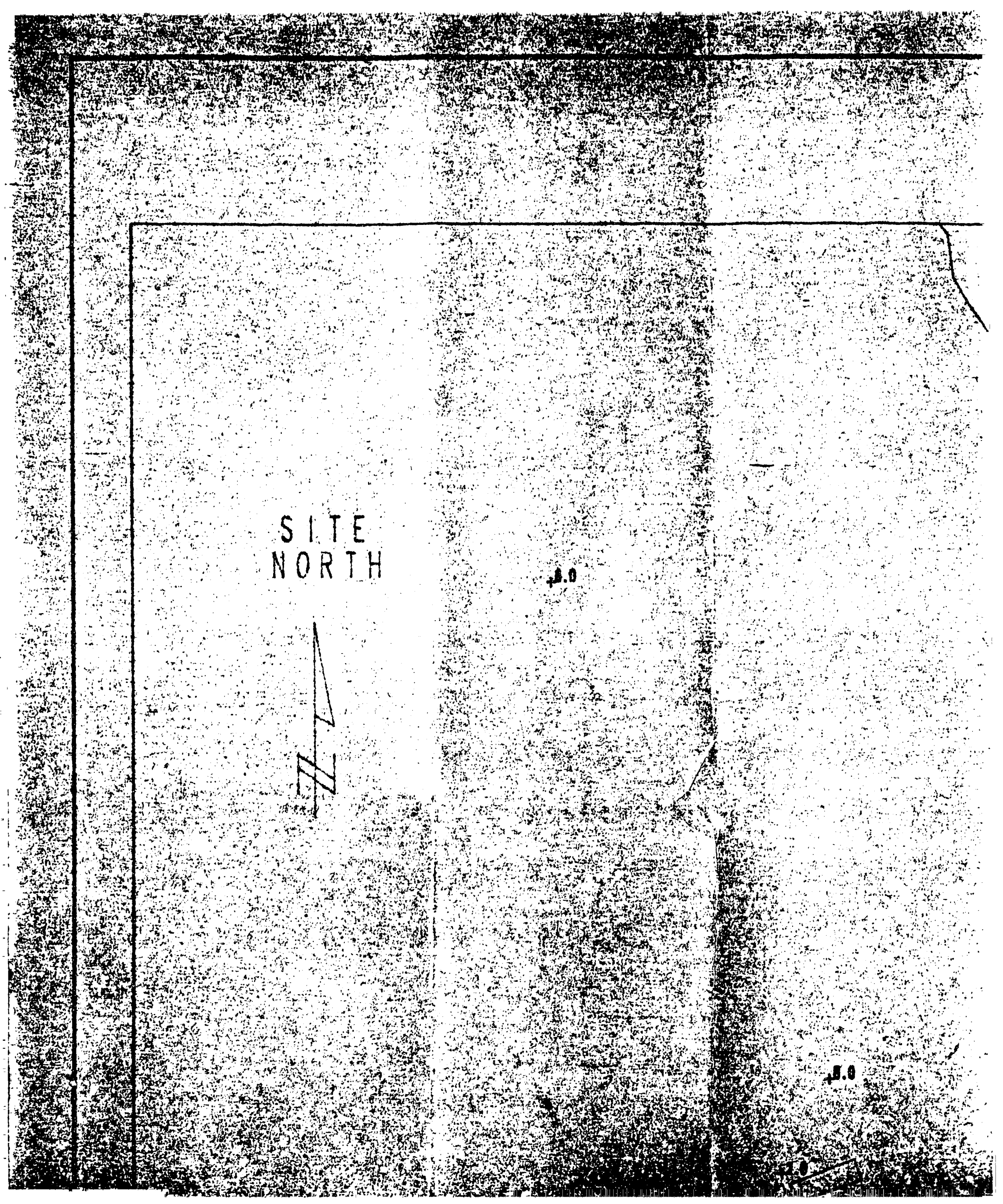




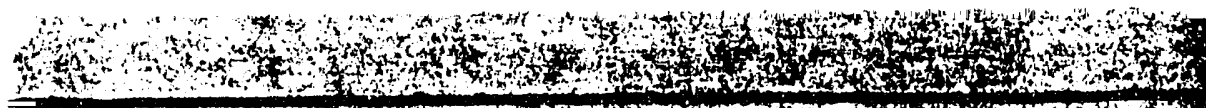

Wy

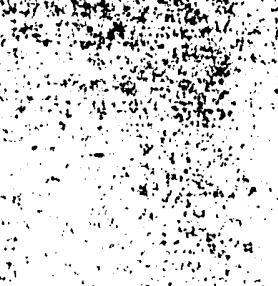

is

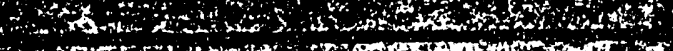

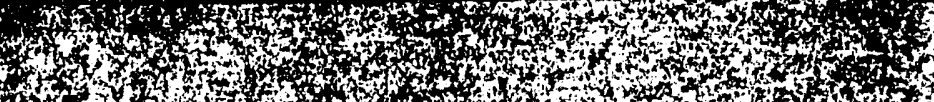

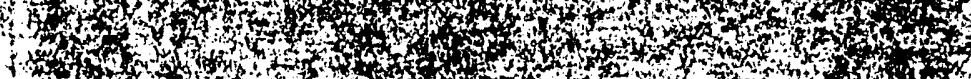
W

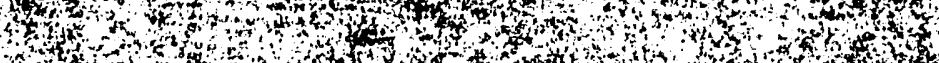

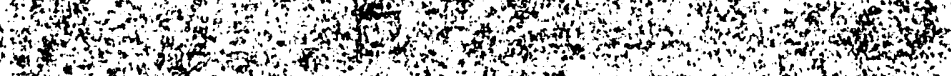

W

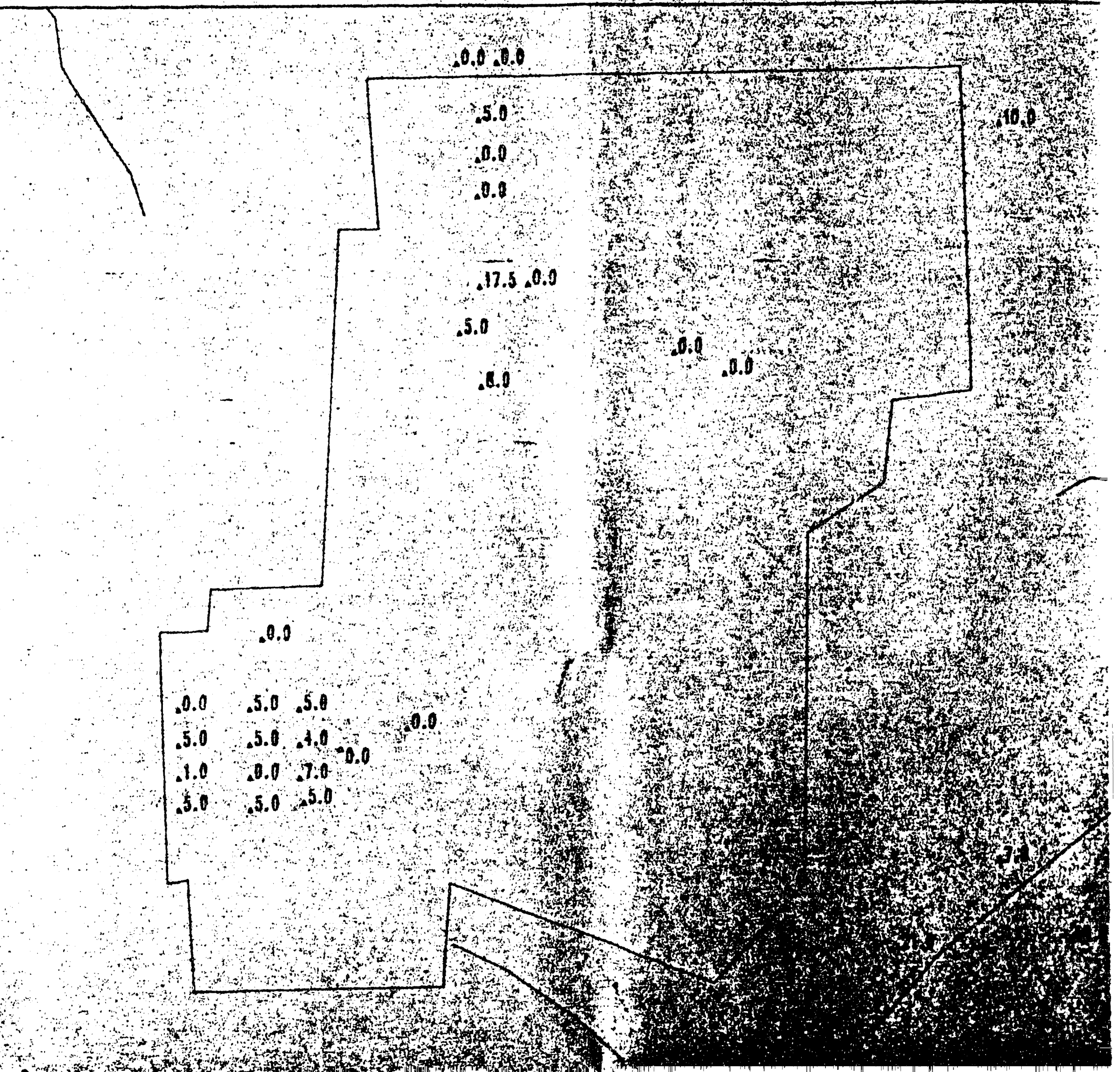

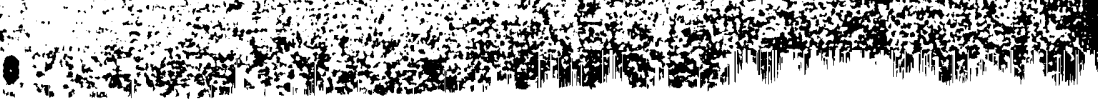




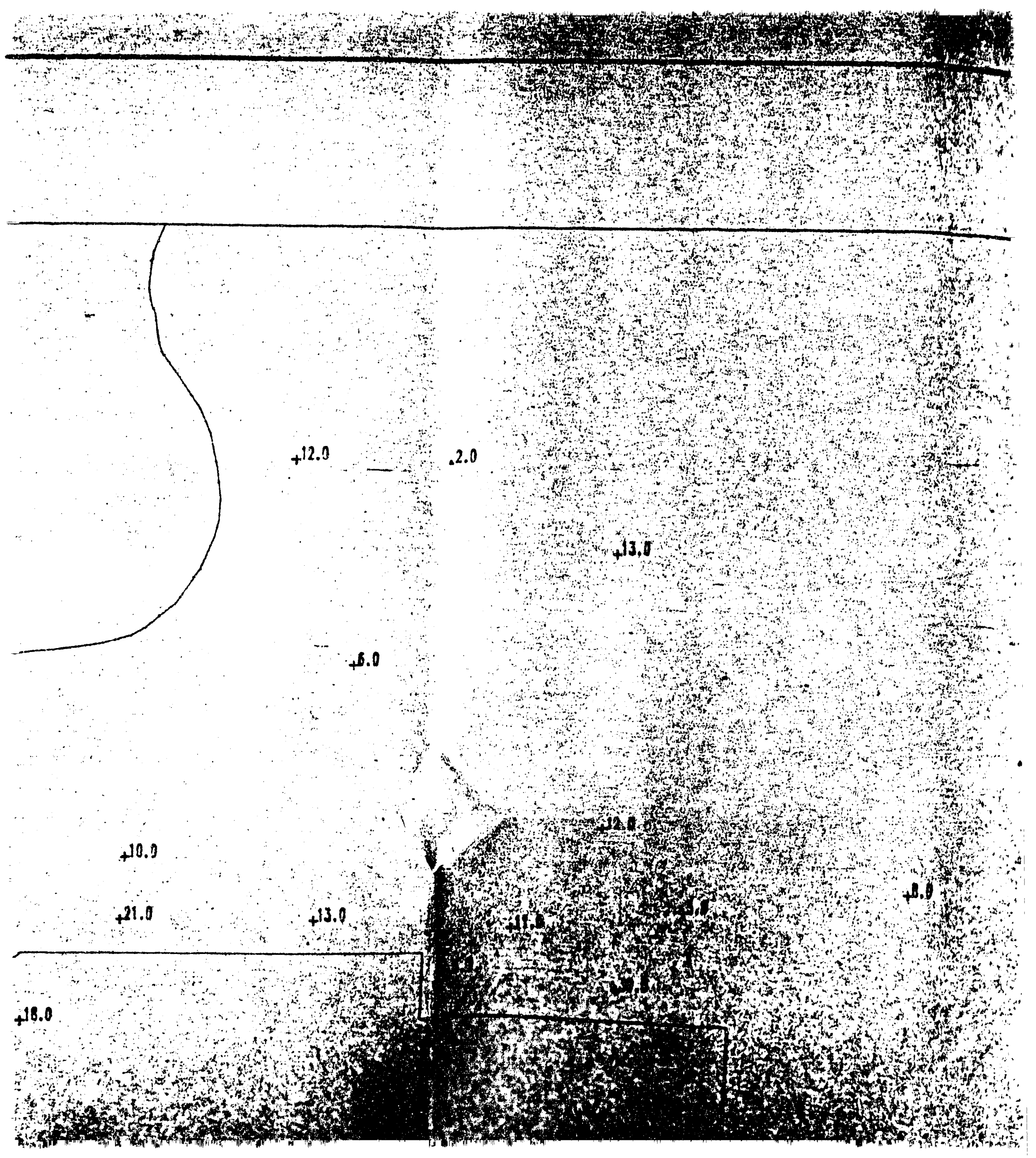





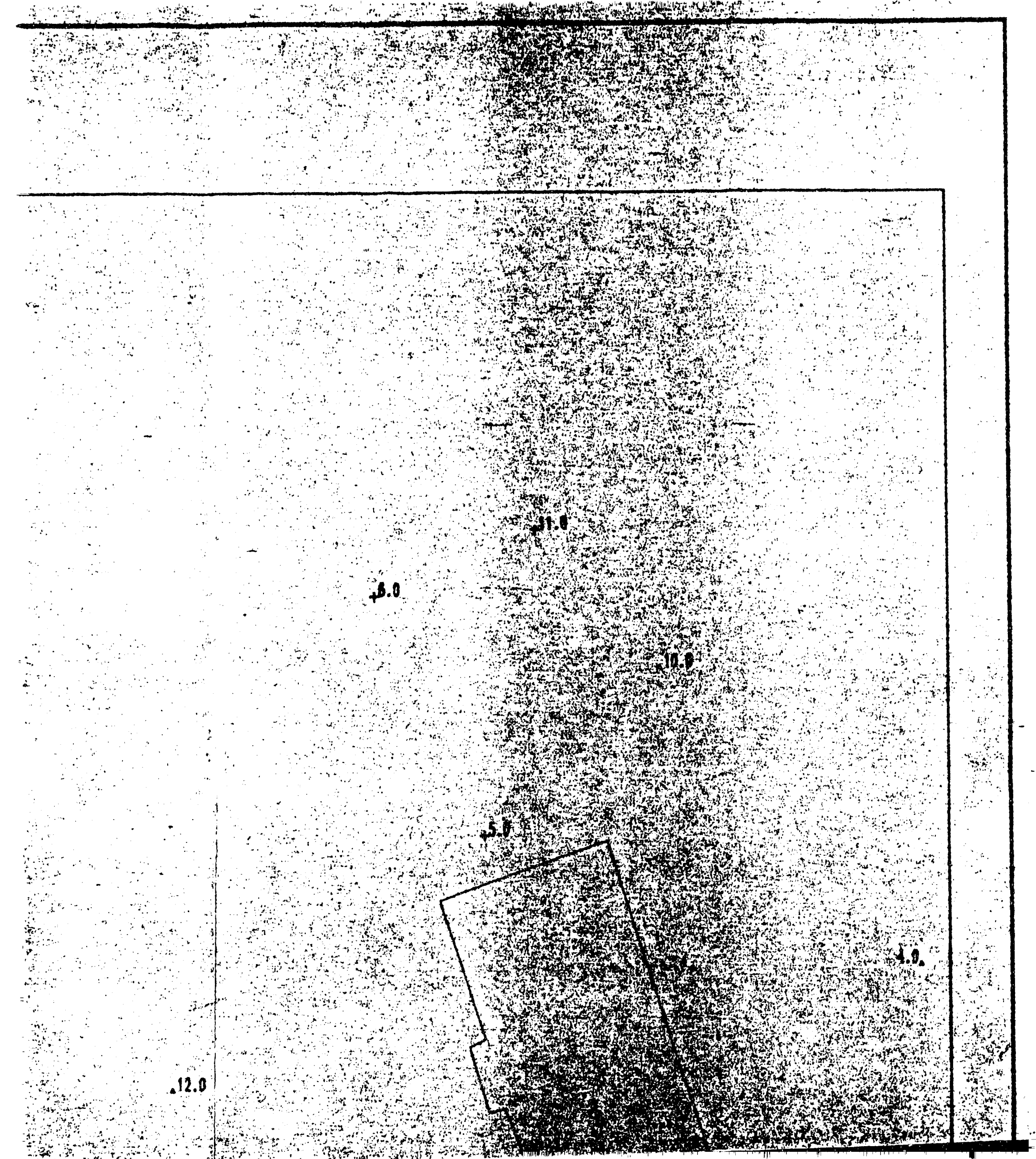




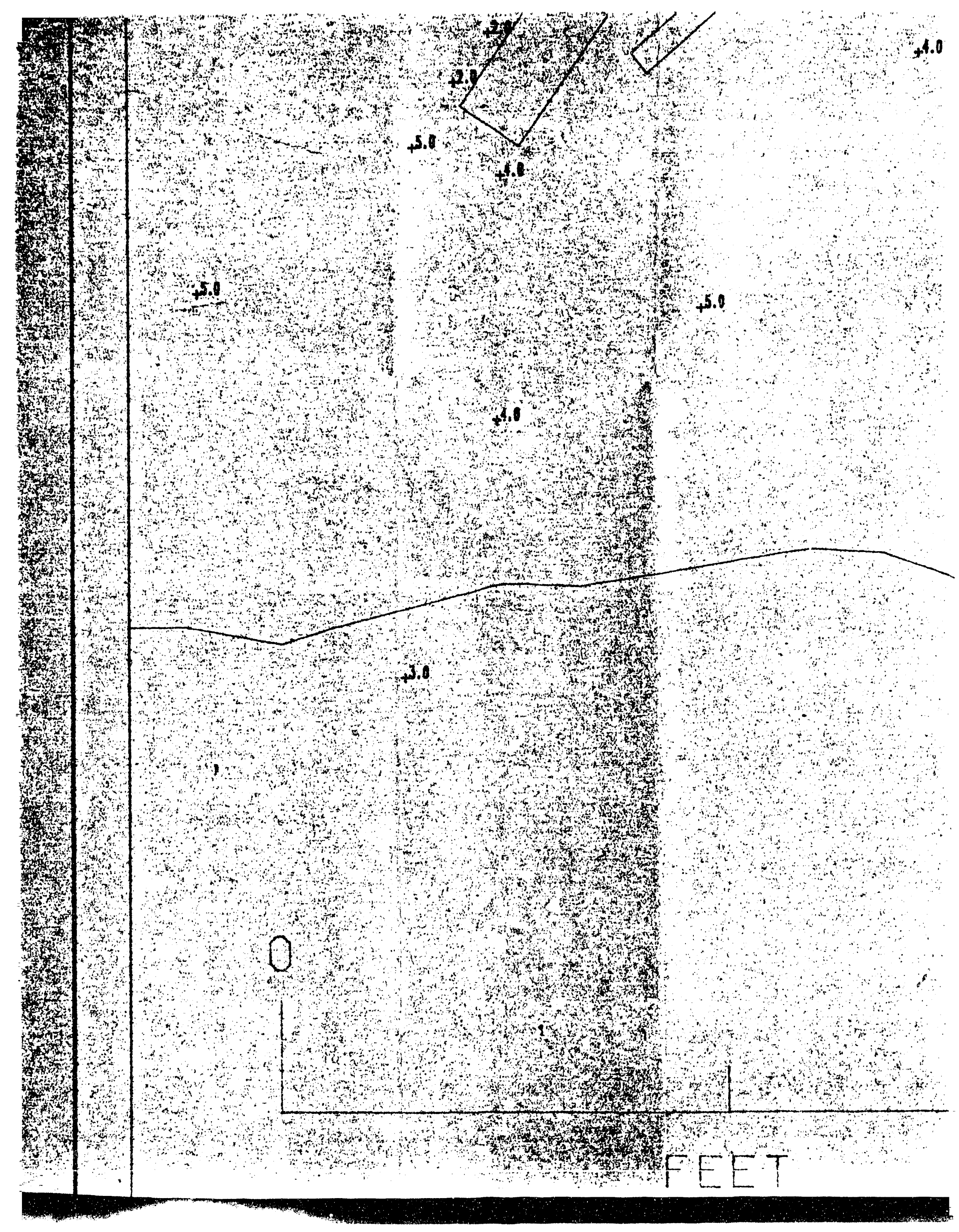




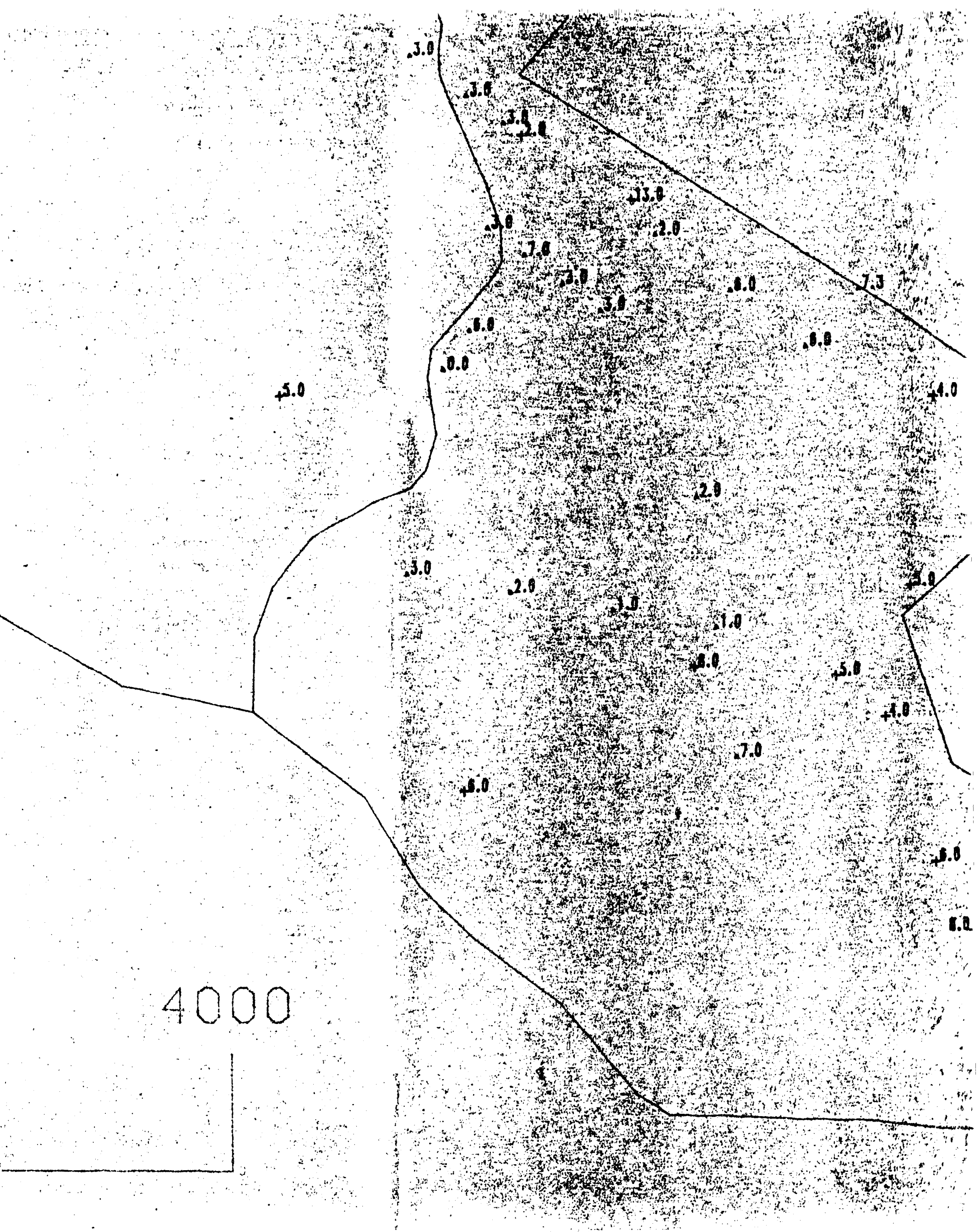




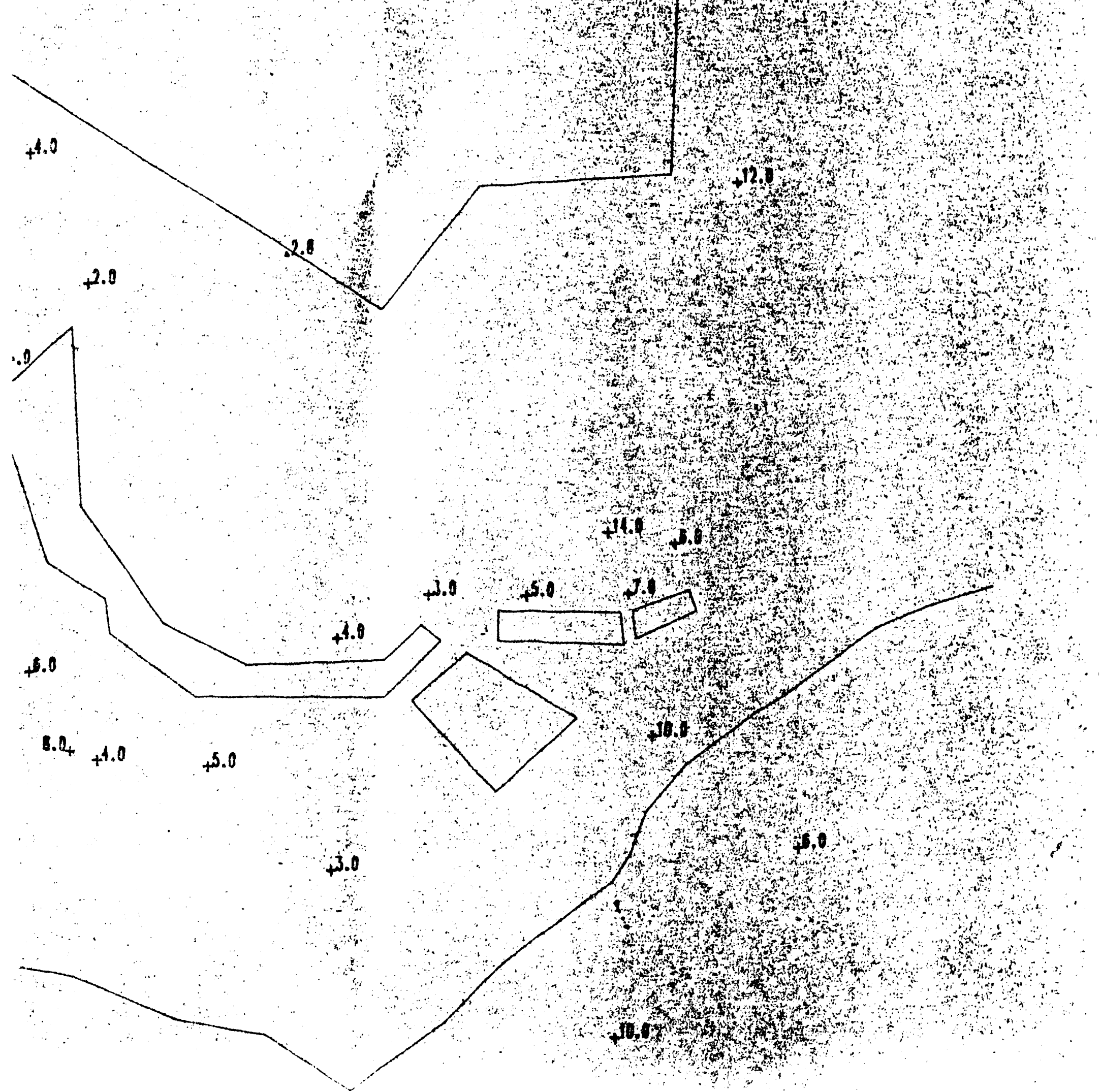




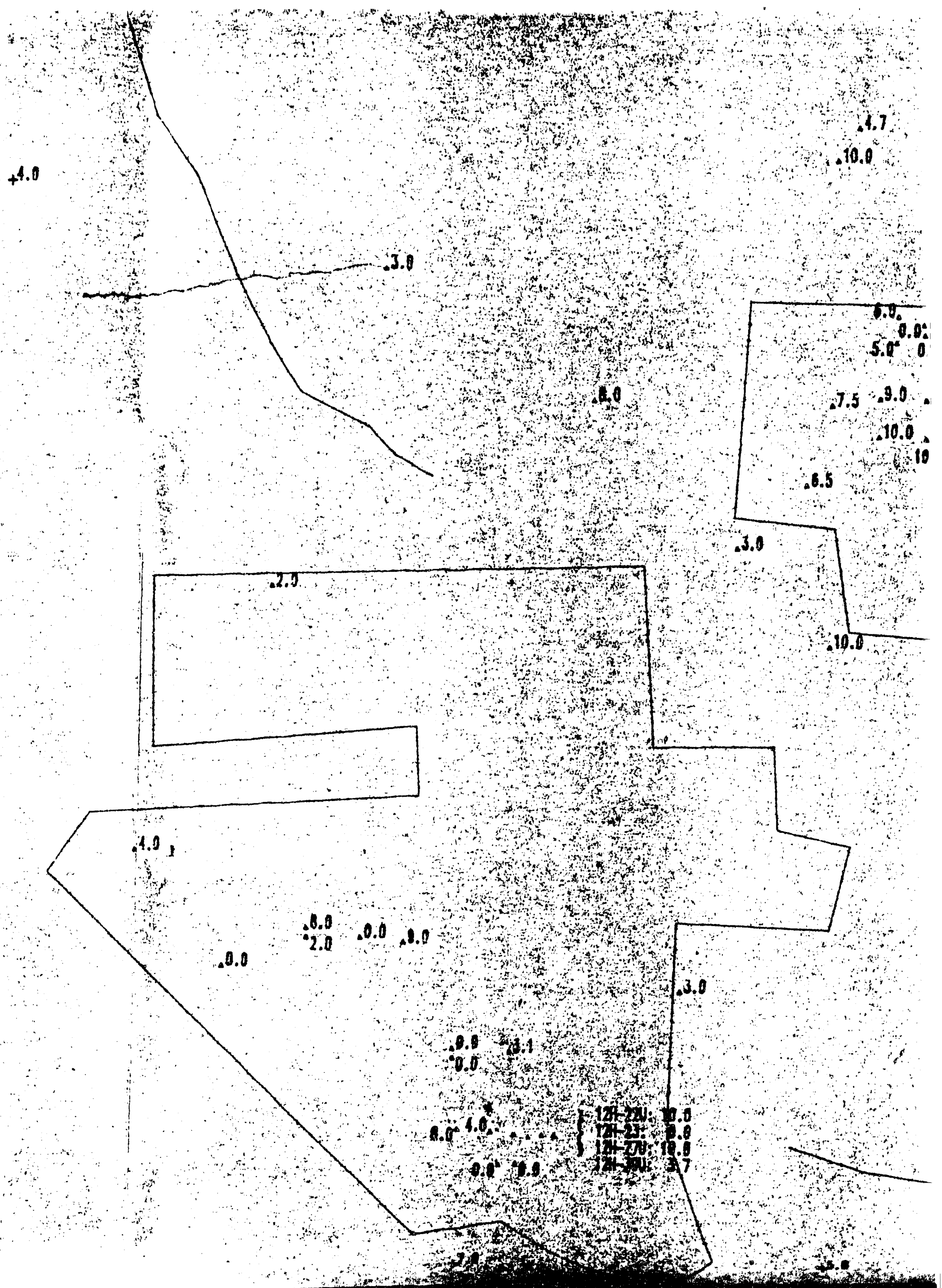




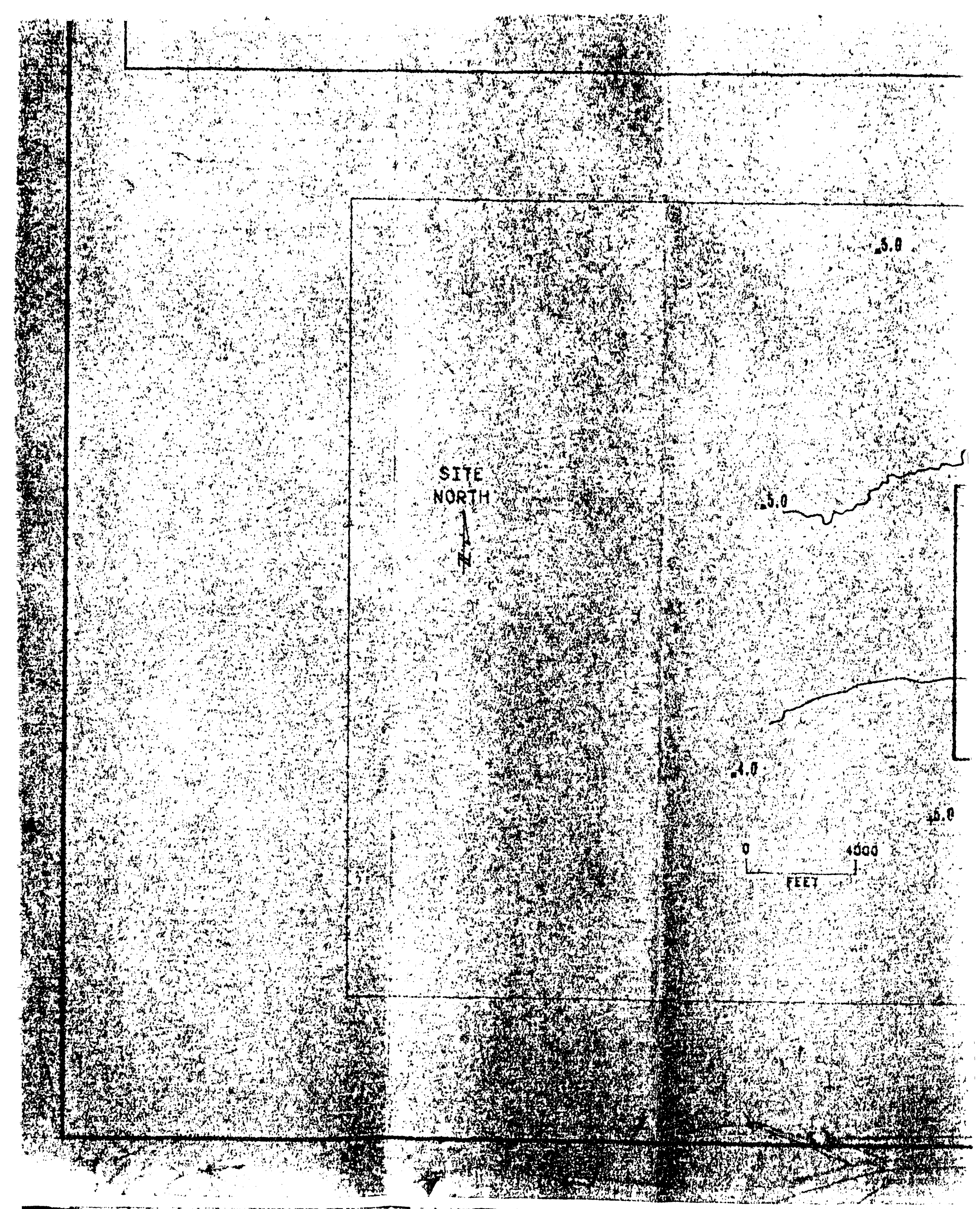




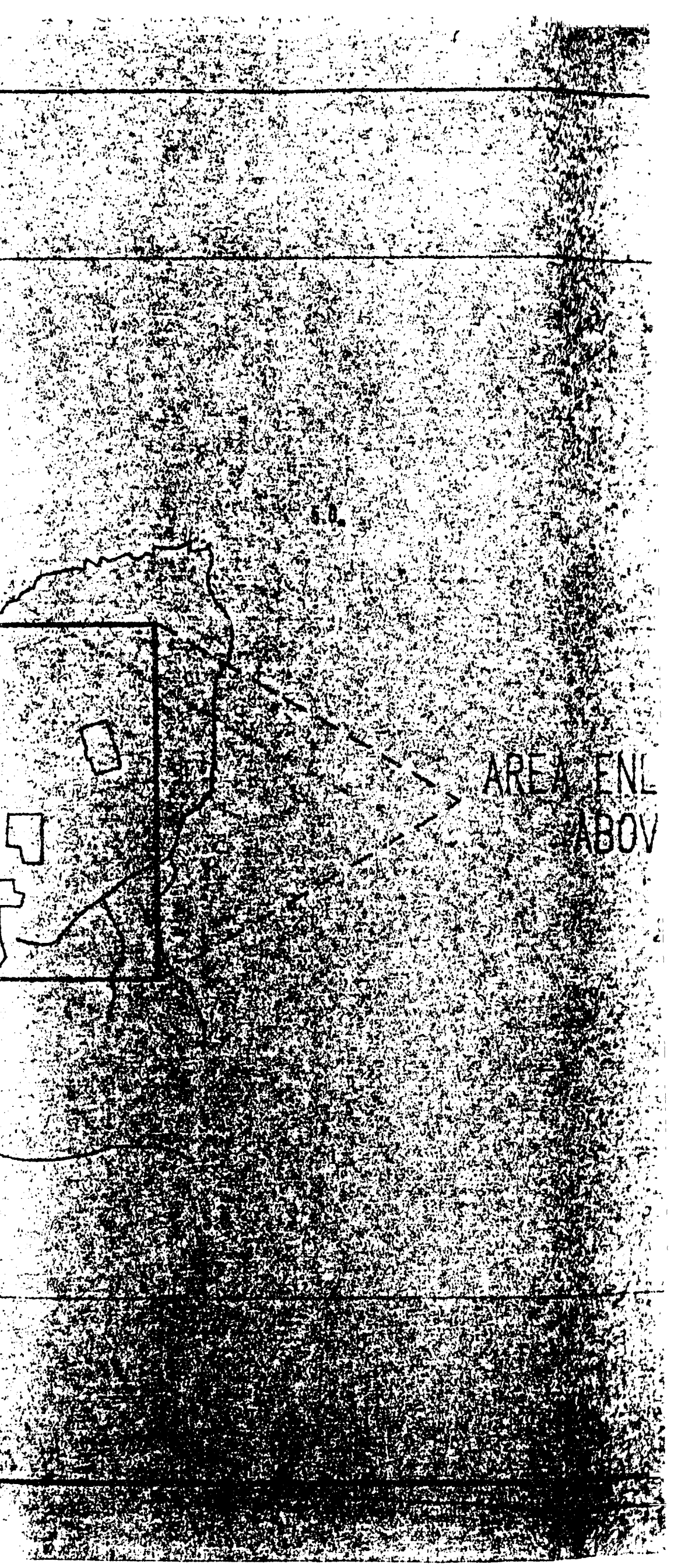



Intint
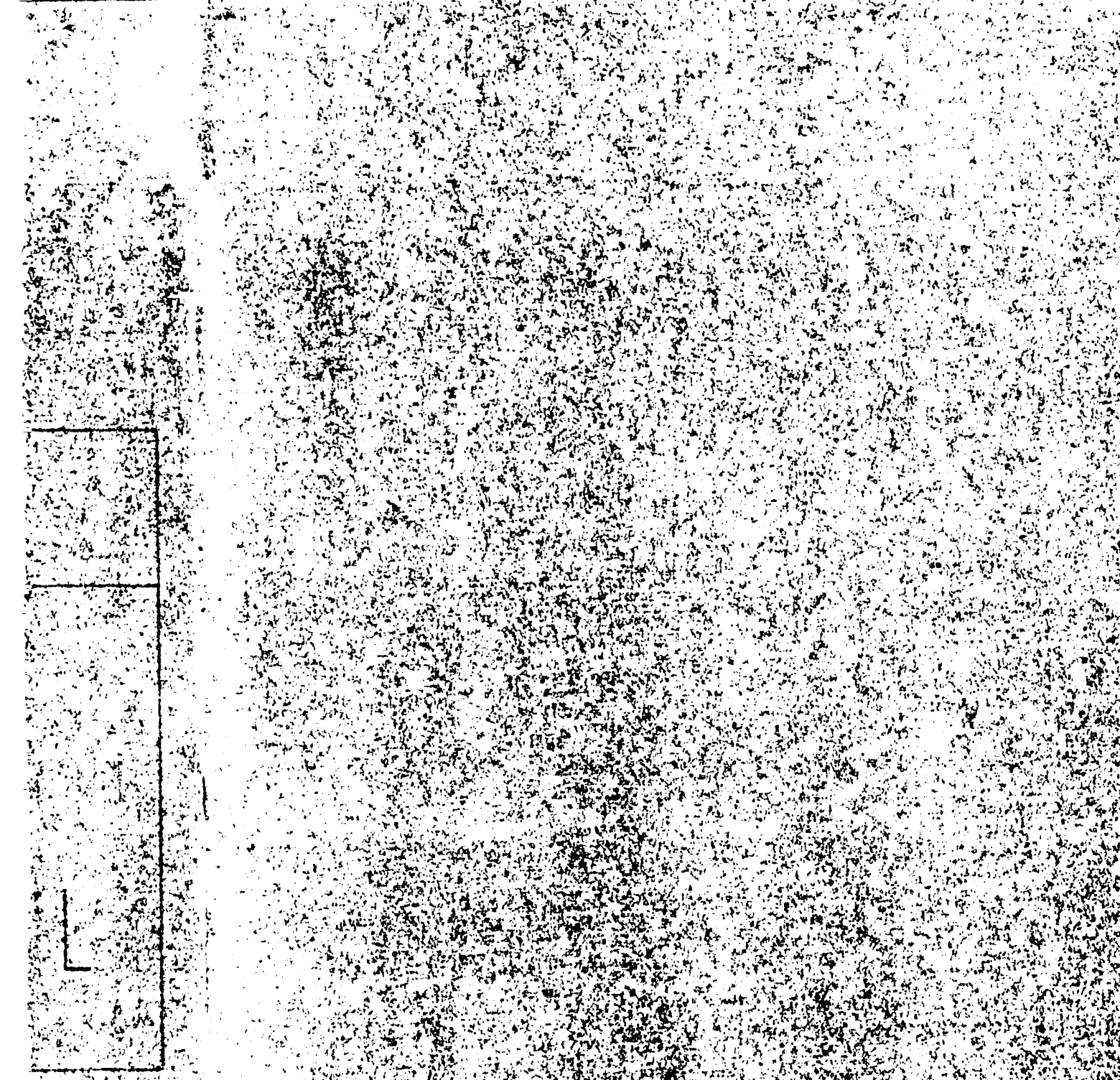

not

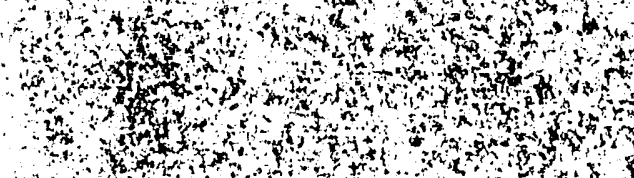

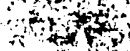

w

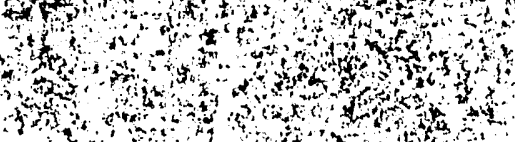

in?

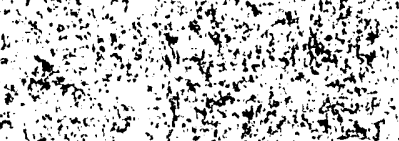

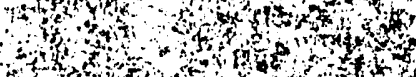

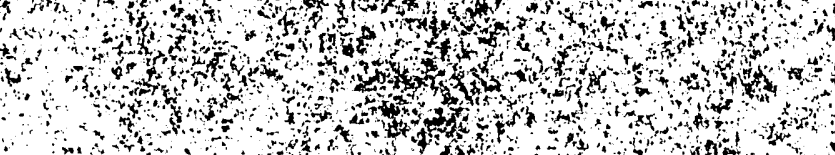

and ond

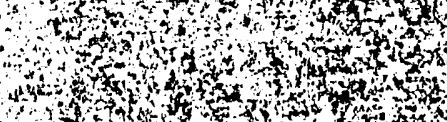

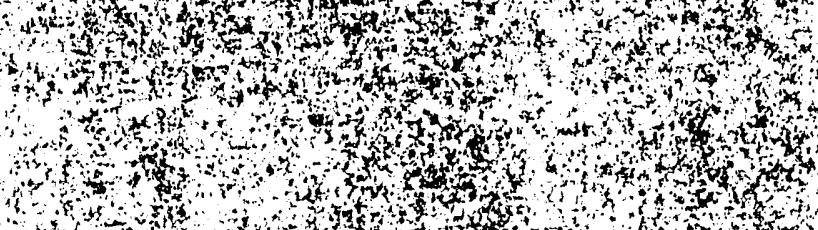

and

ind

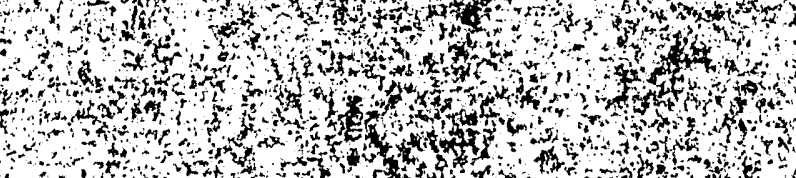

$\operatorname{lin}_{2}$

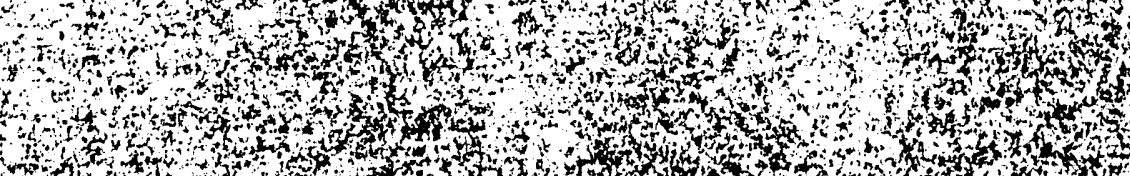

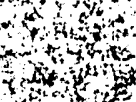

ations

tornt

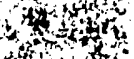

so

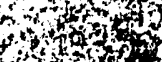

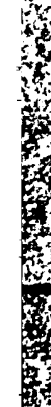

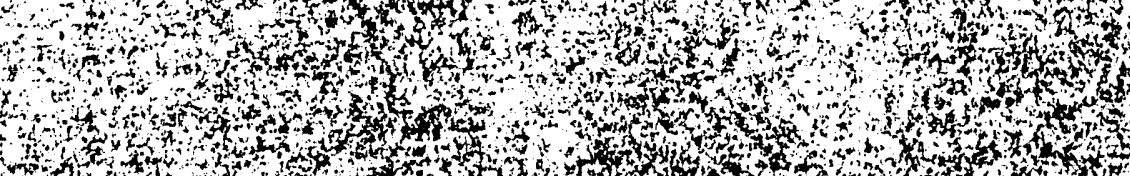

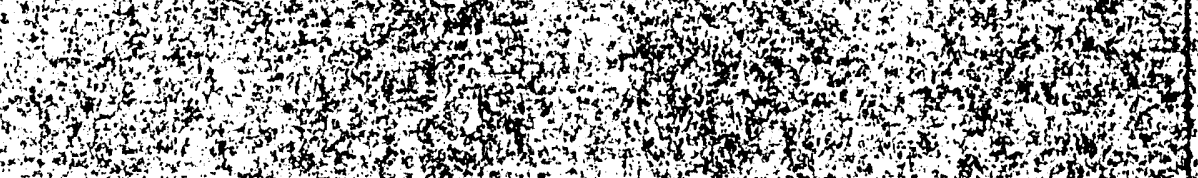

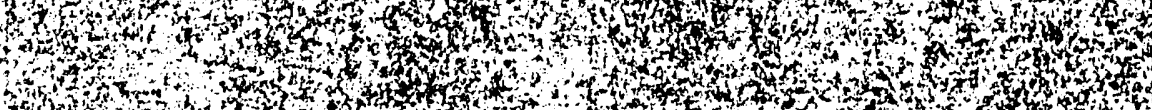

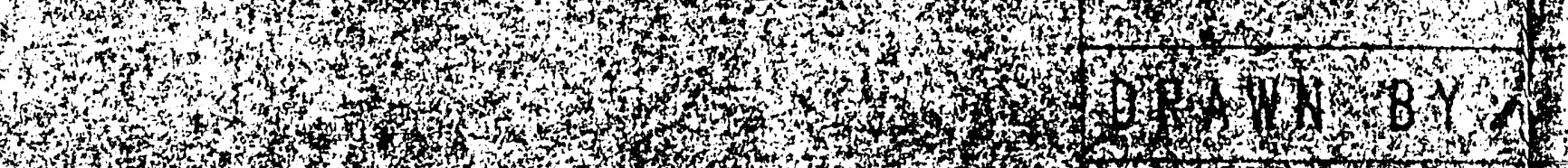

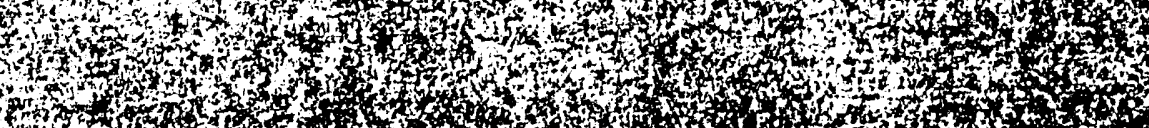




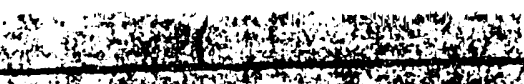

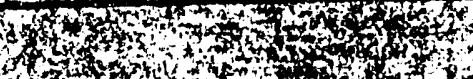

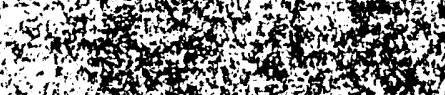

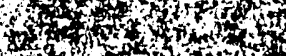

$\frac{4}{4}$

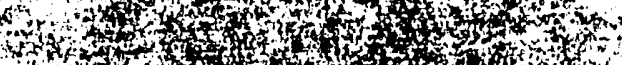

3
3

3
3

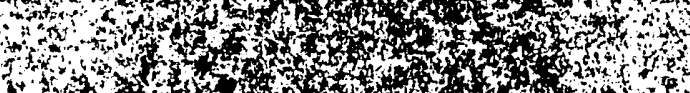

3
5

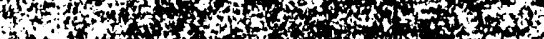

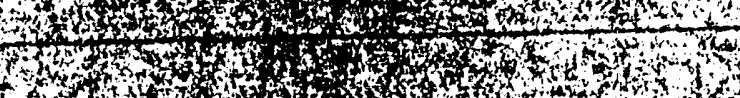

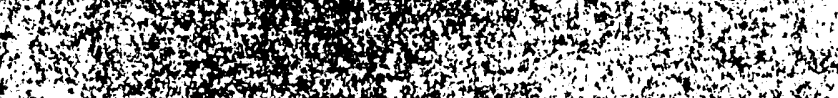

(1) ( on

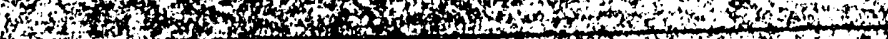

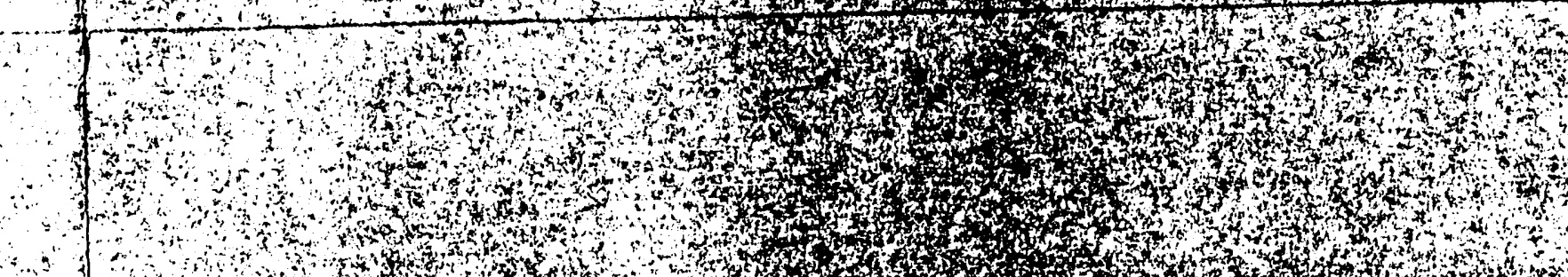

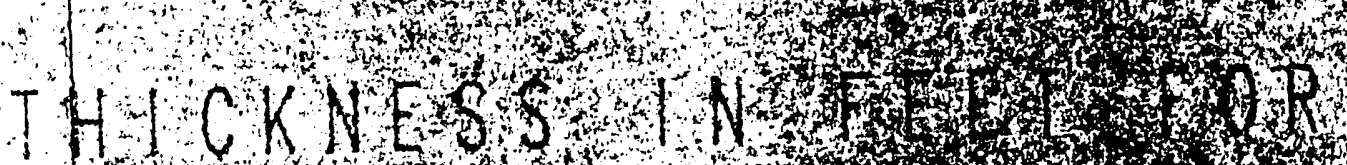

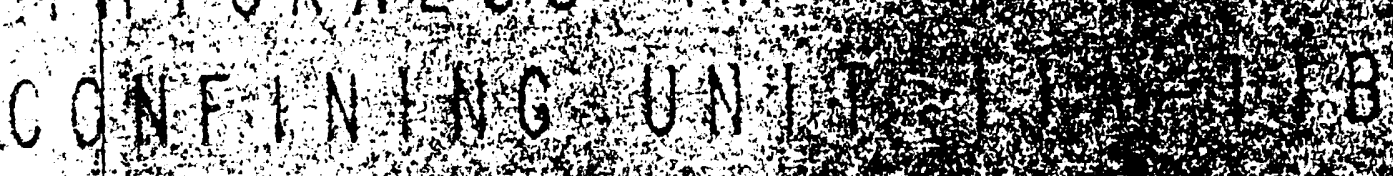

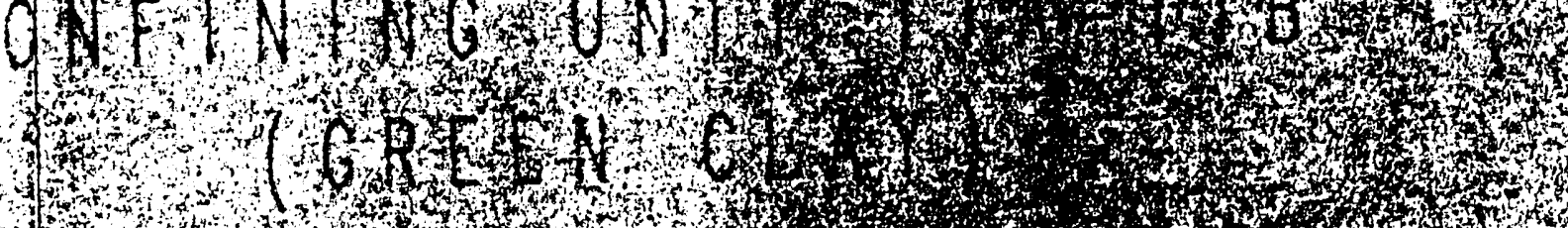

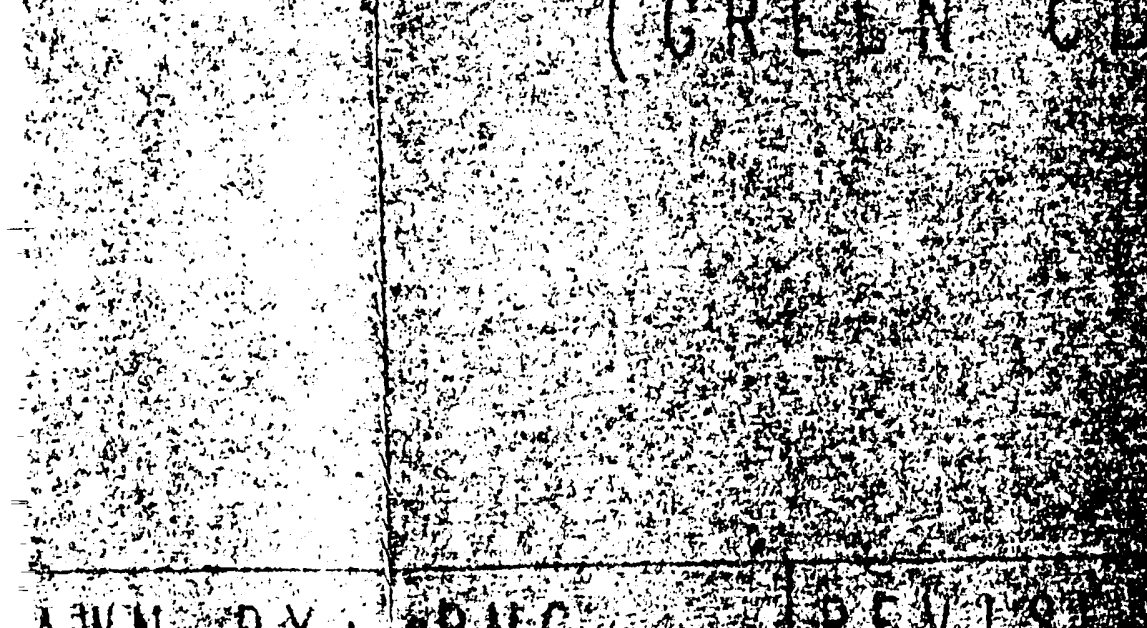

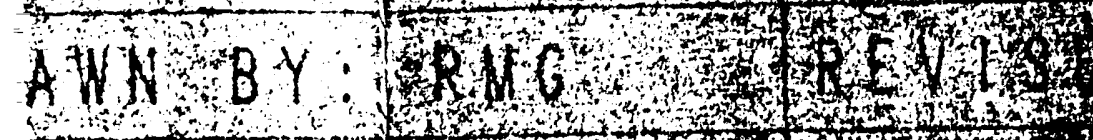

Cok B B 8 ,

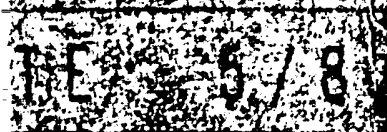

x-7.

\section{,}

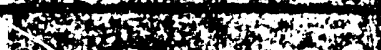

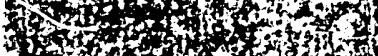

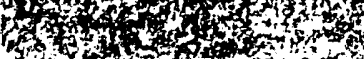

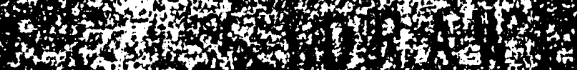

4
4
4

- 


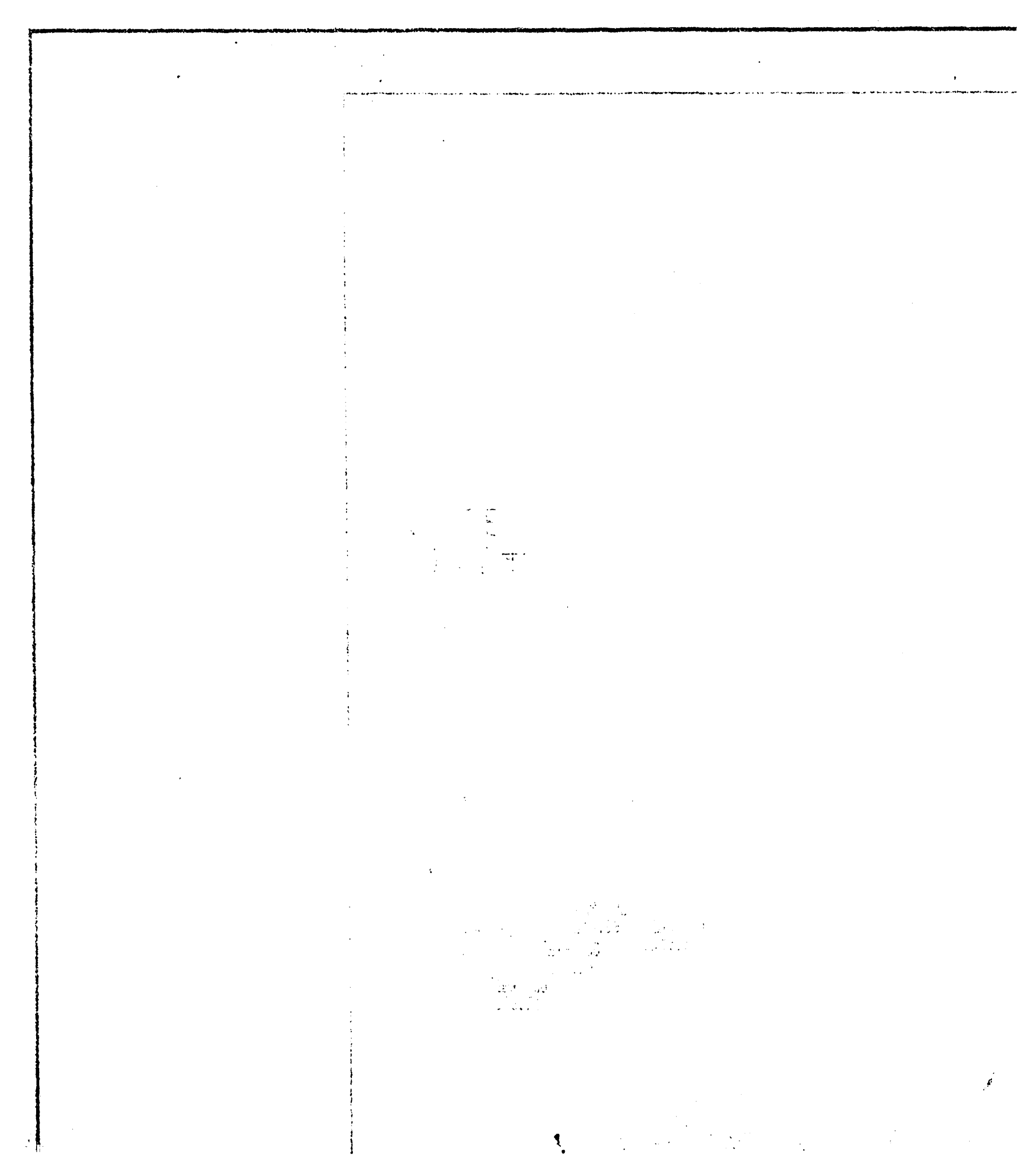


i 


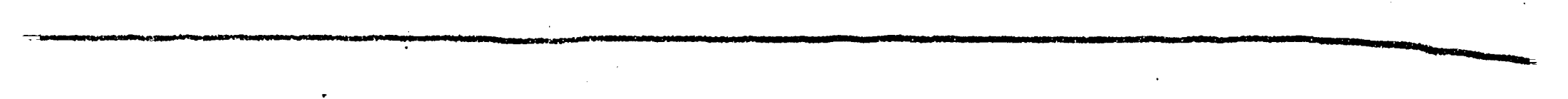


in.

2.18 


$$
\begin{aligned}
& \begin{array}{c}
83 \\
240.40
\end{array}
\end{aligned}
$$

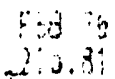

50

ㄴ. ?

$$
\therefore \text { as }
$$

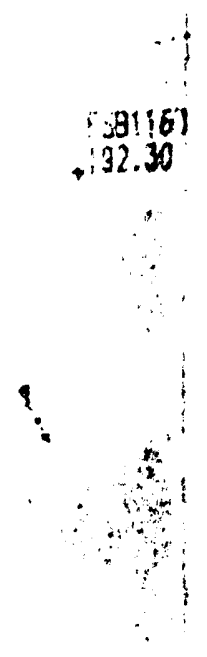




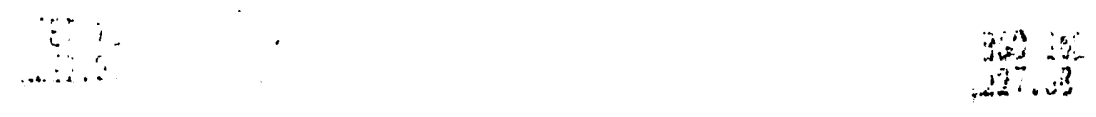

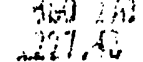

$\because \because$
30

cho.u wo

sin 


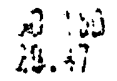

$$
\frac{29}{40.53}
$$

300
15.75

$\therefore$ in

20

8100
+210

2020

3010

52.86

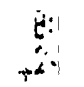

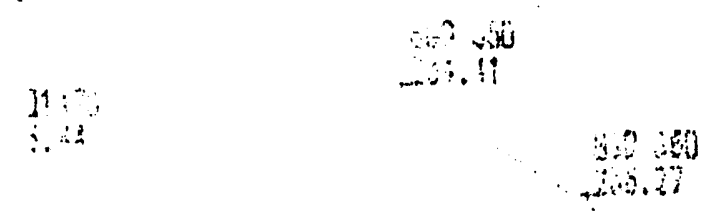

3020

$3 x+5$

ton on

. 35.42

9100
20.50
20.5

(4) ind

240.51

48856

, 238.70

300
+630.21

tous

政:

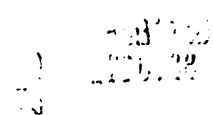

4.

.

ind

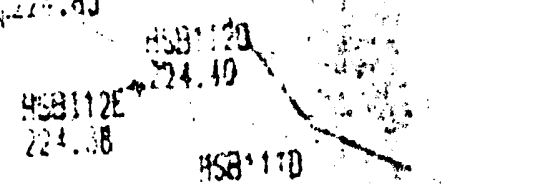

$\therefore$...

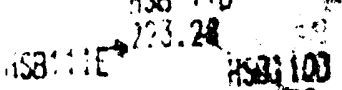

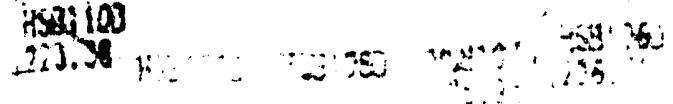

25.25 
He.

4023

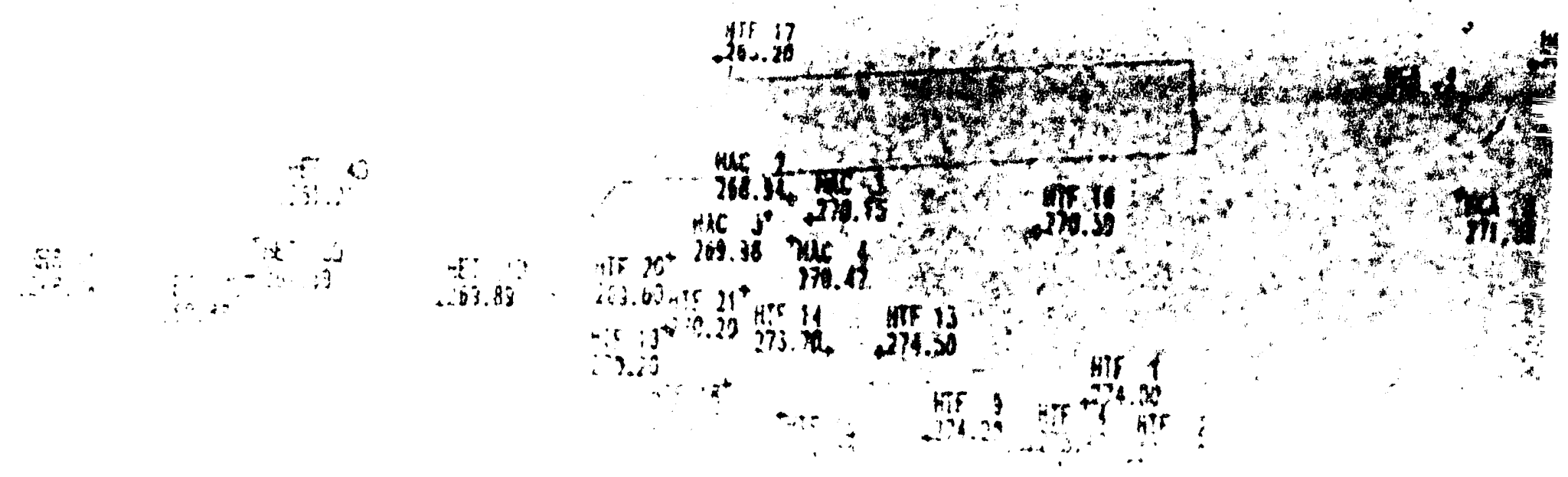


390
-209.86

$\frac{300}{30}$

?
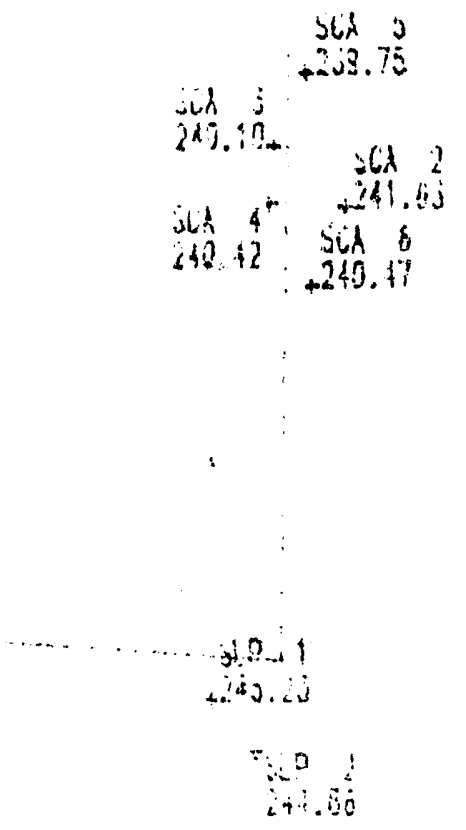

+id

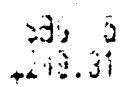

$$
\begin{array}{r}
0 \\
\ddots \\
1
\end{array}
$$


,

$\ldots$

$\cdots+, \quad+\cdots, \cdots+\cdots$

$\cdots$

:

? …......... 


$$
\begin{aligned}
& \because 31,20320 \\
& \because \cdots
\end{aligned}
$$

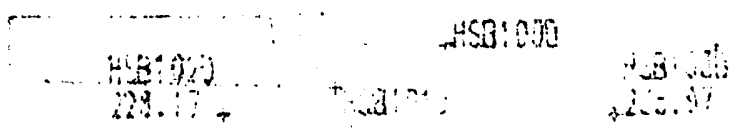

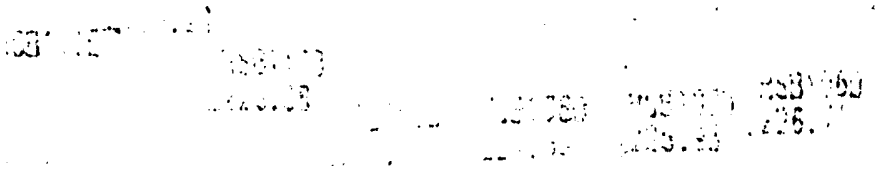

$$
\begin{aligned}
& \therefore .3
\end{aligned}
$$

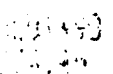

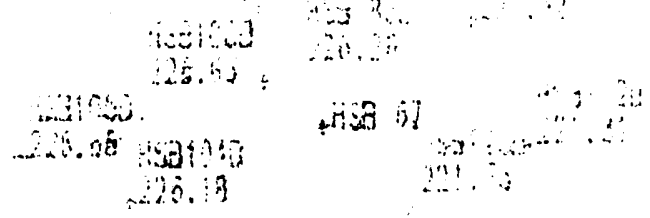

$$
\begin{aligned}
& \therefore: \text { : : }
\end{aligned}
$$

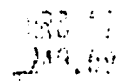

$$
\begin{aligned}
& \begin{array}{c}
\therefore \\
\therefore
\end{array} \\
& \because \because 8 \\
& \text { a. } \\
& \text { and }
\end{aligned}
$$

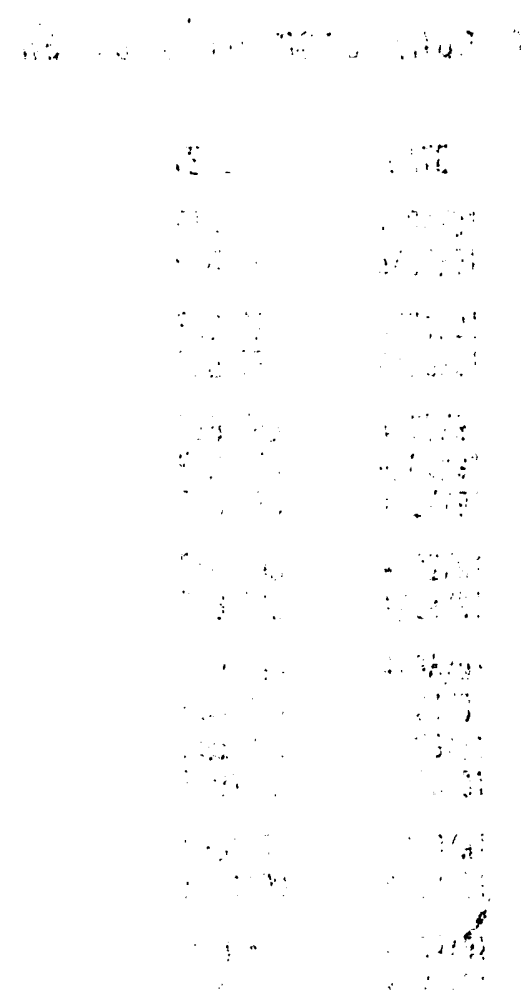




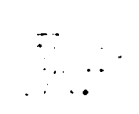

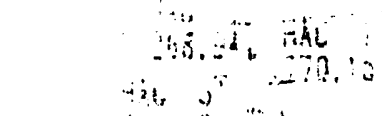

और

$a$
0

$\ldots$

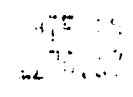

$\because \vdots+1+\cdots$

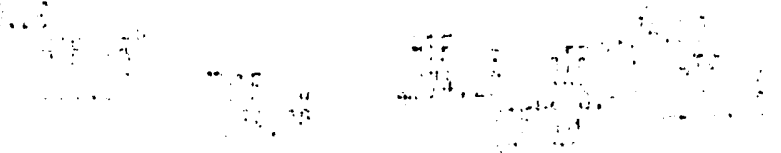

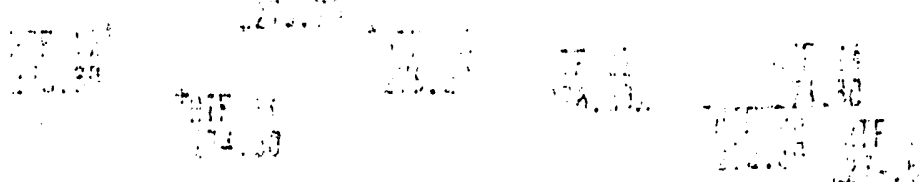

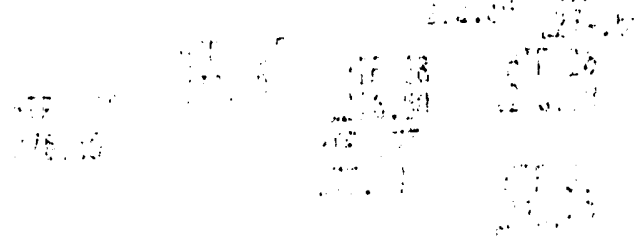

$\because ?$

$\therefore \therefore$ 
$\because \vdots$

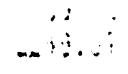

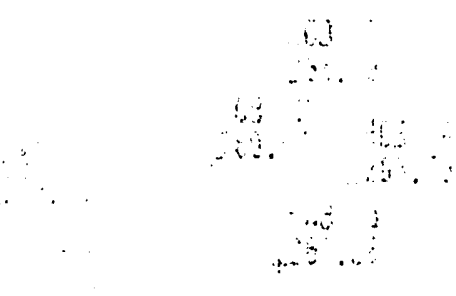

$\cdots$
31

…

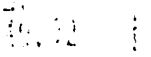






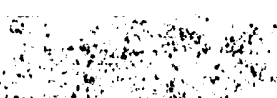

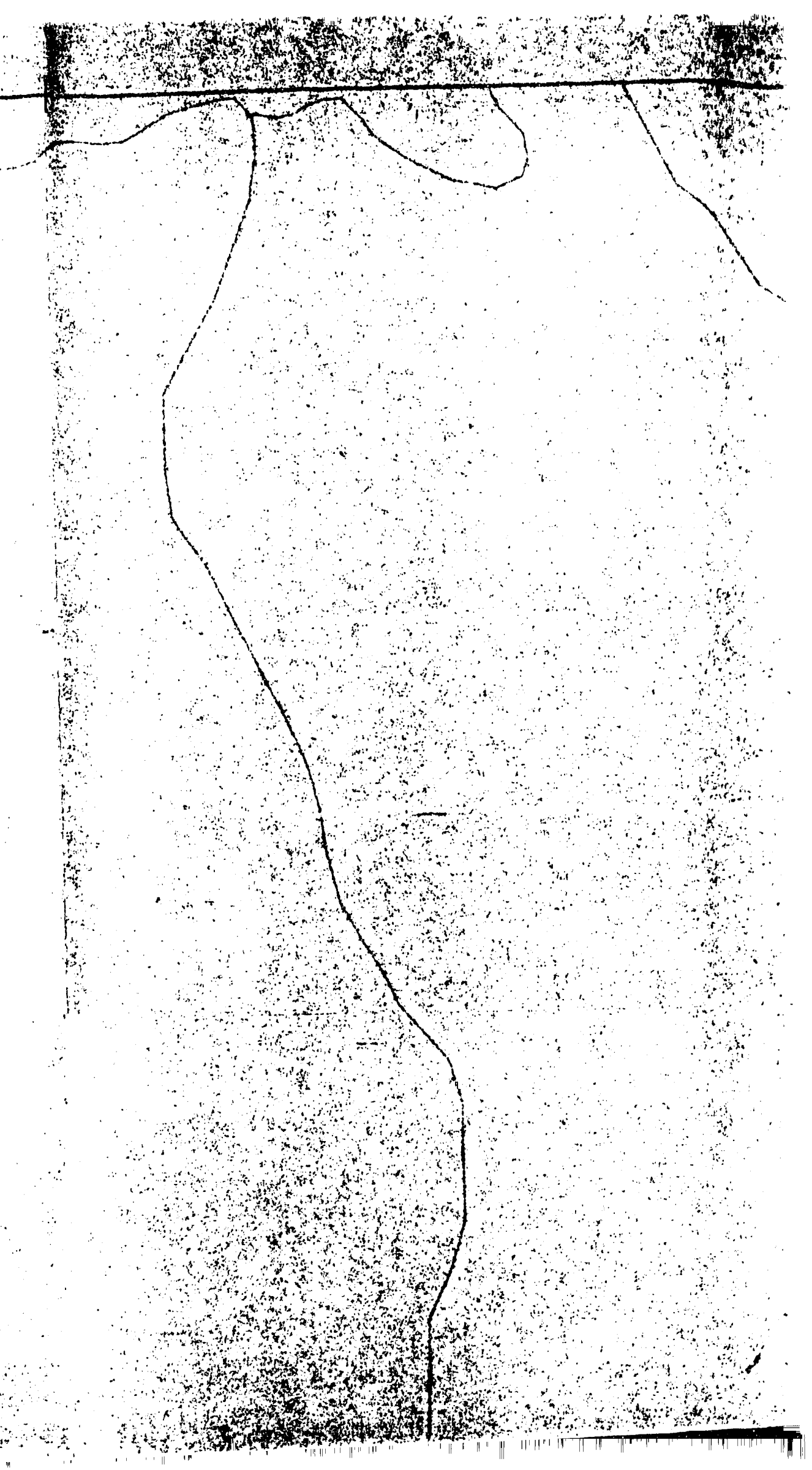



and 


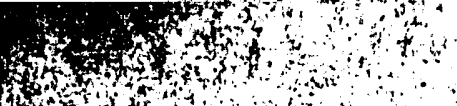
Whith

7 h on -3

$\frac{1}{4}$

2

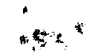

\section{Fsolosit}

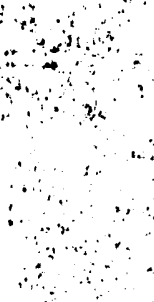




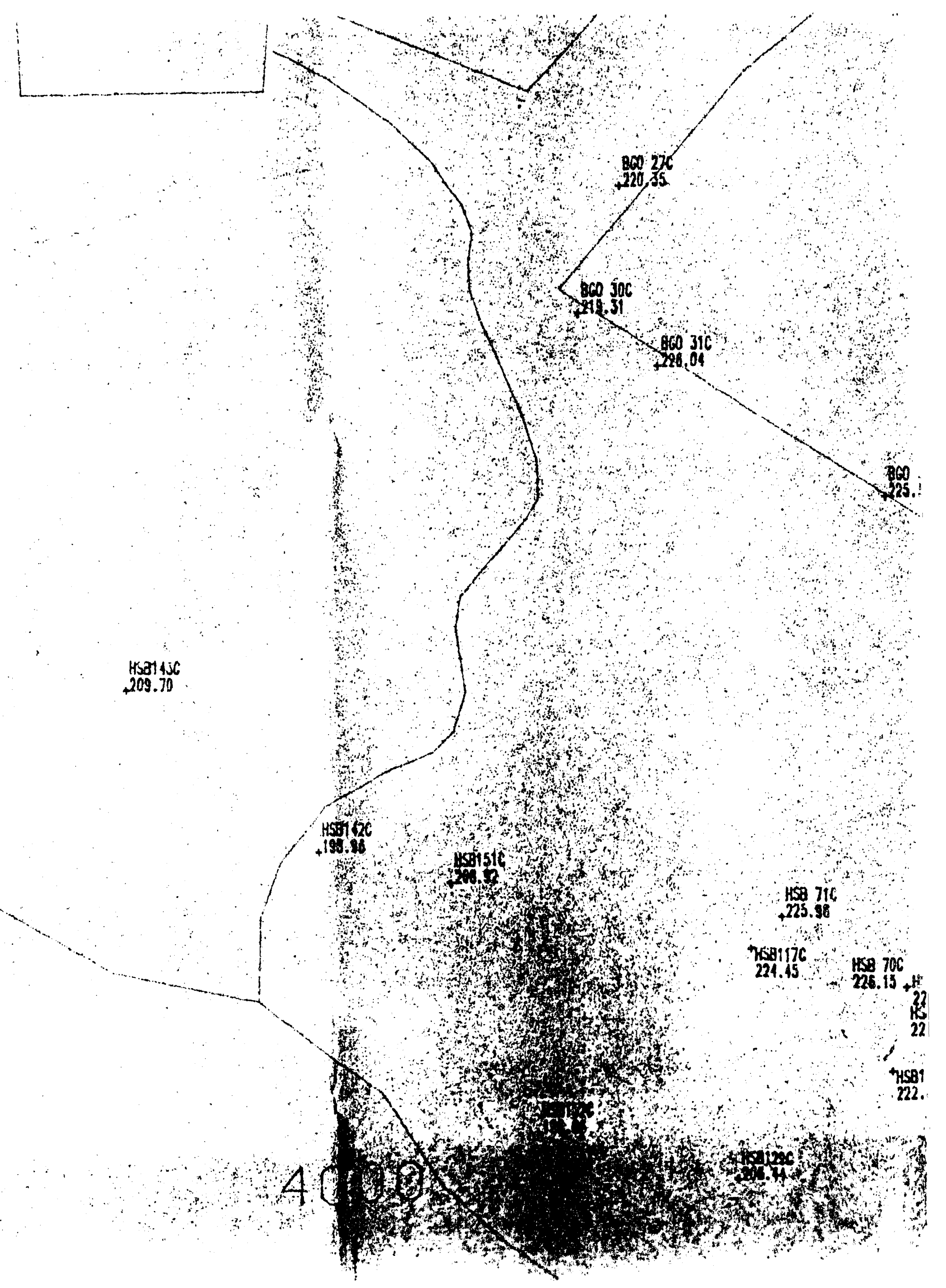


Wht

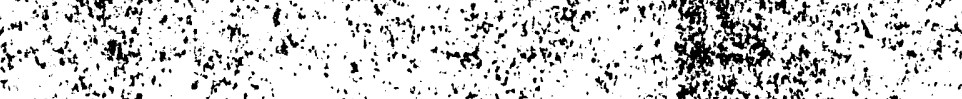

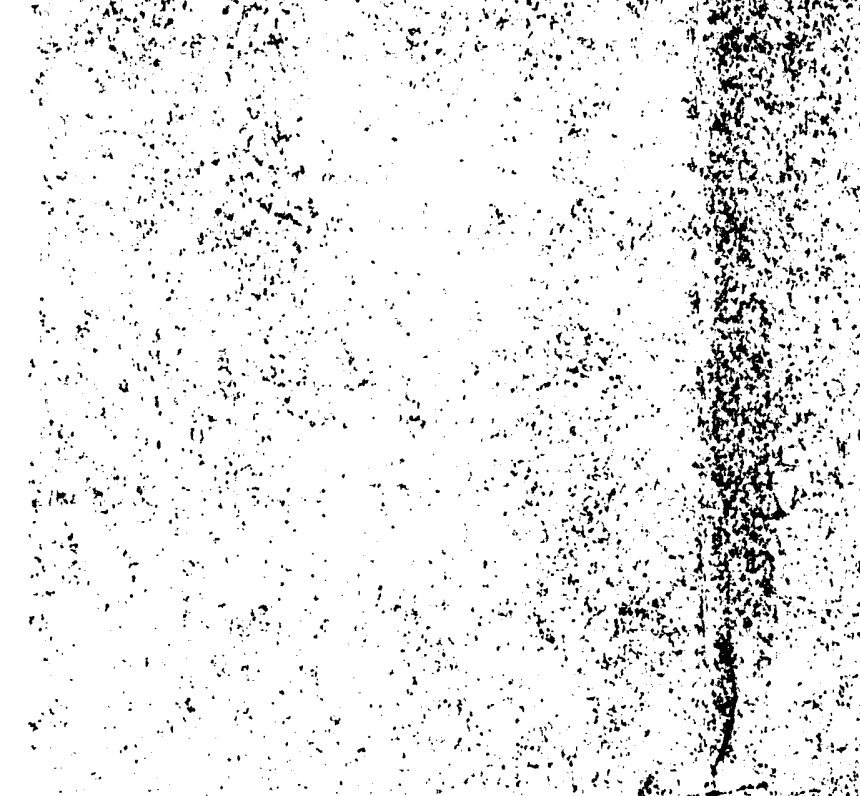

\section{6 \\ 225.51}
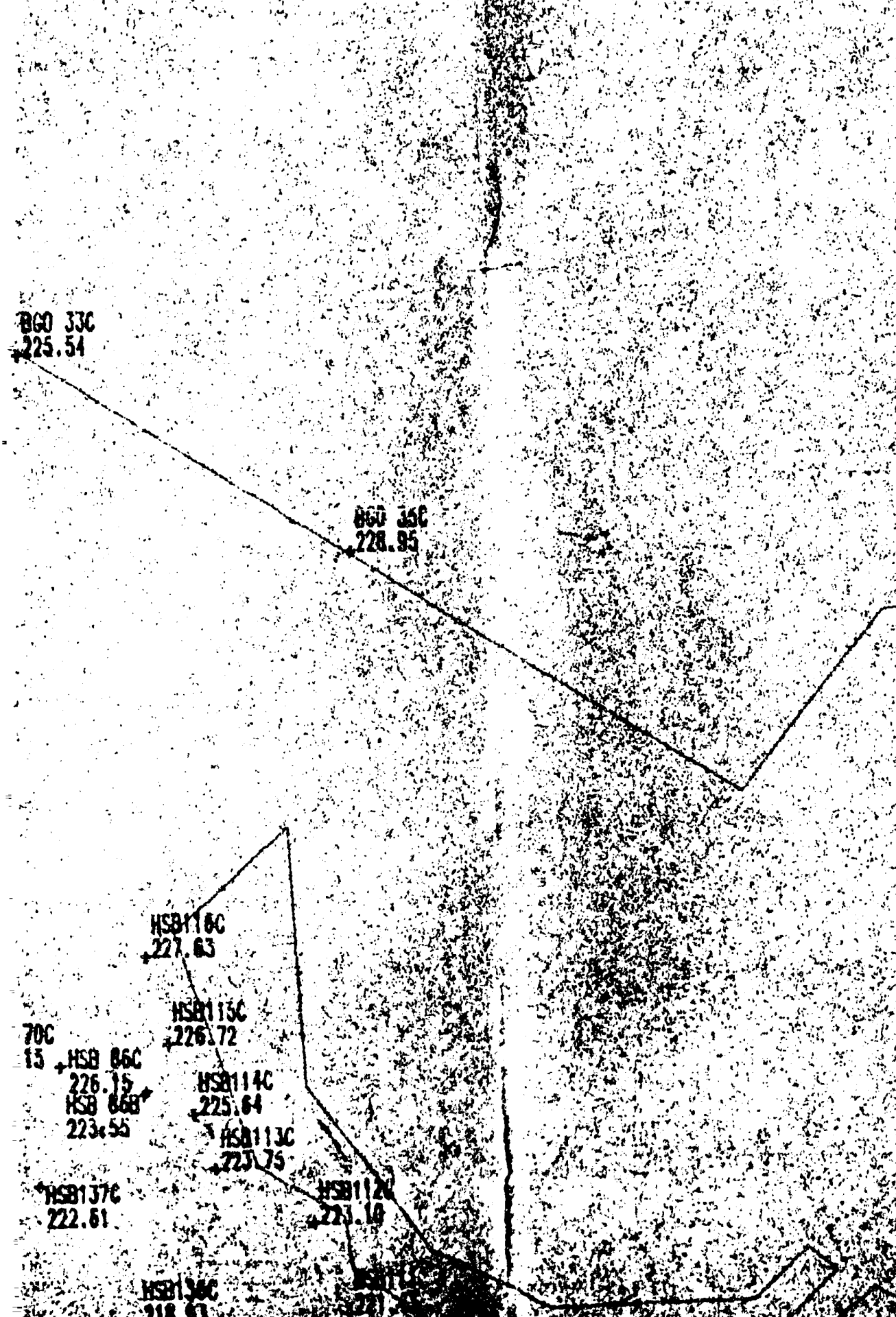
t.

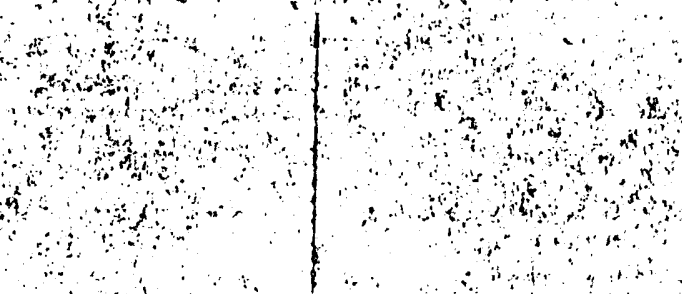

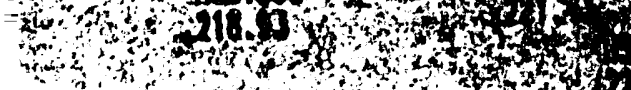

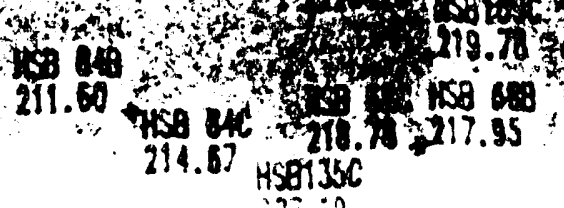




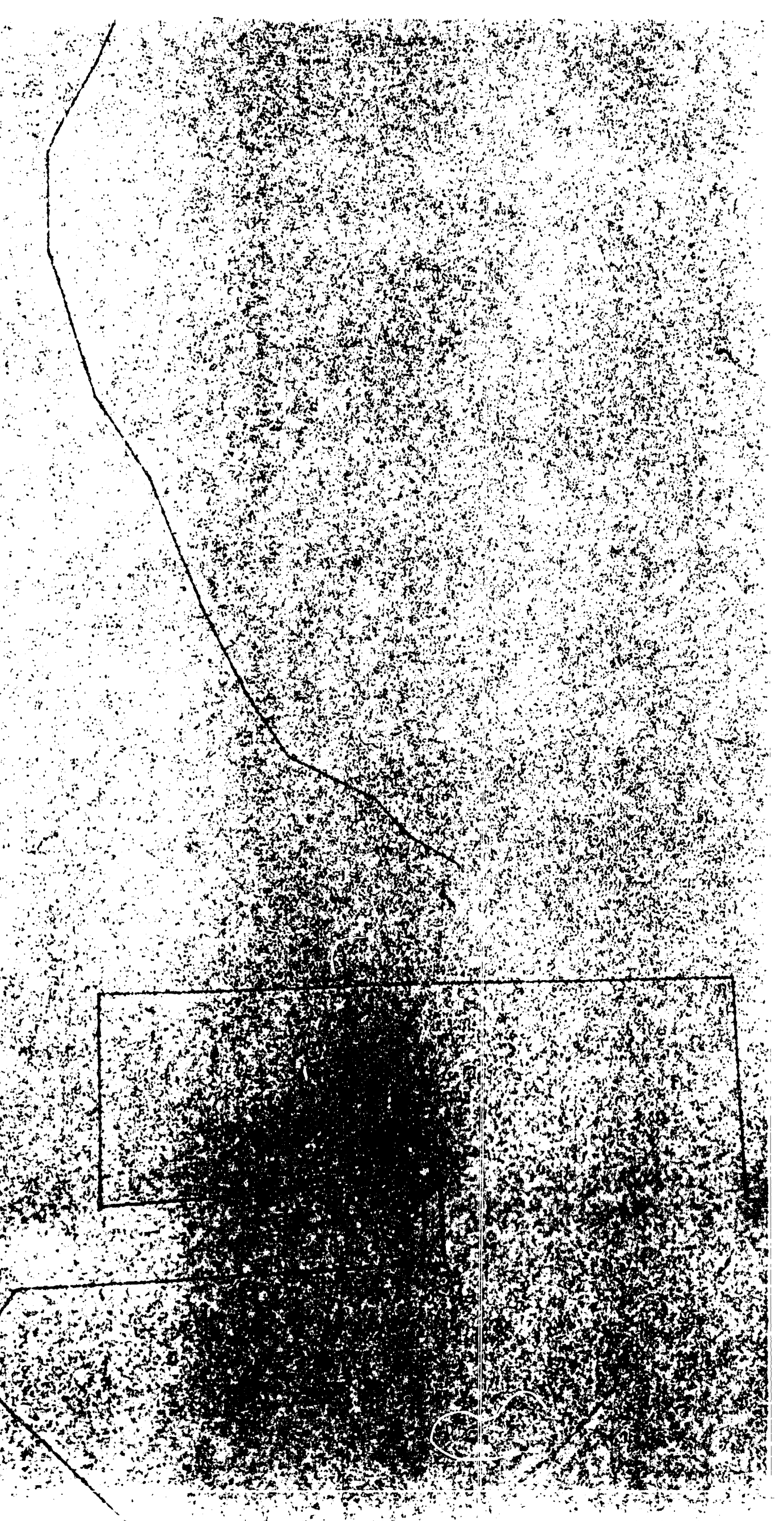




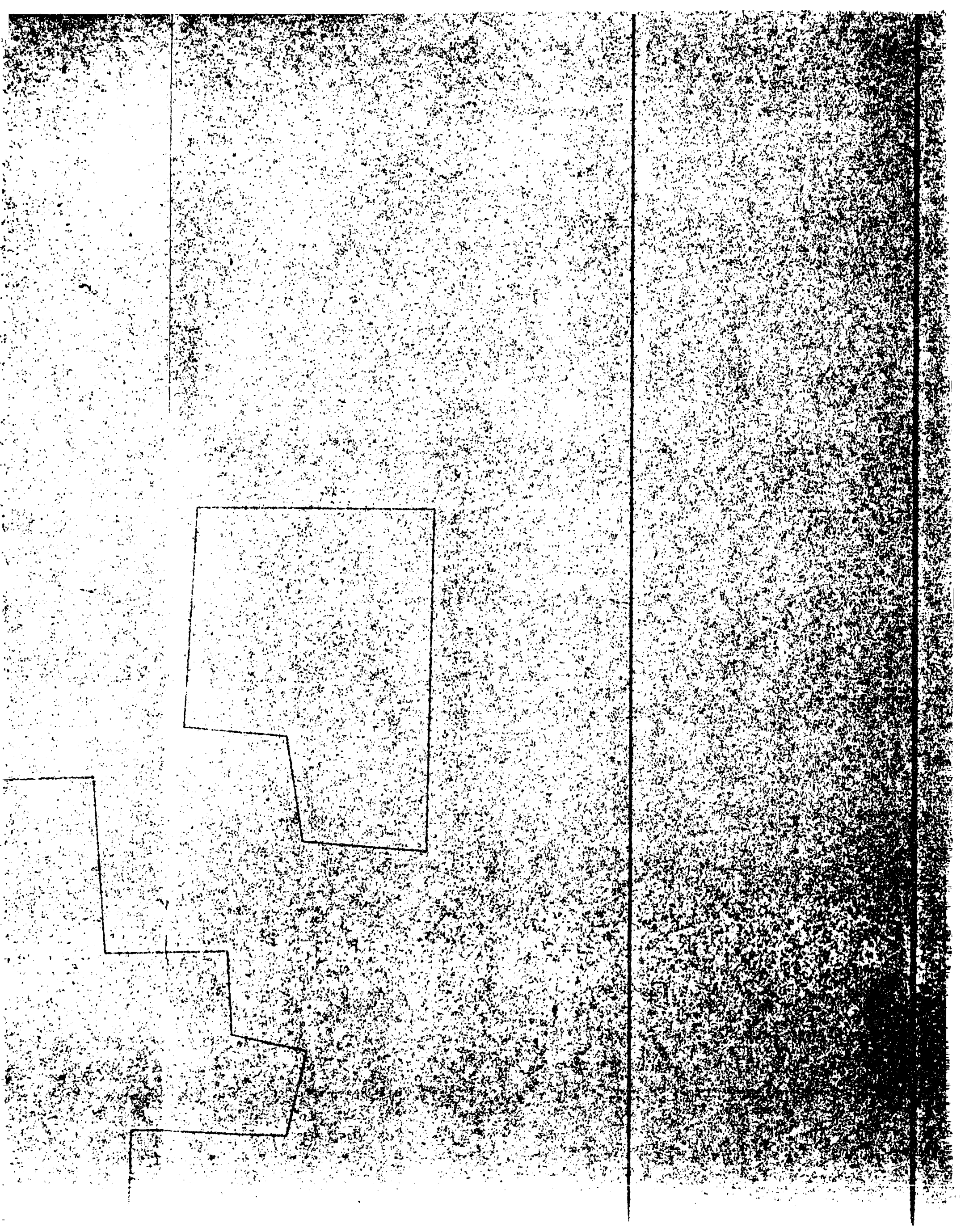




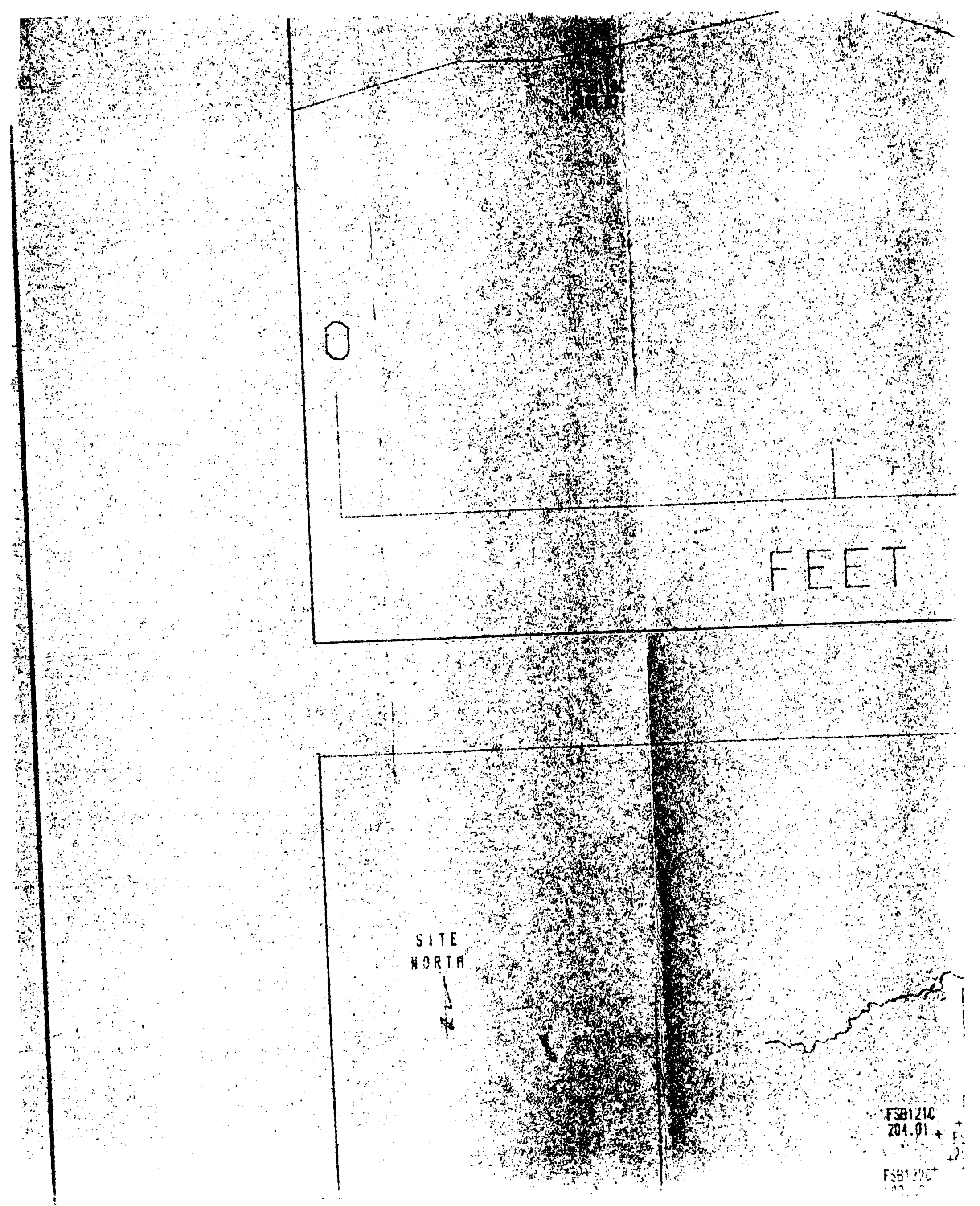




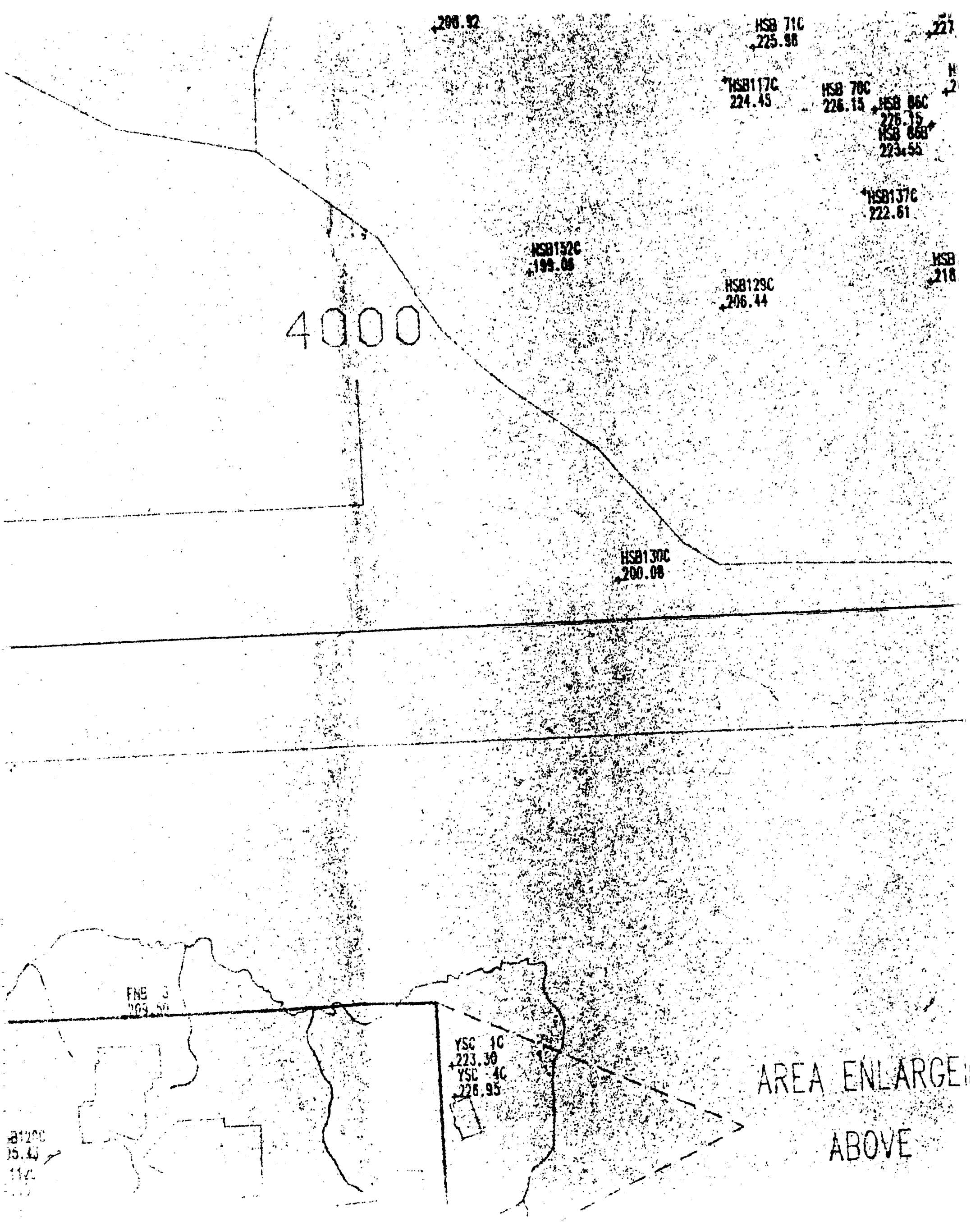




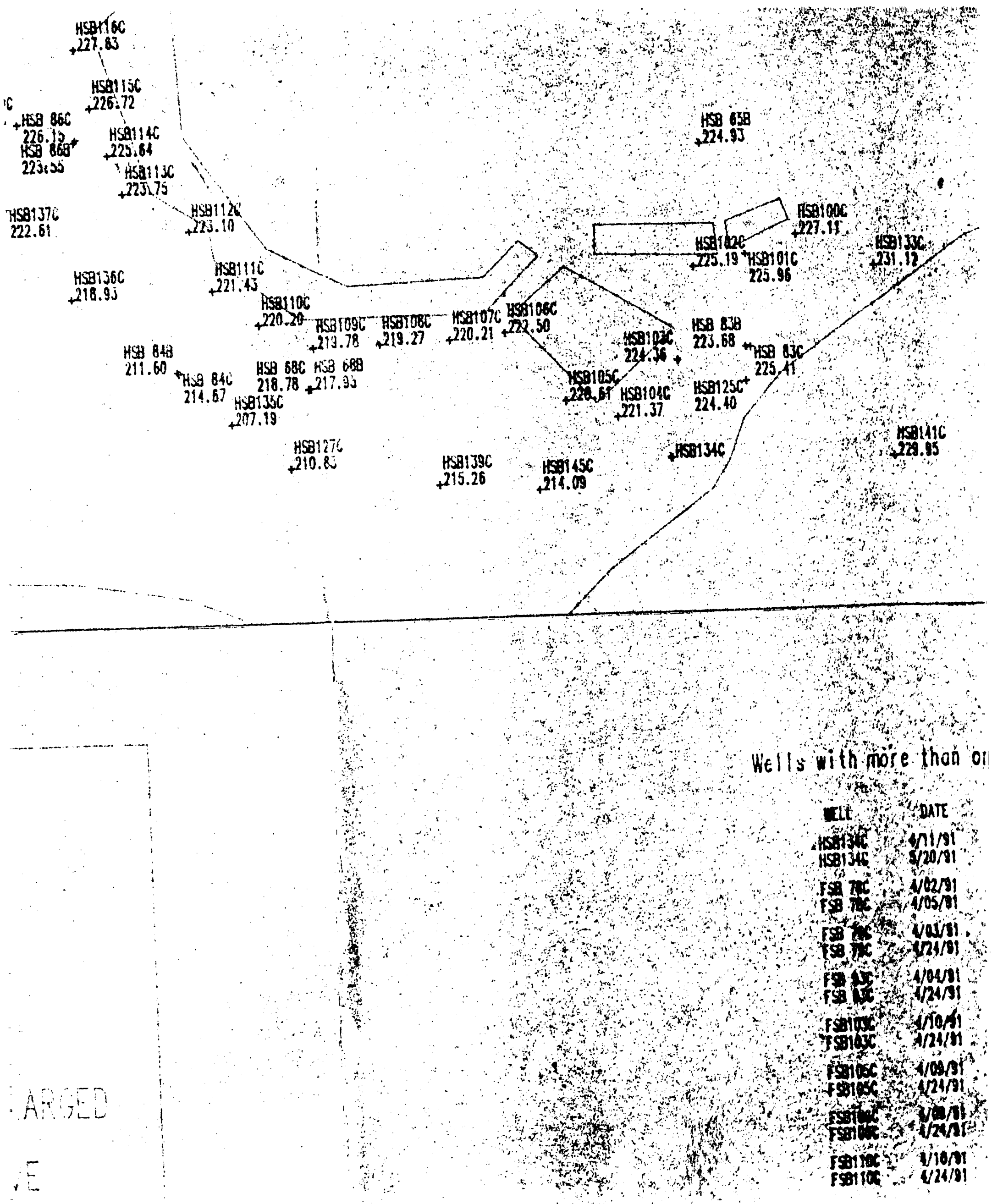




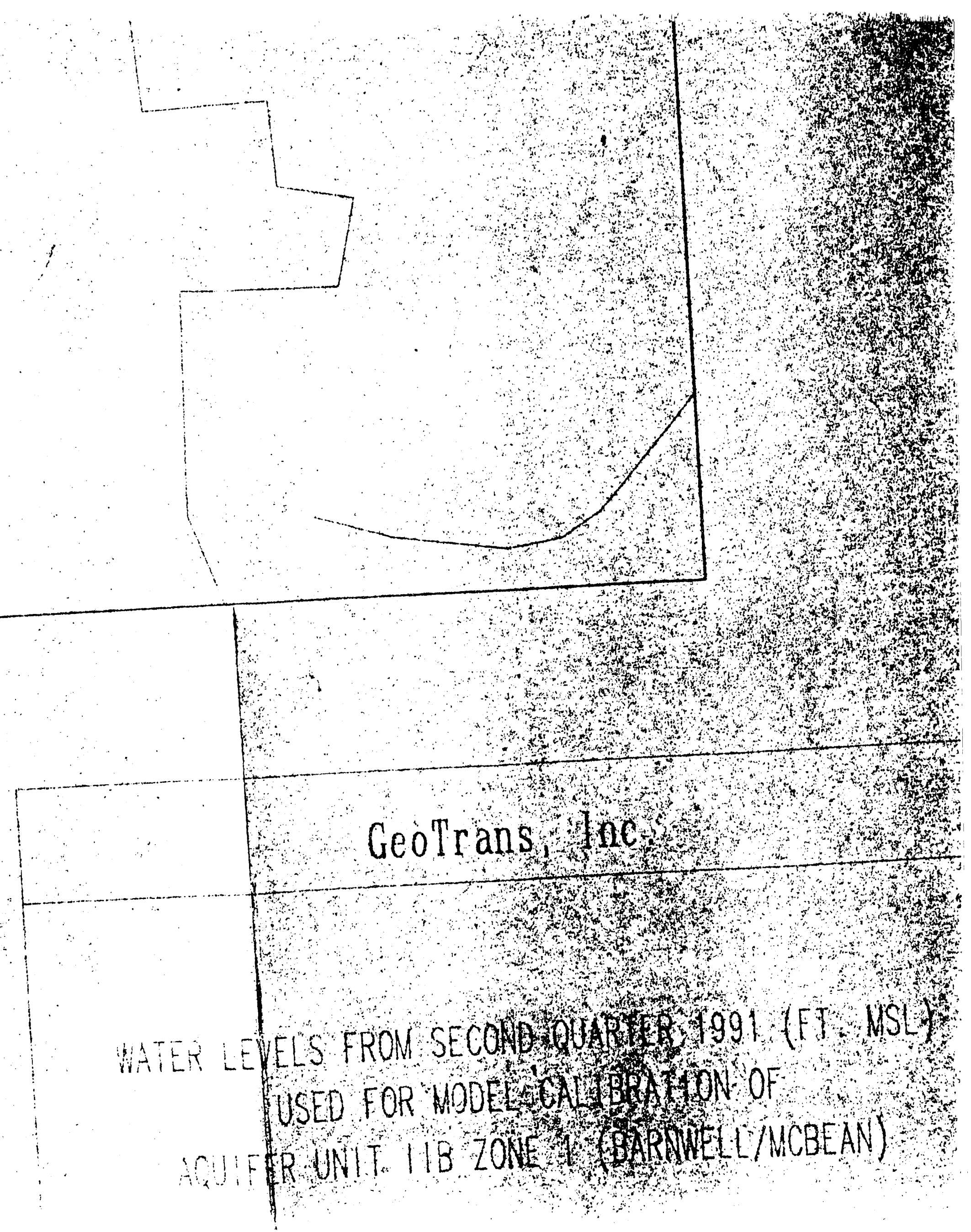




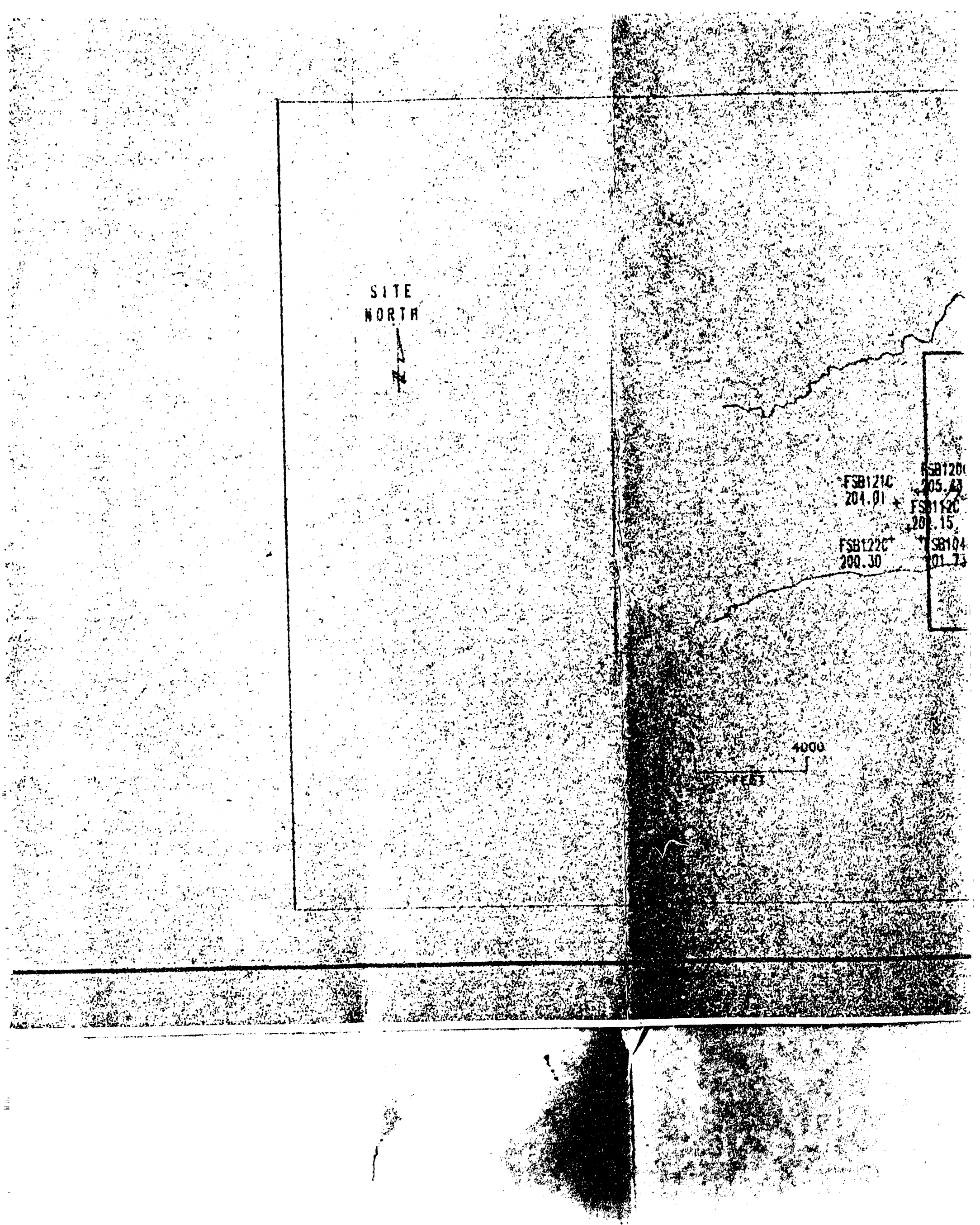




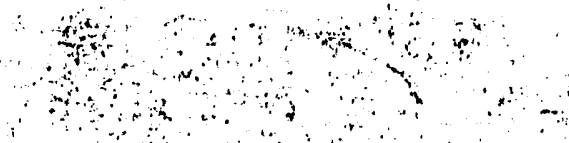

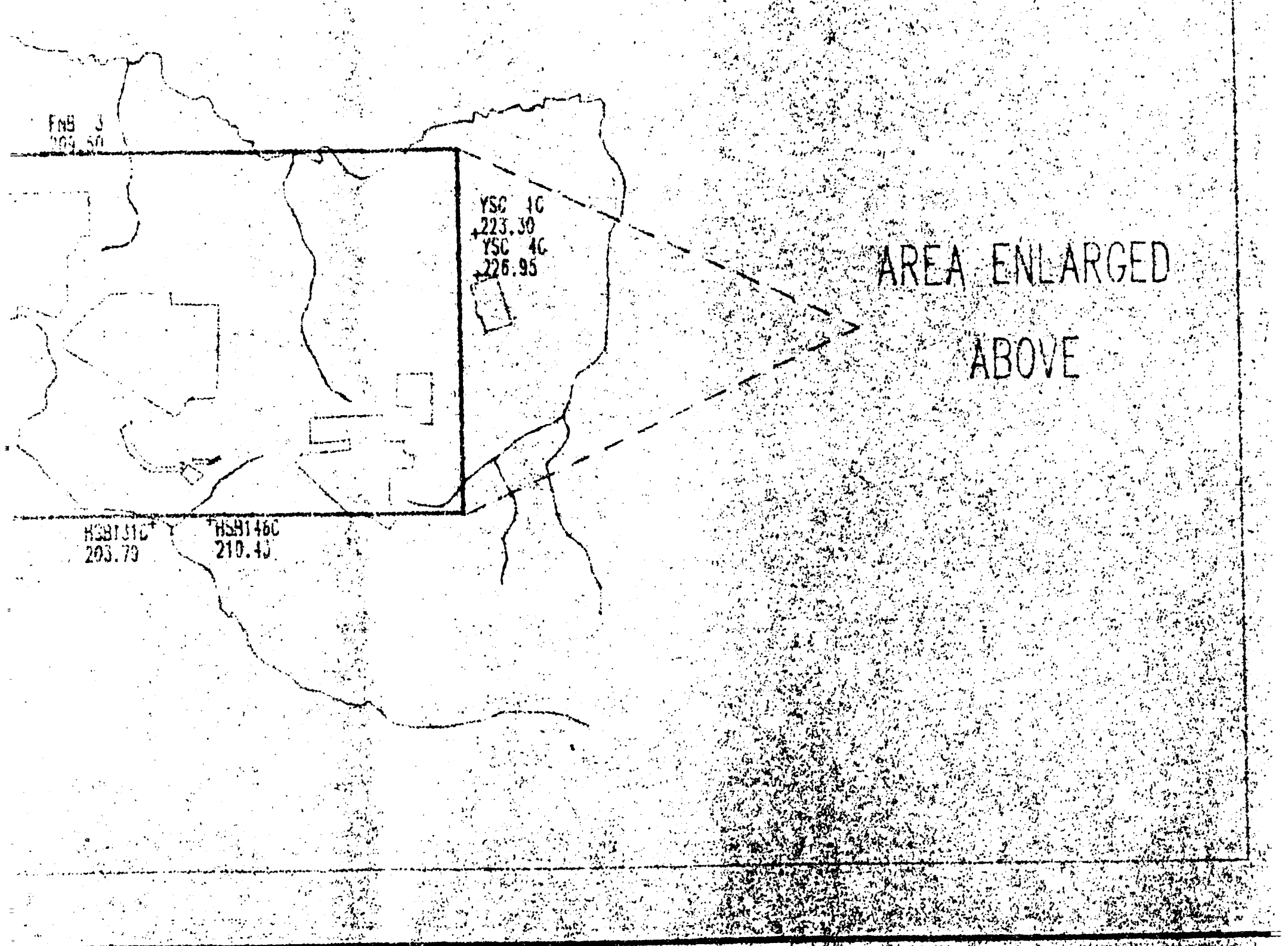

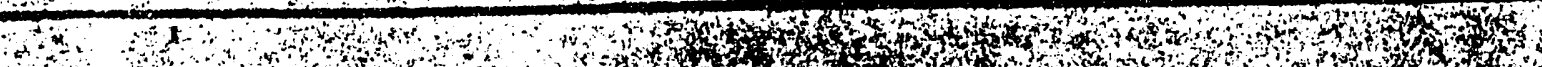

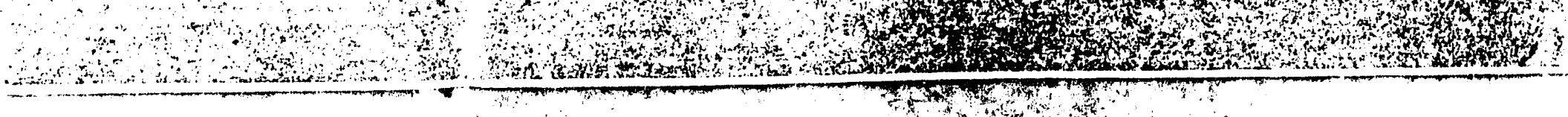
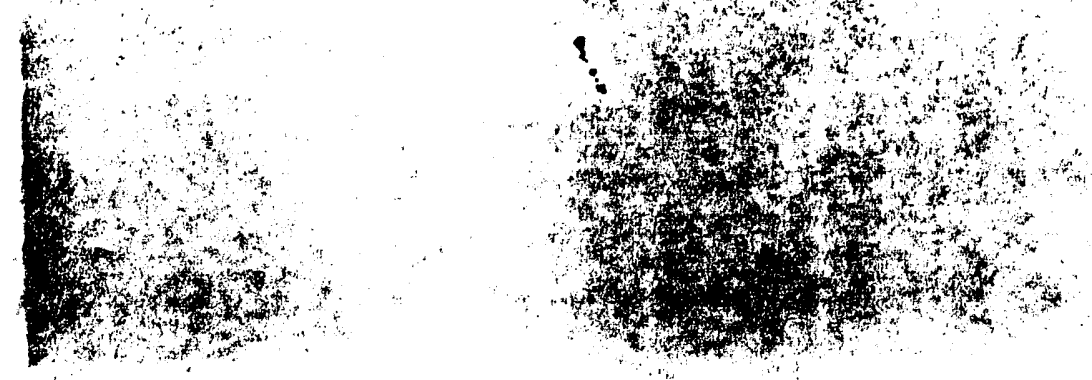


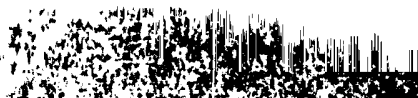

13.t.

Hon

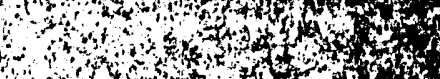

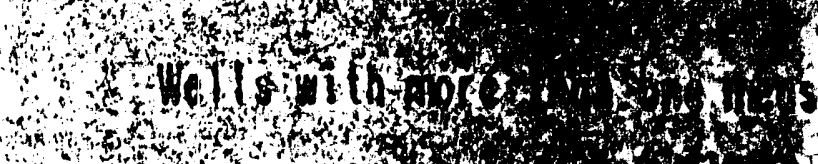

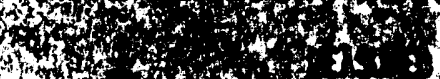

and

ite

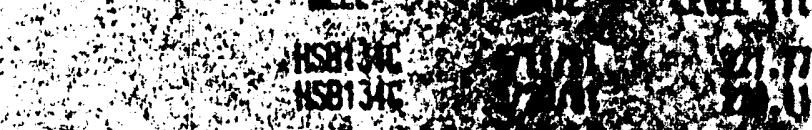

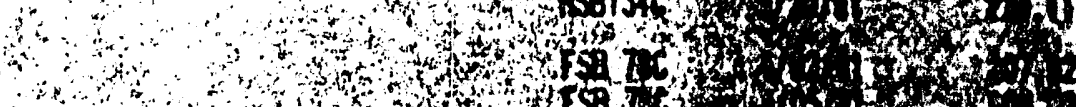

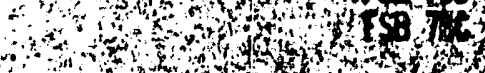

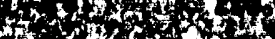

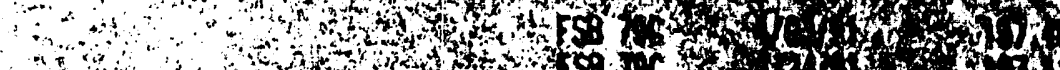

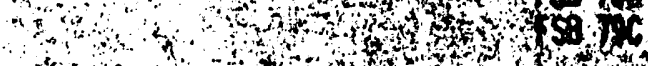

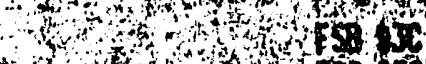

and

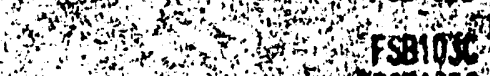

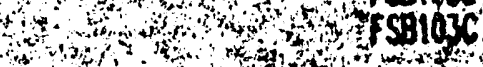

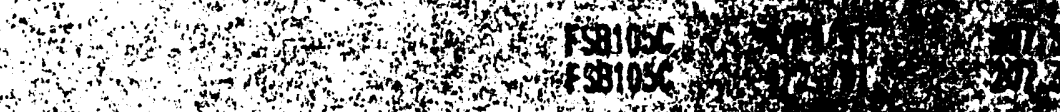

and

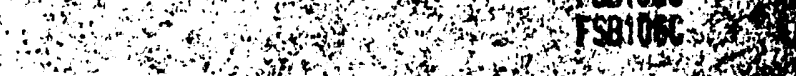

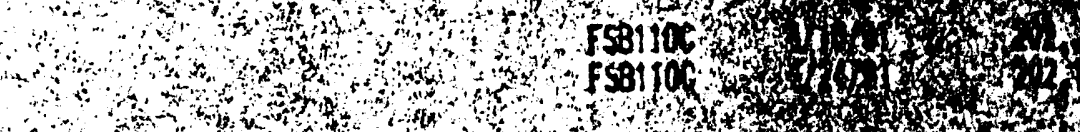

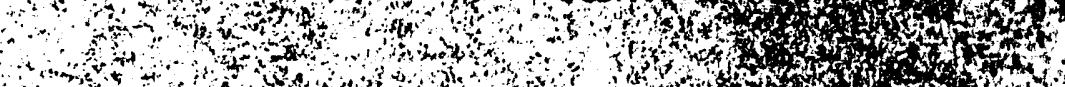

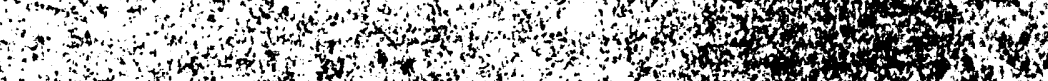

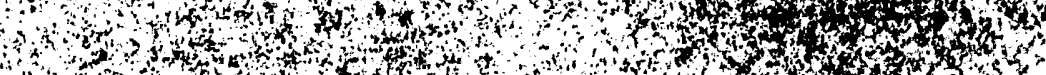

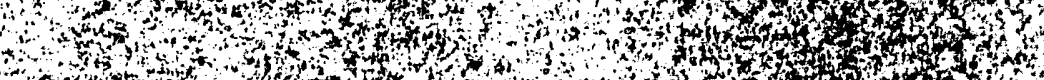

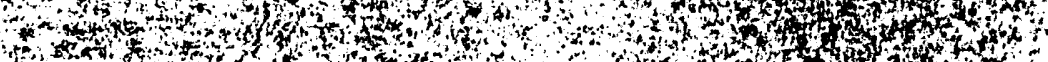

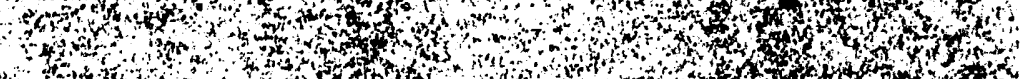

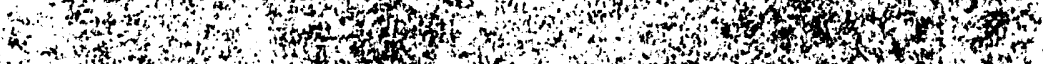

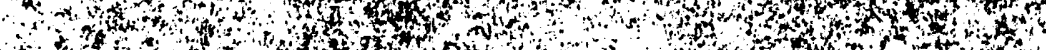

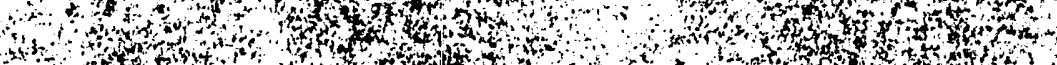

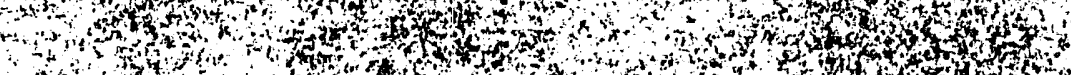

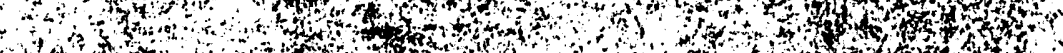

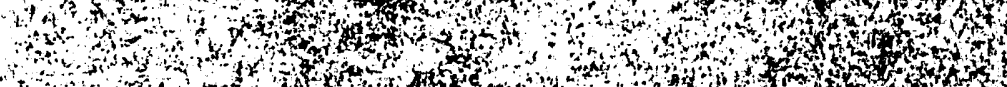

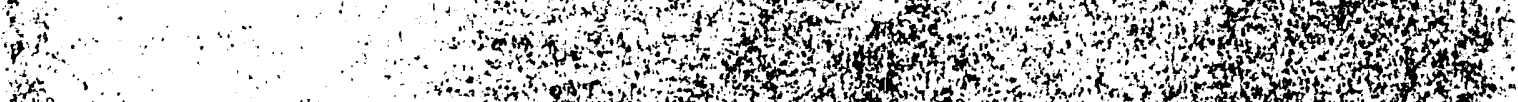

th

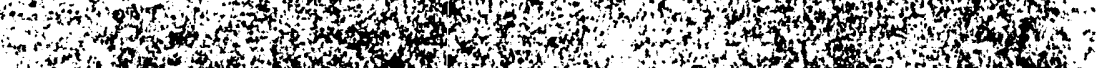

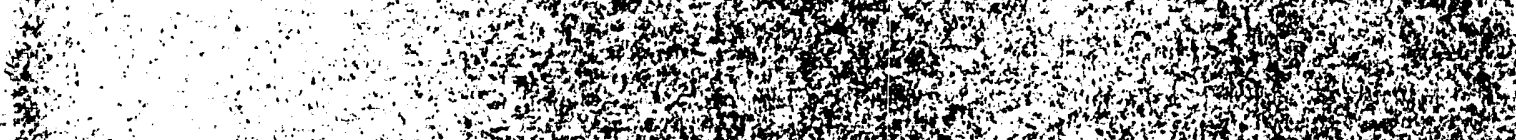

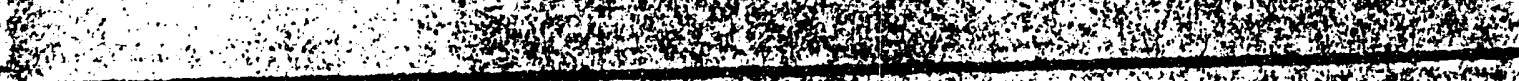

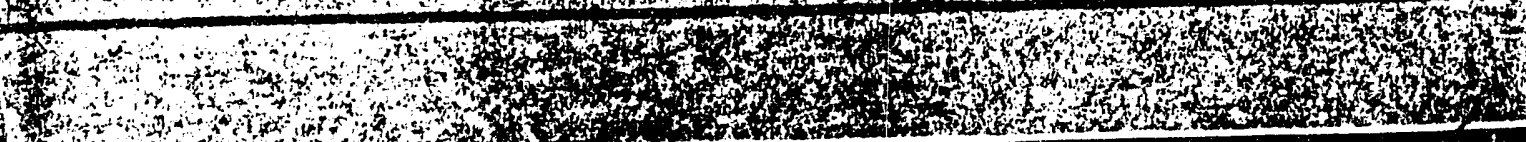

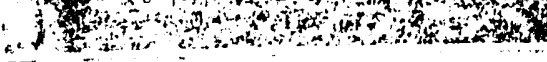

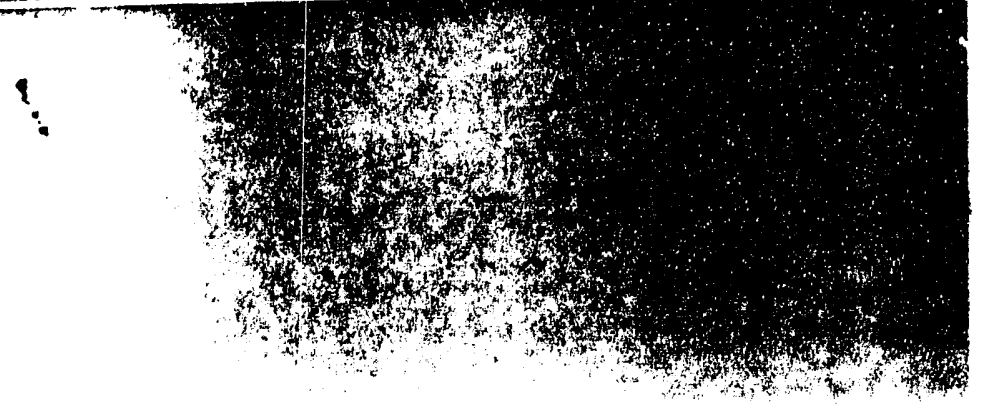


nt:

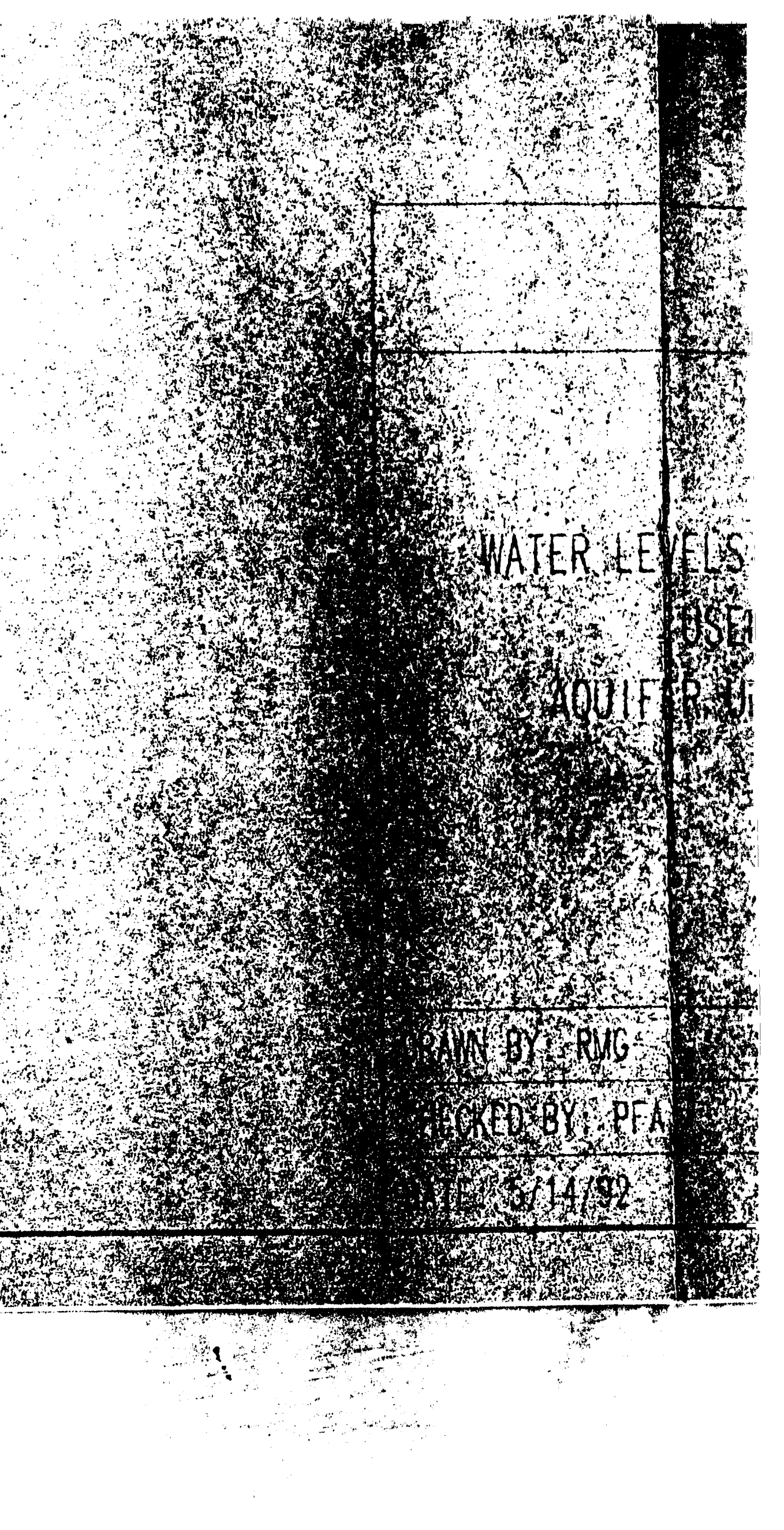




\section{Geotrans, Mnc,}




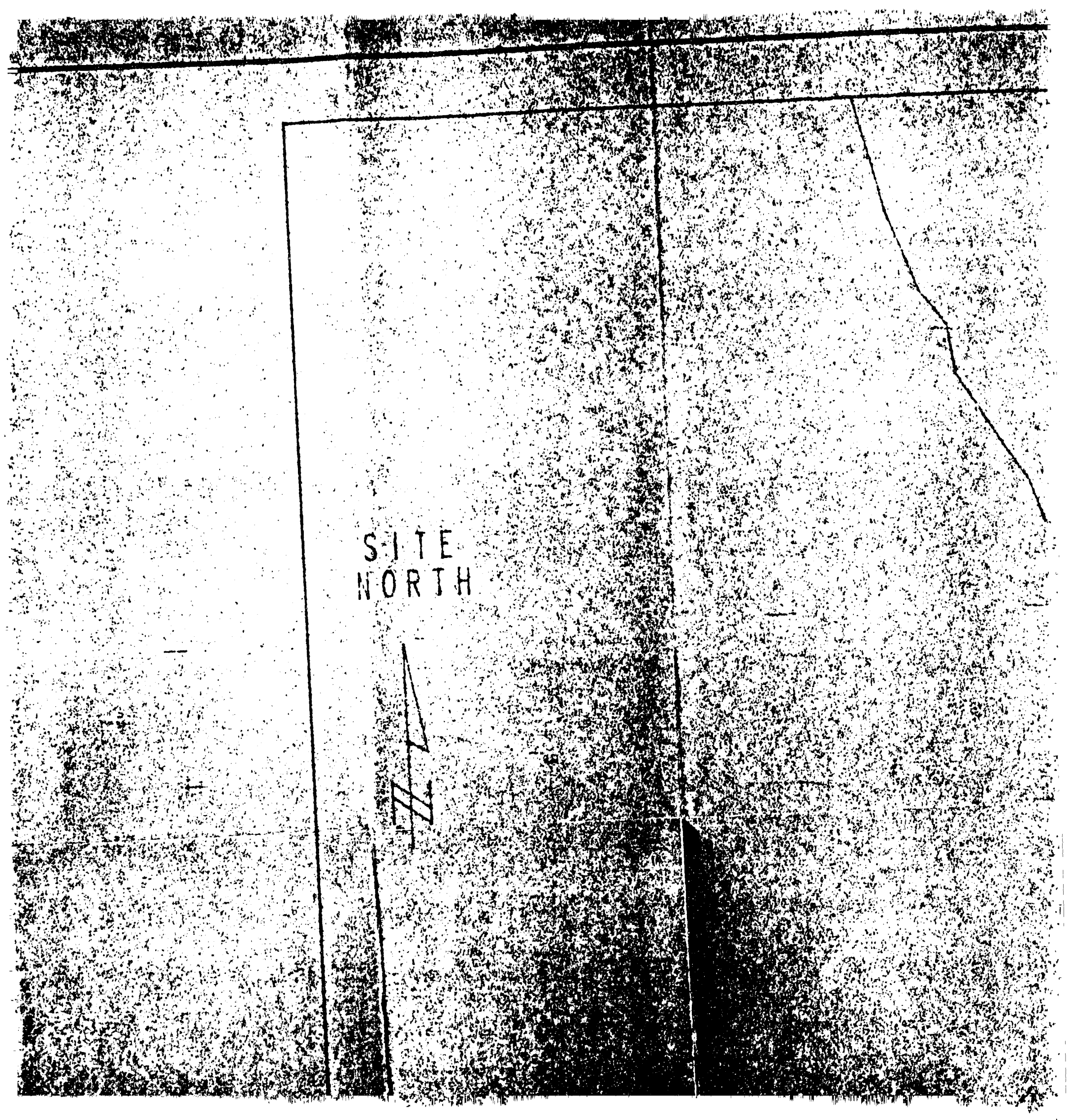





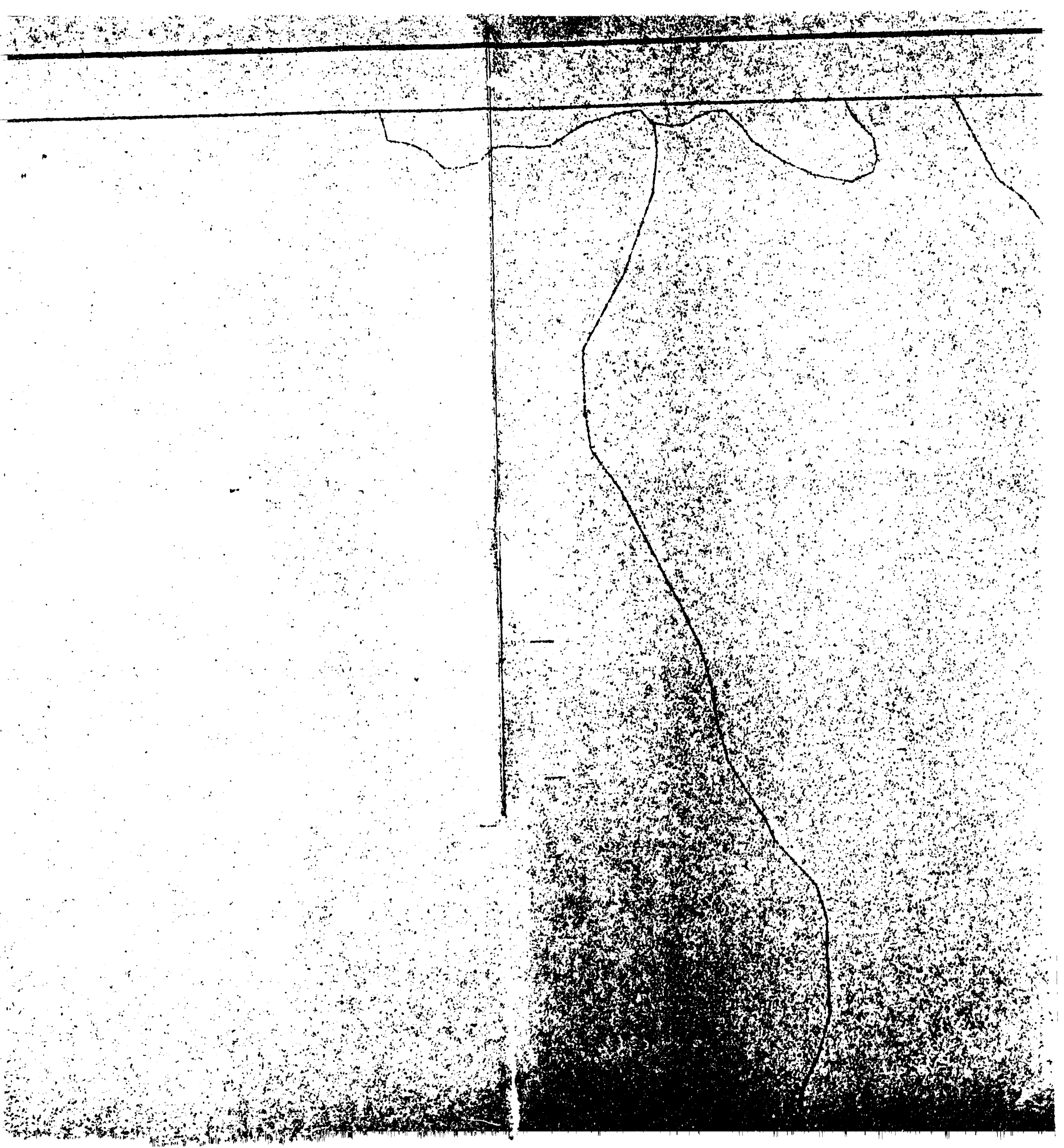




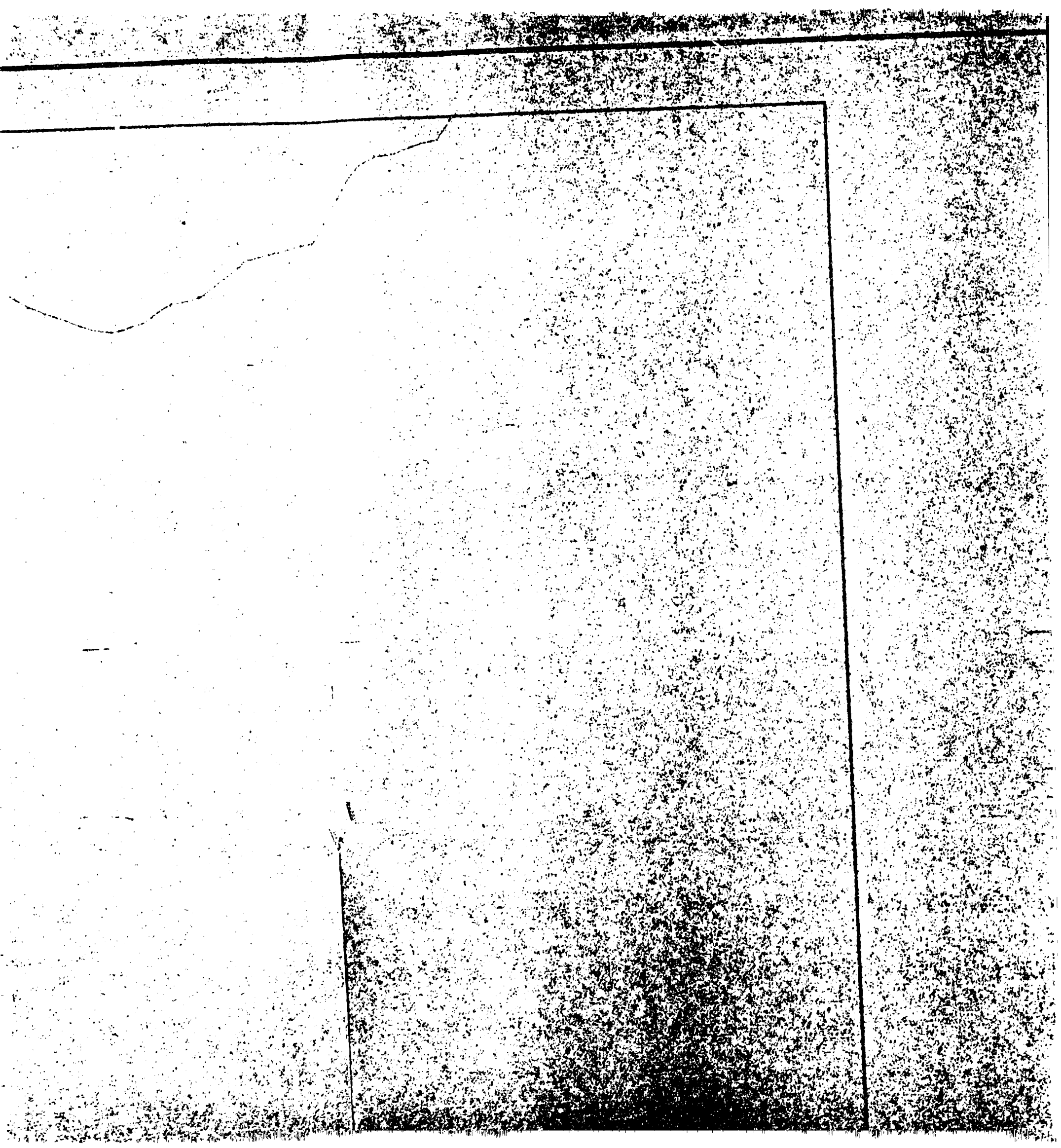




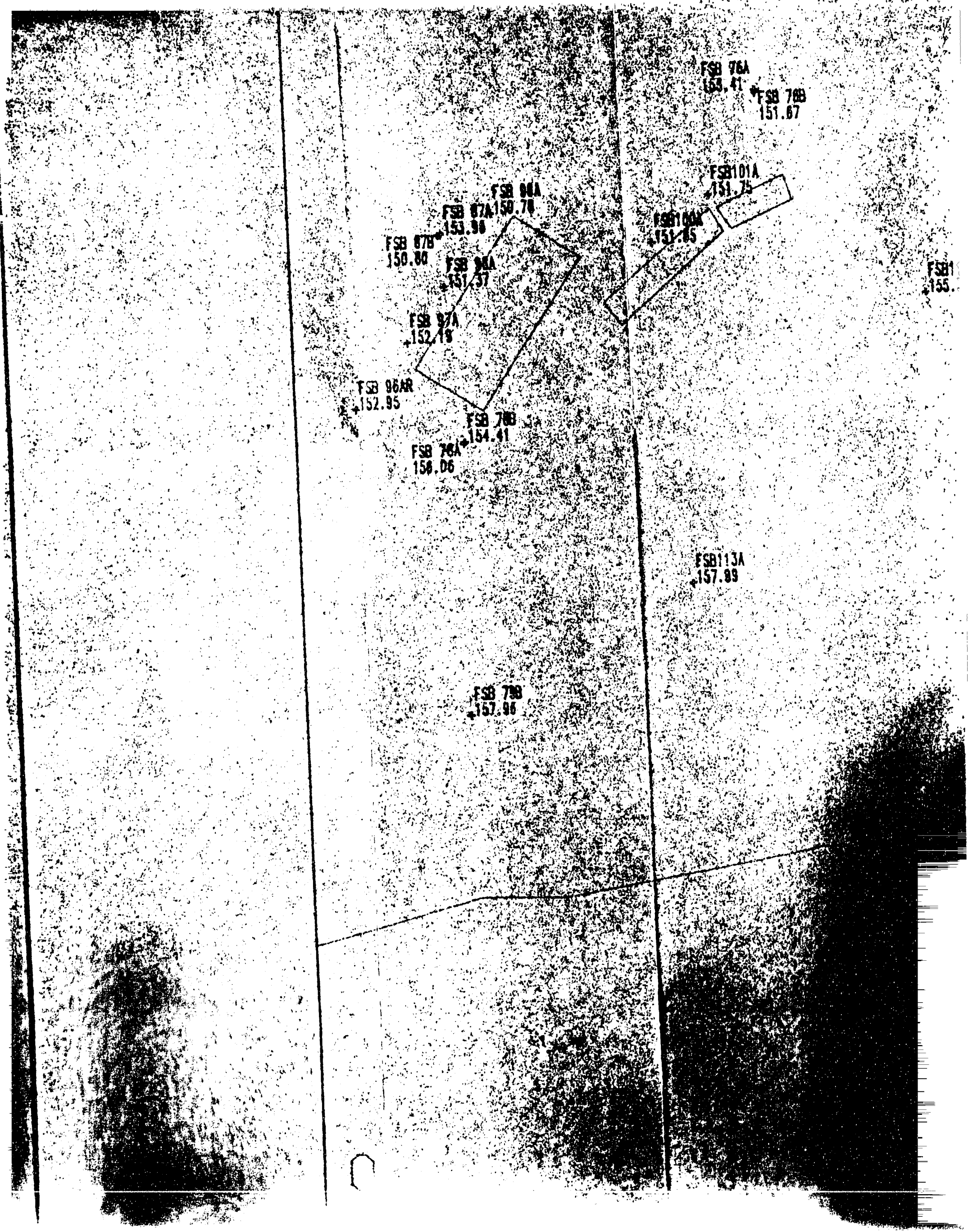


860181
+161.44

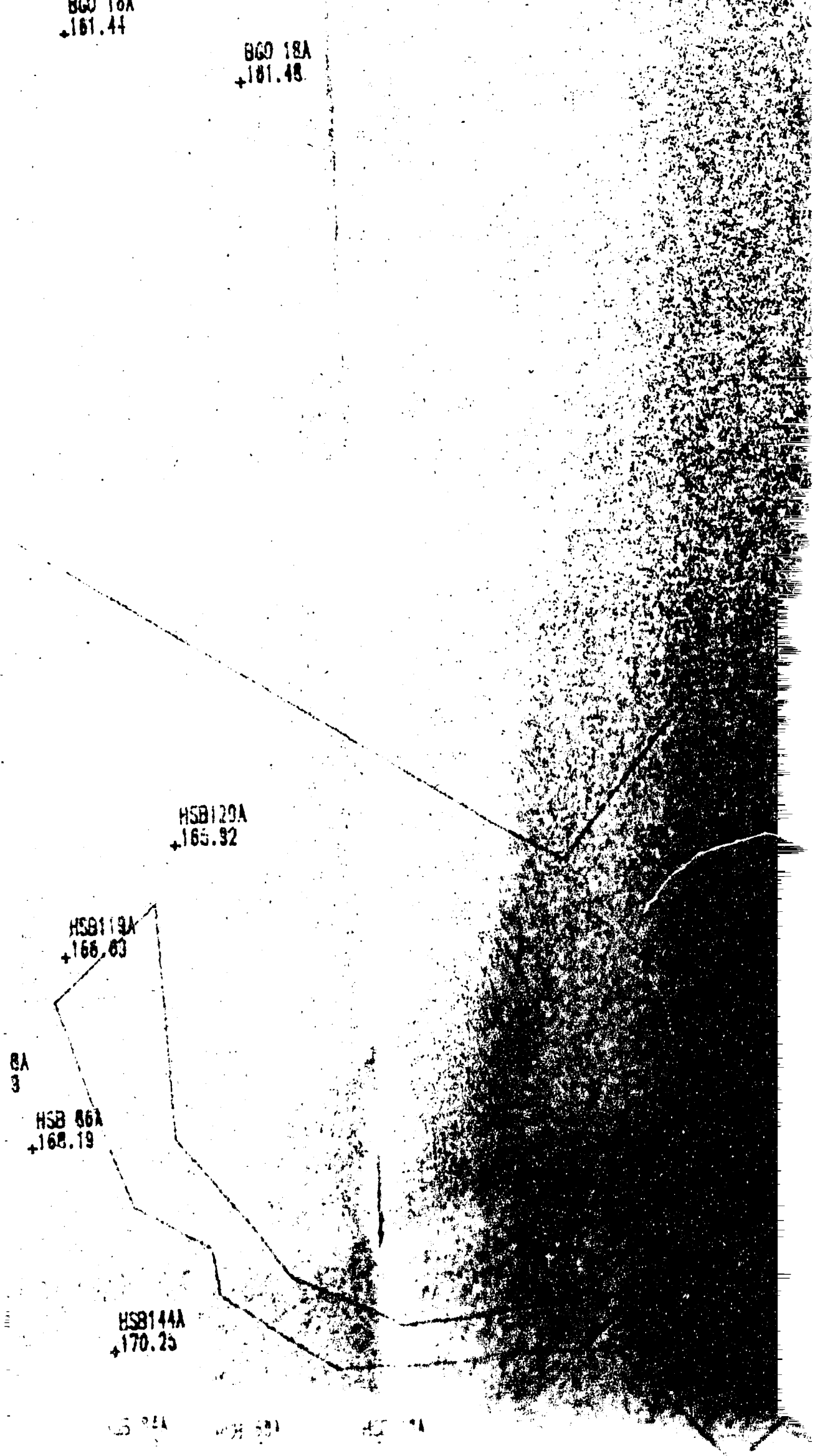




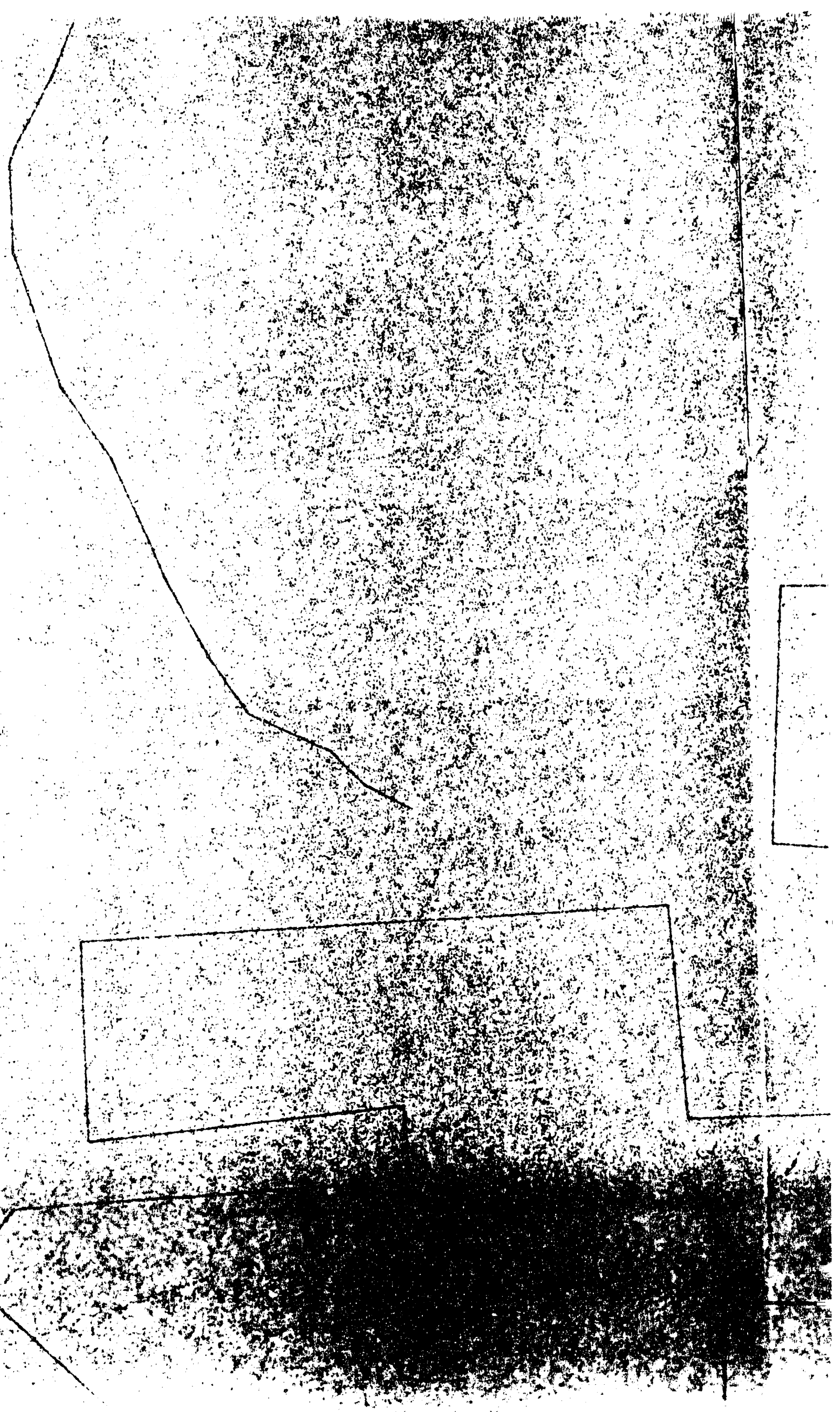




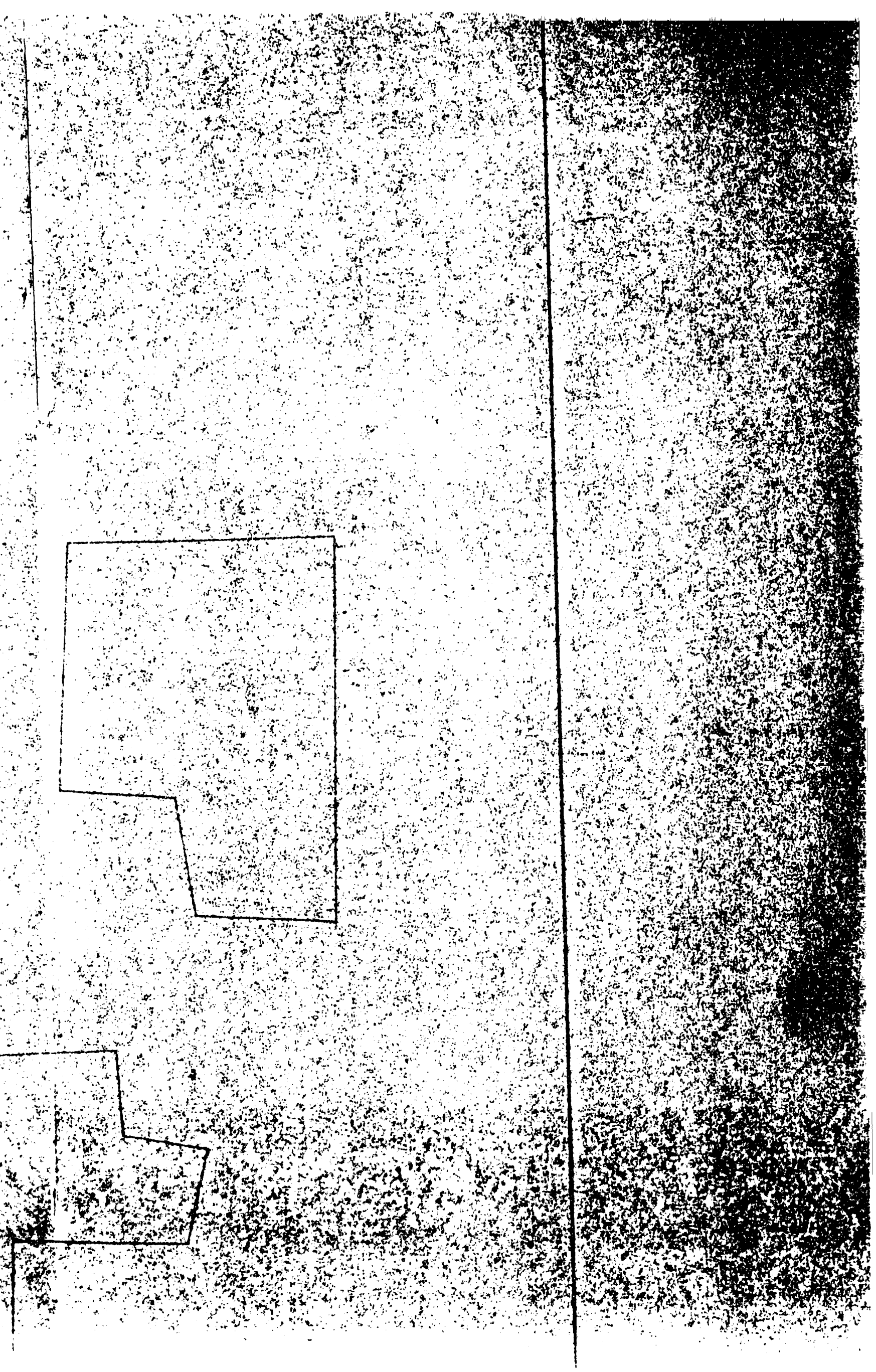




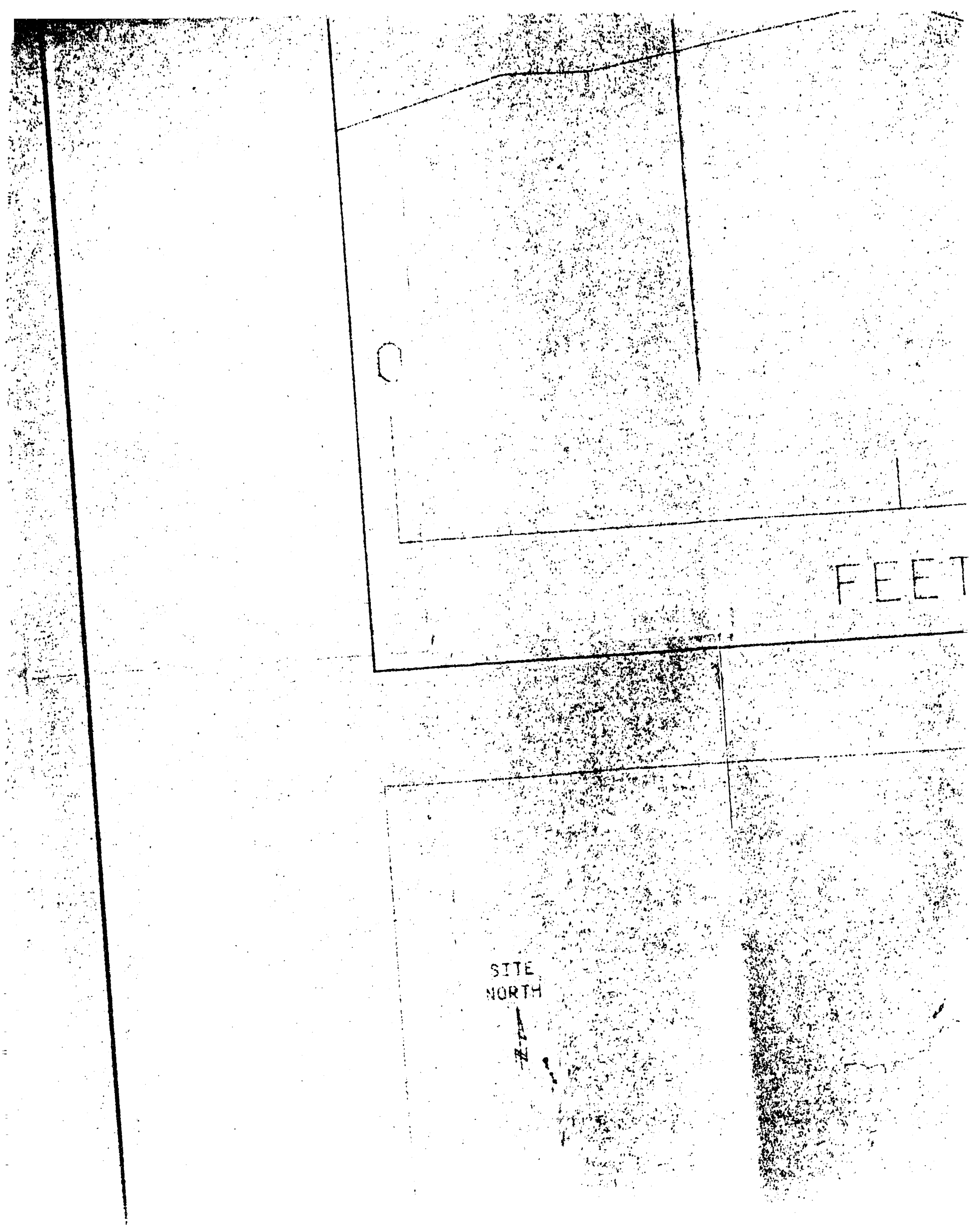




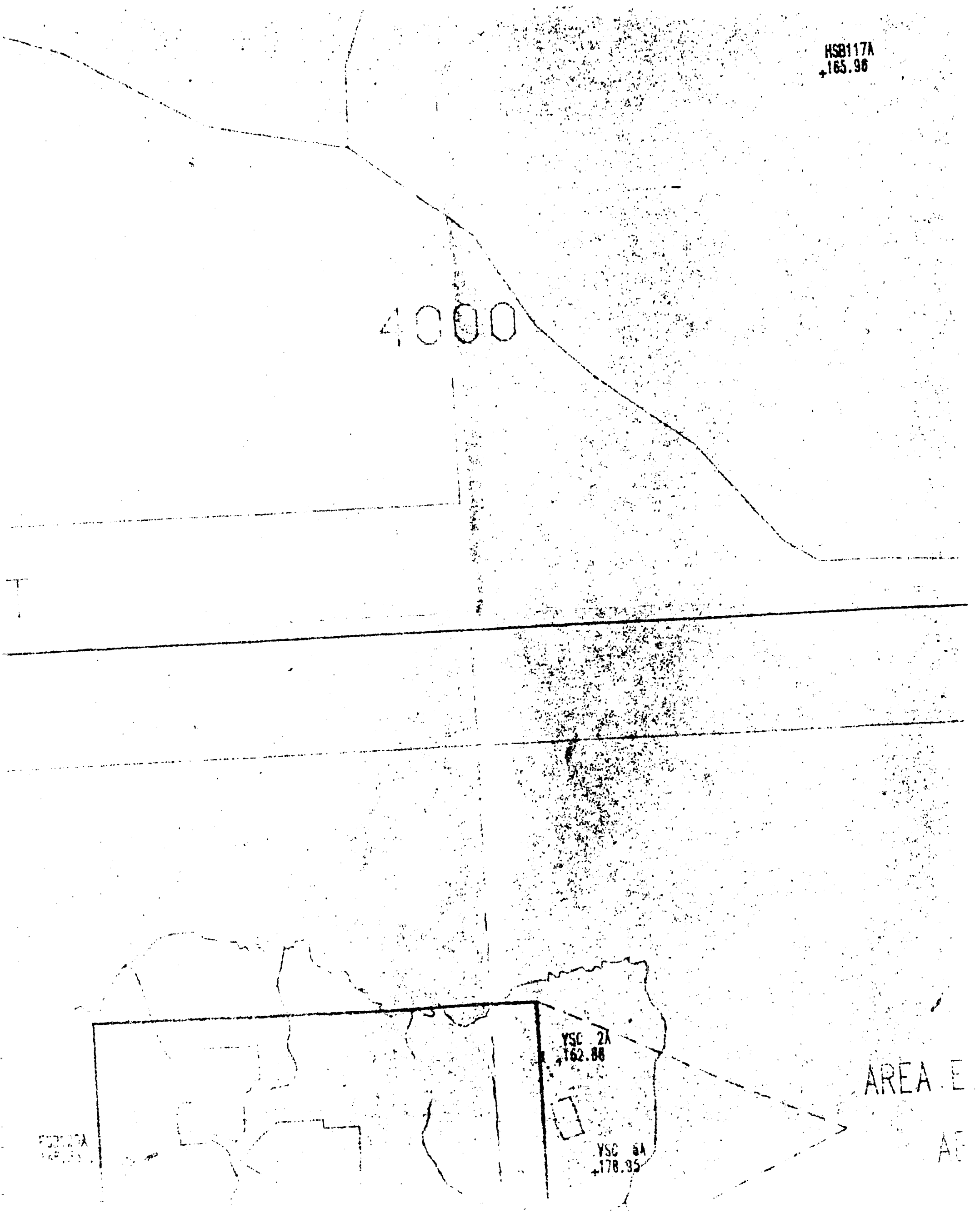




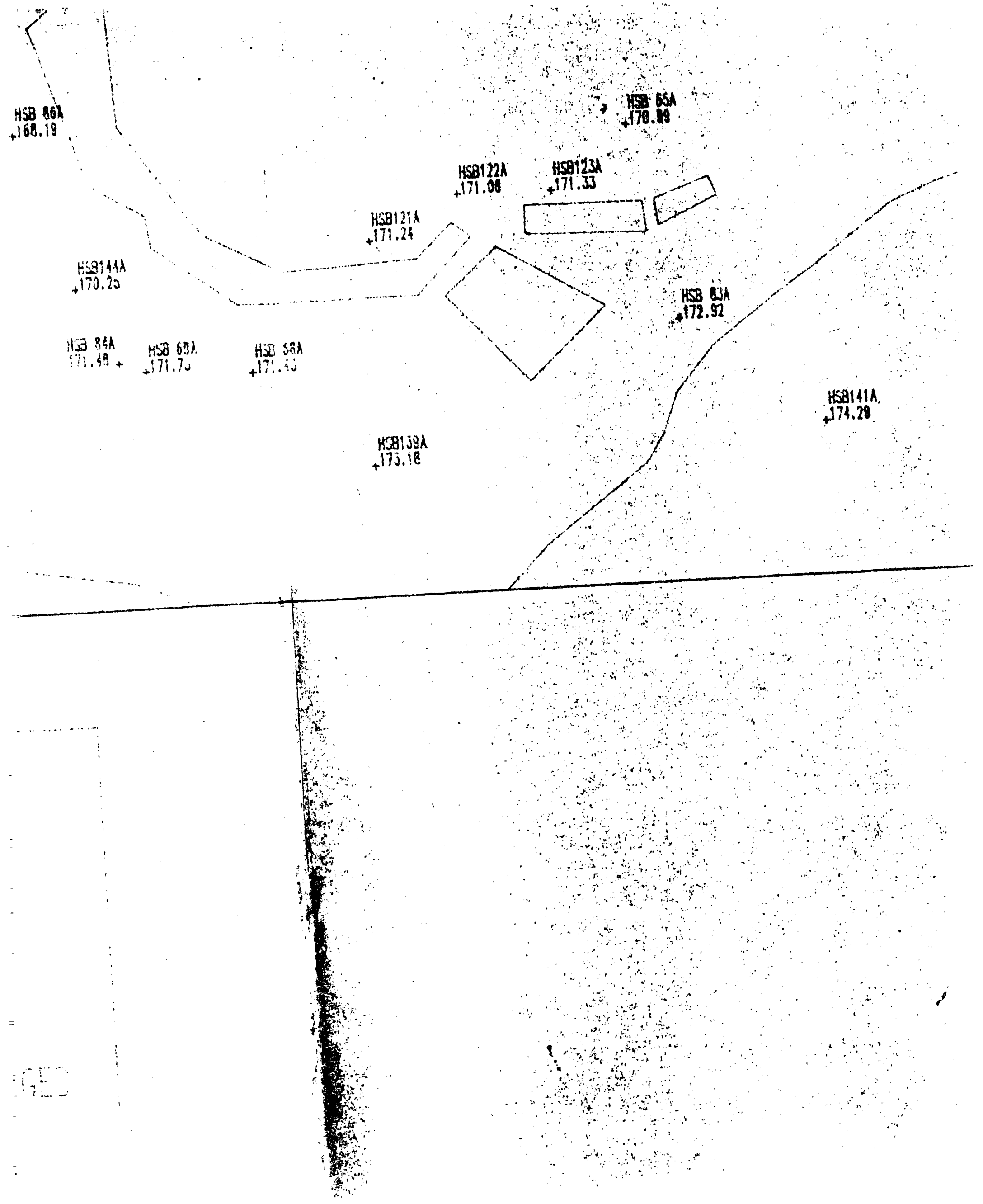




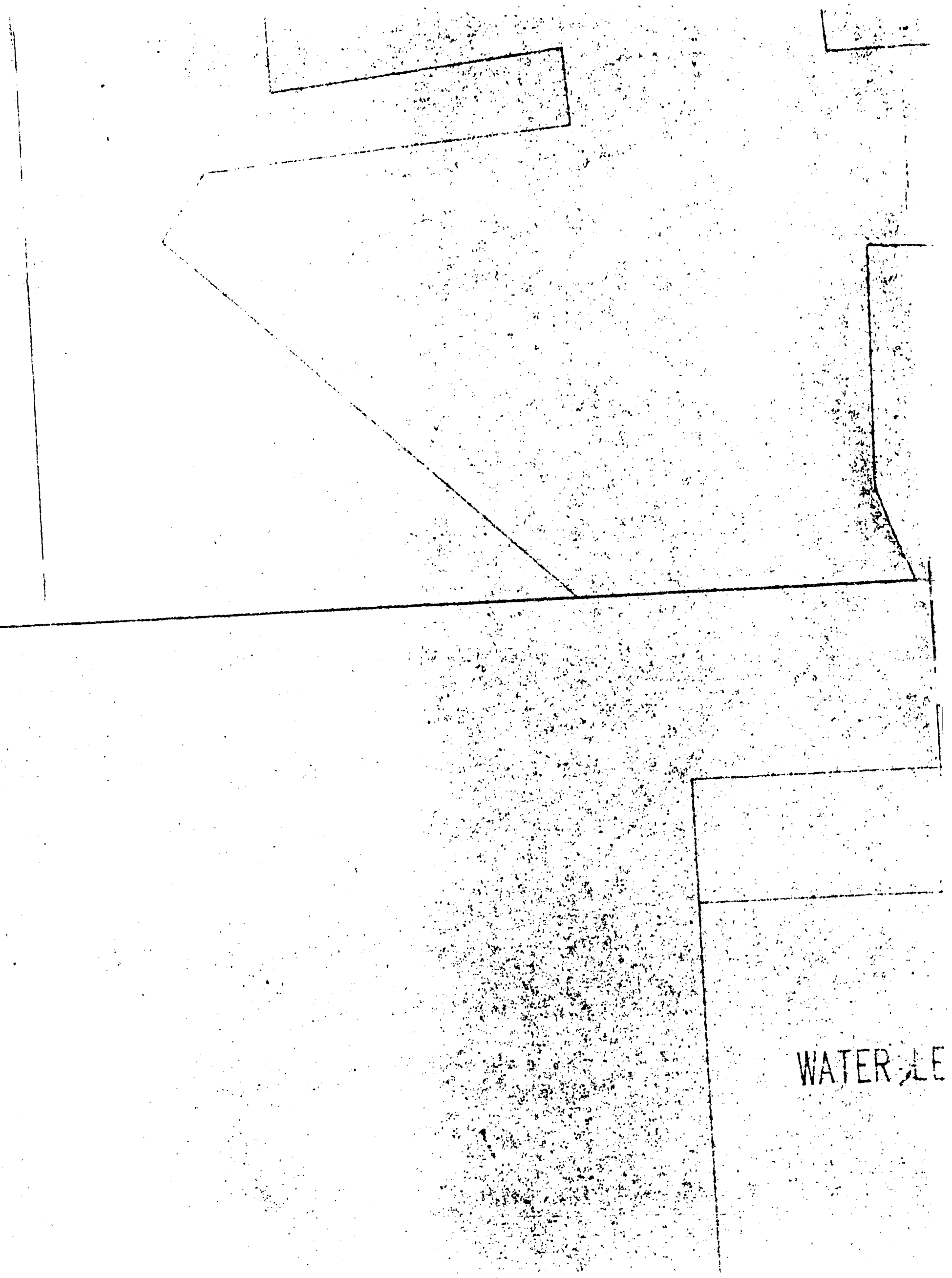




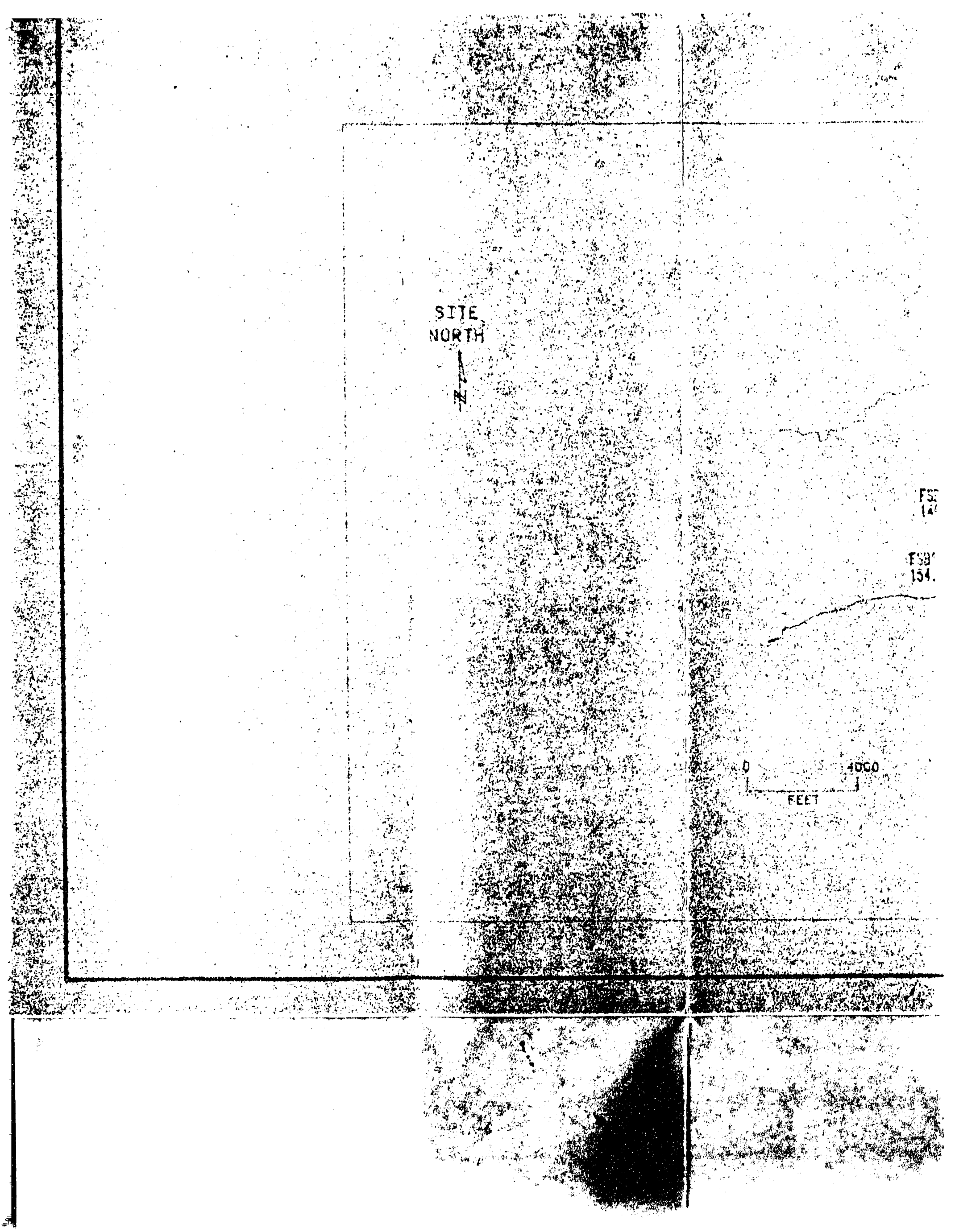




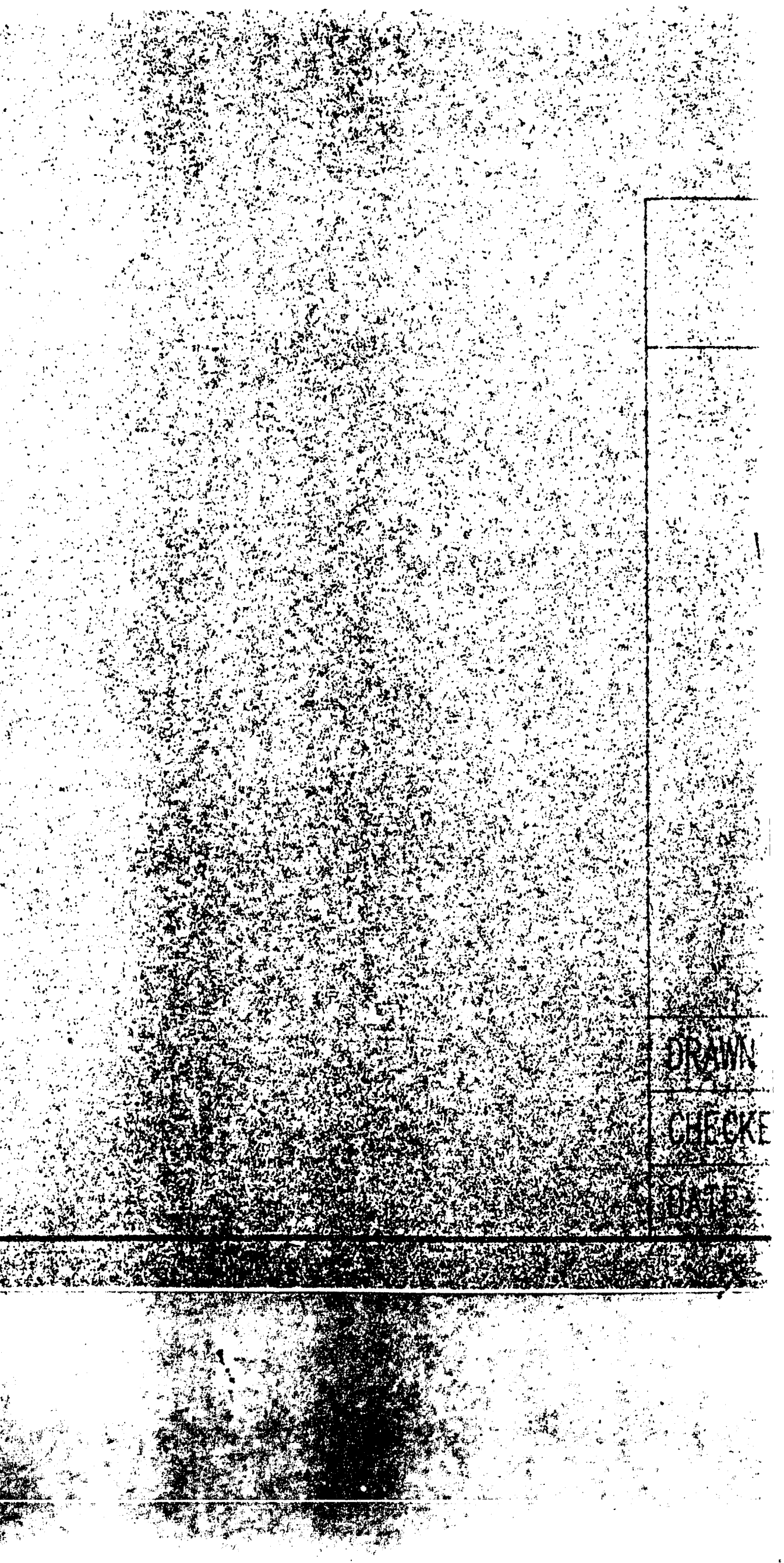




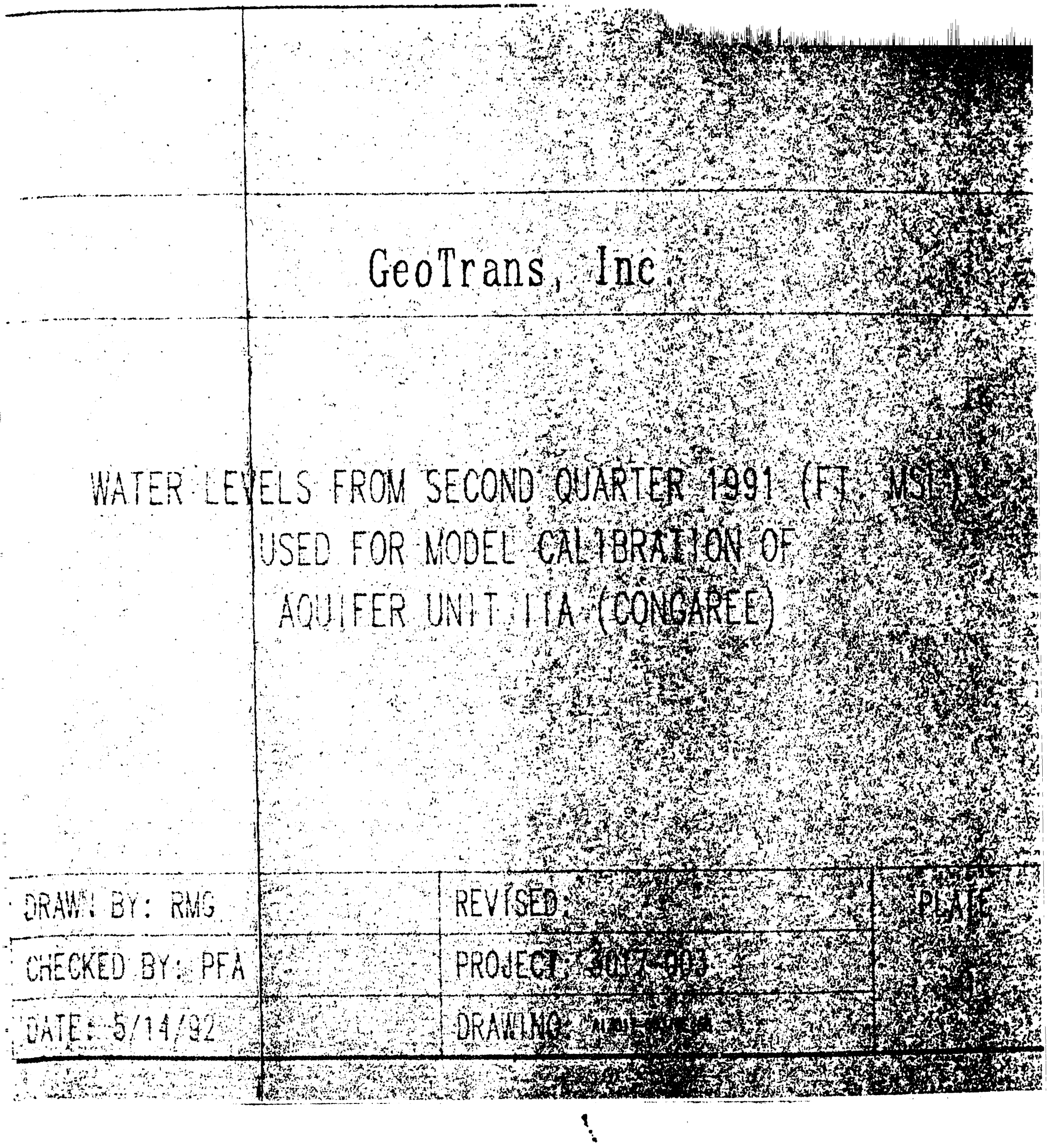



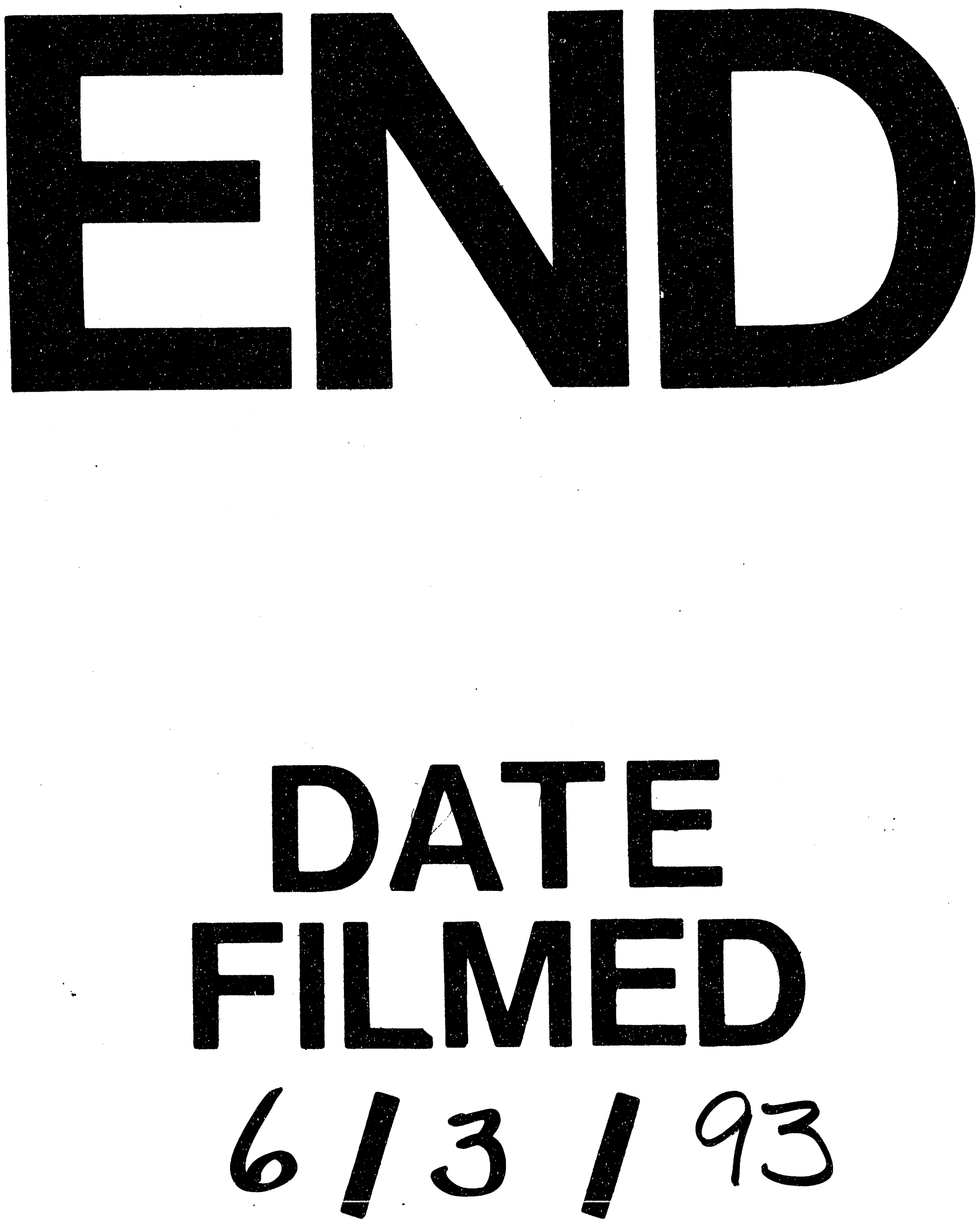
